POLÍTICAS SOCIAIS: acompanhamento e análise 




\section{Governo Federal}

Ministério da Economia

Ministro Paulo Guedes

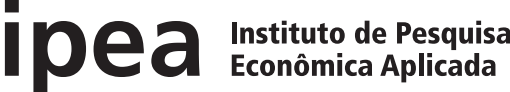

Fundação pública vinculada ao Ministério da Economia, o Ipea fornece suporte técnico e institucional às ações governamentais - possibilitando a formulação de inúmeras políticas públicas e programas de desenvolvimento brasileiros - e disponibiliza, para a sociedade, pesquisas e estudos realizados por seus técnicos.

\section{Presidente}

Carlos von Doellinger

Diretor de Desenvolvimento Institucional

Manoel Rodrigues Junior

Diretora de Estudos e Políticas do Estado, das Instituições e da Democracia

Flávia de Holanda Schmidt

Diretor de Estudos e Políticas

Macroeconômicas

José Ronaldo de Castro Souza Júnior

Diretor de Estudos e Políticas Regionais, Urbanas e Ambientais

Nilo Luiz Saccaro Júnior

Diretor de Estudos e Políticas Setoriais de Inovação e Infraestrutura

André Tortato Rauen

\section{Diretora de Estudos e Políticas Sociais}

Lenita Maria Turchi

Diretor de Estudos e Relações Econômicas

e Políticas Internacionais

Ivan Tiago Machado Oliveira

Assessora-chefe de Imprensa

e Comunicação

Mylena Fiori

Ouvidoria: http://www.ipea.gov.br/ouvidoria

URL: http://www.ipea.gov.br

\section{POLÍTICAS SOCIAIS}

acompanhamento e análise

Diretoria de Estudos e Políticas Sociais

Conselho Editorial

Alexandre Arbex Valadares

Antonio Teixeira Lima Junior

Helder Rogério Sant'ana Ferreira

José Aparecido Carlos Ribeiro

Luana Simões Pinheiro (editora)

Luciana Mendes Santos Servo

Marcelo Galiza Pereira de Souza (editor)

Rodrigo Pucci de Sá e Benevides

Sandro Pereira Silva

Colaboradores

Previdência Social | Luis Henrique da Silva de Paiva Graziela Ansiliero

Assistência Social |Andrea Barreto de Paiva Marina Brito Pinheiro

Marco Antônio Natalino

Elaine Cristina Licio

Letícia Bartholo de Oliveira e Silva

Aline Diniz Amaral

Saúde

Edvaldo Batista de Sá

Fabiola Sulpino Vieira

Luciana Mendes Santos Servo

Rodrigo Pucci de Sá e Benevides

Sérgio Francisco Piola

\begin{tabular}{l|l} 
Educação & $\begin{array}{l}\text { Milko Matijascic } \\
\text { Carolina Esther Kotovicz Rolon }\end{array}$
\end{tabular}

Povos Indígenas $\quad$ Frederico Augusto Barbosa da Silva

Isabella Cristina Lunelli

Trabalho E Renda $\quad$ Sandro Pereira Silva

Marcos Dantas Hecksher

Carlos Henrique L. Corseuil

Brunu Marcus F. Amorim

Desenvolvimento Alexandre Valadares

Rural Fábio Alves

Marcelo Galiza

Igualdade Racial Angélica Kely de Abreu

Antonio Teixeira Lima Júnior

Igualdade de $\quad$ Carolina Pereira Tokarski

Gênero Joana Luiza Oliveira Alencar

Krislane de Andrade Matias

Luana Simões Pinheiro

\begin{tabular}{l|l} 
Nota de Política & Sandro Pereira Silva \\
Social &
\end{tabular} 
C Instituto de Pesquisa Econômica Aplicada - ipea 2020

Políticas sociais : acompanhamento e análise, v. 1 -

(jun. 2000 - ). - Brasília : Ipea, 2000 -

v. : il.

Semestral

ISSN : 15184285

1. Política Social - Periódicos. I. Instituto de Pesquisa

Econômica Aplicada. Diretoria de Estudos e Políticas Sociais.

CDD 362.5

DOI: http://dx.doi.org/10.38116/bps27

Para consulta a todas as edições de Políticas Sociais: acompanhamento e análise, bem como aos respectivos anexos estatísticos, acesse, no site do Ipea, o link <http://www.ipea.gov.br/ portal/index.php?option=com_alphacontent\&section=38\&ltemid=363> ou siga 0 caminho de navegação Início > Publicações > Políticas Sociais.

As publicações do Ipea estão disponíveis para download gratuito nos formatos PDF (todas) e EPUB (livros e periódicos). Acesse: http://www.ipea.gov.br/portal/publicacoes

As opiniões emitidas nesta publicação são de exclusiva e inteira responsabilidade dos autores, não exprimindo, necessariamente, o ponto de vista do Instituto de Pesquisa Econômica Aplicada ou do Ministério da Economia.

É permitida a reprodução deste texto e dos dados nele contidos, desde que citada a fonte. Reproduções para fins comerciais são proibidas. 


\section{SUMÁRIO}

\section{APRESENTAÇÃO}

\section{CAPÍTULO 1}

PREVIDÊNCIA SOCIAL

\section{CAPÍTULO 2}

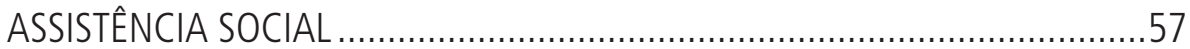

\section{CAPÍTULO 3}

SAÚDE

\section{CAPÍTULO 4}

EDUCAÇÃO.

\section{CAPÍTULO 5}

POVOS INDÍGENAS

\section{CAPÍTULO 6}

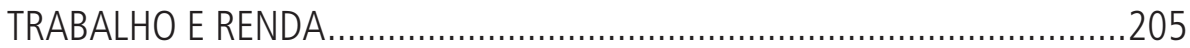

\section{CAPÍTULO 7}

DESENVOLVIMENTO RURAL

\section{CAPÍTULO 8}

IGUALDADE RACIAL

\section{CAPÍTULO 9}

IGUALDADE DE GÊNERO.

NOTA DE POLÍTICA SOCIAL

POLÍTICAS DE INCLUSÃO PRODUTIVA: O "ELO PERDIDO"

DA PROTEÇÃO SOCIAL? 



\section{APRESENTAÇÃO'}

A edição no 27 do boletim Políticas sociais: acompanhamento e análise faz um diagnóstico sobre os desafios que importantes compromissos internacionais assumidos pelo país trazem para as políticas sociais. Entre os diversos compromissos aqui apresentados, assumidos ao longo de todo o século XX, merece destaque - pela atualidade, pela abrangência e pela centralidade que conquistou em todo o mundo - a Agenda 2030 para o desenvolvimento sustentável, e a sua proposta de adequação, realizada pela Comissão Nacional dos Objetivos de Desenvolvimento Sustentável (CNODS). A elaboração dessa proposta de adequação das metas globais da Agenda 2030 ao contexto brasileiro resultou de um trabalho coletivo coordenado pelo Ipea que envolveu 75 órgãos governamentais e centenas de gestores e técnicos do governo federal. ${ }^{2}$

A Agenda 2030 corresponde a um conjunto de dezessete objetivos e 169 metas. Sua estrutura contempla de forma integrada objetivos relativos ao combate à fome e à pobreza, à promoção de uma vida saudável para todos, à educação de qualidade, ao trabalho decente, à superaçấo das diferentes desigualdades, à preservaçâo ambiental, ao acesso à justiça e ao crescimento econômico sustentado, inclusivo e sustentável. O Brasil foi um dos líderes da iniciativa, na Organização das Nações Unidas (ONU), e assumiu o compromisso político com a agenda em agosto de 2015, com outros 192 países. No ano seguinte, instituiu-se a CNODS, principal mecanismo de governança dos Objetivos de Desenvolvimento Sustentável (ODS) no Brasil (Decreto n⿳o 8.892/2016), que, por sua vez, delegou ao Ipea a função de instituição de assessoramento técnico permanente a essa comissão.

Com o início do novo governo, em 2019, o método de governança da Agenda 2030 foi alterado. Em 11 de abril de 2019, a CNODS foi extinta (Decreto no 9.759/2019). Em dezembro do mesmo ano, exclui-se, por meio do Veto Presidencial nº 61/2019, a persecução das metas dos ODS de um dos principais instrumentos de planejamento das políticas públicas do governo federal - o Plano Plurianual 2020-2023 (Lei no 13.971, de 27 de dezembro de 2019). ${ }^{3}$ Tais fatos desencadearam manifestações e

1. DOI: http://dx.doi.org/10.38116/bps27/apresentacao

2. Além disso, a proposta foi submetida à consulta pública pelo período de um mês. Para detalhes sobre a proposta e o seu processo de elaboração, ver Silva, Peliano e Chaves (2018).

3. Até o momento do fechamento desta edição, o veto presidencial ainda não tinha sido votado pelo Congresso Nacional. A última movimentação em sua tramitaçã̃o foi sua inclusão na Ordem do Dia das Sessões Remotas do Congresso Nacional convocadas para quarta-feira, 17 de junho de 2020. A matéria, contudo, deixou de ser apreciada em virtude do cancelamento da sessão. Disponivel em: <https://bit.ly/2Cl77Af>. Acesso em: 6 ago. 2020. 
preocupaçóes de várias organizaçóes da sociedade civil que atuam na implementação e no monitoramento da Agenda 2030. ${ }^{4}$ Diante do debate público em torno do tema, o governo federal reafirmou que a agenda "integra um dos projetos prioritários do planejamento estratégico da Secretaria de Governo da Presidência da República” e que a Secretaria Especial de Articulação Social, responsável pela governança da agenda em âmbito federal, tem trabalhado na "continuidade do processo de nacionalização das metas para os dezessete ODS" e na "identificação das açóes e programas do governo federal que contribuem para o seu alcance”. A previsão do governo federal é de que esse processo seja concluído em novembro de 2020 (O governo..., 2020).

Nesse contexto, esta edição de Políticas sociais: acompanhamento e análise pretende contribuir para esse debate, oferecendo um rico número de informaçôes e análises em seus nove capítulos que tratam dos principais setores que formam o campo da política social: previdência social, assistência social, saúde, educação, cultura, trabalho, desenvolvimento rural, igualdade racial e igualdade de gênero. Neste número, em caráter excepcional, o capítulo de cultura foi substituído por uma análise direcionada aos direitos e às políticas públicas voltados aos povos indígenas diante das proteçôes internacionais oferecidas pelos acordos e compromissos assumidos pelo país. Essa análise faz-se especialmente relevante neste momento, uma vez que, em 2019, o Brasil apresentou seu terceiro relatório à Convenção Internacional sobre a Eliminação de todas as Formas de Discriminação Racial (Cerd), cobrindo o período de 2003 a 2017.5 Neste processo, coube ao Ipea elaborar subsídios para o relatório, que abordou de forma detalhada as condiçôes de vida dos povos indígenas ao longo das duas últimas décadas, trazendo importantes reflexóes a serem consideradas no campo do Estado (Ipea, 2019). Além dos capítulos ordinários, esta edição traz também uma nota de política com interessante discussão sobre inclusão produtiva e laboral. A seguir, apresenta-se uma breve síntese do conteúdo de cada capítulo.

O capítulo 1 , dedicado à previdência social, está organizado em duas partes. Na primeira, é feita uma exposição sobre o processo parlamentar de reforma do sistema previdenciário, da Proposta de Emenda Constitucional (PEC) no 287/2016, enviada pelo Poder Executivo federal ao Congresso Nacional em dezembro de 2016, até a aprovação e sanção da Emenda Constitucional (EC) no 103/2019. O texto aborda os itens alterados pela reforma previdenciária a partir do diagnóstico original de despesas crescentes do sistema vigente, englobando os benefícios segurados do Regime Geral de Previdência Social (RGPS) e dos Regimes Próprios de Previdência Social (RPPS). A segunda parte refere-se ao acompanhamento da política previdenciária. Essa seção se subdivide em outras três partes. Primeiramente, os autores se reportam aos dados da Pesquisa Nacional por Amostra de Domicílios (PNAD)

4. Disponível em: <https://bit.ly/3gN1RV4>. Acesso em: 6 ago. 2020.

5. 0 último relatório apresentado pelo Brasil à Cerd havia sido em 2003. 
para verificar a evolução da taxa de cobertura da população a partir de distintos recortes societários e federativos. Posteriormente, o texto aborda a evolução do resultado previdenciário global, comparando indicadores recentes de pagamento de benefícios previdenciários e acidentários (quantidade, valores totais e médios, e participação relativa na despesa total) entre os subsistemas, bem como a relação contábil entre receitas e despesas, conforme o fluxo anunciado anualmente pela Secretaria de Previdência Social. Por fim, é realizada uma comparação internacional em termos de despesa previdenciária total e estrutura demográfica. Nas consideraçóes finais, o capítulo trata brevemente sobre as Normas Mínimas da Seguridade Social preconizadas pela Convenção no 102 da Organização Internacional do Trabalho (OIT), adotada pelo organismo em 1952 e ratificada pelo Brasil em 2008, que estabelece padrôes mínimos de proteção previdenciária para seus países-membros.

O capítulo 2, dedicado ao tema da assistência social, analisa as fundamentais contribuiçóes da política de assistência social ao cumprimento dos objetivos e das metas da Agenda 2030. Apresentam-se informaçôes e análises das potencialidades e desafios do conjunto de serviços, benefícios e programas dessa política nas transformaçôes almejadas pelo ODS 1, qual seja "acabar com a pobreza, em todas as suas formas, em todos os lugares". As metas e os indicadores que compóem o primeiro ODS são descritos e analisados conectando metas e indicadores com a política de assistência social hoje existente. A partir desse quadro, faz-se um diagnóstico geral da política de assistência social, abordando a sua evolução nos últimos anos, com foco em 2018. Argumenta-se, como resultado da análise, que o cumprimento do objetivo de erradicação da pobreza em todas as suas formas está ameaçado pelos caminhos recentes da política e pelas sérias restriçôes fiscais impostas a ela.

O capítulo 3, dedicado às políticas na área de saúde, traz como tema central de sua análise a Agenda 2030 e os compromissos assumidos pelo governo brasileiro no âmbito dos ODS, em particular o ODS 3, que tem como proposta "assegurar uma vida saudável e promover o bem-estar para todos, em todas as idades". De forma muito interessante, os autores apresentam e discutem esse terceiro objetivo tendo como pano de fundo as propostas anteriores para a área de saúde que constavam dos Objetivos de Desenvolvimento do Milênio (ODM), analisando em que medida esses objetivos se inserem nos ODS, os avanços entre os dois compromissos e os desafios que seguem pendentes de enfrentamento. Para que esses avanços e desafios possam ser mais bem compreendidos, os autores iniciam o texto apresentando uma importante discussão a respeito dos distintos entendimentos que se podem ter do conceito de cobertura universal de saúde. Isso se revela importante não apenas porque o ODS 3 traz uma meta específica para alcance da cobertura universal, mas, em especial, porque o alcance das demais metas, e, portanto, do objetivo de garantir vida saudável e bem-estar para todos, depende diretamente de como se compreende e operacionaliza esse conceito na construção dos sistemas de saúde dos mais diferentes países. 
O capítulo 4, dedicado às políticas de educação, está organizado em quatro seções. A seção 1 introduz, apresenta os ODS e informa que a questão central do capítulo é verificar os efeitos das reformas administrativas do atual governo sobre as metas do ODS 4. A seção 2 relaciona as metas do ODS 4 com a estrutura institucional da educação no Brasil, considerando o Plano Nacional de Educação (PNE) 2014-2024, a Lei de Diretrizes e Bases da Educação (LDB) e a Constituição Federal de 1988 (CF/1988). A seção 3 relaciona as metas do ODS 4 com a estrutura institucional para destacar os efeitos das mudanças administrativas promovidas pela nova gestão federal, iniciada em 2019. A seção 4 apresenta as conclusões, com uma análise crítica sobre o alcance das mudanças nas estruturas administrativas e nos programas do Ministério da Educação (MEC).

O capítulo 5, Direitos e politicas públicas para povos indígenas, parte do exame dos acordos e compromissos internacionais assumidos pelo Brasil no campo da proteção aos direitos dos povos originários e do combate às formas raciais e étnicas de discriminação. Tais acordos influíram sobre a construçẫo dos aparatos legais e institucionais nacionais internos por meio dos quais a política indigenista se configurou. Duas abordagens, que se complementam, tratam desse processo: de um lado, uma discussão teórica que investiga os limites entre a ação discricionária do Estado e o respeito à autonomia dos povos indígenas; de outro, um levantamento da efetividade das políticas indigenistas - com destaque para as políticas demarcatórias - a partir de uma análise do orçamento público.

O capítulo 6, dedicado às políticas de trabalho e renda, aborda a questão dos acordos e compromissos internacionais na área a partir de dois importantes marcos. O primeiro deles se refere aos tratados e às convençôes da OIT que orientaram o Brasil e boa parte dos países em todo o mundo a organizarem e fortalecerem seus sistemas públicos de emprego. No caso brasileiro, os autores apontam que foi apenas após a promulgação da $\mathrm{CF} / 1988$ que o país finalmente instituiu um Sistema Público de Emprego (SPE), conforme as orientaçóes da OIT, ainda que importantes passos nessa direção tenham sido dados, com a implementação do Sistema Nacional de Emprego (Sine), em 1975, e do Programa Seguro-Desemprego, em meados dos anos 1980. O SPE brasileiro, contudo, ainda cobre uma parcela bastante limitada da população trabalhadora do país, orientando boa parte de suas açóes para os ocupados formais e sofrendo com uma série de limitaçôes ao seu financiamento. O segundo marco internacional abordado no texto trata-se dos compromissos assumidos pelo Estado brasileiro no âmbito dos ODS, especificamente o ODS 8, que se refere ao trabalho decente e ao crescimento econômico. Os autores fazem uma análise das metas propostas nesse oitavo objetivo e de como o país tem caminhado ou não em direção ao seu cumprimento, apresentando uma importante evolução dos indicadores na área de mercado de trabalho ao longo dos últimos anos. Questóes importantes, como o comportamento recente da taxa de 
desemprego e o aumento da informalidade, são discutidas no texto, que aponta as dificuldades no cumprimento das metas do ODS 8 se mantidos o ritmo e a evolução do mercado de trabalho brasileiro verificado no final dos anos 2010 . Por fim, alguns programas governamentais são apresentados, assim como a nova organização do Plano Plurianual 2020-2023 para a área.

O capítulo 7, dedicado às políticas de desenvolvimento rural, dialoga diretamente com o ODS 2, "acabar com a fome, alcançar a segurança alimentar e melhoria da nutrição e promover a agricultura sustentável”, apresentando indicadores e avaliando programas e políticas públicas relacionadas à segurança alimentar e à produção sustentável de alimentos. Esse capítulo aborda o conceito de segurança alimentar e indicadores que medem a (in)segurança alimentar da população, além de mostrar que o percentual de domicílios com insegurança alimentar grave reduziu pela metade, de 6,9\%, em 2004, para 3,2\%, em 2013, último ano para o qual a informação está disponível; no entanto, ainda são mantidos níveis mais elevados no meio rural em relação ao meio urbano. Os bons resultados na situação de segurança alimentar estâo relacionados às políticas de transferência de renda e de valorização do salário mínimo. Destaca, também, o crédito para a agricultura familiar advindo do Programa de Fortalecimento da Agricultura Familiar (Pronaf) e a garantia de compra da produção pelo Programa de Aquisiçáo de Alimentos (PAA), em colaboração com o Programa Nacional de Alimentaçáo Escolar (PNAE). Contudo, esses avanços podem ser parcialmente comprometidos. Houve aumento da proporçáo da população em situação de pobreza de $12,8 \%$, em 2013, para $13,3 \%$, em 2017 , bem como na precarização das relaçóes de trabalho, com crescimentos da taxa de desocupação e de subutilizaçáo da força de trabalho. Adicionalmente, outra preocupaçâo refere-se à qualidade dos alimentos, devido ao aumento do uso de agrotóxicos no país. Associam-se a essas preocupaçóes as reduçóes no orçamento dos programas relacionados ao desenvolvimento rural e a desestruturação das instituições responsáveis pela execução dessas políticas. $\mathrm{O}$ combate à fome exige esforços contínuos, alocaçáo de recursos e fortalecimento das instituiçóes para executarem políticas que voltariam a demonstrar o compromisso do governo com esse objetivo.

O capítulo 8, dedicado à pauta da igualdade racial, dialoga com as recomendaçôes do Sistema ONU na promoção de direitos (civis, humanos e sociais), em suas várias formas e níveis. O núcleo da análise é a efetividade dos compromissos assumidos pelo Brasil ao ratificar a Cerd, de dezembro de 1965, e as respectivas respostas a esta convenção por parte do Estado brasileiro. Entendendo que a efetividade é resultado do conjunto de entregas públicas que concorrem para a produção ou mitigação dos marcadores sociais das diferenças, o capítulo analisa a recepção institucional da Cerd nos diferentes ciclos políticos dos últimos quarenta anos. Aponta-se que, após atravessar o período negacionista, consumado na incorporação do mito da democracia racial como leitura oficial, o Estado brasileiro foi lentamente reconhecendo a densidade e a profundidade do racismo na formação da sociedade brasileira. 
Em larga medida, esse reconhecimento se institucionalizou por meio da CF/1988, construída e instrumentalizada pelas organizaçóes negras para tornar efetivo o tratamento antidiscriminatório nela inscrito. Políticas e programas dirigidos à promoção da igualdade racial passaram a repertoriar as intervençóes públicas em diferentes áreas e setores. O período de avanços institucionais foi, porém, também o período em que as formas mais candentes de expressão do racismo na sociedade brasileira se agudizaram, dada a elevação expressiva das taxas de mortalidade violenta e de encarceramento da populaçáo negra nos últimos anos. A partir de 2015, e com maior ênfase a partir de 2016, um novo ciclo se inicia, inaugurado pela execução continuada de um programa político que questiona a viabilidade e a legitimidade dos compromissos sociais forjados com base na CF/1988. Nesse novo ciclo, o sistema antidiscriminatório é afetado, de forma direta, pelo desmonte das estruturas públicas racializadas construídas no período antecedente e, de forma indireta, pela reforma do sistema de proteção social, cujos efeitos são ainda mais negativos sobre os segmentos mais vulnerabilizados.

O capítulo 9, dedicado à pauta da igualdade de gênero, se propóe a analisar os compromissos internacionais para a promoção dos direitos das mulheres e da igualdade de gênero assumidos pelo Estado brasileiro. O capítulo resgata, inicialmente, o desenvolvimento dos direitos das mulheres a partir da fundação da ONU, descrevendo as diferentes fases em que foram criados órgãos e realizadas conferências, bem como foram acordadas pelos países - inclusive pelo Brasil - as cartas, as declaraçôes, as convençóes, os pactos, os tratados, os protocolos, as conferências e as agendas. A narrativa gradualista apresentada pelas autoras não esconde, entretanto, idas e vindas nessa trajetória. A própria atuação da ONU e de suas instituiçóes se transmuta ao longo das décadas analisadas nesse capítulo, das primeiras iniciativas sobre direitos humanos; passando pelas conferências dos anos 1990; até as tentativas de pactuação internacional em torno dos ODMs e dos ODS, com sua Agenda 2030. Ao analisar os desafios para o cumprimento das metas dos ODS no Brasil, as autoras apontam o impacto da reorientação do governo federal em relação à agenda de promoçáo dos direitos das mulheres, mas reconhecem, no princípio da vedação do retrocesso nos direitos fundamentais - já adotado pela Suprema Corte brasileira - e na força dos sistemas internacionais de direitos humanos, o que se poderia chamar de pontos de resistência para a manutenção dos compromissos assumidos historicamente pelo Brasil em relaçáo aos direitos humanos das mulheres.

Por fim, a nota Políticas de inclusão produtiva e laboral: o "elo perdido" da proteçâo social? analisa o repertório de políticas públicas instituído a partir do final do século XX para combater a pobreza e a desigualdade de renda na América Latina e no Caribe, suas características mais centrais e suas relaçôes com os chamados programas de inclusão produtiva. Essa nota também argumenta que esse período 
foi caracterizado por importante expansão e estruturação de políticas de caráter contributivo e não contributivo nos países da região, entre as quais figuram: benefícios previdenciários, transferências condicionadas de renda e programas de inclusão produtiva - uma "espécie de tripé para um sistema integral de proteção social e inclusiva”. Em seguida, o autor trata da inclusão produtiva como um eixo das políticas públicas de proteção social no Brasil e cita diversos programas que têm como objetivo a "geração de oportunidades de trabalho e renda a jovens e adultos em idade ativa com alguma dificuldade de inserção no mercado de trabalho".

Em suma, esta edição do boletim Politicas sociais: acompanhamento e análise apresenta um rico e diversificado panorama das políticas sociais, revelando capacidades e fragilidades do Estado brasileiro no cumprimento de importantes compromissos internacionais assumidos, com foco particular na Agenda 2030. Entende-se que o contexto extremamente desafiador para o país torna essa discussáo ainda mais relevante. As múltiplas crises que se sobrepóem atualmente - política, social, econômica, ambiental e, mais recentemente, a pandemia da Covid-19 - requerem estratégias urgentes de revigoramento das políticas sociais, com o intuito de combater desigualdades e injustiças.

Conselho Editorial

\section{REFERÊNCIAS}

IPEA - INSTITUTO DE PESQUISA ECONÔMICA APLICADA. Subsídio ao Relatório Brasil sobre o cumprimento da Convençáo Internacional sobre a Eliminaçáo de todas as Formas de Discriminação Racial (2003-2017): povos indígenas. Brasília: Ipea, 2019. Disponível em: <https://bit.ly/33WRxWW>.

O GOVERNO brasileiro e a Agenda 2030. Gov.br, 30 jan. 2020. Disponível em: <https://bit.ly/2Q079B3>. Acesso em: 6 ago. 2020.

SILVA, E. R. A.; PELIANO, A. M.; CHAVES, J. V. (Orgs.). Agenda 2030: ODS - Metas Nacionais dos Objetivos de Desenvolvimento Sustentável. Brasília: Ipea, 2018. 



\section{PREVIDÊNCIA SOCIAL ${ }^{1}$}

\section{APRESENTAÇÃO}

A Proposta de Emenda à Constituição (PEC) no $287 / 2016$, enviada pelo Poder Executivo federal ao Congresso Nacional em dezembro de 2016, propôs ajustes paramétricos significativos nos regimes públicos de Previdência Social - Regime Geral de Previdência Social (RGPS) e Regimes Próprios de Previdência Social (RPPS) - e foi bastante alterada ao longo do processo legislativo, assumindo contornos bem mais brandos no parecer substitutivo do relator e, principalmente, na Emenda Aglutinativa Global à PEC no 287-A/2016. A PEC no 287/2016 permaneceu em destaque e como prioridade até meados de 2018, quando a corrida eleitoral, apenas para destacar um fator explicativo, inviabilizou a continuidade de sua tramitaçáo.

Apesar dos ajustes concertados, as perspectivas de apreciação, votação e eventual aprovaçáo de qualquer de suas versóes se mostraram limitadas e fizeram crescer a expectativa em torno dos resultados do processo eleitoral de 2018, dado que este ponto deveria necessariamente seguir no topo da agenda do Poder Executivo. A crise econômica vivenciada pelo país certamente contribui para a preocupante evolução de curto prazo nos indicadores previdenciários, mas os desafios estruturais enfrentados pela Previdência Social brasileira determinam as tendências observadas de deterioração financeira. Assim, como esperado, com a posse do novo governo federal, a reforma da Previdência voltou ao centro do debate nacional, impulsionada pelos recentes diálogos travados em torno da PEC no 287/2016.

Este capítulo se inicia com uma análise dos principais pontos que compóem a PEC n⿳06/2019, apresentada pelo Poder Executivo federal ao Congresso Nacional em fevereiro de 2019 (subseção 2.1) e geradora da Emenda Constitucional (EC) no $103 / 2019$, bem como com a apresentação dos demais componentes do que se configuraria a chamada Nova Previdência (subseçóes 2.2 a 2.5). O tópico seguinte (seção 3) é voltado para o acompanhamento da política previdenciária propriamente, tendo como ponto de partida a evolução dos principais indicadores de formalidade trabalhista e previdenciária no período coberto pela Pesquisa Nacional por Amostra de Domicílios Contínua - PNAD Contínua (subseção 3.1). O resultado previdenciário é tema da última subseção deste capítulo (3.2), que registra despesas, receitas e saldos anuais do RGPS e dos RPPS (União, estados e municípios) em termos absolutos e como proporçấo do produto interno bruto (PIB). O último 
tópico (seção 4), a pretexto de conclusão, sintetiza os principais temas e resultados abordados ao longo do texto.

\section{FATOS RELEVANTES}

\subsection{Reforma previdenciária: PEC no 6/2019}

A PEC no 6/2019 foi desenhada pelo Ministério da Economia (ME) com o intuito declarado de estabelecer uma lógica mais sustentável e justa de funcionamento para a Previdência Social brasileira. A reforma previdenciária, amparada em diagnóstico já conhecido e debatido há décadas no país, foi defendida como imprescindível para garantir a sustentabilidade do sistema atual, evitando custos excessivos para as futuras geraçóes e o comprometimento do pagamento dos benefícios segurados do RGPS e dos RPPS. Os ajustes propostos também evitariam que a despesa previdenciária avançasse ainda mais como proporção do orçamento da União, sobrando cada vez menos espaço para investimentos públicos e outros gastos sociais importantes, como educação, saúde e assistência social. ${ }^{2}$

Adicionalmente, a PEC no 6/2019 teria o suposto mérito de permitir a construção de um novo modelo previdenciário para as futuras geraçóes de trabalhadores, capaz de fortalecer o nível de poupança e o futuro desenvolvimento nacional. Este último ponto, vale dizer, guarda forte relação com a solicitação de autorização, via previsão constitucional, para a proposição de um novo regime previdenciário, calcado em um sistema de capitalização individual, delineado pelo art. 115 do Ato das Disposiçóes Transitórias Constitucionais (ADCT), que estabelece suas diretrizes gerais. Ou seja, a proposta apresentada partiria de ajustes paramétricos no sistema atual, ainda sob a lógica da repartição simples e da solidariedade intra e intergeracional, e culminaria em uma reforma estrutural, com especificidades a serem definidas em etapa posterior da reforma.

Outro aspecto destacável é a opção pela desconstitucionalização, mantendo na Constituição Federal (CF) fundamentalmente os aspectos estruturantes do sistema e seus preceitos básicos, suprimindo, portanto, do seu texto, regras de elegibilidade a benefícios e serviços providos pelo RGPS. Esta opção foi justificada pela desejabilidade de aprimoramento do texto, no sentido de torná-lo mais sintético, mas também menos rígido em caso de (eventuais) alteraçôes futuras, pois os ritos de tramitaçáo e os requisitos para aprovaçáo de emendas constitucionais são mais duros, engessando o processo de adaptação do sistema previdenciário a contextos sociais, econômicos e demográficos em contínua transformação. Uma lei complementar (LC) disporia, então, sobre os critérios e parâmetros dos sistemas

2. Ver proposição e Exposição de Motivos (EM) no 00029/2019-ME da PEC no 6/2019. Disponível em: <https://bit. ly/2yQ3a4K>. 
previdenciários, os quais foram objeto de disposiçôes transitórias (passíveis de alteraçóes pela referida legislação complementar) na $\mathrm{PEC} \mathrm{nº}$ 6/2019. De forma análoga, a PEC nº 6/2019 retiraria do texto permanente da CF as regras para concessão de benefícios pelos RPPS.

Originalmente, as propostas de ajuste paramétrico definidas para a União seriam imediatamente aplicáveis aos servidores de todos os entes federativos, mas, ainda na tramitação na Câmara dos Deputados, a extensão automática a estados, municípios e ao Distrito Federal foi eliminada, cabendo a estes últimos a aprovação de leis próprias para sua implementação local. Esta alteração, imposta por entraves políticos, foi considerada particularmente negativa, dadas as dificuldades adicionais impostas para os ajustes necessários nos mais de 2 mil RPPS existentes no país.

A desconstitucionalização foi também bastante suavizada ainda na Câmara dos Deputados, assim como vários outros pontos do debate foram alterados ou eliminados para permitir a elaboração e a aprovação da resultante emenda aglutinativa (PEC no 6-A/2019). Um dos pontos retirados da PEC foi o gatilho desenhado para o ajuste periódico e automático da idade mínima para requerimento da aposentadoria voluntária, que, nos termos da proposta, seria incrementada quando houvesse aumento na expectativa de sobrevida da população brasileira, de ambos os sexos, na idade de 65 anos. $\mathrm{O}$ texto aprovado, com esta supressão, exigirá novas reformas constitucionais para eventuais alteraçóes neste parâmetro.

No Senado Federal, como solução alternativa às soluçóes insuficientes propostas para os RPPS dos demais entes federativos e aos pontos sem consenso no texto principal, optou-se, via negociação e concertação, por uma PEC paralela (PEC no 133/2019), apresentada pela Comissão de Constituição, Justiça e Cidadania do Senado Federal e delineada no tópico 2.5 deste texto. As poucas alteraçôes realizadas no texto aprovado pela Câmara Federal e sua natureza supressiva permitiram uma tramitação mais célere, tornando desnecessário o retorno do texto à Câmara dos Deputados para nova apreciação.

\subsubsection{Regime Geral de Previdência Social}

Entre as alteraçôes aplicáveis ao RGPS, pode-se destacar as seguintes regras permanentes e suas versóes.

\section{Aposentadoria por idade}

Regra anterior: a aposentadoria por idade (API) é devida ao segurado que, cumprida a carência de 180 contribuiçôes mensais (urbanos) ou 180 meses de efetiva atividade rural no período imediatamente anterior ao requerimento do benefício (rurais), completar 65/60 anos de idade, se homem (urbano/rural), ou 60/55 anos, se mulher (urbana/rural). O salário de benefício consiste na média aritmética simples dos 
maiores salários de contribuição correspondentes a $80 \%$ do período contributivo desde a competência de julho de 1994 ou do início da contribuição, se posterior, e a renda mensal no valor equivalente a $70 \%$ do salário de benefício, mais $1 \%$ a cada grupo de doze contribuiçôes.

Regra aprovada: a EC mantém o tempo mínimo de contribuição em quinze anos para homens e mulheres rurais, mulheres urbanas e homens urbanos já no mercado de trabalho na data de sua promulgação. Para novos segurados urbanos, a carência será de vinte anos de tempo de contribuição para os homens e continuará sendo de quinze anos para as mulheres. As idades mínimas foram mantidas para homens urbanos (65 anos) e homens e mulheres rurais - respectivamente, 60 (homens) e 55 anos (mulheres) -, sendo majorada para mulheres urbanas (62 anos). O valor da aposentadoria será calculado com base na média de todo o histórico de contribuições do trabalhador, ${ }^{3}$ com exceçôes previstas. ${ }^{4}$ Ao atingir o tempo de contribuição de referência (vinte anos, se homem urbano, mesmo que já no mercado de trabalho e sujeito à carência de quinze anos; e quinze anos para os demais grupos), o segurado terá direito a $60 \%$ do valor médio das contribuiçóes, com acréscimo de dois pontos para cada ano a mais de contribuição..$^{5} \mathrm{Ou}$ seja, para os homens que já estão no mercado de trabalho, embora o tempo de contribuição mínimo tenha sido reduzido de vinte anos para quinze anos, o valor do benefício na regra de transição somente subirá a partir de 21 anos de contribuição.

\section{Aposentadoria por tempo de contribuição}

Regra anterior: a aposentadoria por tempo de contribuição (ATC) é devida ao segurado que, cumprida a carência exigida, completar, no mínimo, 35 anos de contribuição, se do sexo masculino, ou trinta, se do sexo feminino. O salário de benefício consiste na média aritmética simples dos maiores salários de contribuição correspondentes a $80 \%$ do período contributivo desde a competência de julho de 1994 ou do início da contribuição, se posterior, e a renda mensal no valor equivalente a $100 \%$ dessa média, multiplicada pelo fator previdenciário (FP). Pode-se optar pela não incidência do FP quando o somatório da idade com o tempo de

3. A PEC nำ6/2019 propunha alterações nos valores e na incidência progressiva e cumulativa das alíquotas de contribuição para os segurados empregados; empregado doméstico e trabalhador avulso, mantendo inalteradas as condições estabelecidas para contribuintes individuais e trabalhadores rurais com outras formas de vínculo previdenciário (salvo segurados especiais, para os quais houve proposta de mudança, rechaçada ainda na (âmara dos Deputados). Pela regra permanente original (pré-PEC), a contribuição destes segurados é calculada mediante a aplicação da correspondente alíquota sobre o seu salário de contribuição mensal, de forma não cumulativa. As propostas de mudança foram mantidas durante a tramitação no Congresso Nacional.

4. Para os trabalhadores com deficiência e os que se aposentassem por incapacidade permanente decorrente de acidente de trabalho, doença profissional ou do trabalho, o valor da aposentadoria seria de $100 \%$ da média.

5. Na regra permanente, o percentual poderia ultrapassar $100 \%$. Para a regra de transição, será limitado a $100 \%$. Tanto para o RGPS como para os RPPS. 
contribuição, para mulheres e homens, respectivamente, for igual ou superior a um determinado número diferenciado por sexo. ${ }^{6}$

Regra aprovada: extinção da ATC.

Aposentadoria dos professores

Regra anterior: os professores podem se aposentar, sem idade mínima, com 25 anos de tempo de contribuição, se mulher, ou com trinta anos de tempo de contribuição, se homem. Em qualquer hipótese, deve-se comprovar exclusivamente tempo de efetivo exercício das funções de magistério na educação infantil e no ensino fundamental e médio. O salário de benefício consiste na média aritmética simples dos maiores salários de contribuição correspondentes a $80 \%$ do período contributivo desde a competência de julho de 1994 ou do início da contribuição, se posterior, e a renda mensal no valor equivalente a 100\% dessa média, multiplicada pelo FP. Pode-se optar pela não incidência do FP quando o somatório da idade com o tempo de contribuição, para mulheres e homens, respectivamente, for igual ou superior a um determinado número diferenciado por sexo.

Regra aprovada: os professores podem se aposentar com 57 anos de idade, se mulher, e 60 anos de idade, se homem, em ambos os casos tendo acumulado 25 anos de tempo de contribuição exclusivamente em efetivo exercício das funçôes de magistério na educação infantil e no ensino fundamental e médio. $\mathrm{O}$ valor deste benefício será definido pela mesma regra estabelecida para a API.

Aposentadoria especial por exposição a agentes nocivos

Regra anterior: a aposentadoria especial é um benefício concedido ao cidadão que trabalha exposto a agentes nocivos à saúde, como calor ou ruído, de forma contínua e ininterrupta, em níveis de exposição acima dos limites estabelecidos em legislação própria. É possível aposentar-se após cumprir quinze, vinte ou 25 anos de contribuição, conforme o agente nocivo. Além do tempo de contribuição, é necessário que se tenha efetivamente trabalhado por, no mínimo, 180 meses, sendo que períodos de auxílio-doença, por exemplo, não são considerados para cumprir este requisito. O salário de benefício consiste na média aritmética simples dos maiores salários de contribuição correspondentes a $80 \%$ do período contributivo e à renda mensal no valor equivalente a $100 \%$ do valor do salário de benefício, sem qualquer cálculo adicional ou aplicação de FP.

Regra aprovada: para os trabalhadores que comprovem quinze, vinte ou 25 anos de contribuição em exercício de atividades com efetiva exposição a agentes nocivos químicos, físicos e biológicos prejudiciais à saúde, ou associação desses 
agentes, seriam exigidas as idades mínimas de 55, 58 e 60 anos, respectivamente, vedados a caracterização por categoria profissional ou ocupação e o enquadramento por periculosidade. Estaria assegurada a conversão de tempo especial em comum ao segurado do RGPS que comprovasse tempo de efetivo exercício de atividade sujeita a condiçóes especiais que efetivamente prejudiquem a saúde, cumprido até a data de promulgação da EC, vedada a conversão para o tempo cumprido após essa data. $\mathrm{O}$ valor deste benefício será definido pela mesma regra proposta para a API, exceto no caso do trabalhador que exerça atividade em condiçôes especiais prejudiciais à saúde por quinze anos, hipótese em que, mesmo para os homens, o acréscimo de $2 \%$ será aplicado ao tempo que exceder a quinze anos. Na versão final da EC, foram introduzidas alteraçóes pontuais no tratamento dado ao enquadramento por periculosidade e nas regras de transição. A PEC originalmente vedava aposentadorias especiais para atividades enquadradas por periculosidade, mas o texto final aprovado retirou essa proibição, sob a condição de que um projeto de lei (PL) seria apresentado para regulamentar o tema e evitar a judicialização.

\section{Aposentadoria por invalidez}

Regra original: benefício, precedido de auxílio-doença, devido ao trabalhador permanentemente incapaz de exercer qualquer atividade laborativa e que também não possa ser reabilitado em outra profissão, de acordo com a avaliação da perícia médica. O benefício é pago enquanto persistir a invalidez, e o segurado pode ser reavaliado a cada dois anos. O salário de benefício consiste na média aritmética simples dos maiores salários de contribuição correspondentes a $80 \%$ do período contributivo desde a competência de julho de 1994 ou do início da contribuição, se posterior, e à renda mensal no valor equivalente a 100\% dessa média.

Regra aprovada: os critérios para a elegibilidade e a concessão do benefício (aposentadoria por incapacidade permanente) seriam similares, mas a regra de cálculo do valor do benefício mudaria substantivamente. $\mathrm{O}$ salário de benefício passa a ser de $60 \%$ mais $2 \%$ por ano de contribuição que exceder vinte anos. Em caso de incapacidade decorrente de acidente de trabalho, doenças profissionais ou do trabalho, o cálculo do benefício não muda, permanecendo como $100 \%$ da média dos salários de contribuição.

\section{Aposentadoria da pessoa com deficiência}

Regra original: a API é devida àquele que comprovar o mínimo de 180 contribuiçôes exclusivamente na condiçâo de pessoa com deficiência, além da idade de 60 anos, se homem, ou 55 anos, se mulher. A ATC é devida àquele que comprovar o tempo de contribuição necessário, conforme o seu grau de deficiência (homens: leve - 33 anos, moderada -29 anos e grave -25 anos; mulheres: leve -28 anos, moderada -24 anos e grave - 20 anos), sendo que, deste período, no mínimo 180 meses devem ter sido trabalhados na condição de pessoa com deficiência. Para ambas as espécies de aposentadoria, o valor da renda mensal segue o mesmo cálculo da regra geral 
de API e ATC, mas, no caso desta última, a aplicação do FP é opcional, ou seja, o valor da aposentadoria tende a ser de 100\% do salário de benefício.

Regra aprovada: a API seguiria as regras propostas para a nova API, enquanto a ATC seria devida àquele que comprovasse o novo tempo de contribuição necessário, conforme o seu grau de deficiência (homens e mulheres: leve - 35 anos; moderada -25 anos; e grave -20 anos). Para ambas as espécies de aposentadoria, o valor da renda mensal seria de 100\% do salário de benefício (ou seja, 100\% da média simples dos salários de contribuição).

\section{Pensão por morte}

Regra original: a pensão por morte (PPM) é um benefício pago aos dependentes (cônjuge, companheiro, filhos e enteados menores de 21 anos ou inválidos, desde que não tenham se emancipado; pais; e irmãos não emancipados, menores de 21 anos ou inválidos) de beneficiário que era aposentado ou trabalhador com qualidade de segurado do RGPS quando do seu falecimento ou de sua morte presumida. A duração do benefício varia conforme a idade e o tipo de beneficiário, sendo vitalício para cônjuges e equiparados a partir dos 44 anos no momento do fator gerador, podendo sê-lo para aqueles acometidos por invalidez ou deficiência. O valor do benefício é fixado em $100 \%$ do valor da aposentadoria que o segurado recebia ou daquela a que teria direito se fosse aposentado na data do óbito, com reversão das cotas dos dependentes que perdem esta condição.

Regra aprovada: os requisitos de elegibilidade seguiriam fundamentalmente os mesmos, mas o valor total da renda mensal seria significativamente alterado. O valor da PPM seria equivalente a uma cota familiar de $50 \%$ do valor da aposentadoria que o segurado recebia ou daquela a que teria direito se fosse aposentado por incapacidade permanente na data do óbito, acrescida de cotas de 10 pontos percentuais (p.p.) por dependente, até o máximo de $100 \%$, exceto em caso de morte decorrente de acidente de trabalho ou doença profissional ou do trabalho, hipótese em que as cotas para cálculo do valor da pensão seriam aplicadas sobre $100 \%$ da média aritmética simples. Em qualquer dos casos, não haveria reversão das cotas dos dependentes que perdem esta condição (preservado o valor de $100 \%$ da pensão por morte quando o número de dependentes remanescente for igual ou superior a cinco). $\mathrm{O}$ somatório das cotas não poderá ser inferior ao piso previdenciário.

\section{Acumulação de benefícios: aposentadoria e pensão por morte}

Regra original: no caso específico de aposentadoria e pensão por morte, é permitida a acumulação de diferentes tipos e regimes (salvo exceçóes para acumulação de diferentes benefícios de uma mesma espécie, em um mesmo regime).

Regra aprovada: o beneficiário receberá 100\% do benefício de maior valor, somado a um percentual da soma dos demais. Esse percentual será de $80 \%$ para benefícios até 
1 salário mínimo (SM); 60\% entre 1 e 2 SMs; $40 \%$ entre 2 e 3 SMs; $20 \%$ entre 3 e 4 SMs; e de $10 \%$ para benefícios acima de 4 SMs.

\section{Desvinculação de receitas da União e redução dos repasses ao BNDES}

Atendendo a calorosos debates empreendidos ao longo das últimas décadas, a PEC no 6/2019 propôs a exclusão das contribuiçôes destinadas ao financiamento da seguridade social da desvinculação de receitas da União (DRU). Desse modo, a totalidade das receitas das contribuiçóes sociais da seguridade social seria vinculada ao custeio das açôes da saúde, Previdência e Assistência Social, aumentando a transparência das contas públicas e encerrando a polêmica em torno do peso desta parcela dos recursos sobre a necessidade de financiamento da Seguridade Social. O texto ainda previu a redução da parcela dos recursos do Programa de Integração Social (PIS) e do Programa de Formação do Patrimônio do Servidor Público (Pasep) destinada ao Banco Nacional de Desenvolvimento Econômico e Social (BNDES), aumentado os recursos disponíveis para a Seguridade Social.

\subsubsection{Regimes próprios de Previdência Social}

Pontos essenciais da reforma previdenciária nos entes federativos (notadamente em estados, municípios e no Distrito Federal) foram tratados pela chamada PEC Paralela (PEC no 133/2019). Entre as mudanças inicialmente propostas pela PEC n⿳o 6/2019 para os RPPS, no momento aplicáveis apenas à União, podem-se destacar as regras permanentes a seguir e suas versóes.

\section{Aposentadoria por idade}

Regra original: a API é devida ao segurado que atinja, além de dez anos de efetivo exercício no serviço público e cinco anos no cargo efetivo, 65 anos de idade, se homem, e 60 anos de idade, se mulher. $\mathrm{O}$ valor do benefício é dado pela média aritmética simples dos salários de contribuiçẫo do servidor nos regimes previdenciários aos quais esteve vinculado, correspondente a $80 \%$ dos maiores valores registrados desde julho de 1994 ou desde o início das contribuiçóes, se posterior. O teto das aposentadorias é a última remuneração e, para os que ingressaram a partir da instituição do regime complementar, o teto do RGPS. É assegurado o reajustamento dos benefícios para preservar-lhes, em caráter permanente, o valor real.

Regra aprovada: a API, nestes moldes, deixaria de existir e seria convertida no que poderia ser chamada de uma aposentadoria voluntária comum por idade e tempo de contribuição, sendo devida ao segurado que, cumprida a carência mínima (25 anos de contribuição para aposentadoria voluntária, dez anos de efetivo exercício no serviço público e cinco anos no cargo efetivo), atingisse 65, se homem, e 62 anos de idade, se mulher. O cálculo seria de $60 \%$ da média aritmética das remuneraçóes e dos salários de contribuição de todo o período contributivo a partir de julho de 
1994, ou do início da contribuição, se posterior, acrescidos de $2 \%$ para cada ano de contribuiçâo que superar vinte anos, salvo para a aposentadoria especial do servidor com deficiência, em que os proventos corresponderão a $100 \%$ da referida média. ${ }^{7} \mathrm{E}$ assegurado o reajustamento dos benefícios para preservar-lhes, em caráter permanente, o valor real. Se o servidor estiver sujeito ao regime de previdência complementar, inclusive por opção, terá benefício limitado ao teto do RGPS.

\section{Aposentadoria por tempo de contribuição}

Regra original: a ATC é devida ao segurado que atinja, além de dez anos de efetivo exercício no serviço público e cinco anos no cargo efetivo, 60 anos de idade e 35 anos de contribuição, se homem, e 55 anos de idade e trinta anos de contribuição, se mulher. $\mathrm{O}$ valor do benefício é calculado de forma idêntica à API.

Regra aprovada: a ATC, nestes moldes, deixaria de existir e seria convertida no que poderia ser chamada de uma aposentadoria voluntária comum por idade e tempo de contribuição, explicada no tópico anterior.

Aposentadoria dos professores

Regra original: o professor que comprove exclusivamente tempo de efetivo exercício das funçôes de magistério na educação infantil e no ensino fundamental e médio tem redução de cinco anos nos requisitos de idade e tempo de contribuição da regra permanente, o que significa 55 anos de idade e trinta anos de contribuição, se homem; 50 anos de idade e 25 anos de contribuiçáo, se mulher. O valor do benefício é calculado de forma idêntica à API.

Regra aprovada: os professores podem se aposentar com 57 anos de idade, se mulher, e 60 anos de idade, se homem, em ambos os casos tendo acumulado 25 anos de contribuição exclusivamente em efetivo exercício das funçóes de magistério na educação básica, além de dez anos de efetivo exercício no serviço público e cinco anos no cargo efetivo. $\mathrm{O}$ valor deste benefício é definido pela mesma regra proposta para a nova aposentadoria voluntária.

\section{Aposentadoria especial}

Regra original: policiais federais e civis podem se aposentar com trinta anos de contribuição, se homens, e com 25 anos de contribuição, se mulheres. Excetuados estes policiais (contemplados por espécie da aposentadoria por atividade de risco), ainda não foram editadas leis complementares tratando das modalidades de aposentadoria especial no setor público (em razão de deficiência, atividade de risco e exposição a agentes nocivos), razão pela qual a concessão dessas aposentadorias especiais encontra-se judicializada. O Supremo Tribunal Federal (STF) tem determinado a

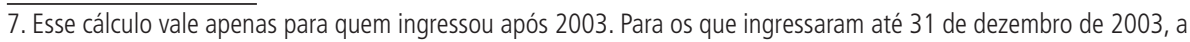
integralidade da aposentadoria (valor do último salário) será mantida para quem se aposentar aos 65 anos (homens) ou 62 (mulheres). 
adoção dos critérios do RGPS aos RPPS enquanto uma lei complementar específica não for editada, em decorrência de decisão na Súmula Vinculante no 33 . O valor do benefício é calculado de forma idêntica à API.

Regra aprovada: a policiais federais e civis a aposentadoria seria devida àqueles que alcançassem 55 anos de idade (ambos os sexos), trinta anos de tempo de contribuição e 25 anos de efetivo exercício em cargo dessa natureza. ${ }^{8} \mathrm{~A}$ aposentadoria voluntária especial por exposição a agentes nocivos exigiria 60 anos de idade (para homens e mulheres), 25 anos de tempo de contribuição com efetiva exposição a agentes nocivos físicos, químicos ou biológicos prejudiciais à saúde, ou associação desses agentes, além de dez anos de efetivo exercício no serviço público e cinco anos no cargo efetivo, vedados a caracterização por categoria profissional ou ocupação e o enquadramento por periculosidade. Como no RGPS, na aposentadoria da pessoa com deficiência o acúmulo do tempo de contribuiçẫo necessário, conforme o grau de deficiência (homens e mulheres: leve -35 anos, moderada -25 anos e grave - 20 anos), dispensando uma idade mínima, mas ainda exigindo dez anos de efetivo exercício no serviço público e cinco anos no cargo efetivo. O valor do benefício é definido pelas mesmas regras aplicadas à API.

\section{Aposentadoria por invalidez}

Regra original: o valor do benefício destinado àqueles com invalidez permanente é proporcional ao tempo de contribuição, sem integralidade e sem paridade, exceto se decorrente de acidente em serviço, moléstia profissional ou doença grave, contagiosa ou incurável. ${ }^{9}$

Regra aprovada: a previsão de aposentadoria se dará por incapacidade permanente, e não mais por invalidez, sendo que tal incapacidade somente será reconhecida se o servidor não puder ser readaptado, e esta condição estará permanentemente sujeita a avaliaçóes periódicas. O salário de benefício da aposentadoria por incapacidade permanente será de $60 \%$ mais $2 \%$ por ano de contribuiçãao que exceder vinte anos. Em caso de invalidez decorrente de acidente de trabalho, doenças profissionais ou do trabalho, o cálculo do benefício não muda, permanecendo como $100 \%$ da média dos salários de contribuição.

\section{Pensão por morte}

Regra original: o valor é igual à remuneração ou ao provento do servidor falecido até o limite do teto do RGPS, acrescido de $70 \%$ da parcela excedente a este limite. ${ }^{10}$

8. A PEC no 6/2019 estendeu essas mesmas condições aos agentes penitenciários ou socioeducativos.

9. Alguns entes estabelecem valores mínimos para os proventos proporcionais da aposentadoria por invalidez. A União não tem previsão nesse sentido, fazendo que o servidor inválido possa se aposentar com benefício de apenas 1 SM, independentemente da remuneração do seu cargo efetivo.

10. A Lei no 13.135/2015 (Conversão da Medida Provisória no 664/2014) alterou as regras para concessão e manutenção de pensão por morte apenas no RGPS (Lei no 8.213/1991) e no RPPS da União (Lei no 8.112/1990). Para que estas alterações alcançassem os RPPS dos estados, do Distrito Federal e dos municípios, seria necessário que cada ente aprovasse lei própria, medida recomendada em atos emitidos pelos então Ministério da Previdência Social (MTPS) e Conselho Nacional de Previdência Social (Conaprev), mas não foram muitos os entes que se ajustaram. 
Regra aprovada: no cálculo da pensão, seria empregada uma cota familiar mínima de $50 \%$, adicionada a cotas de $10 \%$ por dependente, que não seriam revertidas, salvo no caso de haver cinco ou mais dependentes. Todos os demais critérios para a concessão de pensão aos dependentes de servidores seriam iguais aos aplicáveis no RGPS. O somatório das cotas não poderá ser inferior ao salário mínimo.

\subsubsection{Outras alterações}

Adicionalmente, no intuito de melhorar o balanço financeiro e atuarial dos regimes próprios, a proposta também previu a ampliação da base de financiamento dos RPPS, com maior participação dos segurados e pensionistas no financiamento e no equacionamento de desequilíbrios financeiros. Entre as medidas nesse sentido, destaca-se a elevação da contribuição ordinária dos servidores aos RPPS da União, aplicando-a progressiva e cumulativamente, de maneira que a alíquota final seja crescente com o padrão remuneratório. ${ }^{11}$

Indo além, a reforma previu (e concretizou) mudanças na alíquota paga pelos segurados, convergindo o tratamento dado neste quesito a trabalhadores públicos e privados e, ao mesmo tempo, visando ao aumento das receitas e da progressividade destes recolhimentos. Pelas novas regras, aqueles com maiores rendimentos contribuirão mais, enquanto aqueles que recebem menos arcarão com contribuição menor. As alíquotas do RGPS e dos servidores públicos da União foram, portanto, unificadas, são progressivas e aplicadas apenas sobre a parcela do rendimento enquadrada em cada uma das oito faixas criadas (quatro até o limite do teto do RGPS; e quatro deste ponto até o limite dos RPPS).

A PEC no 6/2019 ainda propôs vedaçóes e limites ao acúmulo de aposentadorias e pensốes concedidas após a promulgação da EC, não sendo permitida a acumulação de mais de uma aposentadoria nos RPPS, salvo em caso de cargos acumuláveis; nem de mais de uma aposentadoria ou de mais de uma pensão deixada por cônjuge ou companheiro no âmbito do RGPS. A PPM do RGPS pode ser acumulada com o mesmo benefício do RPPS ou dos sistemas de proteçâo dos militares, assim como com a aposentadoria de qualquer destes sistemas, mas, salvo a opção pelo recebimento do benefício integral de maior valor, os demais benefícios estarão sujeitos à aplicação de redutores que limitarão o valor total a ser recebido pelo segurado.

11. Em caso de deficit atuarial nos RPPS, a reforma abriu a possibilidade de instituição temporária de contribuição extraordinária, a ser imposta ao ente e aos segurados e pensionistas do regime próprio. Esta contribuição extraordinária, que excepcionalmente pode incidir sobre valores que superem o salário mínimo, pode ser aplicada com base em alíquotas diferenciadas por perfis de contribuintes (padrão remuneratório, por exemplo), previsão que favoreceria maior justiça na distribuição do ônus no financiamento do deficit previdenciário. No texto aprovado no Senado Federal, foi suprimida a passagem do texto que mencionava exclusivamente a União, deixando aberta a possibilidade de que estados e municípios instituam contribuição semelhante. 
O texto da proposta, contudo, extrapolou a esfera previdenciária e adentrou outros campos, ${ }^{12}$ como a assistência social, ainda que em seu segmento dedicado ao que se convenciona chamar de aposentadorias náo contributivas. Em relação a este ponto, as mudanças focaram o Benefício de Prestação Continuada (BPC), regulamentado pela Lei no 8.472, de 7 de dezembro de 1993, Lei Orgânica da Assistência Social (Loas), que atualmente paga 1 SM mensal a idosos e pessoas com deficiência de baixa renda, impossibilitados de gerar o próprio sustento. Pela proposta, rechaçada ainda na Câmara dos Deputados, juntamente com a eliminação do polêmico tema da capitalização e da suavização da desconstitucionalização, o BPC dos idosos seria substituído por um benefício fásico, combinando redução na idade mínima de requerimento e variação do valor em função da idade (60-69 anos: valor reduzido, parcial e fixo; 70 anos em diante: salário mínimo).

A PEC no 6/2019 estabeleceu expressamente o direito à obtenção de aposentadoria e pensáo aos que tivessem reunido, antes da EC, todos os requisitos para a sua concessão. Para esses, que possuem direito adquirido, nenhuma exigência ou critério de concessão seria alterado. Garantiram-se também regras de transição para todos os atuais trabalhadores formais e vinculados a RPPS, respeitando as especificidades de cada regime previdenciário e de seus segurados. Em linhas gerais, seu texto final (Emenda Aglutinativa Global à PEC no 6-A/2019), apreciado e alterado pelo Senado Federal, corrige excessos, elimina propostas controversas e em muito se aproxima do conteúdo da Emenda Aglutinativa Global à PEC no 287-A/2016, sobre a qual já havia certo consenso.

\subsection{Aprimoramento da gestão dos benefícios da Previdência Social e ações de combate a fraudes e irregularidades: Medida Provisória no 871/2019}

A Medida Provisória (MP) no 871/2019 (convertida na Lei no 13.846/2019) foi formulada com o intuito de aprimorar a gestão dos benefícios da Previdência Social, reduzir a judicialização e instituir açóes de combate a fraudes e irregularidades, mediante a implementação de um programa permanente de revisão da concessão e da manutenção dos benefícios previdenciários e assistenciais administrados pelo Instituto Nacional do Seguro Social (INSS). As açôes incluiriam dispositivos legais e programas especiais de combate às irregularidades para acelerar a análise administrativa dos processos de revisão e minimizar a possibilidade de recebimento e/ou acumulação indevida de benefícios. A MP no 871/2019 também buscou

12. A PEC de fato abordou temas estranhos à Previdência Social, propondo, por exemplo, o endurecimento das regras para o acesso ao abono salarial, ponto não discutido neste capítulo. 0 abono salarial do PIS/Pasep é uma espécie de bônus anual pago ao trabalhador formal de baixa renda (com rendimento mensal não superior a 2 SMs), o qual assume valor de até 1 SM e varia de acordo com o tempo trabalhado no ano-base. As alterações propostas para o abono salarial foram suprimidas na tramitação no Senado Federal. 
pacificar pontos já decididos pela jurisprudência e dar maior clareza a questôes que geram açôes judiciais de forma recorrente, na tentativa de reduzir ações judiciais.

\subsection{Reforma no sistema de proteção social dos militares: PL no 1.645/2019}

O PL no 1.645/2019, também apresentado pelo governo federal no contexto da

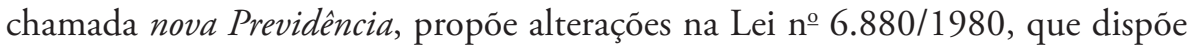
sobre o Estatuto dos Militares; na Lei no 3.765/1960, que dispóe sobre as pensôes militares; na Lei no 4.375/1964, que trata do serviço militar; na Lei no 5.821/1972, que dispóe sobre as promoçóes dos oficiais da ativa das Forças Armadas; e na Lei no $12.705 / 2012$, que dispóe sobre os requisitos para ingresso nos cursos de formação de militares de carreira do Exército. O projeto promove ajustes nos sistemas previdenciários das Forças Armadas, alterando as regras de elegibilidade e contribuição de seus membros, mas também estabelece uma ampla reestruturação das carreiras militares, elevando seu padrão remuneratório, o que limitou significativamente os impactos fiscais da reforma previdenciária dos militares.

\subsection{Medidas para o combate ao devedor contumaz e fortalecer a cobrança da dívida ativa: PL no 1.646/2019}

Ainda no contexto da nova Previdência, o PL no 1.646/2019 estabelece medidas para o combate ao devedor contumaz e de fortalecimento da cobrança da dívida ativa da Uniáo, especialmente das contribuiçóes previdenciárias, e altera a Lei no 6.830/1980, a Lei no 8.397/1992 e a Lei no 9.430/1996, aumentando a agilidade e a eficiência das açóes da Procuradoria-Geral da Fazenda Nacional (PGFN).

\subsection{PEC no 133/2019}

A PEC no 133/2019, de autoria da Comissão de Constituição, Justiça e Cidadania do Senado Federal, altera o texto principal da PEC no 6/2019 e propóe que os estados, o Distrito Federal e os municípios adotem em seus RPPS as mesmas regras aplicáveis ao regime próprio da União, mediante lei estadual ou municipal. Os estados poderiam, por projeto de lei ordinária aprovado nas assembleias legislativas, seguir as mesmas regras da União, enquanto os municípios, se não aprovados critérios próprios, iriam automaticamente aderir ao regime da União, aprovado anteriormente pelo estado do qual fazem parte. A PEC no 133/2019 tem como foco a reforma previdenciária dos demais entes federativos, mas ainda prevê as alteraçóes a seguir, entre outras providências.

1) Modificações nas renúncias previdenciárias (reoneração gradual do agronegócio exportador e das entidades educacionais ou de saúde com capacidade financeira enquadradas como filantrópicas, sem prejuízo a santas casas e entidades de assistência). 
2) Previsão de carência mínima de quinze anos de contribuição para aposentadoria por idade para todos os segurados do RGPS, mesmo aqueles que ainda não entraram no mercado de trabalho.

3) Previsão de benefício da Seguridade Social à criança em situação de pobreza.

4) Mudança nos cálculos da pensão por morte (cota dobrada, de 20\%, na pensão por morte, para os dependentes de até 18 anos de idade) e de aposentadoria por incapacidade no RGPS e nos RPPS (regra mais vantajosa na aposentadoria por incapacidade, em caso de acidente, e aposentadoria por incapacidade de $100 \%$ em caso de incapacidade que gere deficiência ou em caso de incapacidade decorrente de doença neurodegenerativa).

5) Exigência, para optantes do Simples, de contribuiçóes destinadas ao financiamento de benefícios previdenciários concedidos em decorrência de acidente de trabalho ou exposiçáo a agentes nocivos.

6) Reabertura, por seis meses a partir da promulgação da EC, do prazo para migração para o regime de previdência complementar dos servidores federais.

\section{ACOMPANHAMENTO DA POLÍTICA PREVIDENCIÁRIA}

\subsection{Evolução da cobertura previdenciária}

\subsubsection{População ocupada}

Segundo a PNAD Anual (IBGE, 2019b) - descontinuada pelo Instituto Brasileiro de Geografia e Estatística (IBGE) após sua edição de 2015 -, entre 2002 e 2013 , houve uma expressiva expansão dos principais indicadores de formalidade trabalhista e previdenciária estimados para o país. A referida pesquisa, no entanto, já indicava arrefecimento nesta tendência em 2014 e, principalmente, em 2015, quando os indicadores se mantiveram relativamente constantes. Nesse biênio, a proporção de contribuintes e protegidos se manteve relativamente estável, basicamente porque houve redução na população ocupada, com queda na taxa de participação e aumento do desemprego (Costanzi, Ansiliero e Amaral, 2018).

Os dados da PNAD Contínua não podem ser diretamente confrontados com aqueles oriundos da antiga pesquisa, mas parecem corroborar as tendências apresentadas. A análise a seguir se baseia, portanto, na PNAD Contínua para a mensuração da proporção de protegidos (a proporção de ocupados que contribuem para a Previdência Social, são segurados especiais ou, embora não se enquadrem nas categorias anteriores, já declaram receber aposentadorias e/ou pensôes por morte) e da taxa de cobertura da população ocupada (volume de ocupados que contribuem 
para a Previdência Social como proporção da população ocupada), em ambos os casos considerando aqueles com idade entre 16 e 59 anos.

Ambos os indicadores são calculados com base na população ocupada oficial (PO), seguindo os critérios estabelecidos pelo IBGE, e na população ocupada expandida (POE), definida conforme critérios definidos em Ansiliero et al. (2019b). A POE inclui os trabalhadores que na PNAD Contínua não compóem a PO e que, na extinta PNAD Anual, estariam classificados como ocupados na produção para o próprio consumo e na construção para o próprio uso. ${ }^{13}$

GRÁFICO 1

Taxa de cobertura da população ocupada oficial e da população ocupada expandida - Brasil (2016-2018)

(Em \%)

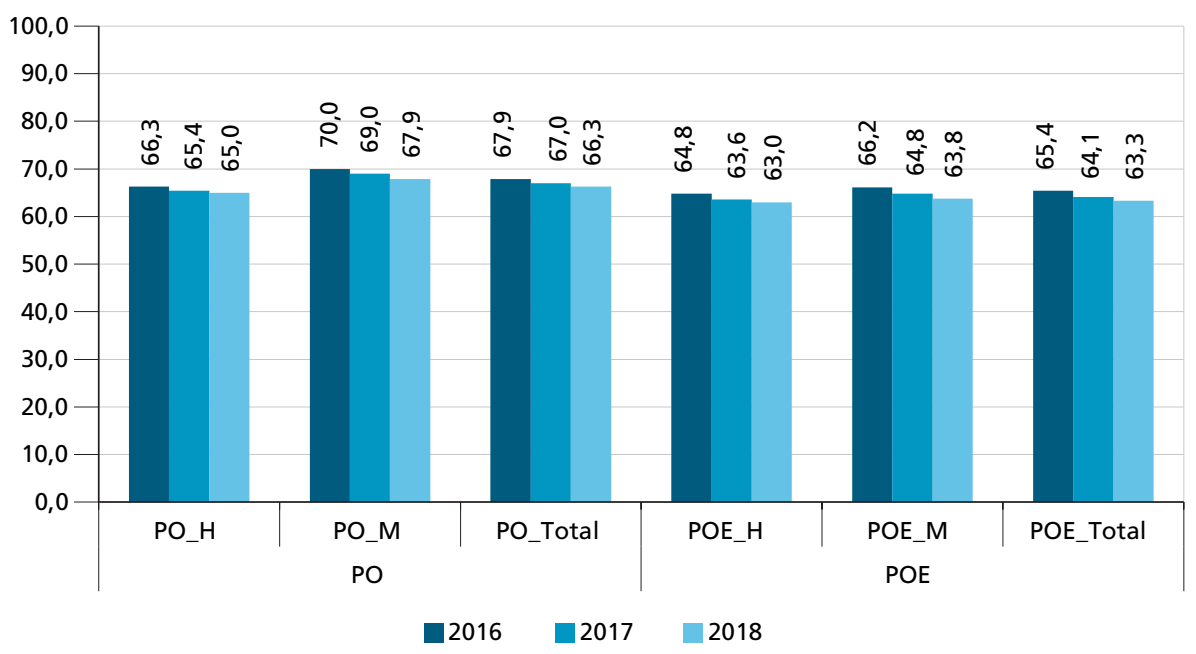

Fonte: PNAD Contínua 2016-2018/IBGE. Disponivel em: <https://bit.ly/2ZFVqNW>. Acesso em: 15 out. 2019.

Elaboração: Ipea.

Obs.: 1. Os dados de 2016 e 2017 foram reponderados em 2019.

2. PO_H = população ocupada oficial homem. PO_M = população ocupada oficial mulher. PO_total = população ocupada oficial total. POE_H = população ocupada expandida homem. POE_M = população ocupada expandida mulher. POE_total = população ocupada expandida total. População com idade entre 16 e 59 anos.

De acordo com a PNAD Contínua 2018, naquele ano, existiam no país, oficialmente, 83,3 milhões de pessoas ocupadas com idade entre 16 e 59 anos. Este contingente, quando contraposto aos subgrupos de pessoas consideradas cobertas e protegidas nessa mesma faixa etária, resulta em uma taxa de cobertura de $66,3 \%$

13. Os indicadores de cobertura e de proteção para a POE são limitados porque a PNAD Contínua não capta informações de contribuição previdenciária para os ocupados em outros trabalhos que não aqueles incluídos na conceituação oficial de ocupação. 0 segmento é considerado porque constitui parte muito importante do universo dos segurados especiais. De qualquer maneira, tomando-se como referência a PNAD Anual, a proporção de ocupados contribuintes neste grupo tende a ser diminuta e pouco afeta os indicadores. 
e em uma taxa de proteção de 70,7\%. Em termos agregados, isso significa que, de cada dez trabalhadores brasileiros, cerca de sete estavam cobertos e/ou protegidos pela Previdência Social. Em relação ao ano anterior, houve ligeira retração nos indicadores, que, em termos gerais, passaram, respectivamente, de 67,0\% (cobertura) e 71,6\% (proteção), em 2017, para os mencionados 66,3\% e 70,7\%, em 2018.

Enquanto a PO se manteve relativamente estável na comparação com o ano anterior $(+0,223 \%)$, o contingente de ocupados cobertos e protegidos decresceu ligeiramente, movimento ligeiramente mais sutil que o registrado entre 20172016. Em outros termos, a cobertura diminuiu, e essa queda apenas não foi maior porque a PO permaneceu quase estagnada no triênio 2016-2018, evidentemente em função da crise econômica enfrentada pelo país e de seus rebatimentos no mercado de trabalho.

\section{GRÁFICO 2}

Taxa de proteção previdenciária da população ocupada oficial e da população ocupada expandida - Brasil (2016-2018)

(Em \%)

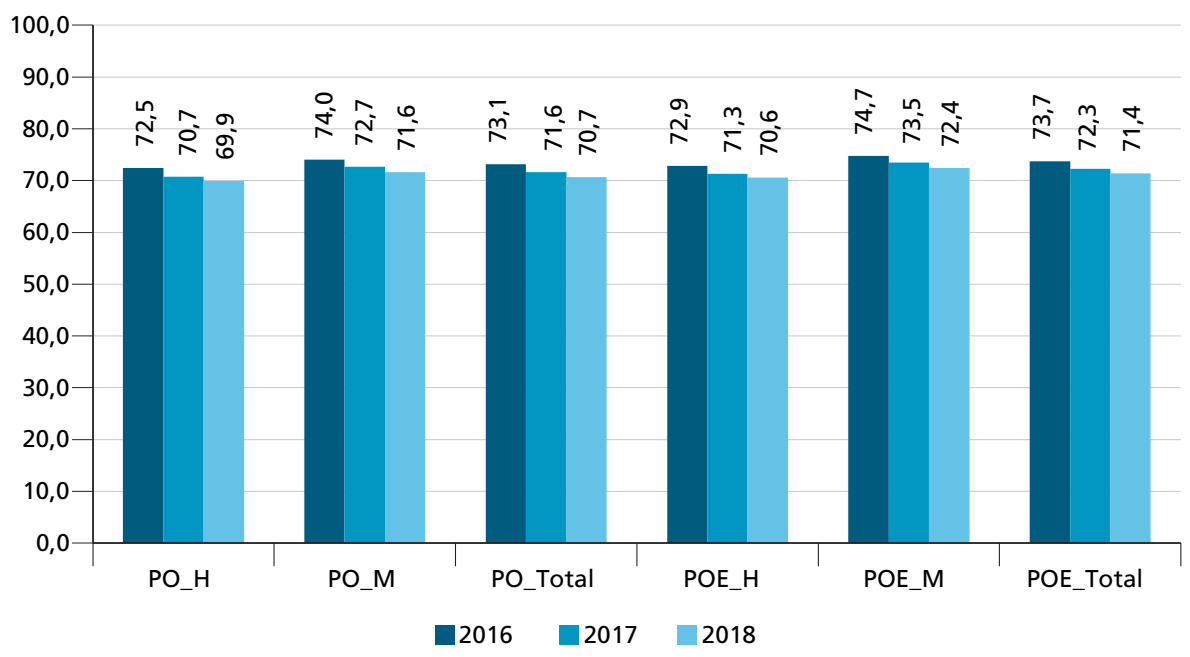

Fonte: PNAD Contínua 2016-2018/IBGE. Disponível em: <https://bit.ly/2ZFVqNW>. Acesso em: 15 out. 2019. Elaboração: Ipea.

Obs.: 1. Os dados de 2016 e 2017 foram reponderados em 2019.

2. PO_H = população ocupada oficial homem. PO_M = população ocupada oficial mulher. PO_total = população ocupada oficial total. POE_H = população ocupada expandida homem. POE_M = população ocupada expandida mulher. POE_total = população ocupada expandida total. População com idade entre 16 e 59 anos.

Quando tomada a POE, o total de ocupados alcança 87,2 milhóes, o percentual de proteção chega a 71,4\% e o de cobertura, a 63,3\%. Em ambos os indicadores, o desempenho feminino foi ligeiramente superior ao masculino (cobertura-homens: 63,0\% e mulheres: 63,8\%; proteção - homens: 70,6\% e mulheres: $72,4 \%$ ). Mais 
precisamente, há relativo equilíbrio entre os sexos, com ligeira vantagem feminina. A taxa de participação econômica nesse grupo segue inferior à masculina, e o desemprego entre as mulheres supera o indicador medido para os homens, mas, para além da tendência de redução destes diferenciais, nota-se que há melhora no padrão de inserção feminina no mundo do trabalho e, consequentemente, na Previdência Social.

$\mathrm{Na}$ série histórica trimestral harmonizada e completa (primeiro trimestre/ 2012-quarto trimestre/2018), que considera apenas a proporção de ocupados (pelo conceito oficial de ocupação da PNAD Contínua) contribuindo para algum regime público de previdência social, os resultados também revelam as diferenças no patamar e na evolução da cobertura (contribuintes/PO) de homens e mulheres. Passados os trimestres iniciais de aparente convergência dos indicadores, desde 2013 a PNAD Contínua trimestral parece confirmar taxas de cobertura mais elevadas entre as mulheres, com incremento dos diferenciais de gênero até o primeiro trimestre de 2016 e subsequente arrefecimento (ainda que não eliminação).

Esse último movimento coincide com um processo de retração no indicador geral de cobertura (64,9\% no quarto trimestre de 2018), que ainda se encontra em patamar superior ao valor inicial da série $(63,7 \%)$, mas sofreu queda digna de nota na comparação com o valor máximo da série (primeiro trimestre de 2016: 67,4\%). Como na curta série do indicador anual (gráficos 1 e 2), os resultados trimestrais de 2018 foram ligeiramente piores que os de 2017, quando confrontados os trimestres correspondentes, mas a variação negativa foi ligeiramente mais modesta que o declínio registrado na comparação 2017-2016. 


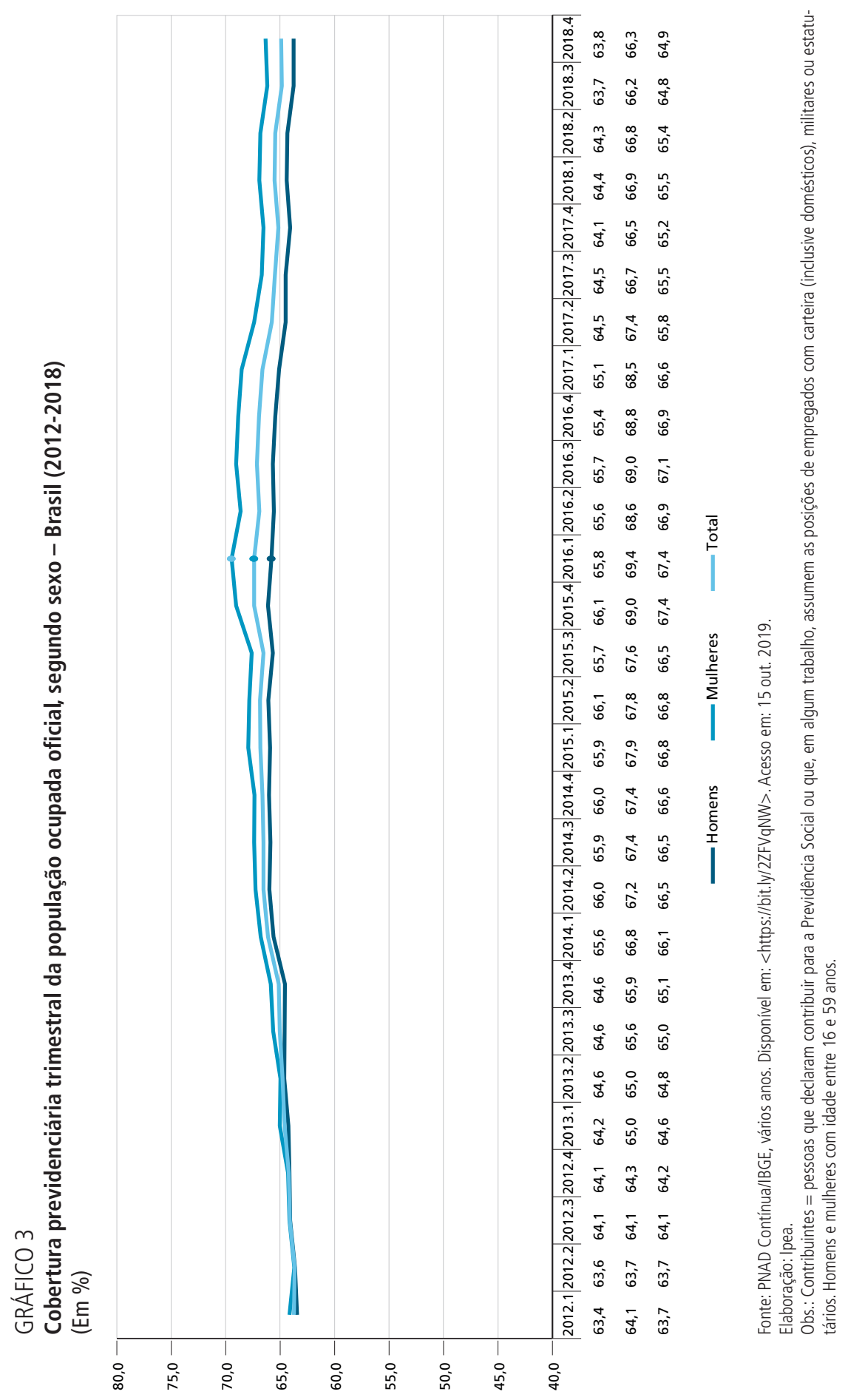


Os resultados agregados, generalizáveis (em tendência, ainda que certamente não em patamar) para os principais grupos integrantes da população ocupada (rurais e urbanos; homens e mulheres), também se confirmam pela evolução dos indicadores calculados para as diferentes posiçôes na ocupação. Pela PNAD Contínua, nota-se que até 2014 houve algum aumento no nível de cobertura geral, seguido de relativa estabilidade (2015) e posterior retração (2016-2018, no primeiro semestre). Essa tendência geral, fortemente determinada pela crise econômica enfrentada pelo país e seus rebatimentos no mercado de trabalho, está mais associada ao grupo dos empregados no setor privado, que possuem a maior participação na $\mathrm{PO}$, mas os demais grupos possuem indicadores com comportamento semelhante.

O ponto em comum é a retração recente nas proporções estimadas, ainda que outros fatores (alteraçôes legais afetando categorias específicas, por exemplo) possam ajudar a explicar pontos de inflexão distintos. O grupo de trabalhadores por conta-própria também registrou queda na taxa de cobertura, mas, entre os demais segmentos, parece ser aquele que mais tem sustentado o patamar do indicador, resultado que encontra certo respaldo nos registros administrativos do RGPS. ${ }^{14}$

\section{GRÁFICO 4}

Taxa de cobertura previdenciária da população ocupada oficial, de 16 a 59 anos, segundo posição na ocupação - Brasil (2012-2018)

(Em \%)

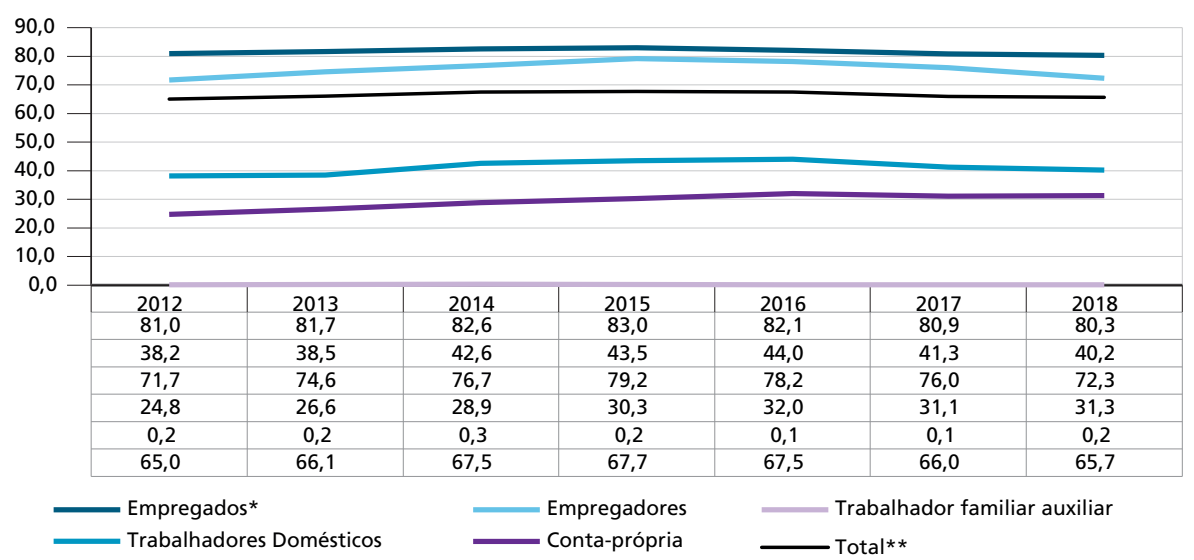

Fonte: PNAD Contínua/IBGE, vários anos. Disponível em: <https://bit.ly/2ZFVqNW>. Acesso em: 15 out. 2019.

Elaboração: Ipea.

Notas: ${ }^{1}$ Empregados: considera todos os empregados no setor público como cobertos.

2 Total: considera militares e estatutários.

Obs.: Contribuintes = pessoas que declaram contribuir para a Previdência Social ou que, em algum trabalho, assumem as posições de empregados com carteira (inclusive domésticos), militares ou estatutários.

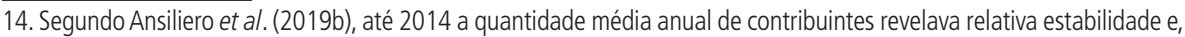
na maior parte dos casos, expansão do volume de contribuintes, mas, entre 2015-2017, houve reversão dessa tendência para todos os grupos (empregados domésticos, facultativos e demais subcategorias de contribuintes individuais), com exceção do microempreendedor individual (MEI), categoria que, na PNAD, poderia ser conta-própria ou empregador. A filiação ao MEI, cuja alíquota contributiva é altamente subsidiada, poderia ser resposta involuntária à perda de proteção em categorias mais estruturadas.
} 
Também se destacam os trabalhadores domésticos, para os quais a cobertura aumentou mais expressivamente entre 2013 e 2014 (justamente o período subsequente à aprovação da chamada PEC das Domésticas), ${ }^{15}$ com continuidade da expansão até 2016, e decresceu desde então. Apesar deste avanço normativo na matéria, o ganho no indicador de cobertura tem se dado mais fortemente por meio da expansão de informais que declaram contribuir (possivelmente de forma autônoma, como contribuintes individuais) para a Previdência Social. Essa percepção é reforçada pelo fato de que os domésticos com carteira de trabalho assinada (CC) perderam espaço no total de contribuintes anuais para os domésticos sem carteira (SC).

\section{GRÁFICO 5}

Participação dos domésticos, entre 16 e 59 anos, CC e SC, no total de trabalhadores domésticos que declaram contribuir para a Previdência Social - Brasil (2012-2018) (Em \%)

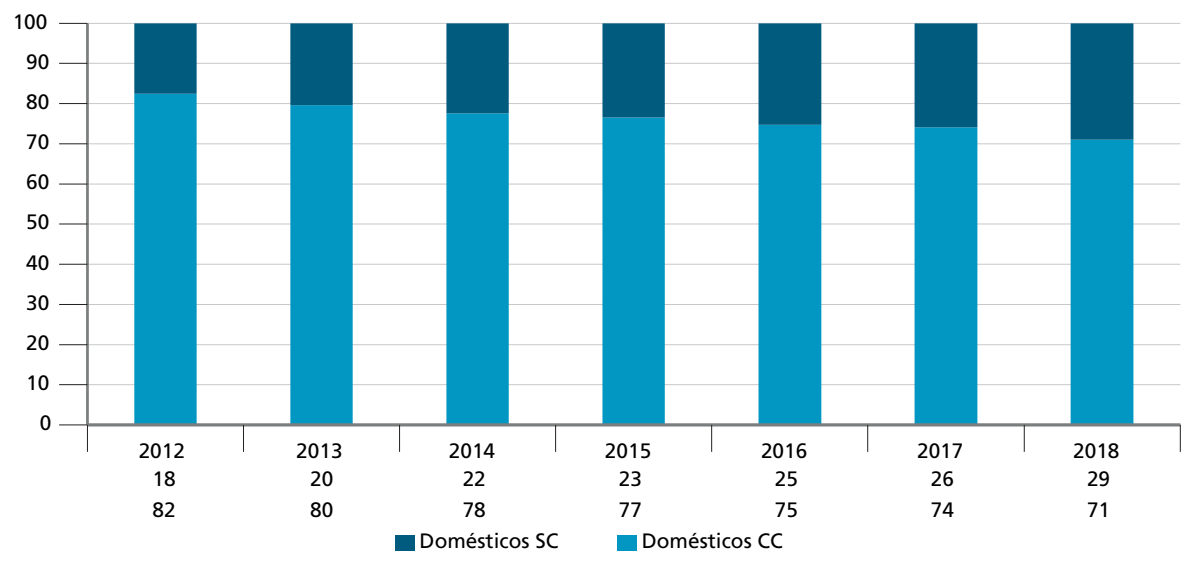

Fonte: PNAD Contínua/IBGE, vários anos. Disponível em: <https://bit.ly/2ZFVqNW>. Acesso em: 15 out. 2019. Elaboração: Ipea.

Os resultados para o conjunto da $\mathrm{PO}$ estáo diretamente associados ao desempenho do mercado de trabalho, claramente em crise desde 2015 (com arrefecimento em sua dinâmica já em 2014), ainda que os rebatimentos sobre a cobertura previdenciária tenham se manifestado apenas mais à frente (notadamente a partir de 2016). ${ }^{16}$ No período 2012-2018, a taxa de participação se manteve relativamente estável entre

15. A EC no 72, mais conhecida como a PEC das Domésticas (PEC no 66/2012), regulamentada pela Lei Complementar no 150/2015, garantiu direito ao Fundo de Garantia do Tempo de Serviço (FGTS), ao seguro-desemprego, ao saláriofamília, ao adicional noturno e ao adicional de viagens, entre outros direitos.

16. Esse aparente descompasso, sabidamente, não é atípico. Em cenários de crise, o movimento inicial esperado é de redução no ritmo de produção e manutenção dos vínculos laborais (ainda que, possivelmente, com a compressão dos rendimentos do trabalho), principalmente em virtude dos custos trabalhistas associados à dispensa de trabalhadores. Com a persistência do movimento de desaceleração econômica e a eventual estagnação do nível de atividade, o desemprego tende a aumentar, e os rendimentos do trabalho tendem a ser mais negativamente afetados, inclusive no setor informal da economia. Nos momentos iniciais de retomada, por sua vez, há mais comumente uma redução da capacidade ociosa da economia, que, em se confirmando a recuperação no nível de atividade, evolve para a recuperação do mercado de trabalho. A reforma trabalhista realizada recentemente no país pode alterar esta dinâmica, mas ainda é cedo para avaliar seus potenciais efeitos, ainda que seu desenho indique maiores riscos para a qualidade da inserção trabalhista e previdenciária do trabalhador. 
os homens (2012.1: 83,4\%; 2018.4: 83,2\%) e aumentou entre as mulheres (2012.1: $60,6 \% ; 2018.4: 64,9 \%)$, mas a taxa de desemprego cresceu expressivamente em ambos os grupos. Houve redução no diferencial de gênero neste indicador, em que pese o incremento na participação econômica feminina, mas a taxa de desemprego entre as mulheres mantém o padrão histórico de superar o indicador masculino.

GRÁFICO 6

Taxa de participação e taxa de desemprego entre as pessoas com idade entre 16 e 59 anos, segundo sexo - Brasil (2012-2018)
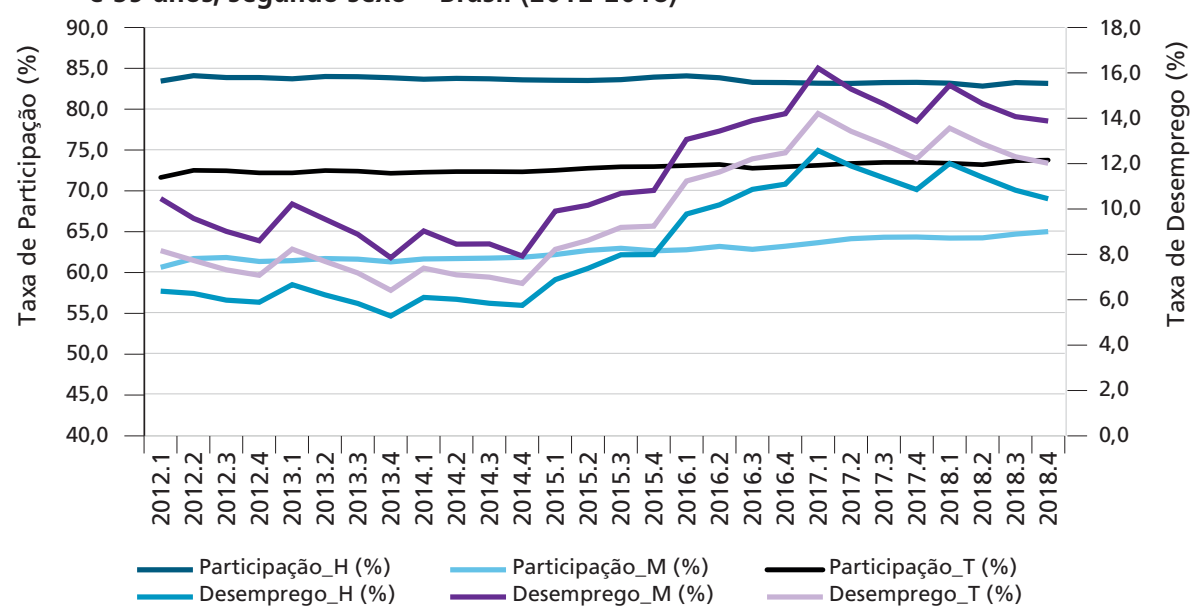

Fonte: PNAD Contínua/IBGE, vários anos (https://bit.ly/2ZFVqNW). Acesso em: 15 out. 2019. Elaboração: Ipea.

Isso destaca ainda mais o resultado da cobertura previdenciária, superior entre as mulheres, sugerindo que há alguma seletividade indesejável na parcela feminina que logra participar do mercado de trabalho, obter ocupação e, principalmente, contribuir para a Previdência Social. Claro que os homens mais pobres também são mais afetados pelo desalento e por outros fatores explicativos para a não participação no mercado de trabalho, bem como pelo desemprego e pela inserçáo laboral precária, mas a combinação dos indicadores analisados indica que os desafios enfrentados pelas mulheres mais pobres se convertem mais comumente em barreiras à inclusão social e, principalmente, previdenciária. ${ }^{17}$

\subsubsection{População idosa}

A cobertura social entre os idosos, entendidos como aqueles com 60 anos ou mais de idade, apresentou uma tendência de expansão significativa ao longo na década de 1990, seguida de uma relativa estabilidade do indicador nos anos subsequentes. ${ }^{18}$ Persistem diferenças no grau de proteção de homens e mulheres, sendo que os

17. Para mais detalhes, ver Amaral et al. (2019).

18. Para mais detalhes, ver Costanzi, Ansiliero e Amaral (2018). 
resultados medidos pela PNAD Anual não pareciam indicar tendência evidente de convergência. A PNAD Contínua ainda não permite a construção de séries históricas longas, mas os indicadores do triênio 2016-2018 assumem composição e patamar semelhantes aos alcançados na medição pela PNAD Anual.

Em 2018, a proteção previdenciária, pelas medidas oficiais, alcançou $84,8 \%$ (88,3\% entre homens; e $82,1 \%$ entre mulheres) dos 32,5 milhóes de idosos no país. Caso, entre os ocupados, fossem ainda considerados aqueles que integram apenas a POE (trabalhadores atuando para o autoconsumo ou na produção para o próprio uso, com destaque para os trabalhadores rurais protegidos pelo exercício destas atividades), o indicador agregado chegaria a $85,3 \%$, alcançando $88,8 \%$ entre os homens e $82,6 \%$ entre as mulheres.

$\mathrm{Na}$ comparação com o ano anterior, não houve alteração significativa nos indicadores agregados para a POE e para a PO, resultado relativamente válido na abertura por sexo. Nota-se apenas que, entre os homens, a variação na população idosa superou ligeiramente o incremento na população protegida (considerando-se a PO ou a POE na construçáo do indicador), ao passo que, entre as mulheres, o contingente de protegidas variou proporcionalmente ao volume de idosas.

\section{GRÁFICO 7}

Taxas de proteção previdenciária da população idosa, considerando os ocupados, em dois cenários (PO e POE) - Brasil (2016-2018)

(Em \%)

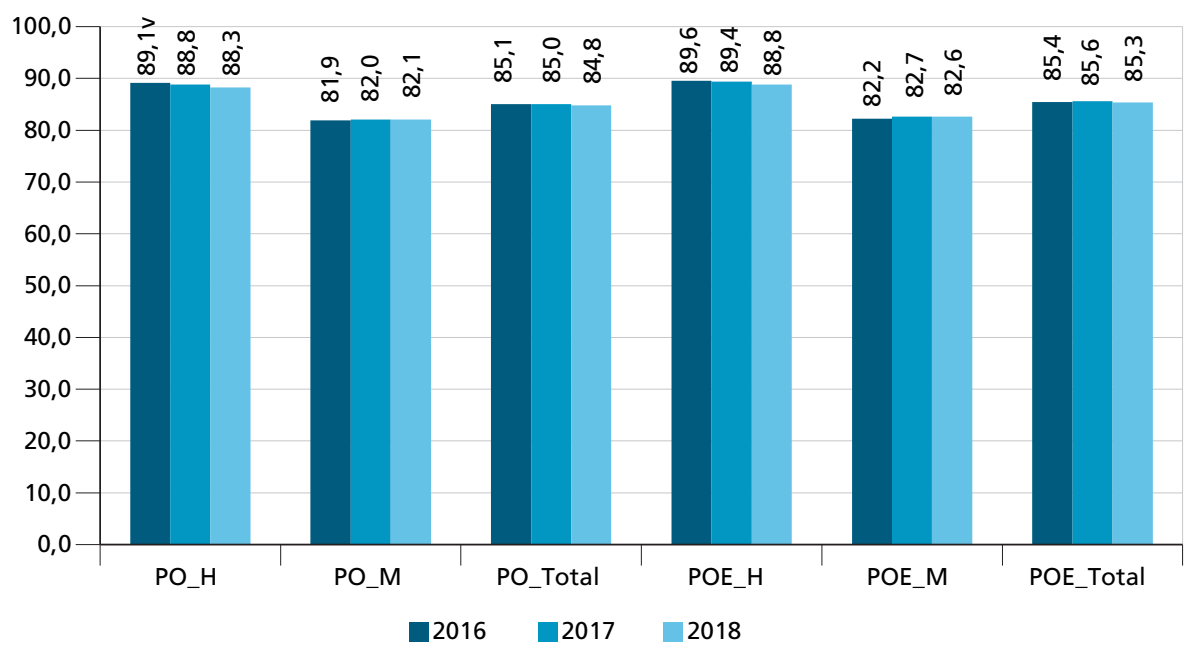

Fonte: PNAD Contínua 2016-2018//BGE. Disponível em: <https://bit.ly/2ZFVqNW>. Acesso em: 15 out. 2019.

Elaboração: Ipea.

Obs.: 1. Os dados de 2016 e 2017 foram reponderados em 2019.

2. PO_H = população ocupada oficial homem. PO_M = população ocupada oficial mulher. PO_total = população ocupada oficial total. POE_H = população ocupada expandida homem. POE_M = população ocupada expandida mulher. POE_total = população ocupada expandida total. 
O resultado geral aponta para certa estabilidade, até mesmo porque este indicador é menos sensível aos fatores conjunturais que afetam mais diretamente a cobertura da populaçáo ocupada adulta (16-59 anos). Em todo caso, vale destacar uma ligeira queda no peso dos idosos ocupados contribuintes e incremento suave, embora não desprezível, no volume de desprotegidos ocupados (não beneficiários que ainda trabalham, mas o fazem sem cobertura previdenciária).

Em 2018, os idosos socialmente protegidos pelo conceito expandido - que recebiam ou benefícios previdenciários (aposentadoria e/ou pensão por morte ou benefícios temporários), ou benefícios assistenciais de prestação continuada, ou contribuíam para a Previdência Social, ou eram segurados especiais - totalizavam 26,7 milhôes de pessoas, de um total de 32,5 milhóes de pessoas com 60 anos ou mais de idade. Entre homens e mulheres prevalecia como determinante da proteção o recebimento de aposentadoria e/ou PPM, seguido da atividade com formalidade previdenciária (contribuiçáo para algum regime de previdência social). Os homens prevaleciam entre aqueles protegidos por contribuiçáo previdenciária, ${ }^{19}$ enquanto as mulheres prevaleciam no subgrupo dos desprotegidos (não beneficiários, tampouco contribuintes). ${ }^{20}$

Esse padrão atual de cobertura dos idosos é explicado por vários fatores, com destaque para melhoria no grau de proteção previdenciária da população ocupada pela via contributiva, movimento que combinou o incremento na participação das mulheres na população ocupada e seu crescente peso entre os segurados contribuintes da Previdência Social. É preciso destacar também a importância da instituição da categoria de segurado especial, regulamentada em 1991, que possibilitou a expansão da cobertura previdenciária no meio rural (com grande efeito também entre as mulheres), e da concessão dos BPCs previstos na Loas, alterada pelo Estatuto do Idoso. ${ }^{21}$

\subsection{Evolução do resultado previdenciário}

\subsubsection{Regime Geral de Previdência Social}

Em dezembro de 2018, o RGPS pagou cerca de 30,3 milhóes de benefícios. Deste total, 29,5 milhôes foram previdenciários e 804 mil, acidentários. Aqueles apresentaram, em relação a dezembro de 2017 , aumento de 484,47 mil benefícios $(+1,7 \%)$, enquanto os acidentários diminuíram em 10,78 mil benefícios $(-1,3 \%)$. Quando tomados os benefícios totais do RGPS (previdenciários e acidentários), o

19. Esse resultado se explica pelos requisitos mais elevados de idade e/ou tempo de contribuição para a concessão de aposentadorias a segurados do sexo masculino.

20. Esse resultado se explica, em parte, pelo fato de que as mulheres idosas, atualmente com idade igual ou superior a 60 anos, entraram em idade ativa quando a realidade da inserção feminina no mercado de trabalho era bastante diversa daquela agora enfrentada pelas mulheres pertencentes à população em idade ativa (PIA).

21. 0 Estatuto do Idoso, vigente desde janeiro de 2004, reduziu de 67 para 65 anos a idade mínima para acesso ao benefício assistencial, além de ter flexibilizado o cálculo do limite máximo de um quarto de salário mínimo de renda familiar per capita, também necessário para a concessão do BPC previsto na Loas. 
crescimento anual foi de 1,6\%, tendo as seguintes espécies crescido expressivamente acima da média geral anual: aposentadorias por idade $(+3,1 \%)$ e aposentadorias por tempo de contribuição $(+3,6 \%)$. O auxílio-doença previdenciário $(-12,5 \%)$ e o auxílio-doença acidentário $(-12,8 \%)$, por sua vez, apresentaram decréscimo significativo na quantidade de emissóes na comparação entre os meses de dezembro de cada ano considerado (2018 e 2017), a exemplo do que já havia ocorrido na comparação entre 2017 e 2016.

Em 2017 e em 2018, tanto o auxílio-doença previdenciário quanto o acidentário apresentaram redução em seus estoques (posição no mês de dezembro), comportamento atípico se considerada a evolução histórica da emissão desses benefícios. Este fenômeno tende a ser explicado, em larga medida, por medidas operacionais recentes no âmbito do INSS, implementadas para aumentar a eficiência no atendimento, no monitoramento e na fiscalização de suas atividades e funções. Mais precisamente, a redução da emissão de auxílios-doença (previdenciários e acidentários) em 2017 se explica fundamentalmente pela edição, em 6 de janeiro de 2017, da MP no 767, convertida na Lei Ordinária nº 13.457, de 6 de junho do mesmo ano, cuja finalidade principal seria estabelecer um conjunto de medidas para viabilizar e efetivar a revisão dos benefícios por incapacidade emitidos no âmbito do RGPS. ${ }^{22}$ A revisão de tais benefícios visou assegurar que estes fossem mantidos apenas para os segurados que de fato se encontrassem incapacitados para o trabalho, evitando, assim, que indivíduos que recuperem a capacidade laborativa recebam benefícios indevidamente por mais tempo que o necessário.

A suspensão ou cessação desses benefícios diminuiu a emissão, mas também pode ter afetado em alguma medida a concessão - por exemplo, em virtude da conversão de auxílios-doença antigos e de longa duração em aposentadorias por invalidez e de um eventual desincentivo a requerimentos infundados, diante do maior escrutínio por parte do INSS. Por seu turno, a vigência da regra 85/95 progressiva e o intenso e prolongado debate sobre uma possível reforma previdenciária, obviamente intensificado pela PEC no 287/2016 e seus desdobramentos, ${ }^{23}$ pode ter favorecido o incremento no volume de novos requerimentos de aposentadorias voluntárias (notadamente no triênio 2015-2017), afetando as concessóes e, consequentemente,

22. A MP no 767/2017, convertida na Lei Ordinária ํㅜ13.457/2017, trata fundamentalmente da revisão dos benefícios por incapacidade concedidos por via administrativa ou judicial, com foco nos benefícios por incapacidade sem perícia médica há mais de dois anos e nas aposentadorias por invalidez de beneficiários com idade inferior a 60 anos.

23. Como sugerido por Costanzi, Ansiliero e Amaral (2018), em que pese qualquer proposta de reforma previdenciária vir acompanhada de regras de transição e respeitar direitos adquiridos, debates nesse sentido tendem a suscitar a antecipação dos requerimentos de aposentadorias. Acrescente-se a isso a edição da MP nำ676, de 17 de junho de 2015, convertida na Lei no 13.183, de 4 de novembro de 2015, que basicamente suavizou a regra de cálculo para as aposentadorias por tempo de contribuição, restringindo a aplicabilidade do FP. A regra 85/95 progressiva, estabelecida pela Lei no 13.183/2015, garante aposentadoria integral para quem, pela soma de sua idade mais o tempo de contribuição, alcançar um determinado número mínimo de pontos, diferente para homens e mulheres e crescente de acordo com a expectativa de sobrevida dos brasileiros. Até o final de 2018, o segurado teria de somar 85 pontos, se mulher, e 95 pontos, se homem; ao final de 2026, a soma para as mulheres será de 90 pontos e para os homens, de 100. 
as emissóes previdenciárias. Também é possível que os dados de fluxo e de estoque de benefícios já tenham começado a reverberar as alteraçóes introduzidas pela MP no ${ }^{\circ} 64 / 2014$, convertida na Lei no $13.135 / 2015$, que tornou mais rígidas as regras para concessão e manutenção de pensốes por morte.

TABELA 1

Evolução da quantidade de benefícios emitidos pela Previdência Social - Brasil (dez./2017 e dez./2018)

\begin{tabular}{lccccc}
\hline Espécies/grupos de espécies & 2017 & Distribuição (\%) & 2018 & $\begin{array}{c}\text { Distribuição (\%) } \\
\text { Variação } \\
\text { (\%) }\end{array}$ \\
\hline RGPS (1+2) & 29.804 .964 & 100,0 & 30.278 .655 & 100,0 & 1,6 \\
\hline Previdenciários (1) & 28.989 .841 & 97,3 & 29.474 .311 & 97,3 & 1,7 \\
\hline Aposentadorias & 19.807 .974 & 66,5 & 20.425 .962 & 67,5 & 3,1 \\
$\quad$ Idade & 10.471 .338 & 35,1 & 10.800 .124 & 35,7 & 3,1 \\
$\quad$ Invalidez & 3.293 .725 & 11,1 & 3.365 .865 & 11,1 & 2,2 \\
$\quad$ Tempo de contribuição & 6.042 .911 & 20,3 & 6.259 .973 & 20,7 & 3,6 \\
Pensão por morte & 7.675 .576 & 25,8 & 7.720 .433 & 25,5 & 0,6 \\
Auxílio-doença & 1.294 .118 & 4,3 & 1.132 .033 & 3,7 & $-12,5$ \\
Salário-maternidade & 81.766 & 0,3 & 53.536 & 0,2 & $-34,5$ \\
Outros & 130.407 & 0,4 & 142.347 & 0,5 & 9,2 \\
\hline Acidentários (2) & 815.123 & 2,7 & 804.344 & 2,7 & $-1,3$ \\
\hline Aposentadorias & 210.877 & 0,7 & 215.092 & 0,7 & 2,0 \\
Pensão por morte & 111.688 & 0,4 & 108.981 & 0,4 & $-2,4$ \\
Auxílio-doença & 123.345 & 0,4 & 107.565 & 0,4 & $-12,8$ \\
Auxílio-acidente & 326.271 & 1,1 & 332.846 & 1,1 & 2,0 \\
Auxílio-suplementar & 42.942 & 0,1 & 39.860 & 0,1 & $-7,2$ \\
\hline
\end{tabular}

Fontes: Anuário Estatístico da Previdência Social (Aeps). Disponível em: <https://bit.ly/3cpVhla>; Boletim Estatístico da Previdência Social (Beps). Disponível em: <https://bit.ly/3ct459U>. Acessos em: 15 out. 2019.

Obs.: A quantidade de emissões, neste texto, é tomada como aproximação do estoque de benefícios do RGPS.

Entre dezembro de 2008 e dezembro de 2018, a quantidade de benefícios previdenciários emitidos pelo RGPS (somados os benefícios previdenciários e os acidentários) aumentou 32,9\%, com o total de emitidos passando de 22,8 milhóes (dezembro/2008) para 30,3 milhóes (dezembro/2018). Isso significa que, em média, o estoque de benefícios (tomado como a quantidade de emissóes em dezembro de cada ano) cresceu em torno de 2,88\% ao ano no período considerado. Em dezembro de 2018, do total de 30,3 milhóes de benefícios previdenciários, cerca de 20,7 milhóes $(68,3 \%)$ foram emitidos para a clientela urbana, sendo os demais 9,5 milhóes $(31,4 \%)$ direcionados à clientela rural (gráfico 8). 
GRÁFICO 8

Evolução da quantidade de benefícios emitidos pelo RGPS - Brasil (dez./2008-dez./2018) (Em milhões)

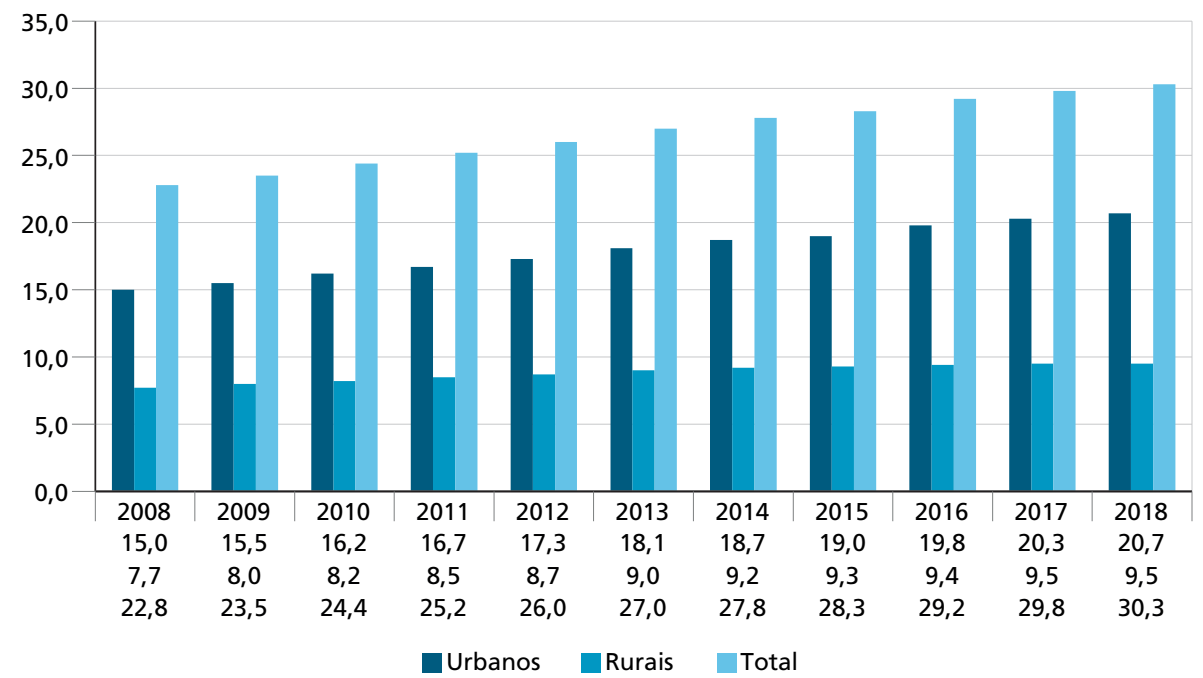

Fontes: Aeps. Disponível em: <https://bit.ly/3cpVhla>; BEPS. Disponivel em: <https://bit.ly/3ct459U>. Acessos em: 15 out. 2019. Elaboração: Secretaria de Previdência do Ministério da Fazenda (SPREV/ME).

Obs.: Os benefícios assistenciais, embora operacionalizados pelo INSS, estavam, então, sob a responsabilidade do Ministério do Desenvolvimento Social e Combate à Fome (MDS), atual Ministério da Cidadania (MCid).

Com respeito a esse fluxo de novos benefícios, o RGPS concedeu, no acumulado do ano de 2018, aproximadamente 4,81 milhóes de novos benefícios (entre previdenciários e acidentários), registrando um crescimento de 3,0\% (mais de 141,34 mil benefícios) no confronto com 2017. A concessão de benefícios previdenciários cresceu em 2,8\% (mais de 126,60 mil benefícios), assim como a concessão de benefícios acidentários, que apresentaram incremento de $6,7 \%$ (mais de 14,73 mil benefícios).

Quando se considera a abertura por principais espécies, ainda na comparação com a quantidade de concessóes do ano anterior, ${ }^{24}$ destacam-se o aumento na concessão de aposentadorias por invalidez $(+24,2 \%$, possivelmente potencializados pela conversão de auxílios-doença, no contexto do programa de revisão dos benefícios de incapacidade com maior duração) e a queda nas aposentadorias por tempo de contribuição $(-21,6 \%)$ e nas aposentadorias por idade $(-4,7 \%)$, possivelmente em

24. Os dados deste biênio, vale dizer, podem ter sido afetados por outro fator atípico. Em 2017, o INSS iniciou a implantação do chamado INSS Digital, novo modelo de atendimento, a ser paulatinamente aplicado a todas as agências da instituição, que passarão a adotar a tramitação eletrônica de processos. O INSS Digital tem o mérito de promover a modernização dos serviços ao cidadão e reduzir a necessidade de atendimento presencial (fundamental em um contexto de escassez de servidores ativos nessa atividade), com potencial de melhora em sua qualidade a médio e a longo prazo. No curto prazo, contudo, sua implantação tem sido associada ao represamento de decisões (concessões e revisões, principalmente) e a dificuldades de acesso por parte dos segurados, em particular daqueles mais idosos e socialmente vulneráveis, para os quais o atendimento digital pode representar uma barreira. Este tema deverá ser explorado em outros trabalhos. 
razão do arrefecimento na movimentação incentivada pela reforma previdenciária e pelos efeitos iniciais da implantação da regra 85/95 progressiva.

TABELA 2

Evolução da quantidade de benefícios concedidos pela Previdência Social - Brasil (2017 e 2018)

\begin{tabular}{lrrrrr}
\hline $\begin{array}{l}\text { Espécies/grupos de } \\
\text { Espécies }\end{array}$ & \multicolumn{1}{c}{2017} & Distribuição (\%) & 2018 & Distribuição (\%) & Variação (\%) \\
\hline RGPS (1+2) & 4.669 .604 & 100,0 & 4.810 .947 & 100,0 & 3,0 \\
\hline Previdenciários (1) & 4.448 .953 & 95,3 & 4.575 .560 & 95,1 & 2,8 \\
\hline Aposentadorias & 1.391 .170 & 29,8 & 1.304 .929 & 27,1 & $-6,2$ \\
$\quad$ Idade & 718.679 & 15,4 & 684.756 & 14,2 & $-4,7$ \\
$\quad$ Invalidez & 202.481 & 4,3 & 251.510 & 5,2 & 24,2 \\
Tempo de contribuição & 470.010 & 10,1 & 368.663 & 7,7 & $-21,6$ \\
Pensão por morte & 400.941 & 8,6 & 351.451 & 7,3 & $-12,3$ \\
Auxílio-doença & 1.988 .169 & 42,6 & 2.271 .033 & 47,2 & 14,2 \\
Salário-maternidade & 630.741 & 13,5 & 608.481 & 12,6 & $-3,5$ \\
Outros & 37.932 & 0,8 & 39.666 & 0,8 & 4,6 \\
\hline Acidentários (2) & 220.651 & 4,7 & 235.387 & 4,9 & 6,7 \\
\hline Aposentadorias & 9.319 & 0,2 & 11.372 & 0,2 & 22,0 \\
Pensão por morte & 298 & 0,0 & 212 & 0,0 & $-28,9$ \\
Auxílio-doença & 191.118 & 4,1 & 202.406 & 4,2 & 5,9 \\
Auxílio-acidente & 19.764 & 0,4 & 21.281 & 0,4 & 7,7 \\
Auxílio-suplementar & 152 & 0,0 & 116 & 0,0 & $-23,7$ \\
\hline
\end{tabular}

Fontes: Aeps. Disponivel em: <https://bit.ly/3cpVhla>; BEPS. Disponivel em: <https://bit.ly/3ct459U>. Acessos em: 15 out. 2019. Obs.: Acumulado nos anos de 2017 e 2018. Exclusive encargos previdenciários da união (EPU).

No resultado agregado de 2018 (gráfico 9), do total de 4,81 milhóes de benefícios previdenciários concedidos, cerca de 3,96 milhóes $(82,2 \%)$ foram reconhecidos para a clientela urbana, sendo os demais 855 mil (17,8\%) destinados à clientela rural. Ao longo do período analisado, nota-se uma tendência de queda na participação da clientela rural no fluxo e no estoque de benefícios previdenciários (gráficos 8 e 9). Este tema deve ser analisado com maior profundidade em estudos futuros, mas, como elementos explicativos iniciais, pode-se aventar o processo de urbanização vivenciado há décadas pelo país ${ }^{25} \mathrm{e}$, mais recentemente, o movimento de interiorização da economia. ${ }^{26}$

25. Para informações sobre a evolução da taxa de urbanização no país, consultar Infologo Aeps, a base de dados históricos da Previdência Social. Disponível em: <https://bit.ly/2T5AdJj>.

26. A esse respeito, ver Grossi, Silva e Campanhola (2001) e IBGE (2010). 


\section{GRÁFICO 9}

Quantidade de benefícios concedidos pelo RGPS ${ }^{-}$- Brasil (2010-2018)

(Em milhares)

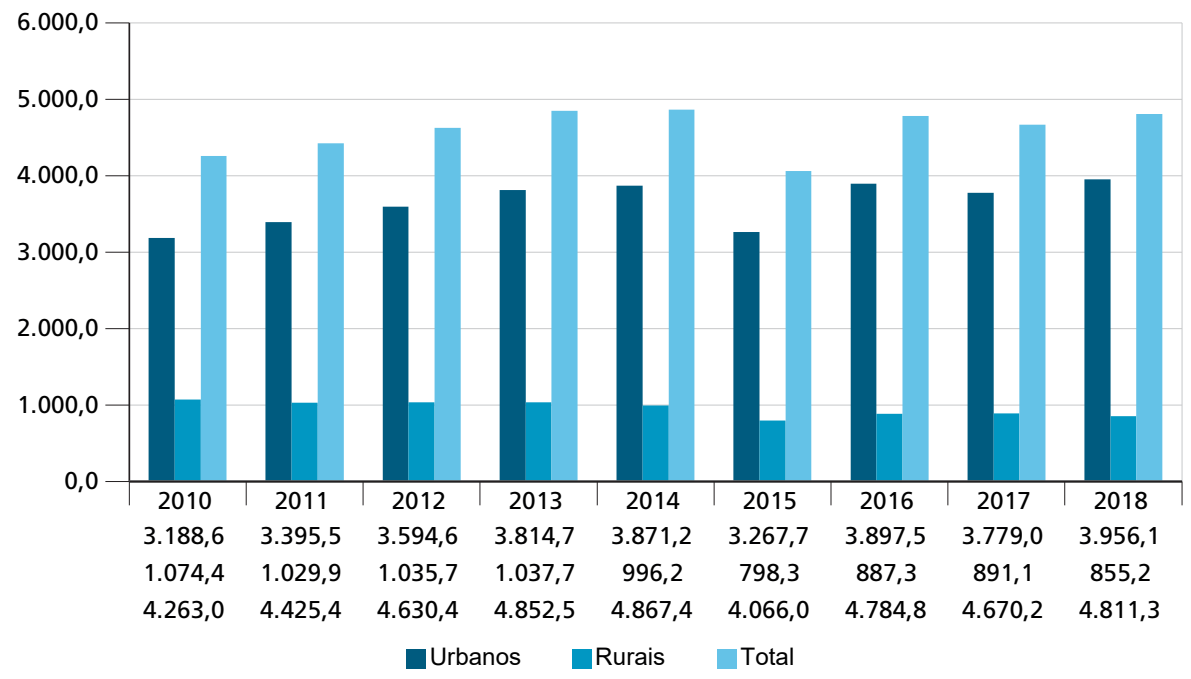

Fontes: Aeps. Disponível em: <https://bit.ly/3cpVhla>; BEPS. Disponível em: <https://bit.ly/3ct459U>; Índice Nacional de Preços ao Consumidor - INPC/IBGE Disponível em: <https://bit.ly/2Yvq8qU>. Acessos em: 15 out. 2019.

Nota: ${ }^{1} \mathrm{~A}$ evolução da concessão de benefícios é mais diretamente afetada por eventos e fatores excepcionais, como greves e outros problemas de acesso e atendimento a segurados, o que explica alguma oscilação nos números apresentados neste gráfico 9. Em 2015, por exemplo, o INSS foi afetado por uma greve nacional de servidores administrativos, com alta adesão e duração aproximada de três meses, bem como por uma greve prolongada de médicos peritos, o que explica a queda na concessão em relação ao ano anterior.

Obs.: Acumulado de janeiro a dezembro (2010-2018). Inclusive EPU.

Ambos os fatores contribuem para a expansão da clientela urbana da Previdência Social, como volume de contribuintes, em um primeiro momento, e segurados beneficiários, ao longo do tempo. Da mesma maneira que seria esperada esta redução na participação da clientela rural no RGPS, uma vez que, paulatinamente, os novos segurados beneficiários exerceriam mais frequentemente atividades não rurais, o atual estoque de segurados se justifica, ao menos em parte, pelo padrão de mortalidade diferenciado no meio rural (tomando-se a situação do domicílio no Censo Demográfico 2010 como aproximação para a atividade econômica prevalente $)^{27}$ e, principalmente, pelo ritmo cadente, mas ainda significativo, de novas concessóes (inclusive com grande parcela de judicialização, outro tema a ser explorado mais a fundo).

O valor médio dos benefícios emitidos foi de $\mathrm{R} \$ 1.404,7$, na média de janeiro a dezembro de 2018 , configurando uma redução real de $0,5 \%$ em relaçáo

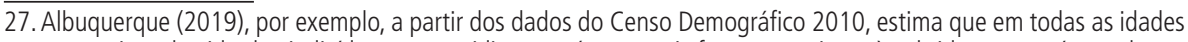
as expectativas de vida dos indivíduos que residiam em áreas rurais foram superiores às obtidas para a área urbana, tanto dos homens quanto das mulheres. 
ao mesmo período de 2017. Entre o acumulado de janeiro a dezembro de 2017 e o mesmo intervalo correspondente de 2011, o valor médio real dos benefícios emitidos cresceu $11,1 \%$ (gráfico 10), movimento explicado principalmente pela política de reajustamento do salário mínimo prevalente no período analisado.

\section{GRÁFICO 10}

Valor médio real dos benefícios pagos pelo RGPS - Brasil (2011-2018) (Em R\$)

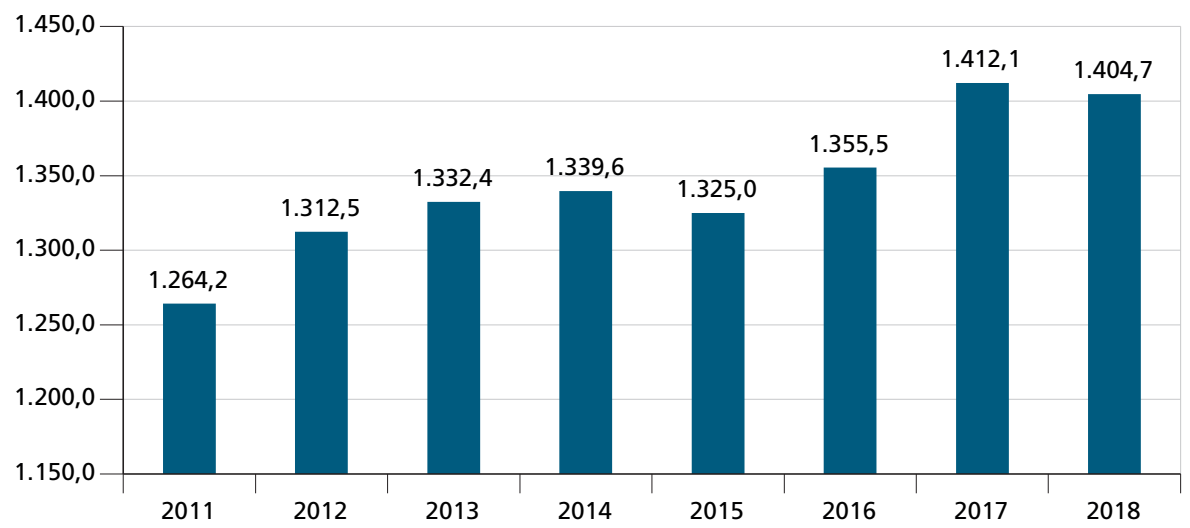

Fontes: Aeps. Disponível em: <https://bit.ly/3cpVhla>; BEPS. Disponivel em: <https://bit.ly/3ct459U>; INPC//BGE Disponível em: <https://bit.ly/2Yvq8qU>. Acessos em: 15 out. 2019.

Obs.: Média de janeiro a dezembro de cada ano segundo o INPC.

Em virtude da queda do PIB em 2015 e 2016, não houve reajuste real do salário mínimo nos anos de 2017 e 2018, ao contrário do que havia ocorrido em anos anteriores, quando os ganhos concedidos ao piso previdenciário foram sistematica e significativamente superiores à inflação. Entre 2017 e 2018, o declínio no valor real médio das emissôes pode estar associado a outros fatores, como a queda no rendimento médio do trabalho (base para o cálculo do salário de benefício) e a redução do volume de concessôes de benefícios de maior valor, em virtude de arrefecimento do movimento impulsionado pela regra 85/95 progressiva nos anos anteriores.

A receita do RGPS está também fortemente atrelada à dinâmica do mercado de trabalho (volume de ocupados que contribuem para a Previdência Social e sua massa salarial correspondente), que, por sua vez, reflete, com alguma defasagem temporal, a conjuntura econômica do país. Até 2014, em virtude do bom momento vivido pela economia brasileira e de seus rebatimentos positivos no mercado de trabalho, houve forte aumento real da receita previdenciária líquida. No último quatriênio, já em razão da crise econômica enfrentada pelo país, os indicadores financeiros do RGPS se deterioraram ainda mais, com queda real da receita líquida e aumento real expressivo na necessidade de financiamento do sistema. 
GRÁFICO 11

Receita (arrecadação líquida), despesa (benefícios previdenciários) e resultado previdenciário do RGPS - Brasil (2009-2018)

(Em R\$ bilhões)

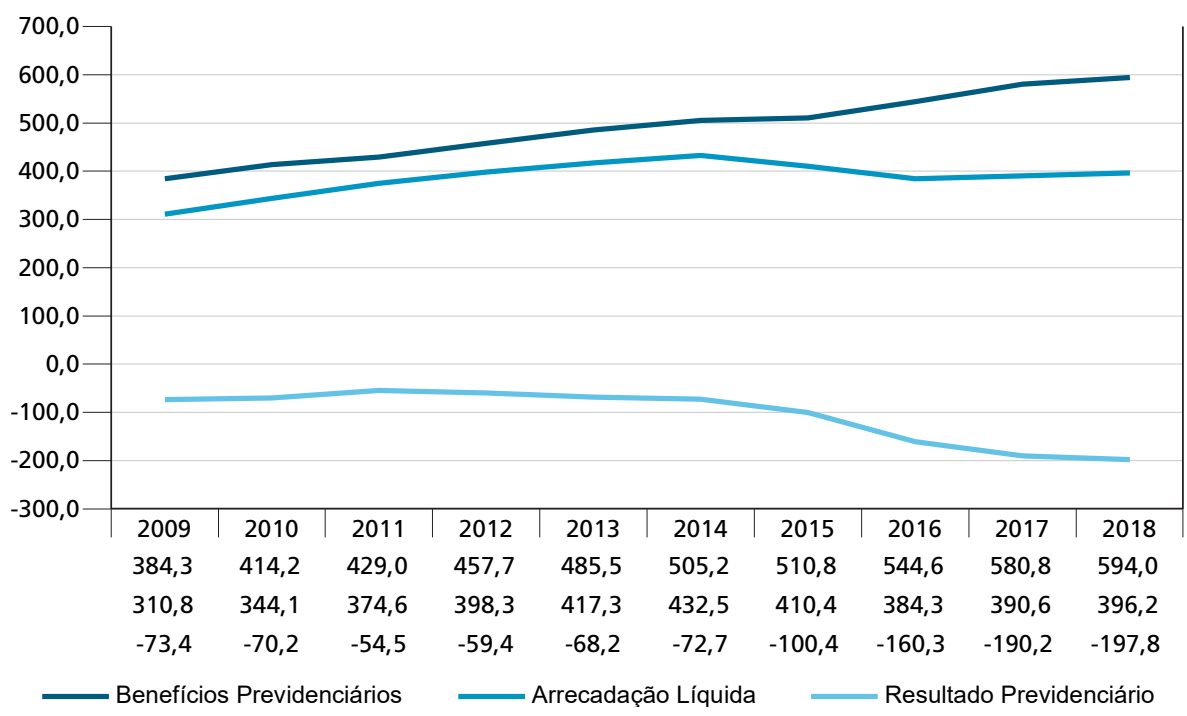

Fonte: Informes de Previdência Social/MF, Vários anos. Disponível em: <https://bit.ly/2Yy3TQW>. INPC/IBGE. Disponível em: <https: //bit.ly/3fluSWC>. Acessos em: 15 out. 2019.

Elaboração: Ipea.

Obs.: A preços de dezembro de 2018 segundo o INPC.

A despesa previdenciária é determinada fundamentalmente pelo comportamento de três elementos, relacionados entre si: o estoque (evolução e composição do estoque) e o fluxo (suspensões e cessaçóes e novas concessóes); a taxa de reposição dos benefícios previdenciários (relação entre o valor do benefício concedido e o salário de contribuição usado como referência para a concessão); e a política de reajustamento (principalmente daqueles que equivalem ao piso previdenciário, valor mais frequente entre os benefícios em estoque). Não houve explosão na quantidade de benefícios, mas o estoque, em volume de benefícios pagos, cresce anualmente a taxas contínuas e significativas (ainda que inferiores àquelas registradas nos anos 1990, pós-regulamentação da Constituição Federal de 1988). 


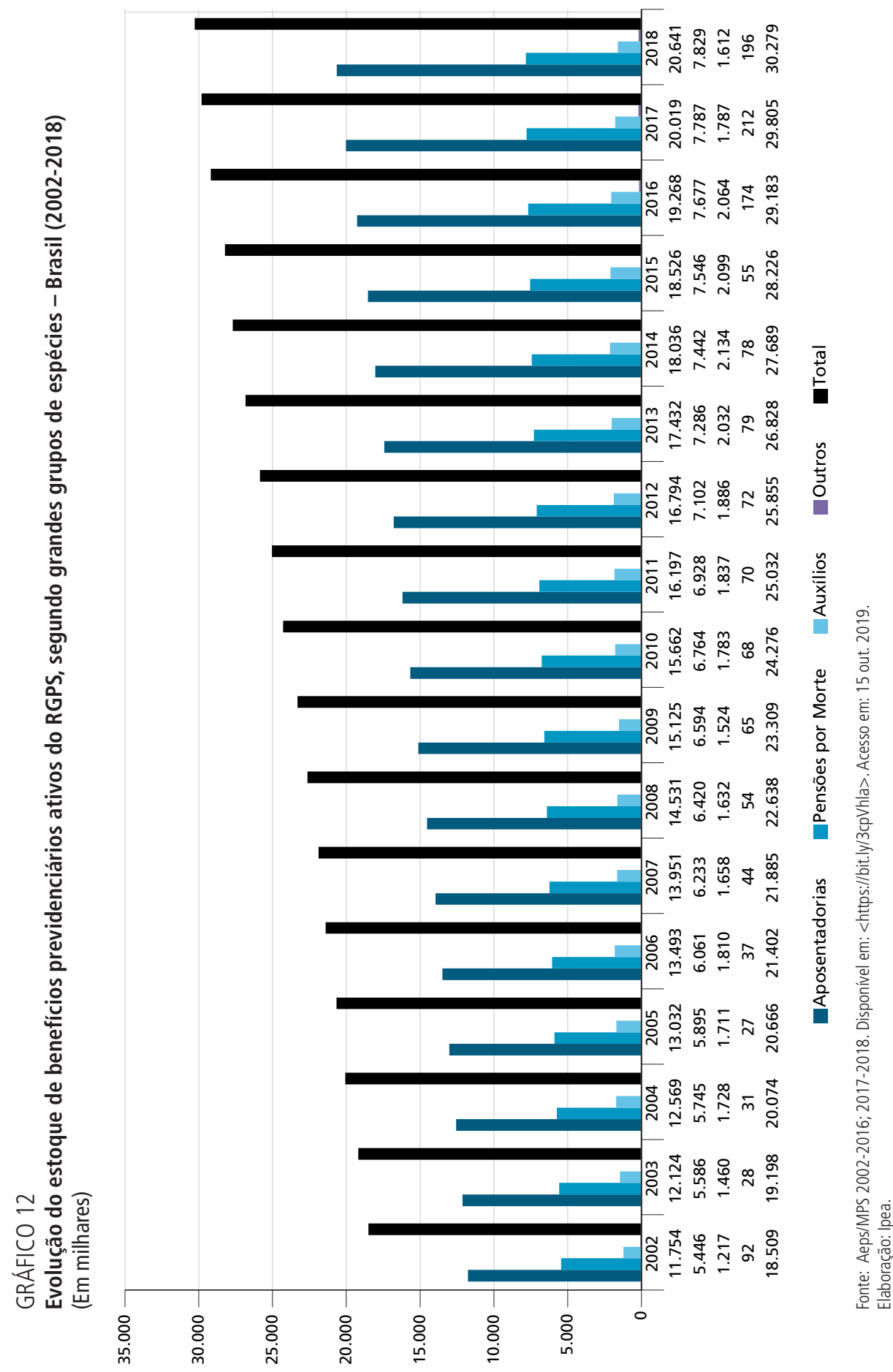


Nos últimos anos (2002-2018), a expansão no estoque de benefícios e o aumento do seu valor médio foram determinantes para o aumento real da despesa. Estes fatores estiveram fortemente vinculados à evolução demográfica (marcada por um acelerado processo de envelhecimento populacional), à evoluçáo positiva dos rendimentos do trabalho (proporcionada pela política de valorização do salário mínimo e pelo aumento no rendimento médio real do trabalho em um mercado de trabalho ainda aquecido, contribuindo, assim, para a variação real positiva no valor médio dos benefícios do RGPS) e a regras e parâmetros considerados frágeis para a concessão e a manutenção dos benefícios (destaque para as regras de elegibilidade e para a taxa de reposição, esta ainda mais afetada pela já mencionada flexibilização do fator previdenciário).

\subsubsection{Regimes Próprios de Previdência Social}

Segundo dados do Aeps, relativos a vários anos, ${ }^{28}$ nos RPPS dos estados e do Distrito Federal, observa-se uma tendência de queda no volume de segurados ativos e de elevação no quantitativo de beneficiários. Nos RPPS municipais, os contingentes de ativos e inativos revelam tendência de expansão, mas, entre os ativos, o movimento é aparentemente mais intenso. Para os regimes da União, de servidores civis e militares, também há quebras nas séries históricas, mas os dados da última década se mostram harmônicos. Há indicação de uma leve tendência de elevação no número de servidores e militares ativos e de relativa estabilidade no quantitativo de aposentados e pensionistas. ${ }^{29}$

Ressalte-se, contudo, que tal estabilidade nos anos recentes não implica sua manutenção nos anos próximos, haja vista que, ainda no curto prazo, uma parcela expressiva dos servidores ativos da Uniâo atingirá os requisitos de elegibilidade a aposentadorias programadas. Estimativa no âmbito do serviço público civil do Poder Executivo federal, realizada por Schettini, Pires e Santos (2018), indica que, até 2027 , cerca de $45 \%$ do contingente que compóe esse grupo específico terá cumprido as regras atuais de elegibilidade que maximizam o valor dos benefícios. A proporção é alarmante, e, mesmo em um cenário pós-reforma, as regras de transição necessariamente presentes nos novos arranjos dificilmente protelarão significativamente os efeitos preditos.

28. Para acesso aos dados, consultar Infologo Aeps, a base de dados históricos da Previdência Social. Disponível em: $<$ https://bit.ly/3fSplT9>.

29. Essas interpretações devem ser tomadas com parcimônia, pois os dados oficiais, publicados pelo ME, oscilam muito no período considerado (2007-2016). Tais oscilações podem ser explicadas, em parte, por diferenças conceituais (por exemplo, pela inclusão, ou não, de policiais militares e bombeiros), imprecisões e/ou atrasos nos informes obrigatórios elaborados pelos entes com regimes próprios, pela criação e extinção de RPPS municipais e também pelo padrão errático de expansão das contratações (com rebatimentos em fluxos igualmente erráticos de entrada em benefício). Para os regimes da União, de servidores civis e militares, também há quebras nas séries históricas (normalmente, em virtude de alterações nos conceitos das medidas empregadas), mas os dados da última década se mostram relativamente harmônicos. 
No curto prazo, a expansão no volume de servidores ativos pode representar algum alívio sobre o resultado previdenciário (mediante expansão das receitas advindas das contribuiçóes adicionais), mas - além de gerar possíveis dificuldades para a sustentabilidade da despesa com pessoal ativo - tal prática tende a resultar em aumentos na quantidade de beneficiários e, consequentemente, no volume da despesa previdenciária a médio e longo prazo. Este ponto é importante principalmente para os regimes próprios municipais, em grande parte instituídos há menos tempo que os regimes estaduais e da União e nos quais a relação entre ativos e inativos (aposentados e pensionistas) ainda assume patamares menos dramáticos. $\mathrm{Na}$ União, esta razão de dependência (contribuintes/ativos e beneficiários) já assume valor bastante reduzido e ameaça sua sustentabilidade, embora o indicador tenha aumentado ligeiramente (mediante expansão do quadro de servidores ativos) nos últimos anos.

Nos regimes próprios da União, se observa uma tendência de relativa estabilidade no resultado previdenciário, sem movimentos expressivos na despesa, na receita e na necessidade de financiamento. Apesar desse cenário de aparente estabilização registrado no período 2009-2017, cumpre ressaltar que o resultado previdenciário anual ainda assume montante expressivo e com risco potencialmente elevado de insustentabilidade futura, como indicado anteriormente. Em outras palavras, o grau de desequilíbrio, que já preocupa no curto prazo, deverá ser intensificado nas próximas décadas.

\section{GRÁFICO 13}

Receita, despesa e resultado previdenciário dos RPPS dos servidores civis e militares da União - Brasil (2009-2017)

(Em R\$ bilhões)

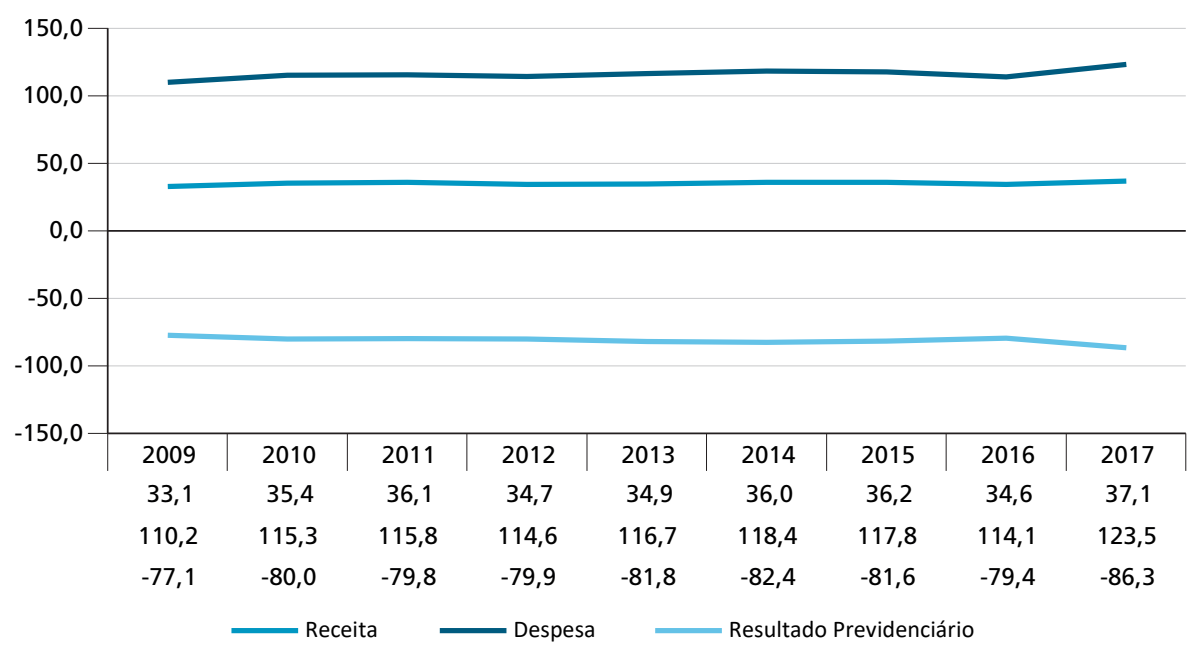

Fontes: Relatório Resumido de Execução Orçamentária (RREO)/MF. Disponível em: <https://bit.ly/2YwDGCf>; INPC/IBGE. Disponível em: <https://bit.ly/3fjwUXv>. Acessos em: 15 out. 2019. 
A EC no 41/2003 atuou no sentido de minimizar os riscos mencionados, notadamente mediante instituição de regimes de previdência complementar, já implantados na União e em algumas Unidades da Federação (UFs). Os efeitos dessa medida devem ser sentidos no longo prazo, quando a transiçâo entre os dois modelos for completada e a necessidade de financiamento, controlada. A curto e a médio prazo, no entanto, deve-se observar, inclusive, uma piora no resultado previdenciário, fruto do custo de transição que afeta inicialmente (e adversamente) a receita e apenas posteriormente atinge significativamente a despesa (quando porções crescentes dos inativos estiverem sujeitas ao limite imposto pelo benefício máximo do RGPS). ${ }^{30}$ No caso específico da Uniáo, a grande massa de servidores elegíveis à aposentadoria nos próximos anos segue vinculada unicamente ao regime de repartição simples, o que tende a agravar o quadro.

\subsubsection{Panorama da Previdência Social: resultado agregado em 2017}

Em 2017, em valores correntes, a despesa previdenciária do RGPS alcançou aproximadamente $\mathrm{R} \$ 557,2$ bilhóes, enquanto suas receitas somaram pouco mais de $\mathrm{R} \$ 374,8$ bilhóes, gerando uma necessidade de financiamento de cerca de R \$ 182,5 bilhóes. Nos RPPS e nos regimes específicos dos militares (reservistas e reformados), o resultado previdenciário agregado foi negativo em $\mathrm{R} \$ 180,1$ bilhóes, quadro gerado pelo confronto de uma despesa total de $\mathrm{R} \$ 333,5$ bilhóes com receitas de R \$ 153,4 bilhóes no ano. Nesse ano, em termos agregados (somados todos os regimes públicos contributivos de Previdência Social), a despesa previdenciária brasileira chegou a aproximadamente $13,6 \%$ do PIB.

\section{TABELA 3}

Quantitativo de segurados (contribuintes e benefícios ativos permanentes), receita, despesa e necessidade de financiamento da Previdência Social, por tipo de regime - Brasil (2017)

(Em R\$ bilhões)

\begin{tabular}{|c|c|c|c|c|c|c|c|}
\hline \multirow[t]{2}{*}{$\begin{array}{l}\text { Regime previ- } \\
\text { denciário }\end{array}$} & \multicolumn{3}{|c|}{ Dados fnanceiros - resultado previdenciário } & \multicolumn{4}{|c|}{ Quantidade de contribuintes e beneficiários permanentes } \\
\hline & Receita (a) & Despesa (b) & $\begin{array}{c}\text { Resultado } \\
\text { previdenciário } \\
(a-b)\end{array}$ & $\begin{array}{c}\text { Aposentados } \\
\text { (a) }\end{array}$ & $\begin{array}{c}\text { Pensionistas } \\
\text { (b) }\end{array}$ & $\begin{array}{c}\text { Contribuintes } \\
\text { (c) }\end{array}$ & $\begin{array}{l}\text { Contribuintes/ } \\
\text { beneficiários } \\
\text { (c) } /(a+b)\end{array}$ \\
\hline RGPS & 374,8 & 557,2 & $-182,5$ & 19.911 .211 & 7.780 .175 & 51.138 .581 & 1,85 \\
\hline RPPS & 153,4 & 333,5 & $-180,1$ & 2.977 .136 & 1.204 .758 & 6.108 .400 & 1,46 \\
\hline União & 36,0 & 124,2 & $-88,1$ & 594.819 & 524.009 & 1.059 .943 & 0,95 \\
\hline Civis & 33,5 & 78,3 & $-44,8$ & 436.535 & 300.937 & 691.342 & 0,94 \\
\hline FCDF & 0,4 & 4,9 & $-4,5$ & - & - & - & - \\
\hline Militares & 2,2 & 41,0 & $-38,9$ & 158.284 & 223.072 & 368.601 & 0,97 \\
\hline
\end{tabular}

30. Nos entes que concretizaram a regulamentação dos regimes complementares, os benefícios pagos sob o regime de repartição simples foram limitados ao teto mensal do RGPS. 


\begin{tabular}{|c|c|c|c|c|c|c|c|}
\hline \multirow[t]{2}{*}{$\begin{array}{l}\text { Regime previ- } \\
\text { denciário }\end{array}$} & \multicolumn{3}{|c|}{ Dados fnanceiros - resultado previdenciário } & \multicolumn{4}{|c|}{ Quantidade de contribuintes e beneficiários permanentes } \\
\hline & Receita (a) & Despesa (b) & $\begin{array}{c}\text { Resultado } \\
\text { previdenciário } \\
(a-b)\end{array}$ & $\begin{array}{c}\text { Aposentados } \\
\text { (a) }\end{array}$ & $\begin{array}{l}\text { Pensionistas } \\
\text { (b) }\end{array}$ & $\begin{array}{l}\text { Contribuintes } \\
\text { (c) }\end{array}$ & $\begin{array}{l}\text { Contribuintes/ } \\
\text { beneficiários } \\
\text { (c) } /(a+b)\end{array}$ \\
\hline Estados & 71,8 & 165,2 & $-93,4$ & 1.671 .827 & 503.908 & 2.454 .573 & 1,13 \\
\hline Municípios & 45,6 & 44,1 & 1,4 & 710.490 & 176.841 & 2.593 .884 & 2,92 \\
\hline Total & 528,2 & 890,7 & $-362,6$ & 22.888 .347 & 8.984 .933 & 57.246 .981 & 1,80 \\
\hline
\end{tabular}

Fontes: SPREV/ME. Disponivel em: <https://bit.ly/3fipkMD>; Aeps 2017/MF. Disponível em: <https://bit.ly/3cpVhla>. Acessos em: 15 out. 2019.

Elaboração: Ipea.

Obs.: 1. A informação relativa ao RGPS consta do fluxo de caixa do INSS.

2. Com respeito ao RGPS, o estoque de benefícios consiste no total de benefícios ativos em dezembro de 2017, em todas as espécies de aposentadorias e pensões por morte.

3. No RGPS, a quantidade de contribuintes corresponde a uma estimativa baseada nas pessoas que tiveram vínculo como contribuinte empregado ou contribuição como contribuinte individual, empregado doméstico, contribuinte facultativo ou segurado especial no ano de referência. Tal estimativa corresponde à soma do número de meses com recolhimentos por cada pessoa, dividido por doze.

O RGPS possui, naturalmente, a maior participação na despesa previdenciária total, mas se encontra sobrerrepresentado no montante total arrecadado a título de receita previdenciária. Isso implica que, em termos relativos e absolutos, o resultado geral (despesas subtraídas das receitas) se encontra bastante influenciado por desequilíbrios expressivos, financeiros e atuariais, em regimes próprios (de servidores públicos civis e, principalmente, militares) com um volume de beneficiários (diretos e indiretos) bem menos numeroso que o quantitativo registrado para o RGPS. Os resultados são preocupantes mesmo para os RPPS municipais, nos quais a estrutura etária tende a ser mais jovem e a relação entre contribuintes e beneficiários ainda não atingiu nível tão baixo quanto o observado nos demais sistemas. ${ }^{31}$

31. A partir do Aeps 2017, o resultado previdenciário foi substituído pelo resultado financeiro, que possui nova metodologia de apuração. Segundo a SPREV, atualmente vinculada ao ME, a metodologia vigente de apuração do resultado financeiro observa as seguintes regras: i) no resultado financeiro, considera-se o resultado do Demonstrativo de Informações Previdenciárias e Repasses (DIPR), do Sistema de Informações dos Regimes Públicos de Previdência Social (Cadprev) ou do Demonstrativo das Receitas e Despesas Previdenciárias do RPPS, anexo ao RREO, encaminhado pelo Sistema de Informações Contábeis e Fiscais do Setor Público Brasileiro (Siconfi), quando existente a informação de apenas um desses documentos, ou o resultado mais conservador (pior), quando houver a informação dos dois documentos. Na ausência de informações tanto do DIPR como do RREO, o resultado é imputado conforme a média do grupo; ii) o resultado financeiro apurado por meio do DIPR considera as receitas totais (exceto os aportes para cobertura de insuficiência financeira, para pagamento de benefícios de responsabilidade do Tesouro e outros aportes e transferências, bem como os aportes destinados ao pagamento dos benefícios dos militares), menos as despesas totais. Como as informações do DIPR são mensais, para os RPPS que não enviaram todas as competências, é definida a proporção entre os doze meses e o total de meses com informações, para estabelecer o valor anual; e iii) o resultado financeiro apurado por meio do RREO considera as receitas totais (exceto os aportes e as demais receitas correntes), menos as despesas totais. 
GRÁFICO 14

Participação dos regimes previdenciários, segundo ente da Federação, por componente do resultado previdenciário brasileiro (2017)

(Em \%)

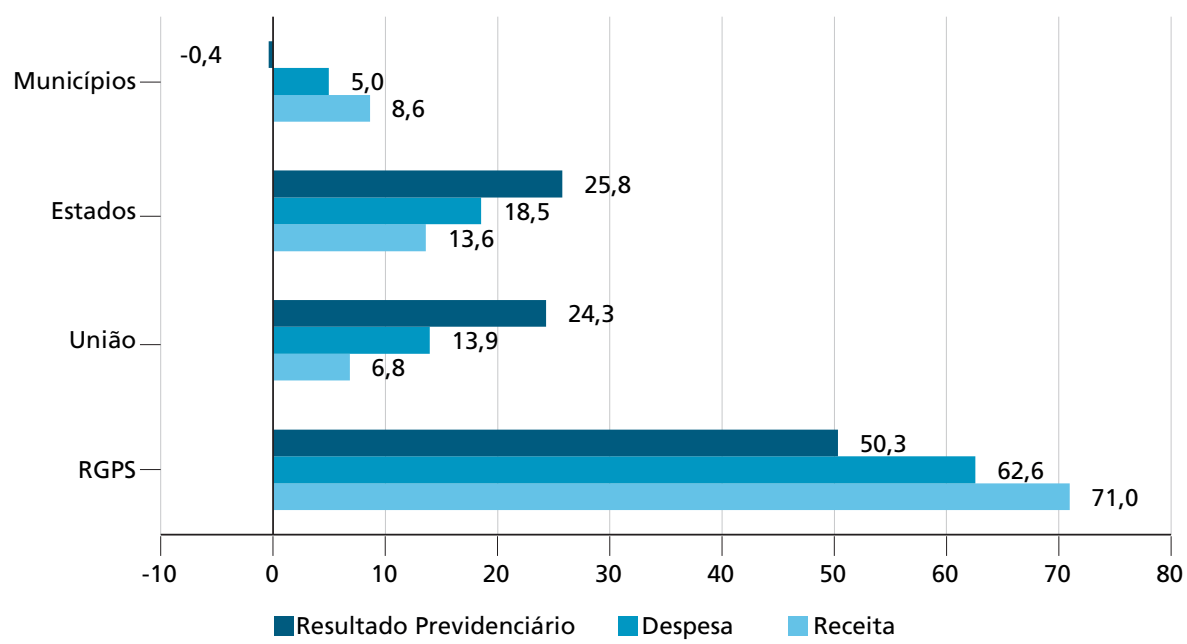

Fontes: Aeps/MF. Disponivel em: <https://bit.ly/3cpVhla>; e RREO/MF. Disponivel: <https://bit.ly/3fjwhND>. Acessos em: 15 out. 2015. Elaboração: Ipea.

O patamar de despesa como proporção do PIB pode não parecer tão alarmante quando comparado unicamente com o mesmo indicador calculado para outros países, mas o desafio é claro quando a demografia é incorporada à análise. Comparativamente a 31 países europeus, para os quais o Departamento Oficial de Estatística da Uniáo Europeia (Eurostat) compilou dados harmonizados entre si para o ano de 2015, nota-se que o nível de despesa brasileiro é muito elevado quando se considera sua atual estrutura demográfica.

O percentual do PIB brasileiro destinado ao pagamento de benefícios previdenciários (13,5\% em 2016, ano adotado na comparação) tende a ser superior àquele observado para países com proporção de idosos assemelhada à brasileira. Mais precisamente, o nível de gasto não pode ser suficientemente explicado pela demografia, tomando-se como referência a participação dos idosos com 65 anos ou mais na população total. 


\section{GRÁFICO 15 \\ Despesa previdenciária total como proporção do PIB versus proporção de idosos na população total de vários países europeus (2015) e do Brasil (2016)}

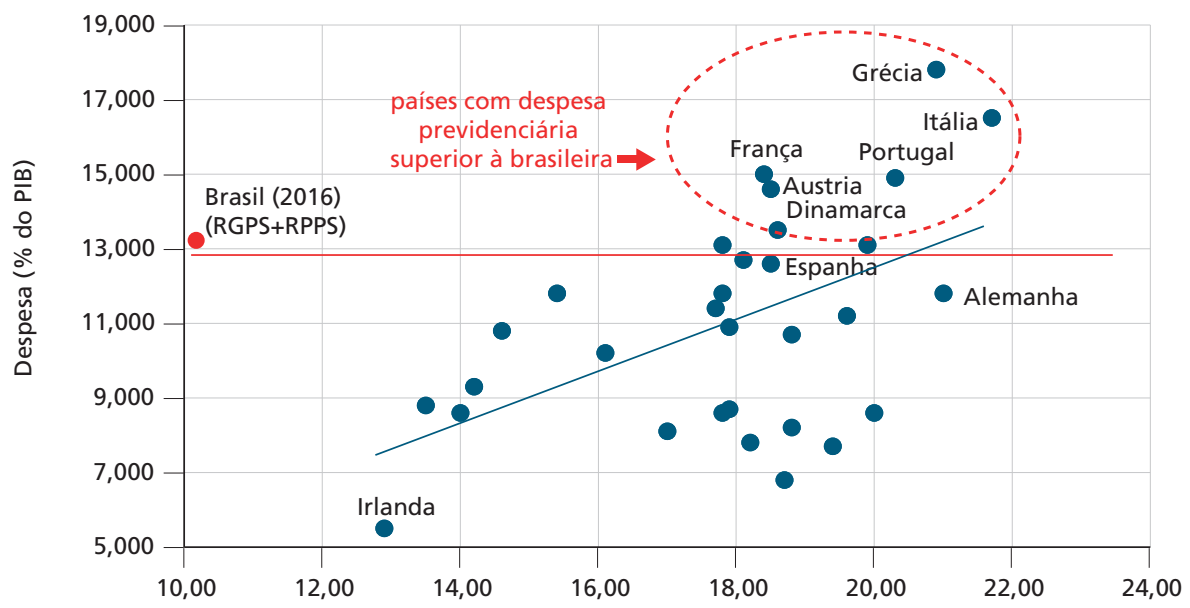

Proporção de idosos (65 anos ou +) na população total (\%)

Fontes: Aeps/MF. Disponível em: <https://bit.ly/3cpVhla>; RREO/MF. Disponível em: <https://bit.ly/2zqRNRc>; Fluxo de Caixa/ INSS. Disponível em: <https://bit.ly/2UFm8mr>; Boletim Estatístico de Pessoal do Ministério do Planejamento, Orçamento e Gestão. Disponivel em: <https://bit.ly/37sSJkO>; Eurostat. Disponivel em: <https://bit.ly/3dMKrGo>; Tábuas Completas de Mortalidade 2016. Disponível em: <https://bit.ly/2N54pAV>. Acessos em: 15 out. 2019.

Elaboração: Ipea.

Obs.: 1. A despesa europeia consiste no total de repasses previdenciários, em dinheiro e por parte de todos os sistemas, concedidos sem qualquer requisito de renda (no means-tested). A despesa europeia, mais precisamente, consiste em parte das transferências monetárias periódicas totais, notadamente aquela concernente aos benefícios por incapacidade temporária e permanente (auxílios-doença e aposentadorias por invalidez, fundamentalmente), às pensões por morte e às aposentadorias (normais, parciais e antecipadas). No Brasil, para os regimes próprios, consideram-se basicamente as despesas com aposentadorias e pensões por morte; para o RGPS, todos os benefícios são considerados (salvo aqueles pagos por empregadores e deduzidos da receita previdenciária devida).

2. A proporção de idosos consiste na razão entre o contingente de idosos (65 anos ou mais de idade) e a população total (todas as idades).

3. Os dados do Brasil foram desconsiderados na estimativa da reta, tanto por serem extremos e influenciarem demasiadamente os coeficientes da regressão, como também porque o objetivo do exercício é justamente comparar a situação brasileira com a média europeia.

4. Os dados da Eurostat fazem referência aos seguintes países: Bélgica, Bulgária, República Checa, Dinamarca, Alemanha, Estônia, Irlanda, Grécia, Espanha, França, Croácia, Itália, Chipre, Letônia, Lituânia, Luxemburgo, Hungria, Malta, Holanda, Áustria, Polônia, Portugal, Romênia, Eslováquia, Eslovênia, Finlândia, Suécia, Reino Unido, Islândia, Noruega e Suiça. Destes 31 países, dezessete (55\%) possuem como sistema principal o seguro social (como o Brasil), frequentemente combinado a um pilar assistencial ou universal; todos os demais (exceção feita à Islândia, que combina capitalização com um sistema universal) possuem sistemas multipilares, nos quais o seguro social está presente como um dos componentes.

Há diferenças sociais e econômicas marcantes entre o Brasil e o conjunto destes países, ${ }^{32}$ mas a comparação se justifica pela relativa convergência do grau de cobertura de idosos nesse conjunto e pelos ganhos analíticos obtidos pela observação

32. Trata-se de países com renda alta, estágio de desenvolvimento social mais elevado e sistemas previdenciários com características distintas, na comparação com o brasileiro (marcado, por exemplo, pelas peculiaridades da previdência rural), mas que possuem patamar de cobertura semelhante ao brasileiro (diferentemente da América Latina e do Caribe) e os quais, em geral, funcionam sob a lógica de seguro social (se não unicamente, ao menos combinadamente com outros pilares). 
de sociedades em estágios bem mais avançados de transformação demográfica. Nos países europeus, em geral, a transição demográfica rumo a populações mais envelhecidas já ocorreu e foi acompanhada por transformaçóes nos sistemas de proteção social, adaptando-os às necessidades de populaçóes mais concentradas no topo da estrutura etária. Por um lado, as iniciativas governamentais brasileiras, nesse contexto mais amplo, são menos compreensivas e robustas e, sem mudanças, dificilmente poderão fazer frente aos câmbios demográficos vivenciados no país; por outro lado, deve-se considerar que o Brasil dispóe de menos recursos que os países desenvolvidos para o financiamento de políticas públicas (Costanzi, Ansiliero e Amaral, 2018).

Um aspecto relevante, como já ressaltado em Costanzi, Ansiliero e Amaral (2018), diz respeito à velocidade e ao momento em que os diferentes grupos de países enfrentaram ou enfrentarão mudanças demográficas mais marcantes. No Brasil, bem como na América Latina como um todo, o envelhecimento populacional se dará em ritmo mais intenso que o já observado nos países europeus, e estas nações, em sua maioria, enfrentaram esse fenômeno quando já possuíam patamar de riqueza e desenvolvimento mais elevado que o padrão latino-americano médio. ${ }^{33}$

Essas comparaçóes são fundamentais para o entendimento dos desafios a serem enfrentados pelo país, pois o Brasil e os demais países da região terão possivelmente menos tempo e menos recursos disponíveis para os ajustes necessários à sustentabilidade do sistema previdenciário. Em levantamento mais antigo (2010), mas ainda pertinente, o patamar da despesa previdenciária brasileira básica (apenas do RGPS) destoa até mesmo em comparação aos países latino-americanos e caribenhos, ainda que se leve em conta que estes possuem, em média, cobertura de idosos inferior à observada no Brasil. ${ }^{34}$

33. Segundo estudos e as projeções elaboradas pela Comissão Econômica para a América Latina e o Caribe (Cepal, 2017), o processo de envelhecimento na América Latina tem determinado o aumento da proporção de idosos na população, sendo esperado, até 2050, um forte incremento na participação de pessoas com 60 anos ou mais. Sobre 0 caso brasileiro, ver, por exemplo, IBGE (2019a).

34. Segundo estudo conjunto da Cepal e da OIT, os dados de oito países representativos da região (Argentina, Brasil, Chile, Colômbia, Costa Rica, Guatemala, México e Peru) indicam que, em média, 57,7\% dos idosos de 65-69 anos e $51,8 \%$ dos idosos com 70 anos ou mais não recebem aposentadorias contributivas. No Brasil, mesmo se excluídos os beneficiários de BPC/Loas, a cobertura supera largamente este referencial médio. Para mais detalhes, ver Cepal e OIT (2018). 


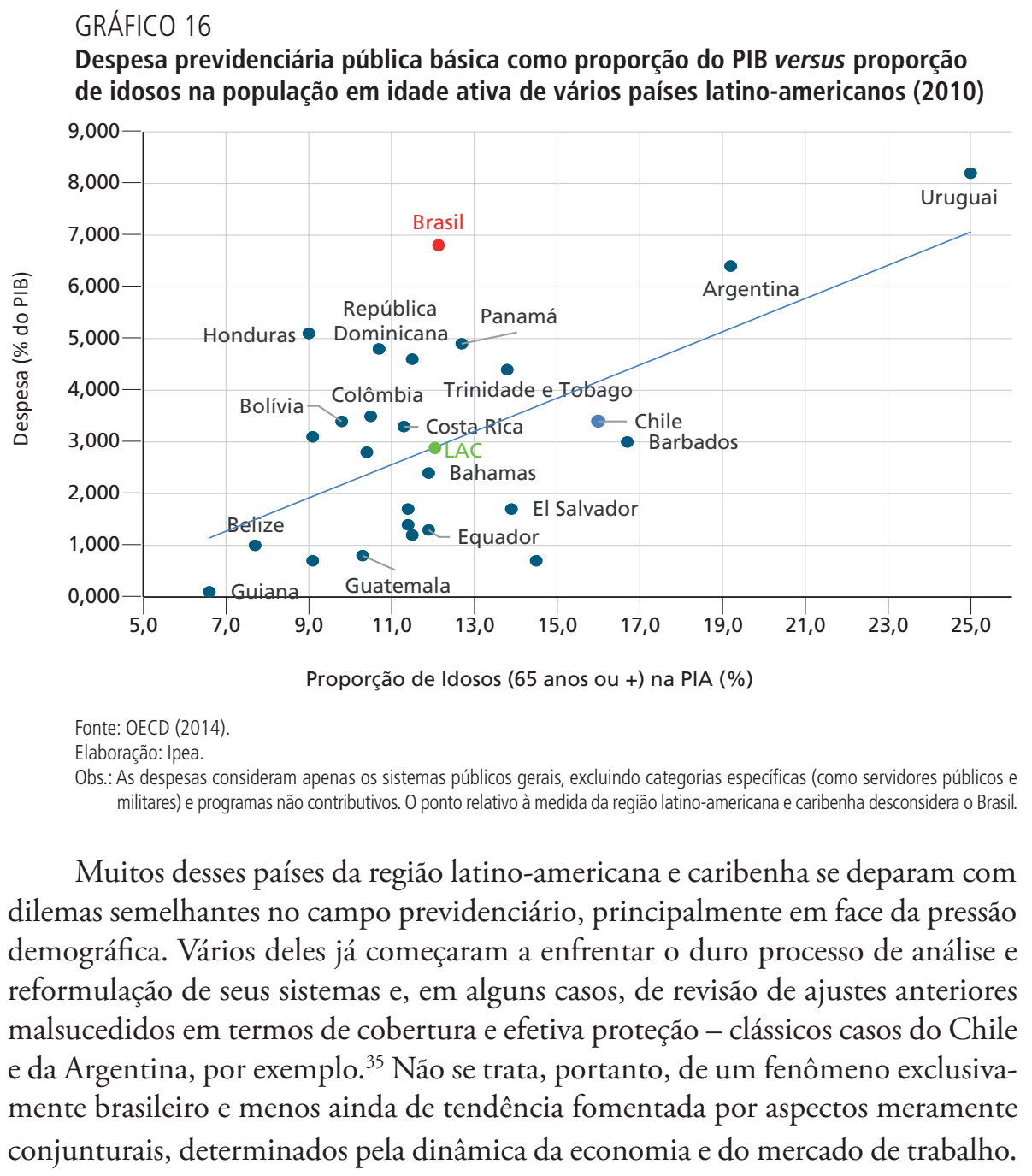

\section{CONSIDERAÇÕES FINAIS}

A crise econômica experimentada pelo país desde 2015 tem gerado turbulências e rebatimentos negativos no mercado de trabalho brasileiro e na cobertura previdenciária, produzindo um agravamento do quadro de desequilíbrio pré-existente (e crescente) no RGPS. Nos RPPS, as trajetórias e magnitudes dos resultados são gastos com proteção social, deixando o país em situação bem mais delicada que a indicada pelo gráfico 16. Ver, nesse sentido, Castiñeira (2018). Dados mais recentes, que ilustram esse quadro (ainda que com métrica distinta da utilizada neste trabalho), podem ser obtidos na base de dados do The World Bank, Pensions: data. Disponível em: < https://bit. ly/2SZ4b1r>. 
distintas entre os entes federativos, mas, em termos agregados, nota-se tendência de crescimento mais acelerado da despesa, comparativamente à receita, em um processo claro de deterioraçáo do resultado previdenciário ainda no curto prazo. A crise econômica contribui, portanto, para os preocupantes resultados de curto prazo, mas os desafios enfrentados pela Previdência Social brasileira são fundamentalmente estruturais e fortemente determinados pela demografia e pela inadequada parametrização dos sistemas que a compóem.

Com base nesse diagnóstico, as propostas recentes de mudanças constitucionais defenderam alteraçóes importantes na Seguridade Social brasileira, aproximando-a das boas práticas internacionais em matéria previdenciária e preparando-a melhor para o desafio do envelhecimento populacional. Tais proposiçôes, especialmente após importantes ajustes promovidos em seus textos originais, preservaram as características fundamentais do sistema de proteção social do país e o respeito às Normas Mínimas da Seguridade Social preconizadas pela Convenção no 102 da Organizaçẫo Internacional do Trabalho (OIT), adotada pelo organismo em 1952 e ratificada pelo Brasil em 2008 (Decreto Legislativo no 269, de 19 de setembro de 2008, aceitando as seçôes II-X).

Esse documento, instrumento fundamental e referência principal para as demais convençóes da OIT relativas à Seguridade Social, ${ }^{36}$ estabelece padróes mínimos para seus nove componentes, de acordo com as contingências a serem cobertas: assistência médica, auxílios-doença, seguro-desemprego, aposentadoria por idade, auxílios-doença acidentários (associados a acidentes e/ou enfermidades laborais), benefícios familiares (em caráter fundamentalmente assistenciais), salário-maternidade, aposentadorias por invalidez (previdenciária e acidentária) e pensôes por morte.

Os princípios fundamentais da Convenção n⿳o 102 , respeitados pela reforma previdenciária aprovada no país, ${ }^{37}$ são: expansão paulatina da cobertura do sistema, abrangendo todos os setores de atividade, todas as categorias de trabalhadores e a

36. Entre outras, o Brasil também ratificou a Convenção no 128: Prestações por invalidez, velhice e sobreviventes (pensões por morte), que supera requisitos estabelecidos na Convenção no 102; a Convenção no 121: Benefícios no caso de acidente do trabalho e enfermidades profissionais; e a Convenção no 118: Igualdade de tratamento entre nacionais e estrangeiros em previdência social.

37. Nesse contexto, dois pontos alterados na tramitação da PEC no 6/2019 merecem destaque. Recomenda-se, por exemplo, que a concessão de API, quando condicionada a uma carência mínima de atividade ou contribuição, seja assegurada, ainda que em valor reduzido, ao segurado que houver completado ao menos parcialmente o requisito normal, abrindo espaço para a instituição de modalidades de aposentadoria parcial. As carências sugeridas (normal e parcial) na Convenção no 102 podem, naturalmente, ser definidas e ajustadas por cada país, mas a ideia principal da orientação parece ser a de que sejam evitadas regras únicas e inflexíveis para este quesito. Nesse sentido, a garantia do piso previdenciário e a manutenção da carência mínima em quinze anos evitam o endurecimento excessivo das regras de acesso, deixando o ajuste para a taxa de reposição dos segurados com maiores rendimentos. Claro que, no caso dos futuros segurados do sexo masculino, este tratamento dependerá da aprovação da PEC nำ133/2019, que define a carência de quinze anos mesmo para trabalhadores filiados após o início da vigência da EC no 103/2019. O segundo ponto trata do valor mínimo das pensões por morte, que, originalmente (pelo texto da PEC n 6/2019), poderia ser inferior ao piso previdenciário e que, pós-relatoria inicial no Senado Federal, retomou o patamar mínimo dos demais benefícios (nunca inferior ao salário mínimo). 
população em geral (mesmo inativa); garantia de um benefício mínimo aos segurados, em valor compatível com a preservação da dignidade humana; administração tripartite apoiada no diálogo social, mas com responsabilidade estatal na provisão de serviços e benefícios e na gestão das instituiçôes; financiamento coletivo mediante contribuiçôes sociais e/ou impostos; e avaliaçôes atuariais regulares, visando a sustentabilidade do sistema.

O desafio, contudo, é dinâmico e não se encerra com a aprovação da PEC no 6/2019, geradora da EC no 103 , de 12 de novembro de 2019. O Brasil deverá seguir se espelhando nas experiências exitosas internacionalmente e, calcando-se nas especificidades sociais, econômicas e laborais brasileiras, desenhar um sistema de proteção social cada vez mais justo e sustentável. A PEC no 287/2016 e, mais recentemente, a PEC no 6/2019 e a PEC no 133/2019, em muito favorecidas pelos consensos previamente alcançados em torno da primeira, ambas destituídas de excessos incluídos em suas versôes originais encaminhadas ao Congresso Nacional, são elementos importantes nesse sentido.

\section{REFERÊNCIAS}

ALBUQUERQUE, F. R. P. C. Tábuas de mortalidade segundo a situação do domicílio utilizando-se o Censo Demográfico 2010. Informe de Previdência, Brasília, v. 31, n. 5, maio 2019.

AMARAL, A. D. et al. A questáo de gênero na idade para a aposentadoria no Brasil: elementos para o debate. Brasília: Ipea, 2019. (Texto para Discussão, n. 2466). ANSILIERO, G.; COSTANZI, R. N.; FERNANDES, A. Z. Análise descritiva das políticas públicas de inclusáo previdenciária dos trabalhadores autônomos: $\mathrm{O}$ Plano Simplificado de Previdência Social (PSPS) e o microempreendedor individual (MEI). Brasília: Ipea, 2019a. (Texto para Discussão, n. 2546).

A cobertura previdenciária segundo a PNAD Contínua: uma proposta de mensuração da proporção de protegidos entre ocupados e idosos residentes no país. Brasília: Ipea, 2019b. (Texto para Discussão, n. 2469).

BRASIL. Ministério da Economia. Anuário Estatístico da Previdência Social: Suplemento do Servidor Público. Brasília: ME, 2017. Disponível em: <https:// bit.ly/2LnUV2B>.

CASTIÑEIRA, R. El Gasto Público en Seguridad Social. Econométrica, feb. 2018. Disponível em: <https://bit.ly/2WrPQgg>.

COSTANZI, R. N.; ANSILIERO, G.; AMARAL, A. D. Previdência Social. Boletim de Políticas Sociais: Acompanhamento e Análise, Brasília, Ipea, n. 25, 2018. Disponível em: <https://bit.ly/2X1rY33>. 
Previdência Social. Boletim de Políticas Sociais: Acompanhamento e Análise, Brasília, Ipea, n. 26, 2019. Disponível em: <https://bit.ly/2WZ9P60>. CEPAL - COMISSÃO ECONÔMICA PARA A AMÉRICA LATINA E O CARIBE. Estimaciones y proyecciones de población total, urbana y rural, y económicamente activa. Santiago: Cepal, 2017.

CEPAL - COMISSÃO ECONÔMICA PARA A AMÉRICA LATINA; OIT ORGANIZAÇÃO INTERNACIONAL DO TRABALHO. Coyuntura laboral en América Latina y el Caribe. La inserción laboral de las personas mayores: necesidades y opciones. CEPAL; OIT, mayo 2018. n. 18. Disponível em: <https:// bit.ly/2Wrf3r9>.

GROSSI, M. E.; SILVA, J. G.; CAMPANHOLA, C. O fim do êxodo rural? Espaço e Geografia, v. 4, n. 1, p. 37-56, jan./jun. 2001.

IBGE - INSTITUTO BRASILEIRO DE GEOGRAFIA E ESTATÍSTICA. Atlas Nacional do Brasil Milton Santos. Rio de Janeiro: IBGE, 2010.

. Projeçóes da populaçáo: Brasil e Unidades da Federação - Revisão 2018. Rio de Janeiro: IBGE, 2019a.

. Microdados da Pesquisa Nacional por Amostra de Domicílios Contínua 2018. Rio de Janeiro: IBGE, 2019 b.

OECD - ORGANISATION FOR ECONOMIC CO-OPERATION AND DEVELOPMENT. Pensions at a Glance: Latin America and the Caribbean. OECD Publishing, 2014. Disponível em: <https://bit.ly/2WB23PP>.

SCHETTINI, B. P.; PIRES, G. M. V.; SANTOS, C. H. M. Previdência e reposição no serviço público civil federal do Poder Executivo: microssimulaçóes. Brasília: Ipea, 2018. (Texto para Discussão, n. 2365). 


\section{ASSISTÊNCIA SOCIAL ${ }^{1}$}

\section{APRESENTAÇÃO}

A Agenda 2030 para o desenvolvimento sustentável, da Organização das Naçóes Unidas (ONU), preconiza que "a erradicação da pobreza em todas as suas formas e dimensóes, incluindo a extrema pobreza, é o maior desafio global e um requisito indispensável para o desenvolvimento sustentável" (ONU, 2015). No Brasil, a política de assistência social ocupa lugar central nos esforços do Estado para a superação da pobreza e da desigualdade, ofertando proteção social por meio de serviços e benefícios, dadas as suas atribuiçóes constitucionais e legais. Mas em que medida essa política contribui com o alcance das metas que compóem o primeiro Objetivo do Desenvolvimento Sustentável (ODS 1), Acabar com a pobreza, em todas as suas formas, em todos os lugares? Este capítulo avança na resposta a essa questão. Para tanto, analisam-se as contribuiçóes e desafios da política de assistência social e, em particular, do seu conjunto de serviços, benefícios e programas que atuam no sentido das transformaçóes almejadas.

O capítulo se divide em cinco seçóes, incluindo esta apresentação e a conclusão. $\mathrm{Na}$ seção 2, são apresentadas as metas e indicadores que compóem o ODS 1, sendo discutida brevemente a relação dessas metas com a política de assistência social. A seção 3 apresenta um diagnóstico geral da política de assistência social, abordando a sua evolução nos últimos anos, com foco em 2018. Analisam-se seus principais benefícios - Programa Bolsa Família (PBF) e Benefício de Prestação Continuada (BPC) - e serviços socioassistenciais. Essa seção também discute alguns dos desafios impostos pelo Novo Regime Fiscal (NRF) e as restriçóes orçamentárias decorrentes da política fiscal, apontando seus efeitos na política de assistência social. Analisa-se, ainda, a evolução da participação social nesta política.

A seção 4 reflete sobre as tendências observadas na transiçẫo para a nova gestão do governo federal, tendo como fio condutor as possibilidades de alcance das metas do ODS, dadas as medidas anunciadas e o novo contexto político oferecido pelo governo empossado em 2019. Por fim, na seção 5, conclui-se discutindo o cada vez mais tortuoso caminho para o cumprimento das metas nacionais de erradicação da pobreza em todas as suas formas, ressaltando o crescente distanciamento da agenda dos ODS. 


\section{ODS 1 E A POLIITICA DE ASSISTÊNCIA SOCIAL}

Nesta seção são apresentadas brevemente as metas do ODS 1, de maneira a informar o diagnóstico e as possibilidades de alcançá-las a partir da perspectiva dos serviços e benefícios da política de assistência social. O ODS 1, Acabar com a pobreza, em todas as suas formas, em todos os lugares, traz um desafio mundial ambicioso a ser atingido até 2030. Foi formulado com base na atualização das metas de redução da pobreza dos Objetivos do Milênio (ODM), após o sucesso na diminuição do número de pessoas extremamente pobres no mundo, principalmente entre 1990 e 2015 (Souza e Vaz, 2019). Essa trajetória bem-sucedida criou um ambiente para a apresentação de metas mais audaciosas, que preconizam a erradicação da pobreza extrema até 2030. Assim, além de postular maiores exigências no que diz respeito à insuficiência de renda, as metas do ODS se alinham com uma perspectiva multidimensional do que implica ser pobre no mundo (Alkire, 2013; Barros, Carvalho e Franco, 2006). ${ }^{2}$

$\mathrm{O}$ conceito de pobreza multidimensional tem sido cada vez mais utilizado pelo Programa das Naçóes Unidas para o Desenvolvimento (PNUD) e por pesquisadoras(es) ${ }^{3}$ da área. Com frequência, ele vem acompanhado da distinção entre pobreza monetária, baseada na renda individual e familiar, e pobreza não monetária. O cotejamento de dimensões não monetárias nos indicadores de pobreza compóe a principal contribuição metodológica dessa linha de investigação, que advoga por uma percepção mais alargada da pobreza. Nesse contexto, o conceito é frequentemente associado ao de desenvolvimento humano e à "abordagem das capacidades" de Sen (2018), interpretando a pobreza como a privação de liberdades vitais e do respeito a direitos (Alkire, 2013; Lopes, Macedo e Machado, 2003). Com efeito, o índice global de pobreza multidimensional compóe, desde 2010, o Relatório de Desenvolvimento Humano. ${ }^{4}$

$\mathrm{Na}$ definição de indicadores ou índices sintéticos multidimensionais, são comumente elencados aspectos como vulnerabilidade, acesso a serviços e políticas públicas, trabalho, moradia adequada, violações de direitos, entre outros (Souza e Vaz, 2019; Barros, Carvalho e Franco, 2006). A definição dessas métricas, principalmente indicadores, no entanto, ainda carecem de consenso. O próprio conjunto dos ODS, enquadrado nessa perspectiva multidimensional, ${ }^{5}$ assim como as propostas brasileiras de metas e indicadores, revela os desafios de se estabelecer maneiras de se mensurar os impactos da ação estatal na superação da pobreza multidimensional, como será possível observar mais adiante.

2. Os ODS, assim como eram os ODM, podem ser considerados o que se caracterizou como uma técnica de abordagem de painel (dashboard approach), na qual diferentes indicadores de pobreza são analisados para a determinação dos níveis de pobreza de uma população (Alkire et al., 2015).

3. 0 uso do gênero masculino para expressar a totalidade de um grupo ou categoria tem o efeito de tornar simbolicamente invisivel as mulheres e suas experiências. Dessa forma, optou-se pela adoção de linguagem inclusiva neste documento, com o uso de palavras flexionadas no feminino e masculino, como forma de dar visibilidade à participação feminina na política de assistência social. Elas são as principais titulares do PBF e são a grande maioria entre as(os) usuárias(os), trabalhadoras(es), gestoras(es) e representantes nos conselhos em todos os níveis de gestão do Sistema Único de Assistência Social - Suas (Brasil, 2018b).

4. Disponível em: <https://bit.ly/3cnH08g>.

5. Os ODS, assim como eram os ODM, podem ser considerados uma abordagem de painel (dashboard approach), na qual diferentes indicadores de pobreza são analisados para a determinação dos níveis de pobreza de uma população (Alkire et al., 2015). 
QUADRO 1

Metas do ODS 1

\begin{tabular}{|c|c|}
\hline Metas globais & Propostas de adequação das metas ao contexto nacional \\
\hline $\begin{array}{l}1.1 \text { - Até } 2030 \text {, erradicar a pobreza extrema para todas as } \\
\text { pessoas em todos os lugares, atualmente medida como pessoas } \\
\text { vivendo com menos de US\$1,25 por dia. }\end{array}$ & $\begin{array}{l}\text { Até } 2030 \text {, erradicar a pobreza extrema para todas as pessoas em todos } \\
\text { os lugares, medida como pessoas vivendo com menos de PPC } \$ 3,20 \\
\text { per capita por dia ( } R \$ 238 / \text { mês). }\end{array}$ \\
\hline $\begin{array}{l}1.2 \text { - Até } 2030 \text {, reduzir pelo menos à metade a proporção de } \\
\text { homens, mulheres e crianças, de todas as idades, que vivem } \\
\text { na pobreza, em todas as suas dimensões, de acordo com as } \\
\text { definições nacionais. }\end{array}$ & $\begin{array}{l}\text { Até } 2030 \text {, reduzir à metade a proporção de homens, mulheres e } \\
\text { crianças, de todas as idades, que vivem na pobreza monetária e não } \\
\text { monetária, de acordo com as definições nacionais. }\end{array}$ \\
\hline $\begin{array}{l}1.3 \text { - Implementar, em nível nacional, medidas e sistemas de } \\
\text { proteção social adequados, para todos, incluindo pisos, e até } \\
2030 \text { atingir a cobertura substancial dos pobres e vulneráveis. }\end{array}$ & $\begin{array}{l}\text { Assegurar para todos, em nível nacional, até } 2030,0 \text { acesso ao sistema } \\
\text { de proteção social, garantindo a cobertura integral dos pobres e das } \\
\text { pessoas em situação de vulnerabilidade. }\end{array}$ \\
\hline $\begin{array}{l}\text { 1.4 - Até 2030, garantir que todos os homens e mulheres, } \\
\text { particularmente os pobres e vulneráveis, tenham direitos } \\
\text { iguais aos recursos econômicos, bem como o acesso a serviços } \\
\text { básicos, propriedade e controle sobre a terra e outras formas } \\
\text { de propriedade, herança, recursos naturais, novas tecnologias } \\
\text { apropriadas e serviços financeiros, incluindo microfinanças. }\end{array}$ & $\begin{array}{l}\text { Até } 2030 \text {, garantir que todos os homens e mulheres, particularmente } \\
\text { os pobres e as pessoas em situação de vulnerabilidade, tenham acesso } \\
\text { a serviços básicos, novas tecnologias para produção, tecnologias de } \\
\text { informação e comunicação, serviços financeiros e segurança no acesso } \\
\text { a terra e recursos naturais. }\end{array}$ \\
\hline $\begin{array}{l}1.5 \text { - Até } 2030 \text {, construir a resiliência dos pobres e daqueles } \\
\text { em situação de vulnerabilidade, e reduzir a exposição e vulner- } \\
\text { abilidade destes a eventos extremos relacionados com o clima } \\
\text { e outros choques e desastres econômicos, sociais e ambientais. }\end{array}$ & Meta mantida sem alteração. \\
\hline $\begin{array}{l}\text { 1.A - Garantir uma mobilização significativa de recursos a partir } \\
\text { de uma variedade de fontes, inclusive por meio do reforço da } \\
\text { cooperação para o desenvolvimento, para proporcionar meios } \\
\text { adequados e previsíveis para que os países em desenvolvimento, em } \\
\text { particular os países menos desenvolvidos, implementem programas } \\
\text { e políticas para acabar com a pobreza em todas as suas dimensões. }\end{array}$ & $\begin{array}{l}\text { Garantir recursos para implementar programas e políticas para erradicar } \\
\text { a pobreza extrema e combater a pobreza. }\end{array}$ \\
\hline $\begin{array}{l}\text { 1.B - Criar marcos políticos sólidos em níveis nacional, regional } \\
\text { e internacional, com base em estratégias de desenvolvimento a } \\
\text { favor dos pobres e sensíveis a gênero, para apoiar investimentos } \\
\text { acelerados nas ações de erradicação da pobreza. }\end{array}$ & $\begin{array}{l}\text { Fortalecer marcos políticos e institucionais para garantir a efetividade } \\
\text { e a sustentabilidade das ações de erradicação da pobreza. }\end{array}$ \\
\hline
\end{tabular}

Fonte: Souza e Vaz (2019).

Obs.: PPC - paridade de poder de compra.

Como é possível observar no quadro $1,{ }^{6}$ a meta global 1.1 trata da erradicação da pobreza extrema, relacionada à renda. A meta dos ODS postula a superação da pobreza extrema em PPC $\$ 1,90$ per capita por dia. ${ }^{7}$ No entanto, a proposição elaborada pelo Brasil adapta essa linha de maneira a estabelecer alvos mais exigentes, dado o diagnóstico de que a incidência da pobreza já é consideravelmente baixa no Brasil e que, dessa forma, haveria condiçóes para assumir uma linha que vá além das exigências

6. Na apresentação deste boletim, discute-se a adequação das metas globais ao contexto brasileiro. Esse debate segue as orientações contidas na Agenda 2030, sobre a necessidade de se pactuarem metas locais que se adaptem aos contextos de cada país.

7. A proposta de adaptação brasileira sugere a utilização da referência monetária de dólar internacional (PPC\$), "dólar na unidade monetária expressa pela paridade de poder de compra" (Ipea, 2018, p. 26). 
das metas globais (Souza e Vaz, 2019; Brasil, 2018b). Desse modo, a linha de pobreza per capita (PPP) recomendada para o Brasil foi a de PPC\$ 3,20. O grupo de trabalho que elaborou a recomendação ainda sugeriu que a meta seria considerada alcançada quando o percentual da populaçáo abaixo da linha da pobreza estivesse abaixo de $3 \%$ do total ${ }^{8}$ e que o indicador relacionado (populaçáo abaixo da linha de extrema pobreza) incluísse o recorte de cor ou raça, além dos já enunciados na pactuação global.

A meta 1.2 também trata da pobreza baseada em renda, mas menciona a noção de dimensôes da pobreza, o que no Brasil foi proposto abordar enunciando aspectos monetários e não monetários, sob a justificativa de que a redação original trazia de maneira vaga a referência a essas dimensóes (Ipea, 2018). Apesar de a meta global preconizar o estabelecimento de parâmetros nacionais para a fixação de linhas de pobreza, não se verifica uma definição oficial delas, tanto no aspecto monetário como no não monetário (Souza e Vaz, 2019). No que diz respeito ao aspecto monetário, uma possibilidade seria a utilização de uma linha de PPC \$ 5,50 per capita por dia, a linha mais elevada comumente utilizada para comparação internacional. Sendo assim, a proposta existente é a de que, no Brasil, sejam utilizadas as PPP de PPC\$ 3,20 para caracterizar a pobreza extrema e de PPC\$ 5,50 para a pobreza. Quanto aos aspectos não monetários, ainda não existem propostas de mensuração da meta, dada a complexidade e falta de consenso sobre a elaboraçáo de indicadores (Ipea, 2018).

A meta 1.3 abrange medidas e sistemas de proteção social, atentando-se principalmente para pobres e pessoas em situaçáo de vulnerabilidade. A proposta de transposição para o contexto brasileiro reforçou a necessidade de assegurar cobertura integral dessa população, por se considerar que já existe no país um sistema de proteção social abrangente e que o obstáculo aqui tem mais relação com a garantia de acesso do que com a implementação (Ipea, 2018). Entretanto, como se apontará na seção 3, os problemas de cobertura da proteção social no Brasil hoje não se restringem à implementação, abarcando também o desenho das políticas e o seu financiamento.

O acesso a recursos produtivos é o principal tema da meta 1.4, que na proposição nacional foi simplificada, abordando principalmente direitos civis e os "insumos necessários à participação no processo produtivo" (Ipea, 2018, p. 36). A redação da meta original global 1.5 foi mantida para o contexto brasileiro, na proposta elaborada sob coordenação do Ipea. Ela ressalta a importância de se garantir condiçóes para que pessoas pobres e em situação de vulnerabilidade tenham capacidade de lidar com eventos extremos ou desastres - resiliência (Ipea, 2018). Como aconteceu com o exercício de adequação nacional das metas 1.3 e 1.4 , a proposta brasileira existente até o momento não identificou os indicadores nacionais relacionados à meta global 1.5 .

8. Os estudos sobre pobreza tendem a considerar erradicada, quando a pobreza atinge patamares residuais e não iguais a zero, sendo convencional utilizar a métrica de 3\%. Como apontam Souza e Vaz (2019, p. 8), " isso ocorre em função de erros de mensuração, volatilidade de renda e outras idiossincrasias inevitáveis, as quais fazem que seja impossível reduzir literalmente a zero o número de pobres de acordo com as pesquisas domiciliares". 
Por sua vez, as metas 1.A e 1.B são definidas como metas de implementação, postulando recursos cruciais para o atingimento das metas finalísticas. A primeira aborda a necessidade de se garantir recursos para a implementação de programas e políticas para erradicar a pobreza em todas as suas dimensôes. Na sugestão de adaptação nacional, o enunciado reforça o papel do Estado brasileiro no financiamento das políticas, mas não há definição de um patamar de volumes de recursos a serem mobilizados e esse também é mais um caso em que não foram apontados possíveis indicadores nacionais para acompanhamento da meta. A proposição de adequação brasileira da meta global 1.B optou por utilizar o termo fortalecer, tendo em vista que já houve avanços importantes no estabelecimento de marcos legais e um arcabouço de políticas de erradicação da pobreza. O debate em torno das possíveis metas nacionais ainda não apontou indicadores que possam ser utilizados pelo país no monitoramento das açôes para o cumprimento da meta.

Em resumo, o alcance das metas do ODS 1 depende da performance da política de assistência social. As metas pactuadas tratam da redução da pobreza, em termos monetários e não monetários, bem como do acesso ao sistema de proteção social. As metas também abordam a garantia do financiamento de políticas de desenvolvimento social, assim como sua gestão e institucionalização. Seu conteúdo se relaciona diretamente, portanto, com a política de assistência social, que tem como público cidadâs, cidadãos e grupos em situaçóes de vulnerabilidade e risco social, e oferta a eles proteção social por meio de serviços, benefícios e programas regulados e financiados pelo poder público.

\section{ESTADO DA ARTE DA POLÍTICA E SUA CONTRIBUIÇÃO PARA O ALCANCE DAS METAS}

A Constituição Federal de 1988 reconhece a assistência social como responsabilidade pública e direito daqueles que dela necessitarem, independente de contribuição previdenciária. A política de assistência social, por um lado, vincula-se, de modo amplo, a todas as metas do ODS 1 . Os benefícios assistenciais atuam diretamente no incremento da renda das famílias, tendo importante papel na superação da pobreza monetária no país. No caso do $\mathrm{PBF}$, seu desenho vinculado à frequência à escola e ao acompanhamento de saúde favorece ganhos de redução da pobreza também nessas dimensôes. Por outro lado, a estrutura de serviços socioassistenciais - equipamentos e serviços, estrutura e servidores - são não só os responsáveis por viabilizar o acesso ao PBF, ao BPC (juntamente ao Instituto Nacional do Seguro Social - INSS) e aos benefícios eventuais, como também contribuem para reduzir vulnerabilidades e riscos sociais por meio do acolhimento e do trabalho social com famílias e indivíduos que se encontram com laços de sociabilidade fragilizados ou rompidos.

Paralelamente a isso, os mecanismos de participação social, consolidados no âmbito da política de assistência social, contribuem para a democratização dos processos de tomada de decisão e se inserem no conjunto de estratégias para a 
promoção dos princípios, objetivos e metas da Agenda 2030. Nesta seção, a análise se debruça sobre esses três eixos, com o propósito de evidenciar os elos entre a política de assistência social - por meio de benefícios, serviços e participação social - e as possibilidades de efetivação dos compromissos internacionais do Estado brasileiro com a promoção do desenvolvimento sustentável.

\subsection{Os benefícios socioassistenciais e seu impacto na extrema pobreza}

Os índices de pobreza no Brasil foram reduzidos de forma significativa durante as últimas duas décadas, como mostra o gráfico 1 . A redução verifica-se independentemente da linha de pobreza utilizada - seja a linha internacional de extrema pobreza (PPP 1,90), seja a linha nacional de extrema pobreza sugerida para o ODS (PPP 3,20 ), ou a proposta nacional de linha de pobreza (PPP 5,50), como discutido na seção 2. De acordo com os dados da Pesquisa Nacional por Amostra de Domicílios (PNAD), do Instituto Brasileiro de Geografia e Estatística (IBGE), entre 2003 e 2014 a queda foi constante. Em 2014, o Brasil apresentou suas menores taxas de pobreza para todas as linhas, mas essa trajetória se modifica a partir de 2015. A mudança de direção coincide com a crise econômica e resultou em um aumento da pobreza de 2,4 pontos percentuais (p.p.), 2,5 p.p. e 2,8 p.p., respectivamente para as linhas de PPP 1,90, PPP 3,20 e PPP 5,50, entre 2014 e 2018. ${ }^{?}$

GRÁFICO 1

Evolução da taxa de pobreza da população total (2001-2018)

(Em \%)

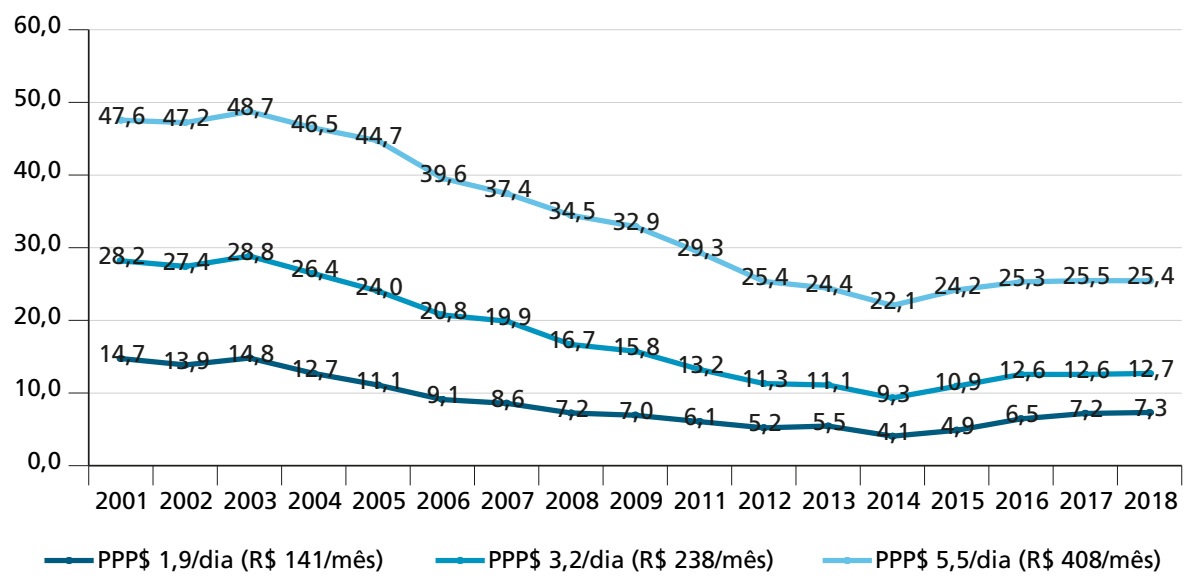

Fontes: PNAD/IBGE, nos dados até 2015; PNAD Contínua/IBGE, nos dados de 2016 a 2018. Disponível em: <https://bit.ly/2yi4tt4>. Elaboração dos autores.

Obs.: Em 2010 não foi realizada a PNAD, e sim o Censo; por isso, esse ano não foi representado no gráfico.

9. As mudanças na forma de captação de informações da PNAD podem ter algum efeito na estimativa, mas não na mudança de direção do gráfico. Foram utilizados dados da PNAD para 2001-2015 e da PNAD Contínua para 2016 e 2017. Se considerarmos apenas os dados da PNAD Contínua desde 2012, a tendência de crescimento da pobreza se confirma. Para mais informações sobre o cálculo da renda na PNAD Contínua, ver IBGE (2017). 
O pagamento de benefícios socioassistenciais tem impactos significativos sobre o nível de pobreza da população brasileira. Para demonstrar o grau de aderência entre os benefícios e a redução da pobreza, mensurou-se a contribuição do BPC e do PBF para o atingimento da meta 1.1. O gráfico 2 apresenta a proporção da população brasileira vivendo com menos de PPC $\$ 3,20$ por dia, ou seja, em situação de extrema pobreza de acordo com a linha nacional proposta, com e sem benefícios assistenciais. Observa-se que, na ausência de ambos os benefícios, a quantidade de extremamente pobres (PPP $\$ 3,20$ por dia), em 2018, representaria 15,7\% da população, e não 12,7\%, mostrando que, unidos, $\mathrm{BPC}$ e $\mathrm{PBF}$ reduziram em 3,0 p.p. a taxa de extrema pobreza nesse ano.

Vale ressaltar que, em 2001, os benefícios assistenciais diminuíram a extrema pobreza muito ligeiramente. A porcentagem de extremamente pobres, desconsiderando-se os benefícios socioassistenciais, seria de $28,4 \%$, e não de $28,2 \%$, reduzindo apenas 0,2 p.p. em relação ao cenário com benefícios. Certamente isso era esperado em um contexto no qual o PBF não existia, os programas de transferência de renda anteriores a ele estavam ainda embrionários e o público do BPC era expressivamente inferior ao atual, tanto pela composição demográfica da população quanto pelo valor do salário mínimo (SM) de 2001, que era pouco mais da metade do verificado para 2018 em termos reais.

GRÁFICO 2

Evolução das taxas de extrema pobreza com e sem benefícios assistenciais (2001-2018) (Em R\$ 238/mês)

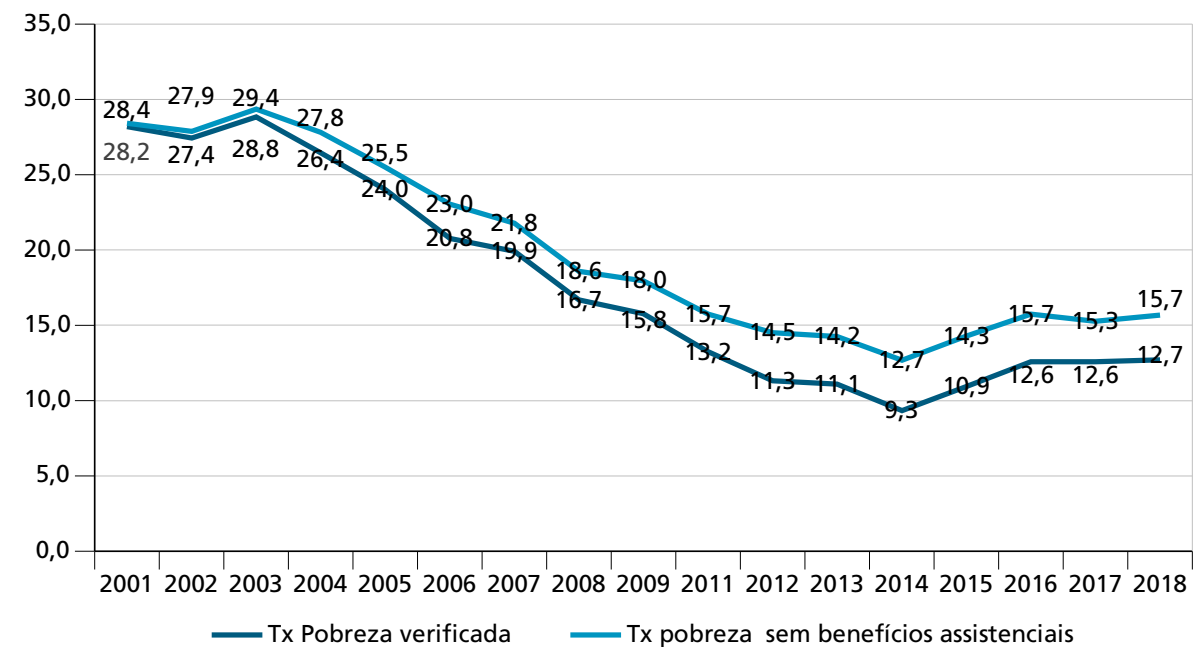

Fontes: PNAD/IBGE, nos dados até 2015; PNAD Contínua/IBGE, nos dados de 2016 a 2018. Disponível em: <https://bit.ly/2yi4tt4>. Elaboração dos autores.

Obs.: Em 2010 não foi realizada a PNAD, e sim o Censo; por isso, esse ano não foi representado no gráfico. 
Chama atenção como a contribuição dos benefícios para a redução da pobreza ao longo do tempo foi crescente a cada ano, atingindo seu ápice em 2015, quando $\mathrm{BPC}$ e PBF reduziram a extrema pobreza em 3,3 p.p. De fato, há algumas exceçóes: em 2007 e 2013, os benefícios assistenciais reduziram sua participação na diminuição da pobreza quando comparados aos anos imediatamente anteriores. Mas isso possivelmente se deve à ampliação expressiva do PBF ocorrida em 2006 e 2011-2012: em 2006, o PBF teve grande aumento de público (chegou-se ao atingimento da meta de 11,2 milhões de famílias) e em 2011-2012 houve não só o aumento da meta de atendimento do PBF (de 12,9 milhóes para 13,9 milhóes de famílias), mas principalmente as duas grandes rodadas de criação e expansão do Benefício da Superação da Pobreza Extrema (BSP).

A primeira expansão, em junho de 2011, ofertou o BSP a todas as famílias beneficiárias que se mantinham em extrema pobreza e tinham crianças entre 0 e 6 anos. A segunda foi feita em novembro de 2011, portanto só captada na PNAD de 2012, e estendeu esse benefício aos núcleos familiares com crianças ou adolescentes entre 7 e 15 anos. A terceira expansão do BSP, que o ampliou para todas as famílias beneficiárias em extrema pobreza, independentemente de sua composição, ocorreu em fevereiro de 2013. No entanto, como a maior parte das famílias em extrema pobreza possuem crianças ou adolescentes, o grande efeito do BSP se fez sentir em 2012. ${ }^{10}$ Os anos de 2014 e 2015 representam o período de maior impacto desses benefícios para a redução da extrema pobreza: na comparação entre cenários com e sem benefícios para aferição de renda da população, a diferença na taxa de pobreza foi de 3,3 p.p. A partir daí, os dados revelam uma queda do impacto desses benefícios para a reduçáo da extrema pobreza por dois anos consecutivos, 2016 e 2017, seguido por uma elevação em 2018, ano em que os benefícios reduziram a extrema pobreza em 3,0 p.p.

Observando o gráfico 3, que demonstra a participação proporcional do $\mathrm{PBF}$ e do BPC na redução da pobreza que juntos propiciam, corrobora-se a importância do triênio 2011-2013 para o programa, período no qual o PBF responde por 70\% ou mais da redução da pobreza efetuada via benefícios assistenciais. 
GRÁFICO 3

Contribuição proporcional dos benefícios assistenciais para a redução da extrema pobreza (2003-2018)

(Em R\$ 238/mês)

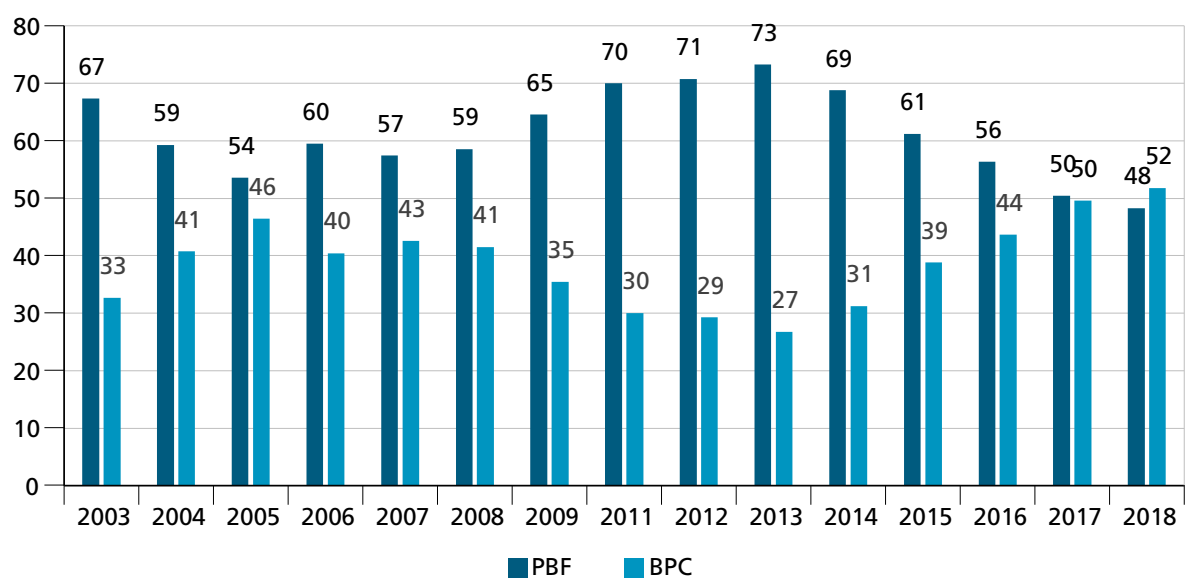

Fonte: PNAD/IBGE, nos dados até 2015; PNAD Contínua/IBGE, nos dados de 2016 a 2018. Disponível em: <https://bit.ly/2yi4tt4>. Elaboração dos autores.

Obs.: Em 2010 não foi realizada a PNAD, e sim o Censo; por isso, esse ano não foi representado no gráfico.

Após esse período, a participação do $\mathrm{PBF}$ cai, igualando-se proporcionalmente à do BPC, benefício com linha de elegibilidade bastante superior ao da transferência condicionada. Essa mudança da trajetória do impacto dos benefícios socioassistenciais para redução da extrema pobreza também pode ser corroborada pela análise do gasto com tais benefícios pelo governo federal (gráfico 4). Esses gastos também apresentaram saltos em 2004 e 2006, seguidos de um crescimento aparentemente constante até 2014. A partir de 2014, o gasto com benefícios socioassistenciais arrefece sua trajetória de crescimento, permanecendo em um patamar de gastos pouco superior ao de 2014 , com um aumento de apenas $\mathrm{R} \$$ 3 bilhóes em 2018. 
GRÁFICO 4

Evolução das despesas federais com benefícios socioassistenciais - BPC e PBF (2002-2018)

(Em R\$ bilhões de 2018)

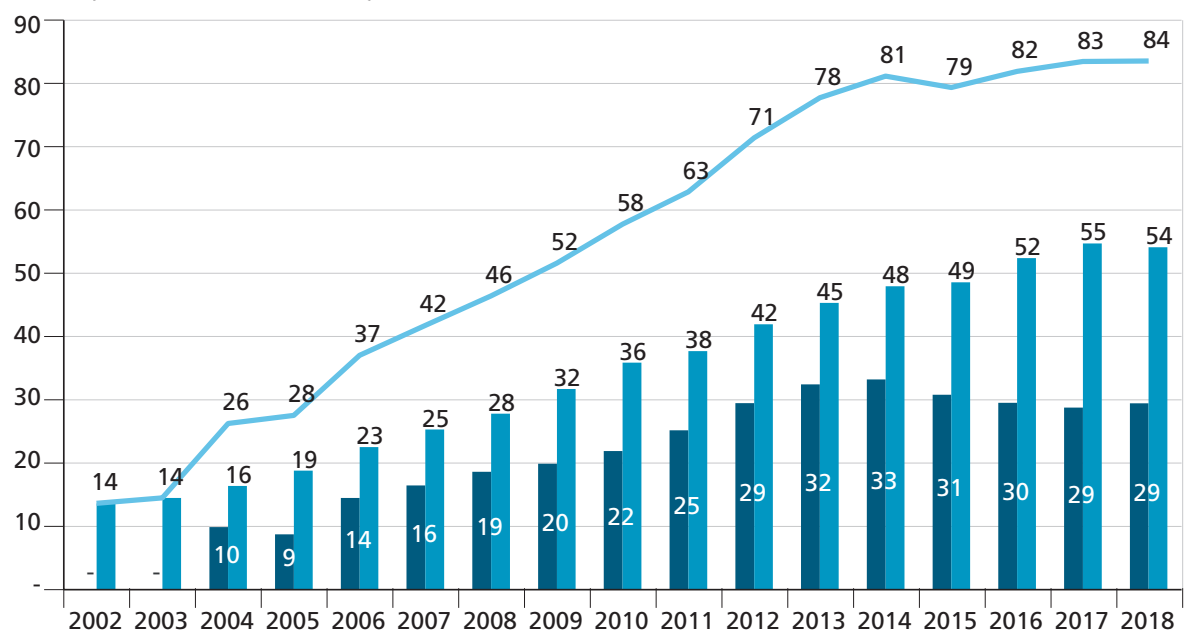

$\square$ PBF $\quad$ BPC Total geral

Fonte: Siga Brasil. Disponível em: <https://bit.ly/3g5CBcl>.

Elaboração dos autores.

Como aponta o gráfico 3, parte expressiva dessa mudança é explicada pela trajetória decrescente de gastos do PBF a partir de 2014. Essa redução decorre principalmente do não reajuste no valor do benefício de forma sistemática nesse período. De fato, o reajuste do PBF nunca foi regular: vale lembrar que entre julho de 2009 e março de 2014 esse programa não passou por alteraçóes no seu componente principal (Ipea, 2019); entretanto, o crescimento do financiamento de recursos nesse período foi impactado pelo BSP, que propiciou expressiva elevação do valor médio do benefício. A partir de 2014, houve reajuste do benefício em 2016 e 2018.

Contudo, ainda que o PBF tenha sido reajustado em 5,7\% em julho de 2018, a despesa com esse programa cresceu, em termos reais, apenas 2,0\% em relação a 2017. A redução do aumento dos gastos com o PBF, a partir de 2015, coincide com a diminuição do efeito dos benefícios na redução da extrema pobreza a começar em 2016. Observa-se, assim, a relevância não só dessas políticas, mas da garantia de financiamento adequado para elas como ações estratégicas do Estado brasileiro para de fato erradicar a extrema pobreza, como postulado pelo ODS 1.

Outro fator que influencia a dinâmica de crescimento do PBF é a quantidade de famílias que recebem o benefício mensalmente (gráfico 5). A média desse fator aumentou de forma sistemática até 2014. Todavia, apresentou uma trajetória 
descendente a partir de 2014, retornando a esse mesmo patamar em 2018. Ou seja, durante o período de recessão (2015-2016) e estagnação (2017-2018) econômica, a quantidade média mensal de famílias que receberam o benefício do PBF foi menor que em períodos anteriores, marcados por trajetórias econômicas mais satisfatórias. ${ }^{11}$

\section{GRÁFICO 5}

Quantidade média mensal de famílias beneficiárias do PBF (2004-2018)

(Em milhões)

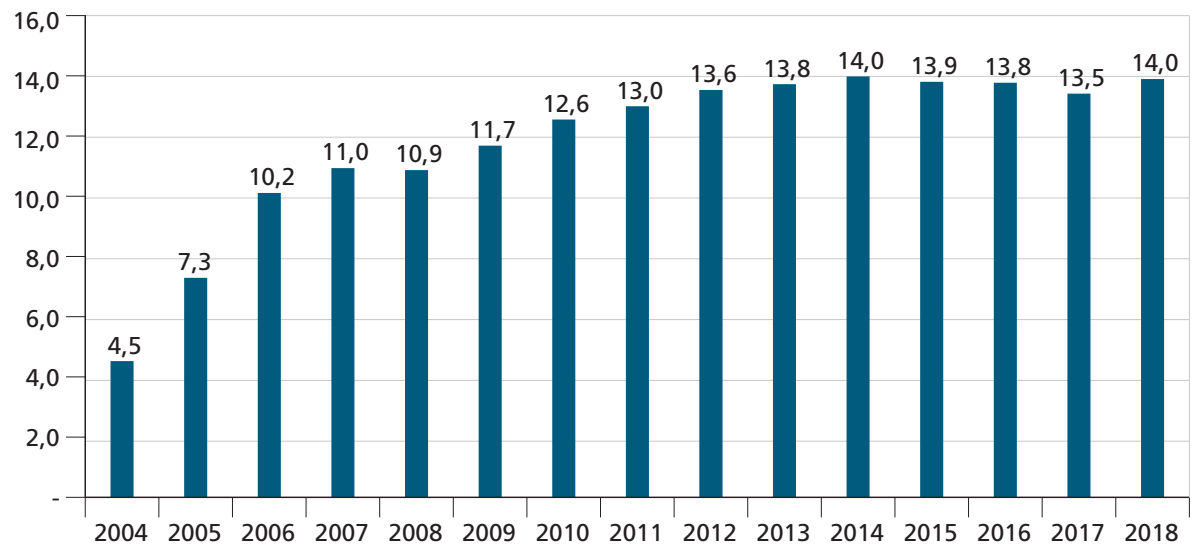

Fonte: Brasil. Disponivel em: <https://bit.ly/2KX2b5x>.

Para fins de análise da contribuição do PBF para a redução da pobreza extrema no âmbito do ODS 1, deve ser ressaltada a dimensão dos baixos valores utilizados para a definição das linhas de extrema pobreza e pobreza do programa. A linha de extrema pobreza do PBF, em 2017 , era de $\mathrm{R} \$ 85,00$ e a de pobreza, $\mathrm{R} \$ 170,00$, isto é, valores bem inferiores àqueles correspondentes aos PPC $\$ 3,20$ propostos pelo grupo de trabalho que elaborou o exercício de adaptação da meta 1.1 ao contexto brasileiro. Isso se torna mais grave se levarmos em conta que o benefício do PBF é basicamente a única proteção monetária disponível às famílias sem adultos incluídos na proteção social contributiva. Dado que metade das crianças e adolescentes brasileiros encontra-se no um terço mais pobre da população (Soares, Bartholo e Osorio, 2019), o valor monetário da linha administrativa utilizada pelo programa está, em especial para esse público, abaixo do necessário para o alcance da meta de erradicação da pobreza extrema. ${ }^{12}$

11. É relevante lembrar que a queda na média anual verificada em 2017 deve-se primordialmente, como abordado na edição deste boletim referente ao ano em questão, ao intento do governo em reduzir a meta de atendimento em quase 1 milhão de famílias em julho de 2017, o que foi revertido rapidamente em consequência das críticas veiculadas pela imprensa. A este respeito, ver Ipea (2019, p. 13-14).

12. Enquanto a linha sugerida de PPC\$3,20 per capita por dia corresponde a uma renda de $\mathrm{R} \$ 238,00$ per capita mensais, a linha administrativa para a extrema pobreza do PBF corresponde, desde 2018, a R\$89,00 per capita mensais (Brasil, 2018a). Para pobreza, considera-se uma renda inferior a R\$ 178,00 mensais. Segundo Souza e Vaz (2019), ao utilizar a linha de PPC \$3,20 como parâmetro, é possível observar que um terço da população extremamente pobre no Brasil não tinha acesso ao PBF, dadas as baixas linhas de elegibilidade do programa. 
Com efeito, conforme bem apontado no Caderno ODS 1, um dos desafios para que os benefícios assistenciais tenham maior contribuição para a redução da pobreza consiste em sua universalização entre os pobres (Souza e Vaz, 2019). Nesse relatório, estima-se que $87,8 \%$ dos idosos brasileiros (65 anos ou mais) possuíam previdência social ou $\mathrm{BPC}$ em $2017 .{ }^{13}$ Entre os 12,3\% náo cobertos, cerca de $40 \%$ está na metade inferior da distribuição de renda brasileira. No caso do BPC para pessoas com deficiência $(\mathrm{PcD})$ e do $\mathrm{PBF}$, a universalização é bem menos satisfatória: cerca de $70 \%$ das pessoas extremamente pobres com deficiência possuíam BPC em $2013^{14}$ e 66\% dos extremamente pobres receberam o auxílio do PBF em 2017, utilizando-se a linha sugerida de PPC\$ 3,20 por dia.

Essas coberturas insuficientes refletem dois problemas fundamentais, que deveriam ser enfrentados para a universalização dos benefícios assistenciais: os valores das linhas de pobreza administrativas utilizadas e as dificuldades de acesso aos benefícios. Em 2018, os PPC \$3,20 por dia equivaliam a uma renda familiar mensal per capita de $\mathrm{R} \$ 238,00$, valor muito próximo ao da linha do BPC nesse ano (um quarto do $\mathrm{SM}$ ou $\mathrm{R} \$ 238,50$ ), mas muito superior às linhas de elegibilidade do PBF ( $\mathrm{R} \$ 85,00$ e R \$ 170,00 em 2017). Faz-se urgente, portanto, estabelecer uma política de recomposição das linhas definidoras de pobreza e extrema pobreza desse programa, assim como dos valores de seus benefícios.

Em termos de dificuldades de acesso, embora o Cadastro Único para Programas Sociais do Governo Federal (Cadastro Único) seja uma base bastante abrangente e o volume da atualização cadastral não tenha se reduzido no período analisado, há que se considerar que a própria dinâmica de concessão dos benefícios do PBF possivelmente não dê conta de abarcar a pobreza transitória integralmente. $\mathrm{O}$ mesmo problema é percebido no caso do BPC, com a diferença fundamental de que, quando instado, o judiciário tem frequentemente se pronunciado em favor da concessão do benefício, uma vez verificada a necessidade (Penalva, Diniz e Medeiros, 2010). Isso vale mesmo que a renda familiar observada seja superior à linha administrativa de concessáo, e é particularmente verdade quando se comprova a existência de gastos excepcionais, o que é comum no caso do BPC para PcD.

As dificuldades de acesso têm se agravado, entretanto isso gera a crescente necessidade de remediar judicialmente as decisóes do Instituto Nacional de Seguro Social (TCU, 2018). Em 2004, 6,7\% das(os) novas(os) beneficiárias(os) obtiveram o BPC para PcD por via judicial. Em 2015, esse número chegou a 29,6\% (Brasil, 2016a). Entre os idosos, esse número passou de $1,0 \%$ para $10,8 \%$ no mesmo período. Em outros termos, distintamente do $\mathrm{BPC}$, o $\mathrm{PBF}$ não é um direito. Famílias que superam meio SM de rendimento deixam o programa, assim como

\footnotetext{
13. Disponível em: <https://bit.ly/2UpSFxa>.

14. A medição é feita para 2013, em decorrência da limitação dos dados necessários, visto que as informações mais precisas sobre a população brasileira com deficiência são coletadas pela Pesquisa Nacional de Saúde, realizada pela última vez em 2013.
} 
aquelas que não realizam a atualização cadastral, conforme prazos e critérios estabelecidos. Ocorre que, dada a volatilidade de rendimento da população mais pobre, as famílias que saem do programa podem, em circunstância de um ou dois meses, voltar a experimentar a pobreza. Para acessar o PBF, deveráo novamente atualizar seu cadastro e aguardar a concessão - durante esse intervalo entre acesso ao cadastramento e concessão, estarão desprotegidas.

No que se refere ao BPC, tendo em vista que é um direito com linha de elegibilidade próxima à adotada pelo ODS e que o valor de seu benefício (1 SM) é capaz de retirar suas(seus) beneficiárias(os) da condição de pobreza, o maior entrave na ampliação da capacidade desse benefício contribuir com a redução da pobreza consiste nas dificuldades de acesso por seus potenciais beneficiárias(os). Apesar de visar ao aprimoramento da política, alteraçôes importantes na forma de atendimento aos pleiteantes e nos requisitos cadastrais podem impor restriçóes no acesso ao benefício. ${ }^{15}$

\subsection{Os serviços socioassistenciais e seu impacto na pobreza}

Os serviços socioassistenciais se consolidaram como importante iniciativa estatal no combate à pobreza no país, constituindo-se referência nos territórios em termos de proteção social de pessoas e famílias a partir de estratégias de fortalecimento de vínculos familiares e comunitários, da promoção do acesso ao mercado de trabalho e da garantia de direitos e liberdades, entendidos como dimensôes nucleares na mensuração da pobreza não monetária (Alkire, 2013; Lopes, Macedo e Machado, 2003). Nos últimos quinze anos, a política de assistência social ganhou capilaridade ao ampliar a oferta de equipamentos públicos para responder, por meio dos serviços, a uma série de situaçóes de vulnerabilidade social e de violaçáo de direitos (Paiva et al., 2016).

Como apontado por Paiva et al. (2016), frequentemente a vulnerabilidade social é relacionada à ausência/insuficiência de renda e, portanto, açóes como o acompanhamento de famílias beneficiárias dos programas de $\mathrm{BPC}$ e PBF são prioritárias nos centros de referência de assistência social (Cras). Essa vulnerabilidade social também pode aparecer nos diferentes ciclos de vida e nas situações de deficiência, associadas a experiências de negligência ou isolamentos, ou, ainda, a contextos de falta de acesso a serviços públicos ou de exclusão social. As violaçóes de direitos, por sua vez, podem ter origem nas relaçóes familiares e comunitárias ou nas situaçóes de pobreza. Dessa forma, os serviços socioassistenciais têm como objetivo não só garantir o atendimento aos indivíduos em situação de vulnerabilidade ou de violação de direitos, mas também às suas famílias.

O Suas, sistema nacional que congrega esses serviços, tem nos Cras e nos centros de referência especializados de assistência social (Creas) seus principais equipamentos socioassistenciais. Os Cras são essenciais para a prestação de serviços como o Serviço de Proteção e Atendimento Integral à Família (Paif) e o Serviço de

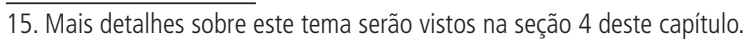


Convivência e Fortalecimento de Vínculos (SCFV). São também estratégicos para as açóes de transferência de renda e redução da pobreza, pois garantem o acesso ao PBF e ao BPC. Segundo dados da Pesquisa de Satisfação de Usuários (2018), ${ }^{16}$ a procura pelos benefícios socioassistenciais é a razão mais comum $(59,7 \%)$ para o comparecimento de cidadâs(ãos) a estes equipamentos. O segundo motivo mais mencionado é a realização de alguma atividade (19,3\%), como atendimentos no âmbito do Paif ou atividades em grupos do SCFV.

Desde sua criação, o Suas experimentou uma rápida expansão, principalmente ao longo dos anos 2000. Conforme Mesquita, Paiva e Jaccoud (2020), em 2005 havia 2.292 unidades públicas de referência do Suas (1.978 Cras e 314 Creas). Em 2018, o número total de unidades chegou a 11.024, ou seja, uma quantidade quase cinco vezes maior. ${ }^{17}$ Tal expansão foi acompanhada de um expressivo aumento da capilaridade da rede de atendimento da política de assistência social nos municípios. Os dados do Censo Suas ${ }^{18}$ revelam que em 2007 os Cras cobriam 56,6\% dos municípios, percentual que chegou a 99,4\% em 2018.

Mesmo com a expansão do número de unidades de Cras, alguns indicadores seguem o sentido oposto ao da expansão da rede socioassistencial. Eles expressam uma redução da oferta de serviços importantes para a população em situação de vulnerabilidade. De acordo com o RMA, em 2018 houve redução de 17\% na média mensal do acompanhamento de famílias em situação de vulnerabilidade ${ }^{19}$ no Paif. Na dinâmica dos acompanhamentos familiares, além das famílias que já participam regularmente das atividades de acompanhamento, novas famílias são inseridas no serviço continuado do Paif todos os meses. Em 2018, o número de famílias inseridas também foi menor, havendo uma queda de 57\% na média de novos casos acompanhados em relação a 2012.

Também cabe notar que se tomarmos como referência os parâmetros definidos pelas Normas Operacionais Básicas do Suas (NOB/Suas) 2005, ainda há um deficit de cobertura ${ }^{20}$ dos Cras, como apresentado na tabela 1 . No Nordeste, percebe-se

16. Pesquisa realizada por demanda da Secretaria Nacional de Assistência Social (SNAS) com usuárias(os) dos Cras, em visitas às unidades no período de realização da pesquisa, entre abril e junho de 2018. Foi estruturada por meio de amostra representativa para todos os Cras brasileiros.

17. Segundo dados do Censo Suas para o período 2007-2018 (disponível em: <https://bit.ly/36gl6kg>).

18. Nessa publicação, a variação entre períodos analisados se deve à disponibilidade das pesquisas e dos registros acerca da política de assistência social. 0 Censo Suas foi criado em 2007, no entanto, a maior parte dos equipamentos e serviços passou a ser investigada pela pesquisa nos anos seguintes. 0 mesmo ocorre com o Registro Mensal de Atendimentos (RMA), criado em 2012, mas que apenas incluiu outras unidades além dos Cras em anos seguintes. Em ambos os casos, tanto do Censo Suas quanto do RMA, determinadas informações passaram a ser coletadas apenas anos depois do início das pesquisas e dos registros.

19. O acompanhamento familiar se refere a um conjunto de intervenções desenvolvidas com as famílias de forma continuada, buscando a superação das vulnerabilidades vivenciadas (Brasil, 2012).

20. No âmbito da política de assistência social, estabeleceu-se em 2005 com a NOB/Suas um padrão para o referenciamento de famílias em situação de pobreza nos territórios e para o número mínimo de Cras que idealmente devem ser implantados de acordo com o porte do município. A partir desses padrões, é possível calcular um indicador com 0 número de Cras necessários para se atingir o parâmetro proposto na NOB (deficit de Cras). Levando-se em conta 0 número de Cras existentes no município, de famílias referenciadas e em situação de pobreza, define-se a medida da cobertura das unidades no território. 
a maior ausência: seriam necessárias 539 novas unidades de Cras para observar os padróes de cobertura e referenciamento propostos pela normativa, levando mais de 2 milhóes de famílias a não contarem com cobertura da proteção social básica, o que, por sua vez, representa mais da metade das famílias descobertas no país (54\%). Considerando-se o já mencionado papel dos Cras na erradicação da pobreza, aumentar a sua cobertura permanece como um desafio para o alcance das metas do ODS 1.

TABELA 1

Deficit de cobertura de Cras e Creas $^{1}$ (2018)

\begin{tabular}{|c|c|c|c|c|c|}
\hline Região & $\begin{array}{c}\text { Número de famílias } \\
\text { descobertas pelos } \text { Cras }^{2}\end{array}$ & Número de Cras & Deficit de Cras & Número de Creas & Deficit de Creas \\
\hline Norte & 668.316 & 634 & 160 & 254 & 30 \\
\hline Nordeste & 2.018 .889 & 2.671 & 539 & 1.026 & 37 \\
\hline Sudeste & 960.690 & 2.890 & 197 & 734 & 131 \\
\hline Sul & 10.436 & 1.541 & 3 & 415 & 25 \\
\hline Centro-Oeste & 81.929 & 624 & 19 & 235 & 19 \\
\hline Total & 3.740 .260 & 8.360 & 917 & 2.664 & 242 \\
\hline
\end{tabular}

Fontes: Cadastro Único (2018); Censo Suas 2018. Disponíveis em: <https://bit.ly/2yjabLn> e <https://bit.ly/36gl6kg>

Notas: ${ }^{1} 0$ cálculo foi realizado utilizando como base o número ideal de unidades por município, definido em normativas e orientações técnicas do Ministério da Cidadania (Brasil, 2005; 2011).

${ }^{2}$ Tendo como referência o número de famílias com renda até meio SM, cadastradas no Cadastro Único em dezembro de 2018.

Outro equipamento central nas estratégias de redução da pobreza são os Creas, principalmente quando se entende que uma dimensão da pobreza não monetária é a maior vulnerabilidade à violência e à violação de direitos (Ipea, 2018; Diprose, 2007). Esses equipamentos têm sido fundamentais para o combate a essas violações, que reforçam a situação de pobreza vivida por milhôes de brasileiras e brasileiros.

Ao contrário dos Cras, que buscam a prevenção do rompimento de vínculos, os Creas se caracterizam por atuar em casos que envolvam vínculos já rompidos, assim como em violações de direitos. É o principal equipamento a abordar as desigualdades interseccionais no Suas, com atendimento a mulheres em situação de violência, homofobia, abuso e exploração sexual de menores, entre outros. Cumpre, portanto, com o princípio da transversalidade de gênero presente nos ODS, atendendo as mulheres pobres na promoção da sua cidadania e autodeterminação, elementos-chave na discussão sobre a pobreza não monetária. Além disso, tem o papel de ofertar o Serviço de Proteção em Calamidades Públicas e Emergências Sociais, cujo objetivo é garantir a proteção social e reduzir a vulnerabilidade das pessoas de baixa renda expostas a calamidades e emergências, tal como apregoado na meta 1.5 do ODS 1.

A expansão dos Creas seguiu um ritmo mais lento que a dos Cras, uma vez que se trata de serviços mais especializados. De 2012 a 2018, o número de Creas subiu de 2.167 para 2.664, acompanhado também por um aumento da quantidade de trabalhadoras(es). No entanto, o número de profissionais que tem como principal 
atividade na unidade o Serviço de Proteção e Atendimento Especializado a Famílias e Indivíduos (Paefi) cresceu apenas $0,8 \%$. Os maiores aumentos estão relacionados a funcionárias(os) que tem como principal função as atividades de gestão dos Creas $(26 \%)$, entre outras atividades $(22 \%){ }^{21}$

Destaca-se, no conjunto de atividades ofertadas pelos Creas, o crescimento no número de atendimentos no âmbito do serviço de abordagem social, realizado em espaços públicos como praças e avenidas e voltados para pessoas em situação de rua. A abordagem visa identificar, nos territórios, "a incidência de situaçôes de risco pessoal e social, por violação de direitos, como: trabalho infantil, exploração sexual de crianças e adolescentes, situaçáo de rua, uso abusivo de crack e outras drogas, dentre outras" (Brasil, 2013, p. 6) e, consequentemente, atua em aspectos que são mencionados de forma recorrente em debates sobre pobreza multidimensional, tais como acesso a serviços de saúde e educaçáo, moradia e outras açóes relacionadas à proteçáo social (Alkire et al., 2015). Segundo dados do RMA dos Creas, houve um crescimento de $32 \%$ no número de pessoas abordadas entre 2012 e 2018 e de $34 \%$ no volume de abordagens realizadas. A intensificação do atendimento do serviço de abordagem foi acompanhada pelo aumento de cerca de $8 \%$ no número de profissionais que têm como principal atividade esse serviço (entre 2014 e 2018).

A abordagem social é, portanto, uma estratégia imediata de atendimento dessa população e identificação de carências e violações de direitos. A partir dessa atividade de busca ativa ou de demandas que chegam aos Creas, as pessoas em situação de rua podem eventualmente ser incluídas no acompanhamento de pessoas e famílias no âmbito do Paefi, com ações contínuas e sistemáticas visando à superação da situação de vulnerabilidade e de violação de direitos. Dessa maneira, para além do atendimento pontual, é possível atuar de forma mais robusta na superação de elementos multidimensionais da pobreza característicos dessa população.

Os dados do RMA revelam que o número de pessoas em situação de rua acompanhadas pelo Paefi caiu 31\% entre 2012 e 2018. Se em $2014^{22}$ elas correspondiam a 16,7\% do número de pessoas abordadas, em 2018 essa proporção baixou para $7,1 \%$. Apesar de o número de abordadas(os) não ter uma relaçâo diretamente clara com o número de pessoas nessa condição que ingressam no Paefi, o crescimento da identificaçáo de pessoas em situação de rua, refletido no aumento dos atendimentos no serviço de abordagem, concomitante com a reduçáo dos acompanhamentos de pessoas com essas características, pode indicar uma dificuldade dos Creas em garantir a cobertura do Paefi para determinados públicos que têm direito a acessar o serviço.

21. As atividades listadas no Censo Suas são de: gestão (administrativo); Paefi; serviço de proteção social a adolescentes em cumprimento de medida socioeducativa (MSE); serviço de abordagem social; serviço de proteção social especial para PCD, idosos e suas famílias; concessão dos benefícios eventuais; e cadastramento e/ou atualização cadastral (Cadastro Único). 22. Os dados sobre o serviço de abordagem social começaram a ser coletados pelo RMA apenas em 2014. 
A despeito do fortalecimento da rede socioassistencial do Suas no início do século XXI, o peso da crise econômica e a consequente política de austeridade fiscal adotada têm provocado restriçóes na oferta de serviços, o que pode inclusive dificultar o encaminhamento para acesso aos benefícios socioassistenciais. Os dados sobre os repasses federais aos municípios para os serviços do Suas revelam como essa política de austeridade tem afetado o financiamento da assistência social, com efeitos prováveis na redução da oferta pelos municípios. ${ }^{23}$

\section{GRÁFICO 6}

Evolução dos repasses ${ }^{1}$ federais aos municípios: serviços, programas e gestão (2002-2018)

(Em R\$ bilhões de 2018)

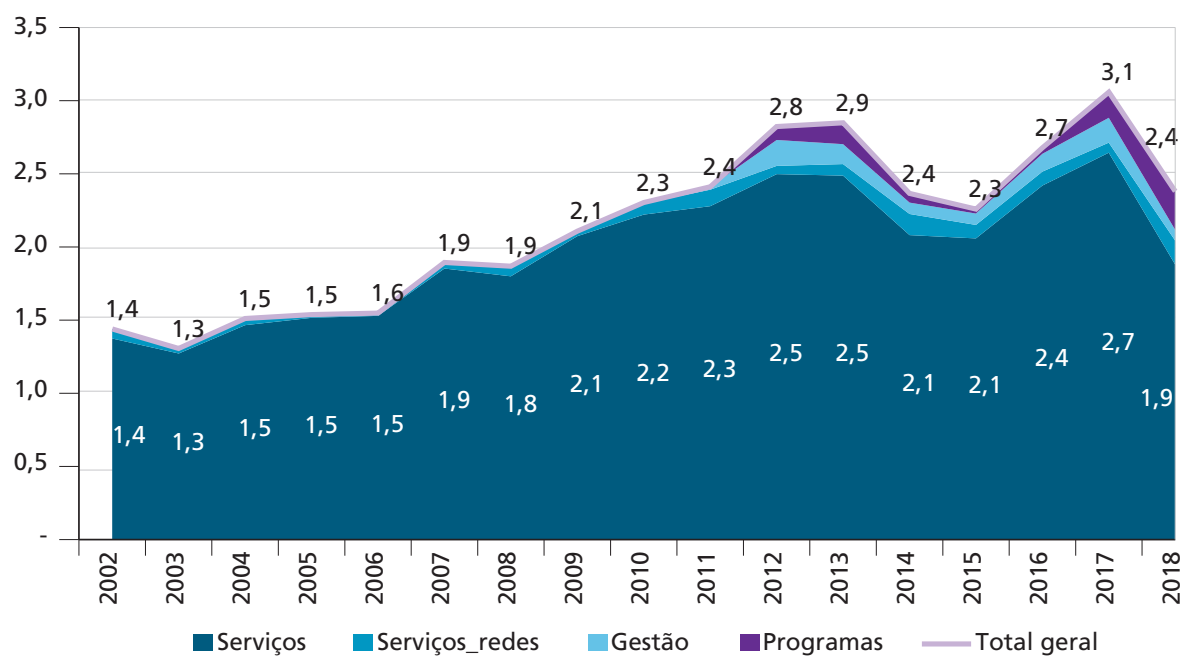

Fonte: Siga Brasil. Disponível em: <https://bit.ly/2Xdo1ay>.

Elaboração dos autores.

Nota: ${ }^{1}$ Os gastos correspondem ao valor total pago, incluindo o pagamento de restos a pagar.

Obs.: Em serviços, foram consideradas as transferências para financiamento dos serviços socioassistenciais ofertados pelos municípios em seus equipamentos públicos (Cras, Creas, centros POP etc.). Os recursos destinados à ampliação ou à reforma dos equipamentos socioassistenciais estão retratados na variável serviços_redes. Os repasses pertinentes à gestão referem-se ao Índice de Gestão Descentralizado do Suas (IGD-Suas) e os relativos aos programas, ao Acessuas Trabalho, na primeira onda, e ao Programa Criança Feliz (PCF), na segunda onda.

O gráfico 6 revela que a expansão de gastos com o Suas, exclusive benefícios, ocorreu até 2013, apresentando uma reversão a partir de 2014, que coincide com o início da crise econômica e política e sua repercussão fiscal. Em 2016 e 2017, os gastos aumentam, mesmo em tempos de restrição fiscal, e voltam a cair em 2018, uma queda de $29 \%$. Ainda que qualquer aumento do volume de repasses para o

23. Entre 2002 e 2018, a retração ou expansão de gastos da União com o Suas foi influenciada, principalmente, pelo comportamento das transferências federais aos municípios, uma vez que estes apresentaram uma participação estável nos gastos com o Suas, e foi responsável, em média, por cerca de 99\% dos recursos federais destinados a serviços, programas, apoio à gestão, funcionamento dos conselhos e vigilância socioassistencial (Mesquita, Paiva e Jaccoud, 2020). 
Suas seja positivo, esse crescimento atípico, principalmente o observado em 2017, que já foi detalhado na última publicação deste mesmo periódico (Ipea, 2019), só foi possível porque metade dos recursos foi repassada apenas em dezembro daquele ano, comprometendo a regularidade do financiamento e a oferta de serviços. Isso aconteceu porque, diante da crise fiscal, em 2016 e 2017 o governo lançou mão de expressivos contingenciamentos após as revisões das avaliçóes de receitas e despesas primárias. ${ }^{24}$

Segundo Tavares, Rodrigues e Moura (2016), o contingenciamento de 2016 foi suavizado gradativamente pelo afrouxamento da meta primária ${ }^{25}$ e, no final do ano, por receitas extras da repatriação de recursos do exterior. ${ }^{26}$ Em 2017, o descontingenciamento observado em dezembro tem como principal explicação o fato de a arrecadação efetiva de novembro ter sido bem acima do esperado, além da redução das despesas obrigatórias previstas no orçamento, conforme disposto no Relatório de Avaliação de Receitas e Despesas Primárias do final de 2017 (Brasil, 2017).

A análise dos repasses aos municípios entre 2015 e 2018, considerando o período acumulado de janeiro a novembro, mostra que o volume de repasses apresentou uma forte queda em 2016 e 2017 em relação aos anos anteriores. Até novembro de 2016, os recursos transferidos aos municípios corresponderam a 76\% do valor total transferido naquele ano; em 2017, esse valor correspondeu a $48 \%$ do realizado no ano. Dessa forma, a regularidade dos repasses foi comprometida nesses dois períodos, principalmente em 2017, ainda que os recursos tenham aumentado no fechamento do ano. Já em 2018, não se nota um grande volume de repasses no último mês do ano, advindos de descontingenciamento. Isso porque a crise fiscal atingiu fortemente o montante de recursos destinados ao Suas no ano todo. Fica evidente, portanto, que a crise fiscal pode afetar tanto a regularidade dos repasses quanto o volume destes, sendo ambos considerados um sério entrave à consolidação do Suas.

24. A Lei de Diretrizes Orçamentárias (LDO) determina que se façam relatórios de avaliações bimestrais sobre a realização de receitas e despesas orçamentárias, de modo a controlar a obtenção da meta fiscal estabelecida. Os relatórios são constituídos basicamente de parâmetros econômicos utilizados, memórias de cálculo das reestimativas de receitas e despesas e distribuição de eventual corte em despesas pelos poderes da União.

25. De acordo com os autores, o resultado primário a ser alcançado em 2016, exercício escolhido como base de projeção para o NRF, foi sendo reduzido para se tornar compatível com a maior despesa primária de que se tem notícia (19,9\% do produto interno bruto - PIB), sugerindo esforço imediato menor de ajuste, folga relativa nos primeiros anos de aplicação da nova regra fiscal e um tempo mais longo para se retornar ao equilíbrio.

26. Conforme os autores, esses recursos extras tiveram uma priorização clara dada pelas autoridades para o pagamento de restos a pagar (Tavares e Moura, 2017). 
GRÁFICO 7

Execução mensal do pagamento de serviços de proteção social do Suas (2015-2018) $7 \mathrm{~A}$ - Participação do gasto acumulado no mês no gasto anual

(Em \%)

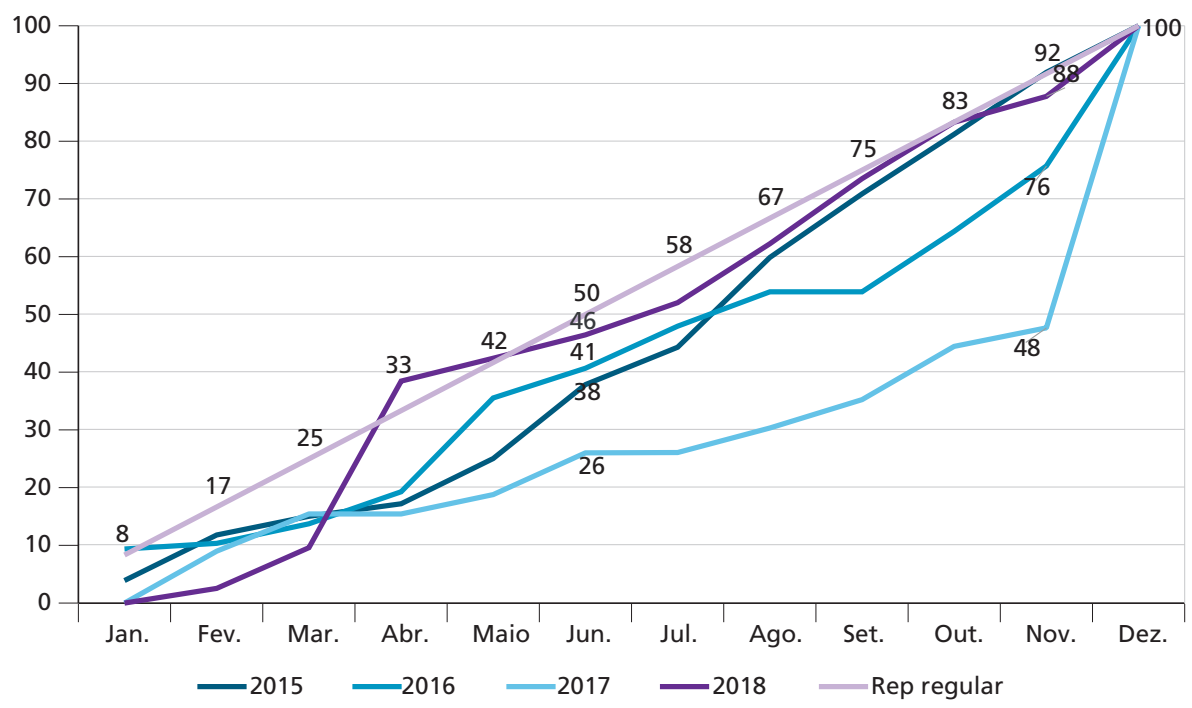

7B - Gasto acumulado no mês

(Em R\$ bilhões de 2018)

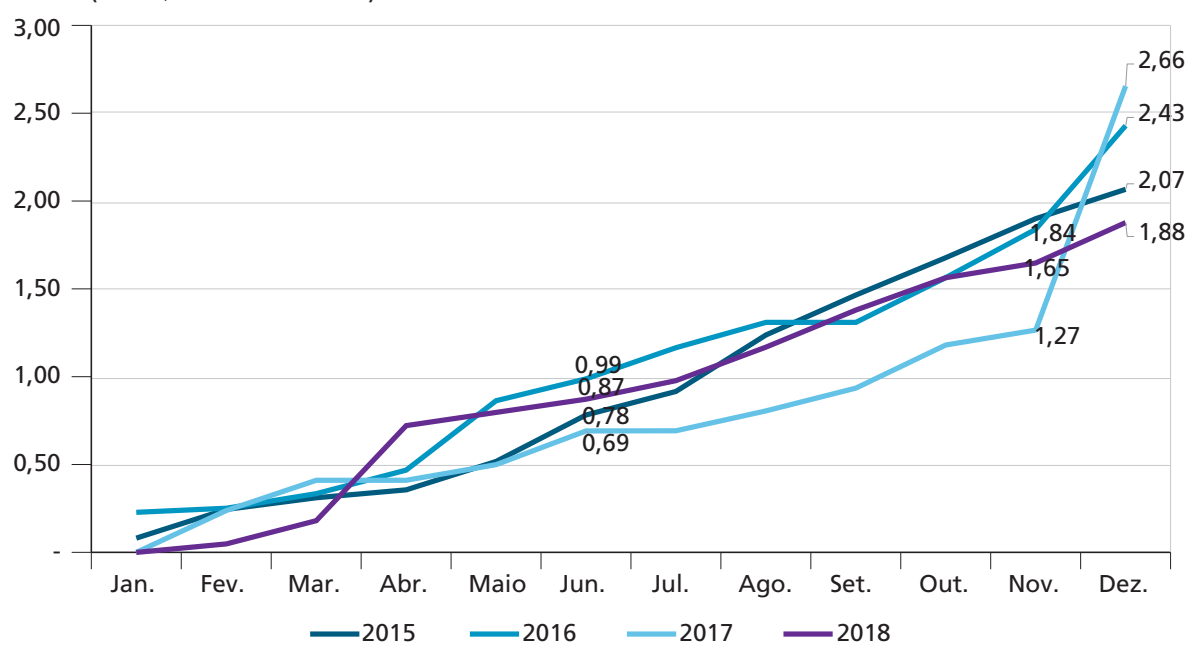

Fonte: Siga Brasil. Disponivel em: <https://bit.ly/2Xdo1ay>.

Elaboração dos autores.

Obs.: Valores pagos é igual a despesas pagas mais restos a pagar pagos. 
É importante ressalvar que, em contexto de restrição fiscal e subfinanciamento de atividades essenciais, a pasta responsável pela política de assistência social optou pela priorizaçáo de um novo programa, o PCF. Em 2018, enquanto os repasses a municípios destinados ao financiamento dos serviços do Suas ${ }^{27}$ reduziram 29\% em relação a 2017 (de $\mathrm{R}$ \$ 2,4 bilhóes para $\mathrm{R}$ \$ 1,9 bilhão), os recursos federais destinados ao PCF experimentaram um incremento de 36\% (de R \$ 175 milhóes para R \$ 238 milhóes). Portanto, a criação desse programa e a alteração da dinâmica dos repasses realizados aos municípios para o cofinanciamento de serviços, programas e gestão modificaram a configuração desses repasses: em 2016, quando não existia o PCF, 94\% dos repasses foram destinados exclusivamente aos serviços de proteção social (básica e especial); em 2018, esse percentual foi reduzido para 85\% do montante repassado aos municípios, enquanto os recursos destinados ao PCF corresponderam a $11 \%$ do total.

\section{TABELA 2}

Repasses aos municípios: IGD/Suas, serviços, PCF e demais programas (2016-2018)

(Em R\$ milhões de 2018)

\begin{tabular}{lrrrc}
\hline Repasses a municípios & \multicolumn{1}{c}{2016} & 2017 & 2018 & Variação 2018/2017 (\%) \\
\hline IGD/Suas & 123,21 & 170,88 & 74,05 & -57 \\
Serviços & $2.433,75$ & $2.659,50$ & $1.888,84$ & -29 \\
PCF & - & 175,19 & 238,06 & 36 \\
Demais programas & 40,96 & 1,86 & 28,05 & 1405 \\
Total & $\mathbf{2 . 5 9 7 , 9 3}$ & $\mathbf{3 . 0 0 7 , 4 3}$ & $\mathbf{2 . 2 2 9 , 0 0}$ & $\mathbf{- 2 6}$ \\
\hline
\end{tabular}

Fonte: Siga Brasil. Disponivel em: <https://bit.ly/2Xdo1ay>.

Obs.: Foram desconsiderados os recursos destinados à construção e/ou à ampliação dos equipamentos socioassistenciais.

A priorização pelo PCF fica mais evidente quando observada a trajetória de cofinanciamento do Paif, ${ }^{28}$ um dos principais serviços da proteção social básica, ofertados nos Cras: em 2016, estes recursos repassados aos municípios somaram a quantia de R \$ 673 milhôes, ${ }^{29}$ reduzindo expressivamente seu volume para R $\$ 430$ milhões em 2018, segundo informaçóes do Ministério da Cidadania. ${ }^{30}$ Enquanto isso, o PCF elevou seu montante para R 238 milhóes em 2018, conforme mencionado anteriormente.

27. Foram desconsiderados os recursos destinados à construção e/ou à ampliação dos equipamentos socioassistenciais. 28. A comparação do PCF com o Paif é pertinente, pois ambas as iniciativas possuem atividades similares junto ao mesmo público-alvo (gestantes, crianças com até 36 meses e suas famílias beneficiárias do PBF e crianças beneficiárias do BPC de até 72 meses e suas famílias). Ambas atuam na perspectiva da prevenção de riscos - sob o escopo da proteção básica - e possuem os Cras como espaço para o desenvolvimento das suas atividades. Ademais, ainda que as atividades desempenhadas pelos profissionais de cada iniciativa tenham especificidades, na prática dos municípios, ambas as equipes realizam visitas domiciliares às mesmas famílias, visto que o público prioritário do PCF também faz parte do público atendido e acompanhado pelo Paif.

29. Em reais de 2018.

30. Disponível em: <https://bit.ly/2RKnw5R>. 
Dado o cenário, as discussōes sobre o orçamento ocuparam espaço privilegiado nas reunióes do Conselho Nacional de Assistência Social (CNAS) e da Comissão Intergestores Tripartite (CIT), no contexto da política de assistência social, no decorrer de 2018. A redução do orçamento e a irregularidade dos repasses foram temas constantes, assim como os mecanismos de priorização de repasses, estabelecidos pelo governo federal como forma de lidar com a diminuição dos recursos financeiros disponíveis. Em outubro daquele ano, foi criado um grupo de trabalho de incidência política no âmbito do CNAS com vistas à recomposição do orçamento da assistência social a partir da articulaçâo com deputados e senadores para angariar apoio e apresentação de emendas parlamentares ao Projeto de Lei Orçamentária Anual (PLOA) 2019 e aos projetos de lei do Congresso Nacional (PLN) de crédito suplementar.

De fato, um dos efeitos da escassez de recursos no contexto político do governo federal foi o aumento da dependência da atuação do Congresso Nacional na destinação de recursos para a política de assistência social, retornando a cenários da década de 1990, quando a política dependia fortemente desse tipo de instrumento para se viabilizar. De acordo com estimativas do Colegiado Nacional de Gestores Municipais de Assistência Social (Congemas), havia em 2018 um deficit de cerca de R \$ 800 milhóes para cumprimento das despesas do ano. Parte desses recursos foi garantida por meio de emendas ao PLOA 2019 (aproximadamente R \$ 100 milhóes) e outra parcela pelo PLN no 44/2018 (pouco mais de $\mathrm{R} \$ 64$ milhóes). Apesar dos esforços, apontou-se que ainda havia um deficit orçamentário de R \$ 400 milhóes relativos ao exercício de $2018 .^{31}$

Ainda no que diz respeito ao constrangimento nos recursos, cabe ressaltar duas questôes. Primeiro, a decisão pela redução orçamentária segue o caminho contrário do que se conclama nos ODS - em particular nas metas de implementação 1.A e 1.B, que assinalam a importância de se garantir os meios para a execução de açôes de combate à pobreza no país. Isso torna improvável que o Brasil tenha bom desempenho no que se refere a elas. Segundo, o financiamento insuficiente dos serviços e benefícios socioassistenciais reforçam as deficiências de ambas.

Por um lado, a demanda reprimida por benefícios não permite que esse mecanismo seja acionado como uma das ferramentas de combate à pobreza. Por outro lado, as unidades de assistência social, ao terem seu financiamento federal constrangido, têm dificuldades em ofertar serviços como o Paif, o Paefi, o SCFV, assim como em gerir a concessão de benefícios tais como o PBF e os benefícios

31. Parte dos movimentos relacionados à incidência para aprovação de legislações que autorizavam crédito suplementar para a política foi capturada por meio de observação das reuniões e análise das atas do CNAS e do CIT. Outras informações complementares também foram coletadas por meio de relatos do Congemas e de outras instituições que acompanharam o processo de disputa em torno da recomposição orçamentária naquele ano. A perspectiva do Congemas sobre a tramitação dos projetos de lei e seu cálculo do deficit orçamentário estão disponíveis em: <https://bit.ly/2Un1MNX>. 
eventuais, levando a dificuldades no acesso a eles. Essas unidades também se tornaram estratégicas para a implantação do BPC, principalmente a partir de janeiro de 2018, quando passou a ser obrigatória a inscrição no Cadastro Único para o recebimento desse benefício. Dessa forma, o subfinanciamento dos centros socioassistenciais pode resultar em uma dificuldade de acesso a esses benefícios, bem como na piora da qualidade do processamento das demandas atendidas.

\subsection{A erradicação da pobreza e a participação social na assistência social}

Identificada como um avanço no debate em torno de objetivos globais de redução da pobreza e das desigualdades (Razavi, 2016), a abordagem da pobreza como um fenômeno complexo e multidimensional engloba também um conjunto de estratégias de promoção da participação social e accountability na gestão das açôes para alcance das metas dos ODS. Esse tema está endereçado em metas específicas do ODS $16,{ }^{32}$ mas deve ser operacionalizado por meio de açóes transversais, refletindo os princípios da integralidade e indivisibilidade dos objetivos e do enfoque inclusivo e participativo constantes na Agenda 2030 (ONU, 2018). Nesse sentido, a implementação dos objetivos requer esquemas de governança que proporcionem a participação de representantes "das populaçôes mais vulneráveis da sociedade na adaptação dos ODS ao contexto nacional, regional e local; na implementação, no monitoramento e na prestaçáo de contas da Agenda 2030" (ONU, 2018, p. 3).

Em relação à participação e à governança no escopo das açôes relacionadas à política de assistência social, como já descrito em outros boletins de política social (BPS), estão o CNAS e as conferências nacionais de assistência social. Também se destaca a CIT, que ocupa o papel de fortalecer o diálogo e a governança entre as três esferas de governo existentes no país.

Uma das principais características desse sistema participativo, particularmente conselhos e conferências, é sua representatividade, a qual expressa a organização dos grupos em torno da política de assistência social. No nível nacional, entidades privadas que prestam serviços de assistência social, organizaçóes de trabalhadoras(es) e representantes de usuárias(os) das políticas têm representação. Esse formato é repetido em maior ou menor grau nos níveis estadual e municipal. Os conselhos municipais de assistência social (CMAS), em especial, têm tido destaque no controle social da implementação das políticas de transferência de renda essenciais para a redução das desigualdades no país e para o alcance das metas do ODS $1 .{ }^{33}$

32. Particularmente as metas globais 16.7, Garantir a tomada de decisão responsiva, inclusiva, participativa e representativa em todos os níveis, e 16.10, Assegurar o acesso público à informação e proteger as liberdades fundamentais, em conformidade com a legislação nacional e os acordos internacionais (Ipea, 2018).

33. Os conselhos de assistência social têm diversas prerrogativas no controle social do PBF e do BPC, como apontado em Brasil (2018c), além de acompanhar e fiscalizar a execução de serviços e programas socioassistenciais. 
A presença de usuárias e usuários nas instituiçóes participativas e no controle social das políticas reforça os vínculos das ações de erradicação da pobreza no país com a Agenda 2030, principalmente no que diz respeito ao envolvimento das populaçôes mais vulneráveis da sociedade nos processos de tomada de decisão. Dados do Censo Suas indicam que, entre 2014 e 2018, houve aumento da porcentagem de conselhos que contam com a participação de usuárias(os). ${ }^{34} \mathrm{~A}$ porcentagem de conselhos nos quais havia usuárias(os) de serviços da proteção social básica passou de $47,1 \%$ para $59,3 \%$; os que contavam com beneficiárias(os) do PBF, de $42,9 \%$ para 55,8\%; e os que tinham representantes beneficiárias(os) ou de família de beneficiárias(os) do BPC, de 15,3\% para 29,1\%. ${ }^{35}$

Isso revela o potencial dessas instituiçóes em promover a inclusão de pessoas de baixa renda na implementação das políticas de erradicação da pobreza, apesar de, na maioria das vezes, não conseguirem garantir a participação efetiva daquelas(es) atendidas(os) por essas políticas, como apontado a seguir. A preocupação com a participação de usuárias e usuários e o aprimoramento do controle social na política têm se materializado em diversas açóes do CNAS nos últimos anos: na produção de cartilhas para informação de pessoas que utilizam os serviços e benefícios socioassistenciais; na formação de conselheiras e conselheiros acerca das prerrogativas das instituiçóes participativas em todos os níveis de governo; na governança e controle social de serviços e benefícios (CNAS, 2017; Brasil, 2018c); entre outras iniciativas. Esse tema também faz parte do planejamento da política de assistência social, estando presente nos pactos de aprimoramento ${ }^{36}$ da gestão municipal e estadual, assim como no Plano Decenal, ${ }^{37}$ sendo objeto de monitoramento constante por meio do estabelecimento de indicadores de gestáo e fortalecimento da participação, como o IDConselho. ${ }^{38}$

No entanto, a despeito de serem formalmente reconhecidos como atores que podem fazer parte desses arranjos participativos, ainda há um longo caminho para o fortalecimento das pessoas usuárias como segmento de representação no Suas, como apontado no último BPS. O segmento, ao contrário das organizaçóes de trabalhadoras(es) e entidades, organizou-se mais recentemente e o fez, sobretudo,

\footnotetext{
34. Disponível em: <https://bit.ly/36gl6kg>.

35. Outras características questionadas na pesquisa foram: representante de associação comunitária ou de moradores (de 60,4\% para 37,2\%); usuárias(os) de serviços socioassistenciais de proteção social especial (de 11,9\% para 17,3\%); representante de fórum ou coletivo de usuárias(os) (de 10,8\% para 8,1\%); e outros (de 22,8\% para 4,9\%).

36. A Resolução CIT no 13/2013 regulamenta as metas e prioridades do Pacto de Aprimoramento das gestões municipais entre 2014 e 2017. Apesar do fim do período do planejamento previsto nessa resolução, ainda não foram pactuadas novas ações para os anos que se seguiram. A Resolução no 2/2017 da CIT regulamenta o Pacto de Aprimoramento Estadual entre 2016 e 2019.

37. A Resolução CNAS no 7/2016 aprovou o II Plano Decenal da Assistência Social (2016-2026).

38. 0 IDConselho é um índice que visa ao monitoramento e ao fortalecimento da participação social no Suas, aferindo o desenvolvimento dos conselhos de assistência em três dimensões: i) estrutura administrativa; ii) dinâmica de funcionamento; e iii) composição do conselho. Os dados que alimentam o índice são originários da pesquisa Censo Suas Conselhos, realizada anualmente com todos os conselhos estaduais e municipais.
} 
em função do aumento das atribuiçóes dos conselhos no controle social da política (Ipea, 2019). Também é notório que, mesmo com o incentivo à inserção desses grupos nos conselhos, o número de CMAS que afirmaram não ter representantes de usuárias e usuários aumentou de 5,1\%, em 2015, para 13,2\%, em 2018.

Ademais, além das barreiras formais à participação, uma pesquisa realizada pela SNAS colheu relatos de representantes em CMAS que revelam situaçóes de constrangimento e preconceito (Santos, 2017a); dificuldades de deslocamento para ida às atividades dos conselhos e no entendimento da linguagem técnica utilizada nas reunióes; assim como obstáculos ao reconhecimento dos fóruns de usuários, modalidade mais recente de organização desse segmento e que não está prevista na maioria das legislaçóes vigentes dos conselhos municipais (Santos, 2017b). Cunha (2009), ao discutir a trajetória dos CMAS no Brasil, observa que há um caminho nítido no sentido da institucionalizaçáo e do aprofundamento do seu papel na governança da política. No entanto, reforça que

a concretização da garantia legal do direito à participação e à deliberação da sociedade na definição e no controle da política de assistência social encontra muitos desafios [...]. Um dos mais significativos relaciona-se à persistência de uma cultura política conservadora e elitista, tanto no interior do Estado quanto da sociedade, que convive com uma cultura democrático-participativa. Na área da assistência social, estas duas culturas expressam-se não só no aspecto da participação, mas também na concepção que orienta as ações socioassistenciais: de um lado, a culpabilização do indivíduo por sua situação social e a responsabilização da própria sociedade em acolhê-lo, gerando relaçóes clientelistas e paternalistas; de outro, a assunçáo da responsabilidade pública pelas consequências do tipo de desenvolvimento econômico que gera a questão social e a expectativa de emancipação dos sujeitos que têm sido marcados por esses efeitos (Cunha, 2009, p. 310).

As disputas entre pontos de vista frequentemente opostos em relação ao lugar da participação política, no âmbito das políticas, têm sido, nas últimas décadas, um grande desafio para a promoção da inclusão dos grupos vulneráveis nos processos decisórios. Por mais que haja avanços importantes na governança das políticas de erradicação da pobreza e reduçáo das desigualdades sociais, a persistência de culturas avessas à participação oferece um impedimento ao pleno atendimento dos princípios da Agenda 2030.

Nos últimos anos, as tensóes em torno do papel da governança e da participação social na política de assistência social tornam-se cada vez maiores, fomentadas em períodos recentes pela presença de novos atores pós-2016. Nesse contexto, tem ocorrido tendências no governo federal de reduzir o protagonismo das instituiçóes participativas nos processos de tomada de decisão, além do pouco interesse em manter uma estrutura de governança que inclua gestoras e gestores de todos os níveis de governo. 
O exemplo mais claro desse processo é a forma como o governo tem lidado com as conferências nacionais de assistência social. ${ }^{39}$ Após o último evento realizado, ocorrido em 2017, o então Ministério do Desenvolvimento Social (MDS) utilizou artifícios jurídico ${ }^{40}$ para tornar inócuas algumas deliberações resultantes do processo conferencial, tendo como um dos pontos sensíveis a oposição da sociedade civil ao PCF, alvo de conflito entre a comunidade de política da assistência social e o ministério. A busca pela redução do papel das conferências nas tomadas de decisão da política continuou a ser uma fonte de conflitos entre instituiçóes participativas e ministério nos anos seguintes, como se abordará na seção 4 .

Em 2018, o momento crítico do processo conferencial, vivido ao final de 2017, ecoou no CNAS, que teve sua agenda de reuniốes para o primeiro semestre daquele ano ameaçada. No início de 2018, o ministro indicou a suspensão da primeira reuniáo do ano, marcada para a segunda semana de fevereiro, afirmando existir a possibilidade de viabilizar a vinda de conselheiras(os) em um prazo de 180 dias. Alegavam-se a falta de recursos e o interstício entre contratos de empresas responsáveis pela logística de passagens do $\mathrm{MDS} .{ }^{41}$ Houve, ainda, a renúncia do presidente do CNAS de seu cargo e da cadeira que ocupava como conselheiro governamental e outros entreveros, conforme relatado em Ipea (2019).

Ademais, em 2018, destacam-se a atuaçáo do conselho e da CIT no debate sobre orçamento e financiamento da política, já mencionado e, mais uma vez, as disputas em torno do PCF. Sobre esse programa, o ministério apresentou por duas vezes proposta de expansão do seu público, o que foi rejeitado por aquele colegiado. ${ }^{42}$ Mesmo que em 2018 o CNAS tenha mostrado a sua capacidade de resistir a posiçóes avessas à participação social, as perspectivas futuras para as instituiçóes participativas têm se afastado de princípios de inclusão e empoderamento, os quais colocam em risco o desempenho brasileiro na Agenda 2030, como discutido a seguir.

\section{AGENDA DO NOVO GOVERNO E PERSPECTIVAS FUTURAS PARA O CUMPRIMENTO DO ODS 1}

Os acenos do governo federal durante o primeiro ano de mandato da nova gestão não parecem caminhar para o alívio do constrangimento de recursos enfrentado não só pela política da assistência social, mas também pelas demais políticas.

39. Uma discussão mais detalhada sobre a realização da última Conferência Nacional de Assistência Social, em 2017, foi realizada no BPS 26. Os conflitos que levaram à não realização da Conferência Extraordinária em 2019 serão discutidos de maneira mais aprofundada na próxima edição desse boletim.

40. Como descrito no BPS 26 (Ipea, 2019), o então MDS mobilizou a consultoria jurídica do ministério para emitir parecer sobre o documento resultante da XI Conferência, que se manifestou apontando que ela tinha o caráter de proposições e não deliberações. Isso selou o entendimento de que o ministério não teria a obrigação de se adequar às decisões tanto da conferência quanto do CNAS, que oficializou as deliberações da conferência por meio de resolução própria. 41. A situação é relatada nas atas do conselho e também por Mariz (2018).

42. Como informado nas atas das 267 e e 268 a reuniões do CNAS. A proposta de ampliação foi rejeitada por votação em uma primeira apresentação ao conselho. Em uma segunda tentativa de incluir na pauta a votação da ampliação, a oposição das(os) conselheiras(os) fez com que a SNAS retirasse a proposta de votação. 
Indicam-se, nesta seção, algumas das principais medidas adotadas em 2019 que sinalizam, para os próximos anos, um distanciamento do ODS 1 e das respectivas metas de erradicação da pobreza em todas as suas formas e dimensóes. ${ }^{43}$

As restriçóes mais significativas permanecem no campo do financiamento em decorrência das medidas de austeridade fiscal. A nova gestão renovou o compromisso com o teto de gastos que, na prática, congelou as despesas primárias do governo federal nos patamares observados em 2016 (Paiva et al., 2016; Ipea, 2019). Como sinalizado anteriormente, esse compromisso tem implicado cortes cada vez maiores nas despesas discricionárias, ${ }^{44}$ os quais têm se traduzido tanto em irregularidade de repasses quanto na redução do cofinanciamento dos serviços socioassistenciais.

Tais medidas também impactam, ainda que indiretamente, as despesas obrigatórias, ${ }^{45}$ nas quais estão incluídos o BPC e o PBF, que também passaram a sofrer revezes. Em 2019, percebe-se uma redução no número de beneficiárias(os) pelo $\mathrm{PBF}$ que, embora tenha alcançado 14,3 milhóes em maio, terminou o ano com apenas 13,1 milhōes de famílias favorecidas. ${ }^{46} \mathrm{~A}$ análise das informações sobre o BPC, no site do Ministério da Cidadania, ${ }^{47}$ aponta para a diminuição do número de benefícios (BPC) pagos durante esse ano: em dezembro de 2018 foi realizado o pagamento de 4.651 .924 benefícios de prestação continuada. Após cortes ao longo de sucessivos meses, chegou-se, em dezembro de 2019, a 4.626 .185 benefícios pagos. A queda, ainda que pequena, representa uma ruptura do padrão de crescimento contínuo do BPC.

Uma das possíveis explicaçóes para a queda são as medidas administrativas referentes à gestão do benefício. Depois de sucessivos adiamentos, em janeiro de 2019 entrou em vigor a exigência de inclusão no Cadastro Único para manutenção do BPC - sem que a totalidade das(os) beneficiárias(os) tivesse sido cadastrada. ${ }^{48} \mathrm{Em}$ que pese os aspectos positivos da medida - como a qualificação do processo de revisão dos benefícios e a ampliaçáo do acesso de idosos e $\mathrm{PcD}$ aos demais programas que utilizam o Cadastro Único para identificação de potenciais beneficiárias(os) - avalia-se que sua aplicação, em um contexto em que o poder público ainda não conseguiu incluir 1,16 milhão de beneficiárias(os) do BPC no Cadastro Único - cerca de um

43. Essas e outras ações implementadas em 2019 serão analisadas mais detidamente na próxima edição do BPS.

44. Despesas primárias que são passíveis de contingenciamento ao longo do ano.

45. Despesas primárias que não são passíveis de contingenciamento ao longo do ano.

46. Segundo dados do Ministério da Cidadania relativos a dezembro/2019. Disponível em: <https://bit.ly/2UK0GMb>.

47. Para mais informações, acessar o link: <https://bit.ly/35wDRAF>.

48. A exigência de inclusão de beneficiárias(OS) do BPC no Cadastro Único como condição para manutenção do respectivo benefício foi determinada pelo Decreto n 8.805/2016 (Brasil, 2016b). Desde então, diversas portarias interministeriais (por exemplo, nos 2/2016 e 5/2017) regulamentaram prazos e procedimentos para efetivação desse cadastro. 0 prazo foi adiado para dezembro de 2018 em função das dificuldades relatadas pelos municípios em cadastrar o público de idosos e PCD. As portarias do MDS nos 2.651/2018 e 631/2019 regulamentaram o processo de suspensão dos benefícios BPC em função da falta de inclusão no Cadastro Único. Esse ato de suspensão fixa um novo prazo para o cadastramento que, caso não cumprido, gera o cancelamento do benefício. 
quarto das(os) beneficiárias(os) -, pode ter levado ao cancelamento dos benefícios de quem não conseguiu se cadastrar ou atualizar seu cadastro.

Outra medida que pode ter comprometido a celeridade na concessão de novos benefícios consiste na implementação do processo conhecido como INSS Digital - novo fluxo de atendimento que fixa processo eletrônico para fins de agendamento e concessão de benefício pela internet para o segurado, bem como distribuição das demandas entre as unidades de atendimento. Ainda que vise aumentar a capacidade da autarquia em reconhecer direitos, essa informatização do atendimento em um contexto de redução do quadro de servidores do instituto em 2019, quando, até julho desse ano, mais de 7 mil servidores se aposentaram, tem apresentado problemas (Gurgel, 2019).

Em pesquisa recente, o Ipea (2019) observou in loco que o público do BPC tem dificuldades em dar entrada com os documentos necessários por não compreender a linguagem utilizada pelo poder público. São pessoas com menor grau de familiaridade com o universo digital e para as quais a perda da capacidade de se informar sobre seus direitos presencialmente, nas agências do INSS, representa um obstáculo importante no acesso aos benefícios. Esse afastamento físico entre a instituição e o seu público demandante se somou à redução das açôes de publicidade de utilidade pública e de educação previdenciária (Ipea, 2019), criando uma situação de agravamento dos problemas de acesso já existentes. De fato, foi amplamente noticiado pela mídia o represamento na análise e concessão dos benefícios. Segundo levantamento do próprio INSS, realizado a pedido do Tribunal de Contas da União (TCU), o tempo médio de análise para concessão de benefícios, em 2019, foi de 74 dias, o maior prazo em cinco anos. ${ }^{49} \mathrm{O}$ próprio governo reconheceu esse atraso na análise dos requerimentos e tem envidado esforços para providenciar força de trabalho extra a regularizar esse processo (Máximo, 2020).

Por fim, outro movimento do governo federal em 2019 que pode afastar o cumprimento dos ODS nos próximos anos diz respeito às mudanças institucionais que ocorreram no âmbito do ministério que conduz a política de assistência social, bem como as mudanças nas instâncias de participação social e de pactuação. A fusão dos ministérios do Esporte e do Desenvolvimento Social, sob a alcunha de Ministério da Cidadania, ${ }^{50}$ e a redução do antigo MDS a uma secretaria especial trouxeram novos desafios à gestão. Nem sempre a aglutinação ou a desagregação de secretarias determinam por si só a efetividade das políticas. Mas, ainda que a fragmentação possa trazer descoordenação e produzir decisōes difíceis de implementar

49. Esse levantamento não foi divulgado pelo INSS. Os dados aqui mencionados referem-se à reportagem de jornal de grande circulação que teve acesso ao documento (Ventura, 2020). Em 2018, o tempo médio foi de 51 dias; em 2017, de 54; em 2016, de 60; e em 2015, de 39 dias.

50. Inicialmente, a pasta da Cultura também foi incluída no Ministério da Cidadania, mas, posteriormente, foi realocada no Ministério do Turismo (Brasil, 2019). 
na prática, a junção do tema do desenvolvimento social a outras políticas que apenas tangenciam a erradicação da pobreza pode tornar os processos de tomada de decisão mais longos e custosos, na medida em que a cadeia decisória passe a contar com mais instâncias intermediárias entre a burocracia e o alto escaláo do ministério. Essa combinação traz risco de diluição de prioridades, podendo relegar açôes de erradicação da pobreza a um lugar de menor protagonismo.

\section{CONCLUSÃO}

Em um contexto de retração econômica e aumento da miséria, as metas nacionais dos ODS recolocam a questão da pobreza na agenda brasileira e elevam o patamar dos compromissos assumidos pelo país. Como parte de um esforço global, houve compromisso com a erradicação da pobreza monetária até 2030. A linha de pobreza, por sua vez, foi elevada para PPC \$3,20 ao dia ( $\$$ \$238/mês). Além disso, o país se comprometeu com a redução pela metade da incidência de dimensóes não monetárias da pobreza (acesso a combustível para cozinhar, água potável, alimentos, energia elétrica, educação, saúde etc.) para homens, mulheres e crianças. Para fazê-lo, houve: o comprometimento com a garantia da cobertura integral dos vulneráveis em sistema de proteção social; a ampliação da resiliência desses a choques sociais, econômicos e ambientais, bem como com o acesso a serviços básicos e recursos naturais; o fortalecimento dos marcos políticos e regulatórios de combate à pobreza; e a garantia dos recursos necessários à implementação de programas que alcancem esses objetivos.

Como demonstrado, dado o arcabouço constitucional-legal e o desenho das políticas sociais, faz-se necessário o fortalecimento da política de assistência social para o alcance dos objetivos propostos. Essa política é o instrumento-chave para o cumprimento dos compromissos assumidos no âmbito da Agenda 2030, promovendo seus princípios e contribuindo para o atingimento das metas, especialmente as do ODS 1. A análise da evolução recente da política de assistência social e dos indicadores de pobreza, entretanto, aponta para uma série de gargalos que devem ser superados.

O Brasil vem apresentando, no período recente, um distanciamento das metas de erradicação da pobreza (ODS 1). Houve deterioração do mercado de trabalho, elevação do desemprego e dos empregos precários. Esse cenário reflete a crise econômica que se instalou a partir de 2014 e se agravou com a adoçáo de medidas de austeridade fiscal em 2015. A austeridade fiscal, por sua vez, foi intensificada pelo estabelecimento de um teto de gastos, aprovado no final de 2016.

Nesse contexto, a forte contração do PIB e a ainda mais forte contração da arrecadação somam-se ao estabelecimento legal de um teto ao gasto público e de metas de resultado primário. Isso bloqueou a possibilidade de combate dos efeitos da crise por meio do orçamento público, explicitando o conflito redistributivo entre 
as políticas sociais. O conflito verifica-se não apenas na disputa por recursos entre as pastas, com a Previdência ocupando lugar de destaque na agenda fiscal do governo e do Legislativo, mas também na atuação interna de cada setor, como no caso da ampliação dos recursos ao PCF de forma concomitante à redução do cofinanciamento dos serviços, em especial o Paif. Esse cenário eleva as incertezas sobre a capacidade do país de atingir as metas acordadas de erradicação da pobreza extrema e redução da pobreza monetária e não monetária, podendo representar o aumento, e não a diminuição das vulnerabilidades que se visam superar com a Agenda 2030.

De fato, nota-se, nos últimos anos, a perversa combinação entre o crescimento da miséria pré-distributiva (resultante do desemprego e do arrocho salarial) e a retração do financiamento das políticas redistributivas, em particular aquelas voltadas aos mais pobres. Ou seja, no momento exato em que a populaçáo vulnerável à pobreza encontra mais dificuldades em ter suas necessidades básicas satisfeitas por meio do trabalho, o aumento consequente da demanda por políticas de assistência social se vê acompanhado de uma retração do auxílio aos cidadãos que delas necessitam. Os efeitos dessa combinação são visíveis a olho nu: saltou-se de 9 milhóes de pessoas extremamente pobres, em 2014, para 13,5 milhóes, em 2018.

A capacidade institucional existente, no entanto, permanece robusta, fruto de décadas de uma política de assistência social formulada e implementada em contexto democrático e sob retaguarda constitucional. Seus resultados são palpáveis no enfrentamento da pobreza em todas as suas formas. O Suas mudou os paradigmas acerca dos direitos sociais de pessoas em situação de pobreza. Por meio da instalaçáo de mais de 10 mil centros socioassistenciais em todo o país, aumentou-se a capacidade estatal em garantir a proteção social dessa população, atuando nas mais diversas causas da vulnerabilidade.

Por sua vez, o BPC, que durante sua primeira década de vida foi pouco mais que uma promessa constitucional, há mais de vinte anos vem expandindo a cobertura da proteção social a idosos e $\mathrm{PcD}$ pobres. $\mathrm{A}$ isso se soma o $\mathrm{PBF}$, que, embora não se constitua propriamente como um direito social - e, portanto, careça da retaguarda legal e orçamentária necessária ao alcance de seu potencial -, foi responsável pela inclusão de cerca de $20 \%$ da nossa população no sistema de garantia de renda. Isso se deve, em grande parte, à criação do Cadastro Único, por meio do qual o PBF serviu de catalisador a toda uma nova institucionalidade includente dos outrora relegados à subcidadania social, ampliando-lhes o acesso a alimentos, educação e saúde. Ainda, a despeito dos percalços, os espaços de participação política e governança têm se mostrado essenciais para a permanência dos resultados positivos das políticas de combate à pobreza em suas mais diversas dimensóes, indicando a necessidade de políticas de participação social sólidas para o alcance da redução da pobreza e das desigualdades sociais - como, aliás, postulado pelos próprios ODS. 
A expansão do Suas e do alicerce de proteção social representado por seus serviços e benefícios não ocorre sem obstáculos, desafiando, também, o desempenho brasileiro na implementação da Agenda 2030. Benefícios como o BPC e PBF ainda têm dificuldades em se tornar universais entre os mais pobres. No caso do BPC, sua concessão é dependente de reclamação em juízo em cerca de $18,5 \%$ dos casos. ${ }^{51}$ No que se refere ao PBF, a manutenção de pessoas em situação de potencial insegurança alimentar "na fila de espera" aparece como um limite institucional importante a ser superado. Os serviços socioassistenciais, por sua vez, ainda não se fazem presentes de forma adequada em determinadas regiōes, particularmente no Nordeste, onde se verifica um deficit de equipamentos sociassistenciais. Por fim, os obstáculos à inclusão de pessoas em situação de vulnerabilidade nas instituiçóes participativas do Suas, assim como as tentativas de reduzir o papel destas na implementação da política de assistência social, contrariam os compromissos de implementação da Agenda 2030.

O aumento nas taxas de pobreza e extrema pobreza no período 2014-2018 coloca em questão o recente sucesso brasileiro no enfrentamento dessas condiçóes. Dada a crise, nota-se que as medidas adotadas pelo governo para enfrentá-la, por vezes, reduziram a capacidade de amortecimento da rede de proteçáo social, como no caso do contingenciamento de recursos para os centros socioassistenciais. Outras vezes, essas medidas deixaram que pessoas ficassem com suas necessidades básicas insatisfeitas devido a questôes administrativas - por exemplo, nas averiguaçóes cadastrais do BPC e do PBF.

O caminho de superação do atual estágio parece difícil, mas, em que pese os retrocessos recentes e os desafios à frente, a institucionalidade das políticas públicas sociais no país é sólida, o que coloca o Brasil em vantagem diante de outros países com grau de desenvolvimento econômico similar. Há uma capacidade estatal instalada, composta por recursos humanos, físicos e regulatórios disponíveis aos governos em todas as suas esferas, capaz de, dada a devida contabilização do financiamento necessário, reverter a trajetória recente, alcançando a população vulnerável com políticas mais incisivas de enfrentamento da pobreza.

\section{REFERÊNCIAS}

ALKIRE, S. Choosing dimensions: the capability approach and multidimensional poverty. In: KAKWANI, N.; SILBER, J. (Orgs.). The many dimensions of poverty. Londres: Palgrave Macmillan, 2013. p. 89-119.

51. Corresponde ao percentual médio de concessões judiciais de BPC em relação ao total de concessões em 2018 e 2019, extraído do Painel Benefícios Previdenciários da Controladoria-Geral da União (CGU). Disponível em: <https:// bit.ly/3b2Q41j>. 
ALKIRE, S. et al. Multidimensional poverty measurement and analysis. Oxford: Oxford University Press, 2015.

BARROS, R. P.; CARVALHO, M.; FRANCO, S. Pobreza multidimensional no Brasil. Brasília: Ipea, 2006.

BRASIL. Ministério do Desenvolvimento Social e Combate à Fome. Norma Operacional Básica do Sistema Único de Assistência Social. Brasília: MDS, 2005.

. Ministério do Desenvolvimento Social e Combate à Fome. Orientaçóes técnicas: centro de referência especializado de assistência social (Creas). Brasília: MDS, 2011.

. Ministério do Desenvolvimento Social e Combate à Fome. Orientaçóes técnicas sobre o Paif. Brasília: MDS, 2012.

- Ministério do Desenvolvimento Social e Combate à Fome. Perguntas e respostas: serviço especializado em abordagem social. Brasília: MDS, 2013. v. 4.

. Nota Técnica no 3/2016/DBA/SNAS/MDS. Nota Técnica sobre as concessóes judiciais do BPC e sobre o processo de judicialização do mesmo. Brasília: MDS, 21 mar. 2016a. Disponível em: <https://bit.ly/3e42I1T>.

. Decreto no ${ }^{\circ} .805$, de 7 de julho de 2016. Altera o Regulamento do BPC, aprovado pelo Decreto no 6.214, de 26 de setembro de 2007. Diário Oficial, Brasília, 8 jul. 2016b.

. Relatório de Avaliaçáo de Receitas e Despesas Primárias: programação orçamentária e financeira de 2017. Brasília: SOF, dez. 2017.

. Decreto $\mathrm{n}^{-}$9.396, de 30 de maio de 2018. Altera o Decreto $\mathrm{n}^{\circ} 5.209$, de 17 de setembro de 2004, e o Decreto no 7.492, de 2 de junho de 2011, para reajustar valores referenciais de caracterização das situaçóes de pobreza e de extrema pobreza e os de benefícios do Programa Bolsa Família. Diário Oficial, Brasília, $1^{\circ}$ jun. 2018a.

. Ministério do Desenvolvimento Social. Boletim Mulheres no Suas. Brasília: SNAS/MDS, jun. 2018b. (Boletim Vigilância Socioassistencial, n. 5). Disponível em: <https://bit.ly/2QP9lMw>. Acesso em: 28 mar. 2020.

. Conselho Nacional de Assistência Social. Caderno de orientaçóes aos conselhos de assistência social para o controle social do Benefício de Prestaçáo Continuada (BPC), Programa Bolsa Família (PBF) e Benefícios Eventuais da Assistência Social. Brasília: CNAS, 2018c. Disponível em: <https://bit. ly/33pVW2d>. Acesso em: 15 jan. 2020. 
. Decreto no 10.107, de 6 de novembro de 2019. Transfere a Secretaria Especial de Cultura do Ministério da Cidadania para o Ministério do Turismo. Diário Oficial, Brasília, 7 nov. 2019.

CNAS - CONSELHO NACIONAL DE ASSISTENNCIA SOCIAL. Sistema Único de Assistência Social: 'modo de usar'. Brasília: CNAS, 2017.

CUNHA, E. S. M. Efetividade Deliberativa: estudo comparado de conselhos municipais de assistência social (1997-2006). 2009. Tese (Doutorado) - Faculdade de Filosofia e Ciências Humanas, Universidade Federal de Minas Gerais, Belo Horizonte, 2009.

DIPROSE, R. Physical safety and security: a proposal for internationally comparable indicators of violence. Oxford Poverty \& Human Development Initiative Oxford Development Studies, v. 35, n. 4, p. 431-458, 2007. (Working Paper, n. 1).

GURGEL, J. B. S. Mais de 7 mil servidores do INSS se aposentaram. Blog Anasps, 19 jul. 2019. Disponível em: <https://bit.ly/2SC5e79>.

IBGE - INSTITUTO BRASILEIRO DE GEOGRAFIA E ESTATÍSTICA. Nota Técnica Alteraçáo na forma de captaçáo de rendimento efetivo de trabalho na PNAD Contínua. Rio de Janeiro: IBGE, nov. 2017.

IPEA - INSTITUTO DE PESQUISA ECONÔMICA APLICADA. ODS: metas nacionais dos objetivos do desenvolvimento sustentável. Brasília: Ipea, 2018. Disponível em: <https://bit.ly/2SXQFeD>.

. Políticas Sociais: acompanhamento e análise. n. 26. Brasília: Ipea, 2019.

LOPES, H. M.; MACEDO, P. B. R.; MACHADO, A. F. Indicador de pobreza: aplicação de uma abordagem multidimensional ao caso brasileiro. Campinas: Unicamp, 2003. (Texto para Discussão, n. 223). Disponível em: <https://bit. ly/2IR6NJh>. Acesso em: 5 set. 2019.

MARIZ, R. Ministro alega falta de dinheiro para suspender reuniōes, e MPF reage. O Globo, 7 fev. 2018. Disponível em: <https://glo.bo/2x9JeJd>. Acesso em: 24 jan. 2020.

MÁXIMO, W. Governo contratará 7 mil militares para reforçar atendimento no INSS. Agência Brasil, 14 jan. 2020. Disponível em: <https://bit.ly/2y9FkQQ>. Acesso em: 27 mar. 2020.

MESQUITA, A. C. S.; PAIVA, A. B.; JACCOUD, L. Instrumentos financeiros de coordenação no Sistema Único de Assistência Social. In: COORDENAÇÃO E RELAÇÓES INTERGOVERNAMENTAIS NAS POLÍTICAS SOCIAIS BRASILEIRAS. Brasília: Ipea, 2020. (No prelo). 
ONU - ORGANIZAÇÃO DAS NAÇÓES UNIDAS. Transformando nosso mundo: a Agenda 2030 para o desenvolvimento sustentável. Brasil: ONU, 2015. Disponível em: <https://bit.ly/2SyFp7W>. Acesso em: 13 jan. 2020.

Articulando os Programas de Governo com a Agenda 2030 para o Desenvolvimento Sustentável e os Objetivos de Desenvolvimento Sustentável: orientaçóes para organizaçóes políticas e a cidadania. Brasil: ONU, 2018. Disponível em: <https://bit.ly/2UbrGUL>. Acesso em: 14 jan. 2020.

PAIVA, A. B. et al. O novo regime fiscal e suas implicaçóes para a política de assistência social no Brasil. Brasília: Ipea, 2016. (Nota Técnica, n. 27).

PAIVA, L. H.; FALCÃO, T.; BARTHOLO, L. Do Bolsa Família ao Brasil Sem Miséria: um resumo do percurso brasileiro recente na busca da superação da pobreza extrema. In: CAMPELLO, T.; NERI, M. C. Programa Bolsa Família: uma década de inclusão e cidadania. Brasília: Ipea, 2013. p. 25-46.

PENALVA, J.; DINIZ, D.; MEDEIROS, M. O Benefício de Prestação Continuada no Supremo Tribunal Federal. Sociedade e Estado, v. 25, n. 1, p. 53-70, 2010.

RAZAVI, S. The 2030 Agenda: challenges of implementation to attain gender equality and women's rights. Gender \& Development, v. 24, n. 1, p. 25-41, 2016. Disponível em: <https://bit.ly/2SBJFUf>. Acesso em: 14 jan. 2020.

SANTOS, P. R. Participação de usuários e controle social no Suas. In: ENCONTRO NACIONAL DE VIGILÂNCIA SOCIOASSISTENCIAL, 11., 2017, Brasília, Distrito Federal. Anais... Brasília: MDS, 2017a. Disponível: <https://bit. ly/3cQJsVh>.

- Mapeamento das experiências de controle social, participaçáo e mobilizaçáo de usuários no Suas. Relatório de Consultoria, 2017b.

SEN, A. Desenvolvimento como liberdade. São Paulo: Editora Companhia das Letras, 2018.

SOARES, S.; BARTHOLO, L.; OSORIO, R. Uma proposta para a unificaçáo dos benefícios sociais de crianças, jovens e adultos pobres e vulneráveis. Brasília: Ipea, 2019. (Texto para Discussão, n. 2505).

SOUZA, P. H. F.; VAZ, F. M. Caderno ODS 1: acabar com a pobreza em todas as suas formas, em todos os lugares. In: SILVA, E. R. A. da (Coord.). Cadernos ODS. Brasília: Ipea, 2019. Disponível em: <https://bit.ly/3bp6fHg>.

TAVARES, J. F. C.; MOURA, M. R. Nota Técnica no 12/2017. Consultoria de Orçamento e Fiscalização Financeira. Brasília: Câmara dos Deputados, 18 abr. 2017. 
TAVARES, J. F. C.; RODRIGUES, J. A. M.; MOURA, M. R. Nota Técnica no 84/2016. Consultoria de Orçamento e Fiscalização Financeira. Brasília: Câmara dos Deputados, 25 nov. 2016.

TCU - TRIBUNAL DE CONTAS DA UNIÃO. Acórdáo no 2.894/2018. Brasília: TCU, 2018. Disponível em: <https://bit.ly/2UMb729>. Acesso em: 28 mar. 2020. VENTURA, L. A. S. Atrasos do INSS deixam 420 mil pessoas com deficiência na fila do BPC. Estadáo, 1 mar. 2020. Disponível em: <https://bit.ly/3bgO4Dy>. Acesso em: 16 abr. 2020. 


\section{CAPÍTULO 3}

\section{SAÚDE ${ }^{1}$}

\section{APRESENTAÇÃO}

Em setembro de 2015, os países-membros da Organização das Nações Unidas (ONU) assumiram o compromisso de acabar com a pobreza, adotando estratégias para melhorar a saúde e a educação, reduzir desigualdades e promover o crescimento econômico, ao mesmo tempo que se combatem as mudanças climáticas e se busca preservar o meio-ambiente. A Agenda 2030, mais conhecida como Objetivos de Desenvolvimento Sustentável (ODS), deu continuidade à agenda inacabada dos Objetivos de Desenvolvimento do Milênio (ODMs), mas tem um escopo muito mais ambicioso.

$\mathrm{Na}$ área de saúde, o ODS 3, que visa "assegurar uma vida saudável e promover o bem-estar para todas e todos, em todas as idades", é composto por treze metas e 27 indicadores globais. Além de metas relativas à saúde materna, à saúde da criança e às doenças infecciosas, que já haviam sido objeto dos ODMs, o ODS 3 inclui também metas relativas às doenças não transmissíveis, à saúde mental, às mortes e lesóes no trânsito, à prevenção e ao tratamento do abuso de drogas e álcool, ao controle do tabaco, aos problemas causados pela contaminação e poluição por produtos químicos, ao apoio à pesquisa e ao desenvolvimento de tecnologias e inovaçóes, a alertas para a redução e gerenciamento de riscos à saúde, ao fortalecimento do financiamento e da formaçăo de recursos humanos para os sistemas de saúde e à cobertura universal de serviços de saúde.

O Ipea coordenou um grupo de trabalho que contou com a participação de mais de oitenta servidores de quase vinte órgãos federais e elaborou uma proposta de adequação das metas e dos indicadores globais do ODS 3 para o contexto brasileiro. O grupo de trabalho propôs alteraçóes em doze das treze metas globais e a definiçáo de 51 indicadores nacionais para o monitoramento do alcance das metas. A proposta elaborada pelo grupo de trabalho foi submetida a consulta pública nos meses de novembro e dezembro de 2018 , sendo respaldada no processo. Vale lembrar, contudo, que a proposta náo foi chancelada pelo governo atual, portanto não configura um compromisso oficial.

O capítulo de saúde desta edição de Políticas sociais: acompanhamento e análise apresenta o compromisso assumido na área de saúde na Agenda 2030. A seção 3 mostra como as metas de saúde constantes nos ODMs foram incorporadas

1. DOl: http://dx.doi.org/10.38116/bps27/saude 
à agenda, traz um resumo da proposta de ajuste para as circunstâncias brasileiras das metas do ODS 3 e um diagnóstico da situação inicial brasileira em relação às metas estabelecidas. Contudo, antes de se entrar na Agenda 2030, abordar-se-á, na seção 2, um importante tema a ela relacionado: o debate em torno do conceito de cobertura universal de saúde. Esse debate se torna relevante no contexto de análise do ODS 3 devido à existência de uma meta específica para o alcance da cobertura universal de saúde e proteção financeira contra gastos elevados com saúde, a meta 3.8 , sendo que o entendimento que se tenha deste conceito poderá ter repercussóes sobre o sistema de saúde brasileiro e sobre o alcance das metas estabelecidas. Ademais, como argumentaremos a seguir, o Brasil avançou em direção a um sistema público de acesso universal, tendo por princípios a igualdade e a integralidade. Esse sistema foi central para o alcance das metas propostas para o ODM e será o que garantirá, junto com outras políticas sociais e econômicas, que o país avance em direção ao alcance das metas proposta pelos ODS.

\section{COBERTURA UNIVERSAL EM SAÚDE}

\subsection{Cobertura universal e financiamento da saúde no Brasil}

Na primeira década dos anos 2000, o acesso universal e o financiamento da saúde ganharam protagonismo no debate mundial. ${ }^{2}$ Esse novo movimento é, de certa forma, subsidiário da proposta da Declaração de Alma-Ata (1978) de alcançar a saúde para todos até o ano 2000 , por meio da priorização do investimento na atenção primária. ${ }^{3}$ Nesse contexto, com o estabelecimento dos ODMs, novos esforços foram realizados nas áreas de saúde materna, saúde da criança e doenças transmissíveis. Os debates prosseguiram, e outro marco foi estabelecido em 2010, com a publicaçáo, pela Organização Mundial da Saúde (OMS), do relatório Financiamento dos sistemas de saúde: o caminho para a cobertura universal e, posteriormente, com a inserção da cobertura universal no ODS 3. Entre suas metas, está a 3.8, cujo enunciado é: "atingir a cobertura universal de saúde, incluindo a proteção do risco financeiro, $\mathrm{o}$ acesso a serviços de saúde essenciais de qualidade e o acesso a medicamentos e vacinas essenciais seguros, eficazes, de qualidade e a preços acessiveis para todos" (Sá e Benevides, 2019, p. 19, grifo nosso).

Na proposta há vários conceitos que merecem esclarecimento, particularmente a universalidade da cobertura, a proteção do risco financeiro e o acesso a serviços essenciais. O foco da discussão nesta seção será a universalidade, mas, ao fazê-lo,

2. A Resolução WHA58.33 (WHO, 2005), Sustainable health financing, universal coverage and social health insurance, recomendou aos países-membros o planejamento da transição para a cobertura universal dos seus cidadãos, com a conformação de sistema de financiamento que protegesse a população dos gastos catastróficos.

3. A Conferência Internacional sobre Cuidados Primários de Saúde, realizada pela OMS em Alma-Ata em setembro de 1978, na República do Cazaquistão, expressava a "necessidade de ação urgente de todos os governos, de todos os que trabalham nos campos da saúde e do desenvolvimento e da comunidade mundial para promover a saúde de todos os povos do mundo". 
tangenciaremos algumas questóes a respeito da proteção do risco financeiro e do acesso a serviços de saúde essenciais. Mas, antes de discutirmos conceitos relacionados à meta de cobertura universal, vamos contextualizar a declaração do $3^{\circ}$ objetivo para entender o debate que ele suscitou.

A OMS conceitua saúde como um "estado de completo bem-estar físico, mental e social, e não meramente a ausência de doenças" (WHO, [s.d.]). Parte dessa condição de bem-estar pode ser alcançada por uma atenção à saúde adequada. Outra parte está relacionada aos determinantes sociais da saúde. ${ }^{4}$ No que diz respeito à atenção à saúde, segundo o Dicionário da educação profissional de saúde, da Fundação Oswaldo Cruz, essa "designa a organização estratégica do sistema e das práticas de saúde em resposta às necessidades da população. É expressa em políticas, programas e serviços de saúde consoante os princípios e as diretrizes que estruturam" (Matta e Morosini, 2009, grifo nosso). Ao passo que o conceito de sistema de saúde inclui "todas as atividades cujo objetivo primário é promover, restaurar e manter a saúde" (WHO, 2000, p. 6).

A discussão internacional sobre como organizar, financiar e gerir um sistema de saúde remete ao final do século XIX e início do século XX, quando foram cunhados dois "sistemas tipo": o bismarckiano e o beveridgiano. Os sistemas bismarckianos têm sua origem no século XIX, na Alemanha de Bismarck, significando, normalmente, uma denominação para sistemas de saúde do tipo seguro social, financiados por contribuiçóes de empregados e empregadores, ainda que possa contar com recursos originários de impostos. Já o sistema beveridgiano é embasado no Relatório Beveridge, de 1942, e refere-se, em geral, a sistemas de saúde com as seguintes características: nacionais, universais com financiamento majoritariamente baseado em impostos gerais. Assim, as principais diferenças entre esses sistemas dizem respeito à maneira como atendem à questão da universalidade da cobertura e à forma como são financiados, pelo menos em suas concepçôes originais. ${ }^{5}$

Como mostram Andrade et al. (2018) e Giovanella et al. (2018), há várias nuances no mundo real que fazem com que sequer os sistemas dos países a partir dos quais esses termos foram cunhados sejam sistemas puros, mesmo no tocante ao financiamento público, ou seja, exclusivamente financiados com impostos gerais ou exclusivamente financiados a partir de contribuições incidentes sobre o mercado formal de trabalho. Na Alemanha, por exemplo, $85 \%$ da população é coberta por um seguro público financiado por uma combinação de contribuiçóes

4. A Carta de Ottawa (1986) qualifica como recursos indispensáveis para ter saúde: paz, renda, habitação, educação, alimentação adequada, ambiente saudável, recursos sustentáveis, equidade e justiça social, com toda a complexidade que implicam alguns desses conceitos.

5. Mesmo em sistemas cujo financiamento provém, majoritariamente, de contribuiç̧ões específicas de empregados e empregadores sobre a folha de salário, o financiamento da universalidade de cobertura é alcançada com o aporte de recursos públicos originários de impostos gerais. 
sociais de empregadores e empregados (89,2\% do gasto público), complementados por impostos gerais (Giovanella et al., 2018). A cobertura por seguro privado de saúde é obrigatória para alguns grupos profissionais, como os servidores públicos, enquanto, para outros, a cobertura por seguro privado de saúde pode ser uma alternativa ao seguro público se algumas condiçóes forem atendidas (por exemplo, trabalhadores por conta própria e empregados com remuneração acima de um limiar estabelecido). Adicionalmente, parte da população é coberta por seguros públicos setoriais específicos, como os militares (Busse e Blümel, 2014). Nas despesas totais com saúde, as fontes públicas contribuíram com cerca de $77 \%$ do gasto total em 2014. ${ }^{6} \mathrm{Na}$ Inglaterra, onde a cobertura pelo Sistema Nacional de Saúde (NHS) é direito decorrente da cidadania e o financiamento público da saúde é realizado por meio de tributos gerais, o gasto público correspondeu a algo em torno de $83 \%$ das despesas totais com saúde em 2014, havendo um espaço para compra de serviços privados de saúde, que alcançaram cerca de $17 \%$ dos gastos totais no mesmo ano. Em suma, os países, de modo geral, têm uma combinação de financiamento público (via contribuiçôes sobre folha e/ou tributos) e financiamento privado. O que varia é a proporção entre recursos de fontes públicas ou privadas.

Como dito anteriormente, a questão da universalidade esteve presente desde o início nos sistemas de inspiraçáo beverigdiana, nos quais se vincula o direito de acesso aos serviços de saúde à cidadania. Mas, mesmo nos regimes de orientação bismarckiana, em que o principal vetor inicial de inclusão é o pertencimento ao mercado formal de trabalho, houve uma busca progressiva pela universalidade da cobertura com o concurso de impostos gerais.

Outra questão relevante na organização dos sistemas de saúde é a igualdade (para necessidades iguais) no atendimento. Nos sistemas de inspiração beverigdiana, seja por declararem a saúde como direito da cidadania, seja pela configuraçáo de seu esquema básico de financiamento, com a predominância de recursos oriundos de impostos gerais e agregação em um "fundo" único, há maior facilidade para o atendimento dos princípios de igualdade de acesso ou de igualdade no atendimento, ${ }^{7}$ bem como para a preservação de aspectos redistributivos. Já em sistemas de inspiraçáo bismarckiana, principalmente naqueles em que o asseguramento teve por base categorias profissionais distintas e nos quais coexistem "fundos" específicos de financiamento, medidas de maior equalização da atenção requerem um esforço regulatório mais acentuado. ${ }^{8}$

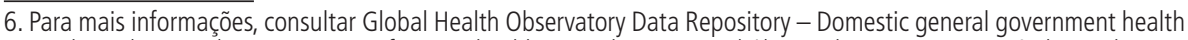
expenditure (GGHE-D) as percentage of current health expenditure - CHE (\%). Data by country. Disponivel em: <https:// is.gd/0mJrYs >. Acesso em: abr. 2020.

7. Entendido como igual atenção para necessidades de saúde idênticas.

8. Esse é o caso da maioria dos sistemas de saúde da América Latina, que se organizaram de forma segmentada em torno das grandes categorias profissionais. 
No caso do Brasil, apesar de o sistema de saúde ter tido início idêntico àquele da maioria dos países da América Latina, o sistema instituído em 1988, o Sistema Único de Saúde (SUS), teve forte inspiração no modelo inglês, no tocante aos seus princípios e à sua forma de financiamento e organização. Também é tributário da Carta de Ottawa (1986), ${ }^{9}$ no que concerne à concepção de saúde e de seus determinantes, conforme se constata no relatório da $8 \underline{a}$ Conferência Nacional de Saúde de 1986. ${ }^{10}$ Dois anos mais tarde, a Constituição Federal de 1988 (CF/1988) criou o SUS, incluindo entre seus princípios e diretrizes o direito à saúde, a universalidade, a igualdade no acesso aos serviços de saúde e a integralidade da atenção, mediante ações de promoção, proteção e recuperação. Em seu art. 196, lê-se: "saúde é direito de todos e dever do Estado, garantido mediante políticas sociais e econômicas que visem à reduçáo do risco de doença e de outros agravos e ao acesso universal e igualitário às açôes e serviços para sua promoção, proteção e recuperação" (Brasil, 1988, grifo nosso).

E continua em seu art. 198:

As açóes e serviços públicos de saúde integram uma rede regionalizada e hierarquizada e constituem um sistema único, organizado de acordo com as seguintes diretrizes:

I - descentralização, com direção única em cada esfera de governo;

II - atendimento integral, com prioridade para as atividades preventivas, sem prejuízo dos serviços assistenciais;

III - participação da comunidade.

S $1^{\circ}$ - O sistema único de saúde será financiado, nos termos do art. 195, com recursos do orçamento da seguridade social, da União, dos Estados, do Distrito Federal e dos Municípios, além de outras fontes (Brasil, 1988, grifo nosso).

O art. 199 (caput) afirma que a assistência à saúde é livre à iniciativa privada e que instituiçóes privadas poderão participar de forma complementar no SUS, mediante diretrizes deste, por meio de contrato de direito público ou convênio, tendo preferência as entidades filantrópicas e as sem fins lucrativos $\left(\$ 1^{\circ}\right.$ do art. 199). Assim, o SUS unificou as ações das instituições públicas, ${ }^{11}$ mas preservou um

9. A Carta de Ottawa foi elaborada pelos participantes da 1ạ Conferência Internacional sobre a Promoção da Saúde, realizada na cidade de Ottawa, no Canadá, em 1986. A carta reconhece a saúde como condição resultante de uma série de pré-requisitos e de políticas extrassetoriais. Além disso, contém orientações para o alcance de "Saúde para Todos no Ano 2000".

10. 0 relatório final da oitava conferência afirma que "em seu sentido mais abrangente, a saúde é a resultante das condições de alimentação, habitação, educação, renda, meio ambiente, trabalho, transporte, emprego, lazer, liberdade, acesso e posse da terra e acesso a serviços de saúde. É, assim, antes de tudo, o resultado das formas de organização social da produção, as quais podem gerar grandes desigualdades nos níveis da vida" (Brasil, 1986, p. 4).

11. Unificou as ações de assistência médica da previdência social no Ministério da Saúde, mas manteve os serviços específicos para os servidores públicos do Executivo, Judiciário e Legislativo, com maior ou menor grau de subsídio, caracterizando para estas categorias uma dupla cobertura com recursos públicos. 
espaço para as instituições privadas dentro e fora do SUS. ${ }^{12}$ Mais recentemente, a Lei no 13.097 , de 19 de janeiro de 2015, passou a permitir também a participação direta ou indireta, inclusive o controle acionário, de empresas estrangeiras ou de capital estrangeiro na assistência à saúde de forma indiscriminada, sem atender às exigências previstas no texto constitucional (Sá et al., 2015).

No que se refere especificamente ao financiamento, dos $9,1 \%$ do produto interno bruto (PIB) destinados à saúde em 2015 no Brasil, somente 3,9\% era proveniente de recursos públicos originários de tributos. Ou seja, somente $43 \%$ dos recursos alocados para os cuidados com a saúde têm origem pública e destinam-se ao financiamento do SUS, do qual depende quase exclusivamente mais de $70 \%$ da população brasileira. O restante, mais da metade do gasto total com saúde, era proveniente de gastos das famílias, por meio de pagamentos diretos e do pagamento de planos e seguros de saúde, bem como de empresas empregadoras (IBGE, 2017). A saúde suplementar, que compreende o segmento de planos e seguros privados de saúde, cobre $27 \%$ da população brasileira (IBGE, 2015). Interessante notar que, embora não sejam computados na estimativa do gasto público com saúde citada, recursos públicos subsidiam os gastos privados com atenção à saúde, uma vez que tais gastos podem ser deduzidos dos rendimentos tributáveis para fins de declaração do Imposto de Renda, gerando, desta forma, um sistema no qual parcela da população tem cobertura duplicada com o concurso de recursos públicos (Santos, 2011; Ocké-Reis e Fernandes, 2018).

Apesar da participação insuficiente do financiamento público (Vieira, Piola e Benevides, 2019), o Brasil conseguiu avançar significativamente em direção ao acesso universal à saúde, por meio do SUS, com importantes resultados sobre a saúde da população (Paim et al., 2011; Castro et al., 2019). A integralidade da atenção, definida no art. 3o da Lei no 8.080/1990 como "o conjunto articulado e contínuo das açôes e serviços preventivos e curativos, individuais e coletivos, exigidos para cada caso em todos os níveis de complexidade do sistema”, também avançou tanto no sentido horizontal da coordenação de açóes promocionais, preventivas e reparadoras, quanto no sentido vertical, aqui entendido como o acesso aos diferentes graus de complexidade dos serviços oferecidos.

\subsection{Cobertura universal em saúde: do que se está falando?}

No debate atual sobre a Agenda 2030, há muitas divergências quanto ao conceito de cobertura universal de saúde presente no texto da meta 3.8 do ODS 3. Qual a diferença entre sistema universal e cobertura universal? A nova formulação representa efetivamente um avanço? A proposta de cobertura universal de saúde tem implicações para a organização e o financiamento do sistema de saúde do Brasil?

12. Fora do SUS, uma vez que as instituições privadas não precisam estar vinculadas a esse sistema para prestarem serviços de saúde. Por seu turno, como previsto no art. 199 da CF/1988, podem prestar serviços para o SUS de forma complementar. 
Em 2005, os países-membros da OMS, na 58a Assembleia Geral, endossaram uma resolução sobre financiamento sustentável, cobertura universal e seguro social da saúde (Resolução WHA58.33) que tem como um de seus pressupostos a necessidade de aperfeiçoamento do financiamento da saúde como condição para garantir à população o acesso aos serviços necessários, com proteçâo contra riscos financeiros. Alertam os Estados-membros que, independentemente da fonte de financiamento que se escolha para custear o sistema, o pré-pagamento (por exemplo, os planos e os seguros privados de saúde) e o compartilhamento (pooling) de recursos financeiros e dos riscos são variáveis importantes. Assumem ainda que a escolha do modelo de financiamento é algo particular ao contexto de cada país, mas que as reformas podem envolver um mix público-privado, incluindo a introduçáo do seguro social. No documento que consolida as resoluçóes dessa assembleia, o termo "cobertura universal" é mencionado dez vezes, mas nenhuma conceituação é apresentada.

Quatro anos depois, Garrett, Chowdhury e Pablo-Mendez (2009) - respectivamente filiados ao Conselho de Relaçóes Exteriores (Council on Foreign Relations), ${ }^{13}$ à Fundação Rockfeller e à Universidade de Columbia - elaboraram documento intitulado Todos pela cobertura universal em saúde (All for universal health coverage), que logo no seu primeiro parágrafo afirma:

quando os Estados Unidos participam no que promete ser um debate vibrante sobre como o sistema de saúde mais caro do mundo pode com eficiência e equidade prover acesso com qualidade a serviços de saúde para toda a populaçáo norte-americana, as controvérsias sobre cobertura universal adquirem alta relevância não só nos Estados Unidos, mas em todo o mundo (Garrett, Chowdhury e Pablo-Mendez, 2009, p. 1294, tradução nossa).

Ou seja, a proposta poderia interessar a quase todos os países, não somente aos mais carentes. E continuam:

assumir que a cobertura universal em saúde requer um pagador único governamental seria um equívoco e adeptos dessa concepçáo condenam a população dos países mais pobres a geraçóes de pessoas com deficiências médicas. Em termos clássicos, o debate pode ser enquadrado como o modelo de Bismarck versus o modelo de Beveridge, mas essa dicotomia é cada vez mais vista como sendo táo falsa quanto aquela que busca colocar em conflito esquemas verticais e horizontais de saúde ("vertical schemes of health against horizontal'). Se um país escolhe um sistema misto de cobertura, a modalidade de pagador único, o mecanismo de voucher emitido por doadores ou outro modelo inovador de financiamento universal não é a questão relevante; a provisão de cobertura universal é a questấo enfrentada por todo o sistema global de saúde (Garrett, Chowdhury e Pablo-Mendez, 2009, p. 1294, tradução nossa).

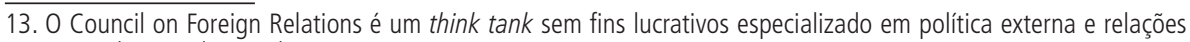
exteriores dos Estados Unidos. 
$\mathrm{Na}$ leitura desse texto, verifica-se que as controvérsias a respeito da proposta da cobertura universal e do financiamento da atenção à saúde se iniciaram muito cedo e que se estava em busca de modelos mais adaptáveis e flexíveis no tocante à forma de organização e financiamento.

Em 2010, a OMS lançou um novo relatório mundial, com o título Financiamento de sistemas de saúde: um caminho para a cobertura universal. A primeira pergunta apresentada nesse relatório é: por que cobertura universal? Ao começar a respondê-la, o texto reconhece que a promoção e a proteção da saúde são essenciais para o bem-estar humano e para o desenvolvimento econômico e social sustentável, o que já tinha sido defendido pelos signatários da Declaração de Alma-Ata em 1978. A OMS reconhece que existem muitos caminhos para promover e proteger a saúde e que algumas açóes com esse intuito ficam fora dos limites do setor da saúde, pois estão relacionadas a condiçôes de vida, educação, habitação, alimentação, trabalho etc. Ou seja, as "circunstâncias nas quais as pessoas crescem, vivem, trabalham e envelhecem" influenciam fortemente como as populaçóes vivem e morrem, enfatizando que a redução das desigualdades nessas condiçóes pode reduzir as desigualdades em saúde (WHO, 2010, p. xi).

Nada obstante, não deixam de reconhecer o importante papel da atenção à saúde:

mas o acesso oportuno a cuidados de saúde - uma combinaçáo de promoçáo, prevenção, tratamento e reabilitação - também é crítico. Isso não será atingido, exceto para uma minoria da populaçáo, sem um sistema de financiamento de saúde bem eficiente, que permita às pessoas usar os serviços de saúde quando deles precisam (WHO, 2010, p. xi).

Antecipando um primeiro alerta para essa questão, os países-membros da OMS comprometeram-se, ainda em 2005, na 58 assembleia Geral, a desenvolver sistemas de financiamento da saúde que permitissem às pessoas acessar serviços sem enormes sacrifícios financeiros para pagá-los. Esta meta foi definida como cobertura universal, por vezes também chamada cobertura universal de saúde.

$\mathrm{Na}$ luta por esta meta, segundo o relatório, os governos enfrentam três questôes fundamentais relacionadas aos recursos financeiros, elencadas a seguir.

1) Como deve ser financiado tal sistema?

2) Como proteger as pessoas das consequências financeiras dos problemas de saúde e do pagamento pelos cuidados de saúde?

3) Como otimizar a utilização dos recursos disponíveis? 
Os governos têm ainda que assegurar a equidade na cobertura, ${ }^{14}$ estabelecer mecanismos fiáveis para monitorar e avaliar a evolução (OMS, 2010, p. ix).

O mesmo relatório faz três recomendaçóes importantes para o alcance da cobertura universal: $i$ ) reunir recursos suficientes; $i$ ) reduzir a utilização do pagamento direto no financiamento da saúde; e iii) aumentar a eficiência e a equidade.

$\mathrm{Na}$ Agenda para ação (à página 87 do relatório), são feitas indicações a respeito do financiamento da cobertura universal. Reconhece-se ser impossível alcançar a cobertura universal por meio do esquema de asseguramento quando a vinculação é voluntária, isto é, por meio de seguro privado de saúde (voluntário). Um caso ilustrativo é o dos Estados Unidos, onde, apesar de existirem seguros públicos para grupos populacionais específicos, o Medicaid e o Medicare, o restante da população depende de seguro privado, adquirido individualmente ou por meio do empregador. Esse modelo de sistema de saúde deixa sem cobertura parcela relevante da população - mesmo após o Obamacare, parcela elevada da população não possuía nenhum tipo de cobertura de seguro de saúde em 2018. ${ }^{15}$ Aqui surge, aparentemente, a questão de que nem todos podem pagar um seguro, mesmo que público, como acontece, por exemplo, nos sistemas bismarckianos, mas não deixa claro que a solução seja o aporte de recursos de outras fontes públicas. A Agenda para açâo recomenda, ainda, a concentração dos recursos em um "fundo" único, em vez de sua vinculação a múltiplos fundos, o que facilitaria o uso mais eficiente e equitativo desses recursos.

Em síntese, portanto, a questão colocada para a cobertura universal nesse relatório poderia ser formulada nos seguintes termos: como garantir e financiar o acesso a serviços de saúde, com proteção ao risco financeiro, de forma equitativa, otimizando os recursos?

Nos anos subsequentes, a proposta de cobertura universal foi ganhando um protagonismo cada vez maior e aliados importantes, entre organismos internacionais multilaterais, fundaçóes privadas e imprensa especializada, representada pelo tradicional periódico The Lancet. $\mathrm{O}$ ápice dessa trajetória foi sua inclusão como um dos objetivos mundiais de desenvolvimento sustentável.

\footnotetext{
14. Os conceitos de cobertura, acesso e equidade têm sido debatidos em diversos documentos. 0 alcance de equidade na cobertura ou no acesso pressupõe dar prioridade a estratégias e ações para incluir as populações mais desprotegidas. 15. O Patient Protection and Affordable Care Act (PPACA), ou apenas Affordable Care Act (ACA), popularmente conhecido como Obamacare, foi adotado nos Estados Unidos durante o governo do presidente Barack Obama com o objetivo de tornar mais acessível seguros de saúde para as pessoas mais vulneráveis. O Obamacare difere dos seguros públicos de saúde tradicionais por não se basear em contribuições obrigatórias dos trabalhadores vinculados ao mercado de trabalho, como ocorre nos sistemas bismarckianos clássicos. Nele há a obrigatoriedade de o trabalhador adquirir um convênio de saúde, regras para evitar a rejeição de pessoas com doenças pré-existentes e regras de subsídios à população mais carente. Nada obstante a intenção, em 2018, 8,5\% dos americanos ainda não tinham cobertura por seguro de saúde. Ver Bercito (2020).
} 


\subsection{Cobertura universal versus sistema universal: existe um problema?}

Autores como Noronha (2013) e Giovanella et al. (2018) têm centrado as principais críticas à proposição da OMS no abandono dos princípios do direito à saúde expresso na Constituição da instituição, na redefiniçẫo de certos conceitos clássicos, como é o caso da universalidade, na desatenção a princípios como o de equidade e integralidade, além de uma ênfase, considerada exagerada, na barreira financeira como principal empecilho ao acesso mais oportuno e regular aos serviços de saúde.

Não menosprezando a discussão dos pontos citados, o fato é que os sistemas de saúde foram sendo criados em momentos distintos, à luz de condiçóes específicas de organização e desenvolvimento vigentes em cada país. Em sua evolução, demonstraram ser extremamente permeáveis aos embates ocorridos nos campos da ideologia, da política e da economia mundial, bem como da própria expansão das tecnologias médicas e de seu imbricamento com os setores produtivos. Visto dessa forma, náo se deve estranhar o fato de que a proposta da OMS tenha alto grau de flexibilidade para ter adesão a realidades distintas, nem que o complexo médico industrial e financeiro da saúde, em notável expansão nas últimas décadas, tenha forte interesse na definição do modelo de expansão da cobertura e do fortalecimento do financiamento da saúde que lhes seja mais funcional (Ocké-Reis, 2016).

A questão do financiamento, aí incluído o problema do gasto catastrófico, ${ }^{16}$ tem sido muito discutida pelo fato de muitos pesquisadores identificarem a opção preferencial pelo asseguramento obrigatório como a alternativa que facilitaria a destinação de recursos públicos ao mercado privado (Noronha, 2013; Giovanella et al., 2018), cujo interesse aparece claramente identificado nas conclusóes do encontro promovido pela Fundação Rockfeller, em dezembro de 2012, sobre o futuro dos mercados da saúde. ${ }^{17}$

Nada obstante, diversos pesquisadores reforçam a importância da pluralidade de fontes, inclusive de recursos privados, para que se tenha a potência necessária para o alcance da cobertura universal (Garrett, Chowdhury e Pablo-Mendez, 2009). Outros atribuem aos recursos originários de impostos gerais a função de assegurar os não incluídos via mercado de trabalho (Kutzin, 2012).

Uma questão também muito debatida é se a proposta de cobertura universal, como está se desenhando, favorecerá ou não um acesso mais equitativo. Há os que consideram que a proposta pode levar a uma segmentação ainda maior dos sistemas

16. Gastos catastróficos são gastos elevados com saúde que podem comprometer o orçamento das famílias a ponto de limitarem o consumo de outros bens e serviços e até gerar endividamento e empobrecimento. Na meta 3.8 do ODS 3 , por exemplo, a proteção contra riscos financeiros é monitorada por um indicador que mede a proporção de pessoas em domicílios que tem gasto com saúde superior a $10 \%$ e a $25 \%$ das despesas de consumo das famílias.

17. Esta é uma das conclusões sobre a cobertura universal de saúde do encontro Future Health Markets, promovido pela Fundação Rockfeller, Bellagio, Itália, em dezembro de 2012: "é provável que fortes agentes de mercado, como fabricantes de produtos farmacêuticos, organizações hospitalares, associações de provedores e companhias de seguros, aumentem a pressão para atrair financiamento público e privado, especialmente nos países de renda baixa e média, para que adotem políticas para financiar o seguro de saúde, como um meio em direção à cobertura universal de saúde". 
de atenção à saúde (Giovanella et al., 2018), enquanto outros, como Gwatkin e Ergo (2011), conforme comentário para The Lancet, julgam que o caminho para alcançar a cobertura universal e, simultaneamente, diminuir a iniquidade está no privilegiamento, desde o início da implantação da proposta, de estratégias de cobertura direcionadas para a população mais carente. Os autores justificam essa posição com os exemplos do programa Saúde da Família, no Brasil, e do Seguro Popular, no México, que começaram atendendo às populaçóes mais carentes para depois alcançar áreas menos desprotegidas. Há, entretanto, a nosso ver, uma diferença básica entre as duas estratégias citadas: o Saúde da Família integra um sistema público de caráter universal, sendo porta de entrada e estratégia de estruturação do sistema. Por sua vez, o Seguro Popular do México, restrito à população mais pobre, baseado em subsídio ao asseguramento, tem uma cesta restrita de açóes de saúde e não se articula com os demais segmentos do sistema.

Outros autores têm uma visão menos crítica da proposta da OMS. ${ }^{18}$ É evidente que, para países que não têm nenhum sistema estruturado, a proposta poderia ser considerada um avanço. Aliás, um dos motivos que podem ter levado os organismos internacionais a abraçarem a proposta talvez tenha sido a constatação de que a ajuda internacional direcionada a problemas específicos (Aids, tuberculose etc.) não apresentou resultados relevantes, a não ser naqueles países que já tinham um sistema de serviços de saúde relativamente estruturado. Nos países que ainda hoje possuem parcelas importantes da população sem acesso aos serviços de saúde, certamente a aderência à proposta pode, no mínimo, significar maior aporte de recursos externos. Em outros países, como os da América Latina, o debate sobre a cobertura universal levou à discussão de estratégias para alcançar as populaçóes ainda sem cobertura e colocou em pauta os problemas da segmentação de clientelas ainda existentes na maioria dos países da região.

Outro tema, também muito discutido, diz respeito ao impacto que a proposta pode ter em países que já avançaram na construção de sistemas universais de saúde, como o Brasil. Dito de outra forma, a proposta de cobertura universal de saúde teria implicaçôes para a organização e o financiamento do sistema de saúde do Brasil? A resposta é incerta. Poderia ser afirmativa, porque sempre há uma tendência à absorção, às vezes de maneira um tanto apressada, de novas proposiçôes no campo das políticas, especialmente se originadas de organismos internacionais, mesmo antes de terem sido avaliadas com maior profundidade. Ou poderia ser negativa, uma vez que o sistema de saúde brasileiro é universal, e, pelo menos aparentemente, uma das características da proposta de cobertura universal é ser bastante flexível. 
Lagomarsino et al. (2012), em estudo publicado na revista Lancet, mostram a pluralidade de caminhos que levaram ao aumento da cobertura com seguro de saúde, expansão na lista de serviços oferecidos, aumento do gasto governamental e diminuição do gasto privado direto em oito países em desenvolvimento do sudeste da Ásia e da África. Conforme discutem Marten et al. (2014) em trabalho publicado pelo Lancet, no caso do Brasil, que já possui um sistema definido constitucionalmente como de cobertura universal e financiamento público, os principais problemas identificados para efetivação da cobertura universal se situam na insuficiência de recursos aportados pelo poder público e no enfrentamento das desigualdades regionais e populacionais de acesso aos serviços, mediante políticas de distribuição de profissionais e equipamentos de saúde. ${ }^{19}$ Outra particularidade do sistema público do Brasil reside no fato de o país já contar com uma oferta de serviços de atenção primária à saúde bastante expandida e de ter adotado a atenção primária à saúde também como estratégia de organização dos demais níveis de atenção do sistema. De qualquer forma, não devemos desconsiderar que a conjuntura política e econômica, fortemente impregnada de um ideário de irrestrita diminuição do papel do Estado nas políticas públicas, pode trazer importantes óbices ao desenvolvimento do SUS, independentemente de inevitáveis "pressōes" externas baseadas em interpretações convenientes da meta de cobertura universal do ODS 3.

Todavia, o fato de o Brasil ter um sistema de cobertura universal garantiu avanços importantes no acesso à atenção à saúde, com redução das desigualdades regionais e entre grupos populacionais (Paim et al., 2011). A evolução dos indicadores que serão apresentados na próxima seção é fruto, entre outros, dos avanços na organização do SUS. Ademais, esse sistema garante alguma proteçáo financeira contra gastos catastróficos em saúde à medida que, antes de incorrerem em tais gastos, as pessoas teriam a opção de tentar o atendimento pelo SUS (Menezes et al., 2006).

\section{ODS}

Como dito anteriormente, o Brasil conta com um sistema de saúde de acesso universal e financiamento público a partir de tributos gerais, o que, a priori, atenderia aos requisitos para alcance da meta 3.8 de cobertura universal e proteção financeira. Além disso, o sistema brasileiro vai além de uma preocupação com a proteção contra riscos financeiros. Ele se propóe a organizar a atençâo integral à saúde e possibilita avançar em direção a uma maior redução da mortalidade infantil e materna, à promoção e prevenção de doenças transmissíveis e doenças crônicas não transmissíveis, bem como ao acesso aos serviços de saúde para aqueles que desenvolveram essas doenças. Assim, a discussão da seção anterior subsidia

19. A insuficiência de recursos públicos no financiamento do SUS tende a se tornar ainda maior como consequência do congelamento das despesas primárias do governo federal até 2036, conforme determinou a Emenda Constitucional (EC) ำ 95/2016. 
a análise a ser feita a partir de agora a respeito das metas do ODS 3. Esta seção, baseada em Silva, Peliano e Chaves (2018) e Sá e Benevides (2019), mostra como as metas de saúde constantes nos ODMs foram incorporadas às metas do ODS 3 e traz um resumo da proposta de ajuste para as circunstâncias brasileiras das metas deste objetivo e um diagnóstico da situação inicial brasileira em relação às metas estabelecidas. Importante ressaltar que a proposta de ajuste para as circunstâncias brasileiras das metas do ODS 3 não foi chancelada pelo atual governo e não configura um compromisso oficial.

\subsection{Transição dos ODMs para os ODS: da Agenda 2015 para a Agenda 2030 na saúde}

Em termos globais, houve significativos avanços na saúde materna, na redução da mortalidade na infância, na saúde sexual e reprodutiva e na incidência de doenças infecciosas durante o período dos ODMs. Mesmo assim, as metas globais na saúde não foram atingidas, e as desigualdades regionais mantiveram-se em níveis elevados. Por exemplo, a taxa global de mortalidade na infância (crianças menores de 5 anos de idade) declinou de 93 óbitos por mil nascidos vivos, em 1990, para 41 óbitos por mil nascidos vivos, em 2016. Contudo, a meta de redução em dois terços da mortalidade na infância, o que significaria reduzi-la para 31 óbitos por mil nascidos vivos, não foi atingida, e as desigualdades permanecem elevadas. Estima-se que a taxa de mortalidade na infância tenha variado de dois óbitos por mil nascidos vivos na Finlândia a 133 óbitos por mil nascidos vivos na Somália (UN IGME, 2017).

Tanto as metas que dáo continuidade à agenda dos ODMs quanto as novas metas adotadas na Agenda ODS parecem muito ambiciosas. Por exemplo, no nível global, mantido o ritmo observado entre 1990 e 2015, se levaria mais uma década para atingir a meta de redução em dois terços da taxa de mortalidade na infância pactuada no ODM. Contudo, existem evidências de que, de modo geral, houve aceleração nos indicadores globais monitorados em direção às metas ODM na área de saúde após o ano 2000. Embora o período de monitoramento compreenda o intervalo entre os anos 1990 e 2015, apenas os últimos quinze anos referem-se ao período pós-pactuação das metas, e mudanças de perspectivas e práticas propícias ao desenvolvimento parecem ter-se consolidado neste período (Friedman, 2013).

Entre as novas metas do ODS 3, vale destacar as referentes às doenças não transmissíveis e à cobertura universal de saúde, esta última objeto de discussão da seção 2 deste capítulo. Embora sejam há algum tempo a principal causa de morte global, as doenças crônicas não transmissíveis (DCNTs) não estavam presentes na Agenda ODM. Para se ter uma ideia, estima-se que, em 2016, as DCNTs tenham sido responsáveis por mais de $70 \%$ dos óbitos ocorridos mundialmente, com destaque para as doenças cardiovasculares, as neoplasias, as doenças respiratórias crônicas e o diabetes. Contudo, a crescente participação na carga de doença dos países de rendas 
baixa e média levou ao compromisso global de se reduzir em um terço a mortalidade prematura ( 30 a 69 anos) por doenças crônicas não transmissíveis até 2030. Essa meta será bastante desafiadora, pois os sistemas de saúde desses países não estão preparados para lidar com os custos epidemiológicos e econômicos das doenças crônicas, tendo baixa cobertura até para serviços de saúde mais básicos (WHO, 2018a).

Como visto anteriormente, a cobertura universal de serviços de saúde também consta das metas a serem atingidas no ODS 3. A meta 3.8 tem por objetivo "atingir a cobertura universal de saúde, incluindo a proteção do risco financeiro, o acesso a serviços de saúde essenciais de qualidade e o acesso a medicamentos e vacinas essenciais seguros, eficazes, de qualidade e a preços acessíveis para todos". Para monitoramento da meta 3.8, são propostos indicadores globais, que medem a cobertura populacional para serviços essenciais, e um indicador relativo à proteção financeira contra gastos elevados com saúde.

QUADRO 1

Comparação dos ODMs saúde com as metas globais e proposta de ajuste do ODS 3

\begin{tabular}{|c|c|c|c|}
\hline Tema & Metas globais & $\begin{array}{l}\text { Proposta de adequação } \\
\text { das metas ao Brasil }\end{array}$ & ODM \\
\hline $\begin{array}{l}\text { Mortalidade } \\
\text { materna }\end{array}$ & $\begin{array}{l}\text { Meta } 3.1 \text { - Até } 2030 \text {, reduzir a taxa } \\
\text { de mortalidade materna global para } \\
\text { menos de } 70 \text { mortes por } 100 \text { mil } \\
\text { nascidos vivos. }\end{array}$ & $\begin{array}{l}\text { Meta } 3.1 \text { - Até } 2030 \text {, reduzir a } \\
\text { razão de mortalidade materna para } \\
\text { no máximo } 30 \text { mortes por } 100 \text { mil } \\
\text { nascidos vivos. }\end{array}$ & $\begin{array}{l}\text { ODM } 5 \text { - Até } 2015 \text {, } \\
\text { reduzir a mortalidade } \\
\text { materna em três quartos } \\
\text { do nível observado em } \\
1990 .\end{array}$ \\
\hline $\begin{array}{l}\text { Mortalidade na } \\
\text { infância }\end{array}$ & $\begin{array}{l}\text { Meta } 3.2 \text { - Até 2030, acabar com as } \\
\text { mortes evitáveis de recém-nascidos } \\
\text { e crianças menores de } 5 \text { anos, com } \\
\text { todos os países objetivando reduzir } \\
\text { a mortalidade neonatal para pelo } \\
\text { menos } 12 \text { por } 1 \text { mil nascidos vivos e } \\
\text { a mortalidade de crianças menores de } \\
5 \text { anos para pelo menos } 25 \text { por } 1 \text { mil } \\
\text { nascidos vivos. }\end{array}$ & $\begin{array}{l}\text { Meta } 3.2 \text { - Até } 2030 \text {, enfrentar as } \\
\text { mortes evitáveis de recém-nascidos e } \\
\text { crianças menores de } 5 \text { anos, objeti- } \\
\text { vando reduzir a mortalidade neonatal } \\
\text { para no máximo } 5 \text { por } 1 \text { mil nascidos } \\
\text { vivos e a mortalidade de crianças } \\
\text { menores de } 5 \text { anos para, no máximo, } \\
8 \text { por } 1 \text { mil nascidos vivos. }\end{array}$ & $\begin{array}{l}\text { ODM } 4 \text { - Até } 2015 \text {, } \\
\text { reduzir a mortalidade na } \\
\text { infância em dois terços } \\
\text { do nível de } 1990 \text {. }\end{array}$ \\
\hline $\begin{array}{l}\text { Doenças } \\
\text { transmissiveis }\end{array}$ & $\begin{array}{l}\text { Meta } 3.3 \text { - Até } 2030 \text {, acabar com } \\
\text { as epidemias de Aids, tuberculose, } \\
\text { malária e doenças tropicais negli- } \\
\text { genciadas, e combater a hepatite, } \\
\text { doenças transmitidas pela água, e } \\
\text { outras doenças transmissíveis. }\end{array}$ & $\begin{array}{l}\text { Meta } 3.3 \text { - Até } 2030 \text { acabar, como } \\
\text { problema de saúde pública, com } \\
\text { as epidemias de Aids, tuberculose, } \\
\text { malária, hepatites virais, doenças } \\
\text { negligenciadas, doenças transmitidas } \\
\text { pela água, arboviroses transmitidas } \\
\text { pelo Aedes aegypti e outras doenças } \\
\text { transmissíveis. }\end{array}$ & $\begin{array}{l}\text { ODM } 6 \text { - Até } 2015 \text {, } \\
\text { interromper a propa- } \\
\text { gação e diminuir a } \\
\text { incidência de HIV/Aids; } \\
\text { até } 2010 \text {, universalizar } \\
\text { o acesso ao tratamento } \\
\text { de HIV/Aids; até } 2015 \text {, } \\
\text { reduzir a incidência } \\
\text { de malária e outras } \\
\text { doenças. }\end{array}$ \\
\hline $\begin{array}{l}\text { Doenças não } \\
\text { transmissíveis }\end{array}$ & $\begin{array}{l}\text { Meta } 3.4 \text { - Até 2030, reduzir em } \\
\text { um terço a mortalidade prematura } \\
\text { por doenças não transmissíveis via } \\
\text { prevenção e tratamento, e promover a } \\
\text { saúde mental e o bem-estar. }\end{array}$ & $\begin{array}{l}\text { Meta } 3.4 \text { - Até } 2030 \text {, reduzir em } \\
\text { um terço a mortalidade prematura } \\
\text { por doenças não transmissíveis via } \\
\text { prevenção e tratamento, promover a } \\
\text { saúde mental e o bem-estar, a saúde } \\
\text { do trabalhador e da trabalhadora, e } \\
\text { prevenir o suicídio, alterando significa- } \\
\text { tivamente a tendência de aumento. }\end{array}$ & Sem metas \\
\hline
\end{tabular}


(Continuação)

\begin{tabular}{|c|c|c|c|}
\hline Tema & Metas globais & $\begin{array}{c}\text { Proposta de adequação } \\
\text { das metas ao Brasil }\end{array}$ & ODM \\
\hline $\begin{array}{l}\text { Prevenção e } \\
\text { tratamento do } \\
\text { abuso de drogas } \\
\text { e álcool }\end{array}$ & $\begin{array}{l}\text { Meta } 3.5 \text { - Reforçar a prevenção e o } \\
\text { tratamento do abuso de substâncias, } \\
\text { incluindo o abuso de drogas entorpe- } \\
\text { centes e uso nocivo do álcool. }\end{array}$ & $\begin{array}{l}\text { Meta } 3.5 \text { - Reforçar a prevenção e } \\
\text { o tratamento dos problemas decorren- } \\
\text { tes do uso de substâncias, incluindo o } \\
\text { abuso de drogas entorpecentes e uso } \\
\text { nocivo do álcool. }\end{array}$ & Sem metas \\
\hline $\begin{array}{l}\text { Redução de } \\
\text { mortes e lesões } \\
\text { por acidente no } \\
\text { trânsito }\end{array}$ & $\begin{array}{l}\text { Meta } 3.6 \text { - Até } 2020 \text {, reduzir pela } \\
\text { metade as mortes e os ferimentos } \\
\text { globais por acidentes em estradas. }\end{array}$ & $\begin{array}{l}\text { Meta } 3.6 \text { - Até } 2030 \text {, reduzir pela } \\
\text { metade as mortes e lesões por aciden- } \\
\text { tes no trânsito. }\end{array}$ & Sem metas \\
\hline $\begin{array}{l}\text { Acesso universal } \\
\text { à saúde sexual e } \\
\text { reprodutiva }\end{array}$ & $\begin{array}{l}\text { Meta } 3.7 \text { - Até } 2030 \text {, assegurar } \\
\text { o acesso universal aos serviços de } \\
\text { saúde sexual e reprodutiva, incluindo } \\
\text { o planejamento familiar, informação } \\
\text { e educação, bem como a integração } \\
\text { da saúde reprodutiva em estratégias e } \\
\text { programas nacionais. }\end{array}$ & $\begin{array}{l}\text { Meta } 3.7 \text { - Até } 2030 \text {, assegurar } \\
\text { o acesso universal aos serviços e } \\
\text { insumos de saúde sexual e repro- } \\
\text { dutiva, incluindo o planejamento } \\
\text { reprodutivo, à informação e educação, } \\
\text { bem como a integração da saúde } \\
\text { reprodutiva em estratégias e progra- } \\
\text { mas nacionais. }\end{array}$ & $\begin{array}{l}\text { ODM } 5 \text { - Até } 2015 \text {, } \\
\text { universalizar o acesso à } \\
\text { saúde reprodutiva. }\end{array}$ \\
\hline $\begin{array}{l}\text { Cobertura } \\
\text { universal de saúde } \\
\text { e acesso a medica- } \\
\text { mentos e vacinas }\end{array}$ & $\begin{array}{l}\text { Meta } 3.8 \text { - Atingir a cobertura } \\
\text { universal de saúde, incluindo a } \\
\text { proteção do risco financeiro, o acesso } \\
\text { a serviços de saúde essenciais de } \\
\text { qualidade e o acesso a medicamentos } \\
\text { e vacinas essenciais seguros, eficazes, } \\
\text { de qualidade e a preços acessíveis } \\
\text { para todos. }\end{array}$ & $\begin{array}{l}\text { Meta } 3.8 \text { - Assegurar, por meio do } \\
\text { SUS, a cobertura universal de saúde, o } \\
\text { acesso a serviços essenciais de saúde } \\
\text { de qualidade em todos os níveis de } \\
\text { atenção e o acesso a medicamentos } \\
\text { e vacinas essenciais seguros, eficazes } \\
\text { e de qualidade que estejam incorpora- } \\
\text { dos ao rol de produtos oferecidos } \\
\text { pelo SUS. }\end{array}$ & Sem metas \\
\hline $\begin{array}{l}\text { Redução das } \\
\text { mortes e doenças } \\
\text { causadas por } \\
\text { produtos químicos } \\
\text { perigosos, } \\
\text { contaminação e } \\
\text { poluição }\end{array}$ & $\begin{array}{l}\text { Meta } 3.9 \text { - Até } 2030 \text {, reduzir } \\
\text { substancialmente o número de mortes } \\
\text { e doenças por produtos químicos } \\
\text { perigosos, contaminação e poluição } \\
\text { do ar e água do solo. }\end{array}$ & $\begin{array}{l}\text { Meta } 3.9 \text { - Até } 2030 \text {, reduzir } \\
\text { substancialmente o número de mortes } \\
\text { e doenças por produtos químicos } \\
\text { perigosos, contaminação e poluição } \\
\text { do ar e água e do solo. }\end{array}$ & Sem metas \\
\hline $\begin{array}{l}\text { Fortalecimento } \\
\text { do controle do } \\
\text { tabaco }\end{array}$ & $\begin{array}{l}\text { Meta 3.a - Fortalecer a implemen- } \\
\text { tação da Convenção-Quadro para } \\
\text { o Controle do Tabaco em todos os } \\
\text { países, conforme apropriado. }\end{array}$ & $\begin{array}{l}\text { Meta 3.a - Fortalecer a implemen- } \\
\text { tação da Convenção-Quadro para o } \\
\text { Controle do Tabaco no Brasil. }\end{array}$ & Sem metas \\
\hline $\begin{array}{l}\text { Pesquisa e } \\
\text { desenvolvimento } \\
\text { de tecnologias } \\
\text { e inovações em } \\
\text { saúde }\end{array}$ & $\begin{array}{l}\text { Meta 3.b - Apoiar a pesquisa e } \\
\text { o desenvolvimento de vacinas e } \\
\text { medicamentos para as doenças } \\
\text { transmissíveis e não transmissíveis, } \\
\text { que afetam principalmente os países } \\
\text { em desenvolvimento, proporcionar } \\
\text { o acesso a medicamentos e vacinas } \\
\text { essenciais a preços acessíveis, de } \\
\text { acordo com a Declaração de Doha, } \\
\text { que afirma o direito dos países em } \\
\text { desenvolvimento de utilizarem plena- } \\
\text { mente as disposições do Acordo TRIPS } \\
\text { sobre flexibilidades para proteger } \\
\text { a saúde pública e, em particular, } \\
\text { proporcionar acesso a medicamentos } \\
\text { para todos. }\end{array}$ & $\begin{array}{l}\text { Meta 3.b - Apoiar a pesquisa e o } \\
\text { desenvolvimento de tecnologias e } \\
\text { inovações em saúde para as doenças } \\
\text { transmissíveis e não transmissíveis, } \\
\text { proporcionar o acesso a essas } \\
\text { tecnologias e inovações incorporadas } \\
\text { ao SUS, incluindo medicamentos e } \\
\text { vacinas, a toda a população. }\end{array}$ & Sem metas \\
\hline
\end{tabular}




\begin{tabular}{|c|c|c|c|}
\hline Tema & Metas globais & $\begin{array}{c}\text { Proposta de adequação } \\
\text { das metas ao Brasil }\end{array}$ & ODM \\
\hline $\begin{array}{l}\text { Aumento do finan- } \\
\text { ciamento da saúde } \\
\text { e da formação de } \\
\text { pessoal }\end{array}$ & $\begin{array}{l}\text { Meta 3.c - Aumentar substancial- } \\
\text { mente o financiamento da saúde e } \\
\text { o recrutamento, desenvolvimento } \\
\text { e formação, e retenção do pessoal } \\
\text { de saúde nos países em desen- } \\
\text { volvimento, especialmente nos } \\
\text { países menos desenvolvidos e nos } \\
\text { pequenos Estados insulares em } \\
\text { desenvolvimento. }\end{array}$ & $\begin{array}{l}\text { Meta 3.c - Aumentar substancial- } \\
\text { mente o financiamento da saúde e } \\
\text { o recrutamento, desenvolvimento, } \\
\text { formação e retenção do pessoal de } \\
\text { saúde, especialmente nos territórios } \\
\text { mais vulneráveis. }\end{array}$ & Sem metas \\
\hline $\begin{array}{l}\text { Alerta precoce, } \\
\text { redução e } \\
\text { gerenciamento } \\
\text { de emergências e } \\
\text { riscos de saúde }\end{array}$ & $\begin{array}{l}\text { Meta } 3 . d \text { - Reforçar a capacidade } \\
\text { de todos os países, particularmente } \\
\text { os países em desenvolvimento, para } \\
\text { o alerta precoce, redução de riscos e } \\
\text { gerenciamento de riscos nacionais e } \\
\text { globais de saúde. }\end{array}$ & $\begin{array}{l}\text { Meta } 3 . d \text { - Reforçar as capacidades } \\
\text { locais para o alerta precoce, redução } \\
\text { e gerenciamento de emergências e } \\
\text { riscos nacionais e globais de saúde. }\end{array}$ & Sem metas \\
\hline
\end{tabular}

Fontes: Silva, Peliano e Chaves (2018, p. 75-105) e PNUD (2019).

Utilizando o índice Universal Health Coverage (UHC), ${ }^{20}$ estima-se que, em 2015, metade da população mundial não tinha cobertura completa para os serviços essenciais de saúde; e, mesmo entre aqueles que tinham acesso aos serviços essenciais, muitos passaram a sofrer dificuldades financeiras devido a gastos catastróficos. Estima-se que, em 2010, mais de 800 milhões de pessoas, quase $12 \%$ da populaçáo mundial, gastaram diretamente do bolso mais de $10 \%$ do orçamento domiciliar com serviços de saúde, sendo que, para 179 milhōes, estes gastos excederam um quarto do orçamento doméstico (WHO, 2018a).

\subsection{ODS: metas globais, metas nacionais e principais resultados para o Brasil}

Nos meses de abril e maio de 2018, mais de oitenta representantes de vinte órgãos federais participaram de três oficinas de trabalho coordenadas pelo Ipea, as quais tiveram por objetivo ajustar as metas globais referentes ao ODS 3 para o contexto nacional (Silva, Peliano e Chaves, 2018). Como mostra o quadro 1, foram feitas propostas de ajustes em doze das treze metas globais, mas nenhuma meta nacional foi criada.

A proposta de ajuste das metas relativas à mortalidade materna e à mortalidade na infância levou em conta o fato de que o Brasil já havia atingido as novas metas globais acordadas. O Brasil já apresentava, em 2016, razão de mortalidade materna (RMM) estimada em 64,4 óbitos por 100 mil nascidos vivos, valor inferior à meta global, que foi estipulada em menos de setenta. Propôs-se que a meta nacional para 2030 seja ajustada para até trinta mortes maternas por 100 mil nascidos vivos, atendendo a compromisso assumido pelo Ministério da Saúde (MS) no dia 28 de maio de 2018, em reunião da Comissão Nacional de Combate à Mortalidade Materna e do lançamento da Semana Nacional de Mobilização pela Saúde das Mulheres.

20. O UHC é um indicador composto que leva em conta: i) a cobertura de serviços essenciais de saúde reprodutiva, materna, do recém-nascido e da criança, de controle de doenças infecciosas e de doenças crônicas não transmissíveis; ii) a capacidade de prestação de serviços; e iii) o acesso. 




Apesar de os dados preliminares indicarem aumento em 2016 e 2017, a mortalidade de mulheres durante a gravidez, o parto e o puerpério tem se reduzido de forma acentuada nas últimas décadas. Estima-se que, de 1990 a 2015, a RMM declinou de 141 óbitos para 62 óbitos por 100 mil nascidos vivos. Contudo, existem marcantes desigualdades regionais. Por exemplo, a RMM estimada para a região Nordeste em 2015 foi de 76 óbitos por 100 mil nascidos vivos, enquanto na regiāo Sul foi menor que 44 por 100 mil (Sá e Benevides, 2019).

A redução da mortalidade materna depende, entre outros fatores, da atenção à saúde de qualidade antes, durante e após o parto. A OMS recomenda que o pré-natal seja iniciado ainda no primeiro trimestre da gravidez, o que permite a identificação e o tratamento precoce de problemas de saúde que podem gerar risco de complicaçóes para a saúde da mulher ou da criança durante e após o parto. ${ }^{21}$

A pesquisa Nascer no Brasil, realizada nos anos 2011 e 2012 com quase 24 mil mulheres, constatou que $60 \%$ das mulheres iniciaram tardiamente o pré-natal. Contudo, a porcentagem de partos realizados em estabelecimentos de saúde (uma proxy para a proporção de partos assistidos por profissionais qualificados) é praticamente universal. Por sua vez, o Programa de Humanização do Pré-Natal e Nascimento do MS preconiza a realização de ao menos sete consultas durante a gestação. Em 2016, um terço $(32,2 \%)$ das gestantes brasileiras não teve a quantidade mínima de consultas recomendada pelo MS (Firjan, 2018).

21. Aproximadamente $92 \%$ das mortes maternas ocorrem por causas evitáveis, principalmente hipertensão, hemorragia ou infecções (WHO, 2018a). 
Os avanços obtidos na redução de mortalidade materna foram, em parte, resultado da organização da atenção básica à saúde e da existência de uma rede hospitalar atendendo pelo SUS, que permitiram uma atenção integral ao parto e ao puerpério (Brasil, 2015). A despeito desses avanços, a RMM encontra-se, desde 2011, entre 60 e 65 mortes por 100 mil nascidos vivos, exigindo melhorias de qualidade da atenção obstétrica que demandarão um sistema mais coordenado entre a atenção básica e a atenção especializada. ${ }^{22}$

No caso da mortalidade na infância, o Brasil também já havia atingido as metas globais. A proposta de novas metas nacionais foi definida pelo MS a partir de subsídios das áreas de saúde da mulher e de saúde da criança. A projeção de redução até 2030 foi estimada a partir de série histórica de 2000 a 2015 dos indicadores de mortalidade neonatal e na infância. Para a taxa de mortalidade neonatal (de 0 a 27 dias de vida), foi proposta meta de reduçáo de 43,7\% no período 2015-2030, que aponta para uma taxa de mortalidade de cinco por 1 mil nascidos vivos. Para a taxa de mortalidade na infância (menores de 5 anos), foi proposta redução de $47,4 \%$, o que representaria redução da taxa de mortalidade para oito por 1 mil nascidos vivos (gráfico 2).

\section{GRÁFICO 2}

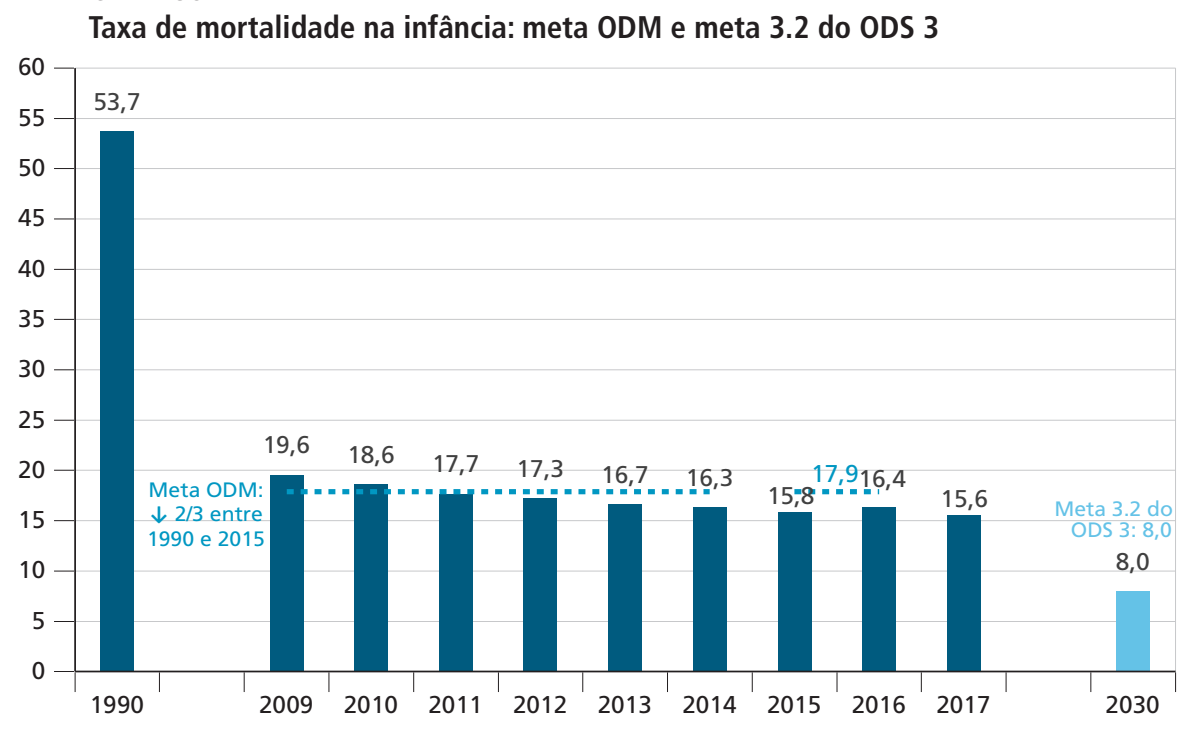

Fontes: Silva, Peliano e Chaves (2018) e Base de dados da SVS/MS. Disponível em: <https://bit.ly/3bnzJVL>. Acesso em: 10 abr. 2020.

Embora em 2016 a taxa de mortalidade na infância tenha interrompido uma trajetória descendente observada desde 1990, os avanços também foram consideráveis. De acordo com estimativas da SVS, do MS, a taxa diminuiu de 53,7 
para 15,8 óbitos por 1 mil nascidos vivos entre 1990 e 2015, chegou a 16,4 óbitos por 1 mil nascidos vivos em 2016 e recuou para 15,6 em 2017. A mortalidade na infância está concentrada no primeiro ano de vida e, durante este, no período neonatal (0 a 27 dias de vida), conforme gráfico 3.

\section{GRÁFICO 3}

Mortalidade na infância e infantil: proporção dos óbitos por idade - Brasil (2016) (Em \%)

$3 \mathrm{~A}$ - Mortalidade na infância por idade

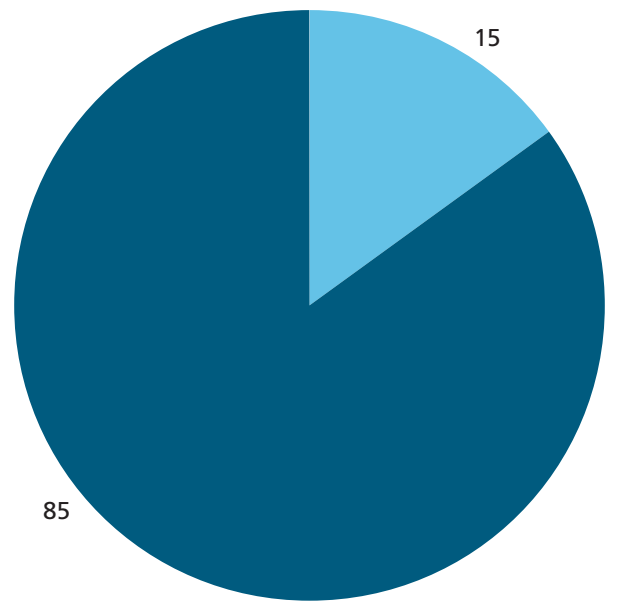

Menor que 1 ano De 1 a 4 anos

3B - Mortalidade infantil por idade

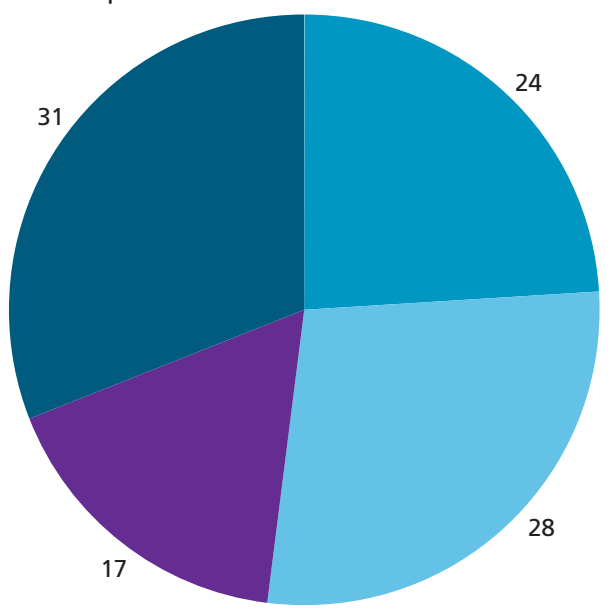

Menos de 24 horas 
Como mostra o gráfico 4, o Brasil obteve significativos avanços na redução da mortalidade na infância. Esses avanços são resultados de diversas políticas públicas, entre as quais a estratégia de saúde da família. Todavia, como os óbitos infantis se concentram cada vez mais no período neonatal precoce, que compreende o período de 0 a 6 dias de vida, o acesso a uma rede de atenção que coordene as açôes de atenção básica e especializada será fundamental. Enquanto a redução dos óbitos no período pós-neonatal é explicado, em parte, pelos avanços na educação, no saneamento básico e nos programas de vacinação, no período neonatal é quando se produz o maior impacto de uma atenção à saúde que coordene uma assistência pré-natal de qualidade com a atenção especializada qualificada na hora do parto.

GRÁFICO 4

Taxas de mortalidade na infância: neonatal e infantil - Brasil (1990-2017) (Em \%)

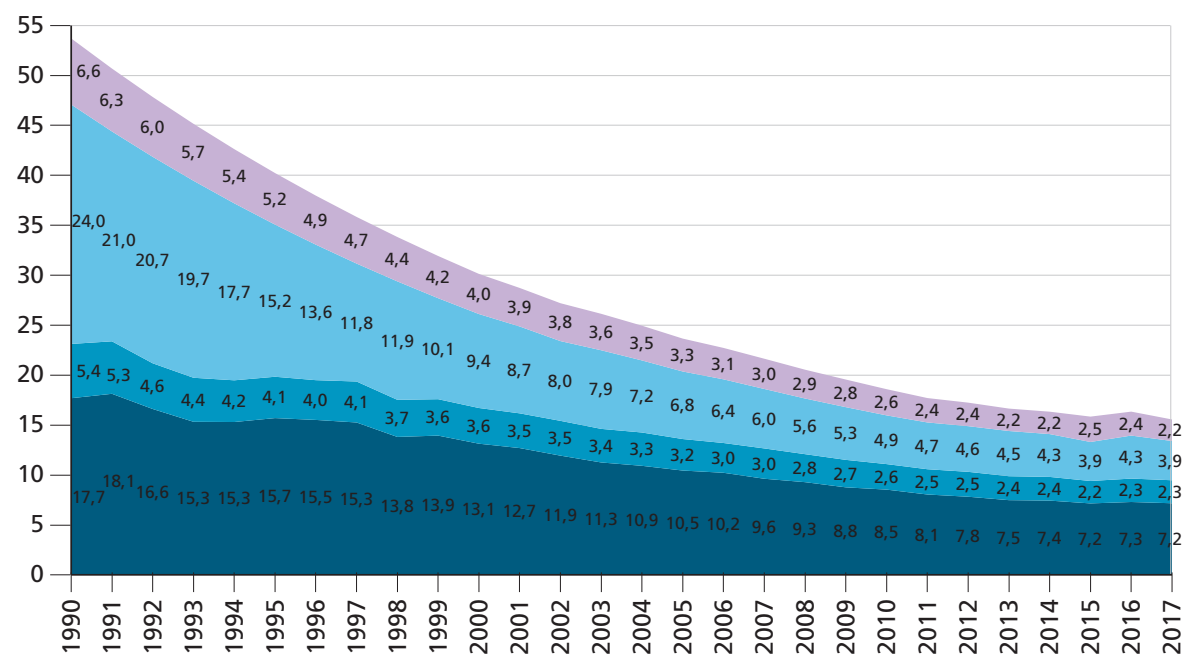

$\begin{array}{ll}\text { Neonatal precoce (0 a } 6 \text { dias) } & \text { Neonatal tardio (7 a } 27 \text { dias) } \\ \text { Pós-neonatal (28 a } 364 \text { dias) } & 1 \text { a } 4 \text { anos }\end{array}$

Fontes: SIM, Sinasc e Brasil (2018).

A despeito da considerável redução observada, ainda morrem muitas crianças no Brasil antes de completar o quinto ano de idade: em 2017 o SIM/SVS/MS registrou mais de 36 mil mortes nessa faixa de idade, entre as quais, mais de 25 mil - cerca de dois terços - por causas evitáveis, reduzíveis por açôes de imunização e de promoção da saúde, pela adequada atenção à mulher na gestação e no parto e ao recém-nascido, além de açôes de diagnóstico e tratamento adequados. Outra característica da mortalidade na infância são as significativas disparidades regionais em todos os seus componentes: a mortalidade no período neonatal entre 2015 e 
2017, por exemplo, superou onze óbitos por 1 mil nascidos vivos nas regiōes Norte e Nordeste, enquanto esteve abaixo de nove na regiáo Sudeste e abaixo de oito na região Sul (Sá e Benevides, 2019).

Propôs-se que as metas relativas às doenças infecciosas (meta 3.3), doenças crônicas não transmissíveis (meta 3.4) e cobertura de serviços de saúde (meta 3.8) sejam ajustadas para se adequarem aos problemas de saúde mais pertinentes à realidade brasileira e à legislação nacional, que garante o direito à saúde na CF/1988.

$\mathrm{Na}$ meta 3.3, o grupo de trabalho julgou adequado destacar as hepatites virais e incluir as arboviroses transmitidas pelo Aedes aegypti, que são recorrentes. Desde o ano de 1998, quando começou a notificação compulsória das hepatites virais no Brasil, as taxas de detecção de hepatite B foram crescentes até 2011, e ficaram relativamente estáveis até 2015, tendo registrado queda a partir de 2016 em quase todas as regióes, de forma mais acentuada nas regióes Sul e Norte, onde foram registradas as maiores taxas de incidência (Brasil, 2017).

Quanto às arboviroses, a dengue é caracterizada por transmissão endêmica e epidêmica, determinada principalmente pela circulaçáo simultânea no Brasil dos quatro sorotipos virais ${ }^{23}$ com importante impacto econômico e social. Embora afete pessoas de todos os níveis sociais, o impacto é maior nas populaçóes mais pobres, devido à infraestrutura precária e às formas inadequadas de abastecimento de água, que favorecem a multiplicação do vetor, o Aedes aegypti. No período 2010-2019, foram notificados 9,0 milhóes de casos prováveis de dengue no Brasil, com 4.710 óbitos confirmados (coeficiente de mortalidade de 2,23 por 100 mil habitantes), dos quais o maior número, 986 óbitos, ocorreu em 2015. Destacam-se cinco anos epidêmicos, 2008, 2010, 2013, 2015 e 2016, sendo que nesses dois últimos anos ocorreu a introduçấo no Brasil dos vírus da febre Chikungunya e da Zika, também transmitidos pelo Aedes aegypti.

Os primeiros casos autóctones de Chikungunya confirmados ocorreram em 2014. Até 2019, foram notificados 589 mil casos prováveis e 495 óbitos confirmados. Os anos de 2016 e 2017 registraram os maiores coeficientes de incidência, de 114,0 e 89,4 casos por 100 mil habitantes, respectivamente. A maior concentração de casos e óbitos foi observada na regiâo Nordeste, com destaque para o Ceará, com $61,4 \%$ dos casos e $80 \%$ dos óbitos do país em 2017, e coeficiente de incidência de 1.264,2 casos por 100 mil habitantes. Em 2018 e 2019, os casos registrados se concentraram no Rio de Janeiro, com coeficiente de incidência de 239,0 e 152,3 casos por 100 mil habitantes, respectivamente, sendo o primeiro local com transmissão importante fora da regiáo Nordeste. 
A circulação do vírus Zika (ZIKV) foi confirmada no Brasil em 2015, após relatos de epidemias ocorridas, em 2007, nos Estados Federados da Micronésia e, em 2013, na Polinésia Francesa. Já haviam sido observados casos de Síndrome de Guillain-Barré relacionadas ao Zika na Polinésia Francesa, mas os casos de malformaçôes congênitas em recém-nascidos foram reportados de forma inédita pelo Brasil no final de 2015. Essas malformaçôes (Síndrome Congênita pelo Vírus Zika) tiveram incidência importante na região Nordeste, ${ }^{24}$ e a doença passou a ser de notificação compulsória em fevereiro de 2016, quando foram confirmados casos autóctones em todos os estados. De 2016 a 2019, foram notificados 244.493 casos prováveis de Zika e 24 óbitos em casos agudos. Nos anos de 2017 e 2018, os casos de dengue, chikungunya e Zika se reduziram no Brasil e nas Américas. Diversos fatores podem ter contribuído para a queda observada. A crise do vírus Zika, ocorrida em 2015, parece ter reforçado no poder público e na população a necessidade de melhor controle da propagaçáo do Aedes aegypti. Adicionalmente, em 2017 houve diminuição das chuvas, ocorrendo, assim, menos pontos de acúmulo de água onde o mosquito se reproduzisse. Outra possível explicação para a redução do número de casos é a população ter se tornado mais resistente ao vírus. Após a infecção por um vírus, os indivíduos que sobrevivem desenvolvem defesas naturais e reduz-se a parcela da população vulnerável a ele, principalmente no caso do Zika e da febre Chikungunya. O caso da dengue é mais complexo, uma vez que existem quatro tipos de vírus que provocam a doença.

Propôs-se que a redação da meta 3.4, referente às DCNTs, seja alterada para explicitar a necessidade de enfrentar os problemas de saúde relacionados às atividades laborais, aos problemas de saúde mental e às crescentes taxas de suicídio no Brasil. As DCNTs causam elevado número de mortes prematuras (de 30 a 69 anos), perda de qualidade de vida, limitaçóes e incapacidades, com importante impacto socioeconômico. $\mathrm{O}$ combate às DCNTs exige grandes esforços, incluindo iniciativas para controle de fatores de risco cruciais, como o uso de tabaco, a poluição do ar, o uso nocivo de álcool, as dietas não saudáveis e o sedentarismo, assim como a melhoria do diagnóstico e do tratamento. Em 2017, as quatro principais DCNTs - doenças cardiovasculares, câncer, doenças respiratórias crônicas e diabetes - foram responsáveis, no Brasil, por $56,9 \%$ dos óbitos na faixa etária de

24. Pesquisa recente realizada em parceria pela Universidade Federal do Rio de Janeiro (UFRJ) e Universidade Federal Rural de Pernambuco (UFRPE) com a Fundação Oswaldo Cruz (Fiocruz) e o Instituto D'Or, divulgada em setembro de 2019, indica que uma toxina liberada por bactéria encontrada em reservatórios de água, a saxitoxina (STX), é capaz de acelerar a morte de células neuronais também expostas à infecção pelo Zika. Nas pesquisas com camundongos, a associação do Zika com essa toxina acelerou em mais de duas vezes a destruição de células do cérebro. A mesma pesquisa descobriu que a presença da cianobactéria Raphidiopsis raciborskii, que produz essa toxina, foi significativamente maior nos reservatórios de água do Nordeste, o que pode indicar uma relação entre a toxina, o Zika e a microcefalia que explicaria a concentração de casos de malformações congênitas mais graves no Nordeste. Notícias disponíveis em: Estadão (Cambricoli e Girardi, 2019), o Globo (D’Elia, 2019) e Metrópoles (Saraiva, 2019). 
30 a 69 anos. O processo de envelhecimento populacional pelo qual o Brasil está passando, com aumento significativo da proporçấo de pessoas com mais de 60 anos, deve aumentar a importância das DCNTs enquanto problema de saúde pública. A última projeção populacional publicada pelo Instituto Brasileiro de Geografia e Estatística (IBGE) prevê aumento da proporção de pessoas com mais de 60 anos de 12,7\% da população, em 2016, para 23,5\%, em 2040 (IBGE, 2019).

Ainda com relação à meta 3.4 , a prevenção ao suicídio foi incluída tendo em vista a tendência de aumento observada nos últimos anos. Em 2017, foram registrados 12.495 óbitos por suicídio no Brasil, correspondentes a uma taxa de mortalidade de 7,3 por 100 mil habitantes, 0,6 ponto superior à registrada em 2011, quando foi estimada em 6,7.

Propôs-se que as metas relativas ao uso de drogas e álcool (meta 3.5), mortes e lesóes por acidentes de trânsito (meta 3.6), saúde sexual e reprodutiva (meta 3.7) e desenvolvimento de tecnologias (meta 3.b) tenham seu escopo ampliado.

Na meta 3.5, incorporou-se o uso episódico de álcool e drogas, tendo em vista que não é somente o abuso de substâncias que traz consequências para a saúde. No Brasil, o consumo per capita de álcool declinou de 8,8 1 de álcool puro (por pessoa com 15 anos ou mais de idade), em 2010, para 7,8 1, em 2016 (WHO, 2018b). Segundo dados da Pesquisa Vigitel, do MS, entretanto, a proporção de adultos que consumiram bebida alcoólica de forma abusiva ${ }^{25}$ aumentou de 15,6\%, em 2006, para 17,9\%, em 2018, sendo maior para os homens (26,0\%) do que para as mulheres $(11,0 \%)$.

Quanto à meta 3.6 (mortes e lesóes por acidentes de trânsito), enquanto a segurança no trânsito mostra sinais de melhora globalmente, no Brasil o trânsito tem se tornado cada vez mais inseguro, com taxas crescentes de acidentes e vítimas. Somente a partir de 2015 surgiram sinais de queda da taxa de mortalidade. Apesar de essa queda ter ocorrido em todo o país, as regióes Norte e Nordeste ainda registraram, em 2017, taxas superiores às de 2000, como mostra o gráfico 5 (Sá e Benevides, 2019).

25. Ingestão de quatro ou mais doses de bebidas alcoólicas para mulheres, ou cinco para homens, em uma mesma ocasião, nos últimos trinta dias. 
GRÁFICO 5

Taxa de mortalidade por acidentes de trânsito - Brasil e Grandes Regiões (2000-2017)

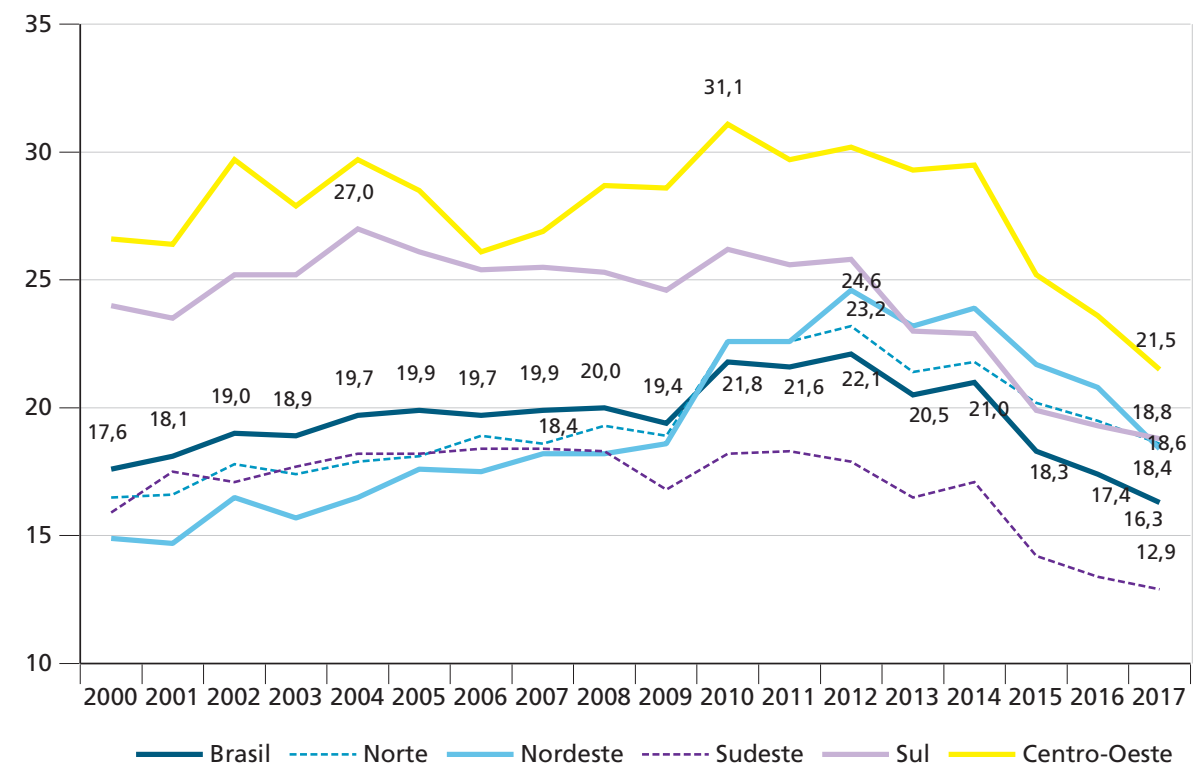

Fontes: SIM, SVS e Sistema IBGE de Recuperação de Dados (Sidra). Disponível em: <https://sidra.ibge.gov.br/tabela/6698>. Acesso em: 10 abr. 2020.

Com relação à meta 3.7, referente ao acesso universal aos serviços e insumos de saúde sexual e reprodutiva, o termo planejamento familiar foi substituído na proposta por planejamento reprodutivo. A porcentagem de mulheres casadas ou em uniáo estável que não usam métodos contraceptivos foi estimada em 18,4\% em 2006, de acordo com dados da Pesquisa Nacional de Demografia e Saúde (PNDS). A nova edição da pesquisa, prevista para 2021, poderá mostrar a evolução do uso de métodos contraceptivos. Contudo, dados anteriores da pesquisa mostram que o conhecimento a respeito de métodos anticoncepcionais é praticamente universal no Brasil, tendo sido registrado um grande aumento do uso desses métodos entre 1986 e 2006. Não há razóes para supor que essa situaçáo tenha piorado, tendo em vista a disponibilizaçáo gratuita de contraceptivos pelo SUS, bem como o aumento da escolaridade da população. Dados do Sinasc mostram uma redução substancial na taxa de nascidos vivos de máes com idade de 15 a 19 anos de 8,0\% para 5,4\% entre 2000 e 2017. Mesmo assim, em 2017, ainda ocorreram quase 460 mil nascimentos de filhos de mães nesta faixa etária.

Propôs-se que a meta 3.8, que trata da cobertura universal de saúde e do acesso a medicamentos e vacinas - na meta global "a preços acessíveis para todos" - seja ajustada ao quadro político, institucional e legal vigente para o setor no Brasil. 
Ou seja, é assumido o objetivo de assegurar a cobertura universal de saúde por meio do sistema público de saúde, conforme previsto na CF/1988 (arts. 194 e 196) e "em todos os níveis de atenção", termo que reforça o princípio da integralidade, previsto na Lei no 8.080/1990 e em legislaçóes posteriores. Outra modificação proposta para a meta nacional é a garantia de acesso a medicamentos e vacinas "que estejam incorporados ao rol de produtos oferecidos pelo SUS" para abranger todas as tecnologias e inovaçóes em saúde incorporadas ao SUS, que é superior ao número de vacinas e medicamentos considerados essenciais na meta global. Para reafirmar a gratuidade do sistema público, suprimiu-se a referência "a preços acessíveis".

Apesar de as propostas de metas nacionais, em alguns casos, serem mais ambiciosas que as metas globais, não se pode deixar de reconhecer que problemas persistem. Uma auditoria do Tribunal de Contas da União (TCU) constatou, por exemplo, que a assistência farmacêutica básica do SUS carece de planejamento e não se ajusta às necessidades de saúde da população, sendo recorrente a falta de alguns medicamentos e o excesso de estoque de outros, gerando desperdício de recursos. O programa nacional de vacinação atualmente contempla quatorze vacinas e cobre todas as faixas etárias, de modo que o país atinge elevadas coberturas vacinais e tem tido efetivo controle de várias doenças imunopreveníveis (Sá e Benevides, 2019). Para garantir a continuidade dessa situação, contudo, é necessário manter o rigor no monitoramento permanente das coberturas vacinais em todos os estados do país.

A única meta que não teve proposta de ajuste foi a 3.9, que propóe "até 2030, reduzir substancialmente o número de mortes e doenças por produtos químicos perigosos, contaminação e poluição do ar e água e do solo". Fatores ambientais são a causa principal de uma elevada carga de doenças que afetam particularmente os países em desenvolvimento. Estima-se que 25\% das mortes e doenças globais estão relacionadas a riscos ambientais, que incluem, entre outros: $i$ ) água poluída, saneamento e higiene inadequados; ii) poluição do ambiente doméstico por combustíveis sólidos (por exemplo, madeira e carvão); iii) poluição urbana gerada por veículos, indústrias e produção de energia; e iv) intoxicação aguda não intencional, geralmente por exposiçấo excessiva e uso inapropriado de produtos químicos tóxicos e pesticidas presentes em ambientes de trabalho e domésticos.

No Brasil, em 2017, a taxa de mortalidade por causas atribuídas a fontes de água inadequadas, saneamento inadequado e falta de higiene foi de 5,0 óbitos por 100 mil habitantes, atingindo de forma mais severa as crianças na faixa de 0 a 4 anos de idade e as pessoas com mais de 60 anos. Embora no caso das crianças tenha havido uma substantiva redução da taxa, que passou de 31,3 óbitos por $100 \mathrm{mil}$ habitantes, em 2000, para 4,4, em 2018, no caso dos idosos na faixa de 80 anos ou mais a taxa tem se mantido elevada (Sá e Benevides, 2019). 
Quanto aos envenenamentos acidentais, após mais de uma década de relativa estabilidade, a taxa de mortalidade registrou crescimento a partir de 2012, alcançando 0,27 óbito por 100 mil habitantes em 2014, declinando a partir de 2015 e voltando, em 2018 (0,13), ao mesmo patamar da década passada.

Por fim, propôs-se que a redação das metas 3.a, 3.c e 3.d fosse alterada apenas para adaptá-las à situação brasileira, sem mudanças em sua essência. A meta 3.a propóe fortalecer a implementação da Convenção-Quadro para o Controle do Tabaco, um tratado internacional de saúde pública adotado na 52 $2^{a}$ Assembleia Mundial da Saúde, de 2005, que reconhece a expansão do tabagismo como um problema mundial e determina um conjunto de medidas para reduzir a oferta e a demanda por tabaco. O consumo de tabaco é um dos mais importantes fatores de risco para as doenças crônicas não transmissíveis, como as doenças cardiovasculares, as neoplasias e as doenças respiratórias crônicas. A prevalência do tabagismo no Brasil se reduziu nas últimas décadas como resultado das políticas públicas relacionadas à implementação da convenção-quadro, que incluem a promoção de ambientes livres de fumo, a restrição à propaganda, a regulamentação das embalagens, a política de preços mínimos, o aumento de impostos para os produtos derivados do tabaco e o combate ao comércio ilegal. Como resultado destas políticas, a prevalência do tabagismo vem diminuindo, e, em 2013, de acordo com a última Pesquisa Nacional de Saúde (PNS), 14,7\% da população com 18 anos ou mais de idade era fumante, contra 34,8\% em 1989. Já a pesquisa Vigitel, do MS, estimou que o percentual de adultos que referiram o hábito de fumar se reduziu de $15,7 \%$, em 2006, para 9,3\%, em 2018.

Com relação à meta 3.c, segundo o relatório estatístico de 2018 da OMS para os ODS (WHO, 2018a), a porcentagem média global de gasto público com saúde em relação ao gasto público total, em 2014 , foi de $11,7 \%$, variando de $8,8 \%$ a $13,6 \%$. No Brasil essa porcentagem foi de 9,7\% no mesmo ano (em 2016 foi de 9,9\%).

O financiamento do sistema público de saúde no Brasil aumentou substancialmente a partir do ano de 2000 , como resultado da vinculação constitucional de recursos, partindo de um patamar inferior a 3\% do PIB, no início dos anos 2000, para cerca de 4\% do PIB, nos anos de 2016 e 2017, considerando o gasto das três esferas de governo. Apesar do aumento, há evidências de subfinanciamento do sistema, principalmente quando o gasto é comparado com os de outros países de renda média ou alta ${ }^{26}$ (Vieira, Piola e Benevides, 2019). A elevada participação do setor privado nos gastos com saúde coloca o Brasil na posição de único país do mundo com sistema público de acesso universal que conta com participação majoritária do setor privado no financiamento da saúde: em 2015, o consumo

26. Entre os países da Organização para a Cooperação e Desenvolvimento Econômico (OCDE), o gasto público representa, em média, mais de $70 \%$ da despesa nacional com saúde. 
final de bens e serviços de saúde no Brasil foi equivalente a 9,1\% do PIB, dos quais $5,2 \%$ ( $57 \%$ do total) corresponderam a gasto privado - despesas de famílias e instituiçóes sem fins lucrativos a serviço das famílias (IBGE, 2017). O congelamento das despesas primárias e do piso federal de despesas com açóes e serviços


de subparticipação dos recursos públicos no financiamento da saúde no Brasil do SUS (Vieira e Benevides, 2016), e já se observa, a partir de 2017, redução do piso de ASPS, seja em termos per capita, seja em proporção do PIB.

\section{CONSIDERAÇÕES FINAIS}

Agendas de desenvolvimento podem ter impacto positivo sobre as condições de vida das populaçôes ao estabelecerem metas a serem alcançadas, ao alinharem perspectivas da sociedade, ao contribuírem para a melhoria da coleta de dados, da produção de informaçóes e da análise das condiçóes sociais, incentivando a adoçáo de práticas propícias ao desenvolvimento, entre outros resultados positivos.

Embora não tenha atingido algumas das metas estipuladas, o Brasil avançou significativamente nas áreas de saúde materna, de saúde da criança e de doenças infecciosas durante o período dos ODMs. Na área de saúde materna e de saúde da criança, por exemplo, além dos avanços observados nos indicadores monitorados, houve melhorias significativas também no dimensionamento dos problemas a serem enfrentados e no aprimoramento das políticas públicas adotadas.

Muitos dos programas e das políticas relacionados aos antigos ODMs, e agora ao ODS 3, têm como pilar o SUS, que tem como um dos princípios básicos a universalidade do acesso à atenção à saúde. Outras políticas são desenvolvidas por outros setores, mas o setor saúde acaba contribuindo para o seu monitoramento e atendendo aos problemas de saúde associados a um funcionamento disfuncional desses.

Nesse contexto, em uma visão prospectiva, algumas metas são objeto de preocupação. Uma delas é a meta 3.9, que visa à redução de mortes e doenças por produtos químicos perigosos, contaminação e poluição do ar, da água e do solo. Nessa área existem questóes, como a expansão dos sistemas de esgotamento sanitário - para começar a superar as nossas baixas taxas de cobertura - e de tratamento do lixo urbano, que permanecem com seus entraves principais não solucionados, seja pela falta de investimentos e de um novo marco regulatório para a área de saneamento básico, seja pelo protelamento do cumprimento pelos municípios de decisóes relacionadas à destinaçáo ambientalmente adequada do lixo urbano. ${ }^{27}$ Ainda com relação a essa meta, registre-se uma preocupação com 
a intensidade e a celeridade de liberações de agrotóxicos (ou defensivos agrícolas) no mercado nacional. A meta 3.6, de redução das mortes e lesōes por acidentes de trânsito, é motivo de preocupação não somente por uma provável redução da segurança nas estradas, devido à falta de investimentos na malha rodoviária, mas também por tentativas de afrouxamento da legislação preventiva nessa área, caracterizadas por propostas de diminuição da fiscalização da velocidade nas rodovias, de abrandamento das puniçōes a infrações de trânsito, até propostas esdrúxulas, como derrogar a obrigatoriedade do uso de cadeira apropriada ao transporte de crianças em veículos. Mesmo algumas das metas mais estritamente relacionadas às açôes do setor saúde - como as relacionadas à diminuição da gravidez na adolescência e de algumas medidas preventivas no campo do controle das doenças sexualmente transmissíveis - podem enfrentar desafios ainda maiores do que os usuais, devido à crescente influência de uma pauta de matiz moral e religioso, ligada aos "costumes" e baseada em açóes voluntaristas, que avança sobre as políticas públicas de saúde reprodutiva e de redução de danos, cujos resultados positivos têm sido largamente comprovados.

A questão da universalidade tem papel de destaque no ODS 3, por meio da meta 3.8, que fala em assegurar cobertura universal de saúde. A esse respeito, considerando-se a existência do SUS, a princípio, o Brasil se coloca em uma posição privilegiada em relação a outros países. Nada obstante, existem dois conjuntos de fatores que contribuem de forma significativa para que o SUS não se aproxime de forma mais rápida e consistente de seus princípios constitucionais de universalidade e equidade no acesso e de integralidade da atenção. Em primeiro lugar, está o já comentado subfinanciamento crônico do sistema, que coloca o nosso país na insólita condição de ser o único país do mundo que, mesmo tendo um sistema público com responsabilidade constitucional de prover cobertura universal, tem um gasto público inferior ao gasto privado. $\mathrm{O}$ quadro passou a ter prognóstico mais grave a partir de um conjunto de medidas de austeridade fiscal que se iniciaram com o congelamento dos gastos públicos federais, por meio da $\mathrm{EC}$ nำ 95/2016. Ao mesmo tempo, o baixo crescimento da economia nos últimos anos lançou milhóes de pessoas ao desemprego, desde 2014; como consequência, essas pessoas que acessavam os serviços médicos hospitalares no setor de medicina suplementar também passaram a recorrer ao setor público, aumentando a demanda no SUS. Nesse contexto, tem havido redução dos recursos federais e estaduais direcionados ao sistema e, ao mesmo tempo, um aumento do sacrifício fiscal dos municípios, que estão na primeira linha do atendimento das necessidades de saúde da população. Para completar esse grave quadro, mesmo que temporariamente afastada, a proposta de extinguir os pisos mínimos de aplicação das áreas de saúde e educação pode ressurgir em novas propostas de emenda constitucional, ainda que esses pisos sejam considerados instrumentos de proteção orçamentária e financeira de direitos 
fundamentais que não podem ser reduzidos ou negados, segundo Comparato e Pinto (2015). Mas, no vale-tudo do ajuste fiscal, se não se pode desvincular, propóe-se a unificação dos pisos de saúde e de educação na chamada Proposta de Emenda à Constituição (PEC) do Pacto Federativo, sob o argumento, à primeira vista atrativo, de aumentar a flexibilidade dos gestores estaduais e municipais na destinação dos recursos vinculados a essas áreas. Em segundo, está a manutenção, e até mesmo o incremento, de incentivos e de condiçôes propícias à expansão do mercado privado, especialmente o de planos e seguros de saúde, seja por meio de subsídios fiscais, seja por alteraçóes legais que passaram a permitir, de forma mais extensa, a participação de capital externo no setor.

O receio maior é de que as medidas de austeridade, centradas quase exclusivamente na retração dos gastos públicos, não representem uma medida circunstancial, ainda que equivocada, de equilíbrio fiscal, mas representem uma mudança de paradigma no enfrentamento das desigualdades sociais e do papel do Estado na promoção do desenvolvimento, na promoção da justiça social e na área da promoção, proteção e recuperação da saúde.

\section{REFERÊNCIAS}

ANDRADE, M. V. et al. Desafios do sistema de saúde brasileiro. In: DE NEGRI, J. A. et al. Desafios da nação: artigos de apoio. Brasília: Ipea, 2018. v. 2.

ANTUNES, A.; MATHIAS, M. Cobertura universal de saúde: a nova aposta do capital. Fiocruz Notícias, Rio de Janeiro, 3 dez. 2014. Disponível em: <http:// bit.ly/350adTh>. Acesso em: 14 nov. 2019.

BERCITO, D. Sistema de saúde que leva famílias à falência será crucial para definir rival de Trump. Folha de S.Paulo, 28 fev. 2020. Disponível em: <https:// bit.ly/2JgNucG>. Acesso em: 2 mar. 2020.

BRASIL. CONFERÊNCIA NACIONAL DE SAÚDE, 8., 1986, Brasília. Relatório final. Brasília: Ministério da Saúde, 1986. Disponível em: <https://is.gd/dUpMjM>.

Constituição da República Federativa do Brasil de 1988. Brasília: Congresso Nacional, 1988. Disponível em: <https://is.gd/qQzK5l>.

. Ministério da Saúde. Saúde Brasil 2014: uma análise da situação de saúde e das causas externas. Brasília: MS, 2015.

Boletim Epidemiológico, v. 48, n. 24, 2017. Disponível em: <http:// bit.ly/2RqPiVG>. 
Evoluçáo da mortalidade na infância nos últimos 10 anos (2007 a 2016). Brasília: SVS/MS, 2018. Acesso em: 10 abr. 2020. (Apresentação). Disponível em: <https://bit.ly/2Gaqw5x>.

BUSSE, R.; BLÜMEL, M. Germany: health system review. Health Systems in Transition, v. 16, n. 2, p. 1-296, 2014.

CAMBRICOLI, F; GIRARDI, G. Bactéria em água pode ter agravado surto de microcefalia associado ao Zika, diz estudo. O Estado de S.Paulo, 2 set. 2019. Disponível em: <https://bit.ly/2QKtSSg>. Acesso em: 3 set. 2019.

CASTRO, M. et al. Brazil's unified health system: the first 30 years and prospects for the future. The Lancet, London, v. 394, n. 10195, p. 345-356, 27 Jul. 2019. COMPARATO, F. K.; PINTO, E. G. Custeio mínimo dos direitos fundamentais, sob a máxima proteção constitucional. Consultor Jurídico, São Paulo, 17 dez. 2015.

D'ELIA, R. Estudo identifica fator ambiental evitável que intensificou efeitos da Zika, como microcefalia. O Globo, 3 set. 2019. Disponível em: <https://glo. bo/31sRJsc>. Acesso em: 3 set. 2019.

DINIZ, B. P. C. et al. Gasto das famílias com saúde no Brasil: evolução e debate sobre gasto catastrófico. In: SILVEIRA, F. G. et al. (Orgs.). Gasto e consumo das famílias brasileiras contemporâneas. Brasília: Ipea, 2007. v. 2. Disponível em: $<$ https://is.gd/kLAd2e>.

FIRJAN - FEDERAÇÃO DAS INDÚSTRIAS DO ESTADO DO RIO DE JANEIRO. Índice Firjan de Desenvolvimento Municipal, ano-base 2016. Rio de Janeiro: Firjan, 2018.

FRIEDMAN, H. S. Causal inference and the Millennium Development Goals (MDGs): assessing whether there was an acceleration in MDG development indicators following the MDG declaration. Munich Personal RePEc Archive, 2013. GARRETT, L.; CHOWDHURY, A. M. R.; PABLO-MENDEZ, A. All for universal coverage. The Lancet, London, v. 374, p. 1294-1299, 2009.

GIOVANELLA, L. et al. Sistema universal de saúde e cobertura universal: desvendando pressupostos e estratégia. Ciência \& Saúde Coletiva, Rio de Janeiro, v. 23, n. 6, p. 1763-1776, 2018.

GWATKIN, D. R.; ERGO, A. Universal health coverage: friend or foe of health equity. The Lancet, London, v. 377, n. 9784, p. 2160-2161, 25 Jun. 2011.

IBGE - INSTITUTO BRASILEIRO DE GEOGRAFIA E ESTATÍSTICA. Pesquisa Nacional de Saúde 2013. Rio de Janeiro: IBGE, 2015.

. Conta-satélite de saúde Brasil: 2010-2015. Rio de Janeiro: IBGE, 2017. 
. Projeçóes da populaçáo, Brasil e Unidades da Federaçáo. Rio de Janeiro: IBGE, 2019. Disponível em: <http://bit.ly/38duTJv>.

KUTZIN, J. Anything goes in the path to universal health coverage? Bulletin of the World Health Organization, 2012.

LAGOMARSINO, G. et al. Moving towards universal health coverage: health insurance reforms in nine developing countries in Africa and Asia. The Lancet, London, v. 380, 8 Sept. 2012. (Series Universal Health Coverage).

MARTEN, R. et al. An assessment of progress towards universal health coverage in Brazil, Russia, India and South Africa (BRICS). The Lancet, London, v. 384, p. 2164-2171, 2014.

MATTA, G. C.; MOROSINI, M. V. G. Atenção à saúde. In: Dicionário da educaçáo profissional em saúde. Fiocruz: Rio de Janeiro, 2009. Disponível em: $<$ http://bit.ly/2PnKPAm>. Acesso em: 23 set. 2019.

MORSE, M. L. et al. Mortalidade materna no Brasil: o que mostra a produção científica nos últimos 30 anos? Cadernos de Saúde Pública, Rio de Janeiro, v. 27, n. 4, p. 623-638, abr. 2011.

NORONHA, J. C. Cobertura universal de saúde: como misturar conceitos, confundir objetivos, abandonar princípios. Cadernos de Saúde Pública, Rio de Janeiro, v. 29, n. 5, p. 847-849, 2013.

OCKÉ-REIS, C. O. Cobertura universal de saúde: inclusão ou exclusão? Boletim de Análise Político-Institucional, Brasília, n. 9, p. 19-26, jan./jun. 2016.

OCKÉ-REIS, C. O.; FERNANDES, A. M. P. Descrição do gasto tributário em saúde - 2003 a 2015. Brasília: Ipea, 2018. (Nota Técnica, n. 48).

PAIM, J. et al. The Brazilian health system: history, advances, and challenges. The Lancet, London, 2011.

SÁ, E. B.; BENEVIDES, R. P. S. ODS 3: assegurar uma vida saudável e promover o bem-estar para todas e todos, em todas as idades. In: SILVA, E. R. A.; PELIANO, A. M.; CHAVES, J. V. (Orgs.). Cadernos ODS: o que mostra o retrato do Brasil? Brasília: Ipea, 2019. Disponível em: <https://bit.ly/2JoeOWa>.

SÁ, E. B. et al. Capital estrangeiro nos serviços de assistência à saúde. In: SOUZA, A. M.; MIRANDA, P. (Orgs.). Brasil em desenvolvimento 2015: Estado, planejamento e políticas públicas. Brasília: Ipea, 2015.

SANTOS, I. S. Evidência sobre o mix público-privado em países com cobertura duplicada: agravamento das iniquidades e da segmentaçáo em sistemas nacionais de saúde. Ciência \& Saúde Coletiva, Rio de Janeiro, v. 16, n. 6, p. 2743-2752, 2011. 
SARAIVA, J. Bactéria em água pode ter agravado surto de microcefalia, diz estudo. Metrópoles, 4 set. 2019. Disponível em: <https://bit.ly/3dtRWTb>. Acesso em: 4 set. 2019.

SILVA, E. R. A.; PELIANO, A. M.; CHAVES, J. V. (Orgs.). Agenda 2030: ODS Metas Nacionais dos Objetivos de Desenvolvimento Sustentável. Brasília: Ipea, 2018. Disponível em: <https://bit.ly/2zb5za4>. Acesso em: 10 mar. 2020.

UN IGME - UNITED NATIONS INTER-AGENCY GROUP FOR CHILD MORTALITY ESTIMATION. Levels and trends in child mortality. (Report 2017).

VIEIRA, F. S.; BENEVIDES, R. P. S. Os impactos do Novo Regime Fiscal para o financiamento do Sistema Único de Saúde e para a efetivaçáo do direito à saúde no Brasil. Brasília: Ipea, 2016. (Nota Técnica, n. 28). Disponível em: <http:// bit.ly/2DQmhe6>.

VIEIRA, F. S.; PIOLA, S. F.; BENEVIDES, R. P. S. Vinculação orçamentária do gasto em saúde no Brasil: resultados e argumentos a seu favor. Brasília: Ipea, 2019. (Texto para Discussão, n. 2516). Disponível em: <http://bit.ly/2quE7QD>.

WHO - WORLD HEALTH ORGANIZATION. Constituição da Organização Mundial da Saúde (OMS/WHO) - 1946. Biblioteca Virtual de Direitos Humanos, [s.d.]. Disponível em: <https://is.gd/bbqvej>.

World health report 2000: health systems: improving performance. Geneva: WHO, 2000.

Resolution WHA58.33: sustainable health financing, universal coverage and social health insurance. Geneva: WHO, 25 May 2005.

. Financiamento dos sistemas de saúde: o caminho para a cobertura universal - relatório mundial da saúde. Geneva: WHO, 2010. Disponível em: <https://bit.ly/3bCUGvL>. Acesso em: 28 set. 2019.

. World health statistics 2018: monitoring health for the SDGs, sustainable development goals. Geneva: WHO, 2018a.

2018b.

. Global status report on alcohol and health 2018. Geneva: WHO,

\section{BIBLIOGRAFIA COMPLEMENTAR}

BOING, A. C. et al. Desigualdade socioeconômica nos gastos catastróficos em saúde no Brasil. Revista Saúde Pública, v. 48, n. 4, p. 632-634, 2014.

BRASIL. Pesquisa Nacional Demografia e Saúde (PNDS) 2006: relatório final. Brasília: MS, 2008. Disponível em: <http://bit.ly/2Q91ZSz>. 
Pesquisa Nacional Demografia e Saúde (PNDS) 2006: dimensóes do processo reprodutivo e da saúde da criança. Brasília: MS, 2009. Disponível em: $<$ http://bit.ly/2MfCNZE $>$.

IPEA - INSTITUTO DE PESQUISA ECONÔMICA APLICADA. Saúde. Políticas Sociais: acompanhamento e análise, Brasília, n. 23, p. 117-179, 2015. ROCKEFELLER FOUNDATION. Future health markets: a meeting statement from Bellagio. Rockefeller Foundation, 18 Dec. 2012. Disponível em: <http://bit. ly/2s1ZlG8>. Acesso em: 14 nov. 2019. 



\section{EDUCAÇÃO $0^{1}$}

\section{APRESENTAÇÃO}

Todos os 193 Estados-membros da Organização das Naçôes Unidas (ONU) adotaram formalmente os Objetivos de Desenvolvimento Sustentável (ODS), também conhecidos como Agenda 2030, por ser o ano final de sua vigência. Os ODS substituem os Objetivos de Desenvolvimento do Milênio (ODM), vigentes até o final de 2015. Em termos de políticas voltadas à educação, é possível observar que os ODMs tinham como foco universalizar o acesso ao ensino básico, enquanto os ODS buscam assegurar a educaçáo inclusiva, equitativa e de qualidade, promovendo oportunidades de aprendizagem para todos ao longo da vida, destacando a sustentabilidade.

Conforme apontaram Matijascic e Rolon (2019), as condiçóes institucionais para atender aos imperativos do ODS 4, relativo à educação, estavam em linha com as metas assumidas com a ONU, ou seja, até 2018, existiam órgãos de governo que poderiam atender àqueles pressupostos. Com a posse do presidente Jair Bolsonaro, foi realizada uma ampla reforma administrativa em termos de organização de instituiçóes da administração direta do governo federal brasileiro. Essa iniciativa, é importante destacar, seguiu os ditames das propostas de sua campanha para as eleiçôes em 2018.

Os efeitos dessas reformas não foram pequenos. Ao diminuírem o número de ministérios, secretarias e diretorias que compunham o Poder Executivo federal, acabaram reduzindo o espaço e a participação de atores que desempenhavam um papel importante em governos anteriores. Além disso, ampliaram o espaço para o novo ideário, que passou a contar com a preferência dos eleitores brasileiros.

Embora o Ministério da Educação não tenha sido extinto nem tenha passado a abrigar outro ministério ou secretaria preexistente, a mudança relacionada ao perfil administrativo, em termos de secretarias e diretorias, não foi pequeno, afetando, também, o processo que envolve os ODS 4. Diante disso, a questão central que se coloca é a de verificar os possíveis efeitos das mudanças institucionais sobre as metas acordadas com a ONU em relação ao ODS 4 e de que modo elas influenciam os rumos do Brasil nesse âmbito até 2030 . 
Para lidar com essa temática, o capítulo conta, além desta introdução, com mais 3 seçóes. Na seção 2, apresenta-se um panorama da relação dos ODS com a estrutura institucional da educação e os efeitos dessas mudanças sobre as metas 4.1, 4.2, 4.3, 4.4, 4.7 e 4.a do ODS $4 .{ }^{2} \mathrm{Na}$ seçâo 3, trata-se das políticas e dos programas do MEC que contribuem para atingir as metas propostas nesse ODS. Ao final, na seção 4, apresenta-se a conclusão.

\section{OS OBJETIVOS DE DESENVOLVIMENTO SUSTENTÁVEL E A ESTRUTURA INSTITUCIONAL DA EDUCAÇÃO NO BRASIL}

A seção referente a assuntos institucionais visa apresentar o quadro existente de 2015 até os nossos dias e os possíveis efeitos das mudanças administrativas no ambiente dos ODS. Para lidar com o problema, a seção será composta por tópicos, relacionando, em primeiro lugar, a conexão dos ODS com o Plano Nacional de Educação - PNE (Lei n 13.005, de 25 de junho de 2014), em vigor. A seguir, serão destacados o papel constitucional e a estrutura institucional do sistema educacional no Brasil. Por fim, a última seção descreve as mudanças administrativas realizadas desde 2019 e como elas podem afetar a consecução das metas dos ODS pactuadas com a ONU.

\subsection{Objetivos de Desenvolvimento Sustentável em Educação e suas interfaces com o Plano Nacional de Educação ${ }^{3}$}

No caso brasileiro, quase todas as metas dos ODS 4 foram previstas por açóes de governo que estavam em curso nos âmbitos federal, estadual e municipal quando da assinatura dos documentos pelo Brasil na ONU, em 2015. O principal instrumento para atingir o ODS 4 é o PNE, de caráter decenal e previsto pela Constituição Federal, em vigor desde 2014 e representando o principal instrumento para estabelecer diretrizes às políticas educacionais brasileiras.

O PNE possui uma vinculação de recursos para o seu custeio, com prevalência sobre os Planos Plurianuais (PPA), e, também, por força do art. 13 da Lei $n^{\circ}$ 13.005 de 2014, cumpre a função de articular o Sistema Nacional de Educação (SNE), o que não foi feito até o momento, ao contrário do que ocorre com a

2. Considerando a amplitude deste estudo, as metas 4.5, 4.6, 4.b e 4.c não foram analisadas. Isso se deve a uma opção por focalizar os aspectos mais aparentes do sistema educacional, ou seja, o foco no ensino fundamental e médio (meta 4.1), na educação infantil (meta 4.2), no ensino técnico e profissionalizante (meta 4.3), no perfil de competências (meta 4.4), na relação entre desenvolvimento sustentável e educação (meta 4.7) e nas questões relativas à infraestrutura escolar (meta 4.a). As metas 4.5, relativa à equidade, e 4.6, que envolve a alfabetização, são muito relevantes, mas serão analisadas num momento posterior, com disponibilidade de indicadores para 2019. A meta 4.b, relativa a dar apoio a alunos vindos de países em desenvolvimento, não se aplica necessariamente ao Brasil, pois ela focaliza os países desenvolvidos, nos quais as demais metas já foram equacionadas, em grande medida. A meta 4.c também não foi focalizada, devido à escassez de ações nessa direção em 2019. Para adaptar as metas ao contexto institucional brasileiro, foi feito um esforço, em Ipea (2018), que pode ser observado nos quadros A.1 e A.2 do anexo A deste capítulo (Corbucci e Matijascic, 2018a; 2018b).

3. Esta seção atualiza e sintetiza o que foi apresentado em Matijascic e Rolon (2019). 
saúde ou a assistência social. O amplo e democrático processo de debate - que começou na Conferência Nacional de Educação (Conae) de 2010 e, com a intensa participação de todos os atores sociais que atuam em questôes relativas à educação, culminou com sua aprovação pelo Congresso Nacional - reforça o caráter amplo e democrático do PNE em vigor. Para o cidadáo, o PNE e os planos de educação estaduais e municipais devem formar um conjunto integrado e articulado para que seus direitos sejam garantidos. O cumprimento das metas do PNE garantiria que $70 \%$ das metas do ODS 4, relativo à educação, fossem atendidas em 2024, ou seja, seis anos antes de 2030, conforme aponta o quadro 1 (Ipea, 2017; 2018).

QUADRO 1

Metas dos ODS 4 e suas contrapartidas em metas do PNE

\begin{tabular}{lcc}
\hline Tema da meta do ODS 4 & Meta ODS 4 & Metas equivalentes PNE \\
\hline Ensino fundamental e médio & 4.1 & $2,3,6$ e 7 \\
Educação infantil: creches e pré-escola & 4.2 & 1 \\
Ensino técnico, profissionalizante e superior & 4.3 & $11,12,13$ e 14 \\
Habilidades para emprego, trabalho decente e empreendedorismo & 4.4 & $9,11,12,13$ e 14 \\
Eliminação de disparidades & 4.5 & 4 e 8 \\
Alfabetizados: conhecimento básico de matemática & 4.6 & 4,5 e 8 \\
Educação e sustentabilidade & 4.7 & BNCC 1 \\
Adequação da infraestrutura & $4 . a$ & Inep 2 \\
Cooperação internacional em educação & 4.6 & 4 e 8 \\
Valorização dos professores & $4 . c$ & $15,16,17$ e 18 \\
\hline
\end{tabular}

Elaboração dos autores.

Notas: ${ }^{1}$ Base Nacional Comum Curricular.

2 Instituto Nacional de Estudos e Pesquisas Educacionais Anísio Teixeira.

O quadro 1 ressalta que das dez metas dos ODS 4, sete foram previstas pelo PNE também. Entre as três restantes, a meta 4.7 pode ser realizada mediante a inserção de seu conteúdo na BNCC, que fixa os parâmetros curriculares para os alunos brasileiros. Além disso, conforme foi previsto originalmente no ODS 4, é preciso que os professores estejam preparados para ensinar os conteúdos que integram as questóes relativas à sustentabilidade. A meta 4.a diz respeito à infraestrutura das escolas, e os dados do Censo Escolar, realizado anualmente pelo Instituto Nacional de Estudos e Pesquisas Educacionais Anísio Teixeira (Inep), tratam desse tema com detalhe.

Das dez metas previstas pelo ODS 4, nove podem ser consideradas como aplicáveis à realidade brasileira e uma não se encaixa nessa definição: a 4.b, pois, em sua formulação original, estava prevista a concessão de bolsas para países com graves carências em seu contexto econômico e social, ou seja, seriam os países desenvolvidos que forneceriam apoio internacional. Não obstante, o Brasil poderia fornecer um maior apoio a países vizinhos com menor poder de compra, além de 
países com esse mesmo perfil e que adotam a língua portuguesa. Nesse sentido, embora a meta 4.b possa ser considerada não aplicável ao país, ela mudou de status com a nova redação para o Brasil.

\subsection{Constituição Federal e organização do sistema educacional no Brasil ${ }^{4}$}

Para apresentar o contexto em que a análise proposta deve se dar no caso brasileiro, cabe explicar, brevemente, mas desde já, o modo pelo qual se organiza o complexo educacional brasileiro e as suas instituiçóes mais importantes.

A Constituição Federal, a Lei de Diretrizes e Bases da Educação Nacional - LDB (Lei $\mathrm{n}^{\circ}$ 9.394, de 20 de dezembro de 1996) e o atual PNE estipulam que as metas nacionais, sobretudo aquelas que dizem respeito às etapas obrigatórias da educaçâo nacional, são responsabilidade conjuntas da União, dos estados, do Distrito Federal e dos municípios.

A educação básica, no Brasil, é constituída da educação infantil (de 0 a 5 anos de idade) e dos ensinos fundamental (de 6 a 14 anos de idade) e médio (de 15 a 17 anos de idade). De acordo com o art. 21 da LDB, a educação escolar ainda inclui o ensino superior. Outras modalidades de ensino existem, como: educação de jovens e adultos (EJA), profissional, para alunos com necessidades especiais e à distância. Existem duas categorias administrativas para as instituiçóes de ensino: i) públicas, mantidas e geridas pelo poder público; e $i$ ) privadas, mantidas e geridas por entidades de direito privado. Segundo a LDB, as instituiçôes públicas e privadas estão a cargo da União, dos estados (incluindo o Distrito Federal) e dos municípios, com as seguintes atribuiçóes:

- União (federal) é a responsável por instituiçōes de ensino superior mantidas pelos órgãos federais e pela regulação da iniciativa privada. Entre suas principais atribuições estão: elaborar o PNE; organizar, manter e desenvolver os órgãos e as instituiçóes federais; prestar assistência técnica e financeira aos estados e municípios; estabelecer competências e diretrizes para a educação básica; organizar e disseminar as informaçôes relativas à educação no país; e aprovar normas sobre cursos de graduação e pós-graduaçáo, bem como efetuar a sua avaliação e credenciamento no âmbito do ensino superior;

- $\quad$ estados (incluindo o Distrito Federal) são os responsáveis pelas instituiçōes estaduais ou distritais de ensino fundamental e médio de órgãos públicos ou privados. Os estados devem manter as instituiçóes oficiais de sua alçada, incluindo aquelas em regime de colaboração com os municípios; elaborar e executar políticas e planos educacionais; autorizar, reconhecer,

4. Esta seção também atualiza e sintetiza o que foi apresentado em Matijascic e Rolon (2019). 
credenciar, supervisionar e avaliar os cursos das instituiçóes de educação superior de sua alçada; e prover o transporte escolar dos alunos da rede estadual ou em convênio com os municípios; e

- municípios (incluindo o Distrito Federal) são os responsáveis por instituições de educação infantil e ensino fundamental. As ações, nessas esferas de governo, podem se integrar ao sistema estadual de ensino ou compor com ele um sistema único de educação básica. Os municípios devem manter as instituiçóes oficiais de sua alçada; autorizar, credenciar e supervisionar os estabelecimentos do seu sistema de ensino; oferecer educação infantil em creches e pré-escolas; e assumir a responsabilidade de prover o transporte para os alunos da rede municipal ou em convênio com as Unidades da Federação (UF).

Os recursos públicos destinados à educação têm origem em:

- receita de impostos próprios da União, estados e municípios;

- receita de transferências constitucionais e outras transferências legais; e

- receita do salário-educação e de outras contribuiçóes sociais.

A Constituição Federal determina que a União aplique em educação, no mínimo, $18 \%$ da receita de impostos, deduzidas as transferências constitucionais e legais para estados e municípios em educação, e que os estados, o Distrito Federal e os municípios apliquem $25 \%$ dessa receita. É da esfera federal que provém a maior soma de recursos para o ensino superior, enquanto os estados e os municípios os destinam mais para o ensino básico - sendo a educação infantil e o ensino fundamental prioritariamente atendidos por municípios, e o ensino médio, pelos estados membros da Federação, embora essa regra não seja rígida. A legislação educacional brasileira define que os recursos públicos devem ser destinados às escolas públicas, podendo ser dirigidos também a escolas comunitárias, confessionais ou filantrópicas.

O Fundo Nacional de Desenvolvimento da Educação (FNDE) é responsável pela execução de políticas educacionais do Ministério da Educação (MEC). Neste contexto, os repasses de dinheiro são divididos em constitucionais, de caráter automático e voluntários (convênios). Entre os programas que merecem destaque no FNDE, constam: Alimentação Escolar, Livro Didático, Dinheiro Direto na Escola, Biblioteca da Escola, Transporte do Escolar, Caminho da Escola, Reestruturação e Aquisiçẫo de Equipamentos para a Rede Escolar Pública de Educação Infantil.

O Inep subsidia a formulação de políticas educacionais dos diferentes níveis de governo. Com esse objetivo, o instituto atua nas seguintes áreas: avaliação, exames e indicadores de educação básica e superior, ações internacionais, bibliotecas e arquivos de documentos relacionados à educação e, muito importante, formulaçáo e 
publicação de estatísticas educacionais. O Inep é amplamente conhecido na sociedade pela formulação e execução do Exame Nacional do Ensino Médio (Enem) e por ser quem organiza, no Brasil, a execução das provas do Programme for International Student Assessment (Pisa - Programa Internacional de Avaliação de Estudantes).

$\mathrm{O}$ combate às desigualdades de raça e renda no acesso ao ensino superior é regido pela chamada Lei de Cotas, Lei ${ }^{\circ} 12.711$ de 2012. Esta lei estabelece que todas as instituiçóes federais de ensino superior e de ensino técnico em nível médio devem destinar $50 \%$ das vagas por curso e turno a estudantes oriundos integralmente do ensino médio público. Destas vagas, a metade é destinada a alunos de famílias com renda per capita de até 1,5 salário mínimo (SM). A preferência para a ocupação dessas vagas é para aqueles que se autodeclararem pretos (ou negros), pardos (mulatos ou mestiços) ou indígenas, em uma proporção no mínimo igual à de pretos, pardos e indígenas da respectiva população da UF em que se encontra a instituição, de acordo com os dados do Instituto Brasileiro de Geografia e Estatística (IBGE).

\subsection{Ministério da Educação: mudanças institucionais a partir de 2019}

Em 2019, começou um novo governo e, com isso, uma nova gestáo no Ministério da Educação (MEC). O Decreto n 9.665, de 2 de janeiro de 2019, deu uma nova estrutura organizacional ao MEC. Comparando as estruturas do ministério de acordo com o Decreto n 9.005 de 2017 e com o Decreto n 9.665/2019, o número de secretarias é o mesmo: sete. A principais mudanças foram a extinção da Secretaria de Articulação dos Sistemas de Ensino (Sase) e da Secretaria de Educação Continuada, Alfabetização, Diversidade e Inclusão (Secadi) e a criação da Secretaria de Alfabetização (Sealf) e da Secretaria de Modalidades Especializadas de Educação (Semesp).

A Sase tinha como função estimular e ampliar a cooperação entre o MEC e as secretarias estaduais e municipais de educação. Como mais de 69,2\% de todas as matrículas da educação básica estavam nestas redes de ensino em 2019, a cooperação e o diálogo do órgão com as secretarias de educação locais são essenciais para o sucesso das ações e políticas do ministério para a educação básica. Entre as funções desta secretaria, estavam a de monitorar a elaboração, a adequação e a avaliação dos planos estaduais e municipais de educação (tendo como base o PNE), bem como a de monitorar a evolução dos indicadores locais para o cumprimento das metas nacionais desse plano. Como vimos, ao atingir as metas do PNE, o Brasil cumpre grande parte das metas do ODS 4.

Perdem espaço no MEC as modalidades de educação do campo, educação escolar indígena e educaçáo quilombola. Cada modalidade destas contava com uma coordenação na Secadi. Com o decreto de 2019, estas foram agrupadas na 
Coordenação-Geral de Educação Indígena, Quilombola e do Campo da Semesp. As políticas voltadas a essas modalidades específicas de educação escolar - que têm currículos adaptados, programas de formação de professores e livros didáticos específicos - são importantes para garantir o direito à educação de qualidade a todos, especialmente devido ao fato de os indicadores de acesso à escola e de rendimento escolar entre as populaçôes do campo e entre não brancos estarem abaixo da média brasileira. Essas modalidades, portanto, perdem espaço justamente quando as políticas voltadas a elas deveriam ser priorizadas.

A meta 4.7 do ODS 4 visa garantir que todos os alunos adquiram conhecimentos e habilidades necessárias para promover o desenvolvimento sustentável, até 2030. Para atingir esta meta, o MEC contava com uma Coordenação-Geral de Educação Ambiental e Temas Transversais da Educação Básica, subordinada à Diretoria de Currículos e Educação Integral da SEB. Esta coordenação era responsável por subsidiar a formulação das políticas curriculares da educação básica, observados os temas transversais e a educação ambiental, de acordo com as Diretrizes Curriculares Nacionais (DCN) e a BNCC, função importante para atingir a meta 4.7 do ODS 4. O decreto de 2019 retira a referência explícita à educação ambiental nos temas transversais da educaçáo básica e integral ao renomear a Coordenação-Geral de Temas Transversais da Educação Básica e Integral. As políticas de educação em direitos humanos e cidadania não são mencionadas no Decreto n 9.665/2019, não sendo de competência declarada de nenhuma diretoria. Com a extinção da Diretoria de Políticas de Educação em Direitos Humanos e Cidadania, as políticas para alcançar a meta 4.7 do ODS 4 ficam enfraquecidas.

As açóes e as políticas voltadas ao fomento das escolas cívico-militares e à alfabetização ganham espaço na estrutura do MEC com o Decreto n 9.665/2019. A Subsecretaria de Fomento às Escolas Cívico-Militares foi criada para

promover, fomentar, acompanhar e avaliar, por meio de parcerias, a adoção por adesão do modelo de escolas cívico-militares nos sistemas de ensino municipais, estaduais e distrital tendo como base a gestâo administrativa, educacional e didático-pedagógica adotada por colégios militares do Exército, Polícias e Bombeiros Militares (Brasil, 2019a, art. 11, XVI).

A alfabetização ganha espaço no MEC com a criação da Sealf, dedicada ao desenvolvimento e à implementaçáo de uma política nacional de alfabetizaçáo.

\section{POLÍTICAS E PROGRAMAS PARA ATINGIR AS METAS DO ODS 4}

Nesta seção, analisamos os programas e as políticas do MEC que contribuem para atingir as metas do ODS 4, tanto aquelas anunciadas pela nova gestáo do MEC ao longo de 2019 quanto aquelas iniciadas em gestóes anteriores e que tiveram continuidade em 2019. Em julho de 2019, o MEC apresentou suas principais 
açóes e propostas por meio do documento Compromisso Nacional pela Educação Básica (Pera e Menezes, 2019), que conta com apoio do Conselho de Secretários Estaduais de Educação (Consed) e da União dos Dirigentes Municipais de Educação (Undime). Em janeiro de 2020, o MEC publicou um balanço de suas atividades (Brasil, 2020a). Da análise desses dois documentos, de decretos e portarias, destacamos os programas que o MEC lançou e aqueles aos quais deu continuidade e que contribuem para atingir seis das dez metas do ODS 4.

Meta 4.1 (Brasil) - Até 2030, garantir que todas as meninas e meninos completem o ensino fundamental e médio, equitativo e de qualidade, na idade adequada, assegurando a oferta gratuita na rede pública e que conduza a resultados de aprendizagem satisfatórios e relevantes.

Para melhorar a aprendizagem nos ensinos fundamental e médio, as duas principais bandeiras da atual gestão do MEC são a Política Nacional de Alfabetizaçâo - PNA (Decreto n 9.765, de 11 de abril de 2019) e o Programa Nacional de Escolas Cívico-militares (Pecim).

A alfabetização ganhou destaque na atual gestáo do MEC com uma secretaria dedicada a ela, como vimos na segunda seção deste capítulo. Em abril de 2019, o MEC lançou uma PNA com o objetivo de melhorar a alfabetização das crianças desde a primeira infância e erradicar o analfabetismo absoluto e funcional entre jovens e adultos. No que tange ao ensino fundamental, a PNA enfatiza a importância de ensinar às crianças por meio do método fônico. O Cadernos $P N A$, disponibilizado online no site do MEC, ressalta ser este um método baseado em evidências científicas (Brasil, 2020b). No entanto, em 2019, nenhuma ação ou programa específico da PNA foi anunciado para os ensinos fundamental e médio, seja de formação de professores e de produção de material didático de acordo com o método fônico, seja de reforço para os alunos que apresentam níveis de alfabetização insatisfatórios.

Um anúncio importante em 2019, no que tange à alfabetização, é a adesão do Brasil ao Progress in International Reading Literacy Study (PIRLS), uma avaliação internacional realizada a cada cinco anos para medir o desempenho em leitura de alunos matriculados no $4^{\circ}$ ano do ensino fundamental. Além disso, aplica questionários com os alunos, seus pais, professores e escolas que fornecem dados contextuais sobre os fatores escolares e extraescolares que influem na aprendizagem de leitura. Na edição de 2016, cinquenta países participaram do PIRLS, e a Organização das Naçóes Unidas para a Educação, a Ciência e a Cultura (UNESCO) o reconhece como fonte de dados sólidos para acompanhar o desempenho dos alunos em leitura. O Brasil participará da edição de 2021 dessa avaliação, o que é importante para o acompanhamento da meta 4.1 do ODS no país, pois fornece dados confiáveis para acompanhar o desempenho dos alunos brasileiros em leitura e permite compará-lo com o de alunos de outros países. 
O Pecim também obteve destaque na atual gestão do MEC, contando como uma subsecretaria dedicada ao fomento às escolas cívico-militares. Bandeira de campanha do presidente Jair Bolsonaro, o programa foi instituído somente no segundo semestre de 2019. De acordo com o Decreto $n^{\circ} 10.004$, de 5 de setembro de 2019, o Pecim visa melhorar a qualidade da educação básica, no ensino fundamental e no ensino médio, especialmente em escolas onde os alunos estão em situação de vulnerabilidade social e apresentam baixo Índice de Desenvolvimento da Educação Básica (Ideb), argumentando que o modelo cívico-militar propicia melhor aprendizagem, pois valoriza o aluno, fomentando nele o sentimento de pertencimento à escola. De acordo com o balanço do MEC, o modelo cívico-militar foi implantado em 39 escolas estaduais (de 22 estados e do Distrito Federal) e em quinze escolas municipais, atendendo a alunos dos anos finais do ensino fundamental e do ensino médio em 2019. A Portaria no 2.015 , de 20 de novembro de 2019, regulamenta a implantação do Pecim em 2020. O objetivo do programa é implantar 54 escolas cívico-militares em 2020 e atingir um total de 112 escolas cívico-militares até 2023 . No total, serão 166 previstas no Pecim até 2023, o que representa $0,25 \%$ do total de 67 mil escolas estaduais e municipais que ofertam os anos finais do ensino fundamental ou o ensino médio em 2019. Tendo em vista o objetivo do programa, a estrutura com a qual ele conta dentro do MEC e a visibilidade que lhe foi dada, seu escopo é muito restrito para impactar significativamente a qualidade da educação básica brasileira.

Os programas Novo Mais Educação e Apoio ao Novo Ensino Médio e a Política de Fomento à Implantação do Ensino Médio em Tempo Integral (Emti), criados em gestóes anteriores e continuados em 2019, propóem, como forma de melhorar o aprendizado nos ensinos fundamental e médio, a ampliação do tempo de permanência dos alunos na escola. No Programa Novo Mais Educação, o foco é o acompanhamento pedagógico em matemática e língua portuguesa para melhorar o aprendizado dos alunos do $3^{\ominus}$ ano ao $9^{\ominus}$ ano do ensino fundamental. As escolas que participam do programa devem obrigatoriamente ofertar aulas de reforço escolar em matemática e língua portuguesa aos alunos inscritos no programa e, de maneira eletiva, atividades complementares em artes, cultura, esporte ou lazer. O Novo Mais Educação foi instituído em 2016, durante o governo Temer, que reformulou o programa Mais Educaçáo, criado em 2008, durante o governo Lula. No Novo Mais Educação, as escolas podem optar por ofertar cinco ou quinze horas semanais de atividades no turno ou contraturno escolar. Todas as atividades ofertadas aos alunos são desenvolvidas por voluntários, apenas os coordenadores estaduais do programa podem receber uma bolsa para coordenar as atividades. $\mathrm{O}$ objetivo é envolver a comunidade escolar, mas o envolvimento do voluntariado pode tornar o programa mais barato. É um programa positivo, pois, dado o baixo desempenho dos alunos em língua portuguesa e matemática, medido pelo Sistema de Avaliação da Educação Básica (Saeb), o reforço escolar com outras abordagens 
pedagógicas pode ajudá-los a aprender, e atividades culturais e esportivas estimulam o envolvimento dos alunos no ambiente escolar.

No que tange ao ensino médio, a Política de Fomento à Implementação de Escolas de Ensino Médio em Tempo Integral e o Programa de Apoio ao Novo Ensino Médio, instituídos durante o governo Temer, têm o objetivo comum de ajudar as redes de ensino estaduais e do Distrito Federal a implantar a reforma do ensino médio, instituída pela Lei $n^{\circ} 13.415$, de fevereiro de 2017. Para melhorar os índices de desempenho e de conclusão do ensino médio, a reforma deste nível de ensino propóe a flexibilização do currículo do ensino médio, formado por uma base comum e itinerários formativos, aliada à ampliação da jornada escolar. Todavia, não há um modelo pré-definido de como construir o currículo e organizar as disciplinas de acordo com as diretrizes da reforma. O Programa Novo Ensino Médio apoia as secretarias estaduais de educaçáo e do Distrito Federal a planejar a implementação da reforma curricular em suas escolas de ensino médio. A Emti prevê apoio financeiro aos estados e ao Distrito Federal para implantar a jornada de tempo integral em escolas de ensino médio de suas redes. Os recursos são transferidos às Secretarias Estaduais de Educação, e estas escolhem as escolas onde farão obras para ampliar a capacidade de oferta de matrículas em tempo integral. As escolas selecionadas recebem suporte financeiro, ao longo de dez anos, para ampliar e adequar sua estrutura à oferta do ensino médio em tempo integral. Motivada pelo baixo Ideb no ensino médio, estas açóes visam manter os jovens por mais tempo na escola e estimulá-los a aprofundar conhecimentos em suas áreas de interesse. A reforma é recente, e não há dados sobre seu impacto na aprendizagem e progressáo dos jovens matriculados no ensino médio; no entanto, a ampliação e a adaptação das escolas de ensino médio para a jornada em tempo integral são modestas: apenas 12\% de todas as matrículas nas escolas de ensino médio da rede pública eram em tempo integral em 2019. Neste mesmo ano, na rede privada, este número é ainda menor: 5\%.

No Compromisso Nacional pela Educação Básica, o MEC se comprometeu a formular uma política para melhorar os índices de desempenho nos anos finais do ensino fundamental. O Programa Escola do Adolescente, instituído no final de 2018 pela Portaria $n^{\ominus} 1.248$, é uma iniciativa interessante, mas que não avançou em 2019. O Escola do Adolescente propóe estimular metodologias ativas e a aproximação dos conhecimentos escolares com os interesses dos alunos para tornar a escola mais atrativa aos adolescentes e os engajar no aprendizado. As escolas inscritas, com a supervisão do MEC, deveriam fazer o diagnóstico da situação, escutando os adolescentes; propor um plano de ação; e avaliar constantemente as ações implementadas na escola. Para oferecer acompanhamento e suporte técnico, o MEC lançou uma plataforma digital, na qual as secretarias estaduais e municipais de educação se inscreveram até início de 2019. Nessa plataforma, seriam ofertados cursos à distância para os gestores e os professores sobre adolescência, abordando, 
por exemplo, como incorporar as mídias digitais no aprendizado, e sobre gestão escolar. $\mathrm{O}$ ambiente também serviria para troca de experiências entre as redes. Este é um programa de baixo investimento, que pode ter um impacto positivo nos índices dos anos finais do ensino fundamental, por isso seria interessante ser levado adiante.

As açóes e os programas implementados em 2019 pelo MEC contribuem para atingir a meta 4.1. O Novo Mais Educaçáo e a Emti contribuem para aumentar o tempo de permanência dos alunos na escola, oferecendo mais aulas e reforço escolar aos que precisam, beneficiando, especialmente, os alunos mais desmunidos, que não contam com supervisão da lição ou recursos pedagógicos em casa. Já os programas Novo Ensino Médio e Escola do Adolescente visam engajar os adolescentes e os jovens na escola ao adaptar o currículo e as abordagens escolares dos conteúdos aos seus interesses e ao utilizar novas tecnologias. Tanto os programas que aumentam o tempo de permanência na escola quanto os que atualizam os currículos e as abordagens escolares podem propiciar melhores chances de aprendizagens efetivas e relevantes aos alunos dos ensinos fundamental e médio no Brasil. O desafio é aumentar o escopo destes programas, beneficiando o maior número de alunos.

Meta 4.2 (Brasil) - Até 2030, assegurar a todas as meninas e meninos o desenvolvimento integral na primeira infância e acesso a cuidados e à educação infantil de qualidade, de modo que estejam preparados para o ensino fundamental.

Para o desenvolvimento na primeira infância, o MEC anunciou, no âmbito da Política Nacional de Alfabetização, açóes de incentivo à literacia familiar, definida na PNA como "o conjunto de práticas e experiências relacionadas com a linguagem, a leitura e a escrita, as quais a criança vivencia com seus pais ou cuidadores" (Brasil, 2019c). O programa Conta para Mim, anunciado em 2019, consiste em estimular as famílias, em especial de baixa renda, a ler, contar histórias e brincar com seus filhos em idade pré-escolar, a fim de melhor prepará-los para serem alfabetizados. Uma ação anunciada pelo MEC no final de 2019 foi a criação de Cantinhos Conta para Mim, concebidos como espaços onde as famílias podem participar de oficinas com tutores para aprender técnicas de literacia familiar. Os tutores serão professores das redes municipal ou estadual de educação que receberão treinamento e uma bolsa para desenvolver as atividades do programa Conta para Mim. 
Esse programa é importante por contribuir para atingir a meta 4.2, de pleno desenvolvimento na primeira infância. O relatório da UNESCO (2017), Global education monitoring report 2017/2018, destaca o papel dos pais e cuidadores no desenvolvimento da criança; e observa que brincar, cantar, contar histórias e desenhar promove o aprendizado das crianças pequenas. $\mathrm{O}$ relatório ressalta que famílias de classes sociais favorecidas tendem a propiciar ambientes e interaçóes estimulantes aos seus filhos na primeira infância mais do que famílias desfavorecidas (UNESCO, 2017). Na maioria dos países selecionados no relatório da UNESCO (2017), menos de $20 \%$ das figuras paternas tinham se engajado em ao menos três atividades de literacia familiar com seus filhos de 36 a 59 meses de idade nos três dias anteriores à pesquisa. O programa Conta para Mim, ao focar a transmissão de técnicas simples de literacia familiar para pais de baixa renda, é uma forma positiva de contribuir para o desenvolvimento das crianças desde os primeiros meses de vida e de combater as desigualdades. Seria importante ter açôes visando especificamente aos pais, pois, como mostram os dados internacionais, eles se envolvem menos com seus filhos em casa.

O Conta para Mim, aliado ao Programa Brasil Carinhoso, é importante para garantir o desenvolvimento das crianças em situação de extrema pobreza. Este foi instituído em 2012 e transfere dinheiro às famílias com crianças de 0 a 6 anos, para garantir sua segurança alimentar e desenvolvimento físico. $\mathrm{O}$ programa também financia a ampliação de creches existentes para atender crianças de 0 a 48 meses beneficiadas pelo Programa Bolsa-Família (PBF).

Para ampliar o acesso a creches e pré-escolas, além do Brasil Carinhoso, em 2019, o MEC deu continuidade ao Programa Nacional de Reestruturação e Aquisição de Equipamentos para a Rede Escolar Pública de Educação Infantil (Proinfância), que financia a construção de novas creches e pré-escolas e transfere recursos para a aquisição de equipamentos e mobiliário aos municípios e ao Distrito Federal. Após finalizadas as obras, estes recebem recursos enquanto as novas matrículas não são computadas para a transferência dos recursos do Fundo de Desenvolvimento da Educação Básica (Fundeb) ao município ou ao Distrito Federal. O Proinfância foi criado em 2007 e já foi alvo de auditorias, que constataram problemas em metodologias adotadas que levaram a obras inacabadas. É importante concretizar as ações anunciadas e dar continuidade ao Brasil Carinhoso e ao Proinfância, sobretudo para a construção de creches, pois pouco mais de um terço das crianças de 0 a 3 anos frequentava creche no Brasil em 2019.

No documento Compromisso pela Educação Básica, a nova gestão do MEC planejou a implementação dos parâmetros de qualidade da educação infantil e de uma avaliação-piloto da educação infantil; todavia, no balanço publicado no início de 2020, não há menção a avanços nestes projetos. Uma avaliação da educação infantil é positiva para acompanhar os resultados das atividades desenvolvidas nas creches e pré-escolas no desenvolvimento das crianças de 0 a 5 anos. 
Os programas e as ações anunciados e continuados pelo MEC em 2019 cobrem diversos aspectos do desenvolvimento na primeira infância: da segurança alimentar, com o Brasil Carinhoso, passando pelo desenvolvimento cognitivo em casa, com o Conta para Mim, até a ampliação do acesso à creche e à pré-escola, com o Proinfância e o Brasil Carinhoso; todos são programas positivos para atingir a meta 4.2 .

Meta 4.3 - Até 2030, assegurar a equidade (gênero, raça, renda, território e outros exemplos) de acesso e permanência à educação profissional e à educaçáo superior de qualidade, de forma gratuita ou a preços acessíveis.

O principal anúncio do MEC em 2019 para o ensino superior foi o Programa Institutos e Universidades Empreendedoras e Inovadoras (Future-se), que visa ampliar o orçamento das universidades e dos institutos federais ao incentivar a captação de recursos próprios e ao conferir maior flexibilidade às instituiçôes de ensino superior (IES) federais para realizar despesas. O projeto Future-se foi apresentado em meados de julho de 2019; a Associação de Reitores das Universidades Federais (Andifes) se posicionou com relação ao Future-se por meio da Carta de Vitória, publicada em 29 de julho de 2019. A carta destaca que, na época, suas instituiçóes estavam com parte de seus recursos orçamentários bloqueados. As principais críticas da Andifes (2019) ao Future-se é quanto à obrigatoriedade de a instituição aderente ao programa firmar um contrato de gestáo com uma organização social (OS), o que feriria a autonomia da IES, garantida constitucionalmente. Outra crítica é quanto ao descompromisso do governo federal com o financiamento das IES federais. Após as reaçôes, o MEC apresentou um novo projeto do Future-se para consulta pública, em outubro de 2019, o qual retira a obrigação de contratação de OS para a gestão das instituiçôes. O projeto de lei do Future-se não foi apresentado ao Congresso Nacional em 2019. Todavia, o programa aponta o posicionamento da atual gestão de que a expansão do ensino superior público deve se dar com recursos captados por meio de projetos de empreendimentos das próprias universidades.

Para promover o acesso e a permanência de jovens e adultos de estratos de renda mais baixos ao ensino superior privado, o MEC mantém o Fundo de Financiamento Estudantil (Fies) e o Programa Universidade para Todos (Prouni). O Fies, criado em 2001 e reformulado em 2017, concede financiamento a estudantes de IES privadas com juros que dependem da faixa de renda do estudante: juros zero para estudantes com renda familiar per capita de até 3 SMs, já as taxas para alunos com renda familiar per capita acima de 3 e até 5 SMs varia de acordo com o banco por meio do qual o financiamento foi concedido. Para obter o financiamento, o aluno deve estar inscrito em uma IES privada cadastrada no Fies e com avaliação positiva no Sistema Nacional de Avaliação da Educação Superior (Sinaes). Em 2019, foram concedidos 85 mil novos financiamentos a juros zero, o que representa um leve aumento com relação a 2018, mas metade do número de bolsas concedidas em 
2017. De fato, o número de novos financiamentos concedidos pelo Fies atingiu o pico de 731 mil em 2014; no ano seguinte, caiu drasticamente para 287 mil, e seguiu em queda até 2017. Para o triênio 2020-2022, o Comitê Gerenciador do Fies estipulou a oferta de 100 mil novas vagas em 2020 e 50 mil novas vagas em 2021 e 2022 (Brasil, 2019f).

Outro programa para promover o acesso de jovens e adultos de baixa renda ao ensino superior é o Prouni, criado em 2004, que concede bolsas de estudo em IES privadas. As bolsas podem ser de 100\%, para pessoas com renda familiar per capita de até 1,5 SM, ou de 50\% do valor da mensalidade do curso, para pessoas com renda familiar per capita de até 3 SMs. Além do critério de renda, o Prouni também adota o critério racial na concessão das bolsas, e pessoas com deficiência, independentemente da renda, também podem concorrer a uma bolsa Prouni. No caso de alunos com bolsa de 50\%, eles também podem se candidatar ao Fies para financiar os 50\% restantes da mensalidade de seu curso. O Prouni contribui para atingir a meta 4.3, pois promove a equidade no ensino superior privado ao considerar critérios de renda, raça e pessoas com necessidades especiais na concessão das bolsas.

A atual gestáo do MEC anunciou, em outubro de 2019, uma série de medidas sob o nome de Novos Caminhos, para fomentar a educação profissional e técnica (EPT). Em 2019, 12\% dos alunos matriculados no ensino médio seguiam a EPT nas modalidades integrada, concomitante e magistério. Incluindo as matrículas na modalidade subsequente, 1,9 milhão de jovens e adultos estavam matriculados na EPT de nível médio no Brasil em 2019 (Inep, 2020). O objetivo do Novos Caminhos é aumentar em $80 \%$ as vagas em EPT nas redes estaduais de ensino médio até 2023 e aumentar em $30 \%$ as matrículas em EPT de nível médio na rede federal. Uma das açôes previstas para atingir este objetivo é o fomento da EPT na modalidade à distância.

Para atingir a meta 4.3, as políticas em curso e anunciadas em 2019 estimulam o setor privado e o financiamento privado na ampliação do acesso ao ensino superior. Já o Novos Caminhos prevê a ampliação do acesso à EPT nas redes estaduais e federal. Além disso, uma política nacional de assistência estudantil, como acesso à moradia, alimentaçáo e materiais utilizados nos cursos a preços acessíveis, poderia favorecer a permanência de jovens e adultos de baixa renda no ensino superior e na EPT.

Meta 4.4 - Até 2030, aumentar substancialmente o número de jovens e adultos que tenham competências necessárias, sobretudo técnicas e profissionais, para emprego, trabalho decente e empreendedorismo.

Para alunos dos anos finais do ensino fundamental e do ensino médio, o MEC anunciou o programa Educação em Prática, que pretende abrir as instalações das IES públicas e privadas aos alunos dos anos finais do ensino fundamental e do ensino médio. O objetivo é inserir jovens no ambiente universitário para estimular 
suas habilidades e aptidóes e permitir a estes vivenciar as profissóes e, assim, ter bases para escolher a futura profissão. Em 2020, as IES que desejam participar do programa devem aderir ao Educação em Prática, cujo piloto está previsto para 2021. Para os alunos do ensino superior, um dos eixos do Future-se é estimular o empreendedorismo e a inovação nas universidades federais. Estes dois programas anunciados não foram colocados em prática até o início de 2020, portanto não é possível saber o impacto.

Meta 4.7 - Até 2030, garantir que todos os alunos adquiram conhecimentos e habilidades necessárias para promover o desenvolvimento sustentável, inclusive, entre outros, por meio da educação para o desenvolvimento sustentável e estilos de vida sustentáveis, direitos humanos, igualdade de gênero, promoção de uma cultura de paz e não violência, cidadania global e valorizaçấo da diversidade cultural e da contribuiçấo da cultura para o desenvolvimento sustentável.

Essa meta não apresentou a necessidade de mudança em sua adaptaçáo ao cenário brasileiro. Todos os atores envolvidos no debate e na consulta pública no Brasil acreditam que a educação para o desenvolvimento e estilos de vida sustentáveis, direitos humanos, igualdade de gênero, promoção de uma cultura de paz e não violência, cidadania global, e valorização da diversidade cultural e da contribuição da cultura sejam temas que merecem a atenção conferida pela ONU.

Desde 2003, foram criados ministérios ou órgãos de alto escaláo na esfera governamental, tendo em vista o destaque conferido a esses temas. Mas, desde 2019, a trajetória foi invertida, e reverteram as mudanças na administração federal, num processo que ainda está em curso. Para os anos de 2016 e 2017, é possível apresentar órgãos, denotando envolvimento com a meta 4.7, como os que são apresentados a seguir.

O Programa Nacional de Educação Ambiental (ProNEA) foi criado com o intuito de planejar, executar e avaliar políticas públicas voltadas à educação ambiental para mudanças culturais, à potencialização de atores locais como educadores ambientais e à efetiva adoção das propostas. Este programa estava vinculado ao Departamento de Educação Ambiental do Ministério do Meio Ambiente (MMA). Desde 2019, foi modificada a forma de atuação do ministério, com a introdução do Decreto $\mathrm{n}^{\circ} 9.672$ de 2019, e as questôes relativas à educação foram descentralizadas da seguinte maneira:

Art. 30. Ao Departamento de Comunicą̧ão (da Secretaria de Ecoturismo) compete:

Art. 31. Ao Departamento de Fomento e Projetos (da Secretaria de Ecoturismo) compete:

III - acompanhar e monitorar açóes, iniciativas, estratégias, programas e projetos de Ecoeconomia, Educação Ambiental e Ecoturismo. 
Entre os programas do MMA, ainda não houve uma menção específica em relação ao papel da educação quando relacionado à área de atuação desse ministério.

A Diretoria de Políticas de Educação em Direitos Humanos e Cidadania do MEC, até 2019, fomentava a produção acadêmica e os projetos de estudantes do ensino fundamental ao ensino superior, como o prêmio Construindo a Igualdade de Gênero, a Conferência Nacional Infanto-Juvenil pelo Meio Ambiente (CNIJMA) e o programa Com Vida, no qual alunos do ensino fundamental II propunham iniciativas sustentáveis e que melhorassem a qualidade de vida na escola e de sua comunidade. A diretoria promoveu a oferta de cursos de formação continuada nas seguintes temáticas:

- educação ambiental;

- direitos da criança e do adolescente;

- gênero e diversidade sexual;

- promoção e defesa dos direitos de crianças e adolescentes; e

- enfrentamento da violência na escola.

Desde 2019, segundo Brasil (2019h), a relação entre educação e direitos humanos passou a ser regida pelo Programa Nacional de Educação Continuada em Direitos Humanos (PNEC-DH), que tem como principal objetivo oferecer formação em direitos humanos na modalidade de ensino a distância, voltada à educação não formal para públicos diversos, haja vista que a educação não formal inclui variadas dimensôes e grupos, como comunidades, movimentos sociais, organizaçóes sociais, espaços governamentais e não governamentais, entre outros.

Segundo o PNEC-DH, os objetivos específicos dizem respeito à promoção do conhecimento sobre direitos humanos para transformação social, ao desenvolvimento da autonomia e a emancipação do sujeito de direitos com sensibilização, e à formação da consciência crítica para os direitos humanos.

O PNEC-DH também possibilita ampliar o alcance da formação nacional para os direitos humanos, por meio da utilização da modalidade de ensino a distância, oferecendo parâmetros metodológicos, conferindo identidade à política pública brasileira de educação em direitos humanos e otimização da utilização dos recursos públicos para a educação em direitos humanos.

O PNEC-DH é realizado em parceria com a Escola Nacional de Administração Pública (Enap) no âmbito da Escola Virtual de Governo, por meio da qual são disponibilizados os diversos cursos em direitos humanos, num formato similar a cursos de extensão. 
Segundo Matijascic e Rolon (2019), a Diretoria de Politicas de Educaçáo Especial (DPEE) do MEC coordenava programas para garantir a acessibilidade na escola, o atendimento aos alunos com necessidades especiais e a formação continuada de professores na educação especial. Os programas Escola Acessível, Transporte Escolar Acessível e Salas de Recursos Multifuncionais transferiam recursos às escolas públicas de ensino regular a fim de adequarem a arquitetura e comprarem veículos adaptados para o transporte escolar e equipamentos destinados às salas de recursos multifuncionais. O Programa Incluir disponibilizava recursos às instituiçôes federais de ensino superior para garantir a acessibilidade aos ambientes físicos e aos recursos pedagógicos. O Programa Livro Acessível e a Comissão Brasileira do Braile desenvolvem recursos pedagógicos para alunos com necessidades especiais. A DPEE atua igualmente na formação de professores da educação básica, ofertando cursos de especialização e aperfeiçoamento na educação especial, formando os professores.

A partir de 2019, a forma de atuação do MEC foi alterada, com a introdução do Decreto $\mathrm{n}^{\circ} 7.480$, e as questóes relativas à educação especial passaram a ser realizadas pela Semesp.

Em 2019, o MEC lançou o Programa Escola de Todos, em parceria com o Ministério da Mulher, da Família e dos Direitos Humanos, visando promover a cultura da paz nas escolas, o respeito às diferenças, a pluralidade de ideias, o combate ao bullying e a prevenção ao suicídio. As ações anunciadas no balanço do MEC de 2019 se referiam à publicação de material informativo nos livros didáticos de língua portuguesa para os anos finais do ensino fundamental em 2020 e, também, à criação de um disque-denúncia.

Em termos de produção de informações para fins de governance e accountability, a alternativa parece ser a verificação da inserçẫo desses conteúdos na BNCC, com vistas a aferir se ele está sendo repassado a alunos do ensino básico de todo o país. Para que o conteúdo inserido na BNCC seja de fato apresentado em sala de aula, é desejável que os exames nacionais de avaliação dos alunos, como o Enem e a Prova Brasil, realizada por alunos da quinta e da nona série do ensino fundamental, bem como a Provinha Brasil, aplicada a alunos da segunda série do ensino fundamental, envolvam questóes relativas à sustentabilidade.

Outra alternativa prevista pela formulação da ONU na organização dos ODS é a necessidade de promover iniciativas de formação continuada para professores da educação básica sobre temas voltados ao desenvolvimento sustentável. Existem iniciativas relativas à realização de atividades dessa natureza, mas não existe nenhuma informação quantitativa e sistemática sobre a abordagem desse tema nos cursos de formação continuada dos professores. 
Por fim, não é possível prever a existência de disciplinas para esses conteúdos na BNCC, mas é necessário lançar mão da transversalidade para poder atingir esses objetivos. Embora não existam indicadores numéricos para aferir se a meta 4.7 está em execução, bastaria uma decisão do MEC para que esse objetivo fosse factível.

A alternativa adotada por UNESCO (2017), analisada de forma comparativa com outros países por Matijascic e Rolon (2020), é descrever como as regulamentaçóes das Naçôes Unidas referentes às bases curriculares (BNCC do Brasil) se manifestam em relação a gênero, direitos humanos e desenvolvimento sustentável. Segundo a avaliação de UNESCO (2017), elas foram consideradas nulas, altas e fracas, respectivamente, para cada uma dessas políticas. Além disso, UNESCO (2017) considerou importante estimar o percentual de alunos com conhecimentos em cultura científica e educação sexual. Os resultados revelam, para o Brasil, que o percentual foi de $43 \%$ no primeiro caso e desconhecido no segundo. Segundo UNESCO (2017), o Brasil possuía, considerando as bases curriculares, um conteúdo referente a sustentabilidade considerado fraco, ao contrário de outros países, cujos resultados eram satisfatórios.

Em suma, a meta 4.7 é de difícil mensuração para o caso brasileiro, conforme já apontavam Matijascic e Rolon (2019). Além disso, de acordo com UNESCO (2017), o Brasil não apresentava resultados satisfatórios em temas envolvendo o desenvolvimento sustentável. Com as mudanças em ministérios e órgãos de governo em 2019, cumprir a meta 4.7 do ODS 4 parece ser ainda mais difícil.

Meta 4.a (Brasil) - Ofertar infraestrutura física escolar adequada às necessidades da criança, acessível às pessoas com deficiências e sensível ao gênero, que garanta a existência de ambientes de aprendizagem seguros, não violentos, inclusivos e eficazes para todos.

As escolas de educação básica brasileira ainda apresentam deficiências de acesso à infraestrutura física para pessoas com necessidades especiais, mas também a serviços necessários à qualidade do ensino, como acesso à internet (Matijascic e Rolon, 2019). O relatório da UNESCO (2019) evidencia a relação entre infraestrutura da escola e qualidade do ensino no Brasil. A meta 4.a é, portanto, de extrema relevância. A atual gestão do MEC manteve muitas das açóes e programas voltados a melhorar as instalaçóes e os equipamentos necessários ao ensino. $\mathrm{O}$ FNDE é uma autarquia federal responsável pelas transferências aos estados, aos municípios, ao Distrito Federal ou direto às escolas para execução dos programas do MEC na área de infraestrutura, e também pedagógicas. Por meio do FNDE, o MEC financia os programas voltados à infraestrutura das escolas, como o Programa Nacional da Alimentaçáo Escolar (PNAE), o Programa Nacional de Apoio ao Transporte Escolar (PNATE) e o Programa Nacional do Livro Didático (PNLD). O FNDE também operacionaliza programas que transferem dinheiro direto às escolas para que adquiram bens e serviços, os chamados Programa Dinheiro Direto na Escola (PDDE). 
A merenda e o transporte escolares são necessários para garantir condiçôes a todos os alunos da educação básica de chegarem à escola e permanecerem nela. O balanço do MEC de 2019 apresenta os valores repassados por meio destes programas e destinados a melhorias na infraestrutura das escolas. O orçamento do PNAE em 2019 foi de R \$ 4 bilhôes para alimentar 40 milhóes de alunos de toda a rede pública. O MEC anunciou o aprimoramento do aplicativo E-PNAE para transparência e controle social da utilização dos recursos destinados à merenda. $\mathrm{O}$ MEC repassou R \$ 697 mil aos estados e municípios para aquisição de transporte escolar, por meio do PNATE, em 2019. Em algumas escolas - especialmente as de ensino fundamental, anos iniciais, localizadas nas regióes Norte e Nordeste do Brasil -, falta abastecimento de água (Matijascic e Rolon, 2019). Para financiar o abastecimento contínuo de água adequada ao consumo humano, o PDDE Água na Escola repassou R \$ 32 milhóes a 669 escolas em 2019.

O PDDE Escolas Sustentáveis é importante para os ODS, pois promove a energia limpa nas escolas. O FNDE repassou R \$ 79,1 milhóes em 2019 para implantar usinas fotovoltaicas em institutos federais (IF), o que vai gerar economia na conta de luz e também modernização e reestruturação de salas de aula e laboratórios dos IFs, que são estabelecimentos de responsabilidade do governo federal. O PDDE Acessível visa adaptar a infraestrutura das escolas da educação básica, ainda pouco inclusivas. O MEC destinou $\mathrm{R}$ \$ 23,4 milhóes para as escolas adquirirem material didático e tornarem suas instalações físicas acessíveis em 2019. Outra açẫo acessível foi a aquisição de livros didáticos em braile, que, de acordo com o MEC, atende a $100 \%$ dos alunos cegos do $1^{\circ}$ ao $5^{\circ}$ ano do ensino fundamental.

O PDDE Campo contou com R $\$ 248,7$ milhóes, destinados a 19 mil escolas do campo, indígenas ou quilombolas para compra de mobiliário, reformas e ampliaçôes de estruturas. O MEC destinou R \$118,3 milhôes em 2019 para escolas de ensino médio implantarem o Ensino Médio em Tempo Integral.

Em 2019, o MEC anunciou a ampliação do Programa de Inovação Educação Conectada. Este programa foi instituído em 2017 pelo Decreto n ${ }^{\ominus} 9.204$ com o objetivo de difundir o uso pedagógico da tecnologia e do acesso à internet e a recursos educacionais digitais. O programa prevê a contratação de serviço de acesso à internet, implantação de infraestrutura para distribuição do sinal da internet nas escolas, aquisição de recursos educacionais digitais e oferta de cursos de formação para professores para uso de tecnologia em sala de aula. De acordo com o balanço do MEC, foram repassados $\mathrm{R}$ \$ 284 milhôes às escolas de educaçáo básica: $\mathrm{R}$ \$ 224 milhôes para conectar, via fibra ótica, 70 mil escolas urbanas; $\mathrm{R}$ \$ 60 milhóes para conectar, via satélite, 8 mil escolas rurais; e, ainda, mais de 100 mil professores foram capacitados para uso da internet. 


\section{CONCLUSÕES}

O Brasil possui instrumentos constitucionais, legais e institucionais para atingir as metas do ODS 4. O PNE 2014-2024 é o principal, pois as metas, acordadas democraticamente pelo plano, englobam $70 \%$ das metas do ODS 4, e isso num horizonte mais curto: enquanto o PNE estabelece como prazo 2024, o ODS o faz para 2030.

Das metas não contempladas pelo PNE, uma não se aplica ao Brasil (meta 4.b). A meta 4.a, que estabelece quais as condiçóes de infraestrutura são adequadas para fins de inclusão social nas escolas, não é objeto das metas do PNE. Todavia, existem diversos programas e açôes do MEC que promovem a melhoria das condições das escolas. Já a BNCC é o instrumento institucional para atingir a meta 4.7, relativa à transmissão de conhecimentos sobre desenvolvimento sustentável, direitos humanos, igualdade de gênero e cultura da paz nas escolas de ensino fundamental.

Além desses instrumentos legais, duas autarquias ligadas ao Ministério da Educação são importantes para atingir as metas do ODS 4. A primeira é o FNDE, que repassa os recursos aos estados, ao Distrito Federal e aos municípios para financiar as políticas educacionais. A segunda é o Inep, responsável pela produção de dados estatísticos e pela conduçáo de exames padronizados, permitindo, assim, acompanhar o cumprimento das metas acordadas. Estas autarquias, somadas à BNCC e ao PNE, são instrumentos institucionais decisivos, que podem dar um apoio decisivo ao MEC para atingir as metas do ODS 4.

O Ministério da Educação foi reestruturado por um decreto logo no dia 2 de janeiro de 2019. Com essa reestruturação, quando comparada com a estrutura do MEC em 2017, na administração Temer, o PNE perdeu espaço, e, diante disso, os ODS 4 passam a se situar num horizonte marcado por inequívocas incertezas. A extinção da Sase e a divisão da Secadi em Semesp e Sealf, fragmentou a formulação e o acompanhamento de políticas que contribuem para a consecuçáo do ODS 4.

A segunda seção do capítulo apresentou os reflexos das mudanças no MEC, envolvendo cinco das dez metas do ODS 4. A atual gestão do MEC deixou claro que o seu foco é a alfabetização. Diante disso, foi lançada uma política nacional de alfabetização, em 2019, e o Brasil aderiu ao PIRLS. Mas estas duas ações ainda não apresentaram resultados concretos. Foi lançado, também, o Programa de Fomento às Escolas Cívico-Militares, para melhorar a qualidade da educação básica pública. No entanto, o alcance do Pecim em 2019 foi reduzido, criando apenas 54 escolas em todo o país. A programação, até 2023, é inaugurar 54 escolas cívico-militares no Brasil por ano, um universo um tanto reduzido diante do número de escolas existentes no país, que supera o total de 62 mil, segundo os dados do Censo Escolar, realizado pelo Inep para o ano de 2018. 
Dentre as ações que a nova gestáo do MEC manteve, figuram aquelas voltadas à ampliação da carga horária para fomentar a educação em tempo integral na educação básica, por meio dos programas Mais Educação, Ensino Médio em Tempo Integral e Novo Ensino Médio. Todavia, como no caso do Pecim, essas políticas atingiram uma parcela muito pequena dos alunos.

O principal problema de acesso à escola no Brasil continua sendo a creche. Em 2019, o MEC deu continuidade ao programa Proinfância, prometendo concluir todas as obras inacabadas. Faltam creches no Brasil, e o acesso à pré-escola não foi universalizado, sendo, portanto, relevante a continuidade do Programa Brasil Carinhoso, que oferece financiamento suplementar às escolas que atendem a famílias de baixa renda. O MEC anunciou um programa de literacia familiar, voltado às famílias de baixa renda.

Para aumentar o acesso ao ensino superior, o MEC manteve o Fies e o Prouni voltados às IES públicas. As políticas públicas de cotas continuam dando apoio às políticas afirmativas, visando à inclusão de pessoas pretas, pardas e indígenas nas universidades públicas. O MEC anunciou, também, o Future-se, mas o projeto ainda não foi apresentado à Câmara dos Deputados. Para desenvolver a educação profissional e técnica, o ministério anunciou uma série de açóes sob o nome de Novos Caminhos, cujo impacto ainda não pode ser mensurado ou avaliado.

Desde 2019, ocorreu uma perda de espaço para as políticas voltadas aos públicos com menores índices de escolaridade - ou seja, as populaçóes do campo, indígenas e quilombolas - e as políticas voltadas à transmissão de conhecimentos sobre cidadania, direitos humanos e desenvolvimento sustentável. Por outro lado, ganharam espaço a alfabetização, as escolas cívico-militares e os projetos de abertura e flexibilizaçâo das IES públicas. Uma questão a se destacar é a inexistência de informaçóes claras quando um programa é extinto. É possível acompanhar o surgimento de um programa ou política via decreto, mas o mesmo processo não ocorre quando há a extinção desses mecanismos.

O novo governo deu continuidade para várias políticas preexistentes e lançou outras novas que contribuem para perseguir as metas do ODS 4, sem esquecer o fato de ter anunciado outras que ainda não entraram em vigor. Existem, portanto, meios para atingir as metas do ODS 4. No entanto, o principal desafio é atender a uma parcela significativa de alunos, sobretudo os mais desfavorecidos, e, assim, ter um impacto efetivo para fins de um desenvolvimento com ênfase na sustentabilidade. 


\section{REFERÊNCIAS}

ANDIFES - ASSOCIAÇÃO NACIONAL DOS DIRIGENTES DAS INSTITUIÇÕES FEDERAIS DE ENSINO SUPERIOR. Carta de Vitória. Vitória: Andifes, 2019. Disponível em: <https://bit.ly/2Yv0O5k>. Acesso em: 17 abr. 2020.

BRASIL. Constituiçáo da República Federativa do Brasil de 1988. Brasília: Assembleia Nacional Constituinte, 1988. Disponível em: $<$ https://bit.ly/37XtOWw $>$. Acesso em: 12 fev. 2020.

. Lei $\mathrm{n}^{\circ}$ 9.394, de 20 de dezembro de 1996. Estabelece as diretrizes e as bases da educação nacional. Brasília: Congresso Nacional, 1996. Disponível em: <https://bit.ly/2BBHvyw>. Acesso em: 12 fev. 2020.

. Lei $n^{\ominus} 13.005$, de 25 de junho de 2014. Aprova o Plano Nacional de Educação - PNE e dá outras providências. Brasília: Congresso Nacional, 2014. Disponível em: <https://bit.ly/3eA1xYA>. Acesso em: 12 fev. 2020.

. Decreto $\mathrm{n}^{\circ} 9.005$, de 14 de março de 2017. Aprova a estrutura regimental e o quadro demonstrativo dos cargos em comissáo e das funçóes de confiança do Ministério da Educação, remaneja cargos em comissão e substitui cargos em comissão do grupo-direção e assessoramento superiores - DAS por funçóes comissionadas do Poder Executivo - FCPE. Brasília: Presidência da República, 2017. Disponível em: <https://bit.ly/2YwnmD2>. Acesso: 20 jan. 2020.

. Portaria $\mathrm{n}^{\circ} 1.248$, de 27 de novembro de 2018. Institui o Programa Escola do Adolescente. Brasília: MEC, 2018. Disponível em: <https://bit.ly/2ViFU7x>. Acesso: 03 fev. 2020.

. Decreto $n^{\otimes} 9.655$, de 2 de janeiro de 2019. Aprova a estrutura regimental e o quadro demonstrativo dos cargos em comissáo e das funçôes de confiança do Ministério da Educação, remaneja cargos em comissão e funções de confiança e transforma cargos em comissão do grupo-direção e assessoramento superiores DAS e funçóes comissionadas do Poder Executivo - FCPE. Brasília: Presidência da República, 2019a. Disponível em: <https://bit.ly/2AYgxRN>. Acesso em: 20 jan. 2020.

Decreto $\mathrm{n}^{\circ}$ 9.672, de 2 de janeiro de 2019. Aprova a estrutura regimental e o quadro demonstrativo dos cargos em comissáo e das funçóes de confiança do Ministério do Meio Ambiente, remaneja cargos em comissão e funçóes de confiança e substitui cargos em comissão do grupo-direção e assessoramento superiores - DAS por funçóes comissionadas do Poder Executivo - FCPE. Brasília: Presidência da República, 2019b. Disponível em: <https://bit.ly/3ez7Mfs>. Acesso em: 12 fev. 2020. 
. Decreto n 9.765, de 11 de abril de 2019a. Institui a Política Nacional de Alfabetização. Brasília: Presidência da República, 2019c. Disponível em: <https:// bit.ly/3eAet0F>. Acesso em: 31 jan. 2020.

. Decreto $\mathrm{n}^{\circ} 10.004$, de 5 de setembro de 2019. Institui o Programa Nacional das Escolas Cívico-militares. Brasília: Presidência da República, $2019 \mathrm{~d}$. Disponível em: <https://bit.ly/2BA1z4e>. Acesso: 31 jan. 2020.

. Decreto $n^{\ominus} 10.195$, de 30 de dezembro de 2019. Aprova a estrutura regimental e o quadro demonstrativo dos cargos em comissão e das funçôes de confiança do Ministério da Educação e remaneja e transforma cargos em comissão e funçôes de confiança. Brasília: Presidência da República, 2019e. Disponível em: <https://bit.ly/3ez7Mfs>. Acesso em: 12 fev. 2020.

. Financiamentos Concedidos. Brasília: FNDE, 2019f. Disponível em: $<$ https://bit.ly/2CJudRb>.

. Portaria n 2.015, de 20 de novembro de 2019. Regulamenta a implantação do Programa Nacional das Escolas Cívico-militares. Brasília: MEC, 2019g. Disponível em: <https://bit.ly/3eBtm30>.

Relatório de 2019: comissão externa destinada a acompanhar o desenvolvimento dos trabalhos do Ministério da Educação (MEC), bem como do seu planejamento estratégico (Comex). Brasília: Câmara dos Deputados, 2019h. Disponível em: <https://bit.ly/3fUSbqL>. Acesso em: 4 dez. 2019.

. Balanço MEC 2019. Brasília: MEC, 2020a. Disponível em: <https:// bit.ly/3i0C3po>. Acesso em: 17 jan. 2020.

. Cadernos PNA. Brasília: MEC, 2020b. Disponível em: <https://bit. ly/3fVM4lT >. Acesso em: 31 jan. 2020.

\section{Programa Nacional de Educaçáo Continuada em Direitos Humanos} (PNEC_DH). Brasília: MDH, 2020c. Disponível em: <https://bit.ly/2Z5ZoO1>. Acesso em: 4 jun. 2020.

CORBUCCI, P. R.; MATIJASCIC, M. ODS 4 - Assegurar a educaçâo inclusiva e equitativa e de qualidade, e promover oportunidades de aprendizagem ao longo da vida para todos. In: ROCHA, E.; PELIANO, A. M.; CHAVES, J. V. Agenda 2030: ODS - Metas Nacionais dos Objetivos de Desenvolvimento Sustentável. Brasília: Ipea, 2018a.

ODS 4 - Relatório das mudanças na redação das metas para fins de adaptação ao caso brasileiro. Brasília: Ipea, 2018b.

INEP - INSTITUTO NACIONAL DE ESTUDOS E PESQUISAS EDUCACIONAIS ANÍSIO TEIXEIRA. Sinopse Estatística da Educação 
Básica 2019. Brasília: Inep, 2020. Disponível em: <https://bit.ly/2AGeNwh>. Acesso em: jul. 2020.

IPEA - INSTITUTO DE PESQUISA ECONÔMICA APLICADA. Políticas sociais: acompanhamento e análise. Boletim de Políticas Sociais, Brasília, n. 24, 2017.

. Políticas sociais: acompanhamento e análise. Boletim de Políticas Sociais, Brasília, n. 25, 2018.

MATIJASCIC, M.; ROLON, C. E. K. ODS 4 - Assegurar a educaçâo inclusiva e equitativa e de qualidade, e promover oportunidades de aprendizagem ao longo da vida para todas e todos. Brasília: Ipea, 2019. (Cadernos ODS). Disponível em: <https://bit.ly/2Z9IGNv>. Acesso em: 12 fev. 2020.

Indicadores de ensino básico brasileiros relativos aos Objetivos de Desenvolvimento Sustentável numa perspectiva internacional comparada. Brasília: Ipea, 2020. (Texto para Discussão, n. 2551).

PERA, G.; MENEZES, D. MEC firma compromisso para tornar Brasil referência na América Latina até 2030. Portal MEC, jul. 2019. Disponível em: <https://bit. ly/31fkgF3>. Acesso em: 30 jan. 2020.

UNESCO - ORGANIZAÇÃO DAS NAÇÕES UNIDAS PARA A EDUCAÇÃO, A CIÊNCIA E A CULTURA. Rendre des comptes en matière d'éducation: tenir nos engagements. Rapport Mondial de Suivi sur l'Education, Paris, 2017.

Qualidade da infraestrutura das escolas públicas do ensino fundamental no Brasil. Brasília: UNESCO, 2019. Disponível em: <https://bit.ly/380EL9M>. Acesso em: 7 fev. 2020. 


\section{ANEXO A}

\section{QUADRO A.1}

Metas finalísticas dos Objetivos de Desenvolvimento Sustentável adaptadas ao Brasil

\begin{tabular}{|c|c|c|}
\hline Meta & Organização das Nações Unidas (ONU) & Reelaboração no Brasil em 2018 \\
\hline 4.1 & $\begin{array}{l}\text { Até 2030, garantir que todas as meninas e meninos } \\
\text { completem o ensino primário e secundário livre, } \\
\text { equitativo e de qualidade, que conduza a resultados } \\
\text { de aprendizagem relevantes e eficazes. }\end{array}$ & $\begin{array}{l}\text { Até } 2030 \text {, garantir que todas as meninas e meninos completem o } \\
\text { ensino fundamental e médio, equitativo e de qualidade, na idade } \\
\text { adequada, assegurando a oferta gratuita na rede pública e que } \\
\text { conduza a resultados de aprendizagem satisfatórios e relevantes. }\end{array}$ \\
\hline 4.2 & $\begin{array}{l}\text { Até } 2030 \text {, garantir que todos os meninos e meninas } \\
\text { tenham acesso a um desenvolvimento de qualidade } \\
\text { na primeira infância, cuidados e educação pré-escolar, } \\
\text { de modo que estejam prontos para o ensino primário. }\end{array}$ & $\begin{array}{l}\text { Até } 2030 \text {, assegurar a todas as meninas e meninos o desen- } \\
\text { volvimento integral na primeira infância, acesso a cuidados e à } \\
\text { educação infantil de qualidade, de modo que estejam preparados } \\
\text { para o ensino fundamental. }\end{array}$ \\
\hline 4.3 & $\begin{array}{l}\text { Até 2030, assegurar a igualdade de acesso para todos } \\
\text { os homens e as mulheres à educação técnica, profis- } \\
\text { sional e superior de qualidade, a preços acessíveis, } \\
\text { incluindo a universidade. }\end{array}$ & $\begin{array}{l}\text { Até } 2030 \text {, assegurar a equidade (gênero, raça, renda, território } \\
\text { e outros) de acesso e permanência à educação profissional e à } \\
\text { educação superior de qualidade, de forma gratuita ou a preços } \\
\text { acessiveis. }\end{array}$ \\
\hline 4.4 & $\begin{array}{l}\text { Até } 2030 \text {, aumentar substancialmente o número de } \\
\text { jovens e adultos que tenham habilidades relevantes, } \\
\text { inclusive competências técnicas e profissionais, para } \\
\text { emprego, trabalho decente e empreendedorismo. }\end{array}$ & $\begin{array}{l}\text { Até 2030, aumentar substancialmente o número de jovens e } \\
\text { adultos que tenham as competências necessárias, sobretudo } \\
\text { técnicas e profissionais, para o emprego, trabalho decente e } \\
\text { empreendedorismo. }\end{array}$ \\
\hline 4.5 & $\begin{array}{l}\text { Até } 2030 \text {, eliminar as disparidades de gênero na } \\
\text { educação e garantir a igualdade de acesso a todos os } \\
\text { níveis de educação e formação profissional para os } \\
\text { mais vulneráveis, incluindo as pessoas com deficiência, } \\
\text { os povos indígenas e as crianças em situação de } \\
\text { vulnerabilidade. }\end{array}$ & $\begin{array}{l}\text { Até 2030, eliminar as desigualdades de gênero e raça na } \\
\text { educação e garantir a equidade de acesso, permanência e êxito } \\
\text { em todos os níveis, etapas e modalidades de ensino para os } \\
\text { grupos em situação de vulnerabilidade, sobretudo as pessoas } \\
\text { com deficiência, populações do campo, populações itinerantes, } \\
\text { comunidades indígenas e tradicionais, adolescentes e jovens } \\
\text { em cumprimento de medidas socioeducativas e população em } \\
\text { situação de rua ou em privação de liberdade. }\end{array}$ \\
\hline 4.6 & $\begin{array}{l}\text { Até 2030, garantir que todos os jovens e uma subs- } \\
\text { tancial proporção dos adultos, homens e mulheres, } \\
\text { estejam alfabetizados e tenham adquirido o conheci- } \\
\text { mento básico de matemática. }\end{array}$ & $\begin{array}{l}\text { Até } 2030 \text {, garantir que todos os jovens e adultos estejam alfa- } \\
\text { betizados, tendo adquirido os conhecimentos básicos em leitura, } \\
\text { escrita e matemática. }\end{array}$ \\
\hline 4.7 & $\begin{array}{l}\text { Até 2030, garantir que todos os alunos adquiram } \\
\text { conhecimentos e habilidades necessárias para pro- } \\
\text { mover o desenvolvimento sustentável, inclusive, entre } \\
\text { outros, por meio da educação para o desenvolvimento } \\
\text { sustentável e estilos de vida sustentáveis, direitos } \\
\text { humanos, igualdade de gênero, promoção de uma } \\
\text { cultura de paz e não-violência, cidadania global, e } \\
\text { valorização da diversidade cultural e da contribuição } \\
\text { da cultura para o desenvolvimento sustentável. }\end{array}$ & Meta mantida sem nenhum tipo de alteração ou adaptação. \\
\hline
\end{tabular}

Fontes: ONU; e Matijascic e Rolon (2019). 


\section{QUADRO A.2}

\section{Metas de implementação dos ODS adaptadas ao Brasil}

\begin{tabular}{|c|l|l|}
\hline 4.a & $\begin{array}{l}\text { Construir e melhorar instalaçães físicas para a educação, } \\
\text { apropriadas para crianças e sensiveis às deficiências e ao } \\
\text { gênero e que proporcionem ambientes de aprendizagem } \\
\text { seguros, não violentos, inclusivos e eficazes para todos. }\end{array}$ & $\begin{array}{l}\text { Ofertar infraestrutura física escolar adequada às necessidades } \\
\text { da criança, acessivel às pessoas com deficieincias e sensivel ao } \\
\text { gênero, que garanta a existência de ambientes de aprendiza- } \\
\text { gem seguros, não violentos, inclusivos e eficazes para todos. }\end{array}$ \\
\hline 4.b $\begin{array}{l}\text { Até 2030, substancialmente ampliar globalmente o } \\
\text { número de bolsas de estudo disponíveis para os países } \\
\text { em desenvolvimento, em particular os países de menor } \\
\text { desenvolvimento relativo, pequenos Estados insulares } \\
\text { em desenvolvimento e os países africanos, para o ensino } \\
\text { superior, incluindo programas de formação profissional, } \\
\text { de tecnologia da informação e da comunicação, pro- } \\
\text { gramas técnicos, de engenharia e científicos em países } \\
\text { desenvolvidos e outros países em desenvolvimento. }\end{array}$ & $\begin{array}{l}\text { Até 2020, ampliar em 50\% o número de vagas efetivamente } \\
\text { preenchidas por alunos dos países em desenvolvimento, } \\
\text { em particular os países de menor desenvolvimento relativo, } \\
\text { tais como os países africanos de língua portuguesa e países } \\
\text { latino-americanos, para o ensino superior, incluindo programas } \\
\text { de formação profissional, de tecnologia da informação e da } \\
\text { comunicação, programas técnicos, de engenharia e científicos } \\
\text { no Brasil. }\end{array}$ \\
\hline 4.c & $\begin{array}{l}\text { Até 2030, substancialmente aumentar o contingente de } \\
\text { professores qualificados, inclusive por meio da coopera- } \\
\text { ção internacional para a formação de professores, nos } \\
\text { países em desenvolvimento, especialmente os países de } \\
\text { menor desenvolvimento relativo e pequenos Estados } \\
\text { insulares em desenvolvimento. }\end{array}$ & $\begin{array}{l}\text { Até 2030, assegurar que todos os professores da educação } \\
\text { básica tenham formação específica na área de conhecimento } \\
\text { em que atuam, promovendo a oferta de formação continuada, } \\
\text { em regime de colaboração entre União, estados e municípios, } \\
\text { inclusive por meio de cooperação internacional. }\end{array}$ \\
\hline
\end{tabular}

Fontes: ONU; e Matijascic e Rolon (2019).

\section{REFERÊNCIA}

MATIJASCIC, M.; ROLON, C. E. K. ODS 4 - Assegurar a educação inclusiva e equitativa e de qualidade, e promover oportunidades de aprendizagem ao longo da vida para todas e todos. Brasília: Ipea, 2019. (Cadernos ODS). Disponível em: $<$ https://bit.ly/2Z9IGNv>. Acesso em: 12 fev. 2020. 


\section{CAPÍTULO 5}

\section{POVOS INDÍGENAS ${ }^{1}$}

\section{APRESENTAÇÃO}

A percepção da diferença entre os modos de comportamentos, dos hábitos, das crenças e das línguas entre os seres humanos há séculos registra interesse e encontra-se evidenciada na historicidade de todo o pensamento ocidental. Entre os muitos caminhos trilhados para buscar compreender a diversidade do "ser humano", está a construção da concepção de cultura. Desde a segunda metade do século XIX, quando Edward Tylor, em 1871, publica Cultura Primitiva: pesquisas sobre o desenvolvimento da mitologia, filosofia, religiäo, linguagem, arte e costume (Tylor, 1903), o uso da palavra culture encontrará grande difusão, sedimentando um campo de pesquisa, estudo e conhecimento.

Como construção social, a concepção acerca do que é cultura variou desde sua constituição, o que torna sua conceptualização tarefa complexa e diversa, ao mesmo tempo que possibilita imensa variabilidade de abordagens. Diante disso, este capítulo sobre políticas culturais para essa edição de Políticas Sociais: acompanhamento e análise trata das políticas indigenistas, dos paradigmas de atuação do Estado em relação à diversidade cultural dos povos indígenas (PIs) em território nacional, de suas transformaçóes históricas e de sua efetividade recente.

É interessante consignar de forma introdutória a essa discussão uma síntese histórica da política indigenista no Brasil, que, com seu processo de independência política e constituição enquanto Estado nacional, se assentou nas relaçôes com os PIs sobre um regime de nacionalismo integracionista. É dizer que a conformação de um exitoso Estado dependia da homogeneização étnica, que se materializava à medida que a dissolução dos sistemas socioculturais indígenas avançasse e a consequente incorporação destes à civilização dita ocidental se consumasse.

De fato, desde o período colonial, os "índios" tiveram dupla classificação, cada qual determinando uma política indigenista de Estado específica a ser aplicada. De um lado, os índios aliados, caracterizados sob o termo pacificados, aos quais lhes era declarado o direito à liberdade mediante o aldeamento e a catequização. De outro, os índios inimigos, o "gentio bravo", cruel e bárbaro, que espalhados 
pelos "sertōes" lhes cabia decretar guerra justa e, diante de sua incapacidade de ser conduzido à civilidade, implementar a escravidão e/ou o extermínio.

$\mathrm{O}$ grau de facilidade com o qual os indígenas se deixavam conduzir ao processo de "civilização" imposto pelo Estado foi decisivo na atuação deste no trato da diversidade cultural e, ao longo das décadas, passou a direcionar as diversas fases $\mathrm{da}$ política indigenista. Mais do que os índios aliados, foi a resistência indígena de manter suas características culturais próprias que fomentou os debates sobre a condução do processo de integração praticado pelo Estado brasileiro.

Desde a sedimentação desse indigenismo integracionista de Estado, a visão praticada sobre os povos indígenas é alterada substancialmente com o marechal Cândido Rondon, no início do século XX, quando a mudança na forma de compreender a diversidade cultural supera a instrumentalização do genocídio diante da viabilidade do controle de trocas de fluxos culturais. Rondon, um militar instruído no positivismo científico de sua época, projetará a instituição de um órgão indigenista para o controle da violência, reorientando as relaçóes da cultura de Estado com os PIs e, assim, o próprio indigenismo estatal praticado.

Com a instituição do Serviço de Proteção ao Índio (SPI), em 1910, decorrente de acusaçôes de extermínio como consequências das políticas estatais implementadas aos povos indígenas no Paraná e em Santa Catarina, este assumiu o protagonismo na pacificação dos índios por meio da assimilação. Pautada no lema "morrer, se necessário, matar, nunca!", a integração dos indígenas por meio da assimilação definia novos padróes comportamentais do Estado com os PIs, de valorização da vida, ainda que ideologicamente inferiorizada e dependente. Vale lembrar que, naquele período, a tutela dos povos indígenas era instituída na mesma proporção que estes eram sentenciados como incapazes de sua própria defesa, proteção e desenvolvimento, condenando-os a depender de regime paternalista e assistencialista.

O que mudou com a implementação de práticas assimilacionistas foi a fixação de princípios orientadores que significavam a imposição de padróes culturais do Estado aos povos indígenas. Direcionados nos termos da lei ao respeito à "progressiva e harmoniosa" integração dos PIs à comunhão nacional, os efeitos jurídicos desse indigenismo assimilacionista podem ser observados ainda nas décadas de $1960 \mathrm{e}$ 1970. Nesse período, estudos sobre a formação da unidade sociocultural brasileira se propagavam ${ }^{2}$ na mesma medida que aos indígenas eram reconhecidos direitos e garantias específicas, sobretudo direitos civis e políticos e à terra. Esses ganharam expressão legal na Lei no $\mathbf{6} .001 / 1973$, conhecida como Estatuto do Índio, e dimensão

2. Na configuração histórico-cultural do povo brasileiro, descrita pelo antropólogo e indigenista Darcy Ribeiro, a miscigenação é constitutiva, sem a qual o "abrasileiramento" da população não se pode explicar. Até mesmo projetando um "racismo assimilacionista" - em que há uma expectativa assimilacionista que guarda relação com o branqueamento, por exemplo -, o "povo brasileiro" é tratado como resultado de um processo de homogeneização decorrente de conjugação de estratos socioculturais, de muitos "brasis". 
institucional com a substituição do SPI pela Fundação Nacional do Índio (Funai), vinculada ao Ministério da Justiça e Segurança Pública (MJSP).

Desde a formaçáo do Estado brasileiro, perpetuava-se a ideia de que qualquer política com enfoque na heterogeneidade cultural da população era considerada segregacionista, incapaz de estabelecer uma consciência nacional unificada. A heterogeneidade de comportamentos era um "problema" a ser resolvido pelo Estado, que passava a ser solucionado com a integração por meio da assimilação. No entanto, depois de mais de um século do emprego dessas políticas, no final dos anos 1970, constata-se a emergência de múltiplas identidades culturais em território estatal. Em processo que ficou conhecido como "emergência étnica", essa autoafirmação identitária, observada em inúmeros países da América Latina, decomporá a universalidade que o projeto de nação se impunha diante das outras culturas.

Ao reafirmar a ideia do valor relativo a cada cultura particular e desencadear a percepção de necessária reorganização social e transformações nos padrôes culturais político-jurídicos do Estado para adaptar-se a essa situação, as políticas indigenistas abrem-se à pluriculturalidade. É, portanto, durante a fase de redemocratização que ocorre a substituição do caráter assimilacionista da política indigenista pela multiculturalidade, que se determina a partir da tolerância com a "experiência da diferença". O impacto na reconfiguração das políticas indigenistas de Estado foi expressivo nas alterações dos textos constitucionais em diversos países da América Latina e em diversos instrumentos normativos internacionais que dispunham sobre a matéria.

No caso brasileiro, a promulgação da Constituição Federal de 1988 (CF/1988) vinculou a atuação estatal ao reconhecimento, ao respeito e à garantia das inúmeras formas culturais indígenas, bem como às formas de controle e desenvolvimento de suas próprias instituiçóes e formas de vida, adequando inclusive o direito coletivo à terra tradicionalmente ocupada às concepçôes culturais próprias (Brasil, 1988, art. 231). Ao afirmar seu compromisso com a pluriculturalidade na construção de uma sociedade sem discriminação, reconhecendo aos PIs suas formas de organizaçáo social, costumes, línguas, crenças e tradição, representou, nos termos da lei (op. cit., caput), a superaçáo do paradigma integracionista e o próprio viés multicultural, dando origem ao "paradigma da interação".

As orientaçóes de superação do indigenismo integracionista deram origem a um novo indigenismo de Estado. Políticas indigenistas de cunho interacionista, como o próprio nome sugere, não se confundem com políticas indígenas ou até mesmo com indigenismo integracionista. Enquanto as políticas indígenas se referem àquelas criadas pelos próprios indígenas, o indigenismo integracionista pressupóe a integração, e não a interação. Dessa forma, integração e interação não se confundem. Enquanto a primeira visa absorver, incorporando a diferença, a segunda tem o objetivo de estabelecer relação, diálogo e convívio com o diferente. 
Essa nova etapa do indigenismo (interacionista) foi respaldada posteriormente por diversos instrumentos normativos internacionais de direitos humanos - como a Convenção da Organização Internacional do Trabalho (OIT) no 169/1989, a Declaração das Naçōes Unidas sobre os Direitos dos Povos Indígenas (2007), a Convenção de Proteção e Promoção da Diversidade das Expressóes Culturais da Organização das Naçóes Unidas para a Educação, a Ciência e a Cultura - UNESCO (2007) e a Declaração Americana sobre os Direitos dos Povos Indígenas (2016). Em comum, essas declaraçôes e convençôes reafirmaram a autodeterminação indígena.

O direito à autodeterminação representa a pedra fundamental desse novo ciclo indigenista, deste se desprendendo de todos os demais direitos humanos dos povos indígenas nesse novo ciclo constitucionalista. A autodeterminação - ou "livre determinação" - assegura que aos PIs compete determinar "livremente sua relação com os Estados nos quais vivem, num espírito de coexistência com outros cidadáos", sendo de sua responsabilidade procurar "seu desenvolvimento econômico, social, cultural e espiritual em condiçôes de liberdade e dignidade" (ONU, 2008, $\$ 11$ do preâmbulo e $\$ 1$, da arte 1, dos parágrafos operativos). Assegura, entre outras palavras, a autonomia cultural, a autonomia econômica, a autonomia territorial (autogoverno), a autonomia alimentar, de práticas de saúde e educação, entre outras.

Se, por um lado, são visíveis os avanços no que concerne à declaração formal de direitos humanos aos povos indígenas, por outro, a efetividade ainda é algo pendente. Atualmente, a implementação do direito à terra, por exemplo, tensiona fortemente os limites do exercício dessa autodeterminação e da relação entre Estado e PIs, dando causa a inúmeros conflitos. Nestes, é nítida a apropriação e o uso de narrativas etnocêntrica de desqualificação da cultura indígena, recolocando a questão indígena como um problema de direitos humanos.

Neste capítulo de Políticas Sociais: acompanhamento e análise, serão analisadas as premissas normativas que constituem a relaçáo entre o Estado brasileiro e os povos indígenas, assinalando-se desafios à efetividade dos direitos dos PIs dentro dos limites da ação discricionária estatal.

A seção 2 do texto caracteriza a complexidade de situaçóes dos povos indígenas no Brasil. As seçóes 3 e 4, ainda que distintas, tratam do quadro jurídico que dá realidade e movimenta a discussão sobre os direitos dos PIs. No centro da discussão, estão as ideias e as práticas que caracterizam o Estado democrático de direito, que tem como premissa o dever de respeito ao pluralismo e aos compromissos estabelecidos em tratados internacionais de direitos humanos, grande parte destes internalizados no ordenamento jurídico estatal em vigência. É evidente que os conteúdos das normas internacionais de direitos humanos precisam ser interpretados; entretanto, o mais importante aqui será investigar as obrigaçóes positivas do Estado e sua efetividade. 
Por isso, na seção 5, alguns problemas importantes e complexos como os limites ao exercício da discricionariedade na execução do orçamento indigenista e dos atos administrativos serão apresentados. Ambos devem ser entendidos à luz da constitucionalização do direito financeiro (Travassos, 2014; Furtado, 2010), trazendo ao debate questóes relacionadas à discricionariedade administrativa e aos compromissos com a efetividade dos direitos fundamentais assumidos por um Estado democrático de direito. Nesse sentido, a descrição da fundamentalidade dos direitos reconhecidos aos PIs, ${ }^{3}$ ou destes como parte dos direitos humanos, contextualiza o tratamento a ser atribuído tanto ao orçamento quanto à administração pública sob a luz dos direitos humanos.

Com isso, fixa-se o objetivo deste trabalho, que é apresentar em um viés pluricultural um estudo sobre os limites que sujeitam o exercício da discricionariedade administrativa estatal na gestão da política pública indigenista. Ao delimitar-se a análise sobre as práticas administrativas-financeiras do Estado, sobretudo orçamentária, serão apresentadas consideraçóes acerca do compromisso estatal de trazer efetividades das normas de direitos humanos e dos impedimentos na realização do direito fundamental pela redução ou pelo simples subfinanciamento das políticas indigenistas.

\section{BREVE CARACTERIZAÇÃO DOS POVOS INDÍGENAS NO BRASIL ${ }^{4}$}

Os dados do último Censo Demográfico do Instituto Brasileiro de Geografia e Estatística (IBGE) demonstraram imensa diversidade cultural no território nacional ao descreverem a existência de 305 "etnias" indígenas, falantes de 274 línguas distintas, que, juntas, somavam aproximadamente 820 mil habitantes (IBGE, 2010). Além da identificação censitária dessa pluriculturalidade indígena, em 2018, registraram-se 114 referências - seja de indivíduos ou coletivos - de indígenas isolados, projetando o Brasil como o país com o maior número de PIs em situação de isolamento. ${ }^{5}$

O Estado brasileiro não apenas abriga o maior registro de povos indígenas isolados, como também a maior diversidade na América Latina. Aliás, segundo a Comissão Econômica para a América Latina e o Caribe - CEPAL (Moseley, 2010), nessa última década, registrou-se a existência de 826 PIs na região, dos quais $37 \%$ se localizavam em território brasileiro. Destes, aproximadamente $23 \%$ - ou seja,

3. A delimitação dos direitos fundamentais indígenas requer a mobilização de argumentação hermenêutica no âmbito dos instrumentos dos diretos humanos e das constituições nacionais. Sensível na nossa argumentação de fundamentalidade dos direitos indígenas é sua presença no rol dos direitos sociais constitucionalizados, mas a argumentação deve compreender a tutela dos direitos territoriais dos PIs e de seus recursos naturais, bem como o direito à vida e à sobrevivência como povos. Ademais, a ideia de fundamentalidade implica a implementação de instrumentos institucionais que assegurem os direitos; especialmente, o da identidade cultural em sentido amplo (Faundes, 2019b).

4. Ver Silva e Lunelli (2019).

5. Inseridas em política pública específica de não contato, com os registros submetidos a procedimentos de estudo de campo, estão confirmadas até o momento apenas 28 referências (2019). 
setenta povos indígenas - foram descritos em situação de extrema fragilidade, com população inferior a cem indivíduos. Os riscos de desaparecimento de línguas e culturas, portanto, da riqueza de cada cultura e de sua diversidade, são evidentes.

A respeito das línguas indígenas registradas no Brasil, 190 destas foram classificadas, em 2009, pela UNESCO "em perigo de extermínio", colocando o Brasil como o terceiro país no mundo com o maior número de línguas ameaçadas (Moseley, 2010). Os dados nacionais descreveram, em 2010, que mais da metade da população indígena em território nacional (aproximadamente 57,1\%) já não fala uma língua indígena.

A perda do conhecimento e da prática linguística, seja por falta de utilidade, seja por substituição impositiva pela língua do colonizador, é mais acentuada entre aqueles que não se encontram em terras indígenas (TIs). Segundo o Censo Demográfico 2010 (IBGE, 2010), 37,4\% dos indígenas de 5 anos ou mais falavam no domicílio uma língua indígena; percentual esse que aumenta para 57,3\% quando consideramos somente aqueles que viviam em TIs. Entre aqueles que vivem fora das terras indígenas, o percentual de não falantes de uma língua própria é de $87,3 \%$. Essa característica confirma o importante papel desempenhado pelas TIs no tocante às possibilidades de permanência das características socioculturais e estilos de vida dos indígenas.

A população indígena é composta por $50,41 \%$ de homens e $49,58 \%$ de mulheres (IBGE, 2010). Seguindo o padrão da população não indígena, contabilizam-se mais mulheres nas áreas urbanas e mais homens nas áreas rurais. Com relação à distribuiçãoo espacial da população, $36,2 \%$ da população encontra-se em áreas urbanas e 63,8\%, em áreas rurais. É interessante ressaltar que há PIs que se situam transitoriamente em contexto urbano para acesso às políticas sociais (educação, saúde e trabalho, por exemplo), outros que tiveram suas terras ("aldeias") absorvidas pelo perímetro urbano e há ainda outros que migraram para as cidades, decorrentes do êxodo rural.

Nesse contexto, a persistência de estereótipos a respeito dos povos indígenas, que os associam à vida em florestas densas, tende a deslegitimar o espaço urbano como espaço a ser ocupado pelos PIs. Por vezes, ao se depararem com a prática por esses povos de novos padrôes culturais, sobretudo relacionados ao uso de tecnologia por exemplo, a utilização de telefones celulares -, a população "não indígena" retoma velhos preceitos integracionistas, ${ }^{6}$ gerando discriminaçóes a respeito da autodeclaração identitária e da capacidade de autodeterminação cultural.

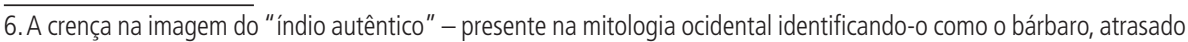
no uso de tecnologias, habitante nu das florestas - traduz-se na prática em ações de restrição de direitos especiais. Desconhecendo-se as particularidades de cada cultura indígena e enxergando-se apenas aquilo que se identifica, ainda se observam discursos medindo a ocidentalização do indígena - classificando-os em graus de integração à sociedade nacional. Esse fato se deve também ao então vigente Estatuto do Índio, publicado em 1973, que prevê os graus de indianidade (Silva e Lunelli, 2019). 
Em suas comunidades, como consequência dessa ampliação do reconhecimento do direito à autodeterminação e à terra, centenas de povos indígenas vivem momentos de recuperaçáo de seus contingentes populacionais, sendo que a população indígena cresce a taxas de $10 \%$ ao ano, ao mesmo tempo que ocorrem movimentos de recuperação identitária. Esse crescimento gera importantes desafios paras as diferentes políticas públicas. As demandas de cuidados de saúde, educação e segurança alimentar são crescentes, pressionando orçamentos e recursos institucionais. Os PIs estâo presentes na totalidade das instituiçôes de políticas sociais, participando das políticas públicas ambientais, de produção, de educação básica, de saúde, de assistência, de ciência e tecnologia, entre outras.

Ainda assim, segundo dados publicados pela Secretaria de Vigilância em Saúde, do Ministério da Saúde (SVS/MS), o suicídio entre indígenas representa a quinta causa de morte em menores de 20 anos e a terceira causa na fase adulta (Brasil, 2017). Os indígenas também apresentam os maiores coeficientes de detecção de casos novos de leishmaniose tegumentar, as maiores taxas de incidência e mortalidade por tuberculose, sendo ainda o único grupo racial classificado como de alto risco para contrair malária, conforme a taxa de incidência parasitária anual (IPA) dessa doença.

Além disso, são observadas elevadas taxas de detecção de sífilis em gestantes, de hepatite A e B, e de internação por doenças respiratórias em crianças menores de 5 anos e na população idosa, correlacionando a maior proporção de casos de intoxicação por agrotóxicos entre os homens, bem como as maiores taxas de prevalência de usuários de tabaco e de incidência de violência relacionada ao trabalho. Muitos desses dados se explicam pela vulnerabilidade socioeconômica a que estáo expostos. "No Brasil, quatro em cada dez indígenas (39,9\%) encontram-se em situação de extrema pobreza” (Brasil, 2017, p. 9).

Sabe-se que reside, pelo menos, um indígena autodeclarado em $80,5 \%$ dos municípios brasileiros, embora tais indígenas autodeclarados apresentem índice pouco expressivo na composição da população nacional $(0,43 \%)$, sendo que os dez municípios com as maiores proporções de população autodeclarada indígena reúnem $15,5 \%$ da população indígena do país (126,2 mil indígenas). ${ }^{7}$

Aliás, os PIs enfrentam problemas crônicos relacionados à invasão de seus territórios, degradação territorial e ambiental, exploração sexual, exploração do trabalho, mendicância, além de todas as mazelas decorrentes de problemas de saúde associadas à pobreza, forçando-os às migraçôes internas em busca de melhores

7. Conforme o Censo Demográfico 2010 (IBGE, 2010), são estes: São Gabriel da Cachoeira (95,5\%, 18.001 indígenas); Uiramutã (93,0\%, 6.734 indígenas); Pacaraima (91,7\%, 5.430 indígenas); Baía da Traição (89,1\%, 43.838 indígenas); Tabatinga (88,2\%, 14.036 indígenas); Marcação (84,2\%, 4.008 indígenas); São João das Missões (81,2\%, 7.528 indígenas); Campinápolis (80,0\%, 7.589 indígenas); Santa Rosa do Purus (78,7\%, 2.204 indígenas); e Oiapoque (77,2\%, 5.137 indígenas). Desses municípios, seis se encontram na região Norte (São Gabriel da Cachoeira-AM, Uiramutã-RR, Pacaraima-RR, Tabatinga-AM, Santa Rosa do Purus-AC e Oiapoque-AP), dois, na região Nordeste (Baía da Tradição-PB e Marcação-PB), um, na região Sudeste (São João das Missões-MG) e um, na região Centro-Oeste (Campinópolis-MT). 
condiçōes de vida nas cidades, em geral em condições precárias. Tal situação exige diferentes formas de implementação da ação pública que se adequem às múltiplas realidades e que considerem os modos de vida e as culturas locais.

\section{A IDEIA DE ESTADO DE DIREITO E A POLÍTICA INDIGENISTA NO BRASIL}

\subsection{Novas diretrizes interculturais sobre a atuação estatal: o direito à autodeterminação}

Os elementos que unem todas as questóes relacionadas aos 305 povos indígenas são, sobretudo, a autonomia, a autodeterminação, a participação social na definição das políticas e a questão fundiária, uma vez que a regularização e a gestão do território são estruturantes para a manutenção das condiçôes de existência e sobrevivência dos modos de vida e saberes coletivos. Todo esse conjunto de questôes pode ser agrupado na fundamentalidade dos diretos dos PIs, expressos em tratados internacionais e na CF/1988.

Ainda que a utilização do termo povos indígenas seja argumentar de maneira a unificá-los em uma aparente categoria genérica, a realidade de cada um destes é singular e heterogênea. A esse respeito, deve-se dizer que as práticas administrativas do Estado ensejam o reconhecimento da complexidade das situaçóes e, sobretudo, da autonomia de cada uma destas.

Necessário sempre enfatizar que, tomado como uma categoria supraétnica, o "índio" não se relaciona com nenhum conteúdo específico ou situação histórica dos diversos grupos que são designados por essa categoria. "Não existe nenhum povo, tribo ou clã com a denominação de índio" (Baniwa, 2006, p. 30). Ao se generalizar uma concepção para os PIs, destituindo-os de suas particularidades étnicas e culturais, o "índio genérico" (Ribeiro, 1970) é muitas vezes projetado como um modelo idealizado de índio, tornando-o "mais real que o real". Essa situação do índio imaginado, distanciado do "índio de carne e osso", do "dia a dia", das suas necessidades básicas locais e das suas concepçôes de mundo específicas, constrói o que se denominou de "índio hiper-real" (Ramos, 1995, p. 11-13).

O aproveitamento da imagem idealizada do "índio", do "índio hiper-real", apropriada corriqueiramente para fundamentar as políticas públicas indigenistas, contraria o reconhecimento da existência da diversidade cultural declarada no ordenamento jurídico interno e nas normas internacionais. Também tende a legitimar a participação política somente daqueles tidos como pacificados, obedientes em aceitar as imposiçóes estatais - ao mesmo tempo que deslegitima a oposição e a resistência.

Ao fixarem construções estereotipadas e estigmatizadas de "índio-modelo", dando causa a generalizaçóes, naturalizaçóes e discriminaçóes, transparece-se uma 
visão de mundo limitada e racista que não apenas contradiz os juízos jurídicos e científicos atuais acerca do respeito à diversidade cultural (pluriculturalidade e interculturalidade), ${ }^{8}$ como também representa um dos obstáculos à efetividade dos direitos humanos dos povos indígenas. Diante disso, qualquer debate sobre a efetividade dos direitos humanos dos PIs perpassa, prementemente, a superação dessa categoria totalizante e reducionista.

Embora os dados e as informaçôes reunidas acerca dos povos indígenas em território nacional possibilitem uma caracterização da complexidade de situaçóes que experimentam esses grupos, é fundamental que se considere a determinação de cada povo para a formulação, o planejamento e a execução das práticas administrativas e legislativas estatais. A constituição dos PIs em sujeitos políticos, como resultado de processos históricos e sociais de consciência de sua identidade, emancipando-os das práticas administrativas tutelares, desautoriza o Estado a pensar, propor ou executar medidas projetas a atender o "índio hiper-real".

À vista disso, o direito à autodeterminação ${ }^{9}$ de cada povo indígena é considerado o elemento reestruturante das relaçóes desses povos com o Estado. Isso porque esse direito conduz à centralidade do debate o exercício direto do poder político por esses sujeitos coletivos. Ou seja, traz à tona a correlação entre participação, protagonismo e democracia com o respeito da vontade desses sujeitos políticos coletivos, que devem ser considerados "mesmo quando tomam decisóes que contrariam o senso comum do politicamente correto" (Entrevista..., 2012, p. 134). Das garantias às muitas formas de autodeterminação indígena, derivam outros direitos intrínsecos à reconfiguração da cidadania desses povos, tais como o direito à participação, à consulta prévia e informada, à autonomia, à gestáo territorial e ambiental etc.

Nesse sentido, a autodeterminação vem a caracterizar-se como dever fixado ao Estado, diante do compromisso de respeitar e proteger seus valores e suas práticas sociais, culturais, religiosas e espirituais. Para tanto, tem o dever de considerar a participação ativa dos povos indígenas a serem afetados. Somente viabilizando que cada povo vocalize suas necessidades, externalizando suas perspectivas sobre seu próprio desenvolvimento econômico, social e cultural e planejando os rumos para sua continuidade existencial comunitária, é que efetivamente avançamos no conhecimento sobre a caracterização dos PIs no Brasil.

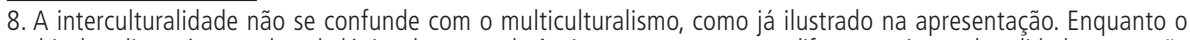
multiculturalismo é marcado pela lógica da mera tolerância com o outro, com o diferente, a interculturalidade pressupõe a inter-relação entre culturas distintas. É interessante destacar que, nas políticas multiculturais, a constatação da diferença não importou na anulação da superioridade nas relações, que insistia em caracterizar a hegemonia de uma cultura em detrimento de outra. Por sua vez, nas políticas interculturais, a centralidade de sua prática pressupõe a igualdade na relação dialógica e afasta-se das ações impositivas ou coordenadas por um dos atores envolvidos.

9. 0 emprego do termo autodeterminação encontra sinônimo na expressão "livre determinação" e não se confunde com o princípio constitucional nas relações internacionais de autodeterminação dos povos. 


\subsection{A legalidade e a discricionariedade como determinantes sobre a ação estatal}

Viver sob um Estado de direito implica a limitação do abuso do poder e a proteção dos indivíduos contra arbitrariedades dos governantes. Nem mesmo em momentos de crises, encontra a administração pública justificativa para ausentar-se do descumprimento da lei e da inobservância de princípios e valores, "porque isto significaria acabar com o Estado de Direito" (Di Pietro, 2012b). Viver sob o direito significa aceitar o contexto normativo, seja pelos seus princípios, seja por suas regras, seja por suas normas de políticas públicas.

A ação pública constitui-se e justifica-se sob a ordem de um Estado de direito corporificado no texto constitucional. As atividades sociais são enlaçadas e determinadas por normas e regras do direito. O Estado social acrescenta aspectos importantes ao tema. Além das condicionantes legais, o Estado deve garantir direitos, por intermédio de políticas ativas - isto é, políticas sociais prestacionais - como saúde, educação, moradia, assistência etc., fixando condições para o exercício das liberdades. As necessidades próprias da ação da administração pública recolocam questôes a respeito da organização legal da ação, em especial por meio dos orçamentos públicos e da administraçáo. O protagonismo da administração desloca os sentidos do complexo problema da discricionariedade (Canotilho, 1999, p. 4).

O tema da discricionariedade é importante para o argumento que será desenvolvido, razão pela qual justifica a atenção para alguns dos seus aspectos. No primeiro momento histórico, a ação pública discricionária somente seria legítima se estivesse identificada com os estritos critérios formais estabelecidos nas normas positivadas; posteriormente, princípios e valores são agregados na análise do mérito dos atos administrativos por esta gerados. Princípios como o interesse público, a moralidade, a razoabilidade, a impessoalidade, a motivaçáo, a publicidade e a eficiência, além da legalidade, da justiça, da igualdade, do bem-estar, da ausência de preconceitos sobre a origem, a raça, o gênero, a cor e a idade. Os critérios de oportunidade e conveniência passaram, pouco a pouco, a fundamentar os limites do exercício discricionário das autoridades estatais (Di Pietro, 2007; Brasil, 1988, art. $1 \mathrm{c} / \mathrm{c}$ art. 3 , inciso IV, art. 5 e art. 37 , caput). ${ }^{10}$

Como se vê, a discricionariedade desloca-se da concepção do inteiro cumprimento da legalidade, para outra na qual a ação pública se movimenta no contexto de normas de conteúdos semânticos abertos, passíveis de interpretação à luz de

10. Conforme Maria Sylvia Zanella Di Pietro (2007, p. 2), existe discricionariedade quando a lei deixa à administração a possibilidade de, no caso concreto, escolher entre duas ou mais alternativas, todas válidas perante o direito. E essa escolha se faz segundo critério de oportunidade, conveniência, justiça, equidade, razoabilidade, interesse público, sintetizados no que se convencionou chamar de mérito do ato administrativo. Disso, decorrem os dados fundamentais para definir a discricionariedade: i) isso envolve a possibilidade de opção entre duas ou mais alternativas; ii) essas alternativas decorrem de lei; iii) por isso, qualquer uma das alternativas que a autoridade escolha é juridicamente válida; e iv) a escolha faz-se diante do caso concreto, com base em critérios de mérito. 
princípios e valores que preveem objetivos de políticas. Nesse sentido, Courtis (2009; 2010) diferencia obrigaçôes positivas e negativas do Estado:

obrigaçóes negativas: náo introduzir distinçôes normativas, ou náo adotar ou implementar as normas, de modo a renunciar aos direitos de grupos de pessoas identificadas por meio desses fatores. (...) obrigaçóes positivas: adotar medidas para eliminar obstáculos que impeçam esses grupos de pessoas de desfrutar plenamente de seus direitos (Courtis, 2010, p. 106-107, tradução nossa). ${ }^{11}$

Em outras palavras, o Estado responde sobre possíveis excessos e arbitrariedades não apenas na ação, mas também na organização do seu próprio dever de agir para garantir direitos. Responder à legalidade e oferecer soluçóes no que concerne aos objetivos a que se propóe ao agir são atividades que implicam tanto contenção quanto constituição da ação estatal pelo direito. Por exemplo, a administração pública quando se envolve nas questóes de garantia dos direitos fundamentais indígenas deve não somente agir em conformidade com a legalidade, como também deve responder aos objetivos de políticas públicas no atingimento de finalidades (aumento da cobertura vacinal, redução da mortalidade infantil e materna, proteção de terras, gestão de territórios, respeito à cultura e modos de vida etc.). Por isso, no caso em questáo, ao se debruçar sobre os direitos e as políticas públicas direcionadas aos PIs, torna-se inescusável aprofundar o debate sobre as premissas normativas que traçam os limites à discricionariedade na gestão da política indigenista, como atividade administrativa do Estado qualificada a atribuir efetividade aos direitos declarados. Diante disso, alguns desafios se colocam à ação governamental.

Para os fins deste trabalho, a política indigenista é entendida como um conjunto de programas de açôes governamentais que, ao coordenar atores diversos e formas jurídicas distintas, vincula-as à realização de objetivos sociais pertinentes; nesse caso, conferir efetividade aos direitos dos povos indígenas. A política indigenista pode ser conceituada também como o conjunto das manifestaçóes discursivas e práticas do Estado sobre os PIs com os quais se relaciona, aduzindo a maneira com que o Estado define as noçóes de diversidade cultural e materializa o respeito e a valorização dos povos, dos conhecimentos e das culturas indígenas. A política indigenista passa a ser compreendida como o conjunto das práticas de ação estatal que, direcionadas aos povos indígenas, regulam funçóes e limitam os poderes e a autoridade governamental.

No cenário internacional, as discussões acerca das diretrizes da política indigenista alcançaram maior adesão e prevalência na América a partir da realização do I Congresso Indigenista Interamericano - em 1940, no México, quando se fixaram

11. No original: "obligaciones negativas: no introducir distinciones normativas, o no adoptar o implementar las normas, de modo de menoscabar los derechos de grupos de personas identificados a través de esos factores. [...], obligaciones positivas: adoptar medidas para eliminar los prejuicios y los obstáculos que impidem a esos grupos de personas disfrutar plenamente de sus derechos" (Courtis, 2010, p. 106-107). 
pela primeira vez princípios orientadores à política indigenista no continente. Ao traçar diretrizes e metas aos Estados para lidar com o "problema indígena", em tentativa de conciliar os anseios políticos, econômicos, sociais e científicos, esses princípios passaram a orientar a ação estatal produzindo consequências multilaterais, tais como acordos e tratados internacionais capazes de vinculá-los globalmente ao enfrentamento dos desafios que lhes eram sinalizados. Em ação coordenada, conjunta e compromissada, foi dessa forma que os princípios orientadores da política indigenista conduziram a política indigenista estatal, no contexto latino-americano, de um estágio de indigenismo integracionista - ou um nacionalismo integracionista para um de indigenismo interacionista - sob o paradigma da interculturalidade.

Com efeito, até o final da década de 1980, a premissa que definia a política indigenista oficial brasileira interna era a integração do índio à sociedade nacional. Como introduzido neste texto, a partir da CF/1988 é que o paradigma integracionista cede lugar ao interacionismo, superando-se a ideia de que os indígenas seriam vítimas de estágios de aculturação. Atualmente, ou eles são indígenas porque assim se reconhecem e são reconhecidos por algum povo, ou não são; não existindo, portanto, o índio em "vias de integração" ou o "meio índio". Não se é condizente com os princípios consagrados em instrumentos internacionais de direitos humanos dos PIs usar conceitos inadequados ou amparados em teorias ultrapassadas, como integração, a não ser que seja para referenciar um passado que se modifica a partir das novas orientaçóes ditadas à política indigenista, sob pena de incorrer em práticas discriminatórias.

Ao longo dessas últimas décadas, a atuação do governo federal no enfrentamento da questão também se transformou, pautando a gestão das políticas públicas indigenistas na coordenação entre diferentes órgãos em variados níveis federativos. A Funai, criada em 1967, é ainda a principal instituição gestora das políticas indigenistas, embora tenha sofrido mudanças e reformas nos últimos anos que reestruturaram sua atuação e retiraram do seu monopólio a gestão destas.

Ao promover ações transversais entre órgãos, organizaçôes não governamentais e indígenas, dados e informações avançaram na caracterização desse específico grupo sujeito a inúmeras formas de vulnerabilidade e de necessidades e limites operantes sobre a ação do Estado. Nessa reconfiguração da atuação estatal, cabe recordar a realização da I Conferência Nacional de Política Indigenista, que, durante 2015, promoveu um espaço de diálogo entre a administração pública e os PIs, restabelecendo novas formas de orientação ainda pendentes de aplicabilidade. $\mathrm{Na}$ atuaçáo conjunta para a redefinição das práticas administrativas que conduziriam a política indigenista, propostas foram apresentadas e diretrizes, fixadas.

Além do documento final da conferência, a instituição do Conselho Nacional de Políticas Indígenas (CNPI) representou um relevante instrumento na articulação 
de políticas públicas voltadas aos PIs, envolvendo órgãos do governo federal e representantes indígenas de todas as regióes do país. A exemplo de açóes interministeriais, elaboradas em atuação conjunta com o Ministério do Meio Ambiente (MMA), tem-se a Política Nacional de Gestão Territorial e Ambiental de Terras Indígenas (PNGATI).

Em suas diversas análises, a atuação do Estado traz claros indicativos da necessidade de ampliação das capacidades institucionais do órgão indigenista, além da compreensão dos atores governamentais acerca das implicaçóes trazidas com a ideia de interculturalidade, da superação do racismo institucional e da consideração de decisóes e especificidades de cada povo na tomada de decisóes que os afetem. A materialização de garantias que promovam condições de reprodução física e cultural de PIs é constantemente desafiada a manter e até mesmo ampliar as capacidades de implementar e coordenar diferentes açóes, sobretudo por meio de políticas de proteção territorial, como a regularização, a fiscalização e o monitoramento, combatendo os usos ilícitos de recursos ambientais, invasóes e violência em TIs - não se exaurindo aqui as proposiçóes possíveis.

\section{DETERMINAÇÕES SOBRE A POLÍTICA INDIGENISTA DIANTE DOS COMPROMISSOS INTERNACIONAIS EM MATÉRIA DE DIREITOS HUMANOS DOS POVOS INDÍGENAS}

Os instrumentos normativos nacionais e internacionais declaram compromissos e direitos, dando forma às atividades administrativas e constituindo as políticas públicas. Estas se caracterizam por extensa rede normativa e pela definição de objetivos respaldados nos direitos humanos fundamentais. Antes de avançar nos limites fixados para o exercício discricionário da atividade administrativa estatal na gestão das políticas indigenistas, cabe relembrar algumas questóes relevantes à sua análise.

A primeira questão refere-se à gradual positivação de direitos reconhecidos aos PIs que acabaram por limitar os excessos do poder estatal - não significando a obliteração das necessidades de certa flexibilidade ou discricionariedade na implementação e na realização dos direitos, nem o retrocesso na garantia de direitos. ${ }^{12}$

Nesse cenário, em que as competências de fiscalização e controle da atividade estatal pelos poderes Legislativo e Judiciário (controle jurisdicional), pelo Ministério Público (MP) e, inclusive, pelo Sistema Interamericano de Direitos Humanos foram expandidas diante da ampliação dos direitos declarados, no mesmo movimento, foram legitimados e autorizados por lei maior número de atores a demandarem fiscalização

12. Como veremos a seguir, a administração pública conserva certa discricionariedade na atividade financeira e criatividade no que se refere aos instrumentos como o Plano Plurianual (PPA), embora, depois de definidos os programas, as ações, os objetivos e as metas, deva a estes ser responsiva. 
e controle. Com isso, o número de atores na arena política multiplicou-se, e os povos indígenas passaram a protagonizar açóes e demandas com apoio na $\mathrm{CF} / 1988$, que criou instrumentos e legitimou acesso ao controle jurisdicional na busca de efetivação de seus direitos. Essa característica de judicialização dos direitos declarados aos PIs, sobretudo dos direitos humanos, trouxe em si a oportunidade de realização de controle jurisdicional a pedido de todo cidadão - individual ou coletivo, como são os povos indígenas - diante da omissão administrativa ou da ação inoportuna e inconveniente na realização de políticas públicas direcionadas à proteção desses direitos.

A segunda consideração é que, à medida que o poder atribuído às autoridades estatais é constantemente (re)legitimado, o rol de sujeitos políticos é dilatado e o controle externo, intensificado, cabe à administração pública transformar-se, a fim de atribuir materialidade às obrigaçóes positivas assumidas. Com isso, não apenas o cumprimento de políticas estabelecidas pela própria administraçáo passa a ser devido, como também certas obrigaçóes na execução de determinada prestação de serviços e uso de bens público tornam-se exigíveis.

Sob essas circunstâncias, é dever da ação pública, quanto ao aspecto legal dos atos estatais, apreciar o caso concreto conforme critérios de oportunidade e conveniência e eleger uma solução válida perante o direito (Di Pietro, 2016). No entanto, sempre que a autoridade administrativa venha a formular juízos de legalidade, interpretando ou aplicando o direito (aspecto do mérito, político), esses atos restam passíveis de controle, especialmente jurisdicional. ${ }^{13}$ Sem desconsiderar o delineamento das competências próprias do Poder Judiciário - sob pena de incorrer em interferência no Poder Executivo -, a revisão do ato administrativo torna-se devida, cabendo-lhe o exame e a ponderação sobre a motivação e os fins da ação pública. ${ }^{14}$

Por último, é pertinente considerar os limites ao exercício do poder estatal fixados na relação estabelecida entre a constitucionalizaçáo dos direitos humanos e a construção de um consenso "global" sobre o respeito a esses direitos a partir do pós-guerra. Nessas circunstâncias, a concomitante construção de aparato de regulação de açôes da administração pública e de "limitação" desta a partir da institucionalidade, vinculada ao reconhecimento de um estatuto "universal" dos direitos humanos, constituiu um parâmetro, ao incorporar os regulamentos jurídicos internos e um limite ao exercício do poder nos Estados nacionais.

13. Recurso em Mandado de Segurança (RMS) no 24.699/DF.

14. Di Pietro (2012a, p. 40-41) cita duas teorias da escola francesa sobre o controle jurisdicional da discricionariedade, que viabilizaram aplicação normativa pelos atores. A primeira possibilitou ao Poder Judiciário "o exame da finalidade objetivada pela Administração Pública com a prática do ato administrativo, para verificar se a autoridade que o praticou não usou de sua competência legal para atingir fins diversos dos que decorrem da lei". A segunda, por sua vez, "permitiu ao Judiciário examinar a legalidade dos motivos (pressupostos de fato e de direito) que levaram a Administração a praticar 0 ato". 
Ante esse cenário, os direitos humanos representam atualmente uma agenda de compromissos públicos que, ao fixar deveres e responsabilidades aos governantes e às autoridades estatais, objetiva não apenas a promoção, a proteção e a defesa desses direitos, como também o avanço nas garantias estabelecidas para sua efetividade. Em outras palavras, isso quer dizer que as açóes públicas, independentemente da linha governamental adotada, restam subordinadas à forma e ao mérito, no que diz respeito às normas internas e internacionais de direitos humanos, devendo atuar em prol da consolidação e da ampliação das políticas que visem fortalecê-los em sua territorialidade.

Recorda-se que os compromissos assumidos com as convençôes, os tratados e os pactos internacionais de direitos humanos - que se encontram ratificados e em vigência em um Estado democrático de direito - são irrenunciáveis nessa forma de Estado, sob pena de sançôes previstas em diplomas internacionais. Ao configurarem-se imperativos de conduta sobre o exercício do poder estatal, gerando inclusive obrigaçóes positivas ao Estado em trazer efetividade a estes, a transgressão desses compromissos pode vir a ensejar a neutralização das açóes públicas que venham a ser caracterizadas como opressoras, abusivas ou discriminatórias.

É relevante que se consigne que, ao considerarmos os direitos humanos reconhecidos e declarados aos PIs, se irrompe com um debate acerca da arquitetura jurídica que condiciona a ação pública. Isto é, a estrutura normativa que institui os limites à discricionariedade da atividade administrativa estatal sobre a formulação e a implementação da política indigenista. Em decorrência desse amplo rol de compromissos e deveres assumidos pelo Estado brasileiro, a partir do conteúdo dessas normas de direitos humanos, geram-se obrigaçóes positivas ao Estado. Estas podem vir, inclusive, a limitar o exercício discricionário da atividade administrativa na alocação e na execução do orçamento, uma vez que é a atividade financeira que atribuirá materialidade aos direitos.

Sem adentrar nas especificidades dos deveres jurídicos, éticos e políticos que elucidam cada instrumento normativo de direitos humanos ou esgotar a lista possível de normas vigentes, o quadro 1 arrola os principais instrumentos que regulam os compromissos internacionais assumidos e relacionados à matéria. 
QUADRO 1

Legislação indigenista internacional vigente sob o Estado brasileiro

Normais internacionais de direitos dos povos indígenas

- Declaração Internacional de Direitos Humanos - adotada e proclamada em 1948 pela Assembleia Geral da

Organização das Nações Unidas (ONU), por meio da Resolução n 217 A, III (ONU, 1948).

- Convenção para a Prevenção e Repressão do Crime de Genocídio (1952).

- Convenção Relativa à Luta contra a Discriminação no Campo do Ensino - adotada em 1960 pela UNESCO.

- Convenção nำ 104 da OIT, sobre abolição penal de trabalhadores indígenas (Decreto ํㅡ 58.821, de 14 de julho de 1966).

- Convenção Internacional sobre a Eliminação de Todas as Formas de Discriminação Racial (Decreto ㄲo 65.810, de

8 de dezembro de 1969).

- Pacto Internacional de Direitos Civis e Políticos - ONU (Decreto no 592, de 6 de julho 1992).

- Pacto Internacional de Direitos Econômicos, Sociais e Culturais - ONU (Decreto no 591, de 6 de julho de 1992).

- Convenção Americana sobre Direitos Humanos - Organização dos Estados Americanos (OEA), Pacto de São José da Costa Rica (Decreto ํo 678, de 6 de novembro de 1992).

- Declaração sobre os Direitos das Pessoas Pertencentes a Minorias Nacionais ou Étnicas Religiosas e Linguísticas aprovada em 1992 pela Assembleia Geral da ONU.

- Princípios Orientadores Relativos aos Deslocados Internos - ONU, 1998.

- Declaração Universal sobre a Diversidade Cultural - UNESCO, 2002.

- Convenção no 169 da OIT sobre Povos Indígenas e Tribais (Decreto no 5.051, de 19 de abril de 2004).

- Princípios para a Restituição da Moradia e da Propriedade dos Refugiados e dos Deslocados.

Internos (Princípios de Pinheiro) - ONU, 2005.

- Convenção para a Salvaguarda do Patrimônio Cultural Imaterial (2006).

- Declaração das Nações Unidas sobre os Direitos dos Povos Indígenas (13 de setembro de 2007).

- Convenção da UNESCO sobre a Proteção e Promoção da Diversidade das Expressões Culturais (2005 - Promulgada no Brasil por meio do Decreto no 6.177, de 1ํde agosto de 2007).

- Convenção Relativa à Proteção das Crianças e à Cooperação em Matéria de Adoção Internacional (Resolução no 12 da Secretaria Especial dos Direitos Humanos - SEDH, de 9 de abril de 2008).

- Convenção Interamericana contra o Racismo, a Discriminação Racial e Formas Conexas de Intolerância (2013).

- Declaração Americana sobre os Direitos dos Povos Indígenas (2016).

Elaboração dos autores.

Não se pode negar que diferentes controvérsias envolvem a aplicação desses instrumentos, tal como as condiçóes de recepçáo dos tratados internacionais no ordenamento jurídico interno. Da mesma forma, não se pode omitir os avanços nesses últimos trinta anos no ambiente interno da positivação de programas e políticas de direitos humanos, mesmo sem se ter dado efetividade a todos os direitos e garantias salvaguardadas aos PIs em seus textos normativos - o exemplo, pela centralidade do tema, é a demarcação de terras tradicionais indígenas.

Em comum, esses instrumentos internacionais de direitos humanos dos povos indígenas subordinam a ação pública indigenista, uma vez tomada como atividade administrativa do Estado qualificada a atribuir efetividade aos direitos declarados a esses grupos específicos. Consagrado em diversos desses instrumentos normativos mencionados anteriormente, esses deveres que sujeitam a ação estatal se fundamentam no reconhecimento, na declaração, no respeito e nas garantias 
ao livre exercício do direito à autodeterminação dos PIs e seus desdobramentos, como o direito à consulta livre, prévia e informada e o direito à autonomia.

Esses instrumentos, embora não esgotem as normativas internacionais ratificadas, trazem à tona a conquista do dever estatal de considerar as prioridades e as estratégias no exercício dos modos de vida dos PIs e suas capacidades de controlar seus próprios processos de desenvolvimento - ou seja, as dimensóes política, econômica, social e cultural. Posto isso, é dever do Estado consultá-los sobre suas prioridades de desenvolvimento e conhecer formas autonômicas indígenas de gestão de assuntos internos e locais.

Nesse "novo" contexto constitucional, é dever do governo brasileiro consultar de boa-fé os "povos interessados, mediante procedimentos apropriados e, particularmente, através de suas instituiçóes representativas", buscando um consentimento acerca das medidas propostas (OIT, 1989, art. 6, \$1, “a”, art. 6, §2).

Como consequência, a participação dos povos indígenas na formulação, na aplicação e na avaliação de planos e programas de desenvolvimento nacional e regional que os afetem deve ser respeitada e viabilizada. Metas como melhoria das condiçôes de vida e de trabalho, do nível de saúde e educação, saneamento, seguridade social, habitação e moradia, emprego, capacitação e aperfeiçoamento profissional, bem como a proteção e a preservação do meio ambiente dos territórios habitados pelos PIs, devem ser prioritárias nos planos de desenvolvimento econômico das regiôes onde estes moram.

Como explicitado nesses documentos, os povos indígenas têm direitos a participar ativamente na elaboração, na determinação e na execução de leis, políticas públicas, programas, planos e açóes que os sirvam e/ou que guardem relação com os assuntos indígenas - a lei fala em afetação direta dos PIs. Ainda que as medidas legislativas e administrativas no tocante ao orçamento público tenham caráter de alcance geral, é inquestionável a repercussão direta sobre as comunidades indígenas que dependem de obrigaçóes positivas do Estado para o enfrentamento de situaçóes de vulnerabilidade extrema a que estấo sujeitas.

Além da consulta, o direito ao autogoverno (autonomia indígena) tem sido considerado jurisprudencialmente como manifestação concreta do direito de autodeterminaçáo dos PIs, indispensável à democracia e vinculado ao seu direito de participação política efetiva. No entanto, a materialização desse direito resta condicionada à presença de recursos necessários para seu desempenho - levando-se em consideração as características populacionais específicas de cada comunidade/ aldeia e suas próprias necessidades. Assim, além da obrigação governamental de 
estabelecer meios para o pleno desenvolvimento das instituições representativas e das iniciativas dos povos interessados, cabe ao Estado, "nos casos apropriados, fornecer os recursos necessários para esse fim" (OIT, 1989, art. 6, \$1, “c"). ${ }^{15}$

É nesse sentido que, ao se apontar os desafios à efetividade dos direitos humanos dos povos indígenas que recaem à nova gestão governamental, traçamos implicações neste estudo aos próprios limites impostos à atividade financeira na gestáo das políticas públicas indigenistas. Se, por um lado, a discricionariedade administrativa sobre a atividade financeira não pode diminuir o orçamento a ponto de inviabilizar que o Estado atue honrando com suas obrigaçóes positivas (princípio do não retrocesso), por outro, o reconhecimento dessa capacidade de autodeterminação dos PIs vem redefinir fundamentos jurídicos que reorientam as práticas administrativas estatais e fixam o compromisso estatal a partir de obrigações negativas. Assim, as medidas legislativas e administrativas orçamentárias devem alinhar-se a esse conjunto normativo que guarda intensa relação com os povos indígenas.

Por fim, como determinam esses dispositivos internacionais mencionados, igualmente nas regras de monitoramento e avaliação dos resultados, os governos devem zelar para que sejam efetuados estudos com os povos interessados "com o objetivo de se avaliar a incidência social, espiritual e cultural e sobre o meio ambiente que as atividades de desenvolvimento, previstas, possam ter sobre esses povos" (OIT, 1989, art. 7). Esses estudos ainda não existem sobre a questão orçamentária, mas, quando existirem, não restam dúvidas de que deverão ser considerados como critérios fundamentais para a execução das atividades mencionadas e o aperfeiçoamento dos instrumentos de política pública em análise.

Ao acompanharmos os gastos para com o atendimento de necessidades humanas dos PIs que dependem da ação pública, ou melhor, de ação pública positiva, passamos a averiguar o lugar do orçamento na política indigenista e sua capacidade de influenciar o alcance dos objetivos sociais, políticos, econômicos e, sobretudo, culturais assumidos.

\section{LUGAR DO ORÇAMENTO NA POLÍTICA INDIGENISTA}

O orçamento é um dos instrumentos mais centrais nas políticas públicas e pode ser compreendido desde diversas perspectivas. O orçamento é capaz de mobilizar tanto ideias republicanas quanto democráticas. Ideias republicanas, por mais

15. A partir de exemplos de decisões de outros países, como o México, determinações judiciais têm compreendido esse fornecimento de recursos como transferência orçamentária para a execução de suas próprias políticas públicas. Fazemos referências específicas à Comunidade Indígena de San Francisco de Cherán, por meio do expediente SUP-JDC no 9.167/2011 (Sala Superior del Tribunal Electoral del Poder Judicial de la Federación), à Agencia municipal de Zapotitlán del Río, por intermédio do expediente JDC/69/2017 (Pleno del Tribunal Electoral del Estado de Oaxaca), e à Comunidade de San Francisco Pichátaro, mediante o expediente SUP-JDC no 1.865/2015 (Sala Superior del Tribunal Electoral del Poder Judicial de la Federación). 
complexas que sejam, implicam, dizendo de forma simplificada, o governo para todos, sem exclusōes. A democracia significa o processo deliberativo que deve ser acessível a todos em suas diferentes formas de participaçáo - ou seja, governo de todos. O orçamento deve responder a projetos societários globais, espelhando prioridades definidas pelo Executivo e Legislativo no contexto constitucional e de todo o arcabouço da legalidade. Deve seguir padróes de racionalidade, planejamento e garantias de direitos, além de todos os outros princípios orientadores da administração pública - como moralidade, publicidade etc.

Quando descrito como atividade financeira, o orçamento é meio capaz de explicitar as decisóes alocativas dos recursos financeiros no Orçamento Geral da União (OGU), dando materialidade às orientações normativas preestabelecidas. Enquanto atividade administrativa, como meio de alcançar os fins e objetivos do Estado e do governo, trata-se de ferramenta tecnopolítica complexa e, à medida que exerce seu comando financeiro, relaciona os poderes em interdependências complexas e contraditórias que se conectam entre si, em distintas temporalidades.

O orçamento também tem a atribuição de facilitar a implementação e potencializar as capacidades de realização dos direitos humanos - sejam econômicos, sociais, políticos ou culturais -, sendo que a atenção ao direito e a todos os seus instrumentos constitucionais, administrativistas e financeiros é vital para a realização de políticas. Em outras palavras, a compra de produtos e a contratação de pessoal para a prestação dos serviços públicos previstos em lei, as subvençóes econômicas e sociais necessárias para o alcance do interesse público, enfim, todas as açóes estatais que se mobilizam para a satisfação das necessidades públicas dependem de planejamento que se corporifica no orçamento. Nesse contexto, o orçamento direciona o alcance dos objetivos do Estado sob a regência de governos diversos, e a atividade financeira envolve a efetividade dos direitos fundamentais. ${ }^{16}$

Entretanto, em muitas situaçóes, especialmente no que se refere às finanças e ao orçamento público, os instrumentos jurídicos não se orientam para a consecução de finalidades, mas para a ativação de controles procedimentais e burocráticos. Os métodos e as formas de estruturação do orçamento, os processos de delimitação das estratégias de governo e suas relaçóes com o orçamento são variáveis que devem ser consideradas, embora nem sempre tenham peso explicativo para a efetividade e a eficiência alocativa na realização de direitos.

16. São estabelecidos como objetivos do Estado brasileiro, definidos no art. 3 da CF/1988, a construção de uma "sociedade livre, justa e solidária", a garantia do desenvolvimento nacional, a erradicação da pobreza e da marginalização, a redução das desigualdades sociais e regionais e a promoção do "bem de todos, sem preconceitos de origem, raça, sexo, cor, idade e quaisquer outras formas de discriminação" (Brasil, 1988, art. 3). 
Longe de ser instrumento meramente técnico, instrumento simples de organização fiscal e da transparência, o orçamento pode ser tomado como parte de um complexo jogo de negociação política, valorização e priorização de algumas linhas de ação em detrimento de outras possíveis. Atores, ideias, interesses e instituiçóes importam e movimentam-se no contexto de maior ou menor rigidez orçamentária, regras fiscais, dinâmica macroeconômica, arrecadação tributárias e interdependências internacionais. Esse quadro geral encontra na CF/1988, nos direitos insculpidos nesta e na arquitetura normativa que organiza a atuação estatal seu contexto de funcionamento.

E, embora a prática orçamentária das últimas décadas possa ser descrita a partir do aumento das vinculaçóes orçamentárias e das despesas obrigatórias - o que diminui os níveis de discricionariedade das escolhas do Poder Executivo-, a questão dos limites da discricionariedade de tal poder, ${ }^{17}$ bem como sua atuação vinculada aos direitos constitucionalizados e à legalidade, deve ser tematizada. O próprio orçamento pode ser discutido a partir da sua constitucionalidade (Furtado, 2010).

Após uma breve caracterização da complexa situação dos povos indígenas no Brasil, incluindo-se suas heterogeneidades e diferenças culturais, bem como a apresentação do quadro jurídico relativo aos direitos dos PIs que orientam as obrigaçóes positivas do Estado, passa-se a evidenciar o lugar do orçamento, peça jurídica formal e material que garante a efetivação de direitos indígenas, percorrendo os limites que sujeitam o exercício da discricionariedade e da legalidade administrativa estatal na gestão orçamentária desta.

\subsection{PPA indigenista}

Esta subseção é motivada pela necessidade de reler as políticas indigenistas à luz dos direitos humanos fundamentais, no qual o orçamento, como instrumento de políticas públicas, passa a ser questionado na mesma direçấo da qual decorre a possibilidade de controle concentrado dos orçamentos públicos pelo Judiciário. Embora possa ser controverso, é inegável a necessidade de legitimação moral, política e argumentativa dos orçamentos, peça política por excelência da atuação estatal, à luz de ideias de justiça e dos valores dos direitos humanos.

Dessa forma, o quadro de fundo é a distinção entre, de um lado, a política (contexto do jogo político agônico no qual competem posiçóes, visóes e projetos diversos de sociedade, em que se dá a lógica da dialogia e do jogo partidário) e, de outro lado, o espaço das políticas públicas, nas quais se mobilizam recursos, instrumentos, instituiçóes e a administração pública para a ação. Os dois contextos,

17. 0 Poder Executivo tem iniciativa de proposição e apresentação das três leis organizadoras dos orçamentos: PPA, Lei de Diretrizes Orçamentárias (LDO) e Lei Orçamentária Anual (LOA). Pode escolher, no quadro do ordenamento jurídico vigente, quais políticas públicas devem ser implementadas e qual volume de recursos será destinado a estas. 
política e política pública, embora diferentes, articulam-se dialeticamente e expressam princípios e interpretações dos preceitos constitucionais. Estes últimos estruturam questôes importantes no que tange à interpretação das políticas indigenistas e do confronto entre direitos humanos e direito positivo; são estes: $i$ ) efetividade na realizaçáo dos direitos humanos e sociais; e $i$ i) legalidade na realização do orçamento e do PPA.

Ambas as questóes têm desdobramentos importantes. Embora a efetividade na realização dos direitos econômicos, culturais, políticos e sociais seja controvertida, ${ }^{18}$ espera-se que estes sejam sistematicamente perseguidos. Ademais, a efetividade traduz-se na questão de realização plena ou condicionada do orçamento. Na nossa lógica orçamentária, há tensão entre a previsão orçamentária e a realização financeira, que desperta uma grande discussão a respeito da relação entre os poderes (Executivo e Legislativo) que definem o orçamento, sua legalidade, controle jurisdicional e discricionariedade. Além disso, há possibilidade de exercício de jurisdição constitucional para dar conformidade dos atos estatais à CF/1988.

Em termos mais simples, as previsôes e dotações não são plenamente executadas ou são adiadas por meio de complexa engenharia de empenho, liquidação, pagamento e restos a pagar (RPs). ${ }^{19}$ Outros pontos importantes são os objetivos, metas e iniciativas que acompanham os documentos legais que, apesar de serem constitutivos das políticas públicas, não vinculam legalmente o Estado à sua realização plena em um momento do tempo (apêndices A e B) ${ }^{20}$ De fato, a tensão entre legalidade e discricionariedade marca as relaçóes entre direito e política pública.

18. É fácil reconhecer o sentido político dos direitos sociais, mas sua configuração jurídica é controvertida. Primeiramente, porque o Pacto Internacional sobre Direitos Econômicos e Sociais, de 1966, alude à progressividade, sugerindo direitos cuja realização e efetividade diferem no tempo, implicando alocação máxima de recursos disponíveis que assegurem, sem prazo definido, as garantias dos direitos aludidos. Essa formulação reconhece diferentes tradições político-jurídicas que ainda não incorporaram condições institucionais e econômicas para a realização plena dos direitos - ou seja, alguns países não efetivaram as condições de liberdade política e outros não apresentam condições de desenvolvimento econômico. As controvérsias desdobram-se na discussão a respeito da natureza dos direitos prestacionais, que podem ser desde direitos de proteção, organização e procedimento e prestações fáticas, em sentido estrito. Disso tudo decorre discussões a respeito do papel ou papéis do Estado, das menores ou maiores margens para a configuração de políticas, em decorrência do papel de orçamentos ou fundos públicos na realização dos direitos.

19. Alguns conceitos relacionados aos estágios que compõem a execução dos orçamentos públicos auxiliam na descrição do comportamento orçamentário-financeiro das políticas indigenistas no Brasil: i) empenho de despesa: é uma reserva - ou seja, uma garantia que se faz ao fornecedor ou prestador de serviços da dotação necessária para honrar o pagamento. Quando há empenho, significa que a despesa foi enquadrada no crédito orçamentário adequado e que a administração dispõe de recursos; ii) liquidação: ocorre após a entrega do bem ou da prestação do serviço, quando se verifica o direito adquirido pelo credor, determinando a origem e objeto do que se deve pagar, a importância e a quem é preciso fazer o pagamento, segundo condições estipuladas; iii) pagamento: é a última fase, na qual se faz emissão de ordem de pagamento, que apenas pode ser emitida após a liquidação da despesa; iv) restos a pagar: despesas empenhadas, mas não pagas até o dia 31 de dezembro. Distinguindo-se entre processadas (quando os bens e serviços já foram entregues e aceitos, portanto, liquidados, mas o pagamento não foi feito, restos a pagar processados - RPPs) e não processados, restos a pagar não processados - RPNPs (quando as despesas foram apenas empenhadas e não liquidadas, ainda não foi reconhecido o direito do credor). Causa estranheza é possibilidade de cancelamento de RPPs, pois implica um credor já reconhecido em seu direito; e v) despesa executada: soma de despesas liquidadas e RPNPS. Ver Vieira e Piola (2016).

20. A eficácia é plena, mas a efetividade é diferida no tempo, pois depende da alocação de recursos e do amadurecimento gradual de políticas e ações para sua realização. 
Quanto à legalidade na realização do orçamento e do PPA, no contexto das políticas públicas voltadas aos PIs, o orçamento tem significado próprio e modus operandi diferenciado, no qual diferentes valores e princípios devem ser perseguidos; entre estes, o pluralismo, a participação e a efetividade das políticas públicas no contexto da interculturalidade. O PPA, por sua vez, refere-se à forma organizacional do planejamento de médio prazo. No caso brasileiro, no entanto, PPA e orçamento confundem-se historicamente. Apesar de lógicas diferentes, acabaram por sobrepor-se, e, a exemplo disso, é a lógica do PPA 2012-2015, que desvinculou relativamente as açôes do orçamento. ${ }^{21}$

Enfatizando a estrutura das açóes indigenistas, esta também sofreu modificaçôes ao longo das décadas - e dos PPAs -, com o redesenho de açóes e programas que visou a um maior nível de agregação, facilitando o remanejamento de recursos e ampliando a flexibilidade da gestão. As açôes perderam um pouco da visibilidade para os atores externos, mas facilitaram o manejo e a administração. $\mathrm{O}$ maior problema, entretanto, não é esse, mas o da efetividade do orçamento indígena na implementação de direitos. É difícil encontrar a dose exata de discricionariedade na execução do orçamento. Se a flexibilidade é necessária ao manejo de instrumentos fiscais e no cotidiano da administração, é possível imaginar que flexibilidade excessiva pode minar as condiçóes de realização dos direitos.

Por isso, é possível dizer que o orçamento deveria funcionar como regra, como na lógica do "tudo ou nada", do "se x, então y". Mais claramente, se foi definido um orçamento para responder à demanda de direitos, entấo esse orçamento deve ser executado para implementar as políticas definidas entre Executivo e Legislativo; entretanto, é evidente que qualquer processo de intepretação envolve ponderação entre princípios. No primeiro caso, o orçamento deveria ser de execução obrigatória, ou pelo menos deveria ser executado como na sua previsão e definição estabelecida no jogo conflitivo e de coordenação entre sua proposição pelo Executivo e sua aprovaçáo pelo Legislativo. No segundo caso, deveria ser objeto de hermenêutica e controle constitucional, especialmente para resguardar os direitos fundamentais.

A seguir, apresentamos a estrutura macro do PPA, passando em seguida para o PPA indigenista e, posteriormente, para o comportamento dos recursos financeiros da Funai e do programa 2065 (Proteção e Promoção dos Direitos dos Povos Indígenas).

21. É possível que a lógica fiscal seja a variável explicativa de maior peso, mas não a exploraremos como hipótese organizadora do comportamento dos recursos das políticas indigenistas. Essas mudanças tentaram responder a uma das questões mais importantes em termo de organização do orçamento-PPA, mas certamente não a única, relacionada à sobreposição e ao espelhamento entre os dois, que é o nível de desagregação, quase similar, entre orçamento e PPA. 
QUADRO 2

Estruturação do PPA - Brasil (2000-2019)

\begin{tabular}{|l|l|l|l|}
\hline \multicolumn{1}{|c|}{ PPA } & \multicolumn{1}{|c|}{ Programa } & Orientações estratégicas & \multicolumn{1}{c|}{ Caracterização geral dos programas } \\
\hline $\begin{array}{l}\text { PPA 2000- 2003; } \\
\text { 2004- 2007; }\end{array}$ & $\begin{array}{l}\text { Programas } \\
\text { (orçamento-programa) }\end{array}$ & $\begin{array}{l}\text { Macroproblemas ou } \\
\text { macro-objetivos (visão } \\
\text { estratégica), problema, } \\
\text { objetivos e indicadores. }\end{array}$ & $\begin{array}{l}\text { Ações dos planos são detalhadas e vinculadas às } \\
\text { ações orçamentárias. } \\
\text { As ações relacionam-se a produtos, bens ou servi- } \\
\text { ços disponibilizados à sociedade. }\end{array}$ \\
\hline $\begin{array}{l}\text { PPA 2012-2015; } \\
\text { 2016-2019 }\end{array}$ & $\begin{array}{l}\text { Programas temáticos: } \\
\text { ações mais conectadas } \\
\text { às políticas públicas } \\
\text { e à sua instituciona- } \\
\text { lidade considerando } \\
\text { transversalidades. }\end{array}$ & $\begin{array}{l}\text { Cenários, macrodesafios } \\
\text { (visão estratégica), obje- } \\
\text { tivos, metas, iniciativas e } \\
\text { indicador. }\end{array}$ & $\begin{array}{l}\text { As ações estão conectadas aos programas no } \\
\text { PPA meio da LOA e da LDO, em que são mais } \\
\text { detalhadas; vinculam-se, assim, ao orçamento. } \\
\text { Os programas e as ações são mais agregados do } \\
\text { que no orçamento, prevendo ações multissetoriais, } \\
\text { transversais e não orçamentárias conectadas ao } \\
\text { programa por objetivos, metas e iniciativas. }\end{array}$ \\
\hline
\end{tabular}

Elaboração dos autores.

Vale lembrar de alguns pontos para a caracterização da estruturação dos PPAs. De 2000 a 2011, foram organizados em programas que se estruturavam em torno de problemas, objetivos, órgão responsável, valor global, prazos, fonte de financiamento, indicadores, modelo de financiamento etc. Essa área de política poderia ter vários programas finalísticos e programas de gestão.

A partir de 2012, os PPAs passam a organizar-se a partir de programas temáticos. Uma das questôes enfrentadas pelas mudanças era a da fragmentação e excessiva aderência do PPA ao orçamento, o que dificultava a priorização. Nesse contexto, o nível de agregação aumentou pela organização dos programas temáticos, e o PPA também se afastou relativamente do orçamento com a proposição de açóes mais agregadas - mais detalhadas no orçamento -, ao utilizar o conceito de plano orçamentário (PO). Na verdade, açóes com descritores semelhantes foram agregadas, e os POs voltaram a separá-las, atribuindo-lhes subprodutos específicos.

A lógica do programa temático seria a de ultrapassar a lógica de cada ministério ou órgão setorial, agregando açôes que convergiriam nestes para temáticas mais amplas. Em algumas situaçôes, a aderência setorial é muito forte. Por exemplo, diferentes ações associadas às políticas indigenistas ligar-se-iam - e, de fato, o fizeram - ao programa temático 2065, por meio de metas, objetivos e iniciativas que podem compor qualquer outro programa temático. De dois programas com açóes transversais com recursos de diferentes órgãos, o PPA indigenista reduz-se a apenas um com as conexôes transversais já apontadas.

A explicação de Santos (2015, p. 86) é que os PPAs anteriores estariam presos à lógica do orçamento; as informaçóes ligar-se-iam a produtos de açóes e indicadores de programa, as responsabilidades seriam estanques. Os posteriores procuram revelar desafios, a análise é situacional de objetivos e indicadores, e a estrutura de metas e iniciativas permitia declarar responsabilidades compartilhadas. Faz sentido. 
QUADRO 3

Programas federais descritivos do PPA indigenista - Brasil (2000-2019)

\begin{tabular}{|l|l|}
\hline $\begin{array}{l}\text { PPA } \\
\text { 2000-2003 }\end{array}$ & $\begin{array}{l}\text { Programa 150 - Etnodesenvolvimento das Sociedades Indígenas } \\
\text { Programa 151 - Território e Cultura Indígena }\end{array}$ \\
$\begin{array}{l}\text { PPA } \\
\text { P004-2007 }\end{array}$ & $\begin{array}{l}\text { Programa 150 - Identidade Étnica e Patrimônio Cultural dos Povos Indígenas } \\
\text { Programa 151 - Proteção de Terras Indígenas, Gestão Territorial e Etnodesenvolvimento }\end{array}$ \\
$\begin{array}{l}\text { PPA } \\
\text { 2008-2011 }\end{array}$ & Programa 150 - Proteção e Promoção dos Povos Indígenas \\
$\begin{array}{l}\text { PPA 2012-2015 } \\
\text { e PPA 2016-2019 }\end{array}$ & Programa 2065 - Proteção e Promoção dos Direitos dos Povos Indígenas \\
\hline
\end{tabular}

Elaboração dos autores.

Já mostramos em outro trabalho a evolução das estruturas do PPA indigenista (Silva e Lunelli, 2020). As mudanças acompanham a evolução metodológica e de concepção institucional. Ao analisar-se o conteúdo do PPA 2000-2019, observa-se que a estrutura programática mudou de maneira significativa e, no caso das políticas indigenistas, em que os PIs são tematizados, a comparação entre as estruturas dos PPAs e as decorrentes mudanças metodológicas instigam reflexóes. Ao analisarmos os programas que se relacionariam na estrutura do PPA com a política indigenista e abstrairmos os programas de gestão, observamos uma diminuição no número dos programas direcionados de forma específica à questão indígena. No PPA 2000-2003, eram dois programas direcionados à questáo indígena, um com 21 e o outro com quinze ações. A partir de 2012, apenas um programa direcionado à questão indígena passa a concentrar nove objetivos, 75 metas, 43 iniciativas e apenas quatro açôes. Por sua vez, em 2016, são observados cinco objetivos, 35 metas e 37 iniciativas.

Como já mencionado, a partir dos anos 2000, foram realizadas mudanças gradativas na estrutura do PPA. No transcorrer dessas primeiras décadas, programas ganharam atributos organizacionais específicos, articulando problemas sociais com orientaçóes setoriais e, por sua vez, com as diretrizes presidenciais, a partir de metodologias que foram gradualmente se transformando.

Analisando o conteúdo do PPA 2000-2019, observamos que a estrutura programática mudou de maneira significativa nesse período. Quanto à forma, verificam-se mudanças conceituais e metodológicas importantes no que se refere ao papel dos programas e dos seus atributos; por exemplo, os objetivos, as metas, os indicadores e as iniciativas; estas últimas inexistentes antes de 2012.

No caso das políticas indigenistas, em que os povos indígenas são tematizados na análise orçamentária, a comparação entre as estruturas dos PPAs e as decorrentes mudanças metodológicas instigam algumas reflexóes. O quadro 4 apresenta uma síntese da estrutura dos programas que referenciam os PIs em algum dos elementos formativos dos PPAs. 


\section{QUADRO 4}

Histórico dos programas federais direcionados aos povos indígenas (2000-2019)

\begin{tabular}{|c|c|}
\hline PPA 2000-2003 & $\begin{array}{l}\text { Programa } 0502 \text { - Amazônia Sustentável } \\
\text { Programa } 0643 \text { - Calha Norte } \\
\text { Programa } 0518 \text { - Desenvolvimento agroambiental do estado do Mato Grosso, por meio do Projeto } \\
\text { de Desenvolvimento Agroambiental (Prodeagro) } \\
\text { Programa } 0150 \text { - Etnodesenvolvimento das Sociedades Indígenas } \\
\text { Programa } 498 \text { - Pantanal } \\
\text { Programa } 517 \text { - Plano Agropecuário e Florestal de Rondônia (Planafloro) } \\
\text { Programa } 0151 \text { - Território e Cultura Indígenas } \\
\text { Programa } 0135 \text { - Novo Mundo Rural: Assentamentos de Trabalhadores Rurais }\end{array}$ \\
\hline PPA 2004-2007 & $\begin{array}{l}\text { Programa } 1215 \text { - Alimentação Saudável } \\
\text { Programa } 0502 \text { - Amazônia Sustentável } \\
\text { Programa } 0499 \text { - Áreas Protegidas do Brasil } \\
\text { Programa } 1140 \text { - Conservação e Uso Sustentável de Recursos Genéticos } \\
\text { Programa } 0508 \text { - Conservação, Uso Sustentável e Recuperação da Biodiversidade } \\
\text { Programa } 0498 \text { - Desenvolvimento Sustentável do Pantanal } \\
\text { Programa } 0685 \text { - Ensino Profissional Diplomático } \\
\text { Programa } 0165 \text { - Identidade Étnica e Patrimônio Cultural dos Povos Indígenas } \\
\text { Programa } 1120 \text { - Paz no Campo } \\
\text { Programa } 1270 \text { - Proambiente } \\
\text { Programa } 0151 \text { - Proteção de Terras Indígenas, Gestão Territorial e Etnodesenvolvimento } \\
\text { Programa } 1287 \text { - Saneamento Rural }\end{array}$ \\
\hline PPA 2008-2011 & $\begin{array}{l}\text { Programa } 1427 \text { - Assistência Técnica e Extensão Rural na Agricultura Familiar } \\
\text { Programa } 0471 \text { - Ciência, Tecnologia e Inovação para Inclusão e Desenvolvimento Social } \\
\text { Programa } 0508 \text { - Conservação e Uso Sustentável da Biodiversidade e dos Recursos Genéticos } \\
\text { Programa } 1426 \text { - Conservação, Manejo e Uso Sustentável da Agrobiodiversidade } \\
\text { Programa } 1377 \text { - Educação para a Diversidade e Cidadania } \\
\text { Programa } 1355 \text { - Identidade e Diversidade Cultural - Brasil Plural } \\
\text { Programa } 1120 \text { - Paz no Campo } \\
\text { Programa } 0150 \text { - Proteção e Promoção dos Povos Indígenas } \\
\text { Programa } 1287 \text { - Saneamento Rural } \\
\text { Programa } 1458 \text { - Vetor Logístico Leste } \\
\text { Programa } 0471 \text { - Ciência, Tecnologia e Inovação para Inclusão e Desenvolvimento Social }\end{array}$ \\
\hline PPA 2012-2015 & $\begin{array}{l}\text { Programa } 2012 \text { - Agricultura Familiar } \\
\text { Programa } 2018 \text { - Biodiversidade } \\
\text { Programa } 2019 \text { - Bolsa Família } \\
\text { Programa } 2020 \text { - Cidadania e Justiça } \\
\text { Programa } 2025 \text { - Comunicações para o Desenvolvimento, a Inclusão e a Democracia } \\
\text { Programa } 2060 \text { - Coordenação de Políticas de Prevenção, Atenção e Reinserção Social de Usuários } \\
\text { de Crack, Álcool e outras Drogas } \\
\text { Programa } 2029 \text { - Desenvolvimento Regional, Territorial Sustentável e Economia Solidária } \\
\text { Programa } 2030 \text { - Educação Básica } \\
\text { Programa } 2031 \text { - Educação Profissional e Tecnológica } \\
\text { Programa } 2032 \text { - Educação Superior (graduação, pós-graduação, ensino, pesquisa e extensão) } \\
\text { Programa } 2034 \text { - Enfrentamento ao Racismo e Promoção da Igualdade Racial } \\
\text { Programa } 2041 \text { - Gestão Estratégica da Geologia, da Mineração e da Transformação Mineral } \\
\text { Programa } 2043 \text { - Integração Sul-Americana } \\
\text { Programa } 2045 \text { - Licenciamento e Qualidade Ambiental } \\
\text { Programa } 2057 \text { - Política Externa } \\
\text { Programa } 2016 \text { - Política para as Mulheres: Promoção da Autonomia e Enfrentamento à Violência } \\
\text { Programa } 2062 \text { - Promoção dos Direitos de Crianças e Adolescentes } \\
\text { Programa } 2063 \text { - Promoção de Direitos de Pessoas com Deficiências } \\
\text { Programa } 2065 \text { - Proteção e Promoção dos Direitos dos Povos Indígenas } \\
\text { Programa } 2066 \text { - Reforma Agrária e Ordenamento da Estrutura Fundiária } \\
\text { Programa } 2068 \text { - Saneamento Básico } \\
\text { Programa } 2069 \text { - Segurança Alimentar e Nutricional }\end{array}$ \\
\hline
\end{tabular}




\begin{tabular}{|c|c|}
\hline PPA 2016-2019 & $\begin{array}{l}\text { Programa } 2078 \text { - Conservação e Uso Sustentável da Biodiversidade } \\
\text { Programa } 2037 \text { - Consolidação do Sistema Único de Assistência Social (Suas) } \\
\text { Programa } 2027 \text { - Cultura: Dimensão Essencial do Desenvolvimento } \\
\text { Programa } 2038 \text { - Democracia e Aperfeiçoamento da Gestão Pública } \\
\text { Programa } 2080 \text { - Educação de Qualidade para Todos } \\
\text { Programa } 2035 \text { - Esporte, Cidadania e Desenvolvimento } \\
\text { Programa } 2015 \text { - Fortalecimento do Sistema Único de Saúde (SUS) } \\
\text { Programa } 2012 \text { - Fortalecimento e Dinamização da Agricultura Familiar } \\
\text { Programa } 2050 \text { - Mudança do Clima } \\
\text { Programa } 2052 \text { - Pesca e Aquicultura } \\
\text { Programa } 2082 \text { - Política Externa } \\
\text { Programa } 2016 \text { - Políticas para as Mulheres: Promoção da Igualdade e Enfrentamento à Violência } \\
\text { Programa } 2044 \text { - Promoção dos Direitos da Juventude } \\
\text { Programa } 2064 \text { - Promoção e Defesa dos Direitos Humanos } \\
\text { Programa } 2062 \text { - Promoção, Proteção e Defesa dos Direitos Humanos de Crianças e Adolescentes } \\
\text { Programa } 2065 \text { - Proteção e Promoção dos Direitos dos Povos Indígenas } \\
\text { Programa } 2083 \text { - Qualidade Ambiental } \\
\text { Programa } 2066 \text { - Reforma Agrária e Governança Fundiária } \\
\text { Programa } 2069 \text { - Segurança Alimentar e Nutricional }\end{array}$ \\
\hline
\end{tabular}

Fonte: Leis de PPAs publicadas no período 2000-2019.

Elaboração dos autores.

Em todos esses programas listados, é possível encontrar referência aos povos indígenas, até mesmo diante de divergências e convergências entre a estrutura dos PPAs. De forma geral, os programas que referenciavam expressamente os PIs, seja no título do programa, seja nos objetivos, nos indicadores e no público-alvo, dando o teor da política indigenista brasileira, saltam de oito no PPA 2000-2003 para vinte no PPA 2016-2019. ${ }^{22}$

Aprofundando o exposto, podemos traçar alguns paralelos. No PPA 2000-2003, encontramos programas que vincularam açóes especificas aos povos indígenas, sem que houvesse indicadores ou objetivos a estes relacionados. Nos PPAs 2004-2007 e 2008-2011, por sua vez, os programas mencionam sem critérios explícitos esses povos. Em alguns momentos, estes aparecem como público-alvo da atuação estatal; em outros, apenas constam da descrição de açôes e, ainda, de indicadores. Nos PPAs 2012-2015 e 2016-2019, a referência aos PIs destaca-se na observação ora dos objetivos, ora das iniciativas.

Na prática, essa estrutura difusa, tal como se apresenta, tem se mostrado de difícil monitoramento e avaliação (Silva e Lunelli, 2020).

O acompanhamento e a avaliação que se seguem ao monitoramento implicam produzir, selecionar, organizar, analisar e interpretar informaçóes, de forma a criar uma visão complexa de natureza técnica e política que permita a qualificação e o aprendizado institucional e social. Avaliar significa dar respostas densas ao processo de determinação de mérito, valor e importância de ação pública e de seus resultados, apontando incompletudes, falhas e insuficiências - ou seja, problemas em alguma dimensão dos fenômenos analisados. O objetivo é que a reflexão sobre a ação e




seus problemas responda a dimensóes formativas, informativa, avaliativa, analítica, prospectiva e corretiva, em dinâmica coletiva de interpretação e uso da reflexão baseada em evidências.

No caso de políticas indigenistas, é fundamental não apenas usar informaçōes e indicadores gerais, mas também implementar estratégias participativas no processo avaliativo. Ademais, também é importante a confrontação de dados de campo e a implementação destes, bem como conhecer as dificuldades de cada território ou PIs específicos.

O uso de dados financeiro-orçamentários é claramente insuficiente ao processo avaliativo, mas pode ajudar a dar um retrato geral da lógica das políticas indigenistas. Decerto, esses dados constituem uma dimensão não negligenciável da açâo pública, que deve, todavia, ser complementada por outras abordagens.

No entanto, sem um acompanhamento das açóes concretas para o desenvolvimento das capacidades e de desempenhos institucionais, de forma a realizar os preceitos constitucionais, a execução das atividades encontra obstáculos e contrariedades, em função do desconhecimento de vulnerabilidades e necessidades. Em referência a esse contexto, analisamos, com maior destaque, a Funai e as açóes do programa 2065 (Proteção e Promoção dos Direitos dos Povos Indígenas).

\subsection{A Funai e as ações do programa 2065}

A Funai vivenciou ao longo dessas últimas décadas uma descentralização de políticas e açóes indigenistas sob sua responsabilidade. Em processo em que suas competências foram realocadas e, em alguns casos, transferidas para outros ministérios - como o MS e o MMA, por exemplo -, o cumprimento da política indigenista tem deixado de ser competência exclusiva da Funai.

Ainda assim, a fundação, desde sua criação em 1967, é o principal órgão do Poder Executivo atuante nos territórios e com a população indígena, desenvolvendo intenso papel nas garantias dos direitos declarados a essa população culturalmente diferenciada. Sua existência justifica-se diante do próprio cumprimento de sua missão institucional, qual se fundamenta em um conjunto de atribuiçóes ao Estado definidas pela CF/1988 e que visa atender às demandas vocalizadas pelas mobilizaçôes indígenas no país, sobretudo a denúncia de violação de direitos.

No esforço de evidenciar a participação do orçamento da Funai nas políticas indigenistas, expomos o comportamento dos recursos da fundação, conforme o gráfico 1. 
GRÁFICO 1

Comportamento dos recursos orçamentários da Funai (2000-2019)

(Em R\$ milhões)

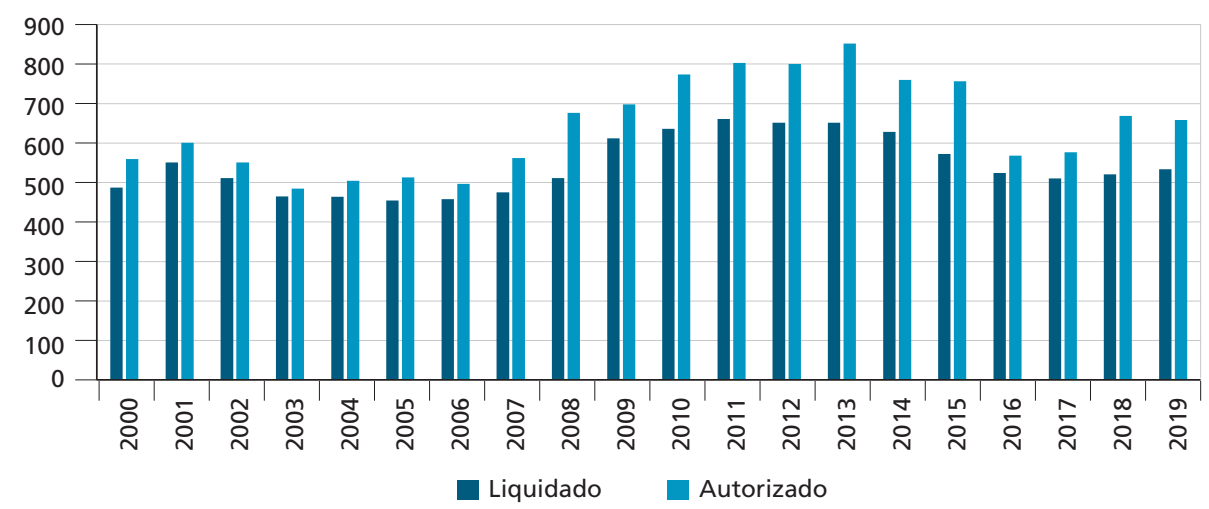

Fonte: Sistema Integrado de Planejamento e Orçamento do Ministério da Economia (Siop/ME).

Obs.: Valores deflacionados para 2019 pelo Índice Nacional de Preços ao Consumidor Amplo (IPCA).

Como se pode constatar da análise do gráfico 1 , os recursos autorizados tiveram intensa oscilação no período destacado (2000 a 2019). De forma global, de 2006 a 2013, apresentaram tendência de crescimento, caindo nos anos seguintes e mostrando uma levíssima composição em 2018 e, novamente, uma pequena queda em 2019. Em termos práticos, os recursos da Funai tiveram seus maiores montantes em 2013 ( $\mathrm{R}$ \$ 742,8 milhóes) e declinaram nos anos seguintes, chegando a R \$ 542,6 milhóes em 2017 - ou seja, 22\% a menos em relação a 2012.

A julgar pelo nível de execução, que foi próximo de $80 \%$ em 2019, as perspectivas para a fundação não são alvissareiras. Ao descrevermos sobre a intrínseca relação entre a efetividade dos direitos humanos dos PIs e o orçamento público da Funai, é dimensionável que a oscilação orçamentária compromete a continuidade e o alcance de políticas e açóes aos quais se responsabiliza. Vale lembrar que, até mesmo nos tempos de ápice orçamentário, ainda eram muitas as demandas indígenas diante das condiçôes de vulnerabilidade em que se encontravam.

Essa situação se agrava mais ainda se acrescida de uma informação específica do orçamento institucional; qual seja, a de que, nesse montante total, o peso dos gastos administrativos e com aposentadorias é crescente - era de $15 \%$ do total em 2000 e passa a constituir-se em 32\% em 2019 - e começa a ocupar volume considerável nesse cômputo.

Dos programas sob responsabilidade da Funai, além da Previdência de Inativos e Pensionistas da União e do Programa de Gestão e Manutenção do MJSP, inserem-se as verbas relativas às operaçôes especiais (cumprimento de sentenças judiciais e outros encargos) e ao programa 2065 (Proteção e Promoção dos Direitos dos Povos Indígenas), o qual nos deteremos com mais interesse. 
O programa 2065 aparece sob esse número e título no PPA 2012-2015 e é reiterado no PPA 2016-2019. Aliás, esse foi o principal mecanismo de coordenação das açôes de política indigenista até 2019, organizando e dando visibilidade para a atuação de diversos órgãos, cada qual subordinado a um ministério específico. Ao lado da Funai, atualmente sob a pasta do MJSP, também atua, por exemplo, a Secretaria Especial de Saúde Indígena (Sesai) do MS, responsável pelo Subsistema de Saúde Indígena do SUS e por açóes de saneamento.

Dos programas que alcançam como público-alvo os PIs, o programa 2065 é o que vincula a execução do orçamento público de forma específica a essa parcela populacional, surtindo determinaçôes abrangentes sobre o planejamento de políticas públicas e, assim, sobre as açôes positivas do Estado. Assim, os alcances da Funai e de outros órgãos do governo federal estão expressos no comportamento e na estrutura alocativa do programa, o qual está organizado em cinco objetivos e sete ações. Entre seus objetivos, estão:

1) Objetivo 1014 - Garantir aos povos indígenas a posse plena sobre suas terras, por meio de açôes de proteção dos PIs isolados, demarcação, regularização fundiária e proteção territorial.

2) Objetivo 0962 - Promover a atenção à saúde dos PIs, aprimorando as ações de atenção básica e saneamento básico nas aldeias, observando as práticas de saúde e os saberes tradicionais, e articulando com os demais gestores do SUS para prover açóes complementares e especializadas, com controle social.

3) Objetivo 1013 - Promover a gestão territorial e ambiental das terras indígenas.

4) Objetivo 1012 - Promover e proteger os direitos sociais e culturais e o direito à cidadania dos PIs, asseguradas suas especificidades nas políticas públicas.

5) Objetivo 1015 - Preservar e promover o patrimônio cultural dos PIs por meio de pesquisa, documentação e divulgação de suas línguas, suas culturas e seus acervos, prioritariamente daqueles em situação de vulnerabilidade.

Vinculadas aos objetivos, as ações com dotações orçamentárias relacionadas ao programa apresentam-se na tabela 1 . 
TABELA 1

Orçamento do programa 2065 (Proteção e Promoção dos Direitos dos Povos Indígenas) por ações (2016-2019)

\begin{tabular}{|c|c|c|c|c|c|c|c|}
\hline Ações & 2016 & 2017 & 2018 & 2019 & $\begin{array}{l}\text { Variação \% } \\
2019 / 2016 \\
2019=100 \\
\end{array}$ & $\begin{array}{l}\text { Variação \% } \\
2019 / 2018 \\
2019=100 \\
\end{array}$ & $\begin{array}{c}\text { Variação } \\
\text { absoluta } \\
\text { 2019/2018 }\end{array}$ \\
\hline $\begin{array}{l}\text { 20UF - Demarcação e } \\
\text { Fiscalização de Terra Indí- } \\
\text { genas e Proteção dos Povos } \\
\text { Indígenas Isolados }\end{array}$ & 17.106 .870 & 19.199.591 & 49.098 .140 & 33.656 .409 & 51 & 69 & -15.441 .731 \\
\hline $\begin{array}{l}\text { 20YP - Promoção, Proteção } \\
\text { e Recuperação da Saúde } \\
\text { Indígena }\end{array}$ & 1.347.169.559 & 1.793 .614 .875 & 1.495 .639 .461 & 1.470 .332 .798 & 92 & 98 & -25.306 .662 \\
\hline $\begin{array}{l}2150 \text { - Gestão Ambiental e } \\
\text { Etnodesenvolvimento }\end{array}$ & 8.461 .750 & 12.533 .927 & 14.347 .286 & 16.912 .863 & 50 & 118 & 2.565 .577 \\
\hline $\begin{array}{l}215 Q \text { - Promoção dos } \\
\text { Direitos dos Povos Indígenas } \\
\text { de Recente Contato }\end{array}$ & 520.779 & 465.117 & 1.202 .128 & 1.690 .833 & 31 & 141 & 488.704 \\
\hline $\begin{array}{l}2388 \text { - Direitos Sociais e } \\
\text { Culturais e à Cidadania }\end{array}$ & 14.313 .613 & 15.490 .923 & 14.203 .126 & 17.345 .626 & 83 & 122 & 3.142 .500 \\
\hline $\begin{array}{l}7684 \text { - Saneamento Básico } \\
\text { em Aldeias Indígenas para } \\
\text { Prevenção e Controle de } \\
\text { Agravos }\end{array}$ & 35.658 .411 & 50.031 .637 & 51.454 .493 & 37.994 .934 & 94 & 74 & -13.459 .559 \\
\hline $\begin{array}{l}8635 \text { - Preservação Cultural } \\
\text { dos Povos Indígenas }\end{array}$ & 4.348 .308 & 3.798 .195 & 3.663 .668 & 1.828 .310 & 238 & 50 & - 1.835 .358 \\
\hline Total geral & 1.427 .793 .766 & 1.895.134.265 & 1.645 .494 .223 & 1.579.761.774 & 90 & 96 & -65.732 .449 \\
\hline $\begin{array}{l}\text { Soma dos programas } \\
\text { descritos }\left({ }^{*}\right)\end{array}$ & 1.418 .596 .763 & 1.882.135.221 & 1.614 .058 .888 & 1.561.158.078 & 91 & 97 & -52.900 .810 \\
\hline
\end{tabular}

Fonte: Orçamento Fiscal e da Seguridade Social, 2018.

Nota: ${ }^{1}$ Valores empenhados atualizados.

Obs.: Valores de 2018 e 2019 em valor corrente.

A ação 20UF (Demarcação e Fiscalização de Terras Indígenas e Proteção dos Povos Indígenas Isolados) teve recursos empenhados que aumentaram de quase R \$ 19 milhóes, em 2017, para R 49 milhôes, em 2018 - ou seja, o empenhado quase triplicou, embora tenha caído para $\mathrm{R} \$ 33,6$ milhóes em 2019. As dificuldades de execução também podem ser percebidas no alto grau de RPs líquidos, que são maiores que a dotação e o empenho em 2017 e mais da metade (54\%) em 2018. Seja como for, a execução é baixa, e as variaçóes de dotação e execução geram incertezas na implementação e dúvidas sobre as prioridades alocativas. Em 2019, os recursos da açáo perderam 32\% em relação a 2018 (aproximadamente $\mathrm{R} \$ 15$ milhóes a menos).

A ação 20YP (Promoção, Proteção e Recuperação da Saúde Indígena) é de responsabilidade da Sesai/MS e tem as maiores execuçóes do programa 2065, 82,4\% e 93,0\% em 2017 e 2018, respectivamente. Entretanto, deixou RPs da ordem de 20,8\% em 2018, mais que o dobro em relação a 2017. O liquidado da ação foi da ordem de $\mathrm{R} \$ 1,3$ bilhão em 2018. Em 2019, a ação foi reduzida em $1,7 \%$, algo próximo a $\mathrm{R} \$ 25$ milhóes a menos. 
A ação 7684 (Saneamento Básico em Aldeias Indígenas para Prevenção e Controle de Agravos) é a terceira ação em termos de montantes do programa 2065. Os gastos dessa ação foram de $\mathrm{R} \$ 30,3$ milhóes em 2018. Ao contrário da ação 20YP, o saneamento tem nível de execuçáo baixo, de aproximadamente 58\%, e nível de RPs alto, sendo que esse valor foi de 38,8\% em 2018, quase o dobro de 2017. A ação teve queda de 50\% em relação a 2018, ficando com algo próximo de R\$ 1,8 milhão.

A ação $215 \mathrm{O}$ (Gestão Ambiental e Etnodesenvolvimento) teve baixa execução, na ordem de $42 \%$ a 44\%, com alto nível de RPs (44,4\% em 2018, praticamente quatro vezes maior que em 2017). O liquidado estava na ordem de $\mathrm{R} \$ 6,7$ milhóes em 2018, valor bem pequeno, dada a dimensão territorial e seus problemas. A ação teve acréscimo de recursos em 2019, quando chegaram a $\mathrm{R} \$ 16,9$ milhôes; portanto, quase $18 \%$ superiores.

A ação 215Q (Promoção dos Direitos dos Povos Indígenas de Recente Contato) teve recursos liquidados na ordem de R \$ 676 mil. Os RPs são baixos e os recursos autorizados quase triplicaram, mas os recursos liquidados náo cresceram no período. Os recursos da ação foram maiores em 2019 (40\%) em relação a 2018, chegando a R \$ 1,6 milhão. Nesse caso, há dúvidas no que concerne aos objetivos. A prática até o momento era a de monitoramento sem forçar o contato; há movimentos que contrariam a orientação, o que pode significar risco a essas etnias, vulneráveis a doenças.

A ação 238 (Direitos Sociais e Culturais e à Cidadania) teve o autorizado na ordem de R \$ 15 milhóes entre 2017 e 2018. Sua execução é baixa (43,7\% em 2017 e 56,2\% em 2018), e os RPs são proporcionalmente altíssimos e praticamente duplicaram entre os anos em análise. Essa ação também teve recursos aumentados, nesse caso em aproximadamente $22 \%$, chegando a $\mathrm{R} \$ 17,3$ milhóes.

A ação 8635 (Preservação Cultural dos Povos Indígenas) manteve-se estável em termo de recursos totais autorizados e liquidados - ou seja, aproximadamente $\mathrm{R}$ \$ 3,6 milhóes autorizados e R \$ 2,6 milhóes liquidados. Os RPs inscritos foram da ordem de $\mathrm{R} \$ 2,3$ milhóes, sendo a execução anual próxima de $60 \%$ do autorizado. A ação perdeu 50\% dos seus recursos em 2018 em relaçáo a 2019, sendo o liquidado nesse último ano de $\mathrm{R} \$ 1,8$ milhão.

Embora o programa 2065 (Proteção e Promoção dos Direitos dos Povos Indígenas) seja transversal, englobando muitos órgãos setoriais, em 2018 apenas a Funai/MJ e a Sesai/MS tiveram recursos específicos alocados. Situação essa distinta dos anos anteriores, quando havia açóes do MMA, do Ministério da Cultura (MinC) e do então Ministério dos Esportes - que atualmente se constitui como pasta do Ministério da Cidadania. Conforme o demonstrativo do orçamento fiscal, 
assinala-se que 24,4\% dos recursos são da Funai, sendo que 19,7\% são despesas relacionadas à gestão e à manutenção administrativa.

Como resultados da análise do quadro financeiro do programa 2065, este revela a redução de capacidades e as adversidades enfrentadas na gestão da Funai no que toca às açóes de proteção, fiscalização e monitoramento de TIs. É, portanto, questão desafiadora para a atuação e a proteção de inúmeros povos indígenas - ou seja, para a própria efetividade dos direitos humanos a estes reconhecidos -, a perda de recursos financeiros e da capacidade de implementação das açóes indigenistas, bem como a alocação centralizadora e a implementação não coordenada com outros órgãos e em contextos territoriais múltiplos dos recursos orçamentários. Em outras palavras, o Estado brasileiro, o qual tem nas obrigaçôes positivas o dever de implementar açóes que venham a dar efetividade aos direitos humanos dos PIs, tem se apoiado na discricionariedade da gestão orçamentária eximindo-se dos alcances finalísticos da política indigenista.

Em adição a esse fato, a deterioração das condiçóes ambientais e de vida dos povos indígenas, acometidas com sucessivas invasões e degradação ambiental, gera inúmeras necessidades e demandas de açôes, sobretudo na área da saúde. Os desafios da Funai e do Instituto Brasileiro do Meio Ambiente e dos Recursos Naturais Renováveis (Ibama), responsáveis pelas áreas que são objeto de grilagem, invasões, desmatamento e garimpo ilegal, são imensos e ampliam-se no contexto das restriçóes de recursos. Sobrepóe-se a esse contexto o saliente acompanhamento da expansão de atividades agropecuárias em economia baseada na venda de commodities, com óbvias consequências observadas no aumento de riscos ambientais e conflitos socioambientais, com perda de áreas de floresta e contaminação da água, além das questóes fundiárias decorrentes (acentuada valorização fundiária e conflitos possessórios).

É no quadro de reorganização das relações entre capacidades institucionais e problemas socioeconômicos a serem enfrentados que despontam, ganhando proeminência, as açôes de promoção, proteção e recuperação da saúde. Por isso, o aumento dos recursos da ação 20YP (Promoção, Proteção e Recuperação da Saúde Indígena) não apenas se relaciona à garantia de direitos e à estruturação do subsistema da saúde indígena, mas também concerne às demandas decorrentes dos riscos produzidos nas relaçóes entre sociedades indígenas e frentes de expansão econômica.

O saneamento básico envolve serviços, infraestrutura e instalaçóes para abastecimento de água, esgotamento sanitário, limpeza, manejo de resíduos sólidos e águas pluviais, sendo determinante para a prevenção de doenças e a promoção da saúde. A deterioração do meio ambiente e das relaçôes dos povos indígenas com agentes da expansão de atividades econômicas terá impacto importante em 
condiçôes e modos de vida que demandam a consolidação do subsistema de saúde indígena. Em geral, os PIs têm como característica epidemiológica a presença de doenças infecciosas e parasitárias, sendo que em muitas situaçôes se constituem na principal causa de mortalidade. Entre os problemas que se devem destacar como de resolução estratégica, há o da qualidade da água consumida e da proteção ambiental de nascentes, córregos e rios. Embora esforços sejam recorrentemente realizados para a melhoria da qualidade da água para consumo por meio de açóes e serviços públicos de saneamento, os esforços ainda são insuficientes, o que, somados à contaminação decorrente de atividades econômicas - entre estas, as atividades agropecuárias e minerarias, muitas vezes associadas a práticas de desmatamento -, agravam os riscos de adoecimento por patologias veiculadas pelo consumo de água contaminada por patógenos, agrotóxicos e metais.

Os indicadores de saúde têm melhorado, mas os PIs encontram-se entre os segmentos populacionais com piores indicadores para a mortalidade infantil e perfil nutricional de crianças. É sabido que há estreitas relaçôes entre saneamento, situaçáo nutricional e ocorrência de doenças infecciosas. Alguns PIs apresentam taxas significativas de mortalidade por suicídio. A taxa de mortalidade infantil (TMI) é maior que a taxa da população brasileira. A tuberculose e a malária alcançam em TIs indicadores que estão acima da média nacional. A ocorrência dessas patologias associa-se com a presença de condiçóes de vulnerabilidade socioeconômicas, insegurança alimentar e deficiências nutricionais. As açoóes de saúde têm aumentado seus recursos, impactando positivamente na reestruturação do subsistema de saúde indígena, mas há ainda muito a ser feito para garantir-se efetiva saúde integral, ao mesmo tempo que se convive com a complexidade das determinaçóes sociais da saúde.

Os desafios das ações de saúde indígena são inúmeros e relacionam-se à implementação de políticas públicas que ofereçam alternativas produtivas sustentáveis no âmbito da gestão ambiental e territorial. Especialmente nas políticas de saúde, são necessárias estratégias capazes de compor explicaçóes culturais e associá-las às açóes biomédicas, respeitando-se as tradições culturais e considerando-se os possíveis desencontros de perspectiva entre os profissionais da saúde biomédica e a saúde indígena; desencontros que têm impactos importante na resolutividade de açóes e serviços e saúde.

Resta evidenciar, por fim, que outras açóes são realizadas, tanto no âmbito da educação, atribuindo garantias ao acesso à educação básica e superior, quanto no das políticas assistenciais associadas a iniciativas relacionadas à moradia, à segurança alimentar e nutricional e à renda, promovendo o acesso ao conjunto de políticas públicas como o Benefício de Prestação Continuada (BPC), o Programa Bolsa Família (PBF), aposentadorias, entre outras. Contudo, a ausência de caracterização 
orçamentária específica coadunada aos PIs impossibilita monitoramento e análise do orçamento executado que, de fato, tenha alcançado as realidades comunitárias indígenas.

\section{CONSIDERAÇÕES FINAIS E DESAFIOS}

Os resultados da trajetória do contato e das relaçóes entre o Estado e os PIs podem ser analisados a partir da positivação de direitos humanos, enquanto conquistas de lutas sociais. No plano nacional ou internacional, convençóes, declaraçóes, constituições e leis reconhecem inúmeros direitos humanos aos povos indígenas. Para além da letra da lei e de promessas sobre garantias e acesso a direitos, é a implementação e o nível de efetividade que esses possam alcançar que importa aos PIs. Não raras as vezes, os direitos indígenas e o dever estatal de implementá-los são desconhecidos ou mal compreendidos como motivação normativa dos atos administrativos. Como consequência, vemos a prática de desvalorização da diversidade cultural e o desrespeito com povos, aldeias, comunidades e seus hábitos, crenças, rituais, religióes, comportamentos e formas de organização social. A inefetividade das ações da administração pública na garantia dos direitos, a despeito de seus esforços e intençôes, torna os PIs alvo fácil de concepçóes equivocadas, muitas vezes etnocêntricas e racistas.

Outras vezes, a qualidade da interpretação depende da proximidade e do conhecimento das questôes colocadas e relevantes para os próprios atores. Até mesmo diante de fatos inequívocos, como o desaparecimento de muitos povos e de padróes culturais em nível mundial, esperam uma linguagem neutra com argumentos filosóficos para públicos universais, escondendo-se no distanciamento social e epistêmico. Da incompreensão acerca da diversidade cultural e da consciência de sua preservação para o desenvolvimento sustentável global, extraem indicativos de pouca significância, atribuídos às garantias de sobrevivência das expressôes culturais e da proteção das manifestações particulares de cada cultura indígena em território brasileiro.

Se a reflexão acompanha os movimentos históricos, as decisóes dos tribunais superiores e as pequenas e importantes rusgas travadas no âmbito das primeiras instâncias, não se tem a menor ilusão sobre o alcance do direito e a verdade das proposiçôes jurídicas ou de que as instituiçôes do direito estão necessariamente a serviço do bem-estar. Levar a sério os direitos, os direitos humanos de maneira mais específica, significa colocá-los em contexto de forma crítica, assimilando-os à reflexão moral, ética e política.

Reconhecer que há preconceitos em relação aos povos indígenas não é simplesmente pressupor um princípio de direito natural acima dos preconceitos, que contém sua finalidade, estando o final da luta política assim determinado pelos seus 
princípios constitucionalizados. Ao contrário, significa reconhecer o valor das ideias, inclusive as que apoiam a discriminação negativa e a necessidade de criticá-las, e do direito como trunfo. Além disso, é necessário dizer, as lutas políticas à direita e à esquerda do espectro político estão contaminadas por um ideário que chega inclusive a afirmar, em muitas situaçóes, os direitos dos PIs, mas que os contradizem nas práticas institucionais por desconhecer a variedade de situaçôes e demandas.

As políticas culturais refletem relaçôes e, inclusive, conflitos entre modos diferentes de existir dos grupos humanos. Não dá para desculpar a ignorância dos bem informados. As políticas culturais por vezes atuam simultaneamente como políticas de extermínio e de imposição simbólica. Em outras situaçôes, implicam o reconhecimento, o resgate e a valorização de modos de vidas, mesmo que se entrelacem com outras culturas e, portanto, devam ser vistos na sua dinamicidade. Embora os termos moderno e tradicional sejam equívocos, referem-se a culturas diferenciadas com suas epistemes (ciências e saberes entrelaçados), seus modos de fazer (tecnologias misturadas aos rituais de cultura do cotidiano) e seus modos de vida, sejam estes contemporâneos como a vida dos artistas, ou tradicionais, quando a arte permeia as crenças ordinárias.

Vale tecer alguns comentários sobre como pensamos as políticas culturais e como estas têm ligação com a questão indígena. Os movimentos indígenas são autônomos do Estado, mas com este se relacionam. Ao mesmo tempo, enfrentam problemas cotidianos e da luta política. Sobre cada um destes, há inúmeras intencionalidades e controvérsias. Sabemos que os movimentos sociais nessa fase das relaçôes intercapitalistas e internacionais se apoiam nos direitos humanos, ou no direito como trunfo. São estes que justificam demandas ao Estado e às suas políticas sociais e culturais, ao mesmo tempo, em nome desses direitos, é que se demanda tratamento digno e respeito à autonomia. A abordagem deste texto não chega a ser idealista, no sentido de volta aos fundamentos, aos princípios e às ideias de justiça e direito natural. Reconhecem-se fragilidades e dificuldades e organizam-se os argumentos capazes de mobilizar os atores institucionais, a exemplo do Judiciário em suas diversas instâncias, capazes de vincular o Estado ao dever de fazer - isto é, realizar políticas previstas orçamentariamente na $\mathrm{CF} / 1988$ e em tratados internacionais dos quais o Brasil é signatário ou com estes mantém compromissos.

Este texto segue a linha dos outros capítulos sobre cultura deste periódico. Mostra como as políticas culturalmente diferenciadas aplicáveis aos PIs se entrelaçam à ideia dos direitos humanos reconhecidos em declaraçóes e convençóes internacionais, bem como à ideia desses direitos no que concerne aos Objetivos de Desenvolvimento Sustentável (ODS) da ONU. No entanto, se, por um lado, seria importante acrescentar uma menção aos ODS que se relacionam, ainda que 
indiretamente, a esse tema, por outro, nenhum ODS específico aos povos indígenas foi elencado explicitamente.

Deve ficar evidente que há políticas culturais para os povos indígenas e políticas culturais próprias desses povos. Em cada caso, os atores são diferentes e as categorias organizativas (arte, ciência, natureza, saúde, educação etc.) têm outros sentidos. Aqui, simplesmente acusamos um dos seus inúmeros pontos. A política cultural estatal reconhece os direitos indígenas internacional e nacionalmente e tem o dever de protegê-los. Entretanto, os instrumentos para tal funcionam mal. Um destes, o orçamento federal, voltado às açóes de proteção e garantia de direitos, é insuficiente, declina de forma sistemática e, ainda, não respeita algumas das premissas constitucionais mais básicas.

No que se refere ao conjunto de ações transversais, a coordenação de açóes que garantam princípios constitucionais com direito ao território, ao meio ambiente, à saúde e à educação, além de segurança alimentar, é parte do problema de organização de agenciamentos pragmáticos na defesa não apenas de PIs, mas também de modelos de desenvolvimento inclusivos, que levem em conta os desafios globais no que toca à preservação ambiental, à sustentabilidade, à mudança de padrôes da matriz energética, às novas tecnologias e aos graus mais elevados de equidade social.

Os desafios de regularização e proteção territorial dos PIs permanecem e somam-se à necessidade de integração de açôes e recursos de órgãos federais, estaduais, municipais e demais organismos da sociedade civil. Esses órgãos devem responder de forma efetiva às transformaçóes econômicas sociais e políticas de forma compatível com os direitos indígenas.

A redução e a imprevisibilidade de recursos, bem como sua descontinuidade, é um sintoma das opçóes administrativas e políticas. As dificuldades da gestão territorial, ambiental e da saúde intercultural são exacerbadas pelas contingências da gestão financeiro-orçamentária e impactam de forma significativa nas vulnerabilidades enfrentadas pela questão territorial; a questão da terra ou do território é estruturante para os direitos dos PIs e que repercute globalmente na garantia de seus direitos.

É possível assinalar a importância da adoção de um procedimento metodológico para o programa 2065, outro que o seguiria ou, ainda, outro para as políticas indigenistas, que considere objetivos, iniciativas e açôes de outros órgãos setoriais. O programa náo oferece completa visibilidade ao conjunto de açóes do governo federal, especialmente os da educação e das políticas de segurança alimentar e nutricional. É positivo que o programa incorpore a totalidade de açōes setoriais voltadas para as questóes indígenas, construindo procedimentos de monitoramento tanto pela Funai quanto pelo CNPI e instrumentos de gestão e implementação participativa das açóes. 
Os governos brasileiros têm envidado esforços, mas estes não têm se mostrado suficientes para garantir compromissos constitucionais de respeito aos modos de vida, justiça e dignidade dos povos indígenas e, mais importante, têm falhado no compromisso de demarcar e proteger as TIs, conforme previsto no art. 231 da $\mathrm{CF} / 1988$. O fortalecimento de capacidades administrativas e funcionais dos órgãos governamentais e a ampliação da participação dos PIs por meio de seus órgãos representativos e de consulta, como o CNPI e as conferências indígenas, deveriam ganhar transparência como objetivos do programa e método de governo.

Por fim, resta enfatizar a obrigatoriedade dos governos na realização da consulta livre, prévia e informada aos povos indígenas em todos os atos administrativos que venham os afetar. A participação social dos PIs na elaboração e na execução de políticas públicas que ganhem execução específicas em seus contextos culturais é assegurada não apenas no âmbito individual, como, sobretudo, no coletivo.

A formulação conjunta, baseada em métodos interculturais, é um caminho a ser trilhado na superação de políticas indigenistas integracionistas e na consequente adequação governamental aos atuais ditames de direitos humanos internacionais. Não parece possível fazer uma leitura dos instrumentos de planejamento sem considerar as complexidades ideológicas, os interesses e a força - ou fragilidade das instituiçốes.

A não efetividade dos direitos humanos dos povos indígenas coloca inumeráveis desafios para a ação. O principal destes é saber como agir; o que é possível ser feito. Nesse caso, o desafio é construir e remodelar instrumentos administrativos e legislativos, de forma a ajustá-los para avançar na efetivação de direitos. Sempre é possível avançar com recursos restringidos, mas o ideal é garantir mínimos que serão amplificados em momentos em que as restriçôes fiscais sejam afrouxadas. Muito se avançou, e é necessário preservar conquistas; entre estas, as legais e de reconhecimento dos PIs e dar novos passos, que seriam náo apenas associar as políticas indígenas a ativos importantes, como a preservação ambiental, mas também ligar a garantia dos direitos indígenas aos da coletividade. Parafraseando Edgard Roquette-Pinto, o problema brasileiro não são os povos indígenas, mas a falta de conhecimento de suas especificidades culturais da população, que se fixa em uma imagem super-real do índio ou nas amarguras do racismo.

\section{REFERÊNCIAS}

BANIWA, G. S. L. O índio brasileiro: o que você precisa saber sobre os povos indígenas no Brasil de hoje. Brasília: UNESCO; MEC, 2006. (Série Vias dos Saberes, n. 1).

BRASIL. Constituição da República Federativa do Brasil de 1988. Brasília: Assembleia Nacional Constituinte, 1988. 
. Ministério da Saúde. Indicadores de vigilância em saúde segundo a variável raça/cor. Boletim Epidemiológico, Brasília, v. 48, n. 4, p. 1-35, 2017.

CANOTILHO, J. J. G. Estado de direito. Lisboa: Gradiva, 1999.

COURTIS, C. Anotaçôes sobre a aplicação da Convenção 169 da OIT sobre povos indígenas por tribunais da América Latina. SUR: Revista Internacional de Direitos Humanos, São Paulo, ano 6, n. 10, p. 52-81, jun. 2009.

. Dimensiones conceptuales de la protección legal contra discriminación. Revista Derecho del Estado, n. 24, p. 105-141, jul. 2010.

DI PIETRO, M. S. Z. Discricionariedade técnica e discricionariedade administrativa. Redae: revista eletrônica de direito administrativo econômico, Salvador, n. 9, fev./ abr. 2007. Disponível em: <https://is.gd/uJ509d>.

Discricionariedade administrativa na Constituição de 1988. 3. ed. São Paulo: Atlas, 2012a.

. Da constitucionalização do direito administrativo: reflexos sobre o princípio da legalidade e a discricionariedade administrativa - atualidades jurídicas. Revista do Conselho Federal da Ordem dos Advogados do Brasil (OAB), Belo Horizonte, ano 2, n. 2, p. 83-106, jan./jun. 2012b. Disponível em: <https://is.gd/OrnR5R>.

. Limites do controle externo da administração pública: ainda é possível falar em discricionariedade administrativa? Gen Jurídico, 22 mar. 2016. Disponível em: <https://bit.ly/2NykOhu>. Acesso em: 17 jan. 2020.

ENTREVISTA: Gersem José dos Santos Luciano - Gersem Baniwa (Entrevistadora: Maria Aparecida Bergamaschi). Revista História Hoje, v. 1, n. 2, p. 127-148, 2012.

FAUNDES, J. J. Derecho fundamental a la identidad cultural de los pueblos indígenas: un nuevo paradigma en la defensa penal indígena en Chile frente al Estado de derecho hegemónico. Izquierdas, Santiago, n. 45, p. 51-78, 2019 a.

. El derecho fundamental a la identidad cultural de los pueblos indígenas: un derecho matriz y filtro hermenéutico para las constituciones de América Latina: la justificación. Revista Brasileira de Políticas Públicas, v. 9, n. 2, p. 512-532, 2019b. Disponível em: <https://is.gd/8q1cSj>.

FURTADO, E. B. M. A constitucionalização das finanças públicas no Brasil: devido processo orçamentário e democracia. Rio de Janeiro: Editora Renovar, 2010. IBGE - INSTITUTO BRASILEIRO DE GEOGRAFIA E ESTATÍSTICA. Censo Demográfico 2010: características gerais dos indígenas - resultados do universo. Rio de Janeiro: IBGE, 2010. 
MOSELEY, C. (Ed.). Atlas de las lenguas del mundo en peligro. 3. ed. Paris: UNESCO, 2010. Disponível em: <https://is.gd/B2hgVq>.

OIT - ORGANIZAÇÁO INTERNACIONAL DO TRABALHO. Convençáo no 169 da OIT sobre Povos Indígenas e Tribais. Genebra: OIT, 7 jun. 1989.

ONU - ORGANIZAÇÃO DAS NAÇÓES UNIDAS. Declaração Universal dos Direitos Humanos In: ASSEMBLEIA GERAL DA ONU. Preâmbulo da declaraçáo universal dos direitos humanos, adotada e proclamada pela Assembleia Geral das Naçóes Unidas (resoluçáo 217 A III). Paris: ONU, 10 dez. 1948.

Declaração das Naçóes Unidas sobre os Direitos dos Povos Indígenas. Rio de Janeiro: ONU, 2008. Disponível em: <https://is.gd/PAd8By>.

RAMOS, A. R. O índio hiper-real. Revista Brasileira de Ciências Sociais, São Paulo, v. 28, n. 10, p. 5-14, 1995.

RIBEIRO, D. Os índios e a civilização: a integração das populaçôes indígenas no Brasil moderno. Rio de Janeiro: Civilização Brasileira, 1970.

SANTOS, E. V. et al. As inovaçóes jurídicas no PPA 2012-2015. In: CARDOSO JUNIOR, J. C.; SANTOS, E. V. (Orgs.). PPA 2012-2015: experimentalismo institucional e resistência burocrática. Brasília: Ipea, 2015.

SILVA, F. A. B.; LUNELLI, I. C. Estudo sobre orçamento indigenista federal: desafios e limitaçóes aos direitos e políticas públicas voltadas aos povos indígenas no Brasil. Brasília: Ipea, 2019.

TRAVASSOS, M. Z. O controle do orçamento à luz dos direitos humanos. Brasília: Penélope Editora, 2014.

TYLOR, E. B. Primitive culture researches into the development of mythology, philosophy, religion, language, art, and custom. 4. ed. London: John Murray, 1903. Disponível em: <https://is.gd/mX3kAR>.

VIEIRA, F. S.; PIOLA, S. F. Restos a pagar de despesas com açóes e serviços públicos de saúde da uniáo: impactos para o financiamento federal do Sistema Único de Saúde e para a elaboração das contas de saúde. Brasília: Ipea, 2016. (Texto para Discursão, n. 2225).

\section{BIBLIOGRAFIA COMPLEMENTAR}

CATAPANI, M. F. A discricionariedade do Poder Executivo na elaboração do Projeto de Lei Orçamentária Anual. In: CONTI, J. M.; SCAFF, F. F. (Coords.). Orçamentos públicos e direito financeiro. São Paulo: Ed. Revista dos Tribunais, 2011. 
CORREAS, O. Acerca de los derechos humanos: apuntes para un ensayo. 2. ed. Ciudade de Mexico: Ediciones Coyoacán, 2015.

HOBBES, T. L. Matéria, forma e poder de um Estado eclesiástico e civil. Tradução: João Paulo Monteiro, Maria Beatriz Nizza da Silva. 3. ed. São Paulo: Abril Cultural, 1983. p. 69-70.

MELLO, C. $\mathbf{6 0}^{\circ}$ aniversário da Declaraçáo Universal dos Direitos da Pessoa Humana. Brasília: STF, 2008. Disponível em: <https://is.gd/kv2G6L>. Acesso em: 28 jan. 2020.

ONU - ORGANIZAÇÃO DAS NAÇÔES UNIDAS; CEPAL - COMISSÃO ECONÔMICA PARA A AMÉRICA LATINA E O CARIBE. Os povos indígenas na América Latina: avanços na última década e desafios pendentes para a garantia de seus direitos. Santiago do Chile: ONU; CEPAL, 2015.

TORRES, R. L. Curso de direito financeiro e tributário. 8. ed. Rio de Janeiro: Editora Renovar, 2001.

VIEIRA, O. V. A desigualdade e a subversão do Estado de direito. In: SARMENTO, D.; IKAWA, D. E.; PIOVESAN, F. (Coords.). Igualdade, diferença e direitos humanos. Rio de Janeiro: Lumen Juris, 2010. 
APÊNDICE A

\section{PLANO PLURIANUAL 2000-2003}

Programa 0150 - Etnodesenvolvimento das Sociedades Indígenas

Ação

262981115 - Aquisição de Veículos para Transporte Escolar nas Comunidades Indígenas

302021131 - Construção de Casas de Estudantes Indígenas

302021712 - Capacitação de Indígenas e Técnicos de Campo para o Desenvolvimento de Atividades Autossustentáveis em Terras Indígenas

302021725 - Construção de Postos Indígenas

302021735 - Edição e Distribuição de Material Didático para Educação Indígena

302021741 - Recuperação e Equipamento de Postos Indígenas

221012178 - Assistência Técnica em Áreas Indígenas

302022699 - Assistência Jurídica às Comunidades Indígenas

302022711 - Fomento às Atividades Produtivas em Áreas Indígenas

302022713 - Funcionamento das Escolas nas Comunidades Indígenas

302022714 - Funcionamento de Casas de Estudantes Indígenas

302022715 - Funcionamento de Postos Indígenas

262983089 - Capacitação de Professores para a Educação Indígena

302023810 - Capacitação de Professores das Escolas Indígenas

362113869 - Implantação, Modernização e Adequação de Unidades de Saúde para Atendimento à Populaçáo Indígena

362113913 - Saneamento Básico em Comunidades Indígenas

262984047 - Distribuição de Material Didático para a Educação Indígena

302026057 - Assistência Social para Indígenas

302026059 - Assistência a Estudantes Indígenas Fora de suas Aldeias 
362116501 - Atendimento à Saúde em Distritos Sanitários Especiais Indígenas (DSEI)

302027313 - Adequação da Infraestrutura dos Postos Indígenas

Programa 0151 - Território e Cultura Indígenas

Ação

302021714 - Capacitação de Técnicos em Assuntos Fundiários e Antropológicos

302021738 - Edição e Distribuiçãoo de Material da Cultura Indígena

302021742 - Estudos de Impacto Ambiental de Empreendimentos em Terras Indígenas

302021808 - Promoção de Eventos para a Revitalização do Patrimônio Cultural Indígena

302021812 - Promoção de Eventos sobre Educação Ambiental em Terras Indígenas

302021818 - Recuperação Ambiental em Terras Indígenas

302022235 - Demarcação e Aviventação de Terras Indígenas

302022630 - Preservação de Acervos Culturais

302022707 - Fiscalização de Terras Indígenas

302022724 - Pesquisa sobre as Sociedades Indígenas

302022814 - Funcionamento do Museu do Índio

302024276 - Identificação e Revisão de Terras Indígenas

302024390 - Regularização Fundiária de Terras Indígenas

302024524 - Localização e Proteção de Índios Isolados e de Recente Contato

302026487 - Organização, Preservação e Divulgação dos Acervos Documentais sobre Índios e a Política Indigenista 
APÊNDICE B

\section{PLANO PLURIANUAL 2012-2015}

Programa 2065 - Proteção e Promoção dos Direitos dos Povos Indígenas

\section{1) Objetivo}

300000943 - Garantir aos povos indígenas a plena ocupação e gestão de suas terras, a partir da consolidaçáo dos espaços e definição dos limites territoriais, por meio de açôes de regularização fundiária, fiscalização e monitoramento das terras indígenas (TIs) e proteçâo dos índios isolados, contribuindo para a redução de conflitos e para ampliar a presença do Estado democrático e pluriétnico de direito, especialmente em áreas vulneráveis.

Metas

03H6 - Constituição de oito reservas indígenas para atender aos casos de maior gravidade de povos indígenas confinados territorialmente ou desprovidos de terras.

03H7 - Delimitação de 56 terras indígenas.

03H8 - Desenvolvimento, implantação e disponibilização de Sistema de Informação Geográfica das Terras Indígenas.

03H9 - Emissão de 45 portarias declaratórias da posse indígena de terras tradicionalmente ocupadas.

03HA - Estabelecimento de acordos de cooperação técnica para o combate ao desmatamento, a incêndios florestais e a outros ilícitos nas terras indígenas.

03HB - Estruturação de cinco unidades descentralizadas da Fundação Nacional do Índio (Funai), especializadas no serviço de monitoramento territorial e na proteção de índios isolados, para atuarem em terras indígenas localizadas na faixa de fronteira do Brasil com Peru, Colômbia e Venezuela.

$03 \mathrm{HC}$ - Estruturação de doze frentes de proteção etnoambiental para fiscalizar e monitorar 23 terras indígenas com referências de povos indígenas isolados confirmadas.

03HD - Estudos e localização de oito novas referências de povos indígenas isolados, com incremento de $30 \%$ sobre as 33 referências já confirmadas.

03HF - Fiscalização e monitoramento efetivo de 210 terras indígenas, com incremento de $30 \%$ das terras indígenas fiscalizadas sistematicamente. 
03HG - Homologação da demarcação de quarenta terras indígenas.

03HH - Implementação do Programa de Capacitação em Proteção às Terras Indígenas.

03HI - Implementação do Projeto de Monitoramento Espacial das Terras Indígenas.

$03 \mathrm{HJ}$ - Indenizar a extrusão de ocupantes de boa-fé de quarenta terras indígenas.

03HK - Inserção do componente indígena na Política Nacional de Fronteira.

03HL - Inserção do componente indígena na Política Nacional de Mudanças Climáticas.

03HM - Promover o monitoramento permanente nas vinte terras indígenas com maior índice de desmatamento.

$03 \mathrm{HN}$ - Redução de ilícitos socioambientais nas terras indígenas, por meio de ações articuladas de fiscalização e etnodesenvolvimento.

03HP - Regulamentação do poder de polícia da Funai.

\section{Iniciativas}

0403 - Articular a garantia da participação indígena nos processos de discussão e regulamentação da Redução de Emissôes por Desmatamento e Degradação Florestal (REDD+) e de outros mecanismos relacionados a mudanças climáticas e pagamento por serviços ambientais.

0406 -- Fiscalizar as terras indígenas por meio de diagnósticos e açôes articuladas de extrusão, vigilância, combate e prevenção de ilícitos e monitoramento territorial, espacial e ambiental.

0408 - Localizar e proteger povos indígenas isolados.

040A - Realizar a delimitação, a demarcação e a regularização fundiária de terras indígenas tradicionais e de áreas a serem reservadas aos povos indígenas.

040B - Regulamentar o poder de polícia da Funai.

\section{2) Objetivos}

300000945 - Implantar e desenvolver a Política Nacional de Gestão Ambiental e Territorial de Terras Indígenas (PNGATI), por meio de estratégias integradas e participativas, com vistas ao desenvolvimento sustentável e à autonomia dos povos indígenas. 


\section{Metas}

03HU - Coordenar e promover, em articulação com instituições de governo, indígenas e não governamentais, a I Conferência Nacional de Gestão Ambiental e Territorial de Terras Indígenas.

03HV - Coordenar e promover, em articulação com instituiçôes do governo, indígenas e não governamentais, o Ano Internacional da Sociobiodiversidade Indígena.

03HY - Coordenar e promover, em articulação com instituições parceiras, seis chamadas públicas de projetos com foco na conservação da agrobiodiversidade em terras indígenas.

03HZ - Coordenar, promover, apoiar e consolidar, em articulação com instituiçôes parceiras, diagnósticos da agrobiodiversidade local e valorização de responsáveis por sua guarda e circulação, entre os povos Guarani, Khraô, Paresi e Xavante.

03I - Coordenar, promover e apoiar a estruturaçáo de oito arranjos produtivos locais, com base em cadeias de valor, visando ao estabelecimento de marcas coletivas, certificação de produtos indígenas, acesso aos mercados e geração de renda.

0314 - Coordenar, promover e apoiar, em articulação com instituições e órgãos parceiros, a elaboração e a implementação de quatro acordos e planos participativos, visando à transição para atividades produtivas sustentáveis em terras indígenas.

03I5 - Coordenar, promover e apoiar, em articulação com instituiçôes parceiras, a conservação da agrobiodiversidade das terras indígenas, por meio da realização de sete eventos de intercâmbio de insumos e práticas tradicionais da agricultura e alimentação indígenas.

03 I6 - Garantir a participação indígena nos processos de licenciamento ambiental de empreendimentos.

$03 \mathrm{I} 7$ - Implantar oitenta projetos de gestão ambiental nas terras indígenas.

03 I8 - Implantar processos e projetos de etnodesenvolvimento em 678 terras indígenas.

03 I9 - Implementar 51 planos de gestão ambiental e territorial de terras indígenas.

03IA - Implementar cinco centros de formação indígena.

03IB - Implementar cursos de formação continuada para trezentos gestores não indígenas e trezentos gestores indígenas para qualificar as ações de gestão ambiental e territorial de terras indígenas. 
03IC - Realizar duas publicaçóes de materiais didáticos sobre licenciamento ambiental e comunidades indígenas e gestão ambiental e territorial de terras indígenas, com vistas à informação qualificada de órgãos públicos, povos indígenas e parceiros.

03ID - Regulamentar a atuação da Funai como interveniente no componente indígena dos processos de licenciamento ambiental de empreendimentos.

03IE - Regulamentar o etnoturismo e o ecoturismo em terras indígenas de forma sustentável.

\section{Iniciativas}

040R - Apoiar o desenvolvimento sustentável dos povos indígenas, visando à manutenção e à disponibilidade dos recursos naturais em seus territórios, necessários à sua reproduçáo cultural e à segurança alimentar e nutricional, bem como incentivar o fortalecimento das organizaçôes comunitárias indígenas, qualificando e ampliando o acesso às políticas públicas e a participação nos espaços de gestão pública.

040S - Articulação e promoção da economia criativa de povos e comunidades indígenas, por meio da identificação de arranjos produtivos locais, do estímulo à formação de competências criativas, a produção, difusão, distribuição, consumo e fruição de produtos e de sua inserção nos mercados nacional e internacional, de modo a promover a diversidade cultural, a geração de renda e a inclusão social dos povos indígenas, respeitadas suas especificidades e sua autonomia.

040T - Articular a qualificação dos serviços de assistência técnica e extensão rural em áreas indígenas para a gestão de seus territórios e estruturação dos processos de produção e acesso a mercados diferenciados.

040U - Articular a qualificação e adequação da Declaração de Aptidão ao Programa Nacional de Fortalecimento da Agricultura Familiar (Pronaf), a ampliação de entidades emissoras e a capacitação das comunidades, para garantir o acesso dos povos indígenas às políticas de desenvolvimento rural sustentável.

040X - Articular parceria para apoio e fomento a projetos produtivos voltados para o autoconsumo e a inclusão produtiva, com vistas a garantir a segurança alimentar e nutricional dos povos indígenas.

040Y - Articular parceria para a qualificação de acordos de pesca, cadeias de valor do pescado e acesso diferenciado dos povos indígenas às políticas de desenvolvimento sustentável da pesca.

040Z - Consolidar parceria com a Empresa Brasileira de Pesquisa Agropecuária (Embrapa) para qualificação de processos e projetos voltados para a conservação da agrobiodiversidade, com foco nas sementes tradicionais. 
0411 - Participação em fóruns e conselhos de políticas públicas para a implementação da Política Nacional de Gestão Ambiental nas Terras Indígenas e inserção do desenvolvimento sustentável, com ênfase no etnodesenvolvimento, nas políticas públicas voltadas aos povos indígenas.

0413 - Promover a gestão ambiental participativa das terras indígenas, por meio de planos, projetos e estruturação da capacidade de gestão etnoambiental, bem como atuar como interveniente nos processos de licenciamento ambiental de empreendimentos que possuam significativo potencial de impacto sobre as terras e os povos indígenas.

0414 - Promover articulação com instituiçốes federais visando à ampliação do acesso diferenciado das comunidades indígenas aos programas e às políticas públicas de desenvolvimento rural sustentável, bem como à conservaçáo da agrobiodiversidade e à garantia da segurança alimentar e nutricional.

0415 - Promover o etnodesenvolvimento, por meio da coordenação, apoio e fomento a processos e projetos, com ênfase na gestão e no uso sustentável dos recursos naturais das terras indígenas, na geração de renda e na garantia da segurança alimentar e nutricional dos povos indígenas.

0416 - Rever a regulamentação da comercialização de produtos indígenas feitos a partir do uso de insumos de origem animal.

\section{3) Objetivos}

300000948 - Promover o acesso amplo e qualificado dos povos indígenas aos direitos sociais e de cidadania, por meio de iniciativas integradas e articuladas em prol do desenvolvimento sustentável desses povos, respeitando sua identidade social e cultural, seus costumes e tradiçóes e suas instituiçóes.

\section{Metas}

03IJ - Apoiar a realização de 150 eventos (seminários, reunióes, cursos etc.) das organizaçôes indígenas nas diversas regiôes do país, em suas iniciativas próprias e em processos de formação, para promoção de seus direitos sociais e qualificação das políticas públicas.

03IM - Contribuir para o alcance da meta nacional de erradicaçáo do sub-registro civil de nascimento.

$03 \mathrm{IO}$ - Definição de legislação específica com diretrizes para a política de implantação de programas e projetos de infraestrutura para povos indígenas e seus territórios, desenvolvidos pelos diferentes órgãos e entes federados.

03IP - Executar 10 mil obras de infraestrutura comunitária ou de habitaçóes em terras indígenas. 
03IQ - Implantação de sistema interligado aos canais remotos do Ministério da Previdência Social (MPS), nas 36 coordenaçôes regionais da Funai, adequando e potencializando o acesso aos direitos previdenciários dos povos indígenas.

03IS - Instituição de acordo de cooperação que garanta o respeito às formas de nominação próprias dos povos indígenas por parte dos registradores nas diferentes regiốes do país.

03IV - Propor adequações das políticas de assistência social, com foco na qualificação das redes e equipamentos sociais (centro de referência de assistência social - Cras, conselhos tutelares etc.), para o atendimento dos povos indígenas, inclusive criando mecanismos de acolhimento e escuta para o atendimento a grupos indígenas que se instalam em ambientes urbanos.

03IW - Realizar treze projetos de substituição de alimentos industrializados da cesta básica, distribuída em aldeias com deficit de produção, por outros itens produzidos por comunidades indígenas e mais condizentes com o padrão alimentar indígena.

03IX - Realizar quatro pesquisas acerca do funcionamento de sistemas alimentares próprios tradicionais de povos indígenas.

03RL - Promoção de Eventos de Capacitação voltados a prevenção à violência contra a criança indígena.

\section{Iniciativas}

0421 - Apoio nas ações de transversalização da temática de gênero e geracional na implementação e construção de políticas públicas direcionadas aos povos indígenas.

0422 - Articular a adequação do conjunto de políticas públicas e programas de desenvolvimento social e segurança alimentar e nutricional para povos indígenas, considerando as especificidades étnico-culturais e territoriais e as perspectivas de gênero e geracional destes povos.

0423 - Articular a promoção da adequação de políticas públicas, programas e açóes de combate ao uso de álcool e drogas, considerando as especificidades étnico-cultural e territoriais dos povos indígenas.

0424 - Atuar em cooperação entre os países que fazem fronteira com o Brasil, com o intuito de regulamentar e promover políticas de proteçáo dos direitos sociais dos povos indígenas.

0425 - Definir estratégias articuladas entre Estado, sociedade civil e organizaçôes indígenas no desenvolvimento de açôes e programas de infraestrutura voltados para os povos indígenas que promovam a sua autonomia, o usufruto exclusivo e a proteçáo de seus territórios. 
0426 - Instituir mecanismos de avaliação da situação de segurança alimentar e nutricional dos povos indígenas, incluindo o monitoramento de seus determinantes diversos, orientando o desenvolvimento de políticas e açóes norteadas pelo conceito de etnodesenvolvimento, com foco em áreas e grupos vulneráveis.

0428 - Promover o acesso às políticas de proteção e promoção social dos povos indígenas, através da gestão compartilhada, da articulação intersetorial com participação indígena e da adequação das políticas sociais do Estado brasileiro, considerando-se as especificidades étnico-culturais e territoriais e as perspectivas de gênero e geracional destes povos.

0429 - Promover, por meio de articulação intersetorial, a identificação de tecnologias adequadas de captação e armazenamento de água para consumo humano e fomento de atividades produtivas dos povos indígenas.

\section{4) Objetivos}

300000949 - Preservar e promover o patrimônio cultural dos povos indígenas por meio de pesquisa, documentação, divulgação e diversas açóes de fortalecimento de suas línguas, suas culturas e seus acervos, prioritariamente aqueles em situação de vulnerabilidade.

\section{Metas}

03IY - Apoiar 168 projetos de atividades e eventos culturais, em conjunto com as unidades regionais da Funai, visando apoio à produção social e à transmissão de saberes, bem como à comercialização e à distribuição de bens materiais.

03IZ - Capacitar 160 pesquisadores indígenas em métodos e técnicas de registro de suas línguas e aspectos de suas culturas e gestão de seus patrimônios.

03J0 - Elaborar o marco legal de proteção dos conhecimentos tradicionais e expressóes culturais indígenas.

03J1 - Implementar o Plano Setorial de Culturas Indígenas.

03J2 - Pesquisar e documentar trinta línguas, culturas e acervos de povos indígenas no país.

03J3 - Promover, nas açóes desenvolvidas e nos projetos apoiados com recursos da ação de proteção, promoção, fortalecimento e valorização das culturas indígenas, a participação direta de indígenas nos estudos sobre suas culturas, bem como na elaboração e gestão de projetos culturais que envolvam diretamente as suas comunidades.

03J4 - Registrar, preservar e difundir 160 mil itens do acervo documental sob a guarda do Museu do Índio e de suas unidades descentralizadas. 


\section{Iniciativas}

042A - Apoiar projetos e eventos que contribuam para a valorização cultural dos povos indígenas.

Ação

421012 C69 - Proteção, Promoção, Fortalecimento e Valorização das Culturas Indígenas.

302028635 - Promoção do Patrimônio Cultural dos Povos Indígenas.

302028635 - Preservação Cultural dos Povos Indígenas.

\section{Iniciativas}

042B - Desenvolvimento de estudos, projetos e oficinas de pesquisa e documentação de línguas, culturas e acervos, com a capacitação de pesquisadores indígenas.

042C - Implementação do registro, preservação e difusão do conhecimento pertencente aos povos indígenas, prioritariamente em risco de desaparecimento e sob a guarda do Museu do Índio e suas unidades descentralizadas, visando torná-lo acessível à sociedade brasileira em geral e, em particular, às sociedades indígenas.

\section{5) Objetivos}

300000950 - Articular as políticas públicas implementadas pelos órgãos do governo federal junto aos povos indígenas, compatibilizando suas estratégias de regionalização e sistemas de informação de modo a otimizar seus resultados, com desdobramentos territoriais.

Metas

03J5 - Elaboração e implementação de 36 planos regionais indigenistas articulados entre as diversas instituições governamentais com atuação no território.

03J7 - Implementação do Conselho Nacional de Política Indigenista.

03J8 - Integração dos sistemas de informação sobre povos indígenas.

\section{Iniciativas}

042D - Integrar o planejamento e a execução das açóes indigenistas do Estado brasileiro por meio da implementação de planos regionais indigenistas.

\section{6) Objetivos}

300000951 - Promover e proteger os direitos dos povos indígenas de recente contato por meio da implementação de iniciativas que considerem sua situação de extrema vulnerabilidade física e cultural. 


\section{Metas}

03J9 - Formulação da política de proteção e promoção aos povos indígenas de recente contato.

03JA - Implementação da política de proteção e promoçáo dos povos de recente contato em onze terras indígenas jurisdicionadas às frentes de proteção etnoambiental da Funai.

03JB - Monitoramento e avaliação de ações governamentais e da sociedade civil nas onze terras indígenas com presença de povos indígenas de recente contato jurisdicionadas às frentes de proteção etnoambiental da Funai.

03JC - Realização de estudos e diagnósticos para orientar as ações governamentais e náo governamentais junto aos povos indígenas de recente contato.

\section{Iniciativas}

042E - Articular com a Secretaria Especial de Saúde Indígena do Ministério da Saúde (Sesai/MS) ações de atenção à saúde que contemplem as especificidades da política de proteção e promoção dos povos indígenas de recente contato.

042F - Formular e implementar política de proteção e promoção aos povos indígenas de recente contato, bem como coordenar, monitorar e articular as açóes governamentais e da sociedade civil junto a esses povos.

\section{7) Objetivos}

300000952 - Promover o direito dos povos indígenas a uma educação diferenciada em todos os níveis e a articulação e o acompanhamento das políticas públicas de educação, com vistas à autonomia e à sustentabilidade desses povos, por meio da valorização da cultura e das suas formas de organização social.

\section{Metas}

03JD - Apoiar financeiramente o estudante indígena fora da aldeia.

03JE - Apoiar técnica e financeiramente cursos de formação de professores indígenas.

03J H - Elaborar, institucionalizar e aplicar instrumentos de acompanhamento das ações de educação escolar indígena e monitoramento das políticas públicas de educação em todos os níveis.

03JI - Elaborar subsídios na perspectiva de construção de um sistema próprio de educação escolar indígena.

03J - Formar técnicos e representantes indígenas para o acompanhamento e o exercício do controle social frente às ações e às políticas de educação escolar indígena. 
03JK - Implantar processos de discussão para implementação dos cursos de ensino médio e ensino médio integrado a partir das demandas apresentadas pelas comunidades indígenas.

\section{Iniciativas}

042G - Promover açóes institucionais e a participação dos povos indígenas na elaboração, implementação e acompanhamento das políticas públicas de educação em todos os níveis, com vistas à valorização de suas culturas, suas línguas e seu conhecimento tradicionais e à promoçáo da autonomia e da sustentabilidade dos povos indígenas.

Ação

302022713 - Fomento e valorização dos processos educativos dos povos indígenas.

Iniciativas

$042 \mathrm{H}$ - Regulamentar os instrumentos de avaliação e acompanhamento das ações de educação indígenas.

\section{8) Objetivos}

300000953 - Promover a consolidação da reestruturação organizacional da Funai com vistas ao seu aperfeiçoamento institucional, por meio da implementação de projetos voltados a estruturação e melhoria dos processos de trabalho, capacitação intensiva de recursos humanos, suporte tecnológico e infraestrutura física.

Metas

03jl - adequação da infraestrutura física e de tecnologia de informação e comunicação da sede e das coordenaçôes regionais da Funai.

03JM - Capacitar e informar 100\% dos representantes indígenas dos comitês regionais da Funai quanto ao conjunto das políticas públicas.

03JN - Desenvolvimento e implantação de um sistema de informaçóes gerenciais e sobre a realidade indígena.

03JO - Desenvolvimento e implementação de um programa de capacitação de recursos humanos para a Funai com foco na melhoria de gestáo.

03JP - Mapeamento e redesenho dos processos de trabalho da Funai.

\section{Iniciativas}

042I - Construção do edifício sede da Funai. 
042J - Formação e capacitação de indígenas para atuação nos comitês regionais e outros colegiados em gestão compartilhada de políticas públicas.

042k - Melhoria e ampliaçáo da capacidade de execução e de prestação de serviços da Funai.

\section{9) Objetivos}

360000962 - Implementar o Subsistema de Atenção à Saúde Indígena, articulado com o SUS, baseado no cuidado integral, observando as práticas de saúde e as medicinas tradicionais, com controle social, garantindo o respeito às especificidades culturais.

\section{Metas}

$03 \mathrm{KJ}$ - Ampliar a cobertura vacinal para $80 \%$ da população indígena até 2015, conforme o calendário de imunização específico estabelecido pelo Ministério da Saúde.

03KK - Estabelecer até 2015, contratos de ação pública com os estados e municípios com serviços de média e alta complexidade na área de abrangência dos 34 distritos sanitários especiais indígenas.

03KL - Implantar a estratégia Rede Cegonha nos 34 distritos sanitários especiais indígenas.

03KM - Implantar, até 2015, sistemas de abastecimento de água em 1.220 aldeias com população a partir de cinquenta habitantes.

$03 \mathrm{KN}$ - Realizar a V Conferência Nacional de Saúde Indígena.

$03 \mathrm{KO}$ - Implantar, reformar e estruturar as 68 casas de saúde indígenas (Casais) até 2015.

\section{Iniciativas}

0443 - Estruturação do Subsistema de Atenção à Saúde Indígena (Sasisus).

369013869 - Estruturação de Unidades de Saúde para Atendimento à População Indígena.

0444 - Implementação de modelo de atenção integral centrado na linha do cuidado, com foco na família indígena, na integralidade e intersetorialidade das açóes, na participação popular e na articulação com as práticas e as medicinas tradicionais.

$3690120 \mathrm{YP}$ - Promoção, proteção, vigilância, segurança alimentar e nutricional e recuperação da saúde indígena.

369016140 - Vigilância e segurança alimentar e nutricional dos povos indígenas. 
369018743 - Promoção, vigilância, proteção e recuperação da saúde indígena.

0445 - Implementação de sistema de abastecimento de água, melhorias sanitárias e manejo de resíduos sólidos nas aldeias, em quantidade e qualidade adequadas, considerando critérios epidemiológicos e as especificidades culturais dos povos indígenas. 


\section{CAPÍTULO 6}

\section{TRABALHO E RENDA ${ }^{1}$}

\section{APRESENTAÇÃO}

A economia brasileira encerrou o ano de 2019 mais uma vez sob um cenário bastante delicado. Após a recessão observada em 2015 e 2016, com queda acumulada de 7 pontos percentuais (p.p.) do produto interno bruto (PIB), o país seguiu pelos três anos seguintes em relativa estagnaçáo econômica, com crescimento na ordem de $1 \%$ ao ano (a.a.), mantendo-se abaixo do nível pré-crise. Essa trajetória de instabilidade possui um rebatimento direto tanto na dinâmica do mercado de trabalho quanto na institucionalidade trabalhista do país. Sobre o mercado de trabalho, não é novidade dizer que as taxas de desemprego seguem em níveis preocupantemente altos, além da erosão de outros indicadores relevantes para esse tipo de análise, como o grau de informalidade e a subutilização da força de trabalho, e da desigualdade de renda, tanto em termos regionais, raciais quanto de gênero.

No tocante à institucionalidade trabalhista, a crise abre espaço para novas pressóes por alteraçóes normativas, de caráter liberalizante, sob a pretensa justificativa de que o aprofundamento da flexibilizaçáo no mercado de trabalho resultaria em uma recuperação mais rápida, sustentada pelo investimento e o emprego na economia brasileira. Esse foi justamente o pano de fundo político que levou à aprovação em tempo recorde de uma ampla reforma da legislaçáo trabalhista em 2017 (Lei no $13.467 / 2017$ ), orientada para a redução de custos do trabalho e maior liberdade dos empregadores na gestão de sua força de trabalho contratada. ${ }^{2}$ Apesar disso, mesmo após dois anos dessas significativas mudanças, não há atualmente qualquer movimentaçáo positiva no mercado de trabalho que possa ser-lhe associada. ${ }^{3}$

Em termos de resultados, o que se tem observado são, na melhor das hipóteses, melhorias na margem em alguns indicadores, acompanhando as taxas residuais de crescimento econômico nos últimos quatro anos. Tal situação surge como fator impeditivo a uma inclusão social mais consistente no país, comprometendo até mesmo o alcance de metas previstas em acordos internacionais - como no caso da Agenda 2030 da Organização das Naçóes Unidas (ONU). Por sua vez, como

1. DOl: http://dx.doi.org/10.38116/bps27/trabalhorenda

2. Para uma análise do processo político que acarretou na reforma trabalhista de 2017 , ver o capítulo sobre trabalho no Boletim Política Social no 26 (Ipea, 2019b).

3. Para análise de primeiros resultados pós-reforma trabalhista de 2017, ver Krein, Oliveira e Filgueiras (2019). 
a dinâmica econômica é determinante na arrecadação fiscal, políticas sociais em geral, e, em particular, as políticas de trabalho e renda, passam a ter seu potencial de cobertura ameaçado devido à instabilidade nos canais de financiamento, inclusive políticas que também são reguladas por acordos internacionais, como o caso do Programa Seguro-Desemprego e programas de ativação do mercado de trabalho.

Com base nessa breve síntese, este capítulo do Boletim Política Social buscou abordar e inter-relacionar aspectos concernentes à atual conjuntura estrutural do mercado de trabalho brasileiro, com metas e acordos internacionais assinados pelo Brasil no campo do trabalho e dinâmica das políticas públicas laborais no Executivo federal. Para tanto, ele está organizado da seguinte forma.

$\mathrm{Na}$ seção 2, aproveitando-se das comemoraçôes referentes ao centenário da Organização Internacional do Trabalho (OIT), em 1919, há um relato sobre o histórico de participação brasileira em uma área relevante de atuação da entidade, que é a disseminação do paradigma de Sistema Público de Emprego (SPE). Além de um acompanhamento histórico das principais convençôes aprovadas, o texto traz ainda o posicionamento do Brasil e os esforços internos para implementar suas diretrizes ao longo do século XX.

Na seção 3, o texto traz uma discussão com base nos chamados Objetivos do Desenvolvimento Sustentável (ODS), mais especificamente o ODS 8, enfocando as metas consensuadas e os principais mecanismos de acompanhamento. Foram listados alguns dos principais desafios presentes na conjuntura atual do mercado de trabalho no Brasil, a partir da evolução recente de indicadores da Pesquisa Nacional por Amostra de Domicílios (PNAD) Contínua, que se colocam para o atingimento das metas propostas pela representação brasileira.

$\mathrm{Na}$ seção 4, são analisados os programas governamentais desempenhados pelo Ministério do Trabalho até 2019, organizados fundamentalmente em torno do Fundo de Amparo ao Trabalhador (FAT), principal mecanismo institucional de financiamento das políticas de emprego no país. A discussão está dividida em duas partes: uma verificação do desempenho orçamentário das distintas açôes previstas no Plano Plurianual (PPA) 2016-2019, aglutinadas no Programa 2071 - Trabalho decente e economia solidária; e algumas consideraçôes ainda que preliminares sobre o desenho aprovado para o PPA 2020-2023.

Por fim, são tecidas algumas considerações conclusivas.

\section{CENTENÁRIO DA OIT E A CONSTRUÇÃO DO SISTEMA PÚBLICO DE EMPREGO NO BRASIL}

O Brasil é signatário de diversos tratados e acordos mediados por distintos organismos internacionais. No âmbito do trabalho, destaca-se a OIT, criada em 1919 
com a assinatura do Tratado de Versalhes, ${ }^{4}$ cujo ambicioso propósito era fomentar "a justiça social e assegurar aos indivíduos um regime de trabalho realmente humano" (Zapata, 2016, p. 17).

Desde os inícios de sua operação, a OIT vem pautando em sua agenda a criação de matrizes propositivas a serem disseminadas em seus países-membros para a construçáo de políticas nacionais. Essas matrizes são projetadas no sentido de favorecer um processo de desenvolvimento econômico que respeite em suas bases os direitos sociais do conjunto dos trabalhadores. As proposiçóes adotadas precisam ser aprovadas em seus encontros anuais - as conferências internacionais do trabalho - para então serem publicadas na forma de convençôes e, em segundo plano, de recomendaçóes. ${ }^{5}$ Após suas publicaçôes, cabe a cada país signatário traçar os meios pelos quais as recomendações serão implementadas em seus territórios.

As convençôes da OIT consistem nos principais instrumentos de regulamentação internacional das relaçôes trabalhistas, estabelecendo padróes mínimos a serem respeitados em termos de direitos dos trabalhadores. ${ }^{6}$ Diferentemente das recomendaçôes (de caráter sugestivo), as convençôes criam obrigaçôes para os Estados que as ratificam, e se submetem ao regime geral dos tratados no direito internacional (Sussekind, 2000; Husek, 2009; Piovesan, 2011).

Ao longo do primeiro centenário de existência da OIT, foram aprovadas e

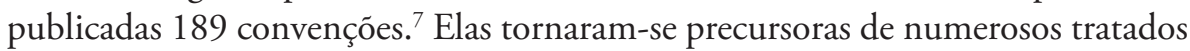
de direitos humanos, dentre os quais estâo a Declaração Universal dos Direitos do Homem, de 1948, e os Pactos das Naçóes Unidas, de 1966.

Um dos campos importantes de regulação via convençôes da OIT refere-se ao enfrentamento do desemprego. Logo em sua Convenção no 2 (sobre o desemprego), aprovada na I Conferência Internacional do Trabalho (ocorrida em 29 de outubro de 1919, em Washington/Estados Unidos), foi proposta a instituição de serviços públicos, controlada por uma autoridade central (art. $2^{\circ}$ ), baseada em dois tipos de programas: intermediação de força de trabalho (agências públicas de colocação) e seguro-desemprego. Os sistemas nacionais de gestão desses programas, que deveriam ter caráter público e participação dos trabalhadores e empregadores em modelos

\footnotetext{
4. 0 Tratado de Versalhes, assinado em 28 de junho de 1919, surgiu como um tratado de paz e foi assinado por um conjunto heterogêneo de países, dentre os quais estavam: Estados Unidos, Grã Bretanha, França, Itália Japão, Bélgica, Bolívia, Brasil (sancionado posteriormente no país pelo Decreto № 3.975, de 11 de novembro de 1919), China, Cuba, Equador, Grécia, Guatemala, Haiti, Hedjaz, Honduras, Libéria, Nicarágua, Panamá, Peru, Bolívia, Portugal, Romênia, Estado Servo-Croata-Sloveno, Sião, Tchecoslováquia e Uruguai. A Alemanha, coagida a assinar após sair como grande derrotada da guerra, foi incluída no grupo das "potências associadas" (Casella, Accioly e Silva, 2010).

5. A primeira Conferência da OIT foi realizada em Washington, ainda em 1919, terminando com a aprovação de seis convenções, cobrindo questões referentes à jornada de trabalho em fábricas, ao desemprego, à proteção da maternidade, ao trabalho noturno para mulheres, à idade mínima e ao trabalho noturno para pessoas jovens em fábricas.

6. As convenções são consideradas tratados multilaterais abertos, de caráter normativo, podendo ser ratificados a qualquer tempo pelos países-membros, sem limite ao número de partes.

7. A aprovação de uma convenção exige um mínimo de dois terços dos votos favoráveis entre os delegados presentes. Todas as convenções e recomendações aprovadas pela OIT podem ser conferidas em: $<$ https://bit.ly/3iCQZKD>.
} 
tripartites de supervisão e acompanhamento, seriam estruturados de acordo com as condiçóes de cada país. Vale ressaltar que, a essa época, já estavam em curso as primeiras experiências de programas de seguro-desemprego no mundo, que aos poucos foram se difundindo. Na América Latina, a primeira experiência (uma das pioneiras no mundo) foi no Uruguai, em 1919.

A atuação da entidade ganhou novo impulso no cenário pós-Segunda Guerra, sobretudo com duas novas e importantes convençóes: a no 88/1948 e a no 102/1952. A primeira avançou nas diretrizes para "serviços de emprego", de caráter público e gratuito, para "colaborar na administração do seguro-desemprego e da assistência-desemprego" (art. 6oㅡ. Ela estabeleceu parâmetros para o enfrentamento do desemprego em um mundo em reconstrução (Borges, 2003), indicando a constituição de uma rede de instituiçóes que intermediassem de forma mais eficiente a relação entre demandantes e ofertantes de força de trabalho. Também previu a manutenção de comissóes consultivas que garantissem a participação de empregadores e trabalhadores nos respectivos canais de decisão.

Tais normativas possibilitaram a estruturaçâo normativa de uma nova institucionalidade de enfrentamento do desemprego e estabilização do mercado de trabalho, sob as bases da economia de mercado e com forte influência do Relatório Beveridge, de 1942. A esta institucionalidade, convencionou-se chamar de SPE, que envolveria uma rede de serviços e benefícios a ser constituída por agentes públicos, dotados das capacidades necessárias que lhes garantissem certa autonomia frente a eventuais mudanças de governo. Com o passar dos anos, outras convenções e recomendaçóes foram aprovadas, dotando o paradigma do SPE de maior densidade normativa e programática.

A representação brasileira teve uma participação ativa na agenda deliberativa da OIT ao longo do século XX. Durante o primeiro centenário da entidade, o Brasil ratificou 96 convençóes (50,7\% do total), atualmente, mantendo-se em vigor oitenta delas, que versam sob diversas áreas e questôes referentes ao universo do trabalho. ${ }^{8}$

A Constituição Federal de 1988 (CF/1988) - $\$ 1$, art. 5o- estabelece que as normas definidoras dos direitos e das garantias fundamentais têm aplicação imediata após sua aprovação, vinculando as entidades públicas e privadas. Por ser o tema trabalho elencado como direito social no caput do art. 6º, os direitos e as garantias a ele atinentes também possuem aplicação imediata (Laraia, 2018).

8. Para um aprofundamento histórico dos processos político-administrativos de ratificação e não ratificação das distintas convenções da OIT, ver: Sussekind (2000); Husek (2009); Piovesan (2011); Zapata (2016); e Laraia (2018). 
Sobre as convenções que tratam especificamente sobre políticas de emprego, o Brasil ratificou cinco das sete principais até então. A primeira delas foi a Convenção no 88/1948, cujo ato de aprovação ocorreu em 1956. O quadro a seguir sintetiza a sequência decisória de incorporação das referidas convençóes orientadoras ao paradigma do SPE.

\section{QUADRO 1}

Convenções da OIT sobre o Sistema Público de Emprego ratificadas pelo Brasil

\begin{tabular}{|l|l|l|}
\hline Ano & Dispositivo & \multicolumn{1}{|c|}{$\begin{array}{c}\text { Ato de aprovação } \\
\text { (Legislativo) }\end{array}$} \\
\hline 1919 & Convenção no 2 & Não foi aprovada \\
\hline 1934 & Convenção no 44 & Não foi aprovada \\
\hline 1948 & Convenção no 88 & Decreto Legislativo no 24/1956 \\
1952 & Convenção no 102 & Decreto Legislativo no 269/2008 \\
1962 & Convenção no 117 & Decreto Legislativo no 65/1966 \\
\hline 1964 & Convenção no 122 & Decreto Legislativo no 61/1966 \\
\hline 1988 & Convenção no 168 & Decreto Legislativo no 89/1992 \\
\hline
\end{tabular}

Fonte: OIT/Brasil. Disponível em: <https://bityli.com/P5jkq>.

Elaboração dos autores.

O quadro 1 demonstra que não existe uma relação de automatismo entre a assinatura da convenção e sua aprovação para inserção no ordenamento jurídico nacional. Porém, para além de sua aprovação, há outro caminho também bastante incerto, que é sua implementação propriamente dita. O processo de implementaçáo da Convenção no $88 / 1948$, por exemplo, passou por diversas tentativas frustradas de leis aprovadas e sem efeito concreto e por propostas de comissóes que não saíram do papel. Somente em 1975, por meio do Decreto no $76.403 / 1975$, foi criado o Sistema Nacional de Emprego (Sine), dentro da estrutura do Ministério do Trabalho. Tal iniciativa se enquadrava como um esforço brasileiro em atender às convençôes da OIT, mais especificamente a Convenção no 88/1948. A missão do Sine consistia em prover serviços para dinamizar o mercado de trabalho no país, tais como: treinamento e aperfeiçoamento de trabalhadores; recolocação laboral; segurança e higiene do trabalho; cadastramento e orientação profissional de imigrantes; e programas especiais visando ao bem-estar do trabalhador.

Ainda assim, uma série de fatores restringiu a capacidade estatal de promover a dinamização do mercado de trabalho com proteção social, de acordo com as diretrizes propostas pela OIT. Primeiramente, havia uma crença de que o crescimento econômico por si só seria capaz de incluir continuamente uma parcela cada vez maior da populaçáo nos arranjos previdenciários, o que justificaria uma manutenção do nível de investimento que assegurasse a dinâmica de expansão 
da economia brasileira nos anos 1970. Com isso, os instrumentos criados para viabilizar as políticas de mercado de trabalho náo receberam muita importância ao longo do período militar. A estratégia de financiamento criada com a instituição do Fundo de Amparo ao Desempregado (FAD) pela Lei no 4.923/1965 se mostrou insuficiente para a construção de um SPE no país. Dessa forma, o Sine ficou praticamente relegado ao ativismo dos governos estaduais. Por sua vez, a criação de um programa nacional de seguro-desemprego, também proposta pela Lei no 4.923/1965, não prosperou.

Por seu turno, as bases do desenvolvimento econômico começaram a desmoronar no fim da década de 1970, primeiro com a elevação abrupta dos preços internacionais do petróleo, que levou a um crescimento bastante significativo dos custos de produção interna, com impactos na inflação; e logo em seguida, com a elevaçáo dos juros pelo governo dos Estados Unidos, levando a uma séria crise da dívida externa brasileira, pois esta estava alicerçada fundamentalmente por contratos pós-fixados. Como consequência, o Brasil enfrentou uma forte recessão entre 1980 e 1983, com a imposição de um rígido controle fiscal e a necessidade de geração de divisas, revertendo os resultados econômicos positivos acumulados na década anterior.

Como era de se esperar, a crise econômica teve efeitos diretos sobre o nível do emprego e da distribuição de renda. Esse contexto, aliado a toda convulsão social e política que culminou no fim do período militar, foi determinante para o retorno do debate em torno da adoção de uma política inédita de seguro-desemprego no país (Silva, 2018a; 2018c; 2019b).

A primeira ação concreta nesse sentido ocorreu em 1986, com o DecretoLei no 2.284, que estabeleceu a criação do Programa Seguro-Desemprego com a finalidade de "prover assistência financeira temporária ao trabalhador desempregado em virtude de dispensa sem justa causa, ou por paralisação, total ou parcial, das atividades do empregador" (art. 25). ${ }^{9} \mathrm{O}$ benefício financeiro previsto seria de até quatro parcelas, desde que o trabalhador não contasse com outra renda nem usufruísse de benefício previdenciário. Esperava-se que essa assistência financeira servisse como eixo organizador das políticas de trabalho, conectando-se a uma rede de serviços já previstos no âmbito do Sine para a efetivação de um modelo próprio de SPE no Brasil. No entanto, a combinação entre critérios restritivos de elegibilidade (cerca de 50\% dos trabalhadores demitidos no Brasil não 
cumpriam os requisitos exigidos) e a instabilidade quanto às fontes de financiamento comprometeu bastante a cobertura inicial do programa. ${ }^{10}$

Tais questóes foram discutidas no âmbito da Assembleia Nacional Constituinte, instalada no início de 1987, resultando em inovaçóes importantes na Constituiçáo Federal, promulgada no dia 5 de outubro de 1988. Pela primeira vez, o conceito de seguridade social foi inserido no texto constitucional (art. 194), com dimensóes programáticas desenhadas de maneira sistêmica para assegurar direitos básicos de cidadania e cobertura dos riscos sociais.

O Programa Seguro-Desemprego foi tratado, juntamente com as demais políticas de mercado de trabalho, no capítulo das Disposiçôes Constitucionais Gerais (art. 239), que dispôs sobre suas diretrizes de execução e fontes financiadoras. Ficou definido que os recursos seriam provenientes dos fundos do Programa de Integração Social e do Programa de Formação do Patrimônio do Servidor Público (PIS-Pasep), a serem direcionados a um novo fundo com regras específicas. ${ }^{11}$ Destaca-se também que o referido artigo garantiu a assistência financeira do abono salarial, no valor de 1 salário mínimo (SM) anual. ${ }^{12}$

Com a gradativa popularização do seguro-desemprego, houve de imediato uma considerável expansão de sua cobertura. A taxa de habilitação subiu para $82 \%$ em 1989, em um universo de requerentes que superou a casa de 1 milhão de trabalhadores. A cobertura em relação ao total de demitidos manteve uma trajetória de crescimento, alcançando 15,5\% em 1988 e 19,1\% em 1989 (Azeredo, 1998).

A regulamentação do art. 239 da CF/1988 ocorreu pouco depois de sua promulgação, com a Lei no $\mathbf{7} .998$, de 11 de janeiro de 1990 . Essa foi a principal estrutura normativa que levou, enfim, à instituiçâo de um SPE no Brasil, conforme os parâmetros definidos no âmbito da OIT ao longo do século XX. O projeto aprovado pelo Congresso Nacional corrigia algumas lacunas da proposta de 1986, eliminando restrições mais severas ao acesso dos trabalhadores ao seguro-desemprego. ${ }^{13}$

Também foram estabelecidas as diretrizes de integração entre os benefícios financeiros ao trabalhador em situação de desemprego por demissão imotivada e a oferta de serviços de intermediação e qualificação profissional, visando aperfeiçoar a dinâmica de contratação no mercado de trabalho. As agências do Sine passaram a contar com novos canais de financiamento via Ministério do Trabalho, possibilitando,

10. Do início de sua vigência, em julho de 1986, até o fim de 1987, somente 885 mil trabalhadores foram atendidos. Sua cobertura em relação ao total de demitidos sem justa causa não chegou a 5\% em 1986, e no ano seguinte foi de $10,9 \%$. Ademais, não foi estabelecida uma estratégia clara de articulação operativa do seguro-desemprego com a rede de agências de intermediação e colocação laboral (Azeredo, 1998).

11. Havia ainda a previsão de uma "contribuição adicional" de empresas que apresentassem índices de rotatividade da força de trabalho superiores à média de seu setor (§ 4ํart. 239). No entanto, esse parágrafo nunca foi regulamentado. 12. As condições estabelecidas para seu recebimento foram: trabalhadores inscritos no PIS-Pasep por pelo menos cinco anos, com rendimento médio mensal de até 2 SMs, empregados por pelo menos um mês no ano de referência. 13. Para mais detalhes, ver Silva (2018a). 
inclusive, a criação de programas específicos de qualificação profissional em nível nacional, ao longo dos anos 1990. Tais mudanças convergiam com a Convenção no 168/1988 da OIT, indicando que o país caminhava em conformidade com as normas internacionalmente consensuadas (Silva, 2018a; 2020a).

Toda essa reestruturação teve como base central a criação do FAT, que estabeleceu um mecanismo de financiamento consistente com os objetivos previstos pela própria Lei no 7.998/1990. As fontes de arrecadação seguiram aquelas previstas na CF/1988, tendo o PIS-Pasep como principal instrumento. ${ }^{14}$ A Lei no 7.998/1990 criou o Conselho Deliberativo do Fundo de Amparo ao Trabalhador (Codefat), com a representação paritária de organizaçôes ligadas aos trabalhadores, aos empregadores, e órgãos da estrutura estatal, com a incumbência de tomar as decisões estratégicas sobre os programas envolvidos em torno do FAT (Silva, 2019a).

Com esse conjunto de inovaçóes, o Brasil passou a dispor de um arranjo complexo que envolve a criação de novos direitos aos trabalhadores, bem como uma série de políticas públicas para efetivá-los (quadro 2). Desde então, a principal reforma desse modelo ocorreu com a Lei no 13.124/2015, que alterou as condiçóes de acesso e de benefícios para o seguro-desemprego e o abono.

QUADRO 2

Características dos principais programas atualmente em vigência - Brasil (2020)

\begin{tabular}{|l|l|}
\hline Nome & \multicolumn{1}{c|}{ Descrição } \\
\hline $\begin{array}{l}\text { Seguro- } \\
\text { desemprego }\end{array}$ & $\begin{array}{l}\text { Assistência financeira temporária ao trabalhador desempregado, em virtude da dispensa sem justa causa de } \\
\text { acordo com a comprovação de vínculo de emprego assalariado no seguinte período imediatamente anterior } \\
\text { à data de dispensa: } i \text { ) pelo menos doze meses nos últimos dezoito meses, quando da primeira solicitação; } \\
\text { ii) pelo menos nove meses nos últimos doze meses, quando da segunda solicitação; e iii) cada um dos seis } \\
\text { meses imediatamente anteriores à data de dispensa, quando das demais solicitaç̃̃es. Concedido em parcelas } \\
\text { mensais, que variam de três a cinco, tendo como piso o valor do salário mínimo. }\end{array}$ \\
\hline $\begin{array}{l}\text { Abono salarial } \\
\text { Intermediação de } \\
\text { emprego }\end{array}$ & $\begin{array}{l}\text { Benefício assegurado aos empregados que recebem até 2 SMs de remuneração mensal, desde que cadas- } \\
\text { trados há cinco anos ou mais no PIS-Pasep e tenham trabalhado pelo menos trinta dias em um emprego } \\
\text { formal, no ano anterior, de pessoa jurídica com contribuição para o PIS-Pasep (não valendo, por exemplo, aos } \\
\text { contratos de empregados domésticos). Valor definido em função do número de meses trabalhados no ano de } \\
\text { referência, tendo como teto o valor do SM. }\end{array}$ \\
$\begin{array}{l}\text { Qualificação } \\
\text { profissional }\end{array}$ & $\begin{array}{l}\text { Oferta de cursos de qualificação profissional para trabalhadores desempregados ou em risco de desemprego } \\
\text { e microempreendedores. }\end{array}$ \\
\hline $\begin{array}{l}\text { Geração de } \\
\text { emprego e renda }\end{array}$ & $\begin{array}{l}\text { Concessão de crédito produtivo a micro e pequenas empresas (MPEs } \\
\text { mos, via bancos públicos oficiais. }\end{array}$ \\
\hline
\end{tabular}

Fonte: Silva (2018a).

14. Vale ressaltar que nem todo o recurso arrecadado via PIS-Pasep é destinado aos programas relacionados ao FAT, pois $40 \%$ do saldo líquido anual é repassado na forma de empréstimo ao Banco Nacional de Desenvolvimento Econômico e Social (BNDES). A ideia presente é que essa relação de complementaridade institucional entre FAT e BNDES possa gerar um arranjo de apoio ao financiamento do investimento (formação bruta de capital fixo) no Brasil, com a disponibilização de linhas de empréstimos de longo-prazo em condições mais favoráveis para sua viabilização. Por sua vez, tais investimentos contribuiriam para a geração de novos empregos e maior dinamização do mercado de trabalho (Silva, 2019b). 
Contudo, isso não exime a experiência brasileira de questóes relevantes a serem problematizadas. Os programas mantêm um vínculo forte com o assalariamento formal, sobretudo no caso do seguro-desemprego e do abono salarial. Mesmo com avanços importantes nos anos posteriores, como a inserção de categorias geralmente caracterizadas como informais (pescadores artesanais, empregadas domésticas e trabalhadores resgatados de situação análoga à escravidão), ainda há um vasto percentual da força de trabalho descoberto. Quanto à estratégia de financiamento das políticas, embora o FAT tenha elevado o potencial de cobertura da seguridade social no país, ele tem sido constantemente alvo de mudanças normativas, de cunho fiscal, que incidem sobre seu potencial de financiamento dos serviços previstos pelo SPE brasileiro. ${ }^{15}$

\section{BRASIL E A AGENDA 2030 PARA 0 TRABALHO}

Quanto o Brasil pretende avançar, nesta década, na geração de boas oportunidades de trabalho? A resposta a essa pergunta não é tão difundida quanto as metas de inflação e de resultado primário do setor público. Entretanto, o país dispóe também de um conjunto de metas sobre trabalho, adequadas à realidade nacional a partir da agenda de Objetivos de Desenvolvimento Sustentável (ODS) e acordada globalmente no âmbito da ONU. Para essa agenda, um dos marcos referenciais fundamentais é o conceito de trabalho decente, formalizado em 1999 pela OIT. Tal conceito sintetiza a missão histórica da instituição na promoção de oportunidades de trabalho produtivo para que homens e mulheres que respeitem as condições de equidade, segurança e dignidade humana, obedecendo os direitos definidos como fundamentais (liberdade sindical, direito de negociação coletiva, eliminação de todas as formas de discriminação em matéria de emprego e ocupação e erradicação de todas as formas de trabalho forçado e trabalho infantil) e a ampliaçáo da proteçáo social. ${ }^{16}$

Esta seção resume o processo brasileiro de adequação das metas relativas à temática do trabalho reunidas no ODS 8 (promoção do trabalho decente e desenvolvimento econômico) e elenca as metas propostas sobre o tema no país, com os respectivos indicadores de acompanhamento. Além disso, discute-se a relação entre os ODS e as metas de longo prazo assumidas pelo governo federal no PPA e na Estratégia Nacional de Desenvolvimento Econômico e Social (Endes). ${ }^{17}$

\footnotetext{
15. Para uma análise da trajetória de mudança institucional vivida pelo FAT, ver Silva (2018a).

16. Sobre o conceito de trabalho decente da OIT e sua forma de mensuração e acompanhamento, ver: Abramo (2015). Para mais informações, ver: <https://bit.ly/2ACO1Vy>.

17. A Endes é um documento que contempla o cenário macroeconômico para os próximos doze anos e está organizado em cinco eixos: econômico, institucional, infraestrutura, ambiental e social. Para cada um desses eixos, declaram-se megatendências, diretrizes, desafios e orientações, índices-chave e metas-alvo. Cada eixo agrega os problemas que o Estado brasileiro deve solucionar e, justamente por isso, representam os grandes campos de políticas públicas que se estruturam em torno desses problemas. Ao todo, são 37 índices-chave e suas respectivas metas-alvo, tornando possível monitorar e avaliar, em termos quantitativos, a implementação do planejamento do desenvolvimento nacional equilibrado no longo prazo. Para mais informaç̧ões, ver: <https://bit.ly/2Cf167G>.
} 
Após a experiência dos oito Objetivos de Desenvolvimento do Milênio (ODM) perseguidos de 1990 até 2015, os 193 Estados-membros da ONU, reunidos na Assembleia Geral de 2015, aprovaram uma nova e ampliada agenda, com dezessete objetivos a serem alcançados até 2030. Esses dezessete objetivos, ligados às dimensóes social, ambiental e econômica, foram detalhados em 169 metas. O objetivo de número 8 refere-se a trabalho decente e crescimento econômico e reúne um conjunto de doze metas voltadas a "promover o crescimento econômico sustentado, inclusivo e sustentável, emprego pleno e produtivo e trabalho decente para todas e todos".

A vigência desse acordo global, embora não vincule as açóes soberanas de cada país, reforça seus compromissos públicos de persistirem na busca de objetivos considerados prioritários e factíveis mundo afora, podendo servir de base para discussôes entre várias instâncias das sociedades, dos governos nacionais e subnacionais, dos diferentes grupos políticos, trabalhadores, empresários e cidadãos em geral. Além disso, a existência de uma agenda comum contribui para que os países se empenhem em produzir indicadores de monitoramento internacionalmente comparáveis sobre cada um dos temas destacados.

Embora devam levar em conta os dados disponíveis no resto do mundo, os países são incentivados pela ONU a adaptar as metas globais e seus respectivos indicadores às realidades nacionais, sem reduzir sua abrangência. Assim, o governo brasileiro criou, em 2016, vinculada à Secretaria de Governo da Presidência da República (Segov/PR), a Comissão Nacional dos Objetivos de Desenvolvimento Sustentável (CNODS), que atribuiu ao Ipea a função de assessoramento técnico aos seus trabalhos. A partir de então, o Ipea coordenou o processo de adequação das metas globais à realidade brasileira, em um trabalho coletivo que envolveu debates com a participação de mais de seiscentos técnicos e gestores de 75 órgãos governamentais, seguidos pela formulação de uma proposta submetida à consulta pública ${ }^{18}$ e ajustes às sugestôes apresentadas (Ipea, 2018). Em 2019, o instituto divulgou os cadernos ODS, apresentando os níveis de partida dos indicadores a serem monitorados no Brasil e os principais desafios para o país alcançar as metas fixadas. ${ }^{19}$

No caso do ODS 8, foi formado em 2018 um grupo de trabalho com representantes de dezoito órgãos existentes. ${ }^{20}$ Das doze metas globais definidas originariamente

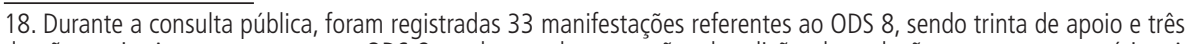
de não apoio. As propostas para o ODS 8 receberam dez sugestões de adição, de exclusão e outros comentários. A maioria das sugestões referiu-se a propostas de implementação ou melhoria de gestão de políticas públicas que podem contribuir para o alcance das metas, não requerendo mudanças na redação originalmente apresentada. Em Ipea (2018), encontram-se todas as sugestões recebidas e os encaminhamentos adotados.

19. 0 portal <http://www.ipea.gov.br/ods/> reúne publicações, vídeos e links sobre a iniciativa.

20. São eles: Ministério do Trabalho, Ipea, Ministério da Fazenda (MF), Ministério da Indústria, Comércio Exterior e Serviços (MDIC), Ministério do Turismo (MTur), Ministério dos Direitos Humanos (MDH), Banco Central do Brasil (BCB), Instituto Brasileiro de Geografia e Estatística (IBGE), Ministério da Ciência, Tecnologia e Comunicação (MCTIC), Ministério da Justiça (MJ), Ministério da Saúde (MS), Ministério do Desenvolvimento Social (MDS), Empresa Brasileira de Pesquisa Agropecuária (Embrapa), Ministério da Educação (MEC), Ministério do Planejamento (MP), Secretaria de Assuntos Estratégicos (SAE), Secretaria de Governo (Segov) e Secretaria Nacional de Articulação Social (Sead) (Ipea, 2018). 
pela ONU para esse objetivo, sendo dez de resultado (numeradas de 8.1 a 8.10) e duas de implementação (8.a e 8.b), apenas a meta de implementação 8.a não foi considerada aplicável ao Brasil, pois refere-se aos participantes da Iniciativa de Ajuda para o Comércio (Aid for Trade), em que países desenvolvidos oferecem suporte à inserção comercial dos países menos desenvolvidos. Para as demais onze metas do ODS 8 , foram elaboradas propostas que se adequassem melhor à realidade nacional, conforme mostra o quadro $3 .{ }^{21}$ Contudo, vale ressaltar que as propostas de adaptação de metas sistematizadas pelo referido grupo de trabalho ainda não foram oficialmente validadas pelo governo brasileiro, de modo que elas ainda podem ser revistas ou rediscutidas ou, no limite, até mesmo desconsideradas.

QUADRO 3

Metas globais do ODS 8 e metas propostas - Brasil

\begin{tabular}{|c|c|c|}
\hline Número & Meta original (Nações Unidas) & Proposta de meta (Brasil) \\
\hline 8.1 & $\begin{array}{l}\text { Sustentar o crescimento econômico per capita, de acordo } \\
\text { com as circunstâncias nacionais e, em particular, pelo menos } \\
\text { um crescimento anual de } 7 \% \text { do PIB nos países de menor } \\
\text { desenvolvimento relativo. }\end{array}$ & $\begin{array}{l}\text { Registrar um crescimento econômico per capita anual } \\
\text { médio de 1,6\% entre } 2016 \text { e } 2018 \text {; e de 2,55\% entre } \\
2019 \text { e } 2030 \text {. }\end{array}$ \\
\hline 8.2 & $\begin{array}{l}\text { Atingir níveis mais elevados de produtividade das economias por } \\
\text { meio da diversificação, modernização tecnológica e inovação, } \\
\text { inclusive por meio de um foco em setores de alto valor agregado } \\
\text { e dos setores intensivos em mão de obra. }\end{array}$ & $\begin{array}{l}\text { Atingir níveis mais elevados de produtividade, por meio } \\
\text { da diversificação e com agregação de valor, modernização } \\
\text { tecnológica, inovação, gestão e qualificação do trabalhador, } \\
\text { com foco em setores intensivos em mão de obra. }\end{array}$ \\
\hline 8.3 & $\begin{array}{l}\text { Promover políticas orientadas para o desenvolvimento que } \\
\text { apoiem as atividades produtivas, geração de emprego decente, } \\
\text { empreendedorismo, criatividade e inovação, e incentivar a } \\
\text { formalização e o crescimento das micro, pequenas e médias } \\
\text { empresas, inclusive por meio do acesso a serviços financeiros. }\end{array}$ & $\begin{array}{l}\text { Promover o desenvolvimento com a geração de trabalho } \\
\text { digno; a formalização; o crescimento das micro, pequenas } \\
\text { e médias empresas; } 0 \text { empreendedorismo e a inovação. }\end{array}$ \\
\hline 8.4 & $\begin{array}{l}\text { Melhorar progressivamente, até 2030, a eficiência dos recursos } \\
\text { globais no consumo e na produção, e empenhar-se para } \\
\text { dissociar o crescimento econômico da degradação ambiental, } \\
\text { de acordo com o Plano Decenal de Programas sobre Produ- } \\
\text { ção e Consumo Sustentáveis, com os países desenvolvidos } \\
\text { assumindo a liderança. }\end{array}$ & $\begin{array}{l}\text { Ampliar a eficiência da utilização de recursos globais no } \\
\text { consumo e na produção, e empenhar-se para dissociar } \\
\text { o crescimento econômico da degradação ambiental, de } \\
\text { acordo com o Plano de Ação para Produção e Consumo } \\
\text { Sustentáveis (PPCS). }\end{array}$ \\
\hline 8.5 & $\begin{array}{l}\text { Até } 2030 \text {, alcançar o emprego pleno e produtivo e trabalho } \\
\text { decente para todas as mulheres e homens, inclusive para os } \\
\text { jovens e as pessoas com deficiência, e remuneraçã̃o igual } \\
\text { para trabalho de igual valor. }\end{array}$ & $\begin{array}{l}\text { Até } 2030 \text {, reduzir em } 40 \% \text { a taxa de desemprego e outras } \\
\text { formas de subutilização da força de trabalho, garantindo o } \\
\text { trabalho digno, com ênfase na igualdade de remuneração } \\
\text { para trabalho de igual valor. }\end{array}$ \\
\hline 8.6 & $\begin{array}{l}\text { Até } 2020 \text {, reduzir substancialmente a proporção de jovens } \\
\text { sem emprego, educação ou formação. }\end{array}$ & $\begin{array}{l}\text { Alcançar uma redução de } 3 \text { p.p. até } 2020 \text { e de } 10 \text { p.p. até } \\
2030 \text { na proporção de jovens que não estejam ocupados, } \\
\text { nem estudando ou em formação profissional. }\end{array}$ \\
\hline 8.7 & $\begin{array}{l}\text { Tomar medidas imediatas e eficazes para erradicar o trabalho } \\
\text { forçado, acabar com a escravidão moderna e o tráfico de } \\
\text { pessoas, e assegurar a proibição e eliminação das piores formas } \\
\text { de trabalho infantil, incluindo recrutamento e utilização de } \\
\text { crianças-soldado, e até } 2025 \text { acabar com o trabalho infantil } \\
\text { em todas as suas formas. }\end{array}$ & $\begin{array}{l}\text { Até } 2025 \text {, erradicar o trabalho em condições análogas } \\
\text { às de escravo, o tráfico de pessoas e o trabalho infantil, } \\
\text { principalmente nas suas piores formas. }\end{array}$ \\
\hline 8.8 & $\begin{array}{l}\text { Proteger os direitos trabalhistas e promover ambientes de } \\
\text { trabalho seguros e protegidos para todos os trabalhadores, } \\
\text { incluindo os trabalhadores migrantes, em particular as mulheres } \\
\text { migrantes, e pessoas em empregos precários. }\end{array}$ & $\begin{array}{l}\text { Reduzir o grau de descumprimento da legislação trabalhista, } \\
\text { no que diz respeito ao registro, às condiçôes de trabalho, } \\
\text { às normas de saúde e segurança no trabalho, com ênfase } \\
\text { nos trabalhadores em situaçâo de vulnerabilidade. }\end{array}$ \\
\hline
\end{tabular}

(Continua)

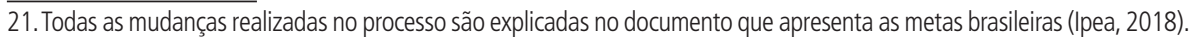




\begin{tabular}{|c|c|c|}
\hline Número & Meta original (Nações Unidas) & Proposta de meta (Brasil) \\
\hline 8.9 & $\begin{array}{l}\text { Até } 2030 \text {, conceber e implementar políticas para promover o } \\
\text { turismo sustentável, que gera empregos, promover a cultura } \\
\text { e os produtos locais. }\end{array}$ & $\begin{array}{l}\text { Até 2030, conceber e implementar políticas para promover } \\
\text { o turismo sustentável e responsável, acessível a todos; e que } \\
\text { gere emprego e trabalho digno, melhore a distribuição de } \\
\text { renda e promova a cultura e os produtos locais. }\end{array}$ \\
\hline 8.10 & $\begin{array}{l}\text { Fortalecer a capacidade das instituições financeiras nacionais } \\
\text { para incentivar a expansão do acesso aos serviços bancários, } \\
\text { de seguros e financeiros para todos. }\end{array}$ & $\begin{array}{l}\text { Expandir de forma sustentável o acesso aos serviços } \\
\text { bancários e financeiros para todos. }\end{array}$ \\
\hline 8.a & $\begin{array}{l}\text { Aumentar o apoio da Iniciativa de Ajuda para o Comércio (Aid } \\
\text { for Trade) para os países em desenvolvimento, particularmente } \\
\text { os países menos desenvolvidos, inclusive por meio do Quadro } \\
\text { Integrado Reforçado para a Assistência Técnica Relacionada } \\
\text { com o Comércio para os países menos desenvolvidos. }\end{array}$ & Não aplicável ao Brasil. \\
\hline $8 . b$ & $\begin{array}{l}\text { Até 2020, desenvolver e operacionalizar uma estratégia global } \\
\text { para o emprego dos jovens e implementar o Pacto Mundial } \\
\text { para o Emprego da OIT. }\end{array}$ & $\begin{array}{l}\text { Até } 2020 \text {, desenvolver e operacionalizar um plano } \\
\text { nacional de promoção de trabalho digno para juventude, } \\
\text { tendo como marcos referenciais: i) a Agenda Nacional de } \\
\text { Trabalho Decente para a Juventude; ii) o Plano Nacional } \\
\text { de Emprego e Trabalho Decente; e iii) o Pacto Mundial } \\
\text { para o Emprego da OIT. }\end{array}$ \\
\hline
\end{tabular}

Fonte: Ipea (2018).

As metas do ODS 8 englobam não apenas aspectos mais diretamente relacionados à capacidade do mercado de trabalho em gerar bem-estar para os trabalhadores, mas também elementos determinantes para a geração e a sustentabilidade de empregos dignos, como o crescimento econômico e da produtividade. Seguindo um critério subjetivo, as seis metas aplicáveis ao Brasil diretamente relacionadas à capacidade do mercado de trabalho em gerar bem-estar para os trabalhadores seriam: 8.3 , 8.5, 8.6, 8.7, 8.8 e 8.b. Em termos de indicadores propostos para seu acompanhamento, as metas finalísticas 8.4 (produção e consumo sustentáveis) e 8.9 (turismo sustentável) não contam com indicadores computados, seja por uma indefinição conceitual (indicador tier 3), ou por não haver dados disponíveis (indicador tier 2). Também não há indicadores disponíveis para a meta intermediária 8.b, sobre a adoção de um plano de promoção de trabalho digno para a juventude. Para todos as demais, Ipea (2019a) apresenta dados com os níveis de partida e cita políticas que podem contribuir para o alcance das metas. ${ }^{22}$

A proposta de modificaçáo introduzida na redação da meta 8.b representa bem o esforço de adequaçáa à realidade brasileira. A redaçáo original proposta pela ONU menciona o desenvolvimento e a operacionalização de uma estratégia para o emprego de jovens, tendo como pano de fundo um documento elaborado pela OIT. Na versão adaptada da redação, faz-se menção a documentos específicos já formulados pelo Brasil que podem subsidiar a referida estratégia.

22. A adequação dos indicadores para o ODS 8 não foi tratada pelo referido grupo de trabalho com o mesmo nível de profundidade alcançado na redação das metas do ODS 8. Como essa é uma tarefa do IBGE, procurou-se tão somente pensar em sugestões que tivessem aderência com os textos propostos para as respectivas metas, partindo de um primeiro conjunto de indicadores publicados em: <https://ods.ibge.gov.br/>. 
As demais cinco metas tiveram suas redações adequadas seguindo dois tipos de motivações, além da motivação geral de adequação para a realidade brasileira. No caso das metas 8.3 e 8.7, a principal motivaçáo adicional foi uma necessidade constatada pelo grupo de trabalho de tornar o texto mais conciso, a fim de facilitar a comunicação. Já as redaçôes propostas para as metas 8.5, 8.6 e 8.8 facilitaram um acompanhamento quantitativo.

Vale destacar as alteraçóes realizadas nas metas 8.5 e 8.6, em que as melhorias visadas não eram quantificadas na redação da $\mathrm{ONU}$, mas passaram a ser na brasileira. Na meta 8.5, a expressão "emprego pleno e produtivo", sem definição consensual, deu lugar aos termos "desemprego" e "subutilização do trabalho", conceitos difundidos pela OIT e por diversos outros órgãos oficiais de estatística. Uma redução do desemprego em $40 \%$, tendo como linha base o índice observado em 2016, permitiria ao Brasil retornar a níveis historicamente baixos como os alcançados em 2014. Contudo, como demonstra o gráfico 1, o país fechou o ano de 2019 com uma média anual não apenas longe da meta proposta, mas em uma situação ainda pior àquela de 2016 (12,1\% em 2019 contra $11,5 \%$ em 2016).

\section{GRÁFICO 1}

Evolução da taxa de desocupação e meta conforme o ODS 8 - Brasil (2012-2019) (Em \%)

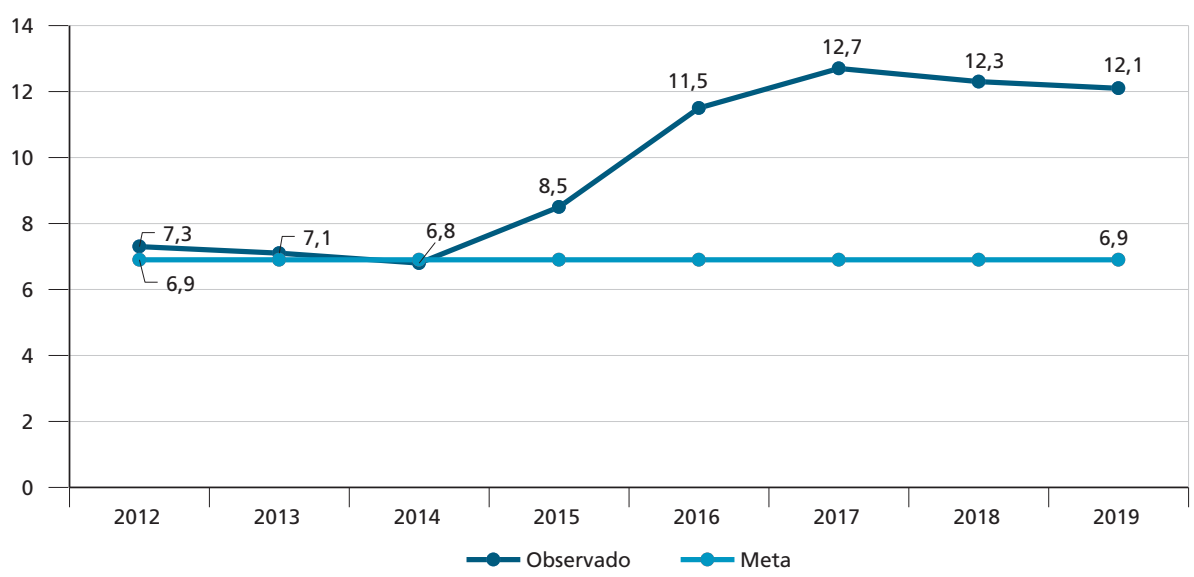

Fonte: IBGE/PNAD Contínua.

Verificando o comportamento da taxa de desocupação por trimestre, é possível notar que ela manteve uma trajetória de queda ao longo do ano, diminuindo até encerrar o trimestre móvel em dezembro com $11,0 \%$, contra $11,6 \%$ em igual trimestre de 2018. Como o nível de partida considerado na meta 8.5 foi a taxa de 
$11,5 \%$ registrada em 2016, ainda é preciso reduzir o desemprego em $38 \%$ para voltar a atingir taxas inferiores a 6,9\%.

Para além da média geral da desocupação em si, alguns aspectos em termos do comportamento de variáveis de mercado de trabalho são de grande relevância para o atingimento da meta proposta para o ODS, dentre os quais pode-se citar: desigualdades no acesso a oportunidades; relaçóes de desemprego de longo prazo; população em situação de desalento; subutilização da força de trabalho; e informalidade dos vínculos de emprego. Todos os dados citados estão organizados nas tabelas do apêndice A.

$\mathrm{O}$ primeiro desses aspectos aqui destacado refere-se às graves desigualdades de oportunidades que acabam sendo ocultadas quando se discute apenas em cima de médias nacionais. Uma dimensão dessas desigualdades consiste na trajetória recente da taxa de desocupação por alguns critérios populacionais (gênero e raça) e regionais. Tendo como base os números do último trimestre móvel de 2019, nota-se a manutenção de uma considerável diferença tanto na relação entre homens e mulheres $(9,2 \%$ e $13,1 \%$, respectivamente) quanto entre brancos e não brancos ${ }^{23}(8,7 \%$ e $12,8 \%)$.

Outra dimensão relevante é a regional. Observando o comportamento da desocupação entre as regióes do Brasil no mesmo período, o menor valor final indicado na série foi no Sul, com 6,8\% de desocupação, enquanto o índice mais alto ficou por conta do Nordeste, com 13,8\%. Tais diferenças marcantes entre as regióes chamam a atenção pelo fato da enorme disparidade territorial que o país possui, fato este que não pode ser negligenciado em qualquer que seja a estratégia de desenvolvimento a ser adotada.

Há ainda a dimensão de desigualdade associada aos indicadores de renda do trabalho, tanto no que tange ao rendimento individual quanto ao rendimento domiciliar. Embora ambos os indicadores apresentem certa estabilidade em 2019, medidos por meio do índice de Gini (0,5089 e 0,5326, respectivamente, para o último trimestre de 2019), a estabilização se deu em valores preocupantemente altos, ainda mais quando se leva em conta o fato de o Brasil possuir uma das maiores taxas de desigualdade da América Latina (Cepal, 2019).

O segundo aspecto diz respeito ao contingente de desocupados de longo prazo (um ano ou mais). No último trimestre de 2019, 40,2\% dos desempregados, em média, encontravam-se nesta situação em todo o país. Esse patamar se manteve estável ao longo de todo o ano, o que indica uma problemática bastante complexa para a redução da desocupação, pois a inclusão laboral dessa população em situação de convivência mais continuada com o desemprego irá exigir esforços mais estruturados em termos de políticas públicas. ${ }^{24}$

23. Incluem-se aqui os indivíduos que se consideram negros, pardos e indígenas.

24. Sobre o tema das políticas de inclusão produtiva e laboral, ver nota de política social nesta mesma edição do BPS (Silva, 2020b). 
$\mathrm{O}$ terceiro aspecto refere-se ao número de pessoas fora da força de trabalho por motivos associados ao desalento. ${ }^{25}$ Esse indicador também vem apresentando pouca variação nos últimos trimestres. A proporção de desalentados em relação ao total da população em idade ativa (PIA) cresceu levemente nos dois primeiros trimestres de 2019, mas apresentou uma queda a partir do terceiro, registrando um valor em torno de 3,0\% no último trimestre, mantendo basicamente o patamar do mesmo trimestre do ano anterior. Contudo, considerando que o mesmo trimestre de 2016, ano-base para as metas do ODS, resultou em um percentual significativamente menor $(2,5 \%)$, pode-se ter uma noção ainda mais apurada da preocupante conjuntura atual laboral do Brasil.

O quarto aspecto a ser considerado no rol dos desafios de alcance das metas de desocupação para os ODS no Brasil é o fenômeno da subutilização da força de trabalho, que subsidia o monitoramento da meta 8.5 e é usado como o índice-chave para acompanhar o desempenho do mercado de trabalho de 2020 a 2031 no âmbito da Endes (Brasil, 2018). Para o cálculo da subutilização do trabalho, um dos indicadores principais refere-se à taxa de subocupação por insuficiência de horas, isto é, o percentual de ocupados com jornada inferior a 40 horas por semana, mas que gostariam de trabalhar mais. ${ }^{26}$ Tomando por base o último trimestre de cada ano, segundo os dados da PNAD Contínua, a proporção da população classificada como subocupada por insuficiência de horas passou de 17,1\% em 2016 para 18,1\% em 2017 e 2018, e, finalmente, 17,4\% em 2019. Assim, embora tenha fechado 2019 em uma situação um pouco mais favorável que a do ano anterior, o índice permanece pior que o observado em 2016, demonstrando outra face preocupante em termos de inclusão produtiva e laboral no país.

O quinto e último aspecto a ser destacado refere-se ao desafio de enfrentamento da informalidade. Em que pese uma pequena elevação das taxas de crescimento do emprego assalariado com carteira assinada em 2019, as ocupaçóes tipicamente associadas ao trabalho informal (assalariados sem carteira assinada e trabalhadores por conta-própria) mantêm uma participação bastante elevada no total da força de trabalho ${ }^{27}$ do país. O grau de informalidade vem apresentando um crescimento praticamente ininterrupto ao longo dos últimos anos, saltando de 45,3\% no

\footnotetext{
25. Tal como o IBGE, consideramos como motivos associados ao desalento as seguintes categorias de respostas à pergunta sobre a razão de o indivíduo não ter buscado emprego na semana de referência: i) nã̃o conseguia trabalho adequado; ii) não tinha experiência profissional ou qualificação; iii) ser considerado muito jovem ou muito idoso; e iv) não havia trabalho na localidade.

26. Taxa de subutilização da força de trabalho $=$ (subocupados por insuficiência de horas + desocupados + força de trabalho potencial) / (força de trabalho + força de trabalho potencial). A força de trabalho é formada pelas pessoas ocupadas e pelas que estavam disponíveis para trabalhar e buscaram trabalho na semana de referência. Já a força de trabalho potencial é formada pelas pessoas sem ocupação que buscaram trabalho, mas não estavam disponíveis, e pelas que estavam disponíveis, mas não buscaram trabalho.

27. 0 IBGE classifica como força de trabalho o total de pessoas com 14 anos ou mais de idade, em situação economicamente ativa, na semana de referência. No terceiro trimestre de 2019, o contingente total da força de trabalho no Brasil era de 106.315 mil pessoas.
} 
último trimestre de 2016 (ano-base) para 48,2\% no mesmo período em 2019, como demonstra o gráfico 2.

\section{GRÁFICO 2}

Evolução do grau de informalidade contemplando todos os conta-própria (2015-2019) (Em \%)

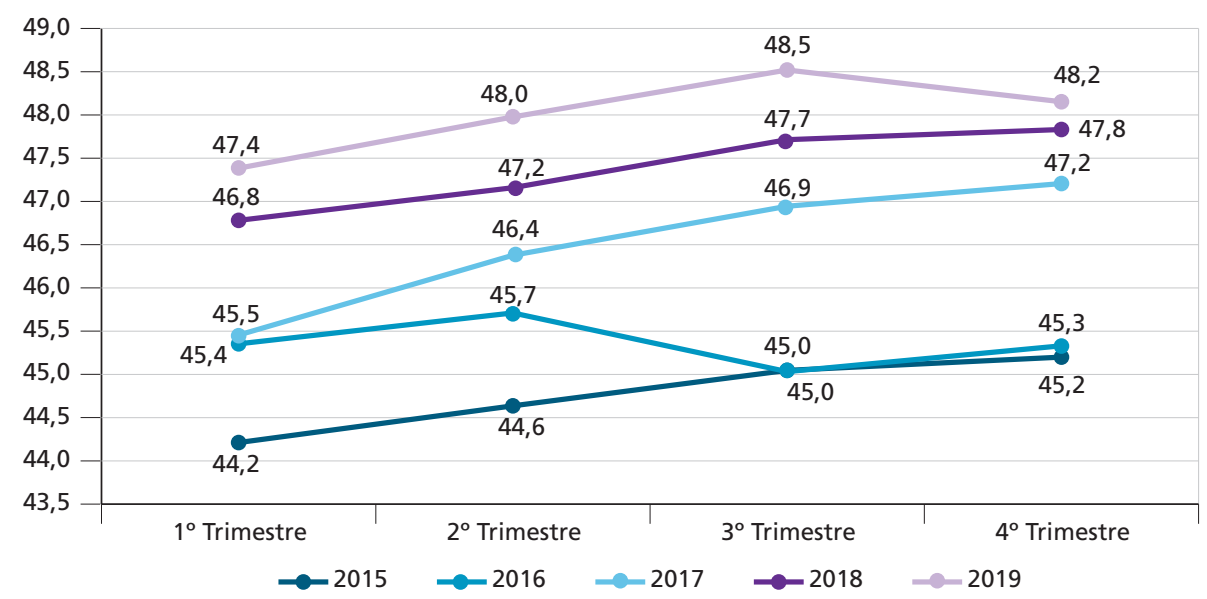

Fonte: IBGE/PNAD Contínua.

A manutenção de indicadores elevados de informalidade no mercado de trabalho brasileiro implica um conjunto de preocupaçóes em termos de desenvolvimento e bem-estar social, tais como: i) perda da proteçáo social e dos diversos tipos de garantia previstos na lei trabalhista (contagem de tempo para aposentadoria, férias remuneradas, décimo-terceiro salário, seguro-desemprego, abono salarial, transporte, refeição etc.); ii) perda de receitas para a seguridade social; e iii) perda de receitas para outros programas sociais ou de custeio de investimentos. Ademais, tanto o vínculo do indivíduo com o posto de trabalho quanto a própria massa de rendimentos derivada do trabalho informal são bastante sensíveis às flutuaçôes da atividade econômica e às condiçôes gerais da economia.

No que concerne à meta 8.6, relativa à proporção de jovens que não estejam ocupados, estudando ou em formaçấo profissional (usualmente denominados "nem-nem"), a expressão original "reduzir substancialmente" recebeu proposta de substituição, no Brasil, para alcançar uma redução de 3 p.p. até 2020 e de 10 p.p. até 2030. Com isso, o objetivo é que o país se aproxime até 2030 da realidade atual de países mais desenvolvidos e das melhores marcas que registrou no início da década passada. A menção a um quantitativo intermediário para este ano de 2020 segue a data estipulada para implementar o Pacto Mundial para o Emprego da OIT.

Segundo a última edição anual disponível dos resultados completos sobre educação da PNAD Contínua, que incluem dados sobre formação profissional, os jovens nessa condiçấo chegavam a 21,7\% do total de jovens de 15 a 24 anos no 
segundo trimestre de 2018. Esse percentual ainda era maior que a taxa de partida em 2016 (20,3\%). Assim, para atingir a meta intermediária de 17,3\% no segundo trimestre deste ano de 2020 em curso, seria preciso registrar uma redução de 4,4 p.p. em apenas dois anos. Para 2030, a meta é uma taxa de até 10,3\%. Ademais, vale ressaltar ainda que a situação do mercado de trabalho para jovens no Brasil tem se deteriorado rapidamente nos últimos anos, inclusive quando se compara com outros países na América Latina (Silva, 2018d).

Sendo assim, os aspectos discutidos nesta seção mostram que, a partir dos indicadores disponíveis, o alcance dos objetivos previstos pelo Brasil no âmbito dos acordos em torno da Agenda 2030 irá requerer um esforço bastante considerável em termos de reestruturação econômica para a dinamização do mercado de trabalho, visando à geração de cada vez mais oportunidades de trabalho digno e bem-estar social aos diferentes segmentos populacionais. Desde o início da vigência dos acordos, o país não apenas tem apresentado avanços em direção às metas como tem piorado em grande parte dos indicadores de mercado de trabalho, levando-se em conta as médias para o ano-base de 2016. Nesse sentido, o empenho em termos de monitoramento é fundamental na geração de subsídios orientadores, para que o Brasil possa contar com um painel de indicadores objetivos que balizem desempenho de suas iniciativas voltadas a melhorar as oportunidades de trabalho no país. Vale ressaltar, porém, que o governo brasileiro ainda não ratificou as metas adaptadas pelo referido grupo de trabalho, o que gera certa incerteza a respeito do real compromisso sobre o esforço no seu cumprimento.

\section{O TRABALHO NO PPA 2016-2019: ACOMPANHAMENTO DA POLÍTICA E DOS PROGRAMAS}

Antes de adentrar no acompanhamento dos programas de trabalho e renda do PPA, vale ressaltar que, com a posse da nova presidência da República em 2019, houve uma mudança bastante significativa na institucionalidade trabalhista brasileira. Conforme Decreto no 9.745, de 8 de abril de 2019, o Ministério do Trabalho foi extinto, algo que não havia ocorrido desde sua criação em 1930 - à época como Ministério do Trabalho, Indústria e Comércio (Decreto no 19.433/1930) - no governo Getúlio Vargas. Suas pastas e atribuições foram distribuídas entre outros ministérios: as políticas de emprego e a gestão do FAT e do Fundo de Garantia por Tempo de Serviço (FGTS) foram transferidas para o recém-criado Ministério da Economia (ME); as açóes de economia solidária foram para o também recém-criado Ministério da Cidadania; e as ações de fiscalização e inspeção do trabalho foram para o Ministério da Justiça.

Segue então a discussão desta seção dividida em duas partes: uma verificação do desempenho orçamentário das distintas açóes previstas no PPA 2016-2019; e o novo desenho aprovado para o PPA 2020-2023. 


\subsection{PPA 2016-2019: Programa Trabalho Decente e Economia Solidária}

O PPA 2016-2019 (Lei no 13.249, de 13 de janeiro de 2016) trouxe algumas mudanças significativas no desenho operativo da agenda governamental para o período em relaçấo ao PPA anterior. Ele conta com 54 programas temáticos, cada um deles relacionado a açôes específicas que visam atingir um conjunto de objetivos, metas e iniciativas predeterminados. Entre esses programas está o 2071 - Trabalho Decente e Economia Solidária, que abrange o conjunto de açóes sob o eixo de trabalho e renda. Ele foi formulado com base em quatro temas estruturantes, cada um deles ligado a um objetivo que, por sua vez, se desdobram, inicialmente, em 22 metas e 39 iniciativas, sendo incorporados outros itens posteriormente.

O conjunto das açóes (metas e iniciativas) previstas, bem como as dotaçóes definidas pelas respectivas Leis Orçamentárias Anuais (LOAs), são acompanhados neste capítulo pelo índice de execução orçamentária (IEO). Esse índice é calculado como o percentual efetivamente gasto para cada item por ano em relação ao total aprovado pela LOA (incluindo créditos adicionais), esses dados estão sintetizados na tabela 1 .

TABELA 1

Valor e execução orçamentária das políticas de economia solidária: PPA (2016-2019)

\begin{tabular}{|c|c|c|c|c|c|}
\hline Projetos/PPA & & 2016 & 2017 & 2018 & 2019 \\
\hline \multirow{2}{*}{$\mathrm{OOH} 4$ - Seguro-Desemprego } & LOA (R\$) & $38.406,6$ & $43.227,2$ & $37.606,0$ & $39.051,0$ \\
\hline & IEO (\%) & 96,3 & 86,15 & 94,9 & 93,4 \\
\hline \multirow{2}{*}{0581 - Abono Salarial } & LOA (R\$) & $17.931,7$ & $16.776,0$ & $18.367,0$ & $18.737,9$ \\
\hline & IEO (\%) & 96,5 & 94,9 & 92,2 & 91,2 \\
\hline \multirow{2}{*}{$\begin{array}{l}\text { 00J0 - Subvenção Econômica em } \\
\text { Operações de Microcrédito }\end{array}$} & $\mathrm{LOA}(\mathrm{R} \$)$ & 0,0 & 0,0 & 6,4 & 0,0 \\
\hline & IEO (\%) & 0 & 0 & 86,3 & 0 \\
\hline \multirow{2}{*}{$\begin{array}{l}\text { 20JT - Manutenção e Ampliação da } \\
\text { Rede de Atendimento do Sine }\end{array}$} & $\mathrm{LOA}(\mathrm{R} \$)$ & 50,2 & 34,5 & 40,1 & 39,5 \\
\hline & IEO (\%) & 0,3 & 0 & 23,6 & 0 \\
\hline \multirow{2}{*}{$\begin{array}{l}20 Y U \text { - Fiscalização de Obrigações } \\
\text { Trabalhistas }\end{array}$} & LOA (R\$) & 54,1 & 53,2 & 67,8 & 70,9 \\
\hline & IEO (\%) & 29,7 & 34,9 & 69,6 & 61,5 \\
\hline \multirow{2}{*}{$\begin{array}{l}\text { 20YV - Democratização das Relações } \\
\text { de Trabalho }\end{array}$} & LOA (R\$) & 1,1 & 1,4 & 0,2 & 0,3 \\
\hline & IEO (\%) & 64,5 & 21 & 35,2 & 16,2 \\
\hline \multirow{2}{*}{$\begin{array}{l}20 Y W \text { - Promoção de Políticas } \\
\text { Públicas em Segurança e Saúde no } \\
\text { Trabalho }\end{array}$} & $\mathrm{LOA}(\mathrm{R} \$)$ & 5,0 & 4,9 & 2,8 & 1,8 \\
\hline & IEO (\%) & 41,9 & 34,5 & 95,8 & 59,9 \\
\hline \multirow{2}{*}{$\begin{array}{l}20 Y X \text { - Cadastros Públicos na Área de } \\
\text { Trabalho e Emprego }\end{array}$} & LOA $(R \$)$ & 45,0 & 36,0 & 13,0 & 16,5 \\
\hline & IEO (\%) & 41,5 & 60,4 & 67,8 & 86,9 \\
\hline \multirow{2}{*}{$\begin{array}{l}20 Y Y \text { - Estudos, Pesquisas e Geração } \\
\text { de Informações sobre Trabalho }\end{array}$} & LOA (R\$) & 8,2 & 5,7 & 2,3 & 2,9 \\
\hline & IEO (\%) & 22,9 & 0 & 19,1 & 5,9 \\
\hline
\end{tabular}




\begin{tabular}{|c|c|c|c|c|c|}
\hline Projetos/PPA & & 2016 & 2017 & 2018 & 2019 \\
\hline \multirow{2}{*}{$\begin{array}{l}20 Z 1 \text { - Qualificação Social e } \\
\text { Profissional de Trabalhadores }\end{array}$} & $\mathrm{LOA}(\mathrm{R} \$)$ & 5,4 & 65,7 & 8,5 & 17,4 \\
\hline & IEO (\%) & 0 & 26,5 & 95,3 & 0 \\
\hline \multirow{2}{*}{$\begin{array}{l}20 Z 3 \text { - Apoio Operacional ao } \\
\text { Pagamento do Seguro-Desemprego } \\
\text { e do Abono }\end{array}$} & $\mathrm{LOA}(\mathrm{R} \$)$ & 50,6 & 18,5 & 2,9 & 0,2 \\
\hline & IEO (\%) & 33,8 & 0,8 & 1,3 & 22,8 \\
\hline \multirow{2}{*}{$\begin{array}{l}215 \mathrm{~F} \text { - Fomento e Fortalecimento da } \\
\text { Economia Solidária }\end{array}$} & $\mathrm{LOA}(\mathrm{R} \$)$ & 47,8 & 41,7 & 12,2 & 35,8 \\
\hline & IEO (\%) & 26,6 & 7,6 & 29,2 & 1,5 \\
\hline \multirow{2}{*}{$\begin{array}{l}2374 \text { - Fomento ao Desenvolvimento } \\
\text { de micro e pequenas empresas }\end{array}$} & LOA (R\$) & 2,9 & 0,0 & 0,0 & 0,0 \\
\hline & IEO (\%) & 0 & 0 & 0 & 0 \\
\hline \multirow{2}{*}{$\begin{array}{l}2553 \text { - Identificação da População } \\
\text { por meio da Carteira de Trabalho }\end{array}$} & LOA (R\$) & 11,8 & 15,4 & 12,4 & 14,7 \\
\hline & IEO (\%) & 61,6 & 13,1 & 10,2 & 51,2 \\
\hline \multirow{2}{*}{$\begin{array}{l}2599 \text { - Execução da Política Laboral } \\
\text { de Imigração e Emigração }\end{array}$} & LOA (R\$) & 2,2 & 1,6 & 0,9 & 1,0 \\
\hline & IEO (\%) & 41,4 & 38,8 & 84,7 & 68,9 \\
\hline \multirow{2}{*}{$\begin{array}{l}\text { 2B12 - Fomento ao Desenvolvimento } \\
\text { de Instituiç̧ões de Microcrédito }\end{array}$} & LOA (R\$) & 1,3 & 1,0 & 0,6 & 0,4 \\
\hline & IEO (\%) & 40,1 & 7 & 0 & 0 \\
\hline \multirow{2}{*}{ 2C43 - Gestão Participativa do FAT } & $\mathrm{LOA}(\mathrm{R} \$)$ & 5,4 & 3,2 & 1,9 & 1,3 \\
\hline & IEO (\%) & 23,7 & 40,5 & 3 & 3,7 \\
\hline \multirow{2}{*}{$\begin{array}{l}4245 \text { - Classificação Brasileira de } \\
\text { Ocupações (CBO) }\end{array}$} & LOA (R\$) & 8,3 & 6,6 & 2,5 & 2,9 \\
\hline & IEO (\%) & 87,8 & 72,2 & 34,9 & 50,9 \\
\hline \multirow{2}{*}{$\begin{array}{l}4641 \text { - Publicidade de Utilidade } \\
\text { Pública }\end{array}$} & $\mathrm{LOA}(\mathrm{R} \$)$ & 6,0 & 4,2 & 0 & 0 \\
\hline & IEO (\%) & 2,3 & 0 & 0 & 0 \\
\hline \multirow{2}{*}{$\begin{array}{l}4741 \text { - Sistema de Integração das } \\
\text { Ações de Emprego }\end{array}$} & LOA (R\$) & 168,2 & 97,5 & 190,4 & 178,6 \\
\hline & IEO (\%) & 33,3 & 58,2 & 41,2 & 56,5 \\
\hline \multirow{2}{*}{$\begin{array}{l}4767 \text { - Sistema de Informações sobre } \\
\text { a Inspeção do Trabalho }\end{array}$} & LOA (R\$) & 6,1 & 2,6 & 2,0 & 0 \\
\hline & IEO (\%) & 29,24 & 90,5 & 74,9 & 0 \\
\hline \multirow{2}{*}{$\begin{array}{l}8617 \text { - Controle, Monitoramento e } \\
\text { Avaliação das Aplicações do FAT }\end{array}$} & LOA (R\$) & 13,0 & 11,3 & 0,3 & 0,3 \\
\hline & IEO (\%) & 52,9 & 64,3 & 0 & 0 \\
\hline \multirow{2}{*}{ Total } & LOA $(R \$)$ & $56.830,8$ & $60.408,3$ & $56.340,1$ & $58.173,3$ \\
\hline & IEO (\%) & 95,8 & 88,2 & 93,7 & 92,9 \\
\hline
\end{tabular}

Fonte: Banco de dados Orçamento Brasil - Câmara dos Deputados.

Elaboração dos autores.

Obs.: Valores deflacionados para dezembro de 2019.

Os dados apresentados permitem alguns apontamentos. Primeiramente, o índice de execução alcançado pelas ações ligadas ao antigo Ministério do Trabalho é alto, quando comparado a outras estruturas ministeriais, mantendo uma média acima de $90 \%$. Porém, essa média é explicada pelo fato de o orçamento do ministério ser quase todo voltado 
para o pagamento dos benefícios do seguro-desemprego e do abono salarial, que, por serem direitos constitucionais dos trabalhadores, constituem despesa obrigatória. Em todos os anos de vigência do PPA 2016-2019, a soma desses dois programas foi superior a $99 \%$ do total aprovado pela LOA, variando entre $99,1 \%$ e 99,3\%.

Isso demonstra que o espaço orçamentário para os demais serviços de ativação do mercado de trabalho está cada vez mais exíguo, tornando-se praticamente residuais. Dessa forma, a análise da execução orçamentária do Programa Trabalho Decente e Economia Solidária está diretamente associada à dinâmica financeira do FAT nesses anos, uma vez que este constitui-se no principal instrumento de financiamento das açóes referentes a essa rubrica. ${ }^{28}$

Os programas que não são financiados via FAT, e sim por recursos do Tesouro Nacional, essa situação também foi similar. Um exemplo é a ação $215 \mathrm{~F}$ - Fomento e fortalecimento da economia solidária, que em 2019 teve uma dotação de R \$ 35 milhóes, mas apresentou um IEO de apenas 1,5\%. Se Silva (2018b) indicava que a açáo de economia solidária já apresentava uma situação de "crise de paradigma", referente a suas constantes quedas orçamentárias, o ano de 2019 praticamente decretou o fim dessa linha programática na agenda do governo federal.

Uma das formas de amenizar essa deficiência de financiamento é o desenvolvimento de plataformas digitais, visando tanto diminuir o custo dos serviços prestados quanto facilitar o acesso ao público em geral. São vários exemplos em curso nesse sentido nos últimos anos. Um deles é o Portal Mais Emprego, criado em 2015, atualmente denominado Emprega Brasil. Ele tem como função promover a integração do atendimento ao trabalhador em distintas açóes (habilitação ao seguro-desemprego, qualificação social e profissional e intermediação de emprego), em toda a rede de atendimento (superintendências regionais do Trabalho, agências regionais do extinto Ministério do Trabalho, agências do Sine ou agências autorizadas da Caixa Econômica Federal). Cursos de qualificação profissional também têm sido disponibilizados por meio de plataformas digitais. Outra inovação é a implantação da Carteira de Trabalho Digital, em substituição ao documento físico.

Contudo, em que pese a necessidade de modernização e digitalização dos serviços, essa estratégia não pode ser substitutiva da rede de atendimento presencial, pois ela é fundamental para o bom funcionamento de um sistema de políticas públicas, sobretudo quando se considera todas as heterogeneidades que existem tanto entre os diversos segmentos sociais que buscam esses serviços quanto a própria estrutura urbano-produtiva na qual se busca a inserção laboral. Ou seja,

28. Para uma análise recente da evolução contábil do FAT, ver Silva (2018b) e Ipea (2019a). Para uma proposta de alteração no arranjo institucional do FAT, visando à liberação de mais recursos para serviços sem corte de direitos dos trabalhadores, ver Silva (2018c). 
não há como expandir e melhorar os serviços do SPE no Brasil sem a destinação de novos recursos. ${ }^{29}$

O governo federal também tem buscado expandir sua rede de oferta de serviços por meio de outros recursos financeiros. Exemplo disso foi a elaboração da Estratégia Nacional de Qualificação para a Produtividade e o Emprego (Decreto no 10.110, de 11 de novembro de 2019), que consiste na negociação junto a entidades formadoras do chamado Sistema $S$ para que elas destinem parte dos recursos que elas recebem via contribuição das empresas para a oferta de cupons (vouchers) que dão acesso a cursos de qualificação para que as empresas treinem seus empregados e novos contratados. Para sua coordenação, o decreto determina a criação do Conselho de Desenvolvimento do Capital Humano para a Produtividade e o Emprego, composto por representantes dos Ministérios da Economia, Educação (MEC), Ciência, Tecnologia, Inovaçóes e Comunicaçóes (MCTIC) e Cidadania (MC).

Embora a proposta seja recente e ainda não possua parâmetros de avaliação estabelecidos, alguns pontos podem ser problematizados. Um deles é que os cupons são destinados às empresas e não aos trabalhadores. Assim, são as empresas que definem quem será qualificado e em quais áreas, o que tira a autonomia dos trabalhadores em buscar suas trajetórias de qualificação. Outro ponto é que as vagas serão ofertadas pela rede de ensino do Sistema $S$ dentro da própria capacidade instalada que ela já possui, isto é, não será advinda de novos cursos ou novas estruturas de ensino. Por fim, a estratégia de coordenação montada na forma de conselho não contempla organizaçóes da sociedade civil (empregadores e trabalhadores), mas somente entidades ministeriais do Executivo federal. Isso fere o princípio do tripartismo defendido pela OIT em suas convençôes, as quais o Brasil é signatário, no desenvolvimento de sistemas públicos de emprego. Ademais, não fica claro porque o próprio Codefat não possa ser o órgão com essa incumbência, já que essa é uma de suas atribuiçóes. ${ }^{30}$

\subsection{PPA 2020-2023: 0 QUE ESPERAR?}

Ao longo do primeiro semestre de 2019, o Ipea participou das discussóes prévias junto ao ME para a definição das metas relacionadas a trabalho, emprego e renda na proposta do PPA 2020-2023. O resultado final, submetido ao Congresso Nacional e formalizado na Lei no 13.971, de 27 de dezembro de 2019, foi um PPA ainda mais sucinto que o anterior, reduzindo para duas açôes ligadas à temática. Cada uma foi formulada na concepçáo de programa, passando a ter, respectivamente, um objetivo e uma meta, contra um total de 27 metas e 47 iniciativas encerradas no ciclo anterior.

29. Para uma proposta de reformulação da estrutura de financiamento do SPE no Brasil, ver: Silva (2018c). 30. Sobre as atribuições e a dinâmica deliberativa do Codefat, ver: Silva (2019a). 
Os dois programas do PPA de reponsabilidade do ME, sob a diretriz de número 12 - Ênfase na geração de oportunidades e de estímulos à inserção no mercado de trabalho, com especial atenção ao primeiro emprego, são descritos no quadro 4.

QUADRO 4

Programas de trabalho e renda no PPA (2020-2023)

\begin{tabular}{|c|c|c|}
\hline Programa & 2210 - Empregabilidade & 2213 - Modernização trabalhista e trabalho digno \\
\hline Objetivo & $\begin{array}{l}1188 \text { - Aumentar a efetividade das políticas ativas de } \\
\text { mercado de trabalho na inserção dos trabalhadores } \\
\text { na atividade produtiva. }\end{array}$ & $\begin{array}{l}1218 \text { - Modernizar as relações trabalhistas para } \\
\text { promover competitividade e proteção ao trabalhador. }\end{array}$ \\
\hline Meta & $\begin{array}{l}050 \text { C - Alcançar } 16 \% \text { de participação das políticas } \\
\text { ativas de emprego (intermediação de mão de obra e } \\
\text { qualificação) na colocação do trabalhador no mercado } \\
\text { de trabalho formal. }\end{array}$ & $\begin{array}{l}0524 \text { - Atingir o índice } 1 \text { de condições e relações de } \\
\text { trabalho (ICRT), que contempla ações de promoção } \\
\text { da conformidade legal e melhoria dos serviços. }{ }^{31}\end{array}$ \\
\hline $\begin{array}{l}\text { Descritor de } \\
\text { desempenho }\end{array}$ & $\begin{array}{l}\text { Taxa de participação das políticas ativas de emprego } \\
\text { (intermediação de mão de obra e qualificação) na } \\
\text { colocação do trabalhador no mercado de trabalho formal. }\end{array}$ & ICRT. \\
\hline Unidade de medida & Percentual & Índice numérico, variando de 0 a 1. \\
\hline Valor 2020 & $\mathrm{R} \$ 37,8$ milhões & $\mathrm{R} \$ 13,1$ milhões \\
\hline Valor 2021-2023 & $\mathrm{R} \$ 98,4$ milhões & $\mathrm{R} \$ 44,9$ milhões \\
\hline
\end{tabular}

Fonte: PPA 2002-2023.

Elaboração dos autores.

Os dois programas do PPA relacionados à temática do trabalho buscaram refletir serviços prestados de forma continuada pelas duas secretarias responsáveis pelo tema, criadas em 2019 no novo ME com atribuiçóes oriundas do antigo Ministério do Trabalho, conforme informado na introdução deste capítulo. O programa de Empregabilidade (2210) está ligado à Secretaria de Políticas Públicas de Emprego e o de Modernização trabalhista e trabalho digno (2213), à Secretaria de Trabalho.

Assim, o novo PPA se concentra em metas intermediárias sobre esforços a serem realizados nas operaçôes de ambas as secretarias e valores a serem aplicados. Embora a lei permita ao governo alterar valores e metas durante a vigência do PPA, seu texto prevê, para o Programa de Empregabilidade, maior aplicação neste ano de 2020 ( $\mathrm{R}$ \$ 37,8 milhôes) do que na média do triênio 2021-2023 ( $\mathrm{R}$ \$ 32,8 milhóes).

31. Conforme a Portaria no 3.900, de 27 de setembro de 2019, isso significa cumprir metas a serem estabelecidas pelo próprio ME para dez indicadores operacionais que compõem o ICRT, relacionados a: $i$ ) acidentes ou doenças do trabalho analisados; ii) ações fiscais estratégicas com irregularidades em segurança e saúde no trabalho; iii) empregados alcançados em situação de registro irregular; iv) valor de FGTS notificado ou recolhido; $v$ ) ações de combate ao trabalho escravo; vi) ações fiscais com constatação de trabalho infantil; vii) pessoas com deficiência inseridas; viii) aprendizes inseridos; ix) redução da emissão de Carteira de Trabalho e Previdência Social (CTPS) em meio físico; e x) redução da habilitação ao seguro-desemprego formal via atendimento presencial. Assim como a lei do PPA, a portaria ainda não prefixa metas quantitativas para todos os componentes em cada período, nem as linhas de base observadas em cada um deles ou na média do ICRT. 
O oposto ocorre no de Modernização Trabalhista e Trabalho Digno, com valor para 2020 ( $\mathrm{R}$ \$ 13,1 milhóes) inferior à média prevista para 2021-2023 ( $\mathrm{R}$ \$ 15,0 milhóes).

Contudo, algumas colocaçôes iniciais podem ser levantadas. $\mathrm{O}$ valor estimado para todo o PPA 2020-2023 nas açóes de ativação de mercado de trabalho (intermediaçáo de emprego e qualificação profissional) corresponde somente a 0,25\% do total executado somente do Programa Seguro-Desemprego em 2019. Isso sem cogitar a possibilidade sempre real de cortes e contingenciamentos ao longo dos exercícios orçamentários, sobretudo considerando a dificuldade de recuperação do crescimento econômico. Daí surge a questão: como o governo espera atingir uma meta tão ousada ( $16 \%$ das colocaçóes no mercado de trabalho a.a.) com um orçamento tão exíguo como este?

Ou seja, a restrição quanto às fontes de receita continuará como o grande entrave para a execução de uma política nacional efetiva e consistente de ativação de mercado de trabalho, que colabore para alavancar o crescimento de empregos de qualidade no Brasil. Somente com a agenda da desoneração dos custos do trabalho, que vem sendo a tônica desde a aprovação da reforma trabalhista em 2017 (Lei no 13.467), seguida pelas Medidas Provisórias (MPs) nos 881 e 905, ambas de 2019, é difícil garantir que uma reversão favorável nos indicadores de mercado de trabalho na magnitude que o desafio atual necessita, dadas as taxas atuais de desemprego, subutilização e informalidade da força de trabalho conforme discutido na seção 2.

Caso não se atenha a essa questão, o próprio alcance das próprias metas estabelecidas para os ODS (sobretudo no caso do ODS 8), ou mesmo a garantia dos acordos estabelecidos via convençóes da OIT sobre políticas de enfrentamento ao desemprego, constituirão desafios extremamente difíceis de serem atingidos.

\section{CONSIDERAÇÕES FINAIS}

Conforme discutido ao longo deste capítulo, a economia brasileira em 2019 mantém-se em uma relativa estagnação, com baixas taxas de crescimento desde a recessão observada em 2015 e 2016. Tal contexto se reflete diretamente na atual conjuntura do mercado de trabalho, cujos indicadores principais apontam um cenário bastante preocupante, sobretudo no tocante ao alto nível de desemprego. Isso faz com que o país encontre sérias dificuldades em cumprir metas e acordos internacionais firmados junto a distintos fóruns e instituiçóes, tanto no sentido de promoção de políticas de proteção e inclusão social quanto no atingimento de patamares mais elevados de oportunidades de trabalho digno para a população.

Sobre esses pontos, o capítulo aproveitou o centenário da OIT para recuperar o histórico das convençóes aprovadas no que diz respeito à disseminação do paradigma do SPE, em especial as Convençóes no 88/1948 e no 102/1952. Elas estabeleceram parâmetros internacionais para a estruturação normativa de 
uma nova institucionalidade de enfrentamento do desemprego e estabilização do mercado de trabalho, centrada em uma rede de serviços e benefícios a ser constituída por agentes públicos, dotados das capacidades necessárias que lhes garantissem certa autonomia frente a eventuais mudanças de governo, além de preverem a manutenção de comissôes consultivas que garantam a participação de empregadores e trabalhadores nos respectivos canais de decisão.

Como visto, o Brasil ratificou boa parte dessas convençôes, mas levou tempo para implementar de forma efetiva suas políticas. A CF/1988 trouxe, por meio do seu art. 239, várias determinaçóes importantes nesse caminho, quais sejam: i) estabelecimento de que as convençóes da OIT no Brasil, após o ato de aprovação, passariam a ter status de lei ordinária; ii) os programas do seguro-desemprego, do abono salarial, entre outras ações citadas ganharam diretrizes de execução e a definição dos recursos provenientes dos fundos PIS/Pasep como fonte de financiamento; e iii) garantia da existência do abono salarial, no valor de $1 \mathrm{SM}$ anual. A isso se somou à promulgação, da Lei no 7.998 , de 11 de janeiro de 1990, que trouxe os seguintes elementos: i) regulamentaçáo do seguro-desemprego, eliminando as restriçóes existentes de acesso que eram mais severas; $i$ i) estabelecimento de diretrizes de integração entre os benefícios financeiros ao trabalhador em situação de desemprego por demissão imotivada e a oferta de serviços de intermediação e qualificação profissional; iii) criaçáo do FAT, que passou a contar com a contribuição ao PIS/Pasep como principal fonte de financiamento, da forma prevista pela CF/1988; e iv) criação do Codefat, com a representação paritária de organizações ligadas aos trabalhadores, empregadores e órgáos da estrutura estatal, com a incumbência de tomar as decisóes estratégicas sobre os programas envolvidos em torno do FAT.

O texto também apresentou uma síntese do processo brasileiro de adequação das metas relativas a trabalho reunidas no ODS 8, que trata do objetivo de "promoção do trabalho decente e desenvolvimento econômico" e reúne um conjunto de metas voltadas a "promover o crescimento econômico sustentado, inclusivo e sustentável, emprego pleno e produtivo e trabalho decente para todas e todos". Foi montado um grupo de trabalho que resultou em um amplo esforço institucional para adaptar essas metas para seu contexto nacional, montando um painel de indicadores para aferir o desempenho de iniciativas voltadas a melhorar as oportunidades de trabalho no país. Falta ainda, porém, a validação da proposta desenvolvida por parte do governo federal brasileiro.

Uma das metas que compóe o ODS 8 é reduzir a taxa de desocupação em $40 \%$ (sendo 2016 o ano de referência), o que permitiria ao Brasil retornar a níveis historicamente baixos como os alcançados em 2014. Porém, a taxa de desocupação observada no fim de 2019 permanece bem acima daquela proposta pelo país. Além disso, outros indicadores para além da desocupação em si também demonstram o grande desafio que precisará ser realizado para que o país se aproxime das metas 
propostas, tais como: consistente desigualdade (regional, de gênero e de raça) nas oportunidades de acesso a trabalho digno, altas taxas de subutilização da força de trabalho, persistência de relações de desemprego de longo prazo em parte considerável da força de trabalho, existência de índices ainda consideráveis de desalento entre os trabalhadores, aliados ainda ao problema da informalidade nos vínculos de emprego, que acarretam uma série de vulnerabilidades para os trabalhadores submetidos a esse tipo de ocupaçáo.

Por fim, foram analisadas algumas das principais políticas de emprego do governo federal a partir do desempenho orçamentário das distintas açóes previstas no PPA 2016-2019 e o novo desenho aprovado para o PPA 2020-2023. No tocante ao PPA 2016-2019, observou-se que as açóes sob o eixo de trabalho e renda, contidas no programa 2071 - Trabalho Decente e Economia Solidária, foram fortemente afetadas pela tendência recente de aperto orçamentário para as açóes discricionárias, com queda tanto nos valores aprovados pelas respectivas LOAs quanto nos índices de execução orçamentária medido para cada ano. Esse processo, bem como alguns de seus determinantes, foi objetivo de análise no capítulo de Trabalho e renda do volume 26 do Boletim de Políticas Sociais.

No caso do PPA 2020-2023, os dois programas relacionados à temática do trabalho refletem, entre outras coisas, a mudança institucional trazida pela extinção do Ministério do Trabalho em 2019 e a transferência de suas atribuiçóes para duas secretarias do novo ME. O programa de Empregabilidade (2210) está ligado à Secretaria de Políticas Públicas de Emprego e o de Modernização Trabalhista e Trabalho Digno (2213), à Secretaria de Trabalho. Contudo, o valor estimado para todo o PPA 2020-2023 nas ações de ativação de mercado de trabalho (intermediação de emprego e qualificaçáo profissional) corresponde somente a $0,25 \%$ do total executado do Programa Seguro-Desemprego em 2019, o que torna difícil, por exemplo, atingir a meta proposta do programa de intermediação participar com $16 \%$ do total de colocados no mercado de trabalho.

Uma das estratégias que tem sido utilizadas nos últimos anos para amenizar a deficiência de financiamento dos programas de ativação do mercado de trabalho é o desenvolvimento de plataformas digitais, visando tanto diminuir o custo dos serviços prestados quanto facilitar o acesso ao público em geral. Por exemplo, uma das iniciativas mencionadas é o Portal Mais Emprego, criado em 2015, atualmente denominado Emprega Brasil. Outro caminho que tem sido adotado pelo governo federal é buscar expandir sua rede de oferta de serviços por meio de outros recursos financeiros. Um exemplo disso foi a elaboração recente da Estratégia Nacional de Qualificação para a Produtividade e o Emprego, que consiste na negociação junto a entidades formadoras do chamado Sistema $S$ para que elas destinem parte dos recursos recebidos via contribuição das empresas para a oferta de cupons (vouchers) que dão acesso a cursos de qualificação para que as empresas treinem seus empregados e novos contratados. Porém, o texto apontou alguns problemas nessas medidas, 
uma vez que elas seguem focadas apenas na desoneração dos custos e não estão associadas a uma estratégia mais ampla de desenvolvimento das forças produtivas nacionais e inclusão laboral da população em idade ativa.

\section{REFERÊNCIAS}

ABRAMO, L. Uma década de promoçáo do trabalho decente no Brasil: uma estratégia de ação baseada no diálogo social Brasília: OIT, 2015.

AZEREDO, B. Políticas públicas de emprego: a experiência brasileira. São Paulo: Abet, 1998.

BRASIL. Lei no 13.249 , de 13 de janeiro de 2016. Institui o Plano Plurianual da União para o período de 2016 a 2019. Diário Oficial, Brasília, 2016a.

. Lei no 13.971, de 27 de dezembro de 2019. Institui o Plano Plurianual da União para o período de 2020 a 2023. Diário Oficial, Brasília, 2016b.

. Ministério do Planejamento, Desenvolvimento e Gestão. Estratégia Nacional de Desenvolvimento Econômico e Social: estudos preparatórios. Brasília: MPDG, 2018.

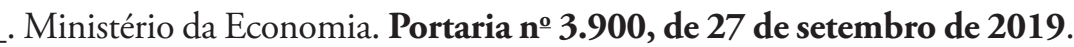
Brasília: ME, 2019.

CASELLA, P. B.; ACCIOLY, H.; SILVA, G. N. Manual de direito internacional público. São Paulo: Saraiva, 2010.

CEPAL - COMISSÃO ECONÔMICA PARA A AMÉRICA LATINA. Panorama Social de América Latina, 2018. Santiago, Chile: Cepal, 2019.

HUSEK, C. R. Curso básico de direito internacional público e privado do trabalho. São Paulo: LTr, 2009.

IPEA - INSTITUTO DE PESQUISA ECONÔMICA APLICADA. Políticas sociais: acompanhamento e análise. Brasília: Ipea, 2015. (Boletim, n. 23).

ODS: metas nacionais dos Objetivos de Desenvolvimento Sustentável. Brasília: Ipea, 2018.

. ODS 8: o que mostra o retrato do Brasil. Cadernos ODS. Brasília: Ipea, 2019a.

Políticas sociais: acompanhamento e análise. Brasília: Ipea, 2019b. (Boletim, n. 26).

KREIN, D.; OLIVEIRA, R. V.; FILGUEIRAS, V. A. (Orgs.). Reforma trabalhista no Brasil: promessas e realidade. Campinas: Curt Nimuendajú, 2019. 
LARAIA, M. I. F. Direito fundamental ao trabalho digno e o contrato de trabalho intermitente. 2018. Tese (Doutorado) - Departamento de Direito, Pontifícia Universidade Católica, São Paulo, 2018.

PIOVESAN, F. Direitos humanos e o direito constitucional internacional. São Paulo: Saraiva, 2011.

SILVA, S. P. Financiamento das políticas públicas de trabalho e renda no Brasil: uma análise a partir da trajetória operacional do Fundo de Amparo ao Trabalhador (FAT). Brasília: Ipea, 2018a. (Texto para Discussão, n. 2437).

A política de economia solidária no ciclo orçamentário nacional (2004-2018): inserção, expansão e crise de paradigma. Brasília: Ipea, 2018 b. (Texto para Discussão, n. 2434).

. Propostas de reformulaçáo no arranjo de financiamento e da agenda programática do Sistema Público de Emprego, trabalho e renda no Brasil. Brasília: Ipea, 2018c. (Boletim, n. 65).

O panorama laboral brasileiro no contexto recente da economia latinoamericana. Mercado de Trabalho: conjuntura e análise, v. 64. Brasília: Ipea, 2018d.

. O panorama laboral brasileiro no contexto recente da economia latino-americana. Mercado de Trabalho: conjuntura e análise. Brasília: Ipea, 2019a. (Boletim, n. 64).

. A dimensáo político-relacional das políticas de mercado de trabalho no Brasil: a agenda deliberativa do Codefat. Brasília: Ipea, 2019b. (Texto para Discussão, n. 2503).

O paradigma de sistema público de emprego da OIT e a sua construçáo histórica no Brasil. Brasília: Ipea, 2020a. (Texto para Discussão, no prelo). . Políticas de inclusão produtiva: o "elo perdido" da proteção social? Boletim Política Social, Brasília, n. 27, 2020b.

SUSSEKIND, A. Direito internacional do trabalho. São Paulo: LTr, 2000.

ZAPATA, S. R. D. As convençóes da OIT no ordenamento jurídico brasileiro. Jundiaí: Paco Editorial, 2016. 


\section{APÊNDICE A}

TABELA A. 1

Indicadores do mercado de trabalho - Brasil (2012-2019)

\begin{tabular}{|c|c|c|c|c|c|c|}
\hline & & $\begin{array}{c}\text { Taxa de } \\
\text { participação }\end{array}$ & $\begin{array}{c}\text { Taxa de } \\
\text { desocupação }\end{array}$ & $\begin{array}{c}\text { Taxa de } \\
\text { informalidade }\end{array}$ & População ocupada & $\begin{array}{l}\text { Rendimento real } \\
\text { médio recebido no } \\
\text { trabalho principal }\end{array}$ \\
\hline & & & $(\%)$ & & (Milhares) & $(R \$)$ \\
\hline 2012 & 1ㅇ Trim. & 61,1 & 7,9 & 45,7 & 87.632 & $2.127,25$ \\
\hline 2012 & $2^{\circ}-$ Trim. & 61,7 & 7,5 & 45,5 & 89.129 & $2.137,46$ \\
\hline 2012 & 3ㅇ Trim. & 61,5 & 7,1 & 45,4 & 89.639 & $2.148,99$ \\
\hline 2012 & $4^{\circ}$ Trim. & 61,3 & 6,9 & 45,2 & 89.857 & $2.142,42$ \\
\hline 2013 & 1으. Trim. & 61,2 & 8,0 & 45,0 & 88.999 & $2.181,91$ \\
\hline 2013 & $2^{0}$ Trim. & 61,5 & 7,4 & 45,1 & 90.099 & $2.209,32$ \\
\hline 2013 & 3으. Trim. & 61,3 & 6,9 & 44,9 & 90.707 & $2.239,16$ \\
\hline 2013 & 4으. Trim. & 61,0 & 6,2 & 44,8 & 91.403 & $2.222,18$ \\
\hline 2014 & 1ำTrim. & 61,1 & 7,2 & 44,0 & 90.782 & $2.266,30$ \\
\hline 2014 & 20 Trim. & 61,1 & 6,8 & 43,8 & 91.577 & $2.253,84$ \\
\hline 2014 & 3으. Trim. & 60,9 & 6,8 & 44,1 & 91.795 & $2.269,15$ \\
\hline 2014 & 4음im. & 60,9 & 6,5 & 44,3 & 92.396 & $2.266,92$ \\
\hline 2015 & 1으. Trim. & 61,0 & 7,9 & 44,2 & 91.555 & $2.267,02$ \\
\hline 2015 & $2^{\circ}-$ Trim. & 61,3 & 8,3 & 44,6 & 91.750 & $2.252,79$ \\
\hline 2015 & 3으. Trim. & 61,4 & 8,9 & 45,0 & 91.635 & $2.222,31$ \\
\hline 2015 & 4ำ Trim. & 61,4 & 8,9 & 45,2 & 91.800 & $2.193,19$ \\
\hline 2016 & 10 Trim. & 61,4 & 10,9 & 45,4 & 90.216 & $2.201,82$ \\
\hline 2016 & $2^{\circ}-$ Trim. & 61,6 & 11,3 & 45,7 & 90.379 & $2.169,54$ \\
\hline 2016 & 3 Trim. & 61,2 & 11,8 & 45,0 & 89.433 & $2.189,33$ \\
\hline 2016 & $4^{\circ}$ Trim. & 61,4 & 12,0 & 45,3 & 89.871 & $2.202,49$ \\
\hline 2017 & $1^{\circ}$ Trim. & 61,6 & 13,7 & 45,5 & 88.579 & $2.230,28$ \\
\hline 2017 & 2ㅇ Trim. & 61,7 & 13,0 & 46,4 & 89.872 & $2.205,01$ \\
\hline 2017 & 3ㅇ Trim. & 61,8 & 12,4 & 46,9 & 90.953 & $2.212,38$ \\
\hline 2017 & 4ㅇ Trim. & 61,8 & 11,8 & 47,2 & 91.770 & $2.221,09$ \\
\hline 2018 & 1ㅇ Trim. & 61,7 & 13,1 & 46,8 & 90.272 & $2.245,54$ \\
\hline 2018 & $2 \cong$ Trim. & 61,4 & 12,4 & 47,2 & 90.941 & $2.246,99$ \\
\hline 2018 & 3으rim. & 61,7 & 11,9 & 47,7 & 92.333 & $2.244,86$ \\
\hline 2018 & 4ำ Trim. & 61,7 & 11,6 & 47,8 & 92.736 & $2.256,20$ \\
\hline 2019 & 1ำ Trim. & 61,7 & 12,7 & 47,4 & 91.863 & $2.271,44$ \\
\hline 2019 & $2^{0}$ Trim. & 62,1 & 12,0 & 48,0 & 93.342 & $2.239,77$ \\
\hline 2019 & 3으. Trim. & 62,1 & 11,8 & 48,5 & 93.801 & $2.242,11$ \\
\hline 2019 & $4^{\circ}$ Trim. & 61,9 & 11,0 & 48,2 & 94.552 & $2.260,92$ \\
\hline
\end{tabular}

Fonte: IBGE/PNAD Contínua. 
TABELA A. 2

Taxa de desocupação - Brasil e regiões (2012-2019)

(Em \%)

\begin{tabular}{|c|c|c|c|c|c|c|c|}
\hline & & Brasil & Centro-Oeste & Nordeste & Norte & Sudeste & Sul \\
\hline 2012 & 10 Trim. & 7,94 & 7,01 & 9,69 & 8,89 & 7,92 & 5,14 \\
\hline 2012 & 2ㅇ Trim. & 7,52 & 6,22 & 9,62 & 8,15 & 7,40 & 4,82 \\
\hline 2012 & 3 Trim. & 7,07 & 5,66 & 9,34 & 7,81 & 6,87 & 4,28 \\
\hline 2012 & 40 Trim. & 6,85 & 5,69 & 9,29 & 7,34 & 6,62 & 3,95 \\
\hline 2013 & 10 Trim. & 7,97 & 6,78 & 10,91 & 8,57 & 7,56 & 4,77 \\
\hline 2013 & 2 Trim. & 7,42 & 6,00 & 9,98 & 8,29 & 7,21 & 4,26 \\
\hline 2013 & 3ㅇ Trim. & 6,93 & 5,48 & 8,94 & 7,55 & 6,95 & 4,10 \\
\hline 2013 & $4^{\circ}$ Trim. & 6,17 & 4,86 & 7,87 & 6,46 & 6,22 & 3,82 \\
\hline 2014 & 10 Trim. & 7,16 & 5,89 & 9,31 & 7,72 & 7,05 & 4,37 \\
\hline 2014 & 20 Trim. & 6,84 & 5,57 & 8,76 & 7,24 & 6,85 & 4,13 \\
\hline 2014 & 3 Trim. & 6,77 & 5,38 & 8,55 & 6,93 & 6,86 & 4,22 \\
\hline 2014 & 4ํ Trim. & 6,49 & 5,29 & 8,24 & 6,79 & 6,60 & 3,76 \\
\hline 2015 & 10 Trim. & 7,93 & 7,27 & 9,54 & 8,68 & 7,98 & 5,10 \\
\hline 2015 & 2ㅇ Trim. & 8,30 & 7,35 & 10,25 & 8,55 & 8,28 & 5,52 \\
\hline 2015 & 3ㅇ Trim. & 8,87 & 7,51 & 10,78 & 8,85 & 9,03 & 5,99 \\
\hline 2015 & 4ㅇTrim. & 8,95 & 7,36 & 10,43 & 8,64 & 9,59 & 5,69 \\
\hline 2016 & 10 Trim. & 10,89 & 9,65 & 12,76 & 10,49 & 11,37 & 7,35 \\
\hline 2016 & 20 Trim. & 11,31 & 9,70 & 13,18 & 11,24 & 11,71 & 8,04 \\
\hline 2016 & 3ㅇ Trim. & 11,79 & 9,98 & 14,08 & 11,46 & 12,28 & 7,89 \\
\hline 2016 & $4^{\circ}$ Trim. & 12,02 & 10,86 & 14,34 & 12,73 & 12,34 & 7,69 \\
\hline 2017 & 10 Trim. & 13,74 & 12,04 & 16,23 & 14,22 & 14,16 & 9,29 \\
\hline 2017 & 20 Trim. & 13,00 & 10,59 & 15,83 & 12,48 & 13,58 & 8,39 \\
\hline 2017 & 3ㅇ Trim. & 12,43 & 9,64 & 14,81 & 12,23 & 13,24 & 7,89 \\
\hline 2017 & 4º Trim. & 11,79 & 9,34 & 13,82 & 11,34 & 12,62 & 7,70 \\
\hline 2018 & 10 Trim. & 13,12 & 10,47 & 15,88 & 12,76 & 13,78 & 8,45 \\
\hline 2018 & 2ㅇTrim. & 12,44 & 9,48 & 14,82 & 12,11 & 13,22 & 8,16 \\
\hline 2018 & 3ㅇ Trim. & 11,88 & 8,89 & 14,38 & 11,58 & 12,50 & 7,86 \\
\hline 2018 & 40 Trim. & 11,59 & 8,46 & 14,34 & 11,69 & 12,12 & 7,32 \\
\hline 2019 & 10 Trim. & 12,72 & 10,80 & 15,26 & 13,08 & 13,22 & 8,14 \\
\hline 2019 & $2^{20}$ Trim. & 12,03 & 10,27 & 14,60 & 11,84 & 12,40 & 7,98 \\
\hline 2019 & 3ㅇ Trim. & 11,77 & 10,15 & 14,44 & 11,73 & 11,90 & 8,14 \\
\hline 2019 & 40 Trim. & 10,95 & 9,35 & 13,57 & 10,55 & 11,36 & 6,76 \\
\hline
\end{tabular}

Fonte: IBGE/PNAD Contínua. 
TABELA A.3

Taxa de desocupação - Brasil e segmentos populacionais (2012-2019)

(Em \%)

\begin{tabular}{|c|c|c|c|c|c|c|}
\hline & & Brasil & Masculino & Feminino & Brancos & Não brancos \\
\hline 2012 & 1ำ Trim. & 7,94 & 6,20 & 10,24 & 6,63 & 9,18 \\
\hline 2012 & $2^{\circ}$ Trim. & 7,52 & 6,13 & 9,34 & 6,14 & 8,81 \\
\hline 2012 & 3 Trim. & 7,07 & 5,76 & 8,77 & 5,67 & 8,36 \\
\hline 2012 & 4 Trim. & 6,85 & 5,71 & 8,35 & 5,43 & 8,16 \\
\hline 2013 & $1^{\circ}$ Trim. & 7,97 & 6,45 & 9,95 & 6,29 & 9,47 \\
\hline 2013 & 2ㅇ Trim. & 7,42 & 6,00 & 9,29 & 5,90 & 8,81 \\
\hline 2013 & 3 Trim. & 6,93 & 5,63 & 8,63 & 5,62 & 8,14 \\
\hline 2013 & 4 Trim. & 6,17 & 5,07 & 7,62 & 4,97 & 7,26 \\
\hline 2014 & 10 Trim. & 7,16 & 5,90 & 8,79 & 5,78 & 8,41 \\
\hline 2014 & 2ㅇ Trim. & 6,84 & 5,80 & 8,20 & 5,50 & 8,04 \\
\hline 2014 & 3o Trim. & 6,77 & 5,64 & 8,24 & 5,56 & 7,84 \\
\hline 2014 & 4 Trim. & 6,49 & 5,54 & 7,71 & 5,34 & 7,50 \\
\hline 2015 & 1 Trim. & 7,93 & 6,62 & 9,63 & 6,42 & 9,25 \\
\hline 2015 & 2ำTrim. & 8,30 & 7,13 & 9,79 & 6,74 & 9,67 \\
\hline 2015 & 3ㅇ Trim. & 8,87 & 7,69 & 10,38 & 7,17 & 10,36 \\
\hline 2015 & 4 Trim. & 8,95 & 7,71 & 10,55 & 7,35 & 10,36 \\
\hline 2016 & $1^{\circ}$ Trim. & 10,89 & 9,47 & 12,73 & 8,75 & 12,74 \\
\hline 2016 & $2 \circ$ Trim. & 11,31 & 9,87 & 13,16 & 9,22 & 13,14 \\
\hline 2016 & 3 Trim. & 11,79 & 10,46 & 13,52 & 9,56 & 13,73 \\
\hline 2016 & 4 Trim. & 12,02 & 10,66 & 13,76 & 9,50 & 14,14 \\
\hline 2017 & 1ㅇ Trim. & 13,74 & 12,14 & 15,76 & 10,88 & 16,14 \\
\hline 2017 & 2ㅇ Trim. & 13,00 & 11,49 & 14,88 & 10,33 & 15,21 \\
\hline 2017 & 3 Trim. & 12,43 & 11,01 & 14,20 & 9,88 & 14,55 \\
\hline 2017 & 4 Trim. & 11,79 & 10,48 & 13,43 & 9,45 & 13,71 \\
\hline 2018 & $1^{\circ}$ Trim. & 13,12 & 11,60 & 15,02 & 10,48 & 15,26 \\
\hline 2018 & $2^{\circ}$ Trim. & 12,44 & 11,01 & 14,22 & 9,88 & 14,52 \\
\hline 2018 & 3 Trim. & 11,88 & 10,47 & 13,64 & 9,38 & 13,92 \\
\hline 2018 & 4ำ Trim. & 11,59 & 10,07 & 13,45 & 9,18 & 13,52 \\
\hline 2019 & $1^{\circ}$ Trim. & 12,72 & 10,94 & 14,91 & 10,17 & 14,77 \\
\hline 2019 & $2^{\circ}$ Trim. & 12,03 & 10,34 & 14,09 & 9,52 & 14,05 \\
\hline 2019 & 3ㅇ Trim. & 11,77 & 10,00 & 13,93 & 9,17 & 13,84 \\
\hline 2019 & 4 Trim. & 10,95 & 9,23 & 13,05 & 8,67 & 12,74 \\
\hline
\end{tabular}

Fonte: IBGE/PNAD Contínua. 
TABELA A.4

Taxas de subocupação e desalento - Brasil (2012-2019)

(Em \%)

\begin{tabular}{|c|c|c|c|}
\hline Ano & Trimestre de referência & Taxa de subocupação & Taxa de desalento \\
\hline 2014 & 1ำTrim. & 11,8 & 1,1 \\
\hline 2014 & 2o Trim. & 11,3 & 1,0 \\
\hline 2014 & 3o Trim. & 11,3 & 1,0 \\
\hline 2014 & 40Trim. & 11,2 & 1,1 \\
\hline 2015 & 10 Trim. & 12,7 & 1,1 \\
\hline 2015 & 2ㅇ Trim. & 13,5 & 1,2 \\
\hline 2015 & 30Trim. & 14,3 & 1,3 \\
\hline 2015 & 4 Trim. & 13,0 & 1,3 \\
\hline 2016 & 1ำ Trim. & 15,0 & 1,9 \\
\hline 2016 & 2ㅇ Trim. & 16,0 & 2,2 \\
\hline 2016 & 3ㅇ Trim. & 16,5 & 2,3 \\
\hline 2016 & 4 Trim. & 17,1 & 2,5 \\
\hline 2017 & 1 Trim. & 18,8 & 2,7 \\
\hline 2017 & 2ㅇ Trim. & 18,6 & 2,6 \\
\hline 2017 & 3 Trim. & 18,4 & 2,8 \\
\hline 2017 & 4ㅇ Trim. & 18,0 & 2,8 \\
\hline 2018 & 10 Trim. & 19,0 & 3,0 \\
\hline 2018 & 2ㅇ Trim. & 18,7 & 3,1 \\
\hline 2018 & 3o Trim. & 18,4 & 3,1 \\
\hline 2018 & 4ㅇ Trim. & 18,1 & 3,0 \\
\hline 2019 & 1o Trim. & 19,1 & 3,1 \\
\hline 2019 & 2ㅇ Trim. & 19,0 & 3,1 \\
\hline 2019 & 3o Trim. & 18,4 & 3,0 \\
\hline 2019 & 4 Trim. & 17,4 & 2,9 \\
\hline
\end{tabular}

Fonte: IBGE/PNAD Contínua. 



\section{DESENVOLVIMENTO RURAL ${ }^{1}$}

\section{APRESENTAÇÃO}

O Brasil, junto de outros 192 Estados-membros da Cúpula de Desenvolvimento Sustentável da Assembleia Geral das Naçóes Unidas, assinou em 2015 o documento Transformando nosso mundo: a Agenda 2030 para o desenvolvimento sustentável. Tal compromisso estabelece uma série de desafios, que, desde 2016, devem orientar um plano de ação condizente com o esforço nacional necessário para se cumpri-lo. A Agenda 2030 é composta de dezessete Objetivos de Desenvolvimento Sustentável (ODS) e 169 metas. Para coordenar sua implementação, o Decreto no 8.892, de 27 de outubro de 2016, criou a Comissão Nacional dos Objetivos de Desenvolvimento Sustentável, da Secretaria de Governo da Presidência da República (Segov/PR).

Neste capítulo, o foco de análise está relacionado com o compromisso fixado no ODS 2, "Acabar com a fome, alcançar a segurança alimentar e melhoria da nutrição e promover a agricultura sustentável”. Sem se debruçar, em particular, sobre cada uma das metas que compóem esse objetivo, ${ }^{2}$ a proposta deste texto é avaliar em que medida programas e políticas públicas existentes no país contribuem para a superação da fome e para o fortalecimento de um modelo de produção diversificada e segura de alimentos. Tais programas e políticas públicas englobam desde a garantia de acesso à alimentação adequada, reconhecida como direito humano, ${ }^{3}$ até a montagem de sistemas de compra pública da produção dos pequenos agricultores, a oferta de créditos subsidiados à produção agrícola e a criação de incentivos a práticas agrícolas sustentáveis.

O ODS 2 é composto de oito metas. Destas, três são de implementação, relacionadas à capacidade institucional de atingir o objeto, tratando de financiamento público e regulação do mercado de alimentos. As demais são metas finalísticas, isto é, visam alterar um aspecto socioeconômico específico relacionado ao objetivo. Das cinco metas finalísticas, as duas primeiras são referentes à segurança alimentar e à garantia do direito ao acesso à alimentação adequada e saudável; a terceira e a quarta

1DOI: http://dx.doi.org/10.38116/bps27/desenvolvimentorural 2. Este trabalho já foi desenvolvido por Valadares e Alves (2019).

3. 0 direito humano à alimentação adequada está contemplado no art. 25 da Declaração Universal dos Direitos Humanos de 1948. Em 2010, a aprovação da Emenda Constitucional (EC) oo 64 incluiu, com o Estatuto de Direito Social, a alimentação no art. 6o da Constituição Federal. 
relacionam-se com a produção sustentável de alimentos e a equidade no acesso aos recursos e na distribuição dos benefícios; e a quinta, com a sociobiodiversidade. ${ }^{4}$ Pelo conjunto de metas do ODS 2, é buscado conciliar o consumo e a produção de alimentos de forma socialmente justa e ambientalmente sustentável. É recepcionado, dessa maneira, pelos princípios constitucionais relacionados ao direito à alimentação (Brasil, 1988, art. 6ㅇ), ao direito ao meio ambiente ecologicamente equilibrado (op. cit., art. 225) e à função social da terra (op. cit., art. 186).

Este texto dará ênfase à questão da segurança alimentar e da produção sustentável de alimentos e está dividido em cinco seções, além desta apresentação. A seção 2 oferece um diagnóstico da situação atual do país quanto ao acesso à alimentação com base na evolução recente de indicadores selecionados de segurança alimentar e renda. A seção 3 traz temas atinentes às questóes da qualidade da alimentação sob a ótica do consumo - com os indicadores de obesidade e sobrepeso - e, em seguida, na seção 4, essa temática é vista sob a ótica da produção, com a questão do crescimento do uso e do licenciamento de agrotóxicos no país. A seção 5 busca delinear uma perspectiva das condiçóes futuras de enfretamento da fome e de promoção de uma alimentação saudável e segura no país a partir de uma leitura dos dados orçamentários. Por fim, a seção 6 apresenta as consideraçôes finais deste capítulo.

\section{PANORAMA DA SEGURANÇA ALIMENTAR NO BRASIL}

$O$ conceito de segurança alimentar é complexo e foi adquirindo uma multidimensionalidade no decorrer do tempo. Surgiu no fim da Segunda Guerra Mundial e se restringia à questão da disponibilidade de alimentos e da capacidade de produção e armazenamento de produtos alimentícios de um determinado país. A partir da década de 1970, passa a envolver a questão do acesso aos alimentos, procurando conciliar, entâo, a oferta e a procura por comida. Em fins da década de 1980, as preocupaçóes com as dimensóes nutricionais, sanitárias e culturais fazem incorporar esses elementos ao conceito, sendo adicionado, finalmente, a questáo da regularidade no acesso (Alem et al., 2015). No contexto brasileiro, esse conceito amplo de segurança alimentar está consolidado como direito na Lei n⿳o 11.346/2006, que, em seu art. 3ํassim a define:

A segurança alimentar e nutricional consiste na realização do direito de todos ao acesso regular e permanente a alimentos de qualidade, em quantidade suficiente, sem comprometer o acesso a outras necessidades essenciais, tendo como base práticas alimentares promotoras de saúde que respeitem a diversidade cultural e que sejam ambiental, cultural, econômica e socialmente sustentáveis (Brasil, 2006).

Em virtude da complexidade conceitual, a mensuração da segurança alimentar também é diversa, havendo diferentes abordagens e variados indicadores usados para medi-la. Os métodos usualmente utilizados para analisar a segurança alimentar

4. 0 anexo A contém a relação das metas nacionais para o ODS 2. 
envolvem disponibilidade calórica per capita diária, medidas antropométricas, renda mínima para consumo alimentar e não alimentar, recordatórios de consumo alimentar, escalas psicométricas de acesso familiar aos alimentos (Pérez-Escamilla e Segall-Corrêa, 2008 apud IBGE, 2014, p. 26). ${ }^{5}$ A Escala Brasileira de Insegurança Alimentar (Ebia) é um exemplo de escala psicométrica. Utilizada pelo Instituto Brasileiro de Geografia e Estatística (IBGE) a partir de informaçóes coletadas na Pesquisa Nacional por Amostra de Domicílios (PNAD), busca analisar a situação de (in)segurança alimentar pela percepção das pessoas afetadas. O conjunto de informaçôes coletadas nos domicílios permite classificá-los em uma das quatro categorias: segurança alimentar; insegurança alimentar leve; insegurança alimentar moderada; e insegurança alimentar grave. $\mathrm{O}$ quadro 1 resume as definiçóes dessas categorias.

\section{QUADRO 1}

\section{Descrição dos graus de (in)segurança alimentar}

\begin{tabular}{|l|l|}
\hline Situação de segurança alimentar & Descrição \\
\hline Segurança alimentar & $\begin{array}{l}\text { A família/domicílio tem acesso regular e permanente a alimentos de qualidade, em quanti- } \\
\text { dade suficiente, sem comprometer o acesso a outras necessidades essenciais. }\end{array}$ \\
\hline Insegurança alimentar leve & $\begin{array}{l}\text { Preocupação ou incerteza quanto acesso aos alimentos no futuro; qualidade inadequada } \\
\text { dos alimentos resultante de estratégias que visam não comprometer a quantidade de } \\
\text { alimentos. }\end{array}$ \\
\hline Insegurança alimentar moderada & $\begin{array}{l}\text { Redução quantitativa de alimentos entre os adultos e/ou ruptura nos padrões de alimenta- } \\
\text { ção resultante da falta de alimentos entre os adultos. }\end{array}$ \\
\hline Insegurança alimentar grave & $\begin{array}{l}\text { Redução quantitativa de alimentos entre as crianças e/ou ruptura nos padrões de alimen- } \\
\text { tação resultante da falta de alimentos entre as crianças; fome (quando alguém fica o dia } \\
\text { inteiro sem comer por falta de dinheiro para comprar alimentos). }\end{array}$ \\
\hline
\end{tabular}

Fonte: IBGE (2014).

Os dados disponíveis para avaliar a (in)segurança alimentar pela escala Ebia abrangem, até o momento, os anos de 2004, 2009 e 2013. ${ }^{6}$ Observando essas informaçóes, infere-se que no período houve uma importante melhoria na situação da segurança alimentar no Brasil. Dados colhidos pela PNAD 2013, expostos no gráfico 1 , revelam que o percentual de domicílios em situação de segurança alimentar saltou de 65,1\%, em 2004, para 69,8\%, em 2009, e para 77,4\%, em 2013. A expressiva melhoria nesses indicadores foi verificada também entre os segmentos mais vulneráveis da população: o percentual de domicílios classificados com situação de insegurança alimentar grave reduziu de 6,9\%, em 2004, para 5,0\%, em 2009, e para 3,2\%, em 2013 (IBGE, 2014). A evolução positiva

5. Pérez-Escamilla, R.; Segall-Corrêa, A. M. Food insecurity measurement and indicators. Revista de Nutrição, Campinas, v. 21, p. 15-26, jul./ago. 2008. Disponível em: <https://bit.ly/2KebsWx>. Acesso em: 13 dez. 2014.

6. Além de permitir uma análise multidimensional do fenômeno da (in)segurança alimentar a partir da percepção das pessoas afetadas, a Ebia é o método que vem sendo utilizado pelo IBGE, permitindo uma análise histórica do fenômeno, constituindo referência para formulação e avaliação de políticas públicas de combate à insegurança alimentar. 
desse indicador fez, inclusive, que o país fosse retirado do Mapa da Fome, da Organização das Naçóes Unidas para a Alimentação e a Agricultura (Food and Agriculture Organization - FAO), que inclui aqueles países com mais de 5\% da população em situação de insegurança alimentar grave (FAO, 2014).

GRÁFICO 1

Domicilios particulares por situação de segurança alimentar - Brasil (Em \%)

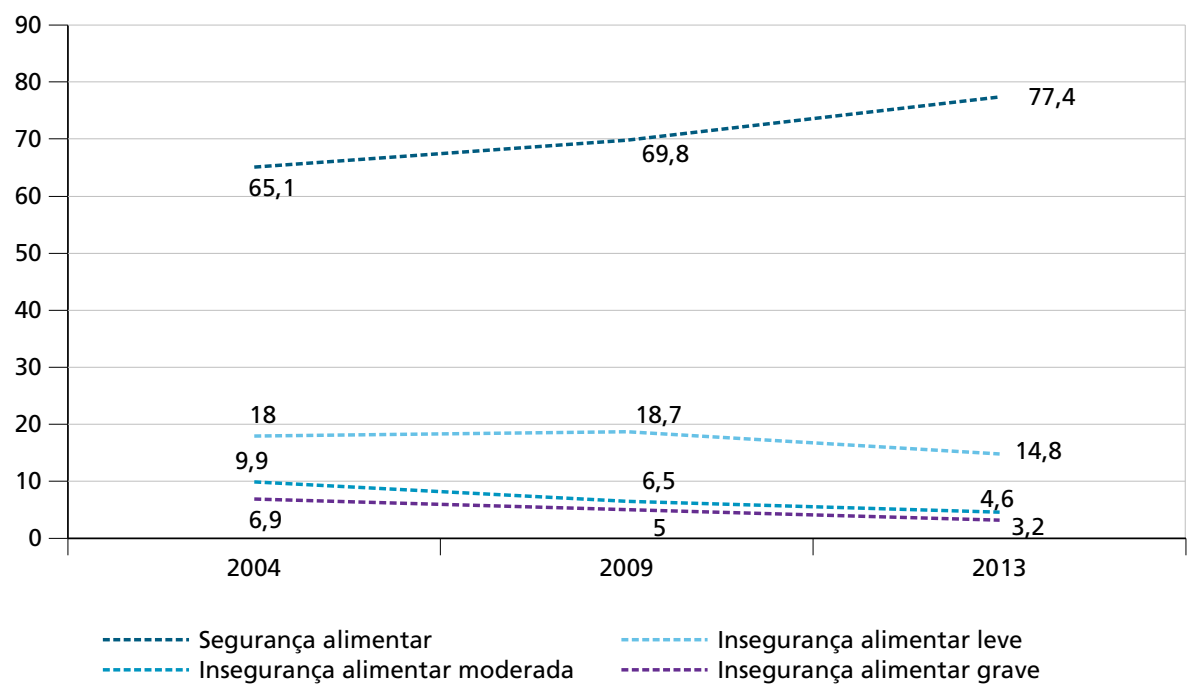

Fonte: IBGE (2014).

Considerando a dimensão do país e suas acentuadas desigualdades sociais e regionais, é importante ressaltar que cenários de avanço não ocorreram igualmente em todo o território brasileiro. Quando se analisam domicílios rurais e urbanos, por exemplo, observa-se que a situação da segurança alimentar em áreas urbanas, que já era mais favorável em 2004, apresentou melhoria maior do que em áreas rurais. De 2004 para 2013, o percentual de domicílios urbanos com segurança alimentar saltou de $66,7 \%$ para $79,5 \%$, ou seja, $+12,8$ pontos percentuais (p.p.), ou $+19,2 \%$. Em áreas rurais, o indicador variou de $56,2 \%$ para $64,7 \%$ no mesmo período (+8,5 p.p., ou $+15,1 \%)$, resultado mais modesto, portanto.

Em contrapartida, é relevante destacar que a situação da insegurança alimentar no campo alterou-se de forma significativa. A queda nos indicadores de insegurança grave e moderada em domicílios rurais, em p.p., foi maior que a queda verificada em domicílios urbanos. De 2004 para 2013, o percentual de domicílios rurais em situação de insegurança alimentar grave e moderada caiu 4,1 p.p. e 5,6 p.p., respectivamente; enquanto o percentual de domicílios urbanos nessa situação reduziu 3,7 p.p. e 5,3 p.p., respectivamente. Ou seja, nas áreas rurais, houve uma forte transição, dentro 
do grupo em situação de insegurança alimentar, das modalidades grave e moderada para a modalidade leve. Esta, por sinal, elevou-se de $20,2 \%$ do total de domicílios rurais, em 2004, para 21,4\%, em 2013.

De qualquer modo, os níveis de insegurança alimentar no meio rural ainda são significativamente maiores do que nas áreas urbanas. Trivellato et al. (2019), ao realizarem revisão sistemática de estudos sobre determinantes de insegurança alimentar no meio rural, constataram a associaçâo dos indicadores de insegurança alimentar com fatores de renda, moradia e acesso a bens e serviços. Essas situaçóes, quando precárias, se intensificam em virtude da pobreza e dos baixos índices de desenvolvimento e educação, além da má distribuição da terra, agravando ainda mais a situação de insegurança alimentar da população rural.

\section{GRÁFICO 2}

Domicílios em situação de insegurança alimentar por situação do domicílio - Brasil (2004 e 2013)

(Em \%)

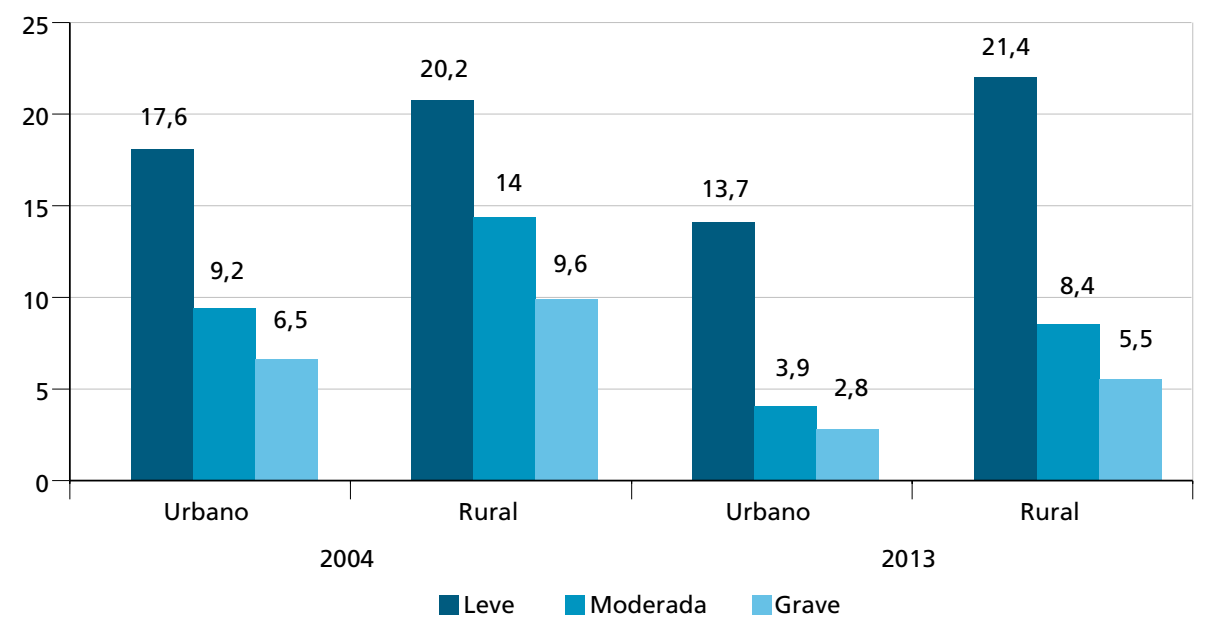

Fonte: IBGE (2014).

Os avanços observados na situação de segurança alimentar da população brasileira são oriundos de um arranjo de políticas públicas direcionadas aos trabalhadores em geral e à população de baixa renda em específico, potencializadas pelo dinamismo econômico que caracterizou os anos 2000. Sob a ótica da renda, podem-se citar o Programa Bolsa Família, que complementa a renda de famílias em situação de pobreza, e a política de valorização do salário mínimo (SM), que propiciou reajustes acima da inflação do salário do trabalhador e do valor dos benefícios previdenciários, impactando positivamente na renda no meio rural e em localidades de pouco dinamismo econômico. 
Do ponto de vista da produçáo de alimentos, vale mencionar o Programa de Fortalecimento da Agricultura Familiar (Pronaf), que se consolidou como o mais importante programa de fomento à agricultura familiar, fornecendo crédito para produção agropecuária; além do Programa Nacional de Alimentação Escolar (PNAE), que garante alimentação para todas as crianças do ensino básico público; e do Programa de Aquisição de Alimentos (PAA), que realiza a compra pública de alimentos produzidos pela agricultura familiar e os distribui para famílias em situação de vulnerabilidade socioeconômica.

Apesar dos avanços substanciais, quase um quarto do total de domicílios no país - algo em torno de 17 milhóes de domicílios - ainda apresentava, segundo os dados de 2013, algum problema ou deficiência em termos de garantia de sua segurança alimentar, o que já apontava para a necessidade de se aprofundarem os avanços obtidos até então. Até o momento, não há dados mais atualizados sobre a segurança alimentar com base na Ebia, mas é muito provável que o quadro tenha sofrido algum retrocesso desde então, em virtude da grave crise econômica iniciada em 2015.

O relatório referente ao ODS 1, realizado para os Cadernos ODS, do Ipea, apresenta indícios preocupantes nesse sentido, ao mostrar que a proporçáo da população vivendo em situação de pobreza subiu de 12,8\%, em 2016, para 13,3\%, em 2017. Em valores absolutos, a variação corresponde a um crescimento de 26,3 milhôes para 27,5 milhôes de pessoas em situação de pobreza entre 2016 e 2017 (Souza e Vaz, 2019). Uma vez que o acesso a alimentos se dá majoritariamente pela compra, os sinais dessa perda de renda podem significar também uma instabilidade na situação de segurança alimentar das famílias pobres.

O trabalho constitui a principal fonte de renda da população. Santos et al. (2018) analisaram, a partir dos dados das PNADs de 2004, 2009 e 2013, os fatores associados à condição de insegurança alimentar. Entre os fatores, destacam a condição de desemprego como um importante determinante de insegurança alimentar. Entre 2013 e 2018, os indicadores sobre trabalho e emprego apontam um aumento da precarização do mercado de trabalho. Dados da PNAD sobre o desemprego mostram que a taxa de desocupação no Brasil aumentou significativamente, saindo de um patamar de 7,2\%, em 2013, para 12,0\%, em 2018. ${ }^{7}$ Outro indicador importante para avaliar o mercado de trabalho é a taxa de subutilização da força de trabalho, que engloba a proporção de pessoas desocupadas, subocupadas e a força de trabalho potencial. ${ }^{8}$ Esse indicador apresentou um aumento significativo entre 2013 e 2018 , indo de $17,1 \%$ a $24,6 \%$ no período.

7. Informações disponíveis em: <https://bit.ly/39VdyF5>.

8. Desocupadas: pessoas que procuraram trabalho, mas não conseguiram no período de referência; subocupadas: pessoas que trabalharam menos de $40 \mathrm{~h}$ semanais, mas que gostariam de trabalhar mais; e força de trabalho potencial: pessoas que gostariam de trabalhar, mas não procuraram. 
Além da observação de indicadores de trabalho e emprego que permitem analisar a condição de segurança alimentar a partir da obtenção de recursos para aquisição de alimentos, é importante considerar o comportamento do preço dos alimentos para esse tipo de análise. De acordo com a Pesquisa Nacional da Cesta Básica de Alimentos, ${ }^{9}$ realizada pelo Departamento Intersindical de Estatística e Estudos Socioeconômicos (Dieese), o custo médio da cesta básica das cidades onde foi feito o levantamento apresentou um aumento real de $4 \%$ entre 2009 e 2018 ( $R \$ 372,43^{10}$ e $R \$ 388,00$, respectivamente), ou seja, os alimentos encareceram. Considerando o crescimento da população em situação de pobreza, a redução de postos de trabalho e o encarecimento dos alimentos, fica evidente o agravamento da situação de insegurança alimentar no Brasil.

Os dados disponíveis da Pesquisa de Orçamentos Familiares (POF) 2017-2018 corroboram essa evidência. Entre 2009 e 2018, o valor despendido pelas famílias das duas faixas inferiores de rendimento apresentou um decréscimo real, enquanto nas demais faixas esse gasto aumentou. Provavelmente, enquanto as famílias com maior rendimento conseguiram absorver o encarecimento da cesta, aumentando seu gasto com comida, as famílias em situação vulnerável tiveram de reduzir o gasto com comida, seja por mudança na composição da cesta, seja por redução do consumo, devido à insuficiência de renda para manter seu patamar de alimentação. ${ }^{11}$

TABELA 1

Despesa média mensal familiar com alimentação por classes de rendimento (2009 e 2018)

\begin{tabular}{ccccccccc}
\hline Ano & Total & Até 2 SMs & $\begin{array}{c}\text { Mais de 2 a } \\
\text { 3 SMs }\end{array}$ & $\begin{array}{c}\text { Mais de 3 } \\
\text { a 6 SMs }\end{array}$ & $\begin{array}{c}\text { Mais de 6 } \\
\text { a 10 SMs }\end{array}$ & $\begin{array}{c}\text { Mais de 10 a } \\
15 \text { SMs }\end{array}$ & $\begin{array}{c}\text { Mais de 15 } \\
\text { a 25 SMs }\end{array}$ & $\begin{array}{c}\text { Mais de 25 } \\
\text { SMs }\end{array}$ \\
\hline 20091 & 683,28 & 335,63 & 452,08 & 613,79 & 846,83 & $1.061,98$ & $1.365,51$ & $1.941,26$ \\
2018 & 658,23 & 328,74 & 444,47 & 631,67 & 855,96 & $1.115,11$ & $1.471,60$ & $2.061,34$ \\
$\begin{array}{c}\text { Variação } \\
(\%)\end{array}$ & -4 & -2 & -2 & 3 & 1 & 5 & 8 & 6 \\
\hline
\end{tabular}

Fonte: POF-IBGE. Disponível em: <https://bit.ly/2K61aHV>.

Nota: ${ }^{1}$ Valores atualizados pelo IGP-DI para janeiro de 2018 (data de referência da POF 2017-2018).

Além disso, o arcabouço de políticas públicas de promoção da segurança alimentar em camadas mais vulneráveis da população e de estruturação da produçấo agrícola familiar tem apresentado um decréscimo orçamentário significativo nos últimos anos. Cita-se, por exemplo, o PAA, cuja execução orçamentária em 2017

9. Essa pesquisa utiliza a estrutura da cesta básica estabelecida pelo Decreto-lei no 399, de 30 de abril de 1938. Disponivel em: <https://bit.ly/2RmoC7G>.

10. Valor deflacionado para 2018 pelo Índice Geral de Preços-Disponibilidade Interna (IGP-DI).

11. A estratificação com base no SM não permite uma simulação do coorte, uma vez que o valor do SM se elevou e ficou acima da inflação, as classes de rendimento não correspondem entre si para os dois períodos apresentados. Em 2018, as classes de renda superiores incorporam famílias da classe imediatamente inferior em relação a 2009. 0 ideal seria uma estratificação por quantis da população amostrada conforme a renda aferida, o que não foi disponibilizada na publicação da POF. Mesmo assim, os dados permitem observar a redução de gasto com alimentação das famílias de renda mais baixa. 
representou menos de um terço da execução em 2014. ${ }^{12}$ Houve, dessa maneira, uma redução da capacidade do Estado de garantir a segurança alimentar de famílias em situação de vulnerabilidade socioeconômica.

\section{QUESTÕES RELATIVAS À QUALIDADE DA ALIMENTAÇÃO}

A segunda meta do ODS 2 direciona-se à erradicação de todas as formas de má nutrição. Como má nutrição entende-se não somente a condição de insuficiência de alimentos, mas também a má qualidade do consumo alimentar. Busca-se, desse modo, conciliar a quantidade e a qualidade da alimentação. Nesta última dimensão, os avanços verificados no início deste século não foram tão significativos. $\mathrm{Na}$ verdade, o esforço do Estado brasileiro nessa área parece não ter assegurado melhoria das condições nutricionais da população; no máximo, evitou um agravamento maior do quadro.

\subsection{Obesidade e qualidade da alimentação}

A prevalência da obesidade é um dos principais indicadores deste problema de saúde pública. Para a população adulta brasileira, dispóe-se de duas pesquisas: a Pesquisa Nacional de Saúde (PNS), realizada pelo IBGE em 2013, de abrangência nacional, e a pesquisa Vigilância de Fatores de Risco e Proteção para Doenças Crônicas por Inquérito Telefônico (Vigitel), realizada anualmente nas capitais. De acordo com os dados da PNS, entre a população com idade acima de 18 anos, 36\% dos indivíduos estavam com excesso de peso e $21 \%$, na condição de obesidade. Ao considerar os grupos etários, observa-se um aumento das prevalências de sobrepeso e obesidade até a faixa de 55 a 64 anos, com redução das faixas correspondentes à população mais idosa, situaçáo que deve estar associada à menor expectativa de vida da população com excesso de peso. ${ }^{13}$

TABELA 2

Prevalência de sobrepeso e obesidade entre pessoas de 18 anos ou mais de idade, por sexo, segundo os grupos etários - Brasil (2013)

\begin{tabular}{ccccccc}
\hline \multirow{2}{*}{ Grupos de idade } & \multicolumn{2}{c}{ Total } & \multicolumn{2}{c}{ Homens } & \multicolumn{2}{c}{ Mulheres } \\
\cline { 2 - 7 } & Sobrepeso & Obesidade & Sobrepeso & Obesidade & Sobrepeso & Obesidade \\
\hline Total & $\mathbf{3 6 , 1}$ & $\mathbf{2 0 , 8}$ & $\mathbf{3 8 , 8}$ & $\mathbf{1 6 , 8}$ & $\mathbf{3 3 , 8}$ & $\mathbf{2 4 , 4}$ \\
18 a 24 anos & 22,5 & 10,3 & 24,8 & 8,6 & 20,1 & 12,0 \\
25 a 29 anos & 32,8 & 15,5 & 36,8 & 13,6 & 28,6 & 17,5 \\
30 a 34 anos & 37,1 & 18,4 & 41,3 & 16,7 & 33,0 & 20,0 \\
35 a 44 anos & 39,6 & 23,5 & 43,6 & 18,8 & 36,1 & 27,6 \\
\hline
\end{tabular}

12. Para informações detalhadas a respeito, ver Lima et al. (2019).

13. Dado que é corroborado pela literatura específica. Ver, por exemplo, Grover et al. (2015). Nesse estudo, os autores constataram uma perda de anos na expectativa de vida de até oito anos, depende do sexo e da idade em que a condição de obesidade for adquirida. 


\begin{tabular}{ccccccc}
\hline \multirow{2}{*}{ Grupos de idade } & \multicolumn{2}{c}{ Total } & \multicolumn{2}{c}{ Homens } & \multicolumn{2}{c}{ Mulheres } \\
\cline { 2 - 7 } & Sobrepeso & Obesidade & Sobrepeso & Obesidade & Sobrepeso & Obesidade \\
\hline 45 a 54 anos & 41,4 & 25,3 & 43,9 & 20,2 & 39,1 & 29,9 \\
55 a 64 anos & 40,3 & 28,0 & 41,6 & 23,0 & 39,2 & 32,2 \\
65 a 74 anos & 40,2 & 24,2 & 42,5 & 18,9 & 38,4 & 28,5 \\
75 anos e mais & 34,1 & 18,7 & 33,6 & 11,7 & 34,5 & 23,8 \\
\hline
\end{tabular}

Fonte: PNS-IBGE. Disponível em: <https://bit.ly/2V9xC0Q>.

Segundo relatório da pesquisa Vigitel Brasil 2018, do Ministério da Saúde, a frequência de adultos maiores de 18 anos com excesso de peso no Brasil aumentou 17\% entre 2006 e 2018, período em que saltou de 43\% para 56\% (Brasil, 2019a). Conforme se observa no gráfico 3 , parte importante dessa piora ocorreu justamente em função do alarmante incremento de $68 \%$ no percentual de adultos considerados obesos, que saltou de $12 \%$ da população adulta, em 2006, para $20 \%$, em $2018 .{ }^{14}$

A desagregação dessa informação revela que a obesidade reflete desigualdades estruturais da sociedade brasileira. É importante notar, a princípio, que a prevalência da obesidade no país é inversamente proporcional ao nível de escolarização: em 2018, o percentual de adultos obesos com nível fundamental, médio e superior era $25 \%, 19 \%$ e $16 \%$, respectivamente. Por sua vez, o crescimento da taxa de obesidade verificada no período para a população com nível médio e superior (113\% e $82 \%$, respectivamente) foi superior ao observado entre a população com nível fundamental (60\%).

Quando o foco é gênero, percebe-se que o percentual de mulheres obesas é maior que o de homens obesos (21\% e 19\%, respectivamente, em 2018); neste caso, a taxa de crescimento da obesidade no período em análise foi, também, maior entre as mulheres: aumentou $71 \%$, enquanto entre os homens foi constatada uma elevaçấo de $64 \%$. Já o recorte etário indica que a prevalência da obesidade aumenta com o avançar da idade. ${ }^{15}$ As faixas de idade entre 25 e 34 anos e 35 e 44 anos apresentaram os maiores incrementos no período: de $84 \%$ e $81 \%$, respectivamente. Malta et al. (2014), analisando os dados da Vigitel entre 2006 e 2012, constataram a tendência de aumento da prevalência de sobrepeso e obesidade, com diferenças estatisticamente significantes entre grupos de sexo, idade e escolaridade distintos.

Os dados deixam claro que fatores socioeconômicos exercem influência decisiva sobre a prevalência da obesidade, embora ela atinja e cresça em todos os grupos socioeconômicos.

14.0 sobrepeso é diagnosticado quando o índice de massa corporal (IMC) alcança valor entre $25 \mathrm{~kg} / \mathrm{m}^{2}$ e $29,9 \mathrm{~kg} / \mathrm{m}^{2}$, enquanto a obesidade é diagnosticada com valor de IMC igual ou superior a $30^{3} \mathrm{~kg} / \mathrm{m}^{2}$. O IMC, por sua vez, é obtido pela divisão do peso, medido em quilogramas, pela altura ao quadrado, medida em metros $\left(\mathrm{kg} / \mathrm{m}^{2}\right)$.

15. Em 2018, o percentual de adultos obesos nas faixas de idade entre 18 a 24 anos, 25 a 34 anos, 35 a 44 anos, 45 a 54 anos, 55 a 64 anos e 65 ou mais anos foi de $7 \%, 18 \%, 23 \%, 24 \%, 25 \%$ e $22 \%$, respectivamente. 
GRÁFICO 3

Proporção de adultos maiores de 18 anos com sobrepeso e obesidade nas capitais brasileiras - Brasil (2006-2018)

(Em \%)

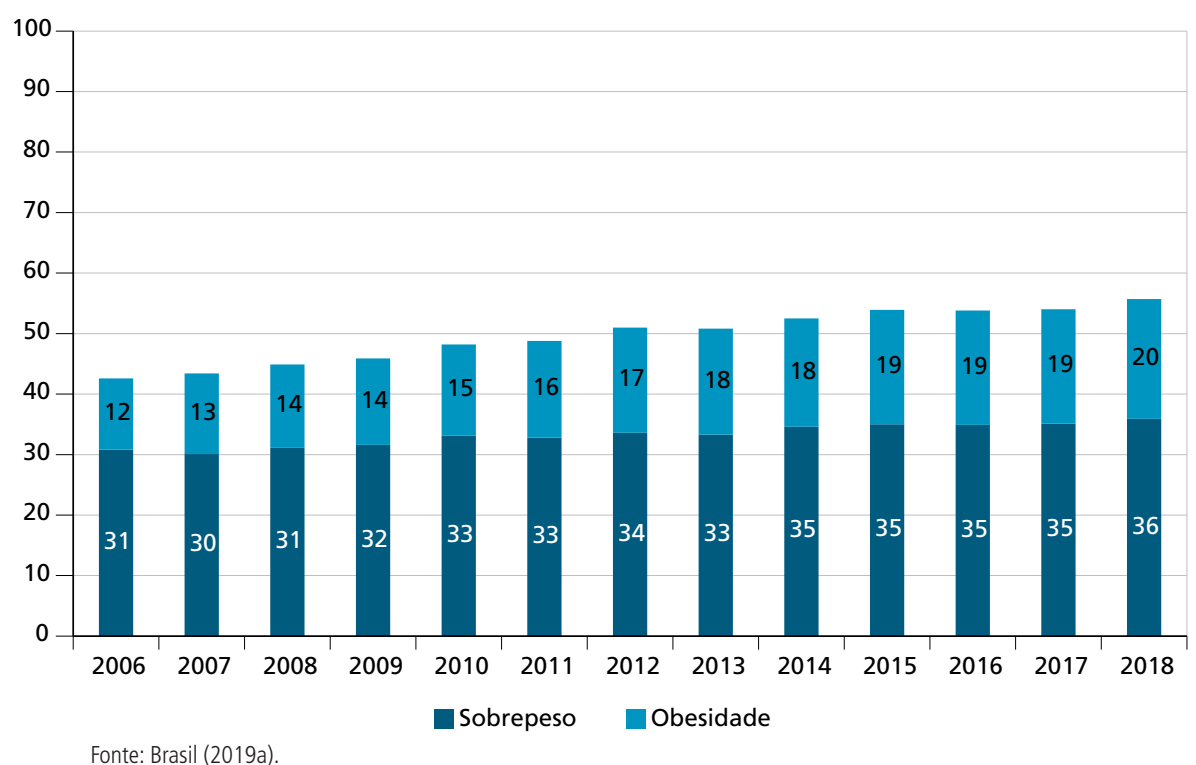

Ao se analisarem os dados de internaçáo por obesidade no Sistema Único de Saúde (SUS), tem-se que, em 2018, este foi o quarto maior motivo de internaçóes por causas endócrinas, metabólicas e nutricionais. De acordo com dados do Sistema de Internação Hospitalar (SIH) do SUS, foram 12.438 internaçóes, que geraram custo de R \$ 64,3 milhôes (Brasil, 2019b). Pode-se argumentar, contudo, que a obesidade tem impacto muito maior no sistema de saúde pública, visto que constitui fator de risco extremamente relevante para uma série de doenças graves que pressionam o sistema, como hipertensão, diabetes e infarto. De acordo com o relatório da pesquisa Vigitel Brasil 2018, as doenças crônicas não transmissíveis (DCNT) foram responsáveis por 74\% do total de mortes no Brasil em 2016, sendo que o consumo alimentar inadequado é considerado o fator de risco que responde pela grande maioria das mortes por DCNT, junto com a inatividade física, o tabagismo e o consumo excessivo de bebidas alcoólicas (Brasil, 2019b).

$\mathrm{Na}$ contramão do aumento dos percentuais de obesidade e sobrepeso, a pesquisa Vigitel Brasil 2018 revela ainda alguns avanços nas práticas de alimentação da população brasileira. Por exemplo, o consumo regular de frutas e hortaliças nas capitais brasileiras cresceu 15,5\% entre 2008 e 2018, passando de 20,0\% para $23,1 \%$ da população adulta. O consumo de refrigerantes e bebidas açucaradas, por sua vez, caiu $53,4 \%$ de 2007 a 2018. São, de fato, resultados positivos que 
merecem ser exaltados, mas indicam, ao mesmo tempo, que o grau epidêmico da obesidade no país requer esforços mais robustos.

\section{USO DE AGROTÓXICOS}

Outro ponto importante relativo à qualidade da alimentação diz respeito ao crescente uso de agrotóxicos na produção agrícola brasileira e ao aumento dos riscos de contaminação dos alimentos consumidos no país. Com relação ao ODS 2 , essa questão se relaciona não apenas com a meta 2.2 , mas também com a meta 2.5, que se refere à garantia de sistemas sustentáveis de produção.

Mais recente documento disponível sobre o tema, o Relatório do Programa de Análise de Resíduos de Agrotóxicos (Para), publicado em 2019 pela Agência Nacional de Vigilância Sanitária (Anvisa), referente à análise das amostras monitoradas no período de 2017-2018, oferece resultados importantes para o debate em relação à qualidade da alimentação: em 4.616 amostras de alimentos, coletadas em estabelecimentos varejistas de 77 municípios de todo o país, ${ }^{16}$ foram encontrados resíduos de 122 ingredientes ativos de agrotóxicos, totalizando 8.270 detecçóes (Anvisa, 2019b). Do total de amostras, 3.544 (77\%) foram consideradas satisfatórias: em 2.254 amostras (49\% do total), não foram detectados resíduos dos agrotóxicos analisados; e, em 1.290 (28\%), a concentração de resíduo encontrada era igual ou inferior ao limite máximo de resíduo (LMR) definido - para cada ingrediente ativo, em relação a cada alimento específico - pela Anvisa. O cálculo dos níveis de LMR, ${ }^{17}$ expresso em miligramas de agrotóxico por quilo de alimento $(\mathrm{mg} / \mathrm{kg})$, é uma atribuição legal da Anvisa e tem como parâmetro o grau de risco à saúde relativo à quantidade de resíduo de agrotóxico presente nos alimentos vendidos para consumo humano. ${ }^{18}$

16. À exceção do estado do Paraná, que deixou de fazer parte do programa em 2016.

17. Os índices de LMR são definidos a partir de estudos toxicológicos, encaminhados à Anvisa pelas empresas que pleiteiam o registro do agrotóxico (ou a inclusão de uma nova cultura no seu rol de aplicação), cujo método estabelece uma relação entre a quantidade mínima de agrotóxico utilizada e a eficiência agrícola desejada. Tal relação corresponderia às chamadas boas práticas agrícolas (BPA) para o agrotóxico analisado, isto é, a obtenção do efetivo controle da praga com a menor quantidade possível de resíduo tóxico no alimento. O LMR é um dos componentes do cálculo de exposiçã̃o e avaliação do risco dietético - probabilidade de efeito adverso à saúde humana resultante da ingestão de alimento com resíduo de agrotóxico - relacionado a um agrotóxico em análise para fins de registro. 0 LMR torna-se, então, um padrão de conformidade para definir a concentração do ingrediente ativo de agrotóxico a ser considerada, juntamente com fatores como consumo médio e peso corporal, na avaliação de risco. Tal avaliação é dada pelo indicador ingestão diária máxima teórica (IDMT), para risco crônico, e pelo indicador ingestão média estimada aguda (Imea), para risco agudo. Nesse caso, é necessário que o Imea seja inferior à DRfA, definida pela quantidade estimada de ingrediente ativo presente nos alimentos que pode ser ingerida em até $24 \mathrm{~h}$ sem causar danos à saúde; no caso do risco crônico, é preciso que o IDMT detectado seja inferior ao IDA, definidO pela quantidade estimada de substância presente nos alimentos que pode ser ingerida diariamente ao longo da vida sem causar danos à saúde. A DRfA e o IDA são estabelecidos pela Anvisa em acordo com parâmetros internacionais usados no âmbito da FAO. Para maiores detalhes, ver Anvisa (2019a). 18. Os estudos toxicológicos para definição do LMR estabelecem a classificação toxicológica dos produtos por nível de toxicidade, que deve constar na embalagem do agrotóxico. As BPAs, associadas ao LMR, envolvem, em conjunto, a forma de aplicação do agrotóxico, que inclui a dosagem, o número de aplicações e o intervalo de segurança, entendido como o intervalo entre a última aplicação do agrotóxico e a colheita ou a comercialização. A permanência de resíduos do ingrediente ativo tóxico nos alimentos indica, portanto, que as boas práticas agrícolas (BPA) não foram respeitadas. 
Foram classificadas como insatisfatórias 1.072 amostras (23\% do total). As principais irregularidades encontradas foram: a detecção de resíduos tóxicos de ingredientes ativos não autorizados para a cultura analisada (caso de 941 amostras, ou $20 \%$ do total); a concentração de resíduos acima do respectivo LMR (caso de 250 amostras, ou 5\% do total); e a presença de vestígios de ingredientes ativos proibidos (caso de quarenta amostras, ou 1\% do total). Esses percentuais englobam as sobreposiçóes - em 3\% dos casos, duas ou três dessas irregularidades foram constatadas simultaneamente.

As 4.616 amostras analisadas pelo relatório englobaram quatorze tipos de alimentos de origem vegetal, ${ }^{19}$ para monitoramento de 270 agrotóxicos diferentes. Os alimentos incluídos nesse primeiro período - 2017-2018 - representam 31\% da aquisição per capita diária, tendo por base os dados de consumo de alimentos da POF 2008-2009 (Anvisa, 2019b, p. 29). ${ }^{20}$

O relatório pondera que, do total de 1.072 amostras insatisfatórias, 24 (2,2\%) apresentam, como única irregularidade, a presença de agrotóxicos não autorizados para a cultura analisada em concentraçóes inferiores a $0,01 \mathrm{mg} / \mathrm{kg}$, índice que, pela prática internacional, é considerado sem significância. Quanto às amostras em que se aferiram resíduos de agrotóxicos não autorizados para a cultura, uma explicação merece ser observada: o relatório nota que, em 35\% das amostras (ou em 68\% do grupo de amostras com algum resíduo de agrotóxico, irregular ou regular), constataram-se vestígios de dois ou mais ingredientes ativos. A presença de múltiplos resíduos em uma amostra pode ser decorrente da aplicação de diferentes tipos de agrotóxicos inseticidas, herbicidas, fungicidas etc. - contra pragas de diversos tipos; "além disso, algumas formulaçôes contêm mais de um agrotóxico” (Anvisa, 2019b, p. 93).

Outras causas podem estar por trás da ocorrência de resíduos múltiplos - mistura de lotes tratados com diferentes agrotóxicos durante o período de amostragem; resíduos afetados pela contaminação cruzada entre as culturas no campo etc. -, mas a múltipla presença de agrotóxicos diferentes em uma mesma cultura é indicador do descumprimento das $\mathrm{BPAs}{ }^{21}$ quando algum deles não tem seu uso autorizado para a cultura. Contudo, uma preocupação adicional intervém nesses casos: é possível que haja a potencialização de um efeito tóxico em virtude da exposição simultânea a resíduos de agrotóxicos que possuem "o mesmo mecanismo de ação tóxica" (Anvisa, 2019b, p. 94), e a Anvisa não dispóe ainda de diretrizes de avaliação capazes de

19. Abacaxi, alface, alho, arroz, batata-doce, beterraba, cenoura, chuchu, goiaba, laranja, manga, pimentão, tomate e uva. 20. Até 2020, planeja-se incluir um total de 36 alimentos nas análises, abrangendo $80 \%$ dos alimentos de origem vegetal consumidos pela população brasileira (Anvisa, 2019b).

21. Em termos gerais, o conceito de BPA diz respeito a um conjunto de princípios, normas, recomendações técnicas para a produção, o processamento e o transporte de alimentos, orientadas a cuidar da saúde humana, proteger o meio ambiente e melhorar as condições dos trabalhadores. No que concerne especificamente ao uso de agrotóxicos, as BPAs incluem o uso de agrotóxicos específicos para a cultura, com menor toxicidade, oficialmente registrados, aplicados de acordo com as recomendações técnicas do receituário agronômico, observando as especificações no rótulo e o período de carência na colheita, como medidas preventivas à contaminação das culturas por resíduos de agrotóxicos. Para mais detalhes, ver: <https://bit.ly/3dfb5Hv>. 
identificar esse risco cumulativo e aferir em que medida ele excede os limites de segurança fixados, como o índice de ingestão diária aceitável (IDA) ou a dose de referência aguda (DRfA).

Do total de agrotóxicos monitorados, foram encontrados resíduos para 122, somando 8.270 detecçóes nas 4.616 amostras analisadas. Os ingredientes ativos que apresentaram o maior índice de detecçóes foram o imidacloprido, o tebuconazol e o carbendazim. Em termos de deteç̧ôes irregulares - que dizem respeito a resíduos náo autorizados para a cultura analisada -, o acefato ( $98 \%$ das detecçóes para essa substância) e os clorpirifós (86\%) tiveram os resultados mais expressivos. No que concerne às detecçôes que ultrapassaram o LMR, o etefom ( $26 \%$ das detecçôes para essa substância) e a cipermetrina $(23 \%)^{22}$ apontaram os maiores índices.

De acordo com os resultados do processo de avaliação de risco para os resíduos detectados, 0,89\% das 41 amostras analisadas, abrangendo cinco alimentos - laranja, uva, abacaxi, goiaba e batata-doce - indicavam potencial de risco dietético agudo à saúde, ou seja, registraram resíduos tóxicos que excederam a DRfA fixada para as substâncias encontradas ${ }^{23}$ - a quantidade estimada de agrotóxico que pode ser ingerida em $24 \mathrm{~h}$ sem causar danos à saúde,$-{ }^{24}$ tendo como parâmetro as metodologias recomendadas pela Organização Mundial da Saúde (OMS) e pela FAO. ${ }^{25}$ Das 41 amostras com potencial de risco agudo - todos os casos são de detecçóes não autorizadas para a cultura -, 37 continham o ingrediente ativo carbofurano, captado principalmente na cultura de laranja. Inseticida de classe toxicológica 1 (extremamente tóxico) e potencial causador de danos neurológicos, o carbofurano estava em processo de reavaliação à época de conclusão e foi, em outubro de 2017, definitivamente proibido pela Anvisa em todo o país. Os processos de reavaliação de agrotóxicos desencadeados pelos relatórios do Para já definiram a suspensão de outros ingredientes ativos de comprovada periculosidade para a saúde humana, como o endossulfam, o triclorfom, o fosmete e o metamidofós.

O relatório ressalta que essa estimativa representa apenas um procedimento de "triagem do risco" (Anvisa, 2019b, p. 76), com base no princípio da precaução. Conforme os resultados sugerem, a incidência de intoxicação por ingestão alimentar é

22. A cipermetrina ainda apresentou, simultaneamente, uma proporção de $12 \%$ de detecções não autorizadas.

23. Pelos métodos disponíveis, foi possível estimar a exposição aguda para 86 ingredientes ativos entre os 122 detectados nas amostras. Destes, " 25 não demandaram avaliação da exposição devido à baixa toxicidade aguda do ingrediente ativo"; além disso, para doze ingredientes ativos, não havia DRfA definida. Considerando-se essas limitações, avaliou-se o risco agudo em 2.324 amostras, abrangendo 7.286 detecções. Em 7.223 delas, os valores de Imea ficaram abaixo de $40 \%$ da DRfA. A faixa de 40 a 100\% da DRfA compreendeu outras 22 detecções. "Com base no conhecimento científico atual, a presença desses resíduos nos alimentos monitorados não caracteriza risco dietético agudo" nas amostras (Anvisa, 2019b, p. 80).

24. As DRfAs foram obtidas a partir da base de dados da Autoridade Europeia de Segurança Alimentar (European Food Safety Authority) ou, suplementarmente, a partir das referências de outras entidades internacionalmente reconhecidas. 25. 0 método presume que, em um curto período, é improvável que uma pessoa consuma grande quantidade de dois ou mais alimentos com resíduos do mesmo agrotóxico nas maiores concentrações detectadas no monitoramento; por isso, a avaliação da exposição aguda se faz separadamente "para cada combinaçãa 'agrotóxico detectado x alimento' nas amostras analisadas" (Anvisa, 2019b, p. 77). 
bastante baixa. Os dados do Sistema Nacional de Informaçóes Tóxico-Farmacológicas (Sinitox), da Fundação Oswaldo Cruz (Fiocruz), confirmam tal conclusão: no total de 43,5 mil casos notificados entre 2007 e 2016, a intoxicação dietética representa $0,15 \%$. Como os casos de intoxicação em que se reconhece um agrotóxico como agente e cuja gravidade determina a família a buscar atendimento hospitalar são, em geral, de intoxicação aguda, esses dados não cobrem eventos de intoxicação crônica.

É, entretanto, possível predizer o grau de risco dietético crônico que um agrotóxico pode oferecer a partir da comparação do grau de exposição alimentar a resíduos de agrotóxicos no longo prazo com os índices de IDA para cada ingrediente ativo. A fórmula de cálculo dessa exposição multiplica a concentração média dos resíduos detectados nos alimentos - ou, na ausência deste dado, os valores de LMR - pela sua quantidade de consumo diário per capita, obtida a partir da POF 2008-2009.

Para a análise de risco crônico, a Anvisa incluiu no relatório de 2017-2018 um total de 28 itens de consumo de origem vegetal. Excetuadas algumas substâncias, cujo monitoramento não foi possível, seja por inexistência de LMR estabelecido, seja pela ausência de valores de referência do IDA, calculou-se o risco de exposição alimentar crônica para 189 ingredientes ativos, sem que fossem identificadas, pela metodologia assumida, detecçóes cuja quantidade projetasse níveis de consumo superiores a $100 \%$ do valor do IDA definido para cada substância. ${ }^{26}$

Tal resultado indica que, segundo o Para, a exposição crônica aos resíduos dos agrotóxicos em alimentos não atinge um grau inaceitável de risco crônico à saúde dos consumidores no Brasil. Mas convém frisar que as condiçôes de aferição desse risco levam em conta apenas a exposição alimentar aos ingredientes ativos considerados isoladamente. É, de todo modo, difícil separar os efeitos decorrentes da ingestão de pequenas doses de resíduos tóxicos por um longo período de outros fatores de risco à saúde, não diretamente associados ao consumo alimentar, para estipular uma relação causal direta entre um problema de saúde e o consumo continuado de agrotóxico. ${ }^{27}$

Com efeito, a avaliação de risco crônico a partir dos resíduos de agrotóxicos em alimentos envolve um conjunto de dificuldades. A princípio, as avaliaçóes desenvolvidas para efeitos de liberação de registro (e de inclusão de novas culturas no espectro de aplicação de um agrotóxico) levam em conta apenas a exposição a um ingrediente ativo por vez, o que não permite aferir nem eventuais efeitos cumulativos de agrotóxicos com o mesmo "mecanismo de ação tóxica" (Anvisa, 2019b, p. 94), nem efeitos combinados de dois ou mais agrotóxicos aplicados ao

26. "Os três agrotóxicos que apresentaram maior exposição crônica calculada foram terbufós (28,77\% do IDA) e fipronil $(21,04 \%)$ e protioconazol (19,03\%). Para 179 agrotóxicos, a exposição crônica foi inferior a 10\% do IDA, sendo que, para 130, a exposição calculada foi menor que 1\% do IDA" (Anvisa, 2019b, p. 91).

27. É também em parte por não ser possível estabelecer um patamar de segurança (ou risco aceitável) para o consumo de substâncias intrinsecamente nocivas à saúde humana - dependendo não apenas das dosagens, mas das condições ambientais em que ocorre a intoxicação, da predisposição do organismo afetado etc. - que a legislação vigente adota o princípio do perigo como etapa preliminar do processo de análise de risco que precede a liberação de novos ingredientes ativos. 
mesmo alimento. Os efeitos agregados, advindos de diferentes formas de exposição a agrotóxicos - pela pele e pela ingestão de alimentos não monitorados, como carne, leite, água e ovos -, também dificultam a verificação do risco crônico.

Grande parte dos estudos científicos que procuram assinalar os riscos de exposição a agrotóxicos tem proposto justamente estabelecer evidências que relacionam a exposição continuada a essas substâncias ao risco crônico de desenvolvimento de doenças e problemas de saúde, sobretudo em trabalhadores rurais ou famílias que vivem próximo a áreas rurais. ${ }^{28}$ As estatísticas de intoxicaçóes, entretanto, versam, em sua grande maioria, sobre os casos de intoxicaçáo aguda, aqueles em que os sintomas são mais intensos e mais facilmente associáveis a um período de exposição recente a agentes tóxicos.

Dois sistemas de informação oferecem estatísticas de intoxicação - o Sistema de Informação de Agravos de Notificação (Sinan), que coleta dados gerados pelo sistema de vigilância epidemiológica, e o Sinitox, que agrupa dados colhidos pelos Centros de Informação e Assistência Toxicológica (Ciats). De acordo com o Sinan, ${ }^{29}$ entre 2007 e 2017, 41,6 mil casos de intoxicação por agrotóxicos de uso agrícola acumularam-se, em escala crescente: no primeiro ano do período, 2,2 mil casos tinham sido notificados; em 2017, foram 5,1 mil, mais que o dobro. Considerando a totalidade dos casos relacionados de 2007 a 2017, 88\% se referem a intoxicaçóes agudas e $42 \%$ foram decorrentes de exposição ocupacional. O Sinitox ${ }^{30}$ revela cenário similar: do total de 43,5 mil casos de intoxicação por agrotóxicos agrícolas registrados de 2007 a 2016, ${ }^{31} 25 \%$ correspondem a acidente individual e $23 \%$ são relativos a exposição ocupacional, somando $48 \%$ de casos de intoxicação presumivelmente relacionados ao trabalho. ${ }^{32}$ As tentativas de suicídio representam 39\% e 45\% de todos os casos de intoxicação por agrotóxico agrícola listado no Sinan (2007-2017) e no Sinitox (2007-2016), respectivamente.

Esses números, bem como os demais, devem ser apreciados com reservas. Em termos gerais, nos dados relativos à intoxicaçáo por agrotóxicos, a subnotificação é a regra: de acordo com a OMS, a subnotificação das intoxicaçôes é da ordem de um caso notificado para cinquenta casos não notificados (Paraná, 2018, p. 20). Um dado do Censo Agropecuário $2006^{33}$ oferece uma dimensão desse hiato: apenas

28. Entre os muitos estudos a respeito da intoxicação crônica, podem ser citados: Rigotto et al. (2013); Dutra e Ferreira (2017); Jobim et al. (2010); e Boccolini et al. (2014). Merece menção especial nesse assunto o Protocolo de avaliação das intoxicações crônicas por agrotóxicos, publicado por Paraná (2013).

29. Dados extraídos do DataSUS/Ministério da Saúde. Disponível em: <https://bit.ly/3bZA7K2>.

30. A página eletrônica do Sinitox (disponível em: <https://bit.ly/2VhlrOt>) adverte que a diminuição do número de casos de intoxicação coletados em anos recentes ocorreu em virtude de um problema de captação, devido à menor participação dos Ciats nesses levantamentos. Por isso, optou-se por usar os dados de 2007 e 2017 do Sinan para estabelecer uma comparação capaz de ilustrar a evolução dos casos de intoxicação no período.

31. Até o fechamento deste texto, os dados de intoxicação por agrotóxico de uso agrícola em 2017 não estavam disponíveis.

32. Na base do Sinan, as categorias circunstância acidental e exposição ocupacional não são claramente separáveis.

33. 0 questionário do Censo Agropecuário 2017 não permite captar essa informação. 
para aquele ano, 25 mil estabelecimentos haviam registrado, ao menos, um caso de intoxicação por agrotóxico - um patamar mínimo, já que poderia haver mais de um caso de intoxicação por estabelecimento -, ao passo que o Sinitox ${ }^{34}$ registrara, naquele mesmo ano, 6,3 mil ocorrências. Em boa parte, a subnotificação se explica pelo fato de que o fluxo dessa informação depende, como ponto de partida, da busca por atendimento em uma unidade de saúde pública. Contudo, ante a distância entre áreas rurais e urbanas e o custo desse deslocamento, as famílias tendem a tratar os efeitos de intoxicação com paliativos caseiros ${ }^{35}$ quando os sintomas não se acentuam. Isso ajudaria a explicar a alta proporção de tentativas de suicídio entre as notificaçôes, uma vez que, nesses casos, a ingestão proposital de agrotóxicos resulta em uma situação emergencial, de risco iminente de vida, que forçosamente leva a família a procurar o serviço de saúde. Cabe acrescentar, ainda a respeito do alto número de tentativas de suicídio, que um conjunto de estudos vem frisando a correlação entre os agrotóxicos e o desenvolvimento de doenças neurológicas. ${ }^{36}$

Conquanto, pelas razóes expostas, seja difícil dimensionar com exatidão os riscos relacionados ao uso e consumo de agrotóxicos, é certo que a forte expansão da comercialização dessas substâncias, bem como a ampliação recorde dos licenciamentos a novos produtos, agrega elementos mais preocupantes a esse quadro geral. O histórico de comercialização dos relatórios de comercialização de agrotóxicos, ${ }^{37}$ do Instituto Brasileiro do Meio Ambiente e dos Recursos Naturais Renováveis (Ibama), mostra que o volume comercializado de agrotóxicos mais que triplicou entre 2000 e 2017, saltando de 163 mil toneladas para 542 mil toneladas de ingredientes ativos. Apenas para ilustrar o sentido dessa proporção, pode-se considerar que, nesse mesmo período, o crescimento da área plantada no país, segundo a Pesquisa Agrícola Municipal (PAM), do IBGE, foi elevado, mas em ritmo menor, de 52 milhôes para 79 milhôes de hectares, pouco mais de $50 \%{ }^{38} \mathrm{O}$ cruzamento dessas informaçóes gerou outro indicador do crescimento do uso de agrotóxicos na produção agrícola do país - consumo nacional de ingredientes ativos de agrotóxicos e afins por área plantada-, calculado pelo instituto para a publicação IBGE (2012): ${ }^{39}$ os resultados apontam que, de 2000 até 2014 , esse consumo cresceu de $3,2 \mathrm{~kg} / \mathrm{ha}$ de agrotóxico para $6,7 \mathrm{~kg} / \mathrm{ha}$.

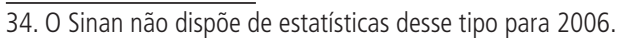

35. Uma literatura recente sobre percepção de risco no uso de agrotóxicos traz elementos de campo a esse respeito. Ver, por exemplo, Espíndola (2011) e Gregolis, Pinto e Peres (2012).

36. Pode-se mencionar, entre outros, Walter (2003). Para uma abordagem que relaciona diretamente o uso de agrotóxicos a tentativas de suicídio e à depressão, ver Pesquisa... (2017).

37. Para mais informações, ver: $<$ https://bit.ly/2PBzVXF>.

38. Embora tenha havido expressivo aumento da quantidade produzida - de 590,7 milhões de toneladas para 1,1 bilhão de toneladas entre 2000 e 2017 -, agregando produtos das lavouras temporárias e permanentes, os dados mostram que, entre os produtos que tiveram aumento da quantidade no período, cana e soja, crescendo respectivamente $133 \%$ e $249 \%$, respondem, juntas, por $85 \%$ desse saldo total. Para mais informações, acessar: $<$ https://bit.ly/2IUNLA1>.

39. De acordo com o IBGE (2012), o indicador expressa a intensidade de uso de agrotóxicos nas áreas cultivadas. As variáveis utilizadas são "a área plantada das principais culturas, expressa em hectares (ha), e as quantidades de agrotóxicos consumidos, discriminados segundo as principais classes de uso (herbicidas, fungicidas, inseticidas etc.) (...). 0 indicador é composto pela razão entre a quantidade de agrotóxico utilizada anualmente e a área cultivada, apresentado em kg/ha/ano". O consumo de agrotóxicos refere-se "à quantidade de agrotóxicos entregue ao comércio e não diretamente aos produtores". 
Nesse contexto, percebe-se o rápido aumento do número de registros concedidos a novos agrotóxicos e afins. Se o período entre 2005 e 2015 assinalou uma média de 140,5 novos registros/ano - ultrapassando em apenas três anos (2007, 2008 e 2012) a marca de 150 registros anuais (203, 191 e 168 registros, respectivamente) -, a partir de 2016, o número salta a 277 novos registros e, em 2017, 2018 e 2019, chega a 405, 449 e, finalmente, 478 novos registros, respectivamente. ${ }^{40}$

Os registros de liberação de agrotóxicos contemplam quatro tipos de produtos: i) produtos técnicos (PT), ingredientes ativos para uso pela indústria de agrotóxicos; ii) produtos técnicos equivalentes (PTE), para uso pela indústria, mas que têm como base ingredientes ativos já licenciados; iii) produtos formulados (PF), que correspondem aos agrotóxicos efetivamente comercializados; $i v$ ) produtos formulados a partir de produtos técnicos equivalentes (PF/PTE), os chamados agrotóxicos genéricos; e $v$ ) produtos de base biológica ou orgânica (bio./org.). Os dados de 2005 a 2019, ${ }^{41}$ no gráfico 4, mostram que, de 2016 em diante, quando o número de concessão de registros tem um crescimento acentuado, a maior parte dos produtos autorizados são PTE (50\% do total de 2016-2019) - destinados à indústria - e PF genéricos (27\% do total de 2016-2019) - destinados à venda direta aos produtores - , ambos elaborados a partir de ingredientes ativos previamente autorizados no país.

GRÁFICO 4

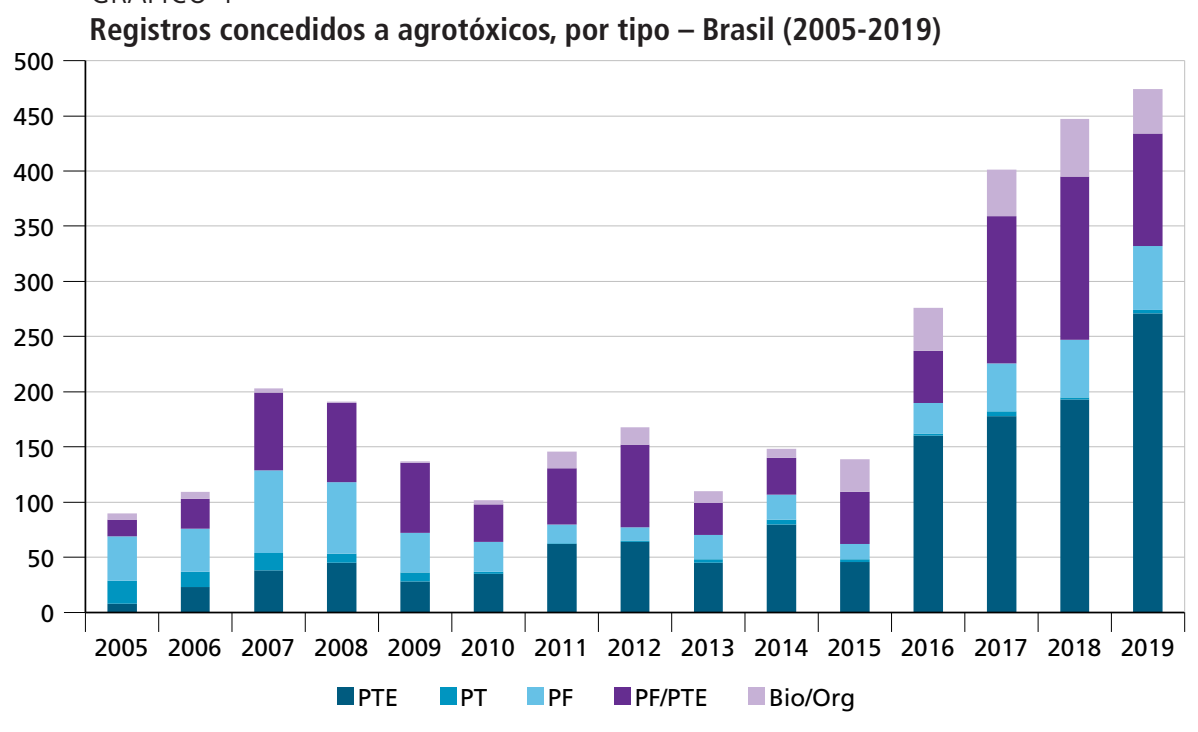

Elaboração dos autores.

Obs.: Os dados que compõem o gráfico estão disponiveis em: <https://bit.ly/35uvtBE >. 
Embora a proporção de produtos formulados, com ingredientes ativos novos, aprovados para venda direta ao consumidor não seja baixa - 11\% do total de autorizaçóes de 2016 a 2019, ou 182 produtos -, o principal efeito da ampliação das autorizações tende a ser o barateamento dos agrotóxicos, trazendo, como potencial consequência, o aumento do consumo. De acordo com os defensores da liberação de um número maior de agrotóxicos, tal medida, além de baratear os produtos, permitiria promover uma "rotação de moléculas", isto é, de ingredientes ativos, para "fazer o manejo da resistência de maneira adequada", ${ }^{42}$ evitando, pois, que o aumento da resistência das pragas pela reiteração do uso das mesmas substâncias obrigasse os produtores a empregar quantidades cada vez maiores de agrotóxicos.

O Relatório Substitutivo do Projeto de Lei (PL) no 6.299/2002,43 que intenta reformular o marco legal relativo à produção, à comercialização e a outras questôes relativas aos agrotóxicos no país, propõe um conjunto de medidas - redução de restriçóes à aprovação de agrotóxicos, aceleração da entrada em circulação de substâncias em avaliação e concentração no Ministério da Agricultura, Pecuária e Abastecimento (Mapa) da competência para o registro e a responsabilidade pela divulgaçáo dos resultados da avaliação de resíduos de agrotóxicos nos alimentos $-{ }^{44}$ que se alinham à visão de que a questão do uso de agrotóxicos deve ser tratada, sobretudo, no âmbito econômico, atendendo às necessidades de eficácia agronômica e combate de pragas do setor agropecuário.

Essa iniciativa e as políticas em curso consolidam a continuidade histórica, no país, de um modelo de desenvolvimento que incentiva, por meio de mecanismos fiscais e outros instrumentos, ${ }^{45} \mathrm{o}$ uso intensivo de agrotóxicos na agricultura. Contudo, os efeitos colaterais dessa "política pública" de estímulo ao uso de agrotóxicos - no campo da saúde, do trabalho e do meio ambiente - vêm se tornando cada vez mais conhecidos e discerníveis.

42. Fala de Regina Sugayama, diretora da Agropec Consultoria, por ocasião da audiência pública de 14 de junho de 2016, na Câmara dos Deputados, que debateu o tema Política Nacional de Defesa Agropecuária, citada no Relatório do Projeto de Lei (PL) no 6.299/2002. Disponível em: <https://bit.ly/3c3YBlu>.

43. Aprovado em comissão especial em junho de 2018 e encaminhado à Mesa Diretora da Câmara.

44. Ver no PL no 6.299/2002, por exemplo: 0 art. 3ㄴ §§ 6 (que cria os registros temporários) e 15 (que define a análise de risco como critério para a concessão de registro de novos produtos, sem mencionar a avalição de perigo intrínseco às substâncias com características carcinogênicas, teratogênicas ou mutagênicas, conforme prevê a Lei no 7.802/1989, $\S 5$ 5, alínea c); 0 art. 4ำ (que define como órgão registrante o órgão federal da agricultura); 0 art. 8o e dispositivos seguintes (que veda aos estados e aos municípios a possibilidade de legislar de modo divergente da União em relação a agrotóxicos); e 0 art. 5으, inciso IX (que atribui ao órgão registrante - o órgão federal da agricultura - a responsabilidade de divulgar os resultados do monitoramento de resíduos).

45. Os agrotóxicos são isentos de Imposto sobre Produtos Industrializados (IPI), Programa Integração Social (PIS), Contribuição para o Financiamento da Seguridade Social (Cofins), imposto de importação e, em vários estados, de Imposto sobre Circulação de Mercadorias e Serviços (ICMS). Um relatório publicado este ano pela Associação Brasileira de Saúde Coletiva (Abrasco) aponta que a desoneração dos agrotóxicos representou uma perda de quase R\$10 bilhões em arrecadação de impostos federais e estaduais em 2017 (Soares, Cunha e Porto, 2020). Além disso, enquanto a taxa de registro de ingredientes novos no Brasil fica, atualmente, entre US\$ 830 e US\$ 16 mil, nos Estados Unidos e no Canadá esse valor pode chegar, respectivamente, a US\$ 600 mil e US\$136 mil (Moraes, 2019). 
Os dados do Censo Agropecuário 2017, ${ }^{46}$ divulgados recentemente, não apenas parecem corroborar o cenário de aumento do uso de agrotóxicos e a potencial ampliação dos riscos de contaminação, como, além disso, indicam que a expansão do uso dessas substâncias tem se dado cada vez mais na esfera da agricultura familiar.

Em linhas gerais, o Censo 2017 registra um aumento significativo, em comparação com os dados do Censo de 2006, quanto ao número de estabelecimentos agrícolas que utilizam agrotóxicos: do total de 5,07 milhóes de unidades agropecuárias recenseadas em 2017, 36\% declararam utilizar agrotóxicos, ao passo que, em 2006, para um total de 51,7 milhóes de unidades, essa proporção era de $30 \%$. Os dados reiteram a relaçáo entre tamanho da área de lavoura e uso de agrotóxicos: embora a proporção de estabelecimentos que usam agrotóxicos cresça em todas as faixas de área de lavoura - mesmo entre as unidades com menos de 1 ha, ela sobe de $18 \%$ para $24 \%$ no período -, ela aumenta mais expressivamente entre os estabelecimentos agropecuários que concentram maiores extensóes de terra cultivada, escalando, por exemplo, de $76 \%$, em 2006, para 95\%, em 2017 , na faixa de estabelecimentos com mais de 500 ha de lavoura.

A relação entre uso mais intensivo de agrotóxicos e lavouras de grande porte é não apenas um dado detectável nas informações censitárias, mas uma decorrência do próprio modelo de exploração predominante em grandes propriedades: monocultura de commodities, cuja produção está atrelada à adoção de pacotes tecnológicos, que têm como componente a utilização intensiva de insumos químicos. Contudo, se o avanço dos agrotóxicos segue relacionado, em geral, à expansão das grandes lavouras, uma leitura das informações dos dois últimos censos agropecuários, a partir do tipo de estabelecimento, indica que o uso de pesticidas disseminou-se consideravelmente na agricultura familiar: de $29 \%$, em 2006 , os estabelecimentos da agricultura familiar que usam agrotóxicos passaram a $36 \%$ em 2017 , variação mais significativa que a observada entre os estabelecimentos não familiares, entre os quais a proporção dos que usam agrotóxicos manteve-se estável, oscilando de 34,9\% para 35,6\%.

De modo mais esquemático, o aumento do uso de agrotóxicos na agricultura familiar pode ser explicado por dois fatores. Em primeiro lugar, conquanto o censo de 2017 tenha registrado uma redução de $9,5 \%$ do número de unidades familiares em relação a 2006, a área total apropriada pela agricultura familiar pouco se alterou, o que pode revelar um processo de concentração de terra no setor da agricultura familiar, reproduzindo, neste nicho, a relação entre maior uso de agrotóxicos e tamanho da área. Em segundo lugar, os números indicam que em 2017, em comparação a 2006, a agricultura familiar passou a ocupar menos trabalhadores, em termos absolutos (redução de 11,4 milhóes para 9,7 milhóes) e relativos (redução de $74 \%$ para $67 \%$ do total de ocupados nos estabelecimentos).

46. Esses dados são tratados com maior nível de detalhamento por Valadares, Alves e Galiza (2020). 
Como essa redução não modificou a composição interna de trabalho nas unidades familiares - em 2006, 88\% dos ocupados em estabelecimentos familiares tinham laços de parentesco com produtor; em 2017, 87\%, sem alteraçóes relevantes do ponto de vista regional -, pode-se supor que o excedente de trabalho criado pelo aumento médio da área dos estabelecimentos familiares tenha sido, em parte, coberto com insumos técnicos poupadores de mão de obra, como os agrotóxicos, mas essa hipótese mereceria investigação mais aprofundada.

O aumento do uso de agrotóxicos entre agricultores familiares é problemático. Os riscos de intoxicaçáo por exposição ocupacional ou acidental tendem a incidir mais fortemente sobre trabalhadores da pequena agricultura familiar do que sobre os da agricultura patronal de larga escala, na qual a aplicação dos pesticidas é mecanizada. Mais numerosos, os agricultores familiares costumam adotar métodos de aplicaçáo menos seguros, como o pulverizador costal, e realizam o preparo das caldas em locais inadequados, às vezes próximo ao espaço doméstico. Estudos recentes têm levantado evidências de que o paradigma do uso seguro de agrotóxicos é infactível diante das condiçóes de produção da agricultura familiar, entre outras razôes, porque "a tecnologia agroquímica" foi desenvolvida para ser utilizada na estrutura produtiva e industrial do agronegócio (Abreu e Alonzo, 2016, p. 11). Ademais, as instruçóes das bulas dos agrotóxicos - de dosagem, diluição, intervalos de aplicação etc. - envolvem uma linguagem técnica complexa e pouco acessível.

Tampouco o uso de equipamentos de proteção individual (EPIs), embora indispensáveis como forma de redução de danos, mostra-se uma solução satisfatória. Para parte dos agricultores, os equipamentos são caros e desconfortáveis, porque não são, de fato, concebidos para a atividade agrícola desempenhada nos moldes da agricultura familiar (Viero et al., 2016). Por fim, a ausência de assistência técnica no local de trabalho e a facilidade de aquisição dos agrotóxicos - que, não raro, têm o próprio vendedor como orientador do uso,$-{ }^{47}$ permitem afirmar que os riscos de intoxicação estão longe de ser devidamente equacionados.

Dois dados recentes agravam consideravelmente esse quadro, apontando para uma ampliação cada vez mais irrestrita do consumo de agrotóxicos no país. Em 2019, as importaçóes de agrotóxicos foram as maiores já registradas desde 1997, chegando a 335 mil toneladas, um patamar 16\% superior ao verificado em 2018 (Resende e Pupo, 2020). Além disso, no início de 2020, a Portaria no 43, publicada pelo Mapa, estabeleceu que os novos pedidos de licenciamento de agrotóxicos submetidos à Secretaria de Defesa Agropecuária devem ser analisados em até sessenta dias; excedido este prazo, os produtos são automaticamente liberados (Brasil, 2020). A medida refere-se à competência da Secretaria de Defesa Agropecuária e não afeta 
diretamente os processos de análise toxicológica realizados pela Anvisa e pelo Ibama, mas pode acelerar a velocidade com que novos pesticidas são lançados no mercado.

\section{PERSPECTIVAS DA AGENDA DE COMBATE À FOME: UMA LEITURA A PARTIR DO ORÇAMENTO PÚBLICO FEDERAL}

As conquistas importantes que o Brasil teve, em anos recentes, no combate à fome - culminando na retirada do país do Mapa da Fome, da FAO, em 2014 foram construídas com apoio em um ciclo de relativo crescimento econômico e em um conjunto de políticas públicas voltadas ao objetivo de ampliar o acesso à alimentação para populaçóes vulneráveis.

Do ponto de vista da oferta, o fortalecimento de políticas de crédito, como o Pronaf, e de compra pública da produção agrícola familiar, como o PAA e o PNAE, a ampliação da assistência técnica com foco no pequeno produtor, além de avanços significativos na política de reforma agrária, como as linhas de fomento e outras açóes, conformaram um quadro favorável ao desenvolvimento da produção de alimentos pela agricultura familiar. A estruturação produtiva induzida por esses programas beneficiou as próprias famílias rurais, contribuindo para a melhoria dos indicadores de segurança alimentar do campo; paralelamente, propiciou a destinação dos alimentos da agricultura familiar a populaçóes vulneráveis, por meio de canais públicos de distribuição, não apenas via merenda escolar, mas também por intermédio de modalidades de aquisição voltadas ao abastecimento de hospitais, presídios e outros órgáos, ou de serviços como restaurantes populares e fornecimento de cestas básicas. Além disso, a produção de alimentos da agricultura familiar tem contribuído para garantir, com seus excedentes, circuitos curtos de comercialização nos pequenos municípios do país.

Do ponto de vista da demanda, a política de valorização do SM, adotada a partir de 2004, e as políticas de transferência de renda e alívio da pobreza, como o programa Bolsa Família, contribuíram, nos últimos anos, para aumentar o poder aquisitivo das famílias. Embora a parte da renda que as famílias brasileiras despendem com alimentação tenha se reduzido de 19,8\% para 17,5\% entre as POFs 2008-2009 e 2016-2017, essa proporção segue sendo bastante expressiva entre as mais pobres: nas famílias com rendimento mensal total de até 2 SMs em 2018, as despesas com alimentaçáo representam, em média, $22 \%$ de seus gastos totais, ao passo que nas famílias com rendimento superior a $25 \mathrm{SMs}$, os gastos com alimentação representam $7,6 \%$ do total. Dada a relevante parcela dos rendimentos familiares comprometida com as despesas com alimentação, pode-se dizer que o crescimento da renda do trabalho e da aposentadoria e a expansão dos benefícios assistenciais tiveram papel importante na melhoria dos indicadores de segurança alimentar, já apontados na seção 2. 
A evolução positiva dos indicadores relacionados à segurança alimentar dependeu, portanto, da consolidação de uma institucionalidade específica, com correspondentes aportes orçamentários, e da criação de uma institucionalidade que presidisse à execução das políticas públicas de combate à fome e de desenvolvimento da agricultura familiar.

O quadro político-institucional e orçamentário que contribuiu para que o Brasil deixasse o Mapa da Fome começou a sofrer alteraçôes com a crise econômica eclodida em 2015. A partir daí, teve início um processo de fragilização dos órgãos que, até então, se vinculavam às políticas de desenvolvimento rural. A mais emblemática mudança ocorrida foi a extinção do Ministério do Desenvolvimento Agrário (MDA), com a absorção de suas funções pelo Ministério do Desenvolvimento Social e pela então Secretaria Especial de Agricultura Familiar e do Desenvolvimento Agrário (Sead). Paralelamente, políticas direcionadas à agricultura familiar, como o PAA, ${ }^{48}$ o Programa Minha Casa Minha Vida - Rural e o Programa Nacional de Apoio à Captação de Água de Chuva e outras Tecnologias Sociais (Programa Cisternas), sofreram perdas orçamentárias e interrupçóes que rebaixaram de modo acentuado sua execução. Além disso, alteraçôes importantes na legislação - como as leis $\mathrm{n}^{\mathrm{os}}$ 13.606/2018, que parcelou as dívidas no Fundo de Assistência ao Trabalhador Rural (Funrural), e 13.467/2017, que modificou a legislação trabalhista urbana e rural -, junto com a política de titulação massiva dos lotes nos assentamentos e a paralisação da obtenção de terras para a reforma agrária, concorreram para redefinir o panorama de ação do Estado na esfera da política agrícola, agrária e fundiária.

Essa tendência desfavorável à continuidade de políticas voltadas à agricultura familiar, já desenhada em período anterior, acelerou-se significativamente a partir de 2016. Este acréscimo ao ritmo adveio, em parte, da redução do espaço institucional reservado àquelas políticas e do diálogo com movimentos sociais do campo, com o consequente estrangulamento das possibilidades de atenuação negociada dos efeitos dessas mudanças. Com a instituiçẫo do novo regime fiscal pela EC no 95/2016 $6^{49}$ que afetou as despesas primárias do Poder Executivo por vinte anos -, a margem financeira para despesas discricionárias se reduziu fortemente ante a exigência legal de manter as despesas obrigatórias e os mínimos constitucionais. Em consequência, o acirramento das disputas pelos recursos orçamentários disponíveis tendeu a privilegiar setores de maior poder político e econômico. Com isso, o peso da representação parlamentar ruralista e a importância econômica do agronegócio, de um lado, e a corrosão da institucionalidade da agenda de desenvolvimento rural e a consequente debilitação de sua capacidade de pleitear recursos, de outro, acabaram por delinear um cenário de retração orçamentária das políticas públicas dirigidas a assentados e agricultores familiares. 
A tabela 3 mostra que a trajetória de perda de recursos dessas políticas, acentuada em 2016 e 2017 - como analisou a última edição deste periódico (Lima et al., 2019) -, manteve-se em patamar quase inalterado em 2018.

TABELA 3

Valores de despesas orçamentárias executadas pelo MDA/Sead e pelo Incra (2014-2018) (Em R\$ milhões)

\begin{tabular}{llcccccc}
\hline \multirow{2}{*}{ Órgãos } & Soma de despesas executadas & 2014 & 2015 & 2016 & 2017 & 2018 & $\begin{array}{c}2018 / 2014 \\
(\%)\end{array}$ \\
& Financeiras & 3,74 & 5,53 & 3,76 & 3,86 & 3,84 & 3 \\
& Obrigatórias & $1.271,26$ & 608,44 & 895,52 & 557,34 & 541,33 & -57 \\
& Discricionárias & 893,60 & 622,56 & 508,60 & 390,23 & 330,43 & -63 \\
\multirow{2}{*}{ MDA/Sead } & Discricionárias (PAC) & 5,10 & 0,00 & 0,00 & 0,00 & 0,00 & -100 \\
& Discricionárias (emendas individuais) & 114,41 & 44,72 & 87,04 & 81,99 & 51,60 & -55 \\
& Valor total & $2.288,11$ & $1.281,25$ & $1.494,91$ & $1.033,42$ & 927,20 & -59 \\
& Financeiras & 114,33 & 107,95 & 95,72 & 99,00 & 107,72 & -6 \\
& Obrigatórias & $1.758,91$ & $2.394,70$ & $1.721,00$ & $1.788,89$ & $2.018,02$ & 15 \\
& Discricionárias & $1.998,61$ & $1.199,52$ & 867,93 & 717,79 & 649,29 & -68 \\
& Discricionárias (emendas individuais) & 23,12 & 22,99 & 27,21 & 22,70 & 22,31 & -4 \\
& Discricionárias (emendas bancadas) & 0,00 & 0,00 & 0,00 & 27,92 & 0,00 & - \\
& Valor total & $3.894,97$ & $3.725,15$ & $2.711,86$ & $2.656,30$ & $2.797,33$ & -28 \\
\hline
\end{tabular}

Fonte: Siga Brasil. Disponível em: <https://bit.ly/2SvTPFR>.

Elaboração dos autores.

Obs.: 1. Valores em reais de 2019, atualizados pelo Índice Nacional de Preços ao Consumidor Amplo (IPCA).

2. Incra - Instituto Nacional de Colonização e Reforma Agrária; e PAC - Programa de Aceleração do Crescimento.

Os dados indicam que, de 2014 a 2018, as despesas executadas em açóes orçamentárias do MDA/Sead e do Incra caíram, respectivamente, em 59\% e em 28\%; considerando apenas a variação de 2017 a 2018, os números apontam uma redução de $10 \%$ dessas despesas pelo MDA/Sead e um aumento de 5\% pelo Incra. A tabela 3 mostra ainda que as despesas discricionárias têm uma trajetória de instabilidade mais oscilante no período: as do MDA/Sead caem $63 \%$ e as do Incra, $68 \%$.

Enquanto no MDA/Sead a proporção das despesas obrigatórias ${ }^{50}$ sobre o total pouco se alterou de 2014 a 2018 - subindo de $56 \%$ para $58 \%$, mas em um contexto de redução abrupta das despesas executadas -, no Incra essa proporção variou de $45 \%$ para $72 \%$ no período. Isso significa que quase três quartos das despesas do Incra em 2018 foram destinados a gastos obrigatórios (precatórios judiciários, benefícios previdenciários e pessoal ativo). A redução do espaço das despesas discricionárias pode refletir o engessamento da capacidade do Estado de promover políticas mais estruturantes, do ponto de vista fundiário ou produtivo.

50. Na tabela 3, a acentuada redução de $R \$ 1,2$ bilhão para $R \$ 586$ milhões nas despesas obrigatórias do MDA/Sead entre 2014 e 2015 deve-se à diferença das despesas de contribuição do fundo do garantia-safra entre aqueles anos. 
A extinção da Sead, em 2019, com a subsequente incorporação ao Mapa - como unidade orçamentária - de grande parte das açóes orçamentárias antes executadas por aquela secretaria (e, anteriormente, pelo MDA) torna difícil estender, até o primeiro ano do governo Bolsonaro, a análise comparativa das despesas executadas, tal como apresentada na tabela $3 .^{51}$ Embora o horizonte deste capítulo não permita oferecer um cotejamento exaustivo, ano a ano, que mostre a variação das despesas em cada uma das ações, pode-se, porém, examinar mais detidamente como se comportaram, na evolução orçamentária, algumas açôes de caráter emblemático para a relaçâo entre desenvolvimento rural e segurança alimentar entre 2014 e 2019. São principalmente essas duas dimensôes que estão contempladas no desenho das propostas de metas brasileiras do ODS 2 voltadas ao combate à fome.

A tabela 4 oferece um panorama dessa evolução, abrangendo um conjunto de ações orçamentárias (três delas agrupadas sob a rubrica PAA) de caráter discricionário, dentro de três programas orçamentários cujo escopo diz respeito ao acesso à terra, à estruturação produtiva de agricultores familiares e à segurança alimentar e nutricional: o P2012 - Fortalecimento e dinamização produtiva da agricultura familiar; o P2066 - Reforma agrária e governança fundiária; ${ }^{52}$ e o P2069 - Segurança alimentar e nutricional. A lista inclui praticamente todas as açôes orçamentárias envolvendo despesas primárias discricionárias ${ }^{53}$ que tiveram continuidade, nos respectivos programas, de 2014 a 2019, e a variável orçamentária selecionada para a análise é o valor pago total (valores pagos mais restos a pagar pagos) registrado no ano para cada ação.

TABELA 4

Evolução orçamentária de ações selecionadas, segundo o valor pago total (2014-2019) (Em R\$ milhões)

\begin{tabular}{|c|c|c|c|c|c|c|c|}
\hline Programas & Ações orçamentárias & 2014 & 2015 & 2016 & 2017 & 2018 & 2019 \\
\hline \multirow{5}{*}{ P2012 } & $\begin{array}{l}\text { Assistência técnica e extensão rural para } \\
\text { agricultura familiar (2100) }\end{array}$ & 71,844 & 170,719 & 294,550 & 263,637 & 92,420 & 125,176 \\
\hline & $\begin{array}{l}\text { Assistência técnica e extensão rural para a } \\
\text { reforma agrária (210S) }\end{array}$ & 233,948 & 323,488 & 301,628 & 133,785 & 88,947 & 39,614 \\
\hline & $\begin{array}{l}\text { Promoção e fortalecimento da agricultura } \\
\text { familiar ( } 210 \mathrm{~V})\end{array}$ & 38,929 & 31,798 & 21,790 & 21,287 & 20,303 & 98,435 \\
\hline & Inclusão produtiva rural (20GD) & 293,733 & 199,774 & 68,153 & 62,391 & 48,465 & 49,238 \\
\hline & $\begin{array}{l}\text { Apoio à organização econômica e promo- } \\
\text { ção da cidadania de mulheres ( } 210 \mathrm{~W})\end{array}$ & 24,115 & 13,072 & 12,294 & 2,412 & 0,757 & 1,751 \\
\hline
\end{tabular}

51. Em relação ao Incra, pode-se dizer que as tendências assinaladas em 2018 se acentuaram em 2019: as despesas obrigatórias passaram a representar $82 \%$ das despesas totais do órgão no último ano, ao passo que as discricionárias (exceto as de emendas individuais) caíram $72 \%$.

52. Até 2016, o P2012 chamava-se agricultura familiar, e o P066, reforma agrária e ordenamento da estrutura fundiária. 53. Foram excluídas as ações de despesas financeiras, as ações interrompidas ao longo do período e outras cujo mapeamento se tornou difícil em função das mudanças de alocação no quadro orçamentário. 


\begin{tabular}{|c|c|c|c|c|c|c|c|}
\hline Programas & Ações orçamentárias & 2014 & 2015 & 2016 & 2017 & 2018 & 2019 \\
\hline \multirow{5}{*}{ P2066 } & Aquisição de terras (211B) & 769,632 & 232,204 & 287,954 & 82,645 & 62,481 & 12,392 \\
\hline & $\begin{array}{l}\text { Consolidação de assentamentos rurais } \\
(211 \mathrm{~A})\end{array}$ & 264,019 & 133,108 & 181,060 & 147,507 & 325,245 & 112,723 \\
\hline & $\begin{array}{l}\text { Estruturação e consolidação de unidades } \\
\text { produtivas - crédito fundiário ( } 210 Q)\end{array}$ & 33,855 & 23,676 & 40,101 & 20,491 & 5,860 & 19,623 \\
\hline & $\begin{array}{l}\text { Assistência social e pacificação no campo } \\
(210 R)\end{array}$ & 4,892 & 2,834 & 2,214 & 0,018 & 0,762 & 0,440 \\
\hline & Promoção da educação no campo (210T) & 39,974 & 26,546 & 28,972 & 15,514 & 9,925 & 10,511 \\
\hline \multirow{5}{*}{ P2069 } & $\begin{array}{l}\text { Distribuição de alimentos a grupos popula- } \\
\text { cionais tradicionais (2792) }\end{array}$ & 72,282 & 62,669 & 12,847 & 33,641 & 30,544 & 16,651 \\
\hline & PAA $(2798,2802,2 B 81)$ & 820,477 & 705,549 & 481,932 & 472,112 & 316,469 & 238,156 \\
\hline & $\begin{array}{l}\text { Segurança alimentar e nutricional na saúde } \\
(20 Q H)\end{array}$ & 26,062 & 37,964 & 21,025 & 36,129 & 31,870 & 72,704 \\
\hline & Educação alimentar e nutricional (2784) & 7,220 & 3,711 & 1,938 & 1,477 & 1,135 & 1,283 \\
\hline & $\begin{array}{l}\text { Acesso à água para a produção de alimen- } \\
\text { tos (8948) }\end{array}$ & 624,476 & 217,902 & 548,582 & 132,214 & 121,926 & 87,760 \\
\hline Total & & 3325,456 & 2185,013 & 2305,040 & 1425,258 & 1157,109 & 886,456 \\
\hline
\end{tabular}

Fonte: Siga Brasil. Disponivel em: <https://bit.ly/2SvTPFR>.

Elaboração dos autores.

Obs.: Valores em reais de 2019, atualizados pelo IPCA.

Conforme se pode verificar na tabela 4, o gasto orçamentário, em valores pagos, em ações de caráter discricionário, reduziu-se de $\mathrm{R} \$ 3,3$ bilhóes, em 2014, para R \$ 886,4 milhóes, em 2019, uma diminuição de 73\%. Algumas ações orçamentárias fortemente associadas à relação entre desenvolvimento rural e segurança alimentar, como as ligadas ao PAA e a denominada acesso à água para a produção de alimentos (8948), no P2069 - Segurança alimentar e nutricional, experimentaram quedas bastante acentuadas, em termos de valores pagos, caindo $71 \%$ (de R \$ 820,5 milhóes para $\mathrm{R}$ \$ 328,2 milhóes) e 86\% (de R \$ 624,5 milhóes para $\mathrm{R}$ \$ 87,8 milhóes), respectivamente, no período considerado. A ação distribuição de alimentos a grupos populacionais tradicionais $(2792)^{54}$ registrou também uma diminuição no seu gasto orçamentário efetivo, perdendo, em 2019, pouco mais de três quartos do valor pago total de 2014. Ainda no P2069, a ação segurança alimentar e nutricional na saúde $(20 \mathrm{QH})^{55}$ foi a única, entre as selecionadas, a assinalar aumento importante no período, saindo de $\mathrm{R}$ 26,1 milhóes para $\mathrm{R}$ 72,7 milhóes. ${ }^{56}$

54. Nomeada, antes, distribuição de alimentos a grupos populacionais específicos, sob o mesmo código.

55. A ação envolve o apoio aos estados para a organização da atenção nutricional no âmbito da atenção básica em saúde, com vistas à realização de vigilância alimentar e nutricional, à promoção da alimentação adequada e saudável, e à prevenção e ao controle dos agravos relacionados à alimentação e à nutrição.

56. Ainda dentro do P2069, a ação implantação e qualificação de equipamentos e serviços públicos de apoio à produção, abastecimento e consumo de alimentos (8929), que, em 2014, pagou um total de R\$25,8 milhões, deixou de ter execução em 2019, com seus objetivos sendo presumivelmente assumidos pela ação consolidação da implantação do Sistema Nacional de Segurança Alimentar e Nutricional (215I), de caráter mais abrangente, que somou R\$23,8 milhões em valores pagos em 2019. 
No P2066 - Reforma agrária e governança fundiária, tanto a ação aquisição de terras (211B) quanto a ação consolidação de assentamentos rurais $(211 \mathrm{~A})^{57}$ deixaram de dispor de um grande volume de recursos, em valores pagos, entre 2014 e 2019, um reflexo da paralisia da política de reforma agrária. Em parte afetados pela restrição orçamentária que atingiu a política de desenvolvimento rural como um todo a partir da crise econômica e da fixação do teto de gastos, esses decréscimos orçamentários explicam-se, ainda, fundamentalmente, pelos efeitos dos acórdãos nos 775/2016 e 1.976/2017, do Tribunal de Contas da Uniáo (TCU), que, a partir da identificação de possíveis irregularidades no programa de reforma agrária, suspenderam o processo de seleção de novas famílias para os assentamentos, as vistorias em imóveis passíveis de desapropriação e a obtenção de novas áreas, até o saneamento das pendências. Ainda no P2066, a ação promoção da educação no campo (210T) teve três quartos de redução no valor pago de 2014 a 2019; este cenário tende a se agravar a partir da publicação do Decreto no 20.252/2020, que, reorganizando a estrutura do Incra, extingue a coordenação responsável pela educação do campo.

A tendência de redução dos valores pagos nas açôes discricionárias se repete para a maior parte das açóes selecionadas no Programa Fortalecimento e Dinamização Produtiva da Agricultura Familiar (P2012). A ação inclusáo produtiva rural (20GD), que envolve apoio a projetos produtivos desenvolvidos por famílias e organizaçóes coletivas de povos indígenas, povos e comunidades tradicionais e agricultores familiares, sofreu uma queda de $83 \%$ no total pago de 2019 em relação a 2014 caindo de R \$ 293,7 milhôes para 49,2 milhóes no período. Contudo, é importante sublinhar que o valor pago em 2019 foi superior ao de 2018.

A assistência técnica e extensão rural (Ater) para a reforma agrária, por sua vez, também conheceu um acentuado decréscimo, diminuindo de $\mathrm{R} \$ 233,9$ milhóes para R \$ 39,3 milhóes de 2014 a 2019, um reflexo, ainda, dos efeitos dos acórdáos do TCU citados anteriormente. Por sua vez, a ação de Ater para a agricultura familiar, que experimentou sucessivos ganhos orçamentários de 2014 a 2016-2017, recuperou em 2019 parte das perdas de 2018, chegando a $\mathrm{R} \$ 125,2$ milhóes. No entanto, todo esse montante de 2019 refere-se a restos a pagar pagos relativos a exercícios de anos anteriores. Pode-se presumir, apesar disso, que os gastos com açôes de Ater para a agricultura familiar foram alocados no último ano na ação promoção e fortalecimento da agricultura familiar $(210 \mathrm{~V})$, que teve um aumento de $\mathrm{R}$ \$ 20,3 milhóes, em 2018, para $\mathrm{R}$ \$ 98,4 milhóes, em 2019, o maior patamar de toda a série para essa ação.

Outro ponto crítico à evolução orçamentária no período analisado diz respeito ao aumento da proporção de restos a pagar pagos no volume dos valores pagos

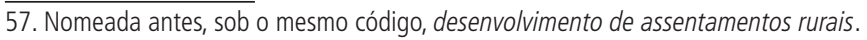


totais das ações orçamentárias selecionadas: em 2014, quando esses valores somavam $\mathrm{R} \$ 3,3$ bilhóes, os restos a pagar correspondiam a 44\% do total; em 2015, 2016 e 2017 , essa proporção variou de $63 \%$ a $60 \%$, chegando a $51 \%$ em 2018 . Em 2019 , porém, os restos a pagar pagos representaram 65\% do valor pago total, o menor da série para as açôes orçamentárias selecionadas. Isso significa, em tese, que apenas dois quintos do valor pago total de 2019 corresponderam a bens e serviços executados ou entregues naquele ano.

As perdas de recursos das políticas de desenvolvimento rural observadas no período analisado podem ser atribuídas, em parte, às restriçóes orçamentárias, que se fizeram sentir, sobretudo, nas açóes de caráter discricionário; e, em parte, à decomposição do quadro político-institucional, que respondia pela realização daquelas políticas e que, portanto, atuava na disputa por recursos que pudessem viabilizá-las. Se o combate à fome, empreendido com relativo sucesso no país nas últimas duas décadas, envolveu, em seu arranjo político-institucional, açóes coordenadas de estímulo à produção agrícola familiar - para a ampliação do acesso a alimentos nas áreas rurais - e de distribuição de alimentos a populaçóes vulneráveis - no campo e na cidade -, o processo de perda de relevância orçamentária que tais açóes vêm sofrendo parece exprimir, de modo preocupante, o processo de perda de especificidade política que tem afetado a agenda de desenvolvimento rural sustentável nos anos recentes.

\section{CONSIDERAÇÕES FINAIS}

Em 2018, de acordo com a Síntese de Indicadores Sociais, do IBGE, o país registrou o maior número de pessoas em extrema pobreza dos últimos sete anos: cerca de 13,5 milhóes de pessoas - $6,5 \%$ da população - sobreviviam com menos de $\mathrm{R} \$ 145$ por mês, ${ }^{58} 4,5$ milhóes de pessoas a mais do que o índice apurado em 2014. Considerando que o segmento populacional que ganha até 2 SMs gasta, segundo a POF, quase um quarto da renda com alimentação - e que, portanto, o acesso a alimentos depende, em boa medida, dos rendimentos -, pode-se estimar o grau das dificuldades alimentares que atingem os grupos sociais empobrecidos se se levar em conta que a renda-limite de $\mathrm{R} \$ 145$ da extrema pobreza equivale a menos da metade do valor médio da cesta básica de alimentos. ${ }^{59} \mathrm{O}$ contexto de estagnação econômica, desemprego alto e contração de programas sociais pode agravar esse quadro nos espaços urbanos e rurais.

As mudanças efetuadas na estrutura administrativa do Executivo a partir do início do novo governo parecem reiterar a tendência, iniciada em 2016, de esvaziamento dos espaços institucionais voltados à implementação de uma agenda de

58. Parâmetro usado pelo Banco Mundial. Disponível em: <https://bit.ly/2SvTPFR>.

59. Média do valor apurado para as capitais do país. A cesta básica de alimentos diz respeito à quantidade de alimentos que seria suficiente para o sustento e o bem-estar de um trabalhador em idade adulta (Dieese, 2016). 
desenvolvimento sustentável. O Serviço Florestal Brasileiro, retirado do Ministério do Meio Ambiente, e o Incra, vinculado anteriormente à Casa Civil, passaram a integrar a estrutura do Mapa. Tais alteraçóes reforçam, de certo modo, a subordinação da pauta ambiental e agrária à agenda do agronegócio. Além disso, a Sead, herdeira das competências do antigo MDA, foi também incorporada ao Mapa, como Secretaria de Agricultura Familiar e Cooperativismo. A estratégia de atuação, porém, mudou significativamente: o discurso oficial passou a apregoar que a agricultura empresarial e a familiar "são o mesmo negócio". De acordo com a ministra Tereza Cristina, em seu discurso de posse,

os pequenos produtores voltam ao Mapa, de onde foram retirados, como se existissem caminhos diferentes - e até antagônicos - para a agricultura. Somos convictos que a agricultura empresarial e a pequena agricultura são o mesmo negócio. (...) Teremos um só ministério que olhará com igual destaque para todos os produtores rurais, independente de seus portes (Tereza..., 2019).

Essa integração subalterna pode produzir um apagamento das diferenças entre as agriculturas familiar e patronal - diferenças que abrangem não apenas o porte ou a dimensão fundiária delas, mas, sobretudo, seus respectivos modelos de produção - que acabe por restringir ainda mais o espaço institucional à colocação de demandas específicas de produtores agrícolas familiares e por desequilibrar, agravando a assimetria econômica, a disputa por recursos entre a grande e a pequena agricultura. As modificaçôes, aludidas mais anteriormente, que fundiram nas mesmas ações orçamentárias (como na assistência técnica e na estruturação produtiva) a clientela da agricultura familiar e a dos médios produtores rurais talvez sinalizem o acirramento dessa disputa desigual.

Por fim, é importante mencionar, como fato preocupante para a continuidade do combate à fome no país, a extinção do Conselho Nacional de Segurança Alimentar e Nutricional (Consea). Estrutura de assessoria e de participação social, criada em 1993, o Consea teve decisiva relevância na formulação de políticas de superação da fome e criação de mercados institucionais. Na primeira tentativa de dissolução do órgão - mediante a Medida Provisória (MP) no 870/2019 -, a Defensoria Pública da União e a Procuradoria dos Direitos dos Cidadãos se pronunciaram pela inconstitucionalidade do ato do Executivo, e organismos internacionais, como o Escritório do Alto Comissariado de Direitos Humanos (EACDH), da Organização das Naçôes Unidas (ONU), criticaram oficialmente a iniciativa, reconhecendo a importância do conselho no esforço de garantir o direito humano à alimentação. Ao aprovar a MP, em 28 de maio de 2019, o Congresso Nacional recriou o órgão; contudo, ao sancioná-la - na forma da Lei no $13.844 / 2019$-, o governo vetou ${ }^{60} \mathrm{o}$

60. A mensagem de veto aponta que os dispositivos inseridos por emenda parlamentar, "remodelando regras de competência, funcionamento e organização de órgão do Poder Executivo e alterando os interesses compreendidos no objeto da norma", invadem a competência privativa do chefe do Poder Executivo. A íntegra pode ser lida em Brasil (2019c). 
inciso correspondente à reinstalação do Consea, com a justificativa de que houve “invasão de prerrogativas". Em 24 de setembro de 2019, o Congresso Nacional apoiou o veto, e o conselho foi definitivamente extinto.

A despeito dos notáveis avanços obtidos nas últimas duas décadas, o compromisso nacional com a erradicaçáo da fome reclama um esforço contínuo e aperfeiçoado do Estado brasileiro. Contextos de crise ou estagnação, que impliquem reduçáo relativa da renda do trabalho ou que agravem situaçôes de empobrecimento e miserabilidade, são uma ameaça recorrente à segurança alimentar e nutricional da população. Manter o país fora do Mapa da Fome e ampliar o acesso da populaçáo, sobretudo de seus segmentos mais vulneráveis, a alimentos saudáveis e diversificados - conforme estabelecem as metas dos ODS - são desafios permanentes que não podem prescindir, para sua realização, de um aparato institucional específico, de investimento público efetivo e de prioridade política.

\section{REFERÊNCIAS}

ABREU, P. H.; ALONZO, H. G. O agricultor familiar e o uso (in)seguro de agrotóxicos no município de Lavras/MG. Revista Brasileira de Saúde Ocupacional, São Paulo, v. 41, n. 18, 2016. Disponível em: <https://bit.ly/2xCnUfS>.

ALEM, D. et al. Segurança alimentar e soberania alimentar: construção e desenvolvimento de atributos. In: ENCONTRO NACIONAL DE ECONOMIA POLÍTICA, 20., 2015, Foz do Iguaçu, Paraná. Anais... Foz do Iguaçu: Enep, 2015. Disponível em: <https://bit.ly/34ijxT4>.

ANVISA - AGÊNCIA NACIONAL DE VIGILÂNCIA SANITÁRIA. Resolução da Diretoria Colegiada (RDC) no 295, de 29 de julho de 2019. Dispóe sobre os critérios para avaliação do risco dietético decorrente da exposição humana a resíduos de agrotóxicos, no âmbito da Anvisa, e dá outras providências. Diário Oficial, Brasília, n. 146, 31 jul. 2019a. Disponível em: <https://bit.ly/39X7dJc>. . Programa de Análise de Resíduos de Agrotóxicos em Alimentos (Para). Relatório das amostras analisadas no período 2017-2018. Brasília: Anvisa, 10 dez. 2019b. Disponível em: <https://bit.ly/3aZtQhp>.

BOCCOLINI, P. M. et al. Stomach cancer mortality among agricultural workers: results from a death certificate-based case-control study. Caderno de Saúde Coletiva, v. 22, n. 1, p. 86-92, mar. 2014.

BRASIL. Constituição da República Federativa do Brasil de 1988. Brasília: Assembleia Nacional Constituinte, 1988. 
. Lei $\mathrm{n}^{\mathrm{o}}$ 11.346, de 15 de setembro de 2006. Cria o Sistema Nacional de Segurança Alimentar e Nutricional (Sisan) com vistas em assegurar o direito humano à alimentação adequada e dá outras providências. Brasília: Congresso Nacional, 2006.

. Ministério da Saúde. Vigitel Brasil 2018: estimativas sobre frequência e distribuição sociodemográfica de fatores de risco e proteção para doenças crônicas nas capitais dos 26 estados brasileiros e no Distrito Federal em 2018. Brasília: SVS/ MS, 2019a. Disponível em: <https://bit.ly/2XlQkoL>. Acesso em: 8 nov. 2019.

. Pesquisa Vigitel Brasil 2018. Brasília: MS, 2019b. Disponível em: <https://bit.ly/2xgMkeI>. Acesso em: 8 nov. 2019.

. Presidência da República. Mensagem no 254, de 18 de junho de 2019. Brasília: Presidência da República, 2019c.

Portaria no 43, de 21 de fevereiro de 2020. Estabelece os prazos para aprovação tácita para os atos públicos de liberação de responsabilidade da Secretaria de Defesa Agropecuária, do Mapa, conforme caput do art. 10 do Decreto oㅜ 10.178, de 18 de dezembro de 2019. Diário Oficial, Brasília, n. 39, seção 1, 27 fev. 2020. Disponível em: <https://bit.ly/2xjWFq9>.

DIEESE - DEPARTAMENTO INTERSINDICAL DE ESTATÍSTICA E ESTUDOS SOCIOECONÔMICOS. Metodologia da Pesquisa Nacional da Cesta Básica de Alimentos. São Paulo: Dieese, fev. 2016. Disponível em: <https:// bit.ly/2JRIPhv>.

DUTRA, L.; FERREIRA, A. Associação entre malformações congênitas e a utilização de agrotóxicos em monoculturas no Paraná, Brasil. Saúde Debate, Rio de Janeiro, v. 41, número especial, p. 241-253, 2017.

ESPÍNDOLA, E. Análise da percepção de risco do uso de agrotóxicos em áreas rurais: um estudo junto aos agricultores no município de Bom Repouso (MG). 2011. Tese (Doutorado) - Universidade de São Paulo, São Carlos, 2011.

FAO - ORGANIZAÇÃO DAS NAÇÓES UNIDAS PARA A ALIMENTAÇÃO E A AGRICULTURA. O estado da insegurança alimentar no mundo 2014 (resumo). [s.l.]: FAO, 2014. Disponível em: <https://bit.ly/2zXKUXx>.

IBGE - INSTITUTO BRASILEIRO DE GEOGRAFIA E ESTATÍSTICA. Indicadores de Desenvolvimento Sustentável 2012. Rio de Janeiro: IBGE, 2012. Disponível em: <https://bit.ly/2yPr6VN>.

Pesquisa Nacional por Amostra de Domicílios (PNAD) 2013: segurança alimentar. Rio de Janeiro: IBGE, 2014. Disponível em: <https://bit.ly/2yIqjpy>. Acesso em: 13 dez. 2014. 
GREGOLIS, T.; PINTO, W.; PERES, F. Percepção de riscos do uso de agrotóxicos por trabalhadores da agricultura familiar do município de Rio Branco. Revista Brasileira de Saúde Ocupacional, São Paulo, v. 37, n. 12, 2012.

GROVER, S. A. et al. Years of life lost and healthy life-years lost from diabetes and cardiovascular disease in overweight and obese people: a modelling study. The Lancet Diabetes \& Endocrinology, v. 3, n. 2, p. 114-122, 2015.

JOBIM, P. F. et al. Existe uma associação entre mortalidade por câncer e uso de agrotóxicos? Uma contribuição ao debate. Ciênc. Saúde Coletiva, v. 15, n. 1, p. 277-288, jan. 2010.

LIMA, S. K. et al. Desenvolvimento rural. Boletim de Políticas Sociais: acompanhamento e análise, Brasília, n. 26, 2019. Disponível em: <https://bit. ly/3cqLAm7>.

MALTA, D. C. et al. Trends in prevalence of overweight and obesity in adults in 26 Brazilian state captals and the Federal District from 2006 to 2012. Revista Brasileira de Epidemiologia, v. 17, p. 267-276, 2014.

MORAES, R. F. Agrotóxicos no Brasil: padrôes de uso, política de regulação e prevenção da captura regulatória. Brasília: Ipea, 2019. (Texto para Discussão, n. 2506).

PARANÁ. Secretaria de Estado da Saúde do Paraná Superintendência de Vigilância em Saúde. Protocolo de Avaliação das Intoxicaçóes Crônicas por Agrotóxicos. Curitiba: Cest, fev. 2013. Disponível em: <https://bit.ly/3c6HZK0>.

. Intoxicaçóes agudas por agrotóxicos: atendimento inicial do paciente intoxicado. Curitiba: Secretaria de Saúde, 2018. Disponível em: <https://bit. ly/3aWOlKJ>.

PERES, F. et al. Desafios ao estudo da contaminação humana e ambiental por agrotóxicos. Ciência \& Saúde Coletiva, Rio de Janeiro, v. 10, n. 0, set./dez. 2005.

PESQUISA revelou que agrotóxico levou pessoas à desordem mental, depressão e suicídio. Carta Campinas, 27 jun. 2017. Disponível em: <https://bit.ly/39YjNbc>.

RESENDE, T.; PUPO, F. Brasil tem importaçáo recorde de agrotóxicos no primeiro ano de Bolsonaro. Folha de S.Paulo, 1ํㅡㄹ. 2020. Disponível em: $<$ https://bit. ly/3fedYtY>.

RIGOTTO, R. M. et al. Tendências de agravos crônicos à saúde associados a agrotóxicos em região de fruticultura no Ceará, Brasil. Revista Brasileira de Epidemiologia, Rio de Janeiro, v. 16, n. 3, p. 763-773, 2013.

SANTOS, T. G. et al. Tendência e fatores associados à insegurança alimentar no Brasil: Pesquisa Nacional por Amostra de Domicílios 2004, 2009 e 2013. Cadernos de Saúde Pública, Rio de Janeiro, v. 34, n. 4, abr. 2018. 
SOARES, W.; ALMEIDA, R. M. V.; MORO, S. Trabalho rural e fatores de risco associados ao regime de uso de agrotóxicos em Minas Gerais, Brasil. Cadernos Saúde Pública, v. 19, n. 4, p.1117-1127, 2003.

SOARES, W.; CUNHA, L.; PORTO, M. Uma política de incentivo fiscal a agrotóxicos no Brasil é injustificável e insustentável. Rio de Janeiro: Abrasco, fev. 2020. Disponível em: <https://bit.ly/2wsDpX7>.

SOUZA, P. H. F.; VAZ, F. M. Caderno ODS 1: acabar com a pobreza em todas as suas formas, em todos os lugares. In: SILVA, E. R. A. (Coord.). Cadernos ODS. Brasília: Ipea, 2019. Disponível em: <https://bit.ly/3bp6fHg>.

TEREZA Cristina dá posse a secretários com ministério fortalecido. Gov.br, 2 jan. 2019. Disponível em: <https://bit.ly/3fffon2>.

TRIVELLATO, P. T. et al. Insegurança alimentar e nutricional em famílias do meio rural brasileiro: revisão sistemática. Ciência \& Saúde Coletiva, v. 24, n. 3 , p. 865-874, 2019.

VALADARES, A. et al. O desempenho recente das políticas de compras públicas da agricultura familiar. Políticas sociais: acompanhamento e análise, Brasília, n. 26, 2019. (Nota de Política Social). Disponível em: <https://bit.ly/39T43pX>.

VALADARES, A.; ALVES, F. Caderno ODS 2: fome zero e agricultura sustentável. In: SILVA, E. R. A. (Coord.). Cadernos ODS. Brasília: Ipea, 2019. Disponível em: <https://bit.ly/2V6BnUW>. Acesso em: 13 abr. 2020.

VALADARES, A.; ALVES, F.; GALIZA, M. O crescimento do uso de agrotóxicos: uma análise descritiva dos resultados do Censo Agropecuário 2017. Brasília: Ipea, 2020. No prelo.

VIERO, C. et al. Sociedade de risco: o uso dos agrotóxicos e implicaçôes na saúde do trabalhador rural. Esc. Anna Nery, Rio de Janeiro, v. 20, n.1, jan./mar. 2016. Disponível em: <https://bit.ly/34HPnZC>.

WALTER, E. V. et al. Efeitos neurológicos causados por agrotóxicos: a realidade mostrada através de prontuários hospitalares. Revista de Enfermagem da UERJ, n. 11, p. 171-176, 2003. 


\section{ANEXO A}

\section{Metas do ODS 2 - Fome Zero e Agricultura Sustentável}

Meta 2.1: até 2030, erradicar a fome e garantir o acesso de todas as pessoas, em particular os pobres e as pessoas em situaçôes vulneráveis, incluindo crianças e idosos, a alimentos seguros, culturalmente adequados, saudáveis e suficientes durante todo o ano.

Meta 2.2: até 2030, erradicar as formas de má-nutrição relacionadas à desnutrição, reduzir as formas de má-nutrição relacionadas ao sobrepeso ou à obesidade, prevendo o alcance até 2025 das metas acordadas internacionalmente sobre desnutrição crônica e desnutrição aguda em crianças menores de cinco anos de idade, e garantir a segurança alimentar e nutricional de meninas adolescentes, mulheres grávidas e lactantes, pessoas idosas e povos e comunidades tradicionais.

Meta 2.3 (Brasil): até 2030, aumentar a produtividade agrícola e a renda dos pequenos produtores de alimentos, particularmente de mulheres, agricultores familiares, povos e comunidades tradicionais, visando tanto à produção de autoconsumo e garantia da reproduçáo social dessas populaçóes quanto ao seu desenvolvimento socioeconômico, por meio do acesso seguro e equitativo: i) à terra e aos territórios tradicionalmente ocupados; ii) à assistência técnica e extensão rural, respeitando-se as práticas e saberes culturalmente transmitidos; iii) a linhas de crédito específicas; iv) aos mercados locais e institucionais, inclusive políticas de compra pública; $v$ ) ao estímulo ao associativismo e cooperativismo; e vi) a oportunidades de agregação de valor e emprego não agrícola.

Meta 2.4 (Brasil): até 2030, garantir sistemas sustentáveis de produção de alimentos, por meio de políticas de pesquisa, de assistência técnica e extensão rural, entre outras, visando implementar práticas agrícolas resilientes que aumentem a produção e a produtividade e, ao mesmo tempo, ajudem a proteger, recuperar e conservar os serviços ecossistêmicos, fortalecendo a capacidade de adaptação às mudanças do clima, às condiçóes meteorológicas extremas, secas, inundaçôes e outros desastres, melhorando progressivamente a qualidade da terra, do solo, da água e do ar.

Meta 2.5.1 (Brasil): até 2020, garantir a conservação da diversidade genética de espécies nativas e domesticadas de plantas, animais e microrganismos importantes para a alimentação e agricultura, adotando estratégias de conservação ex situ, in situ e on farm, incluindo bancos de germoplasma, casas ou bancos comunitários de sementes e núcleos de criação e outras formas de conservaçáo adequadamente geridos em nível local, regional e internacional.

Meta 2.5.2 (Brasil): até 2020, garantir a repartição justa e equitativa dos benefícios decorrentes da utilização dos recursos genéticos e conhecimentos tradicionais associados, conforme acordado internacionalmente, assegurando a soberania alimentar e segurança alimentar e nutricional.

Meta 2.A (Brasil): aumentar o investimento, inclusive por meio do reforço da cooperação internacional, em infraestrutura, pesquisa e assistência técnica e extensão 
rural, no desenvolvimento de tecnologias e no estoque e disponibilização de recursos genéticos de plantas, animais e microrganismos, incluindo variedades crioulas e parentes silvestres, de maneira a aumentar a capacidade de produção agrícola ambientalmente sustentável, priorizando povos e comunidades tradicionais, agricultores familiares, pequenos e médios produtores, adaptando novas tecnologias aos sistemas de produção tradicional e considerando as diferenças regionais e socioculturais.

Meta 2.B (Brasil): corrigir e prevenir as restriçôes ao comércio e distorçôes nos mercados agrícolas mundiais, inclusive por meio da eliminação paralela de todas as formas de subsídios à exportação e todas as medidas de exportação com efeito equivalente, de acordo com o mandato da Rodada de Desenvolvimento de Doha e atendendo, em nível nacional, ao princípio da soberania alimentar e segurança alimentar e nutricional.

Meta 2.C (Brasil): adotar medidas para garantir o funcionamento adequado dos mercados de alimentos e seus derivados, facilitar o acesso oportuno à informação de mercado, promover o fortalecimento de políticas públicas de estoque e abastecimento, incluindo investimento em logística e distribuição, a fim de ajudar a limitar a volatilidade extrema dos preços dos alimentos e garantir, em nível nacional, a soberania alimentar e segurança alimentar e nutricional. 


\section{CAPÍTULO 8}

\section{IGUALDADE RACIAL ${ }^{1}$}

\section{APRESENTAÇÃO}

A construção de esferas públicas ancoradas em regimes jurídicos antidiscriminatórios tem sido perseguida pela Organização das Naçóes Unidas (ONU) como um dos pilares do direito internacional dos direitos humanos (DIDH). ${ }^{2} \mathrm{O}$ combate ao racismo, à xenofobia e à intolerância são fenômenos intrinsecamente ligados ao seu próprio surgimento, logo após a Segunda Guerra Mundial. Foi em resposta às políticas genocidas ocorridas naquele período que cartas, declarações, convenções e protocolos passaram a instituir, no direito internacional, uma linguagem protetiva dos direitos necessários a uma vida digna (Silva, 2011; Piovesan, 1999).

$\mathrm{O}$ ordenamento jurídico reconhece a força política e simbólica do sistema internacional de direitos humanos, atribuindo, a tratados, protocolos, cartas, convênios e convençóes assinados, aprovados e ratificados, a natureza de norma integrante da ordem jurídica interna. O status ${ }^{3}$ dessa norma varia de acordo com as correntes doutrinárias e a matéria sob a qual versa o dispositivo ratificado. As convenções que tenham por matéria os direitos humanos, as quais toda agenda antidiscriminatória integra, possuem o status de norma constitucional, conforme se pode depreender de interpretação sistemática do art. 5ำ, $\$ \$ 2^{\circ}$ e $3^{\circ}$ da CF/1988 (Piovesan, s.d.).

O Brasil aderiu aos principais pactos e convenções de direitos humanos atualmente em vigor (Piovesan, 1999). Ao ratificar tanto os instrumentos de alcance geral (caso dos pactos internacionais) quanto os instrumentos especiais e

1. DOI: http://dx.doi.org/10.38116/bps27/igualdaderacial

2. Por DIDH entenda-se um sistema de normas, procedimentos, protocolos e institutos criados em âmbito internacional para implementar os direitos humanos em todos os países. Este sistema retira do Estado nacional e da legislação doméstica a competência exclusiva para o tratamento de matérias dessa natureza, colocando em questão a soberania absoluta do Estado (Piovesan, 1999).

3. Até 1977 a jurisprudência do STF entendia que os tratados internacionais tinham vigência e eficácia imediatas na ordem jurídica interna. Este entendimento foi alterado após o julgamento do Recurso Extraordinário n 80.004 , através do qual a suprema corte passou a entender que tratados internacionais eram equiparáveis à legislação federal, de natureza infraconstitucional, podendo ser revogadas por lei posterior de teor incompatível com a anterior. A Constituição Federal de 1988 (CF/1988) modificou esse entendimento no que diz respeito aos tratados internacionais de direitos humanos, conferindo, por força dos $\S \S 1^{\circ}$ e $2^{\circ}$ do art. $5^{\circ}$, o status de norma de natureza constitucional. A Emenda Constitucional $n^{\circ} 45 / 2004$ restringiu este entendimento, através da adição do $\S 3^{\circ}$ do art. $5^{\circ}$, que atribui eficácia constitucional apenas aos acordos aprovados em dois turnos e por quórum qualificado de três quintos. A matéria permanece controversa quanto aos tratados que versarem sobre direitos humanos. 0 presente trabalho se alinha à corrente que entende possuírem status de norma constitucional, conforme interpretação sistemática dos $\S 2^{\circ}$ e $3^{\circ}$ do art. $5^{\circ}$ da CF/1988 (Piovesan, s.d.). 
complementares de proteção (caso das convençóes), o Estado brasileiro reconheceu as vulnerabilidades que atravessam a experiência de grupos específicos e comprometeu-se a combatê-las. Em outros termos, reconheceu-se que, além dos direitos comuns a toda vida humana em abstrato, há condições específicas que fazem de negros, mulheres, crianças, refugiados, encarcerados, entre outros grupos, sujeitos de direitos. Isso implica o Estado em uma complexa agenda que precisa combinar igualdade social e políticas de reconhecimento das diferenças (Fraser, 2001).

Porém, quando os direitos são instituídos, em regra, as condiçôes para sua efetivação não estão dadas. A efetividade constitui-se, dessa forma, na arena pública, a partir da qual diferentes sujeitos políticos tensionam os sentidos e os alcances das normas e as responsabilidades envolvidas em sua concreção.

Este trabalho pretende debruçar-se, nesse aspecto, sobre o cumprimento pelo Brasil dos compromissos assumidos ao ratificar um dos principais instrumentos internacionais de direitos humanos: a Convenção Internacional sobre a Eliminação de Todas as Formas de Discriminação Racial (Icerd), adotada pela Assembleia Geral da ONU, em 21 de dezembro de 1965, e promulgada pelo Congresso Nacional no Brasil, em 21 de junho de 1967.

A convenção constitui o mais completo diploma normativo nessa matéria, albergando em seu interior grupos sociais discriminados por cor, raça, descendência, origem nacional ou étnica. Também compreendeu a discriminação como fenômeno complexo, abarcando tanto os atos intencionais quanto os efeitos do racismo e da discriminação. As medidas prescritas para sua prevenção e mitigação demandam a proteção e a promoção de bens jurídicos de natureza cível, política, social e econômica. Além disso, a Icerd prevê a instituiçâoo de um comitê formado por peritos independentes responsáveis pelo monitoramento de sua execução, uma das principais inovaçôes criadas naquele contexto (Silva, 2011).

A construção de instrumentos dotados da capacidade de monitorar o cumprimento das convençôes é, nesse aspecto, uma das dimensôes da esfera pública por meio do qual os conflitos se desenrolam. Como avaliar, porém, a efetividade de seus dispositivos? Que elementos de política precisam ser considerados de forma a garantir que as análises não reproduzam discursos e perspectivas color blind? $\mathrm{O}$ debate sobre a efetividade não é o resultado da avaliação individualizada de cada política, mas do efeito conjunto de açóes públicas que concorrerão para a produção dos marcadores sociais das diferenças.

Para monitorar e analisar a Icerd, convidamos os leitores, no primeiro momento, a pensar a questão racial no plano internacional e sua recepção no plano doméstico, por meio da elaboração de um panorama geral do direito antidiscriminatório instituído no Brasil. No segundo momento, analisamos o processo de institucionalização da pauta racial com ênfase no modo como a agência 
negra instrumentalizou a $\mathrm{CF} / 1988$ para tornar efetivos os diversos compromissos assumidos no âmbito da convenção; por fim, tratamos do novo ciclo que se inicia em 2015 e se aprofunda a partir de 2016, quando um novo programa político se impõe, reformando o escopo do sistema de proteção social e criando novos desafios ao sistema antidiscriminatório até então construído.

\section{A ICERD E A CONSTITUIÇÃO DO DIREITO DA ANTIDISCRIMINAÇÃO NO BRASIL}

Considerada o primeiro tratado internacional sobre os direitos humanos (Alves, 2017), a Icerd surge em contexto de recrudescimento das posiçóes da ONU contra o colonialismo e o apartheid racial. Sua atuaçáo nos primeiros anos de funcionamento da organização foi constrangida pela postura conciliatória e dúbia da maior parte dos países ocidentais, ${ }^{4}$ sendo que parte significativa destes era de colonizadores e/ou de países estruturados internamente à base de políticas explícitas de segregação racial. Embora dedicada desde seu início a empreender esforços contra qualquer tipo de perspectiva supremacista baseada em crenças ou ideologias, a ONU teve atuação apenas retórica contra o apartheid e as políticas segregacionistas ${ }^{5}$ (Silva, 2011).

Assim, até 1959, apenas a Convenção sobre Discriminação no Emprego e Ocupação, adotada pela Organização Internacional do Trabalho (OIT) em 1958, e a Convenção contra a Discriminação no Ensino, adotada pela Organização das Naçôes Unidas para a Educação, a Ciência e a Cultura (UNESCO) em 1960, haviam sido criadas. A pauta antidiscriminatória não tinha ainda instrumento específico e abrangente o suficiente para ancorar as açóes da ONU. Iniciativas mais contundentes apenas se tornaram realidade a partir de 1960, com a entrada de países africanos recém-independentes ${ }^{6}$ e o apoio dos países do bloco socialista e dos Estados do denominado "Terceiro Mundo" (Silva, 2011).

A crescente onda de protestos contra as políticas de segregação e a luta pelos direitos civis nos Estados Unidos, o surgimento de guerrilhas armadas contra o colonialismo em alguns países africanos e a onda de protestos contra o apartheid foram decisivos para fermentar uma mudança de postura da ONU. Em 21 de março de 1960, um protesto contra o regime sul-africano em Shaperville foi reprimido de forma violenta pela polícia de Pretória, resultando na morte de 69 pessoas negras e 186 feridos. O Conselho de Segurança da ONU, em resposta, elaborou a Resolução no $134 / 1960$, a primeira em matéria de direitos humanos. Esta responsabilizou as políticas raciais sul-africanas pelas mortes ocorridas, convidando o governo a

4. Entre os 85 Estados-membros da ONU no fim dos anos 1950, apenas onze eram africanos.

5. A maior parte dos países ocidentais, embora defendesse a igualdade entre os seres humanos, considerava que temas como o apartheid e as políticas racistas de segregação não deveriam ser pautados pela Assembleia Geral da ONU, invocando a não ingerência em assuntos internos como corolária do silêncio em matéria de direitos humanos (Silva, 2011). 6. Em 1960, dezessete Estados africanos recém-independentes passaram a integrar a organização. 
abandonar o apartheid (Silva, 2011). A posição unânime do Conselho de Segurança da ONU, composto por um grupo pequeno e dissonante de países destacados pelo seu peso político, econômico e militar em nível global, elevou o tom da diplomacia, autorizando que novas medidas mais duras contra o regime fossem adotadas.

Após a resolução, a ONU aprovou a Declaração sobre a Concessão da Independência aos Países e Povos Coloniais (Resolução no 1.514 , de 14 de dezembro de 1960) e a Declaração sobre a Eliminação de Todas as Formas de Discriminação Racial (Resolução no 1.904, de 20 de novembro de 1963). O instrumento que viabilizaria atuação mais decisiva do organismo em matéria de discriminação (a Icerd), porém, somente viria a ser aprovado pela Assembleia Geral da ONU em 1965. Em 1966, a data do massacre de Shaperville foi transformada por essa assembleia no Dia Internacional para a Eliminação da Discriminação Racial, em memória dos que tombaram na luta contra o apartheid. No dia 4 de janeiro de 1969, a convençáo entrou em vigor.

Nesse contexto, a Icerd é o mais amplo instrumento de combate às desigualdades resultantes de processos discriminatórios em âmbito internacional. $\mathrm{O}$ conceito nesta adotado reflete essa abrangência, considerando-se discriminação:

toda distinção, exclusão, restrição ou preferência baseada em raça, cor, descendência ou origem nacional ou étnica que tenha por objeto ou resultado anular ou restringir o reconhecimento, gozo ou exercício em um mesmo plano (em igualdade de condiçáo) de direitos humanos e liberdades fundamentais nos campos político, econômico, social, cultural ou em qualquer outro campo da vida pública (Brasil, 1969, [s.p.]).

Sua aplicação pelos Estados-partes é monitorada pelo Comitê para a Eliminação da Discriminação Racial (Cerd), composto por dezoito peritos imparciais, com mandatos de quatro anos. O comitê foi efetivamente constituído a partir de 1970 , quando os primeiros membros tomaram posse, o que implica dizer que há cinquenta anos este vem expedindo alertas e recomendações aos países signatários (Alves, 2017).

A maior parte dos países ratificou inicialmente a convenção como uma espécie de rito formal, que permitia aos países manifestar sua censura ao apartheid e à discriminação racial, mas interpretando-o sempre como um problema do outro. Essa perspectiva foi evidenciada pelo próprio comitê, em que a mera previsão legal de igualdade abstrata e a ausência de dispositivo legal segregacionista figuravam como índices da ausência de discriminação nos relatórios periódicos enviados pelos Estados-partes ${ }^{7}$ (Alves, 2017).

7. Um caso exemplar revelado por Silvio Albuquerque foi o da Argentina, que resumiu seu relatório a um único parágrafo, em que informava não haver discriminação racial sob sua jurisdição (Silva, 2011). 
Primeiro país a assinar a Icerd, o Brasil entregou dezessete relatórios periódicos ${ }^{8}$ entre 1970 e 2020, o último destes em 2004. Nos primeiros 25 anos de vigência da convenção, o Brasil não fugiu das tendências evasivas, defendendo nos fóruns internacionais o mito da democracia racial brasileira. Os sete relatórios enviados pelo Brasil durante a ditadura militar informavam apenas a existência de uma sociedade multirracial e harmônica, acrescida dos dispositivos legais que preconizavam a igualdade formal e a náo discriminação como fundamentos da República. Apenas em 1995, o relatório periódico brasileiro, que agregou o $10^{\circ}, 11^{\circ}, 12^{\circ}$ e $13^{\circ}$ informes, reconheceu, com base em farta documentação estatística, as desigualdades raciais e a necessidade de adotar medidas concretas para sua erradicação (Silva, 2011).

O trabalho dos peritos é relevante para contornar as respostas evasivas dos países. Os relatórios apresentados por estes são contrastados com os contrarrelatórios e denúncias de terceiros formuladas perante o Cerd (Alves, 2010). Embora não possua retórica ofensiva, o trabalho em torno da Icerd tem por base o entendimento de que discriminaçóes existem em todos os lugares, não são esporádicas e devem ser enfrentadas pelos Estados de forma permanente. Essa concepção foi gradativamente acolhida pelos países, o que já representa significativo avanço.

A convenção é composta por 25 artigos divididos em duas partes: a primeira (arts. $1^{\circ}$ a $7^{\circ}$ ) refere-se às medidas de prevenção e promoçáo da agenda antidiscriminatória adotadas pelos Estados-partes; a segunda é composta por dispositivos referentes à formação e à eleição do Cerd, a regras de funcionamento etc. $\mathrm{O}$ escopo normativo da Icerd é composto também pela documentaçáo técnica produzida pelo comitê, a exemplo do documento de orientação para a produção dos relatórios pelos países ${ }^{9}$ e das observações gerais, ${ }^{10}$ que constituem importantes mecanismos interpretativos elaborados pelo comitê. Isso permite que a convenção seja constantemente atualizada, ampliando seu alcance para as distintas conjunturas e contextos em que processos discriminatórios surgem como fenômeno relevante a ser enfrentado.

8. 0 relatório periódico deve ser enviado a cada dois anos pelos Estados-partes. A ausência de elaboração em alguns biênios acarreta a necessidade de envio das informações em um único instrumento no biênio seguinte. No caso do Brasil, foram entregues dezessete relatórios em nove oportunidades. Alguns destes relatórios podem ser acessados no banco de dados dos tratados da ONU. Disponível em: <https://bit.ly/3evean6>. Acesso em: 21 maio 2020.

9. 0 comitê elaborou um documento onde constam as informações efetivamente requeridas em cada artigo. Na prática, eles funcionam como fonte de interpretação atualizada dos dispositivos. A este respeito, ver: <https://bit.ly/3j|z3F0 >. Acesso em: 21 maio 2020.

10. As observações gerais são recomendações elaboradas pelo comitê em resposta aos relatórios enviados pelos Estados-partes, cabendo a estes responder às observações no relatório subsequente. 
QUADRO 1

Estrutura da Icerd

\begin{tabular}{|c|c|c|}
\hline & Artigo da convenção & Síntese do dispositivo (guidelines) \\
\hline Art. 1 & $\begin{array}{l}\text { Estabelece o conceito de discriminação } \\
\text { étnico-racial, com salvaguardas às políticas } \\
\text { de ações afirmativas. }\end{array}$ & $\begin{array}{l}\text { Os Estados-partes devem informar se possuem norma proibitiva da } \\
\text { discriminação, bem como sua abrangência. Devem também informar se } \\
\text { formas diretas e indiretas de discriminação estão contempladas no conceito } \\
\text { legalmente adotado. Devem ser informadas as medidas adotadas para dar } \\
\text { cabo da proibição. }\end{array}$ \\
\hline Art. 2 & $\begin{array}{l}\text { Compromete os Estados-partes a condenar } \\
\text { práticas discriminatórias e implementar } \\
\text { medidas para erradicá-las. }\end{array}$ & $\begin{array}{l}\text { Os Estados-partes devem informar as medidas legislativas, judiciais e } \\
\text { administrativas adotadas para condenar a discriminação quando esta } \\
\text { existir. Deve explicitar também as medidas concretas adotadas para coibir } \\
\text { a discriminaçãa racial praticada por indivíduos. }\end{array}$ \\
\hline Art. 3 & $\begin{array}{l}\text { Compromete os Estados-partes a condenar } \\
\text { a segregação racial e o apartheid, devendo } \\
\text { eliminar qualquer dessas práticas nos territórios } \\
\text { sob sua jurisdição. }\end{array}$ & $\begin{array}{l}\text { Este dispositivo foi dirigido nitidamente aos países que institucionalizaram } \\
\text { regimes de segregação e apartheid. O Comitê para a Eliminação da Discri- } \\
\text { minação Racial, porém, recomenda que os países monitorem e informem as } \\
\text { possíveis tendências à segregação étnico-racial. Ressalta ainda a necessidade } \\
\text { de adotar medidas preventivas para evitar a segregação de indivíduos, } \\
\text { merecendo destaque os povos ciganos e os estrangeiros não naturalizados. }\end{array}$ \\
\hline Art. 4 & $\begin{array}{l}\text { Incita os Estados-partes a adotarem medidas } \\
\text { que coíbam a difusão de toda propaganda } \\
\text { ou ideia ancorada no supremacismo racial. } \\
\text { Devem ser adotadas medidas também contra } \\
\text { organizações que promovam o ódio racial ou } \\
\text { teorias discriminatórias. }\end{array}$ & $\begin{array}{l}\text { Os Estados-partes devem informar não apenas a existência da legislação } \\
\text { instituída para condenar ou tornar ilegal propagandas e teorias de superiori- } \\
\text { dade racial, mas também garantir sua aplicação efetiva. Assim, os signatários } \\
\text { devem declarar as posições dos tribunais nacionais nesta matéria, bem como } \\
\text { inserir dados estatísticos oriundos do Judiciário e análises qualitativas a } \\
\text { respeito de ações, julgamentos e sentenças. }\end{array}$ \\
\hline Art. 5 & $\begin{array}{l}\text { Trata dos direitos humanos que devem ser } \\
\text { garantidos pelos Estados, sem discriminação. }\end{array}$ & $\begin{array}{l}\text { Os países devem destacar todas as medidas adotadas para combater os } \\
\text { efeitos dos processos discriminatórios, devendo incluir todos os grupos } \\
\text { sociais albergados pela convenção (grupos ciganos, povos indígenas, refu- } \\
\text { giados, imigrantes, grupos minoritários etc.). Também é relevante apontar } \\
\text { a interseccionalidade de raça e gênero nos processos discriminatórios. }\end{array}$ \\
\hline Art. 6 & $\begin{array}{l}\text { Trata especialmente do direito de acesso à } \\
\text { justiça, bem como do direito a uma prestação } \\
\text { jurisdicional justa e adequada, em face de } \\
\text { qualquer dano sofrido por vítima de discri- } \\
\text { minação racial e/ou étnica. }\end{array}$ & $\begin{array}{l}\text { Os Estados-partes devem informar as medidas adotadas para garantir que } \\
\text { as vítimas possuem informaçãa adequada a respeito de seus direitos; se } \\
\text { as vítimas com recursos limitados não são constrangidas pelos custos e } \\
\text { complexidades de um processo judicial; e a respeito da habilitação dos } \\
\text { órgãos de direitos humanos e instituições similares para ouvir e considerar } \\
\text { denúncias individuais de discriminação racial. }\end{array}$ \\
\hline Art. 7 & $\begin{array}{l}\text { Estabelece compromissos específicos no que } \\
\text { tange ao combate à discriminação em matéria } \\
\text { de ensino, educação, cultura e informação. }\end{array}$ & $\begin{array}{l}\text { Estados-partes devem informar as ações direcionadas à promoção dos } \\
\text { direitos humanos nas diversas mídias (tv, rádio, internet etc.). Também } \\
\text { devem ser informadas as medidas adotadas para alterar currículos escolares } \\
\text { e livros didáticos. }\end{array}$ \\
\hline
\end{tabular}

Fonte: ONU. Disponível em: <https://bit.ly/3j4M85g>. Acesso em: 1ํ jun. 2020.

Elaboração dos autores.

Para cada artigo, o Cerd requisita informaçóes amplas das medidas executivas, legislativas e judiciais adotadas para combater a discriminação racial, implicando um conjunto amplo de instituiçóes públicas em sua concreção. Também requere informaçóes amparadas em dados primários dos censos populacionais, de pesquisas domiciliares e dos registros administrativos, estimulando que cada Estado-parte confira visibilidade estatística ao fenômeno em cada contexto nacional.

Vale ressaltar que, ao contrário do que se verifica em relação a outros fóruns políticos da ONU, a Icerd não costuma mobilizar a sociedade civil e as organizaçóes não governamentais (ONGs) quanto ao seu cumprimento (Alves, 2010). O modo 
como os países lidam com questóes raciais e étnicas é informado por contextos históricos, demográficos e políticos muito distintos. Essas distinções ganham reflexão na maneira como os sistemas estatísticos coletam ou não a variável étnico-racial. Elementos associados à nacionalidade, ao grupo linguístico, à ancestralidade, à religiosidade, ao pertencimento tribal, à indumentária, aos hábitos alimentares e à cor da pele informam as identidades associadas ao pertencimento étnico e/ou racial em cada país. Os significados dessas informaçōes, nesse aspecto, variam de forma significativa. Levantamento feito pela Divisão de Estatísticas da ONU entre os anos 1990 e 2000, e analisado por Paixão e Carvano (2008), aponta que 22\% de 121 questionários censitários de países independentes possuíam informação desagregada por quesitos ligados à etnia, à raça, à aparência física ou à ancestralidade. Em 2009, apenas nove entre dezenove países latino-americanos possuíam dados sobre a população afrodescendente em seus censos nacionais. ${ }^{11}$

Os países europeus, ${ }^{12}$ por sua vez, não coletam informações desagregadas por quesitos de cor, raça ou etnia, em virtude dos temores de que essa identificação concorra para a produçáo dos próprios preconceitos que se pretende evitar. Orientação semelhante adota a África do Sul, que recusa a classificação por etnia em face das memórias tenebrosas do apartheid (Alves, 2010). Os argumentos seguem, em larga medida, a ideia de que o abandono de termos associados à raça é uma resposta eficiente aos contextos políticos que se valeram da catalogação oficial de indivíduos e grupos sociais para discriminar negativamente. Ignora-se, porém, que os termos são apropriados e reconstruídos pelos sujeitos discriminados para explicitar os efeitos duradouros de formaçóes sociais racializadas. A identidade racial, nesse aspecto, é instrumentalizada para pressionar os Estados à adoçáo de medidas que igualem as condiçóes concretas de viver a vida com dignidade (Paixão e Carvano, 2008).

Esses fatores, aliados ao longo tempo de negação da existência da discriminação racial nas jurisdiçôes nacionais, colocam a Icerd diante de tempos históricos muito distintos, com reflexo na própria disponibilidade de informaçóes que permitam seu monitoramento. Com isso, em parte do globo, a agenda pouco ultrapassou a fase de reconhecimento de sua própria relevância.

No Brasil, o cenário é oposto. O país coletou informaçóes populacionais por raça/cor desde 1872 , quando foi realizado o primeiro recenseamento. $\mathrm{O}$ quesito deixou de ser aplicado apenas duas vezes nos censos decenais (1920 e 1970). Isso permitiu que, a partir de farta documentação estatística, fossem confrontadas as interpretaçóes oficiais do Estado a partir dos dados que este mesmo produzia (Anjos, 2013). Esses dados foram instrumentalizados por cientistas sociais e militantes do

11. Informações fornecidas pela ONU em 22 de junho de 2009. A este respeito, ver: <https://bit.ly/2OtChrE $>$. 12. 0 único país europeu que possui em seus sistemas censitários informação racial é a Grã-Bretanha, ainda que de forma indireta, por meio de perguntas sobre pertencimento étnico (Paixão e Carvano, 2008). 
movimento negro, com o objetivo de evidenciar as desigualdades raciais e confrontar o mito da democracia racial ainda nos anos 1970. Por esse motivo, pode-se afirmar que as condiçôes internas foram mais preponderantes para o avanço institucional da pauta do que as pressóes externas. Foi a partir da agência negra local que se ergueu o direito da antidiscriminação no Brasil.

\section{A CONSTITUIÇÃO DE 1988 E 0 DIREITO ANTIDISCRIMINATÓRIO}

A primeira iniciativa antidiscriminatória no Brasil foi adotada apenas sessenta anos após a abolição da escravatura, com a edição da Lei no 1.390/1951, também conhecida como Lei Afonso Arinos. Criada como reação à ampla repercussão que teve o episódio sofrido por Katherine Dunham ${ }^{13}$ em São Paulo, essa lei transformou a discriminação racial em contravenção penal. Condutas como recusas em atender, hospedar ou servir alguém em virtude de sua cor/raça foram vedadas pela nova legislação. Negação de emprego em empresa pública e obstrução de acesso a cargos do funcionalismo público ou das forças armadas também foram tipificadas pelo dispositivo.

A lei aprovada não foi seguida de nenhuma medida adicional que permitisse vislumbrar sua efetividade, motivando geraçóes sucessivas do movimento negro a apontar as insuficiências e as deficiências da legislação. A dificuldade de constituir prova do delito, o reduzido número de condutas enquadráveis na legislação e a baixa censura penal figuravam entre as principais críticas das organizaçôes negras (Campos, 2015; Fullin, 2000).

A despeito disso, a Lei Afonso Arinos foi o primeiro instrumento legal mediante o qual o Estado reconhecia oficialmente a discriminação racial como fenômeno presente na sociedade brasileira (Campos, 2015). Após esta, outros textos legais reconheceram a questão racial em seu interior, a exemplo da Lei no 2.889/1956, que tipificou o crime de genocídio no Brasil, o Código Brasileiro de Telecomunicações de 1962 e a Lei de Imprensa de 1967 (Fullin, 2000).

A demanda pela edição de uma nova lei passou a integrar a pauta do movimento negro, que se rearticulava na redemocratização. Foi por meio da participação na Assembleia Nacional Constituinte que se esboçaram os eixos de sustentação do que viria a constituir-se o direito da antidiscriminaçáo no Brasil.

As organizaçóes negras construíram sua própria pauta de reivindicaçôes. Em 26 e 27 de agosto de 1986, foi convocada a Convenção Nacional do Negro pela

13. Pesquisadora de danças de origem negra, Dunham possuía uma companhia de dança composta por coreógrafos negros. Vindo ao Brasil com sua companhia para uma temporada de apresentações, foi impedida de hospedar-se no Hotel Esplanada, que não aceitava negros em seu estabelecimento. 0 caso ganhou ampla repercussão à época, sendo estopim de uma movimentação parlamentar que deu origem à Lei Afonso Arinos. 
Constituinte, ${ }^{14}$ findada com o lançamento de declaração contendo uma pauta extensa de propostas, entre as quais destacamos: defesa da tipificação da discriminação racial como crime inafiançável, com pena de reclusão e rito sumaríssimo; vedaçáo da pena de morte; defesa dos direitos dos custodiados pelo Estado e de suas famílias; tipificação da tortura como crime contra a humanidade; definição da justiça comum como jurisdiçáo competente para o julgamento dos casos de abuso de autoridade policial; defesa da unificação do sistema de saúde em bases estatais; inclusão da moradia como direito; descriminalização do aborto e vedação de qualquer tipo de política estatal de controle da natalidade; alteração dos currículos escolares, inserindo a história da África e a história do negro na formação básica; veto a qualquer propaganda que ofenda a identidade das pessoas negras; defesa do direito à terra e ao território das comunidades quilombolas; rompimento de relaçôes diplomáticas e comerciais com países que tenham institucionalizado qualquer política discriminatória; e fixação de direitos trabalhistas referentes a salário, jornada, direito de greve, licenças etc.

Com inúmeras críticas à igualdade formal inscrita nos textos constitucionais precedentes, as organizaçóes negras buscaram incidir de duas formas sobre a Constituinte: por intermédio da elaboraçáo de propostas que afetam de forma majoritária, mas não exclusiva, a população negra; e mediante propostas mais específicas restritas apenas à população identificada pelo seu pertencimento racial. A leitura subjacente era que as condiçóes de vida da população negra eram afetadas por inúmeras variáveis, devendo-se considerar, portanto, os efeitos raciais de políticas aparentemente neutras (Santos, 2015).

A agenda antidiscriminatória inscrita na Constituição extrapola o debate racial, abarcando demandas de forças políticas e sociais diversas. Como se pode observar no quadro 2, o direito da antidiscriminaçấo tem fundamentos constitucionais nas áreas penal, de educação, de cultura, de trabalho, de direito de acesso à terra e ao território e de relaçôes diplomáticas. Esses dispositivos constituem, ao lado das convençóes de direitos humanos ratificadas pelo Brasil, o cerne dos compromissos antidiscriminatórios em vigor.

14. A convenção contou com a participação de 63 entidades (entidades negras, partidos políticos, sindicatos e grupos sociais) de dezesseis estados da Federaçã̃o, totalizando 185 participantes. 0 documento final da conferência pode ser acessado em: $<$ https://bit.ly/2DJYZcU >. 


\title{
QUADRO 2
}

\section{Dispositivos constitucionais antidiscriminatórios definidos na CF/1988}

\begin{abstract}
Art. 3o Constituem objetivos fundamentais da República Federativa do Brasil: (...) IV - promover o bem de todos, sem preconceitos de origem, raça, sexo, cor, idade e quaisquer outras formas de discriminação.

Art. 4º A República Federativa do Brasil rege-se nas suas relações internacionais pelos seguintes princípios: (...) VIII - repúdio ao terrorismo e ao racismo;

Art. $5^{\circ}$ Todos são iguais perante a lei, sem distinção de qualquer natureza, garantindo-se aos brasileiros e aos estrangeiros residentes no País a inviolabilidade do direito à vida, à liberdade, à igualdade, à segurança e à propriedade, nos termos seguintes: I homens e mulheres são iguais em direitos e obrigações, nos termos desta Constituição; XLI - a lei punirá qualquer discriminação atentatória dos direitos e liberdades fundamentais; XLII - a prática do racismo constitui crime inafiançável e imprescritível, sujeita à pena de reclusão, nos termos da lei;
\end{abstract}

Art. 7ำ São direitos dos trabalhadores urbanos e rurais, além de outros que visem à melhoria de sua condição social: (...) XX proteção do mercado de trabalho da mulher, mediante incentivos específicos, nos termos da lei; XXXI - proibição de qualquer discriminação no tocante a salário e critérios de admissão do trabalhador portador de deficiência;

Art. 2150 Estado garantirá a todos o pleno exercício dos direitos culturais e acesso às fontes da cultura nacional, e apoiará e incentivará a valorização e a difusão das manifestações culturais. § 1으 Estado protegerá as manifestações das culturas populares, indígenas e afro-brasileiras, e das de outros grupos participantes do processo civilizatório nacional.

Art. 216. Constituem patrimônio cultural brasileiro os bens de natureza material e imaterial, tomados individualmente ou em conjunto, portadores de referência à identidade, à ação, à memória dos diferentes grupos formadores da sociedade brasileira, nos quais se incluem: (...)

§ 50 Ficam tombados todos os documentos e os sítios detentores de reminiscências históricas dos antigos quilombos.

Art. 242. [...] § $1^{0} 0$ ensino da História do Brasil levará em conta as contribuições das diferentes culturas e etnias para a formação do povo brasileiro.

Art. 68. ADCT Aos remanescentes das comunidades dos quilombos que estejam ocupando suas terras, é reconhecida a propriedade definitiva, devendo o Estado emitir-lhes os títulos respectivos.

Elaboração dos autores.

O texto constitucional, como se pode observar, reconheceu valor jurídico a uma identidade coletiva, transformando-o em um feixe de medidas protetivas contra práticas discriminatórias (Rios, Leivas e Schafer, 2017). Ao fazê-lo, antecipou-se àquilo que seria estabelecido pela Convenção no 169 da OIT sobre Povos Indígenas e Tribais, ${ }^{15}$ atrelando às identidades coletivas o direito de gozo pleno dos direitos sociais, a garantia dos direitos fundamentais e a salvaguarda do patrimônio cultural a partir do qual esses grupos se produzem e reproduzem socialmente. Essa orientação conferiu sustentação jurídica, por exemplo, ao Decreto nº 6.040/2007, que instituiu políticas voltadas à proteção e à promoção dos direitos de povos e comunidades tradicionais.

O ordenamento jurídico brasileiro é composto também por inúmeros tratados e convenções integrantes do sistema de proteção especial dos direitos humanos. Considerando-se que tratados de direitos humanos possuem status de norma constitucional, o universo de instrumentos jurídicos disponíveis para a democratização efetiva da sociedade brasileira ampliou-se de forma significativa após 1988. Todos esses tratados e convençóes interseccionam o debate racial, de forma direta ou indireta. 
QUADRO 3

Tratados e convenções internacionais de direitos humanos ratificados pelo Brasil ${ }^{1}$

\begin{tabular}{|c|c|c|}
\hline Convenções assinadas e ratificadas & Data da assinatura & Data da ratificação \\
\hline $\begin{array}{l}\text { Convenção contra a Tortura e Outros Tratamentos ou Penas Cruéis, } \\
\text { Desumanos ou Degradantes }\end{array}$ & 23 de setembro de 1985 & 28 de setembro de 1989 \\
\hline $\begin{array}{l}\text { Protocolo Facultativo à Convenção contra a Tortura e Outros Trata- } \\
\text { mentos ou Penas Cruéis, Desumanos ou Degradantes }\end{array}$ & 13 de outubro de 2003 & 12 de janeiro de 2007 \\
\hline Pacto Internacional sobre Direitos Civis e Políticos & - & 24 de janeiro de 1992 \\
\hline $\begin{array}{l}\text { Segundo Protocolo Adicional ao Pacto Internacional sobre os Direitos } \\
\text { Civis e Políticos com Vista à Abolição da Pena de Morte }\end{array}$ & - & 25 de setembro de 2009 \\
\hline $\begin{array}{l}\text { Convenção pela Proteção de Todas as Pessoas contra o Desapareci- } \\
\text { mento Forçado }\end{array}$ & 6 de fevereiro de 2007 & 29 de novembro de 2010 \\
\hline $\begin{array}{l}\text { Convenção para a Eliminação de Todas as Formas de Discriminação } \\
\text { contra a Mulher }\end{array}$ & 31 de março 1981 & 1ㅇ de fevereiro de 1984 \\
\hline $\begin{array}{l}\text { Convenção Internacional pela Eliminação de Todas as Formas de } \\
\text { Discriminação Racial }\end{array}$ & 7 de março de 1966 & 27 de março de 1968 \\
\hline Pacto Internacional sobre Direitos Econômicos, Sociais e Culturais & - & 24 de janeiro de 1992 \\
\hline $\begin{array}{l}\text { Convenção Internacional sobre a Proteção dos Direitos dos Trabalha- } \\
\text { dores Migrantes e dos Membros de Suas Famílias }\end{array}$ & 14 de julho de 1966 & $\begin{array}{l}\text { Revogado pelo Decreto } \\
\text { no } 10.088 / 2019 \text {. }\end{array}$ \\
\hline Convenção sobre os Direitos das Crianças & 26 de janeiro de 1990 & 24 de setembro de 1990 \\
\hline $\begin{array}{l}\text { Protocolo Facultativo à Convenção sobre os Direitos da Criança } \\
\text { Relativo ao Envolvimento de Crianças nos Conflitos Armados }\end{array}$ & 6 de setembro de 2000 & 27 de janeiro de 2004 \\
\hline $\begin{array}{l}\text { Protocolo Facultativo à Convenção sobre os Direitos da Criança } \\
\text { Referente à Venda de Crianças, à Prostituição Infantil e à Pornografia } \\
\text { Infantil }\end{array}$ & 6 de setembro de 2000 & 27 de janeiro de 2004 \\
\hline $\begin{array}{l}\text { Convenção Internacional sobre os Direitos das pessoas com } \\
\text { Deficiência }\end{array}$ & 30 de março de 2007 & 1 ํ de agosto de 2008 \\
\hline
\end{tabular}

Elaboração dos autores.

Nota: ${ }^{1}$ Não foram incluídos neste quadro os tratados regionais de direitos humanos.

As organizaçóes entendiam, porém, que a constitucionalização dos direitos da população negra era apenas o primeiro passo. Seu grande êxito foi o de retirar o racismo do âmbito das relaçóes privadas, ampliando de forma significativa a esfera pública (Pires, 2018). A regulamentação desses dispositivos e sua efetivação por intermédio de políticas públicas passariam a ser o novo campo aberto de uma disputa a ser construída nos anos que se seguiram. A CF/1988, por sua complexidade e abrangência, era o novo programa a ser aplicado. 


\section{A CAMINHO DE DURBAN}

Os anos 1990 ficaram marcados também pela realização de inúmeras conferências ${ }^{16}$ sobre temas que passaram a compor uma agenda social planetária então em formação (Alves, 2018). Ao contrário das leituras prevalentes anteriores, tais agendas deixaram de ser de competência única e exclusiva das jurisdiçôes nacionais. O reconhecimento da presença do local no nacional e no global permitiu que fossem superadas as compartimentaçôes que travavam os esforços de colaboração nos diferentes níveis da organização governamental. Isso somente foi possível em razão do processo de redemocratização dos países da América Latina e do fim da Guerra Fria, que trouxeram para a agenda global uma nova onda de otimismo (op. cit.).

A Convençâo de Viena de 1993 foi, nesse aspecto, de suma relevância, pois trazia de forma consensual, pela primeira vez, a ideia de que os direitos humanos são atributos universais e indivisíveis titulados por todas as pessoas pelo simples fato delas serem humanas (Alves, 2018). Essas concepçóes, assim como as decisóes tomadas nas demais conferências, eram incorporadas pelas conferências seguintes, o que atribuiu à agenda social da ONU um caráter sistêmico e incremental.

O debate sobre a discriminação racial ganhava novos contornos nos anos 1990. Até então, além da Icerd, a ONU havia proclamado em 1973 e 1983, respectivamente, a Primeira e Segunda Décadas de Combate ao Racismo. Em ambas, o combate ao apartheid era a pauta prioritária e estratégica. O fim desse regime significava, portanto, o encerramento do último capítulo de uma agenda antidiscriminatória que mobilizou o sistema internacional de direitos humanos desde a década de 1950. Por sua vez, novos conflitos surgiam em todo o mundo. Os graves conflitos étnicos que deram vazão ao genocídio em Ruanda e à guerra da ex-Iugoslávia nos anos 1990, o ressurgimento de organizaçôes supremacistas brancas nos Estados Unidos, a proliferação de conflitos étnico-religiosos na Ásia, os problemas vividos pelos imigrantes na Europa e o crescimento de grupos neonazistas exigiam um esforço de renovação dos compromissos assumidos pelos países, que agora já não tinham no regime sul-africano um álibi para a desconsideração da discriminação como fenômeno global e generalizado de longa duração (Alves, 2018).

Em 1993, a ONU proclama a Terceira Década de Combate ao Racismo e à Discriminação Racial. Porém, nesse novo contexto, os conflitos e os processos discriminatórios que se evidenciavam em todas as partes do globo já não contavam com a presença ofuscante do apartheid. Sem surpresas, alguns países suscitaram dúvidas quanto à oportunidade da realização de uma conferência com esse tema, pelos incômodos que esta gerava (Alves, 2002).

16. Além da Conferência Mundial sobre Direitos Humanos de Viena, de 1993, foram realizadas a Conferência Internacional sobre População e Desenvolvimento, no Cairo, em 1994; a Cúpula Mundial sobre o Desenvolvimento Social, em Copenhagen, em 1995; a IV Conferência Mundial sobre a Mulher, em 1995; e a Conferência das Nações Unidas sobre Assentamentos Humanos (Habitat-II), em Istambul, em 1996. 
A ideia de uma conferência fora finalmente aprovada em 1997, inserindo, além de temas como racismo, discriminação racial e xenofobia, o termo intolerâncias correlatas em seu escopo, ampliando bastante o rol de temas a serem apreciados e deliberados. Além de rever tudo aquilo que foi realizado até então em termos de agenda e apreciar os principais obstáculos à sua execução, a conferência incluiu entre seus objetivos a revisão histórica dos fatores geradores do racismo, o que acarretaria, em derivação, forte demanda por medidas reparatórias em resposta.

A Conferência de Durban ficou marcada pelas inúmeras tensôes que orbitam a pauta. Tensóes externalizadas por meio de abandonos (Israel e Estados Unidos), controvérsias entre árabes e israelenses, bem como divergências dos países ocidentais em relação às propostas de reparação e até mesmo quanto aos parâmetros que definiriam quem seriam as vítimas de discriminação racial. Inclusive, a expressão "açôes afirmativas", cara aos movimentos negros, fora banida da conferência. A objeção à expressão fora construída pelos Estados Unidos, país que a criara, e seus aliados após sua deserção (Alves, 2002).

Durban, de uma forma ou de outra, quebrou a monotonia que caracterizou as conferências ${ }^{17}$ pelo combate ao racismo e à discriminação que a antecederam. Delegaçóes numerosas, elevada participação de ONGs, presença expressiva de organizaçóes negras e a postura mais ativa dos Estados fizeram dessa conferência e de seus resultados um marco na agenda global antidiscriminatória (Alves, 2002).

O Brasil teve participação expressiva em Durban. ${ }^{18} \mathrm{~A}$ leitura elaborada pelas organizaçóes negras brasileiras era que a pauta internacional, concentrando suas atenções na derrubada do apartheid e da política segregacionista norte-americana, estava esgotada. Durban era a oportunidade de adotar compromissos que dessem conta do "apartheid informal" brasileiro, para ficar com expressão de Nilma Bentes (2002). Segundo a autora, durante o processo preparatório, as organizaçóes negras elaboraram onze pontos prioritários que - almejava-se - deveriam ser defendidos pelo governo:

- inclusão do tráfico de escravos como crime de lesa-humanidade;

- adoção de medidas reparatórias aos povos africanos e afrodescendentes;

- enfrentamento das bases econômicas que estruturam o racismo;

17. Tendo como principais objetivos aumentar a pressão pelo fim do apartheid, haviam ocorrido até então duas conferências mundiais, em 1978 e 1983.

18. Merece especial destaque a preparação da participação brasileira na conferência. Em 8 de setembro, fora criado 0 comitê nacional para a preparação da participação brasileira em Durban, com representação paritária do governo e da sociedade civil. 0 trabalho do comitê foi subsidiado por pré-conferências realizadas em todo o país, culminando em uma conferência nacional realizada no Rio de Janeiro entre 6 e 8 de julho de 2001. A conferência reuniu 1.700 delegados de diversas regiões do país (Jaccoud e Beghin, 2002). 
- adoção de políticas públicas nas áreas de saúde, educação, habitação e emprego;

- adoção de políticas destinadas ao desenvolvimento das comunidades negras rurais e urbanas, incluindo-se o acesso às novas tecnologias;

- adoção de políticas específicas para mulheres africanas e afrodescendentes;

- adoção de mecanismos de combate aos efeitos do racismo e da pobreza;

- reconhecimento da prática de racismo no sistema penal e adoção de medidas corretivas, além da reforma do sistema legal nacional e do apoio à adoção de medidas internacionais que permitam o combate eficaz do racismo;

- reconhecimento da múltipla discriminação agravada pela orientação sexual; e

- $\quad$ racismo ambiental ${ }^{19}$ (Bentes, 2002).

A despeito dos bloqueios temáticos gerados pelas tensões e controvérsias, o Programa de Ação de Durban ${ }^{20}$ é bastante abrangente. Embora não tenha falado explicitamente na defesa de políticas de açóes afirmativas, o fez implicitamente, instando os Estados a implementar medidas que garantam o acesso equitativo dos negros nos setores público e privado. Recomendaçóes relacionadas ao acesso à educação, à alteração dos currículos escolares, ao acesso à tecnologia, ao acesso à justiça, à garantia do direito de acesso à terra e ao território e à proteção do direito de crença religiosa integram seu escopo. Também estabeleceu recomendaçôes importantes no que diz respeito ao aporte adicional de investimentos em serviços de educação, saúde pública, saneamento e acesso à energia elétrica, com o objetivo de atender às demandas da população negra em geral e as comunidades de origem africana em particular. Tais compromissos, de longa duração, conferem a Durban o caráter de agenda em aberto, dialogando com a natureza complexa dos problemas que pretende enfrentar.

Conferências, de fato, não resolvem os problemas que estas enunciam por meio dos documentos que elaboram. Embora desprovidas da capacidade de realizar aquilo que prometem combater, essas conferências podem ser encaradas como rotas de um longo percurso, como marco de novos aportes conceituais e compromissos mais alargados (Alves, 2002). Ainda mais fundamental é seu uso e sua instrumentalização para manter a pauta viva em açóes internacionais ou para

19. Por racismo ambiental entende-se a discriminação racial expressa nas formas desiguais de acesso aos recursos socioambientais, à terra e ao território. Este conceito foi desenvolvido originalmente nos Estados Unidos ante a constatação do peso que o fator étnico-racial possui na distribuição desigual dos passivos ambientais gerados por atividades econômicas que violam os direitos socioambientais.

20. A declaração e o programa de ação podem ser acessados em: <https://bit.ly/20zkakg>. 
pressionar os governos nacionais. O reconhecimento da importância de Durban culminou com o endosso da Declaração e do Programa de Ação pelo Cerd.

As controvérsias intensas que atravessaram sua realização, que quase resultaram em ausência da declaração final e do plano de ação, mostraram, porém, que a pauta entraria em um novo tempo de negociaçóes difíceis. O cenário interno no Brasil, porém, era outro. A agência negra, que já havia conseguido estabelecer pontes com a institucionalidade estatal nos anos 1990, daria seguimento à concretização do programa constitucional, por meio de um novo ciclo de políticas públicas voltadas à populaçáo negra.

\section{A ANTIDISCRIMINAÇÃO NO CICLO DAS POLÍTICAS PÚBLICAS}

Após a promulgação da $\mathrm{CF} / 1988$, poucas iniciativas, de imediato, foram adotadas para fazer cumprir seu programa. Em termos institucionais, a pauta racial estava até então restrita à Fundação Cultural Palmares, criada em 1988 para promover e preservar os valores culturais, sociais, políticos e econômicos referentes à presença negra na formação social brasileira.

Do ponto de vista criminal, a Lei no 7.716/1989 (Lei Caó) respondeu em parte às críticas elaboradas pelas organizaçóes negras à ausência de legislação que reconhecesse a gravidade do racismo enquanto fenômeno social. Com o advento da Lei Caó, três grandes tipos de condutas baseadas em elementos discriminatórios foram tipificadas pela legislação criminal, a saber: a formulaçâo genérica e abstrata do crime de racismo; as condutas que envolvem tratamento discriminatório negativo descritas nos arts. 3o a 14 da lei supracitada; e a injúria racial, ${ }^{21}$ subespécie de crime contra a honra pessoal, prevista no $\$ 3^{\circ}$, art. 140 do Código Penal. No total, treze condutas são descritas como crime de racismo, além da injúria racial; conduta penalmente censurada como contravenção, sujeita a sançôes menos graves.

A legislação permaneceu, contudo, com baixa efetividade. Parte dessa inefetividade pode ser explicada pelo descompasso entre o tipo de resposta que o sistema de justiça criminal oferece e a complexidade do racismo e suas formas de expressão na sociedade brasileira. Em face do princípio da culpabilidade que rege o direito penal, somente o indivíduo que agir de forma ilícita, com dolo ou culpa, pode ser penalizado. Isso implica dizer que a via criminal somente seria apta, em tese, a responder às formas diretas (intencionais) de racismo e discriminação racial. As formas indiretas de discriminação, por se reproduzirem por intermédio de mecanismos aparentemente neutros e sem intencionalidade evidente, reclamariam outro conjunto de medidas que a incriminação pura e simples não seria capaz de prover.

21. 0 crime de injúria racial é aquele cuja ofensa, atravessada por referências à raça, à etnia, à religião ou à origem, é dirigida à honra de determinada pessoa. Neste crime, o bem jurídico protegido é a imagem, a individualidade e a intimidade do sujeito inferiorizado pela ofensa. 0 crime de racismo, por sua vez, é aquele direcionado a uma coletividade indeterminada de indivíduos, discriminando toda a integralidade de um grupo social identificado por sua cor/raça, etnia, religião, origem ou procedência nacional. 
Ocorre, porém, que nem mesmo as formas diretas de discriminação foram combatidas de forma efetiva pela via criminal. As condutas enquadráveis na legislação penal são de difícil comprovação, pois práticas racistas exercidas de forma direta costumam ser cometidas apenas por meio da relação imediata entre ofensor e ofendido, sem terceiros que possam servir de testemunha.

Outra barreira à implementação da legislação diz respeito às interpretaçóes judiciais acerca do racismo e seu alcance. Ao contrário do que se supóe, sentenças judiciais não são artefatos neutros resultantes do enquadramento mecânico dos fatos a uma descrição normativa. Sentenças judiciais são também narrativas culturais por meio das quais um grupo social dominante institucionaliza sua visão particular e interessada da realidade. Por intermédio dessas narrativas, portanto, interesses particulares são transformados em interesses da sociedade, veiculados mediante a sanção do que é permitido e do que é proibido (Moreira, 2017).

Nunca é demais lembrar que as instituiçôes do mundo jurídico são ocupadas majoritariamente por membros de um mesmo grupo racial e que esse grupo foi socializado para pensar a raça como elemento neutro em formaçáo social miscigenada, mantendo-se assim a imagem positiva da presença branca na sociedade brasileira (Moreira, 2017). A indiferença tende a constituir-se na forma primordial de convívio com o racismo. Na melhor das hipóteses, falta às instituiçóes capacidades cognitivas para reconhecer, compreender e construir medidas que respondam ao racismo e aos processos discriminatórios como um todo.

O racismo, portanto, opera não apenas mediante a expressão preconceituosa de indivíduos, mas também das instituiçôes incumbidas de condená-las. Luciana Jaccoud (2009) aponta que o tratamento criminal do racismo, além de afetar pouco suas causas, não interfere nas formas dissimuladas do tratamento discriminatório, incluindo-se nisso as práticas institucionais que distribuem de forma desigual os benefícios e os serviços públicos.

Com isso, o direito antidiscriminatório apenas pode aproximar-se da justiça racial mediante o questionamento do poder e sua distribuição desigual na sociedade. Essa foi a direção apontada pela agência negra já em fins dos anos 1980, mas impulsionada sobretudo na década de 1990, quando condições políticas mais favoráveis permitiram que tal ocorresse. A partir disso, pode-se considerar a institucionalização incremental da pauta racial como a opção política de inúmeras organizaçóes que se entremearam nas instituiçóes do Estado, com o objetivo de abrir fendas na estrutura de poder.

Um marco significativo nesse processo foi a realização da Marcha Zumbi dos Palmares contra o Racismo, pela Cidadania e pela Vida, realizada em Brasília em 1995. Convocada para comemorar o tricentenário de nascimento e morte de Zumbi e apresentar uma pauta de reivindicaçôes ao governo recém-empossado, a 
marcha reuniu 30 mil pessoas em Brasília. Foi o resultado desse esforço em associação ao Estado que conduziu o governo à época à criação do Grupo de Trabalho Interministerial (GTI) de Valorização da População Negra.

A principal função do GTI era construir e estimular políticas públicas voltadas à população negra, rompendo com as vertentes culturalistas ${ }^{22}$ que dominavam as percepçốes do Estado sobre a questáo racial (Jaccoud e Beghin, 2002). Por meio do GTI, introduziram-se as açôes afirmativas na linguagem das políticas públicas no Brasil, bem como o tema da saúde da população negra (Ribeiro, 2013).

O GTI foi também fundamental para viabilizar a participação ativa e progressista da diplomacia brasileira na Conferência de Durban; trabalho reconhecido pelas organizaçóes negras que desta participaram (Bentes, 2002). Seu surgimento, portanto, foi importante para transformar a Conferência de Durban em um forte propulsor de iniciativas públicas em direção à promoção da igualdade racial.

A primeira grande iniciativa de sistematização de açóes coordenadas de promoção da igualdade racial surge já em 2002, com a edição, por intermédio do Decreto no 4.228/2002, do Programa Nacional de Açóes Afirmativas. O decreto prevê a adoçáo de medidas afirmativas com reserva de vagas no preenchimento de cargos comissionados da administração pública federal; o condicionamento da transferência de recursos celebrado pela administração pública à adesão ao programa; a inclusão de metas percentuais de inclusão de negros, mulheres e pessoas com deficiência nas contrataçôes de terceirizados, técnicos e consultores; e, por fim, a inserção de medidas afirmativas como critério positivo de pontuação nos procedimentos licitatórios firmados pela administração pública federal. As medidas seriam monitoradas por um comitê de avaliação e acompanhamento, ${ }^{23}$ composto por representaçóes de ministérios, conselhos e grupos de trabalho (GTs) atrelados à pauta.

A pauta racial que havia sido incluída no I Programa Nacional dos Direitos Humanos (PNDH) em 1996, com um tópico específico dedicado à população negra, teve metas mais ampliadas no II PNDH, lançado em 2002. Nesse programa, as propostas ficaram concentradas nas áreas de justiça, educação, trabalho e cultura.

Com a transição de governo, parte desse trabalho foi descontinuado. Merece especial menção a total inefetividade do Decreto no 4.228/2002, que já vinha contando com programas de açôes afirmativas no então Ministério do

22. A despeito dos avanços constitucionais, a institucionalidade tratava da questão racial de forma secundária e reducionista em relação à dimensão que a pauta possui em termos concretos. Estruturada para proteger e promover 0 patrimônio cultural africano na formação social brasileira, a Fundação Cultural Palmares, em que pese sua importância, simboliza essa perspectiva. Sua vinculação ao Ministério da Cultura, pasta com baixa participação orçamentária e pouca expressividade política, sintetiza as concepções vigentes à época no âmbito estatal (Paulo, 2015).

23. Embora nunca tenha funcionado de fato, o comitê teve sua existência revogada pelo Decreto no 10.087/2019. Os demais dispositivos, porém, permanecem em vigor. 
Desenvolvimento Agrário (MDA) - atualmente Secretaria Especial de Agricultura Familiar e do Desenvolvimento Agrário da Presidência da República (Sead/PR) -, no Ministério da Cultura (MinC) e no então Ministério da Justiça (MJ) - na atualidade, Ministério da Justiça e Segurança Pública (MJSP) - (Jaccoud, 2009). A única ação de relevo que remanesceu daquele período foi a criação do Programa Bolsa-Prêmio de Vocação para a Diplomacia. Instituído pelo Instituto Rio Branco, o programa concede bolsas a candidatos negros que desejem ingressar nos quadros do Itamaraty.

O ciclo que se inicia em 2003, porém, anunciava uma nova fase no debate público sobre a igualdade racial. Não sem resistências, a partir desse ano, as placas tectônicas do mito da democracia racial passaram a ser movidas de forma mais intensa no lugar em que esta logrou a condição de leitura oficial do Estado a respeito da sociedade brasileira.

\section{O CICLO DE CONSOLIDAÇÃO INSTITUCIONAL DA PAUTA RACIAL NA ESFERA PÚBLICA}

O ciclo de institucionalização consolida-se a partir de 2003, com a criação da Secretaria Especial de Políticas de Promoção da Igualdade Racial (Seppir) - atualmente Secretaria Nacional -, com status de ministério e vinculada à Presidência da República. A Seppir teve como principal incumbência propor políticas, articular e transversalizar a pauta racial nas políticas públicas. Para cumprir essa tarefa, construiu-se uma extensa rede de institucionalidades interligadas com diferentes funções distribuídas ao longo da cadeia (quadro 4).

QUADRO 4

Principais arranjos institucionais criados para propor, monitorar, organizar e executar políticas de promoção da igualdade racial após 2003

\begin{tabular}{|l|l|}
\hline Arranjo & \multicolumn{1}{c|}{ Objetivos estratégicos } \\
\hline Seppir & $\begin{array}{l}\text { Órgão do Executivo; tem por atribuição propor, formular, articular e } \\
\text { executar ações de promoção da igualdade racial. }\end{array}$ \\
\hline Inclusão da temática racial no Plano Plurianual (PPA) & $\begin{array}{l}\text { Instrumento de planejamento e diretriz orçamentária das ações de } \\
\text { igualdade racial. Ações, iniciativas e programas com enfoque racial } \\
\text { foram visibilizados. }\end{array}$ \\
\hline Política de Promoção da Igualdade Racial & $\begin{array}{l}\text { Democratização da gestão e do processo decisório. Tem por função } \\
\text { propor estratégias de acompanhamento, monitoramento e fiscalização } \\
\text { das ações de igualdade racial; apreciar a proposta orçamentária da } \\
\text { Seppir e indicar prioridades; tutelar as deliberações das conferências } \\
\text { nacionais; propor moções, recomendaçõ̃es ou resoluções referentes a } \\
\text { direitos de indivíduos e/ou grupos étnico-raciais. }\end{array}$ \\
\hline $\begin{array}{l}\text { Definição de objetivos, princípios, diretrizes e ações de igualdade racial. } \\
\text { A política teve na Icerd e no Plano de Ação de Durban um de seus eixos } \\
\text { estruturantes. }\end{array}$ \\
\hline
\end{tabular}




(Continuação)
\begin{tabular}{|l|l|}
\hline Arranjo & \multicolumn{1}{c|}{ Objetivos estratégicos } \\
\hline $\begin{array}{l}\text { Plano Nacional de Promoção da Igualdade Racial } \\
\text { (Planapir) }\end{array}$ & $\begin{array}{l}\text { Definição de açães, metas e prioridades de igualdade racial. Instituiu } \\
\text { um comitê de articulação e monitoramento, com a participação de } \\
\text { diversas pastas setoriais. O comitê foi revogado pelo Decreto no } \\
10.087 / 2019 .\end{array}$ \\
\hline $\begin{array}{l}\text { Fórum Intergovernamental de Promoção da Igualdade } \\
\text { Racial }\end{array}$ & $\begin{array}{l}\text { Estratégia para dar capilaridade às ações de promoção da igualdade } \\
\text { entre entes de governo da Federação. }\end{array}$ \\
\hline Estatuto da Igualdade Racial & $\begin{array}{l}\text { Principal referência legal do conjunto de direitos e políticas destinadas } \\
\text { à população negra. }\end{array}$ \\
\hline $\begin{array}{l}\text { Sistema Nacional de Promoção da Igualdade Racial } \\
\text { (Sinapir) }\end{array}$ & $\begin{array}{l}\text { Instância de organização e articulação das iniciativas governamentais } \\
\text { interfederativas. }\end{array}$ \\
\hline Conferências nacionais & $\begin{array}{l}\text { Democratização da gestão e do processo decisório. Foram realizadas } \\
\text { quatro conferências nacionais desde 2003, contando com a participação } \\
\text { de movimentos sociais. Suas deliberações são incorporadas ao Planapir. }\end{array}$ \\
\hline
\end{tabular}

Elaboração dos autores.

A essas estruturas institucionais, somam-se outras que foram internalizadas pelas pastas setoriais, tendo como uma de suas responsabilidades a condução de iniciativas vinculadas ao combate ao racismo e à promoção da igualdade. Cite-se como exemplo a Secretaria de Educação Continuada, Alfabetização, Diversidade e Inclusão (Secadi) ${ }^{24}$ a Comissão Técnica Nacional de Diversidade para Assuntos Relacionados à Educação dos Afro-brasileiros (Cadara) ${ }^{25}$ e o Comitê Técnico de Saúde da População Negra.

O principal objetivo da Seppir, ao criar ou estimular a criação dessas estruturas, era estabilizar a política de igualdade racial, transversalizar a agenda, transformando-a em tarefa de todo o governo, garantir controle social, conferir dimensão territorial às intervençóes e fortalecer o papel indutor da esfera federal sobre os entes subnacionais. Esse arranjo foi construído de forma incremental, aumentando-se a densidade da política de igualdade racial ao longo do tempo (Ipea, 2013).

O Estatuto da Igualdade Racial, sancionado em 20 de julho de 2010, consolida essa tendência, incorporando juridicamente os compromissos políticos já assumidos com a adesão à Icerd e ao Plano de Ação de Durban. Os 65 artigos que o compóem tratam de matérias referentes ao financiamento das políticas de igualdade racial, do acesso a justiça e segurança, do trabalho, do acesso à terra e à moradia adequada, do direito de livre exercício dos cultos religiosos, do direito a cultura, esporte, lazer, educação, saúde etc. Enquanto norte político-jurídico de atuação do Estado, enunciam-se as açôes afirmativas como o núcleo fundamental das açôes,

24. A Secadi foi extinta por meio do Decreto no 9.465, de 2 de janeiro de 2019.

25. A Cadara, criada pela Portaria no 4.542/2005, foi extinta por meio do Decreto no 9.759/2019. Este decreto determinou a extinção de todos os conselhos, comitês e órgãos colegiados criados por meio de decreto ou ato normativo hierarquicamente inferior. Foram preservados apenas os órgãos colegiados criados ou mencionados em lei, conforme interpretação jurisprudencial consolidada pelo STF em Adin interposta que questionou a legalidade do dispositivo normativo. 
tendo-se em vista a ampliação do acesso da população negra aos direitos, bens e serviços públicos. Do ponto de vista normativo, esse estatuto traz em seu interior a discriminação interseccional como inovação, apontando para as desigualdades de gênero e raça como desencadeadores de processos discriminatórios.

Para dar concretude aos direitos que enuncia, o Estatuto da Igualdade Racial criou o Sinapir. Inspirado no Sistema Único de Assistência Social (Suas) e no Sistema Único de Saúde (SUS), o Sinapir era a aposta em um novo adensamento das açóes de igualdade racial, descentralizando os recursos federais e estimulando os entes subnacionais à criação de conselhos de igualdade racial e à adoção de planos estaduais e municipais de promoção da igualdade.

Em síntese, após dez anos de tramitação, o Estatuto da Igualdade Racial transformou em lei aquilo que já vinha se desenhando nas estruturas públicas preexistentes. Seu principal mérito foi o de sistematizar os compromissos em parte assumidos anteriormente pelo Estado. De modo geral, porém, o texto do estatuto ficou um tanto distante da proposta original. Questôes importantes como o estabelecimento de cotas para ingresso no mundo do trabalho e a instituiçáo do Fundo de Promoção da Igualdade Racial foram derrotadas ao longo da negociação que permitiu sua aprovação (Silva, 2012). Assim, embora determine compromissos, o estatuto é excessivamente vago e genérico, consistindo em norma de eficácia contida e demandando normas específicas posteriores (leis especiais).

Sem pretender esgotar as iniciativas adotadas, pode-se observar no quadro 5 que parte das demandas históricas das organizaçóes negras demandadas na Constituinte teve algum desdobramento institucional. Algumas dessas demandas, como o Programa Brasil Quilombola ${ }^{26}$ e a Agenda Social Quilombola, são um guarda-chuva de iniciativas descentralizadas; outras são reformas legislativas relevantes, que corrigem discriminaçôes históricas operadas pela própria legislação, a exemplo da Emenda Constitucional (EC) no 72/2013; outras constituem políticas criadas, mas com poucas açôes concretas, como a Política Nacional de Saúde Integral da População Negra; por fim, há as políticas de reserva de vagas, cuja legislação federal uniformizou as experiências que já vinham ocorrendo nas universidades Brasil afora. Não foram citadas iniciativas simbólicas, mas numerosas, a despeito de sua importância para a consolidação da questáo racial como elemento da esfera pública no Brasil.

26. Lançada por meio do Decreto oㅜ 6.261/2007, a Agenda Social Quilombola foi o desdobramento do Programa Brasil Quilombola (PBQ), lançado em março de 2004. A agenda foi estruturada a partir de quatro eixos: i) infraestrutura e qualidade de vida, com ações de infraestrutura destinadas a prover demandas de saneamento, saúde e habitação; ii) acesso à terra; iii) inclusão produtiva e desenvolvimento local; e iv) direitos e cidadania, com ações destinadas à garantia dos direitos das comunidades quilombolas no que diz respeito a conflitos, grandes obras, acesso à água, energia etc. Ações específicas em saúde, saneamento e assistência social foram efetivamente adotadas, com repasse adicional de recursos aos municípios que tivessem comunidades quilombolas em sua circunscrição. As pretensões iniciais da agenda eram, porém, mais audaciosas. 


\begin{tabular}{|c|c|}
\hline Tema ou grupo social atendido & $\begin{array}{l}\text { Ações e iniciativas de promoção da igualdade racial } \\
\text { mais relevantes adotadas no período 2003-2014 }\end{array}$ \\
\hline Educação & $\begin{array}{l}\text { Lei no } 10.639 / 2003 \text {, que inclui o ensino de história e cultura afro-brasileira e africana na } \\
\text { educação básica. } \\
\text { Aprovação da Lei no } 12.711 / 2012 \text {, que institui cotas para ingresso de estudantes negros } \\
\text { nas instituições públicas federais de ensino superior e nas instituições técnicas de ciência e } \\
\text { tecnologia de nível médio. }\end{array}$ \\
\hline Saúde & Instituição da Política Nacional de Saúde Integral da População Negra. \\
\hline Trabalho & $\begin{array}{l}\text { Aprovação da Lei no 12.990/2014, que instituiu as cotas no serviço público. } \\
\text { Sanção da EC no 72/2013, equiparando as trabalhadoras domésticas às demais categorias } \\
\text { submetidas à Consolidação das Leis do Trabalho (CLT). }\end{array}$ \\
\hline Assistência Social & Inclusão das comunidades quilombolas no Programa Bolsa Família (PBF). \\
\hline Comunidades quilombolas & $\begin{array}{l}\text { Regulamentação do processo de titulação dos territórios por meio do Decreto n 4.887/2003. } \\
\text { Criação do Programa Brasil Quilombola e da Agenda Social Quilombola. } \\
\text { Inclusão da educação escolar quilombola nas Diretrizes Curriculares Nacionais da educação básica. }\end{array}$ \\
\hline $\begin{array}{l}\text { Povos e comunidades tradicio- } \\
\text { nais de matriz africana }\end{array}$ & $\begin{array}{l}\text { Plano Nacional de Desenvolvimento Sustentável dos Povos e Comunidades Tradicionais de } \\
\text { Matriz Africana. } \\
\text { Lei no } 12.966 / 2014 \text {, que acrescenta a dignidade dos grupos religiosos como bem jurídico a } \\
\text { ser protegido, responsabilizando o ofensor pela reparação dos danos morais e patrimoniais } \\
\text { produzidos pela ofensa. }\end{array}$ \\
\hline Violência e justiça & $\begin{array}{l}\text { Plano Juventude Viva; criação de canais de denúncia de violação de direitos da juventude negra, } \\
\text { mulher ou população negra em geral e módulo específico para receber denúncias de violação de } \\
\text { direitos contra comunidades quilombolas, terreiros e comunidades de religiões de matriz africana. }\end{array}$ \\
\hline
\end{tabular}

Elaboração dos autores.

Merece destaque entre as medidas adotadas as reservas de vagas nas universidades. Entre 2001, quando a primeira política de ação afirmativa foi adotada em uma universidade, e 2014, a presença de negros(as) no ensino superior saltou de $31,5 \%$ para $45,1 \%$, de acordo com os dados da Pesquisa Nacional por Amostra de Domicílios anual do Instituto Brasileiro de Geografia e Estatística (PNAD/IBGE). O estoque de pessoas com ensino superior completo mostrava, porém, as profundas desigualdades acumuladas ao longo do tempo: em 2014, 70,2\% das pessoas com ensino superior completo eram brancas (Silva, 2020). A manutenção da tendência de diminuição dessas distorções depende da continuidade dessas políticas.

Após a aprovação do Estatuto da Igualdade Racial, duas importantes medidas foram aprovadas: a Lei no 12.990/2014 e a EC no 72/2013. Essa EC pôs fim à discriminação legalizada das trabalhadoras domésticas no Brasil. Até 2013, trabalhadoras domésticas, majoritariamente negras, possuíam regime jurídico protetivo restrito em relação às demais categorias de trabalhadores. Com a aprovação da emenda, direitos mínimos como controle de jornada de oito horas diárias e 44 semanais, remuneração pelo serviço extraordinário, compensação de horas extras, proibiçáo de trabalho noturno, perigoso e insalubre a menores de 18 anos, entre outros direitos, foram estendidos às trabalhadoras. 
A principal iniciativa positiva efetivamente adotada em matéria de inserção nas relaçóes de trabalho foi, porém, a Lei no 12.990/2014, mais conhecida como Lei de Cotas no Serviço Público. O referido dispositivo reserva 20\% das vagas nos certames da administração pública federal para candidatos(as) negros(as). Trata-se da primeira política de ação afirmativa em nível federal fundada exclusivamente no critério de raça/cor (Silva e Silva, 2014; Mello e Resende, 2019). Há, contudo, dois óbices à efetividade desses dispositivos: de um lado, as atuais políticas em curso, imprimindo nova dimensão à participação do Estado enquanto ente promotor de políticas de bem-estar, vêm contribuindo para a diminuição expressiva no número de concursos públicos; de outro lado, alguns concursos, a exemplo dos realizados pelas instituiçóes públicas federais de ensino, costumam fracionar as vagas disponíveis, o que diminui o impacto da lei, uma vez que as cotas somente se aplicam em certames com mais de três vagas. ${ }^{27}$

Além dessas iniciativas, a Seppir despendeu esforços em campanhas de enfrentamento ao racismo institucional, lançou editais de apoio a projetos culturais e construiu um sistema de monitoramento das intervençóes públicas em matéria de combate ao racismo e promoção da igualdade racial (Ipea, 2016).

No geral, as pastas ligadas às políticas sociais foram as que apresentaram maior aderência às açôes de promoção da igualdade racial. Isso se deu tanto por meio da criaçấo de institucionalidades próprias ligadas à pauta quanto por intermédio de açóes com disponibilidade orçamentária (Teixeira e Sampaio, 2019). Outras arenas da política pública também tiveram incidência sobre a população negra, mas de forma indireta, por meio de políticas focalizadas cujo público é definido por critérios que concorrem para a redução das desigualdades raciais. ${ }^{28}$

Parte das açóes de igualdade racial foi, porém, constrangida pela ainda pequena participaçáo política dos negros no processo decisório. De acordo com Luiza Bairros, ex-ministra da Seppir no período 2011-2014, foi possível

entrar a partir de um órgáo como a Seppir na disputa por recursos, quando você náo tem uma representação em outros lugares da sociedade (...) e entrar com aquele cabedal que o Movimento Negro construiu, que não está representado convenientemente no Congresso Nacional, no Executivo, no Judiciário, nos governos estaduais e municipais. Por isso acho que, no que quer que a gente tenha avançado, o que quer que a Seppir

27. Levantamento exaustivo elaborado por Mello e Resende (2019) a partir da análise de mais de 3 mil editais de concursos para o magistério superior ocorridos entre 9 de junho de 2014 e 31 de janeiro de 2018 mostra que, do total de vagas disponíveis no período, apenas 4,93\% foram reservadas a candidatas(os) negras(os). Esse dado é resultado do fracionamento das vagas, tornando inócua a medida justamente no lugar em que as ações afirmativas nasceram enquanto experiência política no Brasil.

28. Vale citar, a título de exemplo, os efeitos raciais que as medidas destinadas à pobreza e à extrema pobreza provocaram. Segundo Osório (2019), entre 2004 e 2014, houve redução da desigualdade racial da pobreza, medida pela renda domiciliar per capita. 0 autor utilizou diferentes linhas para defini-la e, em todas elas, os resultados foram semelhantes. As discrepâncias entre os grupos, porém, se mantiveram elevadas. Em 2014, o nível de pobreza de pretos e pardos era similar ao de uma pessoa branca em 2004 (Osório, 2019). 
tenha alcançado em todos esses anos, é fruto de um trabalho louvável, pois operamos em um nível de isolamento político muito grande, ainda (Alves et al., 2018, p. 56).

Os reflexos do isolamento político fizeram-se sentir de diversas formas. As disponibilidades orçamentárias para a execução das políticas com corte racial foram sempre baixas, até mesmo em período de expansão fiscal com ampliação relevante do gasto social público. Algumas açóes de enfrentamento ao racismo e promoção da igualdade ficaram resumidas a iniciativas pontuais e localizadas que preenchiam discurso, com impactos pouco significativos (Theodoro, 2013; Ipea, 2016).

A ausência de priorização governamental e planos de trabalho que viabilizassem sua execução por meio de convênios com Estados e municípios também afetou a execução fiscal das políticas com recorte racial. Apenas a título de exemplo, entre 2012 e 2015, o percentual máximo de execução orçamentária do programa Enfrentamento ao Racismo e Promoção da Igualdade Racial foi de 35,37\%, ocorrido em 2014. Em 2015, o percentual de execução foi de apenas 8,72\% (Teixeira e Sampaio, 2019).

Parte da agência estatal continuou encarando a pauta racial ora como agenda periférica, ora como entrave a interesses setoriais hegemônicos. Em algumas agendas de política pública, isso ficou ainda mais evidente. Cite-se como exemplo o bloqueio da demanda por regularização de terras e territórios quilombolas. Dados atualizados até 26 de maio de 2015 apontam que existiam 1.516 processos de reconhecimento de territórios quilombolas em tramitação no Instituto Nacional de Colonização e Reforma Agrária (Incra) e apenas 143 territórios haviam sido titulados até essa data (Ipea, 2019a).

Outro exemplo digno de nota foram as tímidas respostas institucionais à violência contra a população negra. De acordo com o Atlas da Violência 2019, em 2017, houve 65.602 homicídios no Brasil e 75,5\% das vítimas eram negras. Considerando-se a faixa etária, os jovens corresponderam a 54,5\% das vítimas (Ipea e FBSP, 2019). Entre 2007 e 2017, a taxa de homicídios no Brasil cresceu 37,5\%, mostrando-se, portanto, como fenômeno sustentado por fatores não diretamente relacionados à conjuntura econômica. A única política diretamente vinculada a essa pauta com viés racial foi o plano Juventude Viva, lançado em 2012. Conforme fora atestado em número anterior deste periódico, as açóes neste previstas possuíam frágil interação com os ministérios e os órgãos estaduais incumbidos de gerir em conjunto a política de segurança pública (Ipea, 2014).

O Levantamento Nacional de Informações Penitenciárias, com dados atualizados até junho de 2017, informa que, entre os tipos penais, é o tráfico de drogas o principal crime desencadeador das penas de privação de liberdade. Entre as mulheres, o tráfico foi o tipo de crime responsável por $64,48 \%$ das detençóes nesse período. Quanto à composição étnico-racial, 63,6\% da população carcerária era 
composta por pretos e pardos em junho de 2017 (Silva, 2019). Em síntese, com população carcerária total de 726.354 e taxa anual de crescimento da população prisional girando em torno de 7\% no período 1990-2017, a política carcerária vem assumindo o caráter de política extraoficial de segregação racial no Brasil.

O período final desse ciclo explicitava a intensidade dessas contradições. As cidades brasileiras seguiam reproduzindo novas formas de controle social da população negra mediante políticas de ocupação do espaço urbano (Ipea, 2016). Os fluxos de capitais que irrigaram os projetos de modernização urbana impulsionadas pelos grandes eventos esportivos de 2014 e 2016 tiveram como grande legado a disseminação de novas segregaçóes socioespaciais. A cidade viva por meio dos corpos dos sujeitos enegrecidos em movimento na rua entrava em nova rota de desencanto.

O período mais positivo de institucionalização da pauta racial ficou marcado, portanto, pelo surgimento de "novos" problemas, em larga medida oriundos do próprio avanço institucional da pauta. Ao lado destes, os velhos problemas da formação social brasileira tornaram-se ainda mais agudos. Nos territórios onde a pobreza e a raça se estruturaram mutuamente, tanto a Constituiçáo quanto a democracia que esta enuncia eram uma promessa pendente de realização.

\section{O FIM DE UM CICLO E OS NOVOS DESAFIOS DA AGENDA ANTIDISCRIMINATÓRIA}

Desde 2015, o país vem passando por uma crise econômica e política que impactou os pilares da intervenção estatal sobre as condiçõos gerais de produção e reprodução da vida social. As condiçóes políticas que permitiram que a agenda antidiscriminatória avançasse com base na implementação gradual do programa constitucional foram profundamente alteradas. Com taxas de crescimento econômico negativas em 2015 e 2016, a opção pelas políticas de ajuste fiscal veio acompanhada da alteração do perfil do gasto público, com forte compressão dos gastos sociais.

Embora a agenda de igualdade racial nunca tenha tido participação significativa no conjunto das despesas, já em 2015 a Seppir foi extinta e transformada em secretaria nacional integrante do Ministério das Mulheres, Igualdade Racial, da Juventude e dos Direitos Humanos (MMIRDH). A fusão pode ser interpretada como um duplo ato simbólico: de um lado, servia para demonstrar publicamente o comprometimento do governo com o ajuste fiscal; como fusão, de outro lado, tinha impactos fiscais irrisórios. Na prática, essa fusão serviu para ilustrar o baixo comprometimento do Estado brasileiro com as políticas transversais (Ipea, 2018).

Os sinais do ajuste também se fizeram sentir na distribuição do orçamento. A Seppir passou a enfrentar cortes orçamentários sucessivos; expressão do novo lugar que a agenda de igualdade passaria a ocupar a partir de então. Já em 2015, a pasta 
teve corte de 56,3\% no orçamento, e as ações de regularização fundiária, alocadas em ação orçamentária ligada ao então MDA, tiveram 49,4\% de corte (Inesc, 2020).

Em 2016, a reforma administrativa implementada por meio da Medida Provisória (MP) no 726 do governo deslocou a Secretaria Nacional de Políticas de Promoçáo da Igualdade Racial (SNPIR) e as demais secretarias especiais para o entâo Ministério da Justiça e Cidadania (MJC). A SNPIR foi inserida em estrutura rígida e centralizada, com baixa capacidade de operação do cotidiano típico de uma secretaria de Estado. Políticas foram descontinuadas, e planos de trabalho e agendas institucionais propositivas deixaram de existir (Ipea, 2018). Em 2017, a SNPIR foi retirada da pasta da justiça e inserida na estrutura do então recém-criado Ministério dos Direitos Humanos (MDH) - atualmente, Ministério da Mulher, da Família e dos Direitos Humanos. A nova mudança, porém, pouco representou em relaçáo ao que vinha ocorrendo desde 2016, conduzindo a agenda de promoçáo da igualdade e da antidiscriminação à condição de peça simbólica em estrutura de poder que escorava suas açôes na visão negativa do ciclo de políticas que lhe antecedeu.

A crise econômica, política e social atingiu a agenda antidiscriminatória, mas essa não é a única forma pela qual a população negra foi/tem sido impactada. Enquanto grupo social mais exposto às vulnerabilidades sociais (trabalho desprotegido, desemprego e pobreza), parte significativa dos direitos da população negra é garantida pela manutenção de esferas públicas desmercadorizadas. Isso implica dizer que qualquer alteração negativa nas condiçóes gerais de reprodução da vida social, pelos efeitos raciais que gera, aumenta ainda mais o peso das provisóes públicas de direitos e serviços sobre as condiçóes de vida da populaçáo negra.

Esses efeitos podem ser bem percebidos nos cenários de crise, quando as condiçôes de reprodução da vida se deterioram pelo aumento do desemprego, pela expansão do trabalho desprotegido e pela diminuição da renda do trabalho. As formas indiretas de discriminação, nesses contextos, aprofundam as desigualdades e a vulnerabilidade dos grupos sociais menos protegidos.

Vale recordar que a maior parte a força de trabalho negra está ocupada em atividades caracterizadas por salários abaixo da média geral do mercado de trabalho, a exemplo de atividades agropecuárias $(60,8 \%)$, construção civil $(62,6 \%)$ e serviços domésticos $(65,1 \%)$. Nessas funçôes, concentram-se também os maiores percentuais de ocupados sem instrução ou com ensino fundamental incompleto (IBGE, 2019a). Isso, por si só, já constitui desvantagem comparativa relevante em cenários de escassez de recursos e retração de investimentos públicos e privados.

Em 2018, 64,2\% da força de trabalho desocupada e 66,1\% da força de trabalho subutilizada era composta por pessoas negras. Até mesmo quando considerado o nível de instruçáo, essas desigualdades se expressaram, embora minimizadas em relaçâo aos indivíduos com menores níveis de instrução (IBGE, 2019b). Conforme 
se pode verificar no gráfico 1 , entre os indicadores estruturais do mercado de trabalho, merece especial destaque o peso crescente da taxa de subutilização da força de trabalho e a elevação da taxa de desocupação em seis anos.

GRÁFICO 1

Indicadores estruturais do mercado de trabalho das pessoas negras de 14 anos ou mais de idade (2012-2018)

(Em \%)

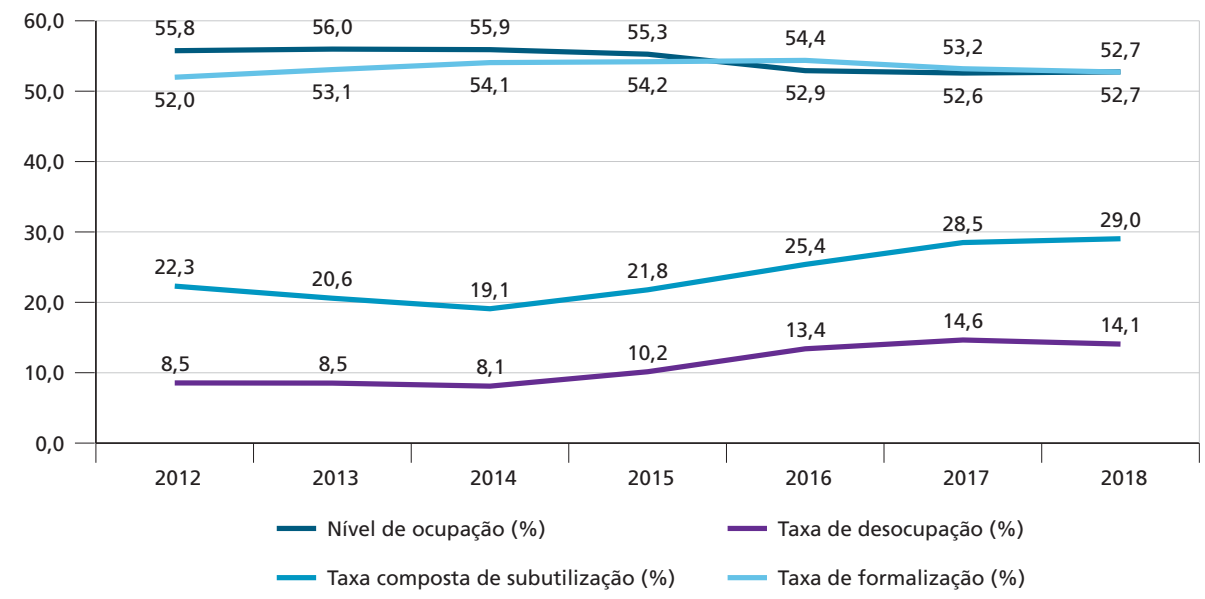

Fonte: PNAD Contínua//BGE. Disponível em: <https://bit.ly/323lwK6>.

Obs.: 1. A taxa de formalização inclui empregado com carteira de trabalho assinada, trabalhador doméstico com carteira de trabalho assinada, militar, funcionário público estatutário, conta própria e empregador que contribuíam para a Previdência Social.

2. A taxa composta de subutilização da força de trabalho é formada pelo percentual de pessoas desocupadas, subocupadas por insuficiência de horas trabalhadas e inativos com potencial para trabalhar.

3. 0 nível de ocupação é a razão entre as pessoas ocupadas na semana de referência e as pessoas em idade de trabalhar.

Essa tendência é corroborada pelo aumento do percentual de domicílios sem renda do trabalho e sob responsabilidade de pessoas negras. Os dados da PNAD Contínua indicam que parte das demandas da população negra já não pode mais contar apenas com a renda do trabalho para atravessar a crise.

O trabalho doméstico remunerado é também um bom parâmetro para inferir os efeitos possíveis da crise sobre a inserção no mundo do trabalho e o sistema de proteçẫo social. A melhoria das condiçôes de inserção no período de expansão da atividade econômica permitiu que inúmeras mulheres, sobretudo as mais jovens, negociassem formas menos precárias de inserção no mundo do trabalho. A alteração do perfil etário e a perda de peso relativo no conjunto das ocupaçóes pareciam apontar para o declínio de um dos mais resilientes mecanismos de reprodução intergeracional da pobreza no Brasil, ancorado na tripla discriminação de gênero, raça e classe. Além disso, a correção de um erro histórico inscrito no programa 
constitucional de 1988 por meio da $\mathrm{EC}$ nํㅜ 72/2013 acenava para o aprimoramento das condiçóes de trabalho para as mulheres inseridas nesse segmento laboral.

\section{GRÁFICO 2}

Proporção de domicílios por faixa de renda domiciliar habitual de todos os trabalhos das pessoas negras responsáveis pelo domicilio (2015-2018)

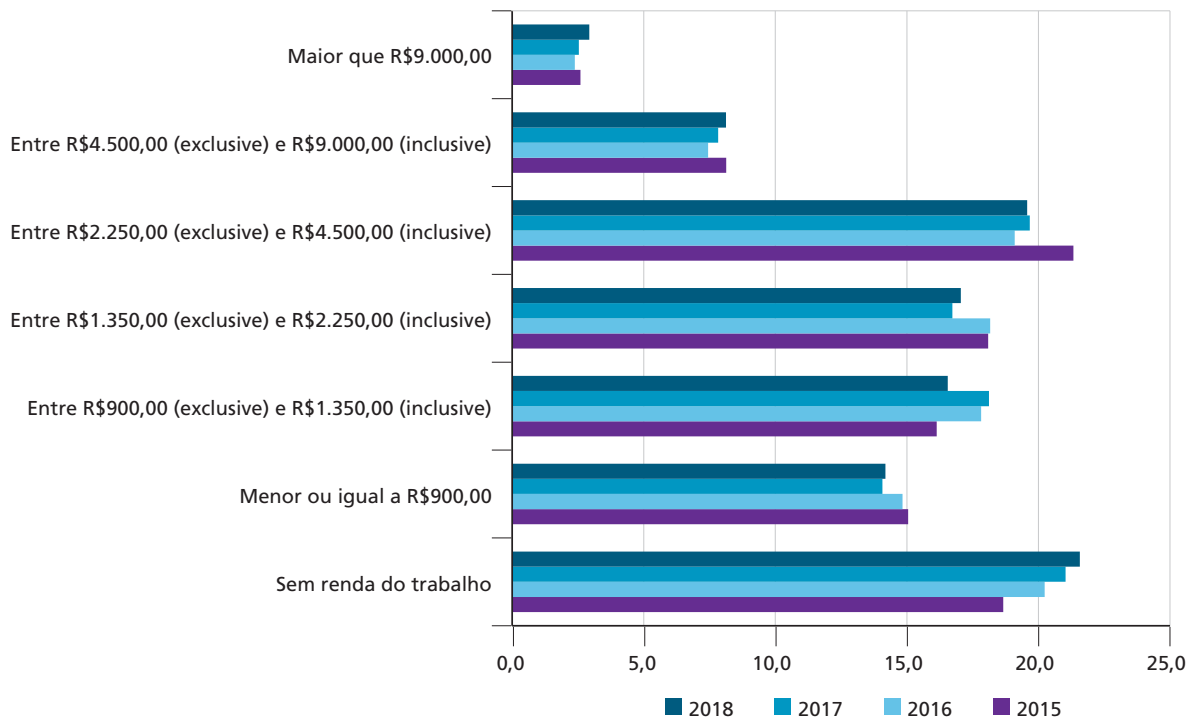

Fonte: PNAD Contínua/IBGE. Disponível em: <https://bit.ly/323lwK6>.

Elaboração: Núcleo de Informações Sociais (Ninsoc) da Diretoria de Estudos e Políticas Sociais (Disoc) do Ipea.

Obs.: Valores deflacionados pelo Índice Nacional de Preços ao Consumidor Amplo (IPCA).

Com a crise econômica, porém, a tendência de queda do peso relativo do trabalho doméstico remunerado no conjunto das ocupaçóes foi interrompida. A despeito do fim da discriminaçáo legal da categoria com o advento da EC, as características gerais do trabalho doméstico não foram alteradas. Com apenas $28,6 \%$ das trabalhadoras ocupadas com carteira assinada e uma renda média do trabalho inferior a 1 salário mínimo (SM) (Ipea, 2019b), o trabalho doméstico continua a ser uma das últimas fronteiras entre a ocupação e a desocupação.

A deterioração geral das condições de reprodução da vida social também reverteu a tendência de queda da pobreza e da extrema pobreza. De acordo com os dados da PNAD Contínua, entre 2015 e 2018, 2,8 milhóes de pessoas negras entraram na condição de pobreza e 2,4 milhôes, na condiçâoo de extrema pobreza. O maior aumento percentual de pessoas nos respectivos grupos nesse período foi o de negros extremamente pobres $(37,8 \%)$, seguido de brancos extremamente pobres $(33,1 \%)$, brancos pobres $(26,2 \%)$ e negros pobres $(22,3 \%)$. Em números absolutos, negros pobres foi o grupo com o maior número de ingressantes nessa 
condição, invertendo a tendência de queda expressiva que vinha se desenhando no período pré-2014.

\section{GRÁFICO 3}

Evolução do número de pobres e extremamente pobres por cor/raça (2012-2018) (Em mil)



Fonte: PNAD Contínua/IBGE. Disponível em: <https://bit.ly/323lwK6>.

Elaboração: Ninsoc/Disoc/lpea.

Obs.: Os indicadores de pobreza e extrema pobreza foram calculados com base nas linhas do PBF.

Em 2018, 74,4\% das pessoas em condição de extrema pobreza e 75,7\% das pessoas em condição de pobreza no Brasil eram negras. Conforme se pode depreender no gráfico 4, o andar mais baixo da pirâmide social brasileira é compartilhado por mulheres e homens negros.

Nesse contexto regressivo, a cobertura social do sistema de proteção funciona como colcha de amortecimento dos impactos do declínio da atividade econômica. Entretanto, o programa político iniciado em 2016 vem comprimindo a noção de esfera pública para transformar as políticas criadas com fulcro no programa constitucional em excesso (Moretti, Melo e Santos, 2018). Entre as principais medidas adotadas nos últimos três anos, situamos duas com incidência indireta sobre o sistema antidiscriminatório: a política de austeridade fiscal e a reforma trabalhista. 


\section{GRÁFICO 4}

Número de pobres e extremamente pobres no Brasil (2018) ${ }^{1}$

(Em mil)

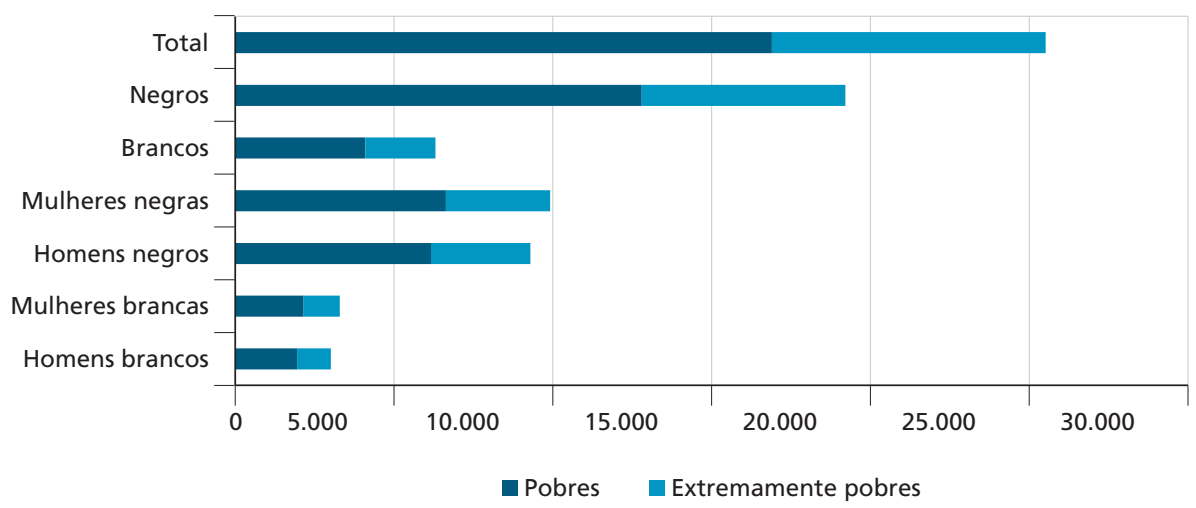

Fonte: PNAD Contínua/IBGE. Disponivel em: <https://bit.ly/323lwK6>.

Elaboração: Ninsoc/Disoc/lpea.

Nota: ${ }^{2}$ Foram consideradas pobres as pessoas com rendimento domiciliar per capita de até $R \$ 178,00$; foram classificadas como extremamente pobres as pessoas com renda domiciliar per capita de até $R \$ 89,00$.

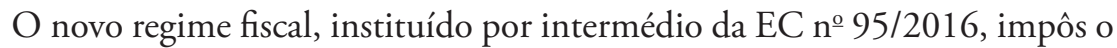
congelamento global das despesas primárias do governo por vinte anos, tomando-se 2016 como ano zero do ajuste. Como parte das despesas primárias é composta por gastos obrigatórios que crescem acima da taxa de inflação, os componentes discricionários da despesa tendem a ser comprimidos. Com a pressão adicional do componente demográfico e os efeitos prolongados da crise econômica, o Estado, impedido de atender à demanda pelo aumento dos gastos sociais, vem acenando com o enrijecimento dos critérios de acesso a bens, direitos e serviços e com a queda dos valores dos benefícios sociais, assistenciais e previdenciários.

No curto e médio prazo, essa iniciativa altera o programa inscrito na CF/1988, adequando os compromissos constitucionais às restriçóes fiscais de longo prazo. Políticas universais tendem a ser fragmentadas, restringindo-se à comunidade de sujeitos-alvo de inclusão, transferindo parte da demanda por bens e serviços públicos para o setor privado.

Além disso, o Estado vem reduzindo substancialmente seu papel enquanto ente regulador das relaçóes laborais. De acordo com as leituras hegemônicas que orientam as reformas em curso, o Estado, erigido com base na Carta Constitucional de 1988, já não dialogaria com as condiçóes atuais de realização social do trabalho, as novas profissóes e as novas tecnologias. Com a promessa de resolver os problemas econômicos e melhorar os indicadores estruturais do mundo do trabalho, foi encaminhado ao Congresso Nacional o Projeto de Lei (PL) nº 6.787/2016, posteriormente transformado na Lei Ordinária 
no 13.467/2017. Precedidos pela aprovação, em março desse ano, da Lei no $13.429 / 2017$, esses dois dispositivos podem ser considerados a mais importante política pública elaborada pelo Estado nos últimos anos em matéria de relações de trabalho. Enquanto a Lei no 13.429/2017 cuida, em especial, do trabalho temporário e da terceirização, a Lei no $13.467 / 2017$ realizou a mais profunda e extensa mudança da CLT desde sua promulgação, ${ }^{29} \mathrm{em} 1943$.

Para compreender os sentidos que uma reforma trabalhista pode produzir para o sistema antidiscriminatório, é necessário recuperar o papel que o direito do trabalho desempenha enquanto política pública integrante do sistema de proteção social. Conforme preleciona o ministro do Tribunal Superior do Trabalho (TST) Maurício Godinho Delgado, ${ }^{30}$ o direito do trabalho possui função econômica, contribuindo para a distribuição de renda e a construção de mercado interno de consumo, dado que percentual significativo de pessoas tem nos salários sua principal, senão única, fonte de renda monetária; assegura a todas as pessoas um tratamento igualitário, independentemente dos seus atributos pessoais, dotando o sistema de forte teor antidiscriminatório; e é uma política de saúde pública que impóe limites à exploração da força de trabalho, reconhecendo que os sujeitos precisam ter respeitadas sua integridade física e psíquica. Por fim, o direito do trabalho também possui um papel fiscal e tributário relevante, pois a transformação do trabalhador em consumidor dinamiza a economia, fornecendo ao Estado os meios necessários para financiar as políticas sociais que comporão de forma indireta o salário daqueles que vivem do trabalho.

Vale ressaltar que a importância do direito do trabalho foi reconhecida pelas organizaçóes negras no processo de elaboraçáo da Carta Constitucional. No documento O Negro na Constituinte, ${ }^{31}$ oriundo da Convenção Nacional do Negro pela Constituinte, há um rol extenso de direitos que, à primeira vista, estariam deslocados dos limites em que se costuma circunscrever a questão racial. Sugere-se que essa presença, além de ser produto da agência negra no sindicalismo brasileiro, também visualizava o repertório de demandas que atravessam e interseccionam a experiência negra no mundo do trabalho.

29. Dos seus 922 artigos, foram alterados 54, inseridos 43 e revogados 9, totalizando 106 dispositivos da CLT atingidos pela reforma.

30. A este respeito, ver: $<$ https://bit.ly/2CNc2Ko>.

31. Em síntese, as organizações negras propunham que a jornada diária do trabalho fosse fixada em seis horas, assegurado o repouso semanal remunerado; a estabilidade do trabalhador no emprego, desde o início do contrato de trabalho; a inclusão das empregadas domésticas no rol de trabalhadores protegidos pelas disposições da CLT; a aposentadoria por tempo de serviço com salário integral; o direito irrestrito de greve; a liberdade e a autonomia sindical; a proibição de diferença de salários e de critérios de admissão no trabalho, por motivo de sexo, cor ou estado civil; a escala móvel de salário, de acordo com a elevação do custo de vida; o direito de sindicalização para os funcionários públicos; a criação do Juizado de Pequenas Causas na área trabalhista; e a responsabilização do Estado pela indenização imediata de acidentes ou prejuízos que vitimem o trabalhador, assegurando ao Estado o direito de ação regressiva contra 0 empregador ou contra o próprio empregado quando apurada a responsabilidade. 0 documento pode ser acessado em: <https://bit.ly/30eakto>. 
A reforma trabalhista brasileira gira, pois, em torno da redefinição das disposiçóes gerais que foram consagradas na $\mathrm{CF} / 1988$. As alteraçóes podem ser sintetizadas nos seguintes pontos-chave, descritos a seguir.

1) Status jurídico da relação de trabalho: terceirização; possibilidade de contrato intermitente, parcial e autônomo; e possibilidade de negociação no momento da dispensa. ${ }^{32}$

2) Tempo de trabalho: jornada de trabalho flexibilizada; não reconhecimento da jornada in itinere; banco de horas ampliado; reduçáo do tempo reconhecido como horas extras; redução do intervalo intrajornadas; e fracionamento maior das férias.

3) Remuneração: diminuição e livre negociação da remuneração.

4) Saúde e segurança do trabalho: possibilidade do labor de gestante em área insalubre.

5) Alteração sindical: descentralização das negociaçóes; e retirada do pagamento obrigatório como contribuição sindical equivalente a um dia de trabalho por ano de todos os trabalhadores.

6) Acesso à justiça: limitação do acesso e poder da Justiça do Trabalho; supremacia dos acordos; e extinção do princípio da gratuidade (Teixeira et al., 2017).

No seu conjunto, a reforma trabalhista instrumentaliza a correspondente e necessária legitimação legal para o quadro de flexibilização dos direitos do trabalhador. Um bom exemplo a ser explorado é o novo $\$ 3$ o do art. 443 da CLT, que torna possível no Brasil o chamado trabalho intermitente. No trabalho intermitente, o empregador determinará, sem uniformidade de tempo de trabalho, o período que estará o empregado sob sua subordinação. $\mathrm{O}$ trabalhador receberá apenas pelas horas trabalhadas. A lei não restringiu esse tipo de contratação a setores específicos, não estabeleceu jornada predefinida, tendo o empregador apenas a obrigação de avisá-la ao empregado com três dias de antecedência. O impacto social e econômico do novo tipo de contratação na vida do empregado é tamanho: tem-se agora chancelada por lei uma prática que já fazia parte da experiência do trabalho informal, tornando-se possível que o trabalhador receba, ao mês, menos que $1 \mathrm{SM}$, com repercussóes sobre as demais garantias, como valor da cobertura previdenciária, Fundo de Garantia do Tempo de Serviço (FGTS), férias e $13^{\circ}$ salário. Apregoam-se vantagens como a conciliação de mais de um vínculo de trabalho, e

32. Com a reforma, foi adicionada ao ordenamento trabalhista uma nova modalidade de dispensa laboral, admitindo-se a demissão consensual entre empregador e empregado. Neste caso, a multa do FGTS passa de $40 \%$ para $20 \%$, o saque do FGTS de $100 \%$ para $80 \%$, as verbas rescisórias são reduzidas à metade e não há direito a seguro-desemprego. 
entre trabalho e estudo, desconsiderando-se os efeitos nocivos que a insegurança e a imprevisibilidade podem gerar a quem trabalha sob essa modalidade de contratação.

Em adição, o atual governo criou mais um instrumento jurídico destinado a aprofundar a liberalização das relações de trabalho. Também conhecida como Lei da Liberdade Econômica, a Lei no 13.874/2019 diminui ainda mais a atuação do Estado como agente normativo e regulador das relaçóes laborais, concedendo maior liberdade aos contratos e atos no âmbito particular. Conforme estabelece o inciso III do art. 2º, o Estado, segundo a lei aprovada, deverá atuar apenas de forma excepcional e subsidiária.

Não há evidências de que em países como o Brasil uma reforma trabalhista redutora de direitos concorra para o incremento da ocupaçáo formal. Para que tal assertiva fosse verdadeira, seria necessário indicar empiricamente as relaçóes diretas entre desregulação e desempenho econômico. ${ }^{33}$ Como a informalidade é característica estrutural do mercado de trabalho brasileiro, com fortes ligaçóes com o setor formal, não parece crível que a reforma produza alterações nessa direção.

Se não há evidências capazes de demonstrar a relação direta entre legislação protetiva e geração ou proteção de vagas de trabalho, pode-se inferir, entretanto, que reformas laborais que fragilizam o aparato protetivo podem, a contrapelo, reforçar a baixa capacidade de socialização da riqueza produzida em uma conjuntura de expansão da atividade econômica, como as experiências em países europeus vêm ilustrando. Nesse aspecto, o desmonte do aparato protetivo, em prol de livre possibilidade de transacionar em relaçóes de trabalho, concorre para fazer das desvantagens comparativas de grupos e indivíduos elemento ainda mais decisivo para a consolidação de posiçóes sociais e econômicas preestabelecidas.

Náo havendo horizontes coletivos alternativos e ante um sistema de proteção também combalido pelas políticas de austeridade, aos estratos mais fragilizados do sistema sobram poucas saídas. Parte dos indivíduos desorganizados vem aderindo ao novo ethos por meio da qual a literatura empresarial e econômica agencia casos particulares e isolados de mobilidade social imbuídos de forte conteúdo moral, transformando a pobreza dos trabalhadores em combustível das novas formas de obtenção de lucro, competitividade e eficácia dos empreendimentos (Boltansky e Chiapello, 2009). As reformas, nesse aspecto, concorrem para a construção de

33. Pesquisa realizada por Silva (2018) mostra que, em um ranking de 69 países, o Brasil ocuparia a 55a posição em rigidez da legislação trabalhista, tomando-se como base o Indicador de Proteção ao Emprego (IPE), elaborado pela Organização para a Cooperação e Desenvolvimento Econômico (OCDE). Em suma, na comparação com os países da OCDE, o Brasil está abaixo da média no indicador. Além disso, como há países com renda per capita tanto maior quanto menor do que a do Brasil em posições no ranking tanto superiores quanto inferiores, conclui-se que o grau de rigidez da legislação trabalhista não tem correlação direta com a performance econômica (Silva, 2018). Suas conclusões divergem, portanto, do discurso apresentado nos relatórios da proposta de lei ao atribuir ao caráter protetivo da legislação laboral um entrave ao desenvolvimento econômico. 
modelo normativo que emula um novo sujeito, uma nova forma de engajamento no trabalho e de relacionamento entre trabalhadores e empresas.

As políticas de austeridade e a reforma trabalhista, em seu conjunto, privatizam a definição dos salários diretos e indiretos, retirando parcialmente da esfera pública o direito à saúde, à renda básica de cidadania, à proteção contra os riscos sociais e a violaçáo de direitos, a salários dignos e à estabilidade. Na esfera privada, esses direitos seriam alcançáveis por intermédio de estímulos à livre iniciativa, ao mérito e ao esforço individual. Nesse contexto, as condiçôes precárias de vida assumem peso ainda mais decisivo sobre as possibilidades de fruiçáo de direitos mínimos associados a uma vida digna. Para os negros, isso tende a significar ainda o endurecimento das vias ascensionais que vinham se desenhando com a melhoria dos indicadores educacionais e a incorporação paulatina da linguagem das ações afirmativas no mundo do trabalho.

\section{CONSIDERAÇÕES FINAIS}

O sistema internacional de direitos humanos constitui relevante instrumento político e simbólico capaz de pressionar a construção e a consolidação de políticas antidiscriminatórias nos contextos locais. Isso é ainda mais importante quando as agendas locais de política colocam em risco direitos e garantias fundamentais consagrados globalmente.

A Icerd engendrou a pauta racial nos fóruns internacionais. Sua instrumentalização, ao longo de seis décadas, consolidou, paulatinamente, o entendimento de que todas as sociedades reproduzem discriminaçáo racial, devendo-se adotar medidas para monitorá-la, combatê-la e minimizar seus efeitos. Reconhecendo a complexidade da matéria e das práticas sociais e institucionais nesta envolvidas, a convenção estabelece que as práticas discriminatórias diretas e indiretas devem ser combatidas por meio de uma série de compromissos em matéria de direitos sociais, civis, políticos e econômicos interdependentes.

A despeito da impossibilidade de uma leitura linear, muito se produziu em termos de iniciativas tanto do Estado quanto da sociedade civil, no sentido de eliminar os efeitos dos processos discriminatórios no Brasil. Impulsionados pela Icerd, pelo programa constitucional iniciado em 1988 e pela agenda aberta após a Conferência Mundial contra o Racismo, Discriminação, Xenofobia e Intolerâncias Correlatas, realizada em Durban em 2001, Estado e sociedade engendraram novas formulaçôes, demandas e respostas às discriminaçōes. Medidas repressivas, ampliação das políticas sociais e políticas de açóes afirmativas tornaram a igualdade racial questão de natureza pública. Metas, medidas, planos de ação e políticas foram criados, embora a escala, a efetividade e os efeitos concretos das iniciativas variem de forma significativa. 
A introdução da agenda de igualdade racial na esfera pública produziu mudanças incrementais nas instituiçôes. Porém, até mesmo no período de ampliação das ofertas públicas de direitos e serviços, conviveu-se com taxas de mortalidade e encarceramento negras que têm nas próprias políticas de Estado suas raízes mais profundas. Com o fim de um ciclo político mais poroso à institucionalização da pauta racial, os efeitos positivos do ciclo econômico já não poderiam mais ser utilizados como atenuante da face mais perversa do racismo brasileiro.

A partir de 2016, o Estado brasileiro vem promovendo sucessivas transformaçôes nas ofertas públicas de bens e serviços e em sua estrutura regulatória, redefinindo os horizontes da ação estatal e suas responsabilidades enquanto ente provedor de proteção e garantidor de direitos. A pauta racial corre sérios riscos nesse contexto, podendo mais uma vez transformar-se em questão privada e individualizada, destituindo-a de sua potência política transformadora.

\section{REFERÊNCIAS}

ALVES, D. S. et al. (Orgs.). Promovendo a igualdade racial para um Brasil sem racismo. Brasília: Editora IABS, 2018.

ALVES, J. A. L. A Conferência de Durban contra o Racismo e a responsabilidade de todos. Revista Brasileira de Política Internacional, v. 45, n. 2, jul./dez. 2002. Disponível em: <https://is.gd/MPwkIA>. Acesso em: 10 jan. 2020.

. Viagens no multiculturalismo: o Comitê para a Eliminação da Discriminação Racial. Brasília: Funag, 2010.

. Cinquenta anos da convenção sobre a eliminação da discriminação racial: uma apreciação crítica de dentro. Lua Nova, São Paulo, n. 100, p. 25-82, 2017. Disponível em: <https://is.gd/wZGgxa>. Acesso em: 20 maio 2020.

. A década das conferências: 1990-1999. Brasília: Funag, 2018.

ANJOS, G. A questão "cor” ou "raça” nos censos nacionais. Indicadores Econômicos FEE, Porto Alegre, v. 41, n. 1, p. 103-118, 2013.

BENTES, N. Brasil - Durban - Brasil: um marco da luta contra o racismo. Revista Estudos Feministas, Florianópolis, v. 10, n. 1, p. 229-236, jan. 2002. Disponível em: <https://is.gd/3S74PS>. Acesso em: 3 jun. 2020.

BOLTANSKY, L.; CHIAPELLO, E. O novo espírito do capitalismo. São Paulo: Martins Fontes, 2009. 
BRASIL. Presidência da República. Decreto n 65.810/1969. Promulga a Convenção Internacional sobre a Eliminação de Todas as Formas de Discriminação Racial. Diário Oficial, Brasília, 1969. Disponível em: <https://bit.ly/3eE6vCT>. Acesso em: 25 maio 2020.

CAMPOS, W. O. Expectativas em torno da Lei Afonso Arinos (1951): a "nova abolição" ou "lei para americano ver"? Revista Latino-Americana de História - Unisinos, v. 4, n. 13, p. 257-278, jul. 2015. Disponível em: <https://bit.ly/2Clu5Hz>. Acesso em: 8 jul. 2020.

FRASER, N. Da redistribuição ao reconhecimento? Dilemas da justiça na era pós-socialista. In: SOUZA, J. (Org.). Democracia hoje: novos desafios para a teoria democrática. Brasília: Editora Universidade de Brasília, 2001. p. 245-282.

FULLIN, C. Direito e racismo: observaçóes sobre o alcance da legislação penal antidiscriminatória no Brasil. Revista da Faculdade de Direito de Sáo Bernardo do Campo, v. 6, n. 2, p. 21-35, 2000. Disponível em: <https:// is.gd/EpLRxw>.

IBGE - INSTITUTO BRASILEIRO DE GEOGRAFIA E ESTATÍSTICA. Síntese de indicadores sociais: uma análise das condiçôes de vida da população brasileira. Rio de Janeiro: IBGE, 2019a. Disponível em: < https:// bit.ly/2WtMTeB>. Acesso em: 8 fev. 2020.

- Desigualdades sociais por cor ou raça no Brasil. Rio de Janeiro: IBGE, 2019b. (Estudos e Pesquisas: informação demográfica e socioeconômica, n. 41).

INESC - INSTITUTO DE ESTUDOS SOCIOECONÔMICOS. O Brasil com baixa imunidade: balanço do Orçamento Geral da União 2019. Brasília: Inesc, abr. 2020. Disponível em: <https://is.gd/ZjySrF>. Acesso em: 31 jul. 2020.

IPEA - INSTITUTO DE PESQUISA ECONÔMICA APLICADA. Igualdade racial. Políticas sociais: acompanhamento e análise, Brasília, n. 21, p. 421-480, 2013.

. Igualdade racial. Políticas sociais: acompanhamento e análise, Brasília, n. 22, p. 485-551, 2014.

Igualdade racial. Políticas sociais: acompanhamento e análise, Brasília, n. 24, p. 429-480, 2016. 
. Igualdade racial. Políticas sociais: acompanhamento e análise, Brasília, n. 25, 2018.

. ODS 16 - Promover sociedades pacíficas e inclusivas para o desenvolvimento sustentável, proporcionar o acesso à justiça para todos e construir instituiçóes eficazes, responsáveis e inclusivas em todos os níveis. Brasília: Ipea, 2019a.

. Os desafios do passado no trabalho doméstico do século XXI: reflexóes para o caso brasileiro a partir dos dados da PNAD Contínua. Brasília: Ipea, 2019b.

IPEA - INSTITUTO DE PESQUISA ECONÔMICA APLICADA; FBSP - FORUM BRASILEIRO DE SEGURANÇA PÚBLICA. Atlas da Violência 2019. Brasília; Rio de Janeiro; São Paulo: Ipea; FBSP, 2019. JACCOUD, L. Racismo e República: o debate sobre o branqueamento e a discriminação racial no Brasil. In: THEODORO, M. (Org.). As políticas públicas e a desigualdade racial no Brasil: 120 anos após a abolição. 1 . ed. Brasília: Ipea, v. 1, p. 45-64, 2009.

JACCOUD, L.; BEGHIN, N. Desigualdades raciais no Brasil: um balanço da intervenção governamental. Brasília: Ipea, 2002.

MELLO, L.; RESENDE, U. P. Concursos públicos para docentes de universidade federais na perspectiva da Lei 12.990/2014: desafios à reserva de vagas para candidatas/os negras/os. Sociedade e Estado, v. 34, n. 1, p. 161-184, jan./abr. 2019. Disponível em: <https://bit.ly/2OBGvO5>. Acesso em: 17 fev. 2020.

MOREIRA, A. Direito, poder, ideologia: discurso jurídico como narrativa cultural. Revista Direito e Práxis, Rio de Janeiro, v. 8, n. 2, p. 830-868, 2017.

MORETTI, B.; MELO, E. B. B.; SANTOS, E. A. V. Razão neoliberal e o desafio da afirmação dos direitos sociais no Brasil. In: CARDOSO JUNIOR, J. C. (Org.). A Constituição golpeada: 1988-2018. São Paulo: Fundação Perseu Abramo, 2018.

PAIXÃO, M.; CARVANO, L. M. Censo e demografia: a variável cor ou raça no interior dos sistemas censitários brasileiros. In: PINHO, A.O.; SANSONE, L. Raça: novas perspectivas antropológicas. 2. ed. rev. Salvador: EdUFBA, 2008. p. 25-61.

PAULO, C. A. S. As respostas do Estado às demandas sociais e étnico-raciais: particularidades no Brasil entre 20003 e 2013. 2015. Tese (Doutorado) - Instituto de Ciências Humanas, Universidade de Brasília, Brasília, 2015. 166 p. Disponível em: <https://bit.ly/3jd0bpn>. Acesso em: 7 jul. 2020. 
PIOVESAN, F. A Constituiçáo brasileira de 1988 e os tratados internacionais de direitos humanos. Brasília: STJ, 1999. Disponível em: <https://is.gd/IyHKY3>. Acesso em: 31 maio 2020.

. Tratados internacionais de proteçáo dos direitos humanos: a jurisprudência do STF. Washington: OAS, [s.d.]. Disponível em: <https://bit. ly/3hd6ZSq $>$. Acesso em: 31 maio 2020.

PIRES, T. Racializando o debate sobre direitos humanos. Sur - International Journal on Human Rights, v. 15, n. 28, p. 65-75, 2018.

RIBEIRO, M. Institucionalizaçáo das políticas de promoçáo da igualdade racial no Brasil: percursos e estratégias - 1986 a 2010. 2013. Tese (Doutorado) - Pontifícia Universidade Católica de São Paulo, São Paulo, 2013. Disponível em: $<$ https://bit.ly/2ClYtBB>. Acesso em: 5 jun. 2020.

RIOS, R. R.; LEIVAS, P. G. C.; SCHAFER, G. Direito da antidiscriminação e direitos de minorias. Revista Direitos Fundamentais \& Democracia, v. 22, n. 1, p. 126-148, jan./abr. 2017.

SANTOS, N. N. S. Vozes negras no Congresso Nacional: o movimento negro e a Assembleia Nacional Constituinte de 1987-1988. In: ENCONTRO ANUAL DA ANPOCS, 39. Caxambu: Anpocs, 2015. Disponível em: <https://is.gd/ DRHyWe>. Acesso em: 31 jul. 2020.

SILVA, M. V. M. (Org.). Levantamento Nacional de Informaçóes Penitenciárias. Brasília: MJSP; Departamento Penitenciário Nacional, 2019. Disponível em: $<$ https://bit.ly/3eFxDBE>. Acesso em: 9 jun. 2020.

SILVA, S. J. A. As Naçóes Unidas e a luta internacional contra o racismo. Brasília: Funag, 2011.

SILVA, S. P. A estratégia argumentativa da reforma trabalhista no Brasil à luz de dados internacionais. Brasília: Ipea, 2018.

SILVA, T. D. O Estatuto da Igualdade Racial. Rio de Janeiro: Ipea, 2012. (Texto para Discussão, n. 1712).

Ação afirmativa e populaçáo negra na educação superior: acesso e perfil discente. Brasília: Ipea, 2020. (Texto para Discussão, n. 2569).

SILVA, T. D.; SILVA, J. M. Reserva de vagas para negros em concursos públicos: uma análise a partir do Projeto de Lei 6.738/2013. Brasília: Ipea, 2014. (Nota Técnica, n. 17). Disponível em: <https://bit.ly/3jdCuxl>. Acesso em: 17 fev. 2020.

TEIXEIRA, M. O. et al. Contribuiçáo crítica à reforma trabalhista. São Paulo: Cesit/IE/Unicamp, 2017. 
TEIXEIRA, T. G.; SAMPAIO, C. A. M. Análise orçamentária do Programa Brasil Quilombola no Brasil e no Maranhão: o ocaso de uma política pública. Revista de Administração Pública, Rio de Janeiro, v. 53, n. 2, p. 461-480, mar./abr. 2019. THEODORO, M. As relaçôes raciais, o racismo e as políticas públicas. In: ENCONTRO ANUAL DA ANPOCS, 37., 2013. Águas de Lindóia, São Paulo. Anais... Águas de Lindóia: Anpocs, out. 2013. Disponível em: <http://goo.gl/ EGrJwr>. Acesso em: 10 out. 2015.

\section{BIBLIOGRAFIA COMPLEMENTAR}

ARANTES, P. O novo tempo do mundo: e outros estudos sobre a era das emergências. São Paulo: Boitempo, 2014.

BRASIL. Decreto-Lei n 5.452, de $1^{\circ}$ maio de 1943. Aprova a Consolidação das Leis do Trabalho. Diário Oficial, Rio de Janeiro, 1943. Disponível em: <https:// bit.ly/3jo1m5I $>$.

. Decreto $n^{\circ}$ 63.223, de 6 de setembro de 1968. Promulga a convençáo relativa à luta contra a discriminação no campo do ensino. Brasília: Congresso Nacional, 1968.

. Lei $\mathrm{n}^{\ominus} 6.019$, de 3 de janeiro de 1974. Dispóe sobre o trabalho temporário nas empresas urbanas, e dá outras providências. Diário Oficial, Brasília, 1974. Disponível em: <https://is.gd/xgbLEI>.

. Lei n ${ }^{\circ} 13.189$, de 19 de novembro de 2015. Institui o Programa SeguroEmprego - PSE. Diário Oficial, Brasília, 20 nov. 2015. Disponível em: <https:// bit.ly/3h4MRl2>.

- Ministério dos Direitos Humanos. Presidência da República. Secretaria Especial de Políticas de Promoção da Igualdade Racial. Levantamento de órgáos e conselhos de igualdade racial para o Sinapir. Brasília: Seppir/PR; MDH, 2015. Disponível em: <https://is.gd/aFcRHb>. Acesso em: 10 dez. 2018.

. Lei $\mathrm{n}^{\mathrm{a}} 13.429$, de 31 de março de 2017. Altera dispositivos da Lei $\mathrm{n}^{\circ}$ 6.019, de 3 de janeiro de 1974, que dispóe sobre o trabalho temporário nas empresas urbanas e dá outras providências; e dispóe sobre as relações de trabalho na empresa de prestação de serviços a terceiros. Diário Oficial, Brasília, 1ํo abr. 2017. Disponível em: <https://bit.ly/32slb5z>.

. Lei $\mathrm{n}^{\circ} 13.456$, de 25 de junho de 2017. Altera o programa de que trata a Lei $n^{\ominus} 13.189$, de 19 de novembro de 2015, para denominá-lo Programa SeguroEmprego e para prorrogar seu prazo de vigência. Diário Oficial, Brasília, 26 jun. 2017. Disponível em: <https://bit.ly/2Wrew7R>. 
Lei n 13.467 , de 13 de julho de 2017. Altera a Consolidação das Leis do Trabalho (CLT), aprovada pelo Decreto-Lei n 5.452, de $1^{\circ}$ de maio de 1943 , e as Leis $\mathrm{n}^{\mathrm{os}}$ 6.019, de 3 de janeiro de 1974, 8.036, de 11 de maio de 1990, e 8.212, de 24 de julho de 1991, a fim de adequar a legislação às novas relaçôes de trabalho. Diário Oficial, Brasília, 14 jul. 2017. Disponível em: <https://bit.ly/32rQqxK>. FIGUEIREDO, A. Classe média negra: trajetórias e perfis. Salvador: EdUFBA, 2012.

IBGE - INSTITUTO BRASILEIRO DE GEOGRAFIA E ESTATÍSTICA. Pesquisa Nacional por Amostra de Domicílios: aspectos das relaçóes de trabalho e sindicalização. Rio de Janeiro: IBGE, 2017. Disponível em: <https://bit. ly/2OxDG0e>. Acesso em: 10 dez. 2019.

NASCIMENTO, A. O genocídio do negro brasileiro: processo de um racismo mascarado. Rio de Janeiro: Paz e Terra, 1978.

SILVA, J. M.; CARDOSO, M. R. H. C.; SILVA, T. D. Planejamento, orçamento e a promoçáo da igualdade racial: reflexôes sobre os planos plurianuais 2004-2007 e 2008-2011. Brasília: Ipea, 2014. Disponível em: <https://bit.ly/2BenMVO>. Acesso em: 7 jun. 2020.

SILVA, S. P. A estratégia argumentativa da reforma trabalhista no Brasil à luz de dados internacionais. Brasília: Ipea, 2018.

SILVA, S. J. A. Combate ao racismo. Brasília: Funag, 2007.

\section{SITE}

CERD - COMMITTEE ON THE ELIMINATION OF RACIAL DISCRIMINATION. Monitoring racial equality and non-discrimination. Disponível em: <https://bit.ly/3jewi8k>. Acesso em: 14 ago. 2011. 



\section{IGUALDADE DE GÊNERO'}

\section{APRESENTAÇÃO}

A Declaração Universal dos Direitos Humanos (DUDH) constitui marco mundial no campo dos direitos sociais, civis, econômicos e políticos. Proclamada em 1948, pela Assembleia Geral da Organização das Naçóes Unidas (AGNU), a declaração integra aquilo que se poderia chamar de primeira fase de atuação da Organização das Naçóes Unidas (ONU) no campo dos direitos das mulheres, com instrumentos como a Carta das Naçóes Unidas (ONU, 1945) e a Comissão sobre o Status da Mulher (CSW - em inglês, Commission on the Status of Women), ${ }^{2}$ instância da ONU criada pelo Conselho Econômico e Social da ONU (ECOSOC), que reúne anualmente lideranças mundiais, governamentais, de organizações não governamentais (ONGs), de empresas, ativistas e outros parceiros e parceiras atuantes no campo da promoçáo da igualdade de gênero e empoderamento das mulheres. A CSW foi instituída em 1936 e reúne-se periodicamente até os dias atuais, com o objetivo de discutir a situação da mulher ao redor do mundo. Desde então, os compromissos internacionais destinados ao aprimoramento das condiçóes de vida das mulheres e à promoção da igualdade de gênero multiplicaram-se no âmbito da ONU, podendo-se falar em pelo menos seis fases de atuação, que se iniciam nos anos 1940 e seguem até o presente, com a proposta da Agenda 2030 para o Desenvolvimento Sustentável, operacionalizada pela adesão aos Objetivos de Desenvolvimento Sustentável (ODS).

No caso brasileiro, os tratados internacionais sobre direitos humanos foram absolutamente relevantes para a constituição de um país mais democrático, tendo sua importância expressa na Constituição Federal de 1988 (CF/1988), considerada um marco na institucionalização da democracia e na consolidação dos direitos sociais e dos direitos humanos no Brasil. A Carta estabelece que os direitos e as garantias expressos em seu texto

não excluem outros decorrentes do regime e dos princípios por ela adotados, ou dos tratados internacionais em que a República Federativa do Brasil seja parte. A Constituiçáo de 1988 inova, assim, ao incluir, dentre os direitos constitucionalmente protegidos, os direitos enunciados nos tratados internacionais de que o Brasil seja 
signatário. Ao efetuar tal incorporação, a Carta está a atribuir aos direitos internacionais uma natureza especial e diferenciada, qual seja, a natureza de norma constitucional (Piovesan, 2000, p. 97).

Esta edição de Políticas sociais: acompanhamento e análise pretende analisar os compromissos internacionais para a promoção dos direitos das mulheres e da igualdade de gênero assumidos pelo Estado brasileiro, a partir da criação da ONU, da qual o Brasil é um membro fundador. Ainda que a incorporação de tratados e acordos internacionais ao arcabouço jurídico brasileiro seja nebulosa em termos de obrigatoriedade de cumprimento e aplicabilidade de sançôes, tais compromissos têm se revelado estrategicamente importantes para as mulheres. É o caso, por exemplo, da conquista obtida com a Lei Maria da Penha - LMP (Lei no 11.340/2006), resultado de condenação do Brasil pela Comissão Interamericana de Direitos Humanos da Organização dos Estados Americanos (CIDH/OEA) no caso da farmacêutica Maria da Penha, vítima de violência doméstica e tentativa de homicídio por parte de seu companheiro. Nesse caso, a violação da Convenção de Belém do Pará (1994) foi utilizada para garantir a condenação do Estado brasileiro, constituindo-se em um caso exemplar de como os tratados e as convençóes podem ser utilizados para ampliar direitos e garantir melhores condiçóes de vida à sociedade.

Este texto se encontra dividido em dois grandes blocos: o primeiro - que cobre as seçóes 2 a 6 - apresenta o conjunto de acordos e tratados internacionais ratificados ou assinados pelo Brasil desde a década de 1940; por sua vez, o segundo bloco, consubstanciado na seção 7 , traz os desafios para o cumprimento de tais compromissos diante dos contextos social, político e econômico pelos quais passa o país no começo dos anos 2020. Para fins didáticos, optamos por utilizar perspectiva de narrativa gradualista, que apresenta os progressos e as conquistas dos direitos humanos das mulheres. Entretanto, é importante destacar que o processo histórico de conquista e construção de direitos - que ocorre via lutas sociais, atuação do Estado mediante política externa brasileira (PEB) etc. - não é linear, e envolve rupturas, retrocessos e conciliações que não serão abordadas neste documento, por tratar-se de texto com limite previamente estabelecido.

Os tratados internacionais apresentados na seção 2 estão divididos de acordo com as fases de atuação da ONU em relação aos direitos humanos das mulheres. Por sua vez, a seção 3 aborda as três primeiras conferências mundiais sobre as mulheres e a Convenção sobre a Eliminação de Todas as Formas de Discriminação contra a Mulher (CEDAW - em inglês, Convention on the Elimination of All Forms of Discrimination Against Women); e eventos históricos que promoveram debate sobre a proteção e a garantia dos direitos humanos das mulheres. Logo após, na seção 4, são apresentados os acordos internacionais resultantes de uma série de conferências mundiais de temática social convocadas pela ONU no decorrer dos anos 1990, cujo objetivo era promover uma agenda global que conseguisse 
avançar nessas temáticas. Nas conferências sociais, cujo tema principal nem sempre era dedicado especificamente às mulheres, foram realizados importantes acordos relacionados a esse grupo específico.

Nas seçôes 5 e 6, são analisados o modelo de pactuação internacional da ONU iniciado com os Objetivos de Desenvolvimento do Milênio (ODMs). Essa fase marca a mudança de estratégia da entidade, que passou a estabelecer metas e objetivos mensuráveis que deveriam ser alcançados pelos países signatários. Essa primeira experiência recebeu críticas por tratar-se de agenda construída pelos países mais desenvolvidos para os países em desenvolvimento, com pouca participação destes. Por sua vez, a Agenda 2030 para o Desenvolvimento Sustentável foi elaborada a partir de projeto que tentou considerar e superar algumas das críticas anteriores aos ODMs. A nova agenda constitui-se em um documento político ambicioso que pretende atingir, em nível global, o desenvolvimento sustentável em suas três dimensóes (ambiental, econômica e social). O documento é formado por dezessete objetivos, indivisíveis e integrados, e 169 metas globais, que devem ser adequados à realidade de seus respectivos países. $\mathrm{O}$ objetivo que propóe alcançar a igualdade de gênero no país, o ODS 5: Alcançar a igualdade de gênero e empoderar todas as mulheres e meninas, será explorado no texto.

A seção 7 traz os imensos desafios quanto à possibilidade de a agenda ser plenamente implementada até 2030 , destrinchando as metas que compóem o objetivo e abordando as iniciativas em andamento sobre cada uma destas. Nesta seção, são apresentados alguns resultados da pesquisa $O$ Poder Judiciário no enfrentamento à violência doméstica e familiar contra as mulheres (Ipea e CNJ, 2019), realizada pelo Ipea em parceria com o Conselho Nacional de Justiça (CNJ), que apontam aspectos importantes na análise da meta 5.2, por exemplo, que diz respeito à eliminação de todas as formas de violência de gênero nas esferas pública e privada. A seção também aponta mudanças factuais recentes no posicionamento da PEB, como a orientação formal do Itamaraty sobre a palavra gênero, a defesa da inexistência de direitos sexuais e reprodutivos, ${ }^{3}$ a rejeição a expressóes como "igualdade de gênero" ou quaisquer outras que, de alguma forma, possam questionar a visão religiosa sobre a reprodução entre seres humanos. Por fim, a seção 8 apresenta algumas consideraçôes finais sobre os direitos humanos das mulheres como patrimônio fundamental da sociedade brasileira, assegurados pela CF/1988.

\section{OS TRATADOS INTERNACIONAIS E OS DIREITOS HUMANOS DAS MULHERES}

As mulheres brasileiras atualmente dispóem de instrumentos para a expansão e a proteção de seus direitos, além de espaços significativos de participação e reivindicação destes no âmbito internacional (Pra e Epping, 2012). A longa jornada

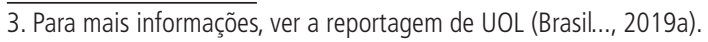


de construção dos direitos das mulheres, travada por meio das lutas sociais e da atuação do Estado via PEB, materializou-se em açôes cotidianas na vida das mulheres ao longo do século XX e das primeiras décadas do século XXI. Trabalhar, votar, ter e administrar propriedades, ingressar judicialmente, decidir livremente com quem se casar ou se divorciar são açôes precedidas da luta política por direitos femininos que se tornaram parte do patrimônio social brasileiro. Ainda que não se possa considerá-las como conquistas definitivas - pois são passíveis, em menor ou maior grau, de retrocessos em contextos específicos -, é importante considerar que tais conquistas históricas foram ampliadas por intermédio de atos internacionais adotados e ratificados pelo Estado brasileiro e contribuíram para a constituição de uma "concepção de cidadania fundamentada na ideia do reconhecimento e da ampliação de direitos da população feminina, incluindo os civis, políticos, sociais, culturais, além dos sexuais e reprodutivos. ${ }^{4}$ Enfim, o reconhecimento dos direitos humanos das mulheres" (Pra e Epping, 2012, p. 33).

A conversão de acordos e tratados internacionais em normas com status constitucional, contudo, não é imediata, demandando um rito jurídico específico. A Emenda Constitucional (EC) no 45/2004, que inseriu o $\$ 3$ o no art. 5o da $\mathrm{CF} / 1988$, definiu que "os tratados e convençóes internacionais sobre direitos humanos que forem aprovados, em cada Casa do Congresso Nacional, em dois turnos, por três quintos dos votos dos respectivos membros, serão equivalentes às emendas constitucionais" (Brasil, 2004, art. 5오 $\$ 3^{\circ}$ ).

Assim, a interpretação que atualmente vigora no Supremo Tribunal Federal (STF) sobre a recepçáo dos tratados internacionais pelo direito pátrio - inclusive os relativos a direitos humanos - é a de que, uma vez que os instrumentos não tenham passado pelo rito disposto no artigo referido anteriormente, estes serão recepcionados pelo direito brasileiro com status supralegal - ou seja, estariam acima de lei ordinária, mas abaixo dos dispositivos constitucionais (STF, 2018b). Apenas os documentos de direitos humanos submetidos aos ritos descritos no dispositivo constitucional é que teriam status de EC.

Por essa interpretação, portanto, apenas os documentos de direitos humanos submetidos ao mesmo rito de votação de uma proposta de emenda à Constituição (PEC) - ou seja, com necessidade de aprovação da maioria qualificada, em dois turnos, em cada casa legislativa - teriam status de emenda constitucional. Dessa forma, o status legal dos instrumentos internacionais que garantem os direitos humanos das mulheres podem tanto ser equiparados a ECs quanto a normas

4. É importante destacar que os compromissos internacionais impactam os países de diferentes formas e intensidades. As mudanças procedentes de atos internacionais dependem de conjunturas, pressões políticas externas e internas, positivação de direitos na legislação interna, compromissos e prioridades dos diferentes governos que se sucedem. Em virtude desses fatores, as conquistas alcançadas, em geral, não estão presentes em todos os países. Por fim, em contextos complexos, as conquistas podem ser perdidas, o que demanda prontidão. 
supralegais, dependendo da forma como foram internalizados à legislação nacional e do momento em que se deu essa integração. Ainda que vigore essa diversidade de status normativo, pode-se considerar a exigibilidade plena do cumprimento desses documentos aqui apresentados como um patrimônio de direitos e garantias de todas as brasileiras, uma vez que integram o direito interno brasileiro.

No art. 102 do capítulo XVI da Carta das Naçôes Unidas (ONU, 1945), ${ }^{5}$ consta que os tratados e os acordos internacionais concluídos pelos membros da ONU deverão, o mais breve possível, ser encaminhados ao Secretariado da ONU para serem registrados e publicados. Essa carta é o marco de fundação que estabeleceu a organização internacional conhecida como ONU, "organização internacional formada por países que se reuniram voluntariamente para trabalhar pela paz e o desenvolvimento mundiais" . ${ }^{6}$ No preâmbulo desse tratado, a igualdade de direitos entre homens e mulheres ${ }^{7}$ é incluída nos direitos fundamentais:

Nós, os povos das Naçóes Unidas, resolvidos a preservar as geraçóes vindouras do flagelo da guerra, que por duas vezes, no espaço da nossa vida, trouxe sofrimentos indizíveis à humanidade, e a reafirmar a fé nos direitos fundamentais do homem, na dignidade e no valor do ser humano, na igualdade de direito dos homens e das mulheres, assim como das naçóes grandes e pequenas, e a estabelecer condiçóes sob as quais a justiça e o respeito às obrigaçôes decorrentes de tratados e de outras fontes do direito internacional possam ser mantidos, e a promover o progresso social e melhores condiçôes de vida dentro de uma liberdade ampla (ONU, 1945).

Tatiana Guarnieri (2010) aponta que o reconhecimento da igualdade entre homens e mulheres na Carta das Naçóes Unidas (ONU, 1945) foi fundamental para que outras mudanças ocorressem, pois esse documento marca o envolvimento internacional da ONU com a igualdade de gênero. Segundo ela, "as questôes de gênero, antes relegadas ao domínio doméstico das jurisdiçóes nacionais, passam em definitivo para o âmbito das consideraçóes globais. Inicia-se, com isso, um processo internacional de codificação dos direitos das mulheres" (Guarnieri, 2010, p. 4).

Apesar do reconhecimento da igualdade entre homens e mulheres no documento fundador da organização, essa ação não foi suficiente para que os direitos das mulheres adquirissem visibilidade nos direitos humanos. Para fins didáticos,

5. A Carta das Nações Unidas, elaborada por representantes de cinquenta países presentes à Conferência de São Francisco, em 1945, é o tratado que estabeleceu a ONU e, por isso, é considerado o documento mais importante da organização. 0 art. 103 do documento estabelece que "no caso de conflito entre as obrigações dos membros das Nações Unidas, em virtude da presente Carta e as obrigações resultantes de qualquer outro acordo internacional, prevalecerão as obrigações assumidas em virtude da presente Carta" (ONU, 1945, p. 65).

6. Disponível em: <https://nacoesunidas.org/conheca/>.

7. A cientista, diplomata e sufragista brasileira Bertha Lutz desempenhou papel fundamental na construção da Carta das Nações Unidas (ONU, 1945), ao reivindicar e conseguir - com apoio de delegadas do México,da República Dominicana, da Austrália e do Uruguai - a inclusão da expressão "igualdade de direitos dos homens e das mulheres" em substituição a "igualdade de direitos dos homens" na carta. Das quatro mulheres que assinaram a Carta das Nações Unidas, apenas Lutz e a diplomata dominicana Minerva Bernardino defenderam os direitos das mulheres na ocasião da Conferência de Organização Internacional das Nações Unidas, em 1945. 
é possível distinguir em diferentes fases a atuação da ONU quanto aos direitos humanos das mulheres e para a garantia destes (quadro 1), tal como propóem Boutros-Ghali (1996) e Guarnieri (2010). Tais fases obedecem a um critério cronológico mais que a características similares aos diferentes instrumentos que possam agrupá-los em categorias distintas. A primeira fase transcorreu entre 1945 e 1962 e tem como marcos a Carta das Naçôes Unidas (ONU, 1945), a criação da CSW (1946) e da DUDH (1948). A principal característica daquele período foram os esforços concentrados para a questão da equidade das mulheres em relação aos homens e para a codificação internacional dos direitos das mulheres. A criação da CSW representou o primeiro marco após a Carta das Naçóes Unidas para que os direitos das mulheres ganhassem visibilidade nos direitos humanos, incorporando à arena política internacional debates sobre os direitos econômicos, políticos e sociais das mulheres, os quais embasaram declaraçóes e resoluçóes que recomendavam a construção de políticas que assegurassem esses direitos. Sobre esse aspecto, Ana Laura Lobato Pinheiro (2019, p. 3) informa:

o estabelecimento de uma comissão específica para monitorar a situação das mulheres significava, já naquele momento, o reconhecimento da necessidade de um olhar pormenorizado a este segmento da população mundial. (...) Sua preocupaçáo com uma linguagem sensível às questóes de gênero cuidou de manter evidente a perspectiva da igualdade entre homens e mulheres, para além do implícito no homem como significante de humanidade. Nos anos seguintes, seus esforços na elaboração de diagnósticos e documentos foram fundamentais à consolidação de uma perspectiva de gênero ao conjunto dos direitos humanos.

A CSW foi importante na construçâo da DUDH, proclamada dois anos depois, em 1948, pelos Estados-membros da ONU, por defender a inserção da igualdade de direitos entre homens e mulheres no principal documento da organização. A declaraçáo resguarda em seus artigos iniciais a liberdade e a igualdade em dignidade e direitos, sem distinção de sexo ou de qualquer outra situação. A Comissão sobre o Status da Mulher também foi responsável por organizar a Convenção dos Direitos Políticos das Mulheres (1952), a Convenção sobre a Nacionalidade de Mulheres Casadas (1957) e a Convenção sobre Consentimento para o Matrimônio, Idade Mínima para Casamento e Registros de Casamentos (1962), eventos importantes por considerarem os direitos das mulheres como direitos fundamentais. 
QUADRO 1

Fases de atuação ${ }^{8}$ da ONU na temática dos direitos humanos das mulheres

\begin{tabular}{|c|c|c|}
\hline Fase & Período & Marcos \\
\hline 1 a fase & 1945 a1962 & $\begin{array}{l}\text { Carta das Nações Unidas (1945), criação da Comissão sobre o Status da Mulher (1946), Decla- } \\
\text { ração Universal dos Direitos Humanos (1948), Convenção Interamericana sobre a Concessão dos } \\
\text { Direitos Civis à Mulher (1948), Convenção sobre os Direitos Políticos da Mulher (1953), Convenção } \\
\text { sobre a Nacionalidade de Mulheres Casadas (1957), Convenção sobre Consentimento para o } \\
\text { Matrimônio, Idade Mínima para Casamento e Registros de Casamentos (1962). }\end{array}$ \\
\hline 2 a fase & 1963 a1975 & $\begin{array}{l}\text { Convenção para a Eliminação de Todas as Formas de Discriminação Racial (1965), Pacto Interna- } \\
\text { cional de Direitos Civis e Políticos (1966), Pacto Internacional de Direitos Econômicos, Sociais e } \\
\text { Culturais (1966) e I Conferência Mundial da Mulher (1975). }\end{array}$ \\
\hline 3 a fase & 1976 a1985 & $\begin{array}{l}\text { II Conferência Mundial da Mulher (1980), III Conferência Mundial da Mulher (1985) e Convenção } \\
\text { sobre a Eliminação de Todas as Formas de Discriminação contra a Mulher (1979) }\end{array}$ \\
\hline 4 fase & Década de 1990 & $\begin{array}{l}\text { Declaração e Programa de Ação de Viena (1993), Convenção Interamericana para Prevenir, Punir } \\
\text { e Erradicar a Violência contra a Mulher, Convenção de Belém do Pará (1994) e IV Conferência } \\
\text { Mundial da Mulher (1995). }\end{array}$ \\
\hline 5 a fase & 2000 a 2015 & $\begin{array}{l}\text { Protocolo Facultativo à Convenção sobre a Eliminação de Todas as Formas de Discriminação contra } \\
\text { a Mulher (2000) e Objetivos de Desenvolvimento do Milênio (2000). }\end{array}$ \\
\hline $\begin{array}{l}\text { Fase } \\
\text { atual }\end{array}$ & 2015 a 2030 & Agenda 2030 para o Desenvolvimento Sustentável e os Objetivos de Desenvolvimento Sustentável. \\
\hline
\end{tabular}

Elaboração: Diretoria de Estudos e Políticas Sociais (Disoc) do Ipea.

A segunda fase de atuação da ONU no campo dos direitos das mulheres começa em 1963 e vai até 1975, sendo marcada pelo processo de descolonização e consequente ampliação do número de Estados-membros da organização, com o surgimento de novas agendas na ordem internacional e a incorporação, ao centro do debate onusiano, das relaçóes econômicas entre países ricos e países em desenvolvimento. Problemas até então compreendidos como exclusivos do "terceiro mundo" entraram na agenda, assim como a importância dos papéis sociais desempenhados pelas mulheres, agentes fundamentais de mudanças que acarretariam o desenvolvimento social e econômico das sociedades (Boutros-Ghali, 1996, p. 22).

Segundo Newton de Oliveira Lima (2011) e Sven Peterke, em 1963, a CSW foi encarregada de elaborar uma declaração sobre a eliminação da discriminação contra mulheres, cuja iniciativa de ser escrita data de 1946, embora nessa época não tenha sido levada adiante. Esse trabalho resultou na Declaração sobre a Eliminação da Discriminação contra a Mulher, ${ }^{9}$ aprovada em 1967, que conseguiu integrar diferentes demandas dos movimentos feministas da época. Esse documento, porém, tinha caráter recomendatório, e não coercitivo.

$\mathrm{O}$ ano seguinte, marcado pelos vinte anos da DUDH, foi escolhido pela ONU como o "Ano dos Direitos Humanos". Na AGNU de 1968, como aponta Guarnieri (2010, p. 7), foi recomendado que "os Estados-membros deveriam voltar

8. As fases de atuação da ONU não são mutuamente excludentes, uma vez que alguns processos ocorrem simultaneamente. É o caso da Conferência de Durban, que ocorreu no século XXI, mas que também pode ser vista como pertencente à fase 4. 9. Esse documento foi proclamado pela Assembleia Geral a ONU na Resolução no 2.263 (XXII), de 7 de novembro de 1967. Para mais informações, ver UN (1967). 
seus trabalhos para a temática dos direitos humanos e para os tratados e convençóes ainda pendentes de ratificação". Essa autora acentua que, entre as resoluçóes adotadas ao final da Conferência de Teerã, que ocorrera naquele ano, "constava como objetivo a elaboração de programa voltado para o progresso das mulheres no mundo moderno" (Guarnieri (2010, p. 7). Nesse contexto, a ONU criou estratégias para ampliar a assistência legal e garantir igualdade às mulheres, especialmente nos países em que estas não acessavam direitos sociais e individuais. Apenas em 1972, a AGNU, "consistindo principalmente de representantes masculinos, resolveu pedir à Comissão sobre o Status das Mulheres para usar a Declaração sobre a Eliminação da Discriminação contra a Mulher como base de trabalhos preparatórios para uma convenção internacional" (Lima e Peterke, 2011, p. 7).

Como resultado, 1975 foi proclamado como o Ano Internacional da Mulher pela AGNU. ${ }^{10}$ A CSW realizou em 1975, na capital do México, a I Conferência Mundial sobre as Mulheres, com o objetivo de promover a agenda contra as discriminaçôes enfrentadas pelas mulheres, que teve como tema a eliminação da discriminação da mulher e seu avanço social.

As demais fases de atuação da ONU e os resultados destas advindos serão abordados mais detalhadamente nas próximas seçóes. Cabe destacar brevemente, apenas, que foi na terceira fase, conhecida como "Década das Mulheres" (entre 1976 e 1985), que aconteceram a Conferência de Copenhague (1980) e a Conferência de Nairóbi (1985), conferências mundiais das mulheres, e foi aprovada a CEDAW, em 1979. A quarta fase inicia-se em 1986 e vai até o final da década de 1990, período marcado pelas várias conferências sociais ${ }^{11}$ organizadas pela $\mathrm{ONU}$, com destaque para a IV Conferência Mundial sobre a Mulher, em Pequim, em 1995. A quinta fase começou em 2000, com a adoção dos ODMs pelos Estados-membros da ONU, e a fase atual começou oficialmente em 2015, quando os Estados-membros da organização adotaram os dezessete ODS globais que compóem a Agenda 2030 para o Desenvolvimento Sustentável.

\footnotetext{
10. Em 1975, a ONU passou a celebrar em 8 de março o Dia Internacional das Mulheres. Em dezembro de 1977, a Assembleia Geral da ONU adotou resolução recomendando aos países-membros que adotassem anualmente um dia para prestar homenagem e celebrar os direitos das mulheres. Para mais informações, ver Unesco (1979).

11. A década de 1990 ficou conhecida como "A Década das Conferências Mundiais da ONU". As conferências de maior destaque foram: a Cúpula Mundial sobre a Criança, em 1990 (Nova York, Estados Unidos); a Conferência das Nações Unidas sobre Meio Ambiente e Desenvolvimento (Rio-92), em 1992 (Rio de Janeiro, Brasil); a Conferência Mundial sobre os Direitos Humanos, em 1993 (Viena, Áustria); a Conferência Internacional das Nações Unidas sobre População e Desenvolvimento, em 1994 (Cairo, Egito); a Conferência Mundial sobre a Mulher (Pequim, China) e a Cúpula Mundial sobre o Desenvolvimento Social, ambas em 1995 (Copenhague, Dinamarca); e a Conferência das Nações Unidas sobre Assentamentos Humanos, em 1996 ( Istambul, Turquia). Ainda que a III Conferência Mundial de Combate ao Racismo, Discriminação Racial, Xenofobia e Intolerância Correlata (Durban, África do Sul) tenha ocorrido já em 2001, também pode ser listada aqui pela natureza semelhante às demais elencadas.
} 


\section{AS CONFERÊNCIAS MUNDIAIS SOBRE AS MULHERES E A CEDAW}

A I Conferência Mundial sobre as Mulheres, realizada em 1975, no México, foi um marco por envolver as mulheres na criação, no desenvolvimento e na plena participação nas açóes políticas, diferente do que era praxe na esfera internacional, que considerava as mulheres receptoras das açóes políticas. Sob o lema igualdade, desenvolvimento e paz, participaram da conferência 133 delegaçóes, das quais 113 lideradas por mulheres. ${ }^{12}$ Paralelamente à conferência, ocorreu o Fórum das Organizaçôes não Governamentais, evento independente realizado por representantes de ONGs, com o mesmo tema da conferência. $O$ fórum contou com a participação de mais de 4 mil ativistas e conseguiu consolidar-se como espaço estratégico de discussão para ONGs e representantes da sociedade civil nas conferências seguintes.

O Plano de Ação para a Implementação dos Objetivos do Ano Internacional das Mulheres, ${ }^{13}$ que resultou dos trabalhos das delegaçóes na conferência, foi o primeiro programa mundial de compromissos especificamente voltados para as mulheres a serem adotados pelos governos, e trazia como objetivos: $i$ ) eliminar a discriminação contra mulheres; ii) garantir plena igualdade com homens; e iii) promover açóes para a participação das mulheres na cena social, política e econômica de seus respectivos países e internacionalmente, com foco no desenvolvimento e na paz mundial. O plano, composto por 219 tópicos, orientou atuaçóes nacionais e internacionais nas seguintes áreas: cooperação internacional e fortalecimento da paz internacional; participação política; educação; desenvolvimento; saúde e nutrição; população; habitação e instalaçóes correlatas; família; e outras questôes sociais. Esse documento previa a realização de outras duas conferências e ações para o progresso feminino nos dez anos seguintes, período declarado pela ONU como a "Década da Mulher" (1975-1985). Interessante notar como o Brasil se posicionou de forma progressista sobre os resultados da Conferência Mundial sobre as Mulheres em seu relatório final, demandando mais compromissos e lamentando o pouco envolvimento das organizaçóes de mulheres presentes no encontro. ${ }^{14}$

No Brasil, as iniciativas da ONU e as açóes resultantes da Conferência do México foram bem recebidas pelos movimentos organizados de mulheres, que

12. A delegação brasileira na Conferência Mundial do Ano Internacional da Mulher foi chefiada pelo então embaixador do Brasil no México Lauro Escorel Rodrigues De Morais. Participaram como delegadas Bertha Lutz, Dorina Nowill, Maria Alice Silva, Carmem Barroso, Heleieth Saffioti, entre outras. Para mais informações, ver os links disponíveis em: <http:// bit.ly/36Hotlb> e <http://bit.ly/2K2OSjX>.

13. Os planos de ação das conferências mundiais de mulheres são guias de caráter recomendatório, não coercitivo e que requer compromisso por parte dos Estados-membros para ser efetivado. Na prática, esse fator limita os efeitos reais e 0 acesso à igualdade material, uma vez que esses planos não garantem acessibilidade aos direitos humanos das mulheres de forma imediata (Tomazoni e Gomes, 2015).

14. Conforme disposto no relatório, o Brasil defendeu que "o plano teria sido mais eficaz se tivesse estabelecido mais prioridades. Foi lamentável que o tempo não tivesse permitido uma maior participação de organizações não governamentais em seu planejamento e formulação" (tradução das autoras). Para mais informações, ver UN (1976a). 
muitas vezes atuavam clandestinamente. ${ }^{15} \mathrm{Um}$ dos resultados da Conferência do México foi a Convenção sobre a Eliminação de Todas as Formas de Discriminação contra as Mulher. Elaborada pela ONU em 1979, a convenção é dedicada à proteção e à promoção dos direitos humanos das mulheres, e foi pensada como maneira de comprometer os Estados-membros, com açóes que eliminassem a discriminação contra as mulheres. A CEDAW é considerada marco histórico nos tratados internacionais de direitos humanos porque aborda, a partir de uma perspectiva global, os direitos civis, econômicos, políticos e sociais das mulheres. No art. 1o da convenção, a "discriminação contra a mulher" é definida como

Toda a distinção, exclusão ou restrição baseada no sexo e que tenha por objeto ou resultado prejudicar ou anular o reconhecimento, gozo ou exercício pela mulher, independentemente de seu estado civil, com base na igualdade do homem e da mulher, dos direitos humanos e liberdades fundamentais nos campos político, econômico, social, cultural e civil ou em qualquer outro campo (ONU, 1979, p. 2).

A convenção está fundamentada na dupla obrigação de eliminar a discriminação e assegurar a igualdade entre homens e mulheres (Pimentel e Piovesan, 2004) e é influenciada pelas vertentes repressivo-punitiva e positivo-promocional. ${ }^{16} \mathrm{~A}$ CEDAW é composta por trinta artigos, divididos em seis partes, conforme o quadro 2.

QUADRO 2

Composição da CEDAW

\begin{tabular}{|l|l|}
\hline Parte & \multicolumn{1}{c|}{ Conteúdo } \\
\hline $\begin{array}{l}\text { Parte I } \\
\text { (Arts. 10 ao 60) }\end{array}$ & $\begin{array}{l}\text { Definições, obrigações de natureza geral e criação de medidas especiais de caráter temporário (ações afirmati- } \\
\text { vas), inclusive de caráter legislativo, para atingir igualdade. }\end{array}$ \\
\hline $\begin{array}{l}\text { Parte II } \\
\text { (Arts. 70 ao 9o) }\end{array}$ & $\begin{array}{l}\text { Garantias de igualdade relativas à participação na vida política e pública; e direitos iguais para adquirir, mudar } \\
\text { ou conservar a nacionalidade. }\end{array}$ \\
\hline $\begin{array}{l}\text { Parte III } \\
\text { (Arts. } 10 \text { a 14) }\end{array}$ & $\begin{array}{l}\text { Garantias de igualdade na esfera social e econômica; acesso à educação, ao mercado de trabalho e ao sistema } \\
\text { de saúde; e medidas específicas para as mulheres que vivem nas zonas rurais. }\end{array}$ \\
\hline $\begin{array}{l}\text { Parte IV } \\
\text { (Arts. 15 a 16) }\end{array}$ & $\begin{array}{l}\text { Garantia de igualdade para firmar contratos e administrar bens, bem como tratamento igual em todas as etapas } \\
\text { do processo nas cortes de justiça e nos tribunais; e direito à liberdade de movimento e à liberdade de escolha de } \\
\text { residência e domicílio. }\end{array}$ \\
\hline $\begin{array}{l}\text { Parte V } \\
\text { (Arts. 17 a 22) }\end{array}$ & $\begin{array}{l}\text { Cria mecanismos de controle internacional (Comitê da CEDAW); e estabelece que Estados-partes deverão } \\
\text { submeter relatório quadrienal com os esforços feitos para eliminar a discriminação contra as mulheres. }\end{array}$ \\
$\begin{array}{l}\text { Parte VI } \\
\text { (Arts. 23 a 30) }\end{array}$ & \begin{tabular}{l} 
Regula as formalidades da vigência do tratado internacional com os Estados-partes. ${ }^{1}$ \\
\hline
\end{tabular} \\
\hline
\end{tabular}

Elaboração: Disoc/lpea.

Nota: ${ }^{S}$ São denominados Estados-partes cada um dos países signatários dessa convenção.

15. A partir da década de 1960, os Estados Unidos e a Europa Ocidental vivem período de intensa efervescência cultural e política. Neste contexto, grupos que questionavam a ordem estabelecida, como os movimentos estudantis, feministas e negros ganharam força.

16. Segundo Piovesan (2005), a vertente repressiva-punitiva tem por objetivo punir, proibir e eliminar a discriminação, enquanto a vertente promocional tem por objetivo promover, fomentar e avançar a igualdade. 
A CEDAW tornou-se referência para os Estados signatários da convenção na criação de políticas públicas que considerem os direitos das mulheres e figura entre os instrumentos internacionais de direitos humanos que possuem mais adesão. ${ }^{17}$ A estratégia utilizada para sua popularização foi a de conseguir muitos países signatários, ainda que a adesão não necessariamente fosse feita na integralidade da CEDAW. De fato, apesar da pretensa universalização, esse documento possui um alto número de reservas de caráter religioso, cultural e/ou legal feitas pelos Estadospartes. ${ }^{18}$ Ainda que os Estados estejam proibidos de realizar reservas incompatíveis ${ }^{19}$ com a convenção, esta situação acarreta diferentes níveis de comprometimento em relação à CEDAW, visto que "não cria as mesmas obrigaçóes para seus Estados-partes e muitos optaram por não aceitar várias provisões de grande importância para a efetiva proteção dos direitos da mulher" (Lima e Peterke, 2011, p. 11).

O Brasil foi um dos países que fez reservas ao assinar, em 1981, e ao ratificar, em 1984, a CEDAW. As reservas à convenção referiam-se aos artigos ${ }^{20}$ que concediam direitos iguais para homens e mulheres na legislação relativa ao casamento e às relaçóes familiares; ao direito das pessoas à liberdade de movimento; e à liberdade de escolha de residência e domicílio. À época, o Estado brasileiro justificou-se informando que essas disposiçôes eram contrárias à legislação nacional em vigor. Essas reservas apenas foram oficialmente retiradas com o Decreto Legislativo no $26 / 1994$.

Apesar das reservas, a CF/1988 reafirmou o princípio da igualdade entre homens e mulheres em seu art. 5을 inciso I, o que foi associado, por especialistas, aos efeitos da CEDAW no território brasileiro. A advogada Leila Linhares Barsted (1995) aponta que, além do Plano de Ação da Conferência do México, em 1975, a CEDAW foi particularmente importante para o fortalecimento das demandas feministas no Brasil. Como bem lembra a historiadora Celi Pinto (2010, p. 16), no Brasil, o "regime militar via com grande desconfiança qualquer manifestação de feministas, por entendê-las como política e moralmente perigosas”. A convenção ocorreu concomitantemente com o período de liberalização do regime militar e o consequente processo de redemocratização do país, e, com esses eventos, as demandas das feministas brasileiras passaram a ter "legitimidade em face de sua consonância com a nova perspectiva do direito internacional" (Barsted, 1995, p. 191). Conforme previsto no art. 18 da convenção, os Estados-partes comprometem-se a prestar contas, a cada quatro anos ou sempre que solicitados, das "medidas legislativas, judiciárias, administrativas ou outras que adotarem para tornarem efetivas as disposiçóes desta Convenção e sobre os progressos alcançados a esse

17. Atualmente, a CEDAW conta com 189 Estados-partes, conforme indicado no link disponível em: <http://bit.ly/205w2tJ>. 18. Para consultar as reservas, ver o link disponível em: <http://bit.ly/2Q0pBe2>.

19. 0 exame das reservas apresentadas depende dos outros Estados-partes, que podem protestar contra as reservas durante o processo de ratificação.

20. Art. 15, § 4, e art. 16, §1, alíneas "a", "c", "g" e "h". 
respeito (ONU, 1979, art. 18)”. A necessidade de apresentar esse relatório oficial na reunião da CEDAW, na sede da ONU, em Nova Iorque, diante de diversos outros países, constitui-se em coerção - ainda que de natureza simbólica - para os governos ali presentes.

Em 1980, aconteceu em Copenhague, na Dinamarca, a II Conferência Mundial sobre a Mulher, com o lema educação, emprego e saúde, cujo objetivo principal foi avaliar a implementação e atualizar o plano de ação elaborado em 1975, no México. Participaram do evento delegaçóes de 145 países, 135 ONGs e cerca de 7 mil representantes da sociedade civil, que estiveram presentes a mais um fórum paralelo. ${ }^{21}$ Sobre esse aspecto, Maria Angélica Breda Fontão (2011) observa que o fórum foi responsável por trazer o debate de temas que não estavam na pauta do evento oficial e abordou "questôes fundamentais para as mulheres como a escravidão sexual, o feminismo, a violência doméstica, apropriação de tecnologias, estudos sobre a mulher e o que significa o desenvolvimento na vida das mulheres" (op. cit., p. 29).

No processo de avaliação das metas, constatou-se que os avanços nos direitos das mulheres em relação ao que foi estabelecido na I Conferência Mundial sobre a Mulher ficaram aquém do esperado. A assinatura de atos internacionais progressistas e inclusivos sob a perspectiva de igualdade entre os sexos pelos Estados-membros não assegurava que as mulheres conseguiriam exercer de fato estes direitos, especialmente o direito à custódia dos filhos, à nacionalidade, à posse, à propriedade e à herança. ${ }^{22}$ Ao final da II Conferência sobre a Mulher, o Instituto Internacional de Pesquisa e Treinamento para a Promoçáo da Mulher (INSTRAW) foi convertido em organismo autônomo do Sistema ONU, e foi recomendada a realização da III Conferência Mundial sobre a Mulher para marcar o fim da "Década das Naçóes Unidas para a Mulher".

Assim, em 1985, teve lugar, em Nairóbi, a III Conferência Mundial sobre a Mulher, ${ }^{23}$ com o objetivo de analisar as açóes propostas nas conferências anteriores e estabelecer novas metas a partir do tema central: estratégias orientadas ao futuro para o desenvolvimento da mulher até o ano 2000. A conferência contou com a participação de 157 delegaçóes e 163 ONGs. O fórum de representantes da sociedade civil aconteceu paralelamente aos eventos oficiais e, dessa vez, contou com a participaçáo de cerca de 15 mil mulheres. Um resultado inicial da conferência foi a ampliação do Fundo Voluntário para a Década da Mulher. Criado em dezembro de 1976 para apoiar a promoção da igualdade entre homens e mulheres, a participação política, a segurança e o empoderamento das mulheres por meio

21. Ver o relatório final da II Conferência Mundial sobre as Mulheres (UN, 1980).

22. 0 programa de ação da segunda metade da "Década das Nações Unidas para a Mulher" está no primeiro capítulo do relatório final da II Conferência Mundial sobre as Mulheres (UN, 1980).

23. Ver o relatório final da III Conferência Mundial sobre as Mulheres (UN, 1985). 
de programas e vínculos com organizaçóes de mulheres nas principais regióes do mundo, o fundo foi transformado, ${ }^{24}$ durante a própria Conferência de Nairóbi, no Fundo de Desenvolvimento das Naçóes Unidas para a Mulher (UNIFEM), que atualmente faz parte da ONU Mulheres.

A ONU enviou aos Estados-partes, antes da III Conferência Mundial sobre a Mulher, questionário de avaliação das açôes realizadas pelos países signatários da CEDAW, com o objetivo de verificar o cumprimento da convençáo, os avanços e os impactos das açóes desenvolvidas, bem como os obstáculos que surgiram durante sua implementação. Barsted (1995, p. 4) informa que muitas “instituições de mulheres também apresentaram suas avaliaçóes que em muitos casos contrariavam as otimistas avaliações oficiais", e comprova que, além de os objetivos traçados não terem sido alcançados, houve perpetuação da discriminação e poucas mudanças no cotidiano das mulheres, especialmente no daquelas provenientes de países em desenvolvimento. Os resultados apresentados nos relatórios enviados pelos Estados signatários da CEDAW e nos "relatórios-sombra", produzidos por ONGs e pelo movimento de mulheres, ${ }^{25}$ foram utilizados como base para o diagnóstico realizado pela III Conferência Mundial sobre a Mulher e para a formulação de estratégias de ação para os quinze anos.

$\mathrm{Na}$ Conferência de Nairóbi, as demandas feministas, especialmente das mulheres negras, foram essenciais para o estabelecimento de açóes de enfrentamento ao racismo e para a ampliação dos direitos humanos das mulheres, por compreenderem que alguns elementos, ainda que não afetam exclusivamente as mulheres, as tornam socialmente mais vulneráveis. Ainda que a questão da diversidade das mulheres tenha aparecido em conferências e relatórios anteriores, foi apenas em Nairóbi que ganhou força e destaque. A percepção de que mulheres diferentes enfrentam desafios distintos ampliou a ideia de que "assuntos de mulheres" eram apenas aqueles relacionados à maternidade ou à violência, por exemplo, levando à adoção da abordagem no enfrentamento às discriminaçôes, que considera todos os assuntos como "assuntos de mulheres”. O plano de ação resultante, conhecido como Estratégias de Nairóbi, foi inovador em três aspectos: $i$ ) mencionar a violência contra a mulher; $i$ ) incluir as especificidades vivenciadas por mulheres em diferentes contextos; e iii) recomendar aos Estados-membros a criaçáo de mecanismos institucionais exclusivos no combate à discriminação contra as mulheres (Fontão, 2011).

24. Resolução 133 da 31ㄹ sessão da Assembleia Geral da ONU. A/RES/31/133, em 16 de dezembro de 1976 (UN, 1976b). 25. Antes da III Conferência Mundial sobre as Mulheres, a ONU enviou aos Estados-partes signatários da CEDAW um questionário de avaliação das ações promovidas naquele Estado. Nesse questionário, os países deveriam apontar as ações desenvolvidas, seus impactos, os obstáculos que surgiram para sua implementação e os avanços conseguidos. Em geral, os países conferiam neste documento oficial ênfase às avaliações positivas das ações que ocorreram em seus países, sendo, em muitos casos, demasiadamente "otimistas". Por sua vez, ONGs e o movimento organizado de mulheres também responderam ao mesmo questionário. Foi o chamado "relatório sombra", envido por essas instituições/ segmentos que, ao contrário, conferiam ênfase aos desafios, apresentando uma visão menos "otimista" e mais próxima da realidade no que se refere aos atos e ações realizados pelos Estados após as conferências e a CEDAW. 
No Brasil, em 1985, a chapa composta por Tancredo Neves e José Sarney foi escolhida pelo colégio eleitoral em eleiçôes indiretas, o que marcou o rompimento oficial do país com o regime militar. No processo de reconstruçáo da democracia brasileira, o direito à livre expressão de pensamento e à liberdade de imprensa foi fundamental para a rearticulação e o avanço dos movimentos sociais, incluindo-se as reivindicações das mulheres. O fato de o Brasil voltar a ser um Estado democrático de direito e estar comprometido com os atos internacionais e os planos de ação das conferências realizadas na Década das Mulheres foi importante para a criação de açóes afirmativas voltadas para as mulheres. Nesse contexto, Heleieth Saffioti (1995) lembra que a pressão dos movimentos de mulheres foi fundamental para os primeiros passos do Estado brasileiro nessa arena, com a criação, em 1985, da primeira delegacia da mulher do país, localizada em São Paulo, e do Conselho Nacional dos Direitos da Mulher (CNDM), responsável por articular as demandas das mulheres nas instâncias governamentais.

\section{A DÉCADA DAS CONFERÊNCIAS SOCIAIS DA ONU}

A partir de meados da década de 1980, teve início a transformação do contexto sociopolítico mundial, até então dominado por duas potências: Estados Unidos e União das Repúblicas Socialistas Soviéticas (URSS). Com a desagregação da União Soviética e o consequente fim da Guerra Fria, a geopolítica mundial passou por reconfiguração, e teve início uma "nova ordem internacional", em que temas antes considerados menores começaram a ganhar destaque. A segurança global passou a ser compreendida a partir de perspectiva mais ampla, trazendo à tona temas como meio ambiente, desenvolvimento, direitos humanos, população e situação das mulheres (Guarnieri, 2010). Considerando esse novo contexto, a ONU convocou, no decorrer dos anos 1990, os países-membros para uma série de conferências mundiais, com o objetivo de promover uma agenda social global que conseguisse avançar nessas temáticas. ${ }^{26}$ Embora a principal conferência sobre direitos das mulheres tenha sido a Conferência de Pequim, as outras conferências também promoveram avanços nessa temática, tal como se verá a seguir.

\subsection{Conferência das Nações Unidas sobre Meio Ambiente e Desenvolvimento}

A Conferência das Naçóes Unidas sobre Meio Ambiente e Desenvolvimento inaugurou o ciclo de conferências organizadas pela ONU. O evento reuniu delegaçóes de 175 países e cerca de 30 mil participantes, entre representantes governamentais e não governamentais, com o objetivo de estabelecer compromisso global com o

26. A agenda social da ONU foi composta pelas seguintes conferências: Conferência das Nações Unidas sobre Meio Ambiente e Desenvolvimento (Rio de Janeiro, 1992); Conferência Mundial sobre os Direitos Humanos (Viena, 1993); Conferência Mundial sobre População e Desenvolvimento (Cairo, 1994); Cúpula Mundial sobre o Desenvolvimento Social (Copenhague, 1995); IV Conferência Mundial sobre as Mulheres (Pequim, 1995); e II Conferência das Nações Unidas sobre Assentamentos Humanos ou Habitat II (Istambul, 1996). 
desenvolvimento sustentável. Em 1991, foi realizado o I Congresso Mundial de Mulheres por um Planeta Saudável, evento preparatório para a Rio-92, que contou com a participação de mulheres de diferentes países e produziu a plataforma de ação Agenda 21 de Ação das Mulheres.

Na Rio-92, a participação de mulheres na pressão de movimentos feministas e ONGs conseguiu incluir nos documentos oficiais do evento propostas específicas sobre as mulheres e o desenvolvimento sustentável. Sobre esse aspecto, a pesquisadora Sonia Corrêa (2018, p. 6) adverte que, na Declaração do Rio, que, com a Agenda 21 , foi o principal documento da conferência, ${ }^{27}$ a tensão deu-se em torno do direito à saúde reprodutiva e ao planejamento familiar, temas que não entraram na pauta, ainda que as feministas procurassem incorporar tais discussōes a partir de visão mais ampla do que seria incorporado ao tema do meio ambiente.

A Agenda 21 propôs em seu programa bases para a ação, os objetivos, as atividades e os meios de implementação para atingir padrão de desenvolvimento aliado à responsabilidade ambiental, e citou as mulheres em diversos momentos, especialmente nos capítulos sobre saúde, alimentação e consumo. O capítulo 24 da agenda (Medidas mundiais em favor da mulher para conseguir um desenvolvimento sustentável e equitativo) foi dedicado às mulheres e teve como objetivo melhorar a participação feminina nos processos decisórios de ordenação dos ecossistemas e na luta contra a degradação ambiental. Ademais, propôs medidas que os Estados deveriam desenvolver para garantir essas metas, conforme informa a pesquisadora Emma Siliprandi (2009, p. 84). Por sua vez, o princípio 20 da Declaração do Rio proclamou que "as mulheres desempenham um papel fundamental na ordenação do meio ambiente e no desenvolvimento. Portanto, é imprescindível contar com a sua plena participação para obter o desenvolvimento sustentável” (1992).

\subsection{Conferência Mundial de Direitos Humanos}

Em 1993, aconteceu em Viena a Conferência Mundial de Direitos Humanos. O evento contou com a participação de delegaçóes representantes de 171 Estados, centenas de ONGs participando do fórum paralelo ao evento e cerca de $10 \mathrm{mil}$ participantes. Em Viena, as reivindicaçôes das mulheres ganharam destaque. A intensa pressáo dos movimentos de mulheres presentes na conferência e o contexto político favorável ao reconhecimento de demandas de grupos historicamente minoritários colaboraram para o reconhecimento dos direitos das mulheres como direitos humanos no documento final adotado pela conferência. Para Guarnieri (2010), um dos efeitos da conferência foi a Declaraçáo sobre a Eliminação da Violência contra a Mulher, adotada pela AGNU como um tipo de "reforço" à CEDAW, no

27. A Declaração do Rio é a declaração oficial do evento, com uma série de propostas que deveriam ser adotadas pelos países. A Agenda 21 é uma espécie de instrumento para o planejamento dessas propostas. Esses documentos estão em ONU (1992) e no link disponível em: <https://is.gd/3FyFis>. 
mesmo ano em que a conferência foi realizada. Na própria Declaração e Programa de Ação de Viena, é expresso que a ONU deveria "promover a meta da ratificação universal por parte de todos os Estados, da Convenção sobre a Eliminação de Todas as Formas de Discriminação contra a Mulher até o ano 2000" (ONU, 1993, p. 17).

Consta da Declaração e Programa de Ação de Viena que

Os direitos humanos das mulheres e das meninas são inalienáveis e constituem parte integral e indivisível dos direitos humanos universais. A plena participaçáo das mulheres, em condiçōes de igualdade, na vida política, civil, econômica, social e cultural nos níveis nacional, regional e internacional e a erradicaçáo de todas as formas de discriminaçáo, com base no sexo, são objetivos prioritários da comunidade internacional (...). Deve-se estimular formas e meios para solucionar a questáo do número particularmente elevado de reservas à Convençáo. Entre outras medidas, o Comitê para Eliminação da Discriminação contra a Mulher deve continuar examinando as reservas à Convenção. Os Estados são instados a retirar todas as reservas contrárias ao objeto e propósito da Convenção ou que de outra maneira são incompatíveis com o direito internacional convencional (op. cit., p. 5).

O Programa de Ação de Viena contribuiu para os direitos humanos das mulheres em outros dois pontos fundamentais. O primeiro foi o reconhecimento de que "a violência e todas as formas de abuso e exploração sexual, incluindo o preconceito cultural e o tráfico internacional de pessoas, são incompatíveis com a dignidade e valor da pessoa humana e devem ser eliminadas" (op. cit., p. 5). O segundo tópico foi reafirmar os direitos das mulheres como direitos humanos universais, interdependentes, inalienáveis e indivisíveis, com o reconhecimento do direito à igualdade para a construçáo de sociedades mais justas.

\subsection{Conferência Internacional sobre População e Desenvolvimento}

Em 1994, foi realizada a Conferência Internacional sobre População e Desenvolvimento (CIPD) ${ }^{28}$ na cidade do Cairo. Também conhecida como Cairo 94, essa conferência reuniu representantes de cerca de 180 governos e 1,2 mil ONGs. O programa de ação (ONU, 1994) resultante foi inovador ao propor objetivos e açóes orientadoras de políticas públicas que reconheceram a importância da igualdade entre homens e mulheres, fundamental para a promoção do bem-estar humano. Na apresentação do Relatório da Conferência Internacional sobre População e Desenvolvimento (op. cit.), a representante da ONU, Tania Patriota, informou que, na Conferência Cairo 94, a comunidade internacional chegou a um consenso sobre três metas que deveriam ter sido alcançadas até 2015: i) a redução da mortalidade infantil e materna; ii) acesso à educação, especialmente para as meninas; e iii)

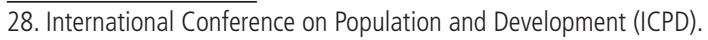


acesso universal a uma ampla gama de serviços de saúde reprodutiva, incluindo-se o planejamento familiar.

Corrêa (2018) adverte sobre a importância que a categoria gênero ganhou na Conferência do Cairo, terminologia legitimada, definida à época como "camada cultural sobreposta ao sexo biológico e que ordena papéis e esferas do masculino e do feminino, tal como pensado por autoras como Caroline Moser, Gita Sen e Nail" (op. cit., p. 8). No programa de ação da conferência, os direitos humanos de mulheres e meninas receberam destaque como direitos individuais e como conjunto de direitos que contribui para melhorar a qualidade de vida de toda a sociedade. Foi enfatizada a necessidade de criar mecanismos capazes de prevenir e eliminar a violência contra mulheres e outras práticas, cujo objetivo é subalternizar as mulheres a partir de construções sociais de gênero. Em seu princípio 4, o Relatório da Conferência Internacional sobre População e Desenvolvimento orienta que "o progresso na igualdade e equidade dos sexos, a emancipação da mulher, a eliminação de toda espécie de violência contra ela e a garantia de poder ela própria controlar sua fecundidade são pedras fundamentais de programas relacionados com população e desenvolvimento" (ONU, 1994, p. 42).

Durante a Conferência do Cairo, em 1994, foi estabelecido novo paradigma no debate sobre populaçôes. A questão demográfica e os direitos reprodutivos foram inseridos no âmbito dos direitos humanos, reivindicação antiga do movimento de mulheres. No princípio 8 do programa de ação, consta que "toda pessoa tem direito ao gozo do mais alto padrão possível de saúde física e mental" (op. cit., p. 43), e que os Estados deviam assegurar o acesso universal aos serviços de assistência médica relacionados à saúde reprodutiva - que inclui saúde sexual e planejamento familiar - sem qualquer forma de coerção. O programa foi inovador ao vincular a questão demográfica e populacional e o desenvolvimento econômico aos direitos reprodutivos no âmbito dos direitos humanos.

Segundo Jefferson Drezett e Daniela Pedroso (2012, p. 36), foi na CIPD de 1994 que "os países participantes reconheceram o aborto inseguro como grave problema de saúde pública, comprometendo-se, nas circunstâncias que não contrariem a lei, em garantir acesso ao aborto em condiçóes médicas seguras”. $\mathrm{O}$ acesso a procedimentos seguros, realizados por profissionais capacitados em serviços de saúde qualificados, previne mortes maternas e sequelas causadas pelo aborto inseguro (op. cit.). Donald Sawyer (2019, p. 7) informa que algumas contribuições brasileiras foram fundamentais para o sucesso da CIPD, entre as quais:

uma definição dos princípios que permitiu o consenso de todos os países presentes na conferência, com respeito pleno aos valores religiosos e éticos, de um lado, e o pluralismo, de outro e aborto em casos e circunstâncias em que não estavam contra a lei, já que a linguagem "aborto legal” era inadmissível. 


\subsection{Cúpula Mundial para o Desenvolvimento Social}

A Cúpula Mundial para o Desenvolvimento Social ocorreu em 1995, em Copenhague, na Dinamarca, e, diferentemente das outras conferências da década de 1990, não teve precedentes, tornando-se o primeiro grande evento internacional sobre o tema desenvolvimento social (Alves, 1997) e bem-estar humano de todos. $\mathrm{Na}$ Cúpula de Copenhague, o conceito de desenvolvimento social, que não constava originalmente na Carta das Naçôes Unidas (ONU, 1994), passou a ter significado humanista, definido na Declaração de Copenhague ${ }^{29}$ como indispensável "para a consecução e a manutençáo da paz e da segurança”" (ONU, 1995b) e como conceito que somente será atingido em situaçóes de paz, segurança e respeito aos direitos humanos e das liberdades fundamentais.

Entre os compromissos presentes nos documentos finais, constam promover capacitaçóes e acesso ao pleno emprego de homens e mulheres, bem como à igualdade e equidade entre gênero e garantia da promoção da participação das mulheres na vida social, política, econômica e cultural dos países. A Cúpula de Copenhague proclamou o papel decisivo das mulheres na luta contra a pobreza e o desemprego. A declaração e seu respectivo plano de ação mantiveram as conquistas adquiridas na Conferência de Viena e na Conferência do Cairo (Guarnieri, 2010, p. 17), que destacaram a igualdade entre homens e mulheres nos dez compromissos presentes na Declaraçáo dos Chefes de Estado e de Governo (Alves, 1997).

\subsection{Conferência Mundial sobre a Mulher}

Em 1995, foi realizada em Pequim a IV Conferência Mundial Sobre a Mulher, resultado da avaliação dos relatórios da CSW que apontavam para poucos avanços em direção à paridade entre homens e mulheres desde o estabelecimento da Década das Mulheres, em 1975. Conhecida como Conferência de Pequim, a conferência foi o maior fórum de discussão já organizado pela ONU e reuniu aproximadamente 50 mil pessoas, das quais mais de dois terços eram mulheres. Considerada em conjunto com o fórum paralelo não governamental de Huairou, reunido imediatamente antes do evento, nos arredores da capital chinesa, a Conferência de Pequim trouxe nova agenda para o campo em disputa, uma vez que, além dos direitos das mulheres definidos anteriormente, foi reivindicada a efetivação dos compromissos assumidos, por meio da implementação de políticas públicas.

A Conferência de Pequim encerrou um ciclo de conferências internacionais, e suas propostas abordaram temáticas que foram anteriormente discutidas nas reuniôes que ocorreram em Cairo, Viena e Copenhague. Em todos esses encontros, foram propostas açóes que reconheceram as mulheres como sujeitos de direitos e propagaram a equidade entre homens e mulheres. Em Pequim, as açôes a respeito

29. Disponivel em:<https://bit.ly/2XitRJa>. Versão em português disponível em: <http://bit.ly/2RqWsJn>. 
dos direitos humanos das mulheres resultantes das conferências anteriores foram fortalecidas, o que resultou em uma espécie de "consenso mundial" sobre direitos das mulheres, algo até então inédito e que deu destaque à questão.

No ciclo de conferências da década de 1990, inclusive na IV Conferência Mundial sobre a Mulher, novos elementos foram visibilizados, singularidades foram expostas e diversidades ganharam espaço nas demandas das mulheres. As mulheres negras foram essenciais no processo de ampliação da agenda global de combate ao sexismo e ao racismo, como defendem Ribeiro (1995) e Carneiro (2002 apud Pinheiro, 2019, p. 7).

Os tensionamentos provocados pelas mulheres negras referiam-se tanto à agenda específica das mulheres - desvelando as dinâmicas do racismo inscritas na composiçáo das questóes que singularizam os direitos humanos das mulheres e expandindo aos direitos humanos das mulheres negras - quanto ao entrecruzamento das dimensóes de gênero e raça nas agendas associadas a demografia, desenvolvimento sustentável, segurança e paz, habitaçáo, entre outras.

A Plataforma de Ação e a Declaração de Pequim (ONU, 1995), documentos que resultaram da conferência, consolidaram avanços jurídicos, acúmulo de conhecimentos e aprendizados adquiridos ao longo de cinco décadas no que tange à igualdade das mulheres. Composta por doze grandes áreas, a plataforma busca ser o mais abrangente possível, abordando os seguintes temas: $i$ ) mulheres e pobreza; ii) educação e capacitação de mulheres; iii) mulheres e saúde; iv) violência contra as mulheres; $v$ ) mulheres e conflitos armados; vi) mulheres e economia; vii) mulheres no poder e na liderança; viii) mecanismos institucionais para o avanço das mulheres; $i x$ ) direitos humanos das mulheres; $x$ ) mulheres e a mídia; $x i$ ) mulheres e meio ambiente; e xii) direitos das meninas.

A Plataforma de Ação de Pequim é um guia de ação construído para servir como parâmetro para os Estados-membros na construção de políticas voltadas para mulheres, o qual consagrou "três inovaçóes dotadas de grande potencial transformador na luta pela promoçáo da situação e dos direitos da mulher: o conceito de gênero, a noção de empoderamento e o enfoque da transversalidade" (ONU, 1995, p. 149). A inclusão do conceito de gênero permitiu transitar de análise baseada no aspecto biológico para compreensão que evidencia a natureza relacional das hierarquias sociais entre homens e mulheres, e reflete sobre padrôes culturais sexistas que estão naturalizados em diversas sociedades. O empoderamento foi incluído para realçar a importância do controle das mulheres sobre seu desenvolvimento, as prioridades e os processos de tomadas de decisão, nos quais o governo e a sociedade criariam condiçóes para apoiá-las nesse processo. A transversalidade de gênero (gender mainstreaming) surgiu como metodologia para açóes governamentais, com o intuito de realizar diagnósticos para execução de políticas públicas que considerassem necessidades de homens e mulheres, acolhendo ambos igualmente. ${ }^{30}$ 


\subsection{Convenção de Belém do Pará: Convenção Interamericana para Prevenir, Punir e Erradicar a Violência contra a Mulher}

Outro importante marco internacional para os direitos das mulheres, em especial no que se refere ao enfrentamento da violência contra as mulheres, é a Convenção Interamericana para Prevenir, Punir e Erradicar a Violência contra a Mulher, também conhecida como Convenção de Belém do Pará. ${ }^{31}$ Essa convenção foi adotada, em junho de 1994, pela Assembleia Geral da Organizaçáo dos Estados Americanos (OEA), organismo regional que integra o Sistema ONU, tendo sido ratificada pelo Brasil em 1995. Ao ratificar a convenção, o Brasil - e os demais países que assim agiram - comprometeu-se a adotar açóes para prevenir, punir e erradicar a violência contra mulheres no âmbito dos poderes Executivo, Legislativo e Judiciário (Pimentel e Pandjiarjian, 2000).

A Convenção de Belém do Pará determina os mecanismos interamericanos de proteção às mulheres, aponta direitos garantidos, designa os deveres dos Estados participantes, reconhece a categoria gênero e define violência contra a mulher como "qualquer ato ou conduta baseada nas diferenças de gênero que cause morte, dano ou sofrimento físico, sexual ou psicológico à mulher, tanto na esfera pública quanto na esfera privada" (Brasil, 1995). No Guia para aplicação da Convenção de Belém do Pará, ${ }^{32}$ publicado em 2014, a secretária executiva da Comissão Interamericana de Mulheres (CIM) entre 1986 e 1996, Linda Poole, afirma que

A Convenção de Belém do Pará contribuiu para aumentar a conscientização acerca da gravidade do problema da violência contra a mulher e sobre a responsabilidade dos Estados de adotar medidas concretas para prevenir e erradicar a violência. Cria um sistema de direitos para garantir uma vida livre de violência contra as mulheres e um sistema de obrigaçôes para os Estados respeitarem, garantirem esses direitos e agirem com a devida diligência para proteger as mulheres contra todas as formas de violência de gênero. Ainda que antes de sua aprovação houvesse uma preocupaçấo regional acerca da grave situaçáo de violência de que as mulheres eram vítimas, essa preocupação não acarretou em reflexâo legal na maioria dos Estados. Graças a esse instrumento, houve no continente mais aceitaçáo do fato de que a violência contra a mulher, seja na esfera pública ou privada, é uma violação dos direitos (Mesevvi, 2014 , p. 5 , tradução nossa). ${ }^{33}$

31. Disponivel em: <http://bit.ly/20P9TkV>.

32. 0 documento completo está no link disponível em: <http://bit.ly/2QfLDYL>.

33. Do original, em espanhol: "La Convención de Belém do Pará ha contribuido a crear conciencia sobre la gravedad del problema de la violencia contra la mujer y de la responsabilidad del Estado de adoptar medidas concretas para prevenirla y erradicarla. Crea un sistema de derechos para garantizar una vida libre de violencia a las mujeres y un sistema de obligaciones para los Estados de respetar y garantizar esos derechos y de actuar con la debida diligencia para proteger a la mujer contra toda forma de violencia por razones de género. Si bien antes de su aprobación existía una preocupación regional por la grave situación de violencia de que eran víctimas las mujeres, esta preocupación no tenía un reflejo legal en la mayoría de los Estados. Gracias a este instrumento se inició en el continente una mayor aceptación del hecho de que la violencia contra la mujer, ya sea en el ámbito público o privado, es una violación de derechos humanos" (Mesevvi, 2014). 
Em 1998, por ocasião das comemoraçóes do cinquentenário da DUDH, o Estado brasileiro reconheceu oficialmente a competência jurisdicional da Corte Interamericana de Direitos Humanos (Corte IDH) da OEA "em todos os casos relativos à interpretação ou aplicação da Convençâo Americana de Direitos Humanos para fatos ocorridos a partir do reconhecimento", conforme estabelecido no Decreto Legislativo no 89/1998 (Brasil, 1998). Isso significa que o Brasil passou a estar sujeito aos julgamentos da Corte IDH, e, em 2001, a OEA condenou o Brasil por violar a Convenção Americana, a Declaração Americana dos Direitos e Deveres do Homem e a Convenção de Belém do Pará $^{34}$ no caso Maria da Penha Maia Fernandes. No relatório, consta que

a falta de julgamento e condenação do responsável nessas circunstâncias constitui um ato de tolerância, por parte do Estado, da violência que Maria da Penha sofreu, e essa omissão dos tribunais de justiça brasileiros agrava as consequências diretas das agressóes sofridas (OEA, 2001), tratando-se de tolerância do Estado brasileiro que contribui para a perpetuação dos fatores históricos, sociais e psicológicos que produzem a violência contra a mulher.

Como resultado da condenação, o Brasil elaborou e promulgou uma legislação específica para tratar sobre violência doméstica contra a mulher, que teve como base a Convenção de Belém do Pará. A Lei no 11.340/2006 (Brasil, 2006), conhecida como Lei Maria da Penha (LMP), foi aprovada pelo Congresso Nacional em agosto de 2006 (Bandeira e Almeida, 2015). ${ }^{35}$ Inovadora, a lei "configura violência doméstica e familiar contra a mulher qualquer ação ou omissão baseada no gênero que lhe cause morte, lesão, sofrimento físico, sexual ou psicológico e dano moral ou patrimonial" (Brasil, 2006), tendo como pena a detenção de até três anos para a ação violenta praticada contra o cônjuge, o ascendente, o descendente, a irmã ou pessoas com as quais se tenha convívio ou convivido. De acordo com Wania Pasinato (2010, p. 219), a LMP está adequada à Convenção de Belém do Pará, à CEDAW e à CF/1988. Uma de suas inovaçóes é sua organização em três eixos de atuação: o primeiro trata das medidas criminais para a punição da violência; o segundo abrange as medidas protetivas com caráter de urgência; e o terceiro eixo está voltado para a prevenção e a educação (op. cit.).

34. No Relatório no 54/2001, Caso 12.051, Maria Da Penha Maia Fernandes, consta que o Brasil violou os arts. 1으 (obrigação de respeitar os direitos), 8 (garantias judiciais), 24 (igualdade perante a lei) e 25 (Proteção judicial) da convenção americana, em relação aos arts. II e XVIII da Declaração Americana dos Direitos e Deveres do Homem - doravante denominada a Declaração -, bem como os arts. 3, 4,a,b,c,d,e,f,g, 5 e 7 da Convenção de Belém do Pará (OEA, 2001). 35. A norma foi proposta por um consórcio de ONGs, em parceria com a então Secretaria Especial de Política para as Mulheres (SPM), ligada à Presidência da República, atual Secretaria Nacional de Políticas para as Mulheres, do Ministério da Mulher, da Família e dos Direitos Humanos. 
É importante compreender a Lei Maria da Penha, no contexto de análise da relevância de acordos e compromissos internacionais para os direitos das mulheres, como resultado não apenas dos compromissos firmados nas conferências globais e regionais que ocorreram na década de 1990, mas também do impacto legal que esses compromissos podem assumir quando ratificados pelos países. A ratificação da convenção já se constituiu em importante marco na luta das mulheres, mas a possibilidade de utiliza sua violaçẫo para garantir uma condenação do Brasil na OEA possibilitou de forma muito direta a criação de legislação tão importante e conhecida como a LMP. Essa lei cita a Convenção de Belém do Pará na sua exposição de motivos e prevê, em seu art. 6o, que "a violência doméstica e familiar contra a mulher constitui uma das formas de violação dos direitos humanos” (Brasil, 2006), reivindicaçáo antiga do movimento de mulheres que ganhou destaque na Conferência Mundial de Direitos Humanos (Viena, 1993). Assim como ocorreu com o Brasil, a América Latina avançou na criaçáo de mecanismos normativos para combater a violência contra a mulher, e a Convenção de Belém do Pará obteve papel fundamental nesse contexto, pois foi "o primeiro tratado específico sobre combate à violência contra a mulher, oriundo do continente sul-americano, e que está repercutindo de forma crucial em diversos países do globo terrestre" (Bandeira e Almeida, 2015, p. 513). Nessa perspectiva, Tânia Almeida e Lourdes Bandeira destacam que "foi a Convenção de Belém do Pará que abriu espaço formal para os países engajarem-se no combate à violência contra a mulher, assim como é ela que demarca uma nova fase na ordem jurídica internacional, contraditória ao poder político patriarcal" (Bandeira e Almeida, 2015, p. 513).

\subsection{Outros marcos}

A III Conferência Mundial de Combate ao Racismo, Discriminação Racial, Xenofobia e Intolerância Correlata ocorreu em agosto de 2001, em Durban, África do Sul. ${ }^{36}$ Participaram 2,3 mil delegados oficiais de 163 países, cerca de 4 mil representantes de organizaçóes não governamentais, além dos eventos paralelos que ocorreram antes e durante a conferência, como o Fórum de ONGs, que contou com 8 mil participantes. Alves (2002) lembra que no Brasil foram intensos os preparativos para a Conferência de Durban, tendo sido realizada conferência nacional para discutir a temática, que envolveu governo e sociedade civil. A professora brasileira Edna Roland, mulher, negra e ativista, foi a relatora-geral da conferência. ${ }^{37}$

36. Alves (2002) lembra que no Brasil foram intensos os preparativos para a Conferência de Durban, tendo sido realizada conferência nacional para discutir a temática, que envolveu governo e sociedade civil.

37. Para mais informações, ver Dossiê... (2002). 
A Conferência de Durban recebeu críticas por, entre outros fatores, ter optado por não cobrar dos países participantes o cumprimento das obrigaçóes que assumiram ao aderirem à CEDAW (Alves, 2002, p. 218). A Declaração e o Programa de Ação da Conferência de Durban (ONU, 2001) - ainda que apresentem apenas recomendaçóes, não exigindo aprovação pelo Congresso, ratificação e promulgação - propuseram compromissos baseados em novos conceitos, com o objetivo de combater o racismo estrutural, ${ }^{38}$ construir políticas públicas ${ }^{39}$ e guiar a atuação dos Estados internacionalmente e em seu território. Esse documento constituiu instrumento jurídico importante no combate ao racismo, à xenofobia e às intolerâncias correlatas. O termo "gênero", utilizado em Pequim, foi aceito e empregado nos documentos produzidos na conferência. A Declaração e o Programa de Ação da Conferência de Durban instam os Estados a reconhecerem que "a interseção das discriminaçóes com base em raça e gênero faz com que mulheres e meninas sejam particularmente vulneráveis" (ONU, 2001, p. 51). Em abril de 2009, ocorreu a Conferência de Revisão de Durban contra o Racismo, a Discriminação Racial, a Xenofobia e as Formas Correlatas de Intolerância, em Genebra, Suíça, com o objetivo de avaliar os progressos pós-2001. Participaram dessa conferência 187 países, e o Brasil foi um dos Estados que assinaram o documento que confirma a Declaração de Durban. ${ }^{40}$

Ainda que esse conjunto de conferências - que marcaram os anos 1990 e o início dos 2000 - não tenha tido, necessariamente, as mulheres ou a igualdade de gênero como temas centrais, alcançou, de uma forma ou de outra, este debate. O quadro 3 apresenta uma síntese do que foi aqui apresentando, trazendo as conferências sociais da ONU e a forma como estas abordaram a questão de gênero em seus textos.

38. A Recomendação no 41, de 9 de agosto de 2016, do Conselho Nacional do Ministério Público (CNMP), considera que, tendo assinado a Declaração de Durban, o Estado brasileiro reconhece que os afrodescendentes "enfrentam barreiras como resultado de preconceitos e discriminações sociais predominantes em instituições públicas e privadas" e que "a igualdade de oportunidades real para todos, em todas as esferas, incluindo a do desenvolvimento, é fundamental para a erradicação do racismo, discriminação racial, xenofobia e intolerância correlata". Ver CNMP (2016).

39. 0 Estatuto da Igualdade Racial e o critério de autodeclaração de cor/raça utilizado pelo Censo Demográfico do Instituto Brasileiro de Geografia e Estatística (IBGE) são exemplos da influência da Declaração de Durban no Brasil. Para mais informações, ver Fundação Cultural Palmares ([s.d.]) e o link disponível em: <http://bit.ly/2wPRvS7>.

40. Após a Conferência de Revisão, foi realizada audiência pública conjunta com a Comissão de Relações Exteriores e de Defesa Nacional e com a Frente Parlamentar pela Igualdade Racial sobre o processo de revisão da Conferência contra o Racismo. Para conferir a transcrição da audiência, ver Brasil (2009). Para outras informações sobre o evento, ver Brasil ([s.d.]). 
QUADRO 3

Síntese das principais abordagens sobre gênero na década de conferências sociais da ONU

\begin{tabular}{|c|c|c|c|}
\hline Evento & Local & Ano & Principais avanços \\
\hline $\begin{array}{l}\text { Conferência das } \\
\text { Nações Unidas } \\
\text { sobre Meio } \\
\text { Ambiente e } \\
\text { Desenvolvimento }\end{array}$ & $\begin{array}{l}\text { Rio de } \\
\text { Janeiro, } \\
\text { Brasil }\end{array}$ & 1992 & $\begin{array}{l}\text { Propostas específicas sobre mulheres e o desenvolvimento sustentável } \\
\text { (Capítulo } 24 \text { da Agenda 21, Princípio } 20 \text { da Declaração do Rio). }\end{array}$ \\
\hline $\begin{array}{l}\text { Conferência } \\
\text { Mundial de } \\
\text { Direitos Humanos }\end{array}$ & $\begin{array}{l}\text { Viena, } \\
\text { Áustria }\end{array}$ & 1993 & $\begin{array}{l}\text { Reforçou a CEDAW e reafirmou os direitos das mulheres } \\
\text { como universais, interdependentes, inalienáveis e indivisíveis. } \\
\text { Reconheceu a violência e todas as formas de abuso e exploração sexual } \\
\text { como incompatíveis com a dignidade e o valor da pessoa humana. }\end{array}$ \\
\hline \multirow{6}{*}{$\begin{array}{l}\text { Conferência } \\
\text { Internacional } \\
\text { sobre População e } \\
\text { Desenvolvimento }\end{array}$} & \multirow{6}{*}{ Cairo, Egito } & \multirow{6}{*}{1994} & $\begin{array}{l}\text { Propôs que as políticas públicas reconhecessem a igualdade entre homens } \\
\text { e mulheres como fundamental para a promoção do bem-estar humano. } \\
\text { Estabeleceu consenso sobre as seguintes metas: redução da morta- } \\
\text { lidade infantil e materna; acesso à educação, especialmente para as } \\
\text { meninas; e acesso universal a uma ampla gama de serviços de saúde } \\
\text { reprodutiva, incluindo-se o planejamento familiar. Essas metas deveriam } \\
\text { ser alcançadas até } 2015 \text {. } \\
\text { Enfatizou a importância de mecanismos capazes de prevenir e eliminar } \\
\text { a violência contra mulheres. }\end{array}$ \\
\hline & & & $\begin{array}{l}\text { Ressaltou a importância da igualdade, a emancipação da mulher, } \\
\text { a eliminação da violência doméstica e o controle sobre a própria } \\
\text { fecundidade como fundamentais nos programas relacionados sobre } \\
\text { população e desenvolvimento. }\end{array}$ \\
\hline & & & $\begin{array}{l}\text { Novo paradigma no debate sobre populações: a questão demográfica e } \\
\text { os direitos reprodutivos foram inseridos no âmbito dos direitos humanos. }\end{array}$ \\
\hline & & & $\begin{array}{l}\text { Programa de ação inovador ao vincular a questão demográfica e } \\
\text { populacional e o desenvolvimento econômico aos direitos reprodutivos } \\
\text { no âmbito dos direitos humanos. }\end{array}$ \\
\hline & & & $\begin{array}{l}\text { Destacou no programa de ação (princípio 8) que os Estados deveriam } \\
\text { garantir acesso universal aos serviços de assistência médica relacionados } \\
\text { à saúde reprodutiva sem qualquer forma de coerção. }\end{array}$ \\
\hline & & & Reconheceu o aborto inseguro como grave problema de saúde pública. \\
\hline \multirow{3}{*}{$\begin{array}{l}\text { Cúpula } \\
\text { Mundial para o } \\
\text { Desenvolvimento } \\
\text { Social }\end{array}$} & \multirow{3}{*}{$\begin{array}{l}\text { Copenhague, } \\
\text { Dinamarca }\end{array}$} & \multirow{3}{*}{1995} & $\begin{array}{l}\text { Incluiu nos documentos finais os seguintes compromissos: promoção } \\
\text { de capacitações e acesso ao pleno emprego de homens e mulheres; } \\
\text { acesso à igualdade e à equidade entre homens e mulheres; e promoção } \\
\text { da participação das mulheres na vida social, política, econômica e } \\
\text { cultural dos países. }\end{array}$ \\
\hline & & & $\begin{array}{l}\text { Proclamou o papel decisivo das mulheres na luta contra a pobreza e } \\
\text { o desemprego e manteve as conquistas adquiridas na Conferência de } \\
\text { Viena e na Conferência do Cairo. }\end{array}$ \\
\hline & & & $\begin{array}{l}\text { Destacou a igualdade entre homens e mulheres nos dez compromissos } \\
\text { presentes na Declaração dos Chefes de Estado e de Governo. }\end{array}$ \\
\hline
\end{tabular}

(Continua) 


\begin{tabular}{|c|c|c|c|}
\hline Evento & Local & Ano & Principais avanços \\
\hline $\begin{array}{l}\text { Convenção } \\
\text { Interamericana } \\
\text { para Prevenir, } \\
\text { Punir e Erradicar } \\
\text { a Violência contra } \\
\text { as Mulheres }\end{array}$ & $\begin{array}{l}\text { Belém do } \\
\text { Pará, Brasil }\end{array}$ & 1994 & $\begin{array}{l}\text { Determinou os mecanismos interamericanos de proteção às mulheres, } \\
\text { apontou direitos garantidos e designou os deveres dos Estados participantes. } \\
\text { Definiu violência contra a mulher como "qualquer ato ou conduta baseada } \\
\text { nas diferenças de gênero que cause morte, dano ou sofrimento físico, sexual } \\
\text { ou psicológico à mulher, tanto na esfera pública quanto na esfera privada". } \\
\text { Reconheceu a categoria gênero. } \\
\text { Os países signatários comprometeram-se a prevenir, punir e erradicar } \\
\text { a violência contra mulheres. }\end{array}$ \\
\hline $\begin{array}{l}\text { IV Conferência } \\
\text { Mundial sobre a } \\
\text { Mulher }\end{array}$ & $\begin{array}{l}\text { Pequim, } \\
\text { China }\end{array}$ & 1995 & $\begin{array}{l}\text { Fortaleceu as ações sobre direitos humanos das mulheres resultantes } \\
\text { das conferências anteriores. } \\
\text { Consolidou os avanços jurídicos, bem como o acúmulo de conhecimentos } \\
\text { e aprendizados adquiridos ao longo de cinco décadas no que tange à } \\
\text { igualdade das mulheres. } \\
\text { Produziu guia de ação (Plataforma de Ação de Pequim) para a construção } \\
\text { de políticas voltadas para mulheres. } \\
\text { Utilizou o conceito de gênero e a noção de empoderamento, bem como } \\
\text { enfocou a transversalidade. }\end{array}$ \\
\hline $\begin{array}{l}\text { III Conferência } \\
\text { Mundial de } \\
\text { Combate } \\
\text { ao Racismo, } \\
\text { Discriminação } \\
\text { Racial, Xenofobia } \\
\text { e Intolerância } \\
\text { Correlata }\end{array}$ & $\begin{array}{l}\text { Durban, } \\
\text { África do Sul }\end{array}$ & 2001 & $\begin{array}{l}\text { Adotou a categoria gênero nos documentos da conferência. } \\
\text { Enfatizou a importância da interseção de gênero e raça para a } \\
\text { compreensão das discriminações. }\end{array}$ \\
\hline
\end{tabular}

Elaboração: Disoc/lpea.

Em 1999, a AGNU adotou o Protocolo Facultativo à CEDAW (UN, 1999), com o objetivo de fortalecer a Convenção da Mulher e ampliar as funçóes e a responsabilidade do Comitê da CEDAW. O protocolo prevê que esse comitê poderá analisar comunicaçôes apresentadas por indivíduos ou grupos que aleguem ser vítimas de violaçáo dos direitos previstos - e garantidos pelos Estados que ratificaram a Convenção da Mulher - na CEDAW. Ao ratificarem o protocolo, os Estados poderão receber visitas in loco realizadas pelo comitê, que passou a ter como funçôes adicionais os seguintes procedimentos: análise de queixas individuais e investigação. O governo brasileiro assinou o Protocolo Facultativo à CEDAW em 2001; em 2002, o documento foi ratificado. ${ }^{41}$ A Convenção da Mulher e o Protocolo Facultativo constituem formas de concretizar, no âmbito internacional, os direitos humanos das mulheres.

Finalmente, vale destacar que, em junho de 2011, ocorreu na sede da Organização Internacional do Trabalho (OIT), em Genebra (Suíça), a 100ª 
Conferência Internacional do Trabalho (CIT). Nesse evento, foi finalizada a discussão sobre trabalho decente para trabalhadores domésticos e foram definidos dois instrumentos internacionais sobre o tema: a Convenção sobre o Trabalho Decente para as Trabalhadoras e os Trabalhadores Domésticos no 189 e a Recomendaçâo $\mathrm{n}^{\circ} 201 .{ }^{42} \mathrm{O}$ grande desafio desses documentos é promover proteção ao trabalho doméstico, que possui características peculiares no tocante ao mercado de trabalho, está profundamente relacionado à perpetuação de desigualdades de gênero, classe e raça e cujos trabalhadores sofrem sistematicamente com violaçóes aos seus direitos trabalhistas e desrespeito aos direitos humanos. Em 2017, o Congresso Nacional aprovou o texto da Convenção no 189 e da Recomendação no 201, e, em 31 de janeiro de 2018, o governo brasileiro depositou a ratificação a esses documentos no escritório da OIT. Com essa ação, o Brasil, que, segundo essa instituição, é o país com mais trabalhadores domésticos do mundo (cerca de 7 milhóes de pessoas), tornou-se o 25ำ Estado-membro da organização e o $14^{\circ}$ Estado-membro das Américas a ratificar a Convenção no 189 e a Recomendaçâo no $201 .^{43}$

\section{UMA NOVA ERA: OBJETIVOS DE DESENVOLVIMENTO DO MILÊNIO}

A quinta fase de atuação da ONU no campo dos direitos das mulheres corresponde a uma importante mudança de estratégia. Depois de um grande conjunto de conferências e convençóes, que delinearam as linhas políticas de atuação em diversos Estados, a organização propôs compromisso com metas e objetivos mensuráveis. A primeira experiência nesse sentido foram os ODMs, que compreendem oito grandes objetivos globais sobre temas como pobreza, acesso à saúde e à educação, eliminação da fome, promoção da igualdade entre os sexos etc. Esses compromissos foram assumidos pelos países-membros da ONU - à época, 191 - em setembro de 2000, durante a 55ª sessão da AGNU, conhecida como "Cúpula do Milênio das Nações Unidas".

Os ODMs alcançaram êxito especialmente no campo político, "em especial para a ONU, que alcançou uma projeção na área social nunca antes obtida, principalmente em relação à redução da extrema pobreza e à fome" (Carvalho e Barcello, 2014, p. 222). No entanto, foram também alvo de críticas desde sua elaboração. O fato de ser instrumento sem força coercitiva produziu dúvidas acerca do interesse dos países em cumprir as metas propostas. $\mathrm{O}$ conceito de desenvolvimento foi criticado por ser compreendido, por alguns setores, como imposiçáo do modelo utilizado pelos países mais ricos. Crítica semelhante diz respeito ao pouco envolvimento dos países em desenvolvimento no processo de construção dos objetivos, e, consequentemente, os ODMs teriam se constituído em agenda criada pelos países

42. Para mais informações, ver OIT (2011a; 2011b).

43. Para mais informações, ver OIT (2018). 
desenvolvidos para ser seguida pelos países em desenvolvimento - como é o caso, por exemplo, de Alonso e Ayuso (2017).

Importante destacar que o conjunto dos objetivos do milênio representou pressão internacional em relação a diferentes questôes, e não apenas aos direitos das mulheres. Os países signatários comprometeram-se a executar 21 metas, mensuráveis e comparáveis por meio de sessenta indicadores, até 2015 . Os oito objetivos estabelecidos foram:

- erradicar a extrema pobreza e a fome;

- universalizar a educação primária;

- promover a igualdade entre os sexos e a autonomia das mulheres;

- reduzir a mortalidade na infância;

- melhorar a saúde materna;

- combater o(a) HIV/Aids, a malária e outras doenças;

- garantir a sustentabilidade ambiental; e

- estabelecer parceria mundial para o desenvolvimento.

Ainda que os ODMs incluam temas relevantes e o façam, em alguma medida, de forma progressista, chama a atenção o fato de que não existem objetivos voltados especificamente para populaçóes negras, indígenas ou de outras etnias subalternizadas em diferentes países. Essa ausência perdurou - como se poderá ver na próxima seção - na definição dos ODS, até mesmo diante das experiências acumuladas pelos países da ONU - em especial, após a Conferência de Durban - e das reivindicaçóes dos movimentos sociais.

Ao longo das etapas de discussão e negociação dos ODMs, o Brasil ganhou destaque ao sustentar posição progressista e avançada nos temas concernentes à agenda de direitos humanos e redução das desigualdades, característica histórica de sua atuação no âmbito das relações internacionais (Ipea, 2019). Esse posicionamento se manteve quando o país iniciou o processo de acompanhamento das metas estipuladas pela ONU, tendo o governo brasileiro estabelecido para si próprio um conjunto de metas e indicadores mais avançados do que aqueles propostos e ratificados na Cúpula do Milênio. Pode-se citar como exemplo a meta 2 do primeiro objetivo, que, originalmente, falava em reduzir à metade a proporçáo da população que sofre fome, mas que foi, para o caso brasileiro, transformada em um compromisso de erradicar a fome até 2015. Ademais, o Estado brasileiro incorporou a dimensão racial transversalmente, adicionando, sempre que possível, as informaçóes para as populações brancas e negras, de modo a acompanhar a evoluçáo e o cumprimento das metas considerando-se as desigualdades raciais que tanto marcam o país. 
Especificamente no caso dos objetivos 3 e 5 , que tratavam, respectivamente, da promoção da igualdade entre os sexos e da autonomia das mulheres e da melhoria da saúde materna, os compromissos brasileiros também ampliaram o rol dos compromissos internacionais. Para o objetivo 3, cuja meta era "Eliminar as disparidades entre sexos nos ensinos fundamental e médio, se possível, até 2005, e em todos os níveis de ensino até 2015 ”, as proposiçóes brasileiras concentraram-se apenas na inclusão de novos indicadores a serem monitorados, ainda que a meta estabelecida fosse pouco significativa para o caso brasileiro, uma vez que as mulheres já contavam, naquele momento, com escolaridade superior à dos homens. Os indicadores propostos pela ONU abordavam as desigualdades de gênero no acesso à educação (razão de sexos no ensino básico, médio e superior e razão entre homens e mulheres alfabetizados) e incluíam apenas o monitoramento da proporção de mulheres assalariadas no setor não agrícola e da proporção de mulheres ocupando mandatos no Parlamento nacional. A inclusão de novos indicadores, portanto, permitiu trazer para o debate análise mais aprofundada sobre as desigualdades de gênero no mercado de trabalho, a participação política nas esferas subnacionais e a violência contra as mulheres, tema tão relevante e presente no sistema ONU, mas que não tinha visibilidade na Declaração do Milênio.

Por sua vez, em relação ao objetivo 5 , houve inclusão de novas metas para o Brasil. Assim, para além do compromisso de reduzir em três quartos a taxa de mortalidade materna, o país também se comprometeu a: $i$ ) promover, na rede do Sistema Único de Saúde (SUS), cobertura universal por ações de saúde sexual e reprodutiva; e ii) até 2015 , ter detido o crescimento da mortalidade por câncer de mama e colo de útero, revertendo a tendência existente à época. ${ }^{44}$ Importante destacar o esforço do governo para ampliar a discussão de saúde para além do campo da saúde materna, buscando incorporar a ideia de saúde das mulheres e de saúde sexual e reprodutiva. Novos indicadores somaram-se àqueles previstos pela ONU - razão de mortalidade materna e proporção de partos assistidos por profissionais de saúde qualificados -, e o país passou a monitorar as causas dos óbitos maternos, o nível de cobertura das consultas de pré-natal, o número de internaçóes por aborto e a taxa de mortalidade de mulheres de 30 a 69 anos segundo os tipos de neoplasia e as causas selecionadas e informá-la sobre esses aspectos.

Esse compromisso político, contudo, não foi suficiente para garantir que o Brasil cumprisse as metas relacionadas à saúde das mulheres. O Relatório nacional de acompanhamento dos Objetivos do Milênio (Ipea, 2014) destaca que a meta estipulada pela ONU era bastante arrojada, de 35 óbitos por 100 mil nascidos vivos. Salienta, ademais, que, apesar de não ter cumprido, teve desempenho melhor que as médias registradas por países em desenvolvimento e países da América Latina. Houve redução de 55\% da taxa de mortalidade materna entre 1990 e 2011, passando de

44. Para mais informações, ver o link disponível em: <http://bit.ly/2xqBpia>. 
141 para 64 óbitos por 100 mil nascidos vivos. Ainda segundo o documento, nos países em desenvolvimento, a mortalidade materna caiu de 440 para 240 óbitos por 100 mil nascidos vivos, redução de $45 \%$. Por sua vez, na América Latina, a queda foi de 130 para 72 óbitos por 100 mil nascidos vivos, redução também de 45\% (Brasil, 2014). Outro aspecto importante ressaltado no relatório revela que um dos fatores que dificulta a redução da mortalidade materna no país é o elevado número de partos cesáreos, que não apenas se mantinha alto no período analisado na publicação, como também apresentava tendência de crescimento em todas as regióes. Em 1990, o índice nacional era de 41\%; em 2011, estava em 54\%. A Organização Mundial da Saúde (OMS) recomenda que o percentual de cesarianas não ultrapasse os $15 \%$ do total de partos. Além de não ter cumprido o compromisso internacional assumido, as mortes maternas estáo estabilizadas em níveis altos, com 64,5 mortes por 100 mil (Mortalidade..., 2018). Ressalta-se que a experiência adquirida com os ODMs contribuiu para a criação, de forma mais democrática e participativa, em mais um esforço internacional, dos ODS.

\section{A ATUAL FASE DA ONU: AGENDA 2030 PARA O DESENVOLVIMENTO SUSTENTÁVEL E OBJETIVOS DE DESENVOLVIMENTO SUSTENTÁVEL}

Em 2015, com o fim do período para alcance dos ODMs e a partir da experiência acumulada com sua implementação, a ONU propôs aos países-membros a Agenda 2030 para o desenvolvimento sustentável, que foi adotada pelos 193 Estados-membros que a compóem, incluindo-se o Brasil. A agenda tornou-se compromisso que o Estado brasileiro - em suas três esferas - pactuou com outros países e instituiçóes internacionais para os quinze anos seguintes.

O eixo central da Agenda 2030 para o desenvolvimento sustentável são os ODS, cujo intento é ambicioso: atingir o desenvolvimento sustentável global de forma integral, considerando as dimensóes ambiental, econômica e social. Os objetivos sáo instrumento político complexo, extenso e robusto, constituído por dezessete objetivos e 169 metas globais, cujos signatários são países em diferentes estágios econômicos. Tais países, contudo, são incentivados a considerarem suas realidades e prioridades nacionais no momento da definição de estratégias para alcançar os objetivos da agenda; contudo, as metas são integradas, indivisíveis e universais. Assim como nos demais acordos internacionais, as metas universalmente estabelecidas pelos ODS podem se adequar mais ou menos à realidade de cada país. Para o caso brasileiro, dadas as suas especificidades e a sua diversidade populacional, a adequação das metas é variável. Em algumas situaçóes, o Brasil já alcançou as metas determinadas, enquanto em outras as metas se referem a problemas que não são observados internamente ou não possuem relevância para o país.

Com o objetivo de contribuir para difundir, estruturar e internalizar o processo de implementação da Agenda 2030 para o desenvolvimento sustentável e dar 
transparência a este (Brasil, 2016), e considerando a complexidade sociodemográfica do país, foi criada - por meio do Decreto Presidencial no 8.892/2016 - a Comissão Nacional para os Objetivos de Desenvolvimento Sustentável (CNODS). De natureza consultiva e com representantes das três esferas de governo e da sociedade civil, a missão estabelecida para a comissão ${ }^{45}$ foi a de criar mecanismos institucionais que determinassem as condiçóes adequadas à implementação dos ODS, incluindo-se estratégias para a territorializaçáo, a definição de metas e indicadores, os processos participativos, bem como os meios de implementação, acompanhamento e monitoramento da Agenda 2030 para o desenvolvimento sustentável (op. cit.), adaptando-os ao contexto nacional.

\subsection{ODS 5: Alcançar a igualdade de gênero e empoderar todas as mulheres e meninas}

Nesse contexto de adaptação das metas à realidade do país, foram pactuadas algumas propostas de alteraçóes no texto originalmente apresentado pela ONU quanto às metas de diversos ODS. O relatório ODS: metas nacionais dos Objetivos de Desenvolvimento Sustentável (Ipea, 2018), publicado em 2018, apresenta proposta de adequação das metas globais para a realidade nacional, realizada por gestoras(es) e técnicas(os) de 75 órgáos governamentais em trabalho coordenado pelo Ipea, em cumprimento à atribuição elaborada pela CNODS. Essas propostas, contudo, ainda não foram validadas oficialmente pelo governo federal, sendo passíveis de alteraçóes ao longo do caminho.

A iniciativa de construir instrumento para adequar os ODS à realidade nacional foi realizada por poucos países. Essas adaptaçóes buscaram reconhecer a diversidade da população brasileira, assumindo-se que a própria desigualdade de gênero se expressa de forma distinta para diferentes grupos. Nesse sentido, entende-se que, para a efetiva redução da desigualdade e da discriminação de gênero, é preciso enxergá-las como fenômenos perpassados pela desigualdade racial, pelo ciclo de vida, pela segmentação territorial e regional e pelo capacitismo, entre outros exemplos. Por esse motivo, o projeto de adequaçáo das metas do ODS 5 ao contexto nacional buscou dar visibilidade aos diversos fenômenos sociais, que, ao se interseccionarem ao gênero, conferem experiências de discriminação e desigualdade diferenciadas entre os mais variados grupos sociais presentes em nossa sociedade. Outro aspecto que deve ser ressaltado em relação às novas propostas de redação é sua postura progressista e ambiciosa, com o aprofundamento de termos enfáticos como "acabar" e "eliminar", a fim de frisar o comprometimento do país com a redução total da desigualdade de gênero. 
No caso do ODS 5, que tem como meta alcançar a igualdade de gênero e empoderar todas as meninas no país, o relatório propôs adaptaçōes na redação e a inclusão de novas metas. O resultado foi uma proposta com onze metas nacionais, sendo nove adaptações das metas globais e duas inclusões de metas novas, ${ }^{46}$ como pode ser visto no quadro 4 .

QUADRO 4

Metas, objetivos e adequações do ODS 5 ao contexto brasileiro

\begin{tabular}{|c|c|}
\hline Meta e objetivo & Adequação da meta ao Brasil \\
\hline $\begin{array}{l}\text { 5.1 Acabar com todas as formas de discrimi- } \\
\text { nação contra todas as mulheres e meninas } \\
\text { em toda parte. }\end{array}$ & $\begin{array}{l}\text { Eliminar todas as formas de discriminação de gênero, nas suas intersecções com raça, } \\
\text { etnia, idade, deficiência, orientação sexual, identidade de gênero, territorialidade, } \\
\text { cultura, religião e nacionalidade; em especial para as meninas e mulheres do campo, } \\
\text { da floresta, das águas e das periferias urbanas. }\end{array}$ \\
\hline $\begin{array}{l}\text { 5.2 Eliminar todas as formas de violência } \\
\text { contra todas as mulheres e meninas nas } \\
\text { esferas públicas e privadas, incluindo o tráfico } \\
\text { e exploração sexual e de outros tipos. }\end{array}$ & $\begin{array}{l}\text { Eliminar todas as formas de violência de gênero nas esferas pública e privada, } \\
\text { destacando a violência sexual, o tráfico de pessoas e os homicídios, nas suas inter- } \\
\text { secções com raça, etnia, idade, deficiência, orientação sexual, identidade de gênero, } \\
\text { territorialidade, cultura, religião e nacionalidade; em especial para as mulheres do } \\
\text { campo, da floresta, das águas e das periferias urbanas. }\end{array}$ \\
\hline $\begin{array}{l}\text { 5.3 Eliminar todas as práticas nocivas, como } \\
\text { os casamentos prematuros, forçados e de } \\
\text { crianças e mutilações genitais femininas. }\end{array}$ & $\begin{array}{l}\text { Eliminar todas as práticas nocivas, como os casamentos e uniões precoces, forçados } \\
\text { e de crianças e jovens, nas suas intersecções com raça, etnia, idade, deficiência, } \\
\text { orientaçãa sexual, identidade de gênero, territorialidade, cultura, religião e nacio- } \\
\text { nalidade; em especial para as mulheres do campo, da floresta, das águas e das } \\
\text { periferias urbanas. }\end{array}$ \\
\hline $\begin{array}{l}\text { 5.4 Reconhecer e valorizar o trabalho de } \\
\text { assistência e doméstico não remunerado, por } \\
\text { meio da disponibilização de serviços públicos, } \\
\text { infraestrutura e políticas de proteção social, } \\
\text { bem como a promoção da responsabilidade } \\
\text { compartilhada dentro do lar e da família, } \\
\text { conforme os contextos nacionais. }\end{array}$ & $\begin{array}{l}\text { Eliminar a desigualdade na divisão sexual do trabalho remunerado e não remunerado, } \\
\text { inclusive no trabalho doméstico e de cuidados, promovendo maior autonomia de todas } \\
\text { as mulheres, nas suas intersecções com raça, etnia, idade, deficiência, orientação } \\
\text { sexual, identidade de gênero, territorialidade, cultura, religião e nacionalidade; em } \\
\text { especial para as mulheres do campo, da floresta, das águas e das periferias urbanas, } \\
\text { por meio de políticas públicas e da promoção da responsabilidade compartilhada } \\
\text { dentro das famílias. }\end{array}$ \\
\hline $\begin{array}{l}5.5 \text { Garantir a participação plena e efetiva das } \\
\text { mulheres e a igualdade de oportunidades para } \\
\text { a liderança em todos os níveis de tomada de } \\
\text { decisão na vida política, econômica e pública. }\end{array}$ & $\begin{array}{l}\text { Garantir a participação plena e efetiva das mulheres e a igualdade de oportunidades } \\
\text { para a liderança em todos os níveis de tomada de decisão na esfera pública, em } \\
\text { suas dimensões política e econômica, considerando as intersecções com raça, etnia, } \\
\text { idade, deficiência, orientação sexual, identidade de gênero, territorialidade, cultura, } \\
\text { religião e nacionalidade; em especial para as mulheres do campo, da floresta, das } \\
\text { águas e das periferias urbanas. }\end{array}$ \\
\hline $\begin{array}{l}\text { 5.6 Assegurar o acesso universal à saúde sexual } \\
\text { e reprodutiva e os direitos reprodutivos, como } \\
\text { acordado em conformidade com o Programa } \\
\text { de Ação da Conferência Internacional sobre } \\
\text { População e Desenvolvimento e com a Plata- } \\
\text { forma de Ação de Pequim e os documentos } \\
\text { resultantes de suas conferências de revisão. }\end{array}$ & $\begin{array}{l}\text { Promover, proteger e garantir a saúde sexual e reprodutiva, os direitos sexuais e } \\
\text { direitos reprodutivos, em consonância com o Programa de Ação da Conferência } \\
\text { Internacional sobre População e Desenvolvimento e com a Plataforma de Ação de } \\
\text { Pequim e os documentos resultantes de suas conferências de revisão, considerando } \\
\text { as intersecções de gênero com raça, etnia, idade, deficiência, orientação sexual, } \\
\text { identidade de gênero, territorialidade, cultura, religião e nacionalidade; em especial } \\
\text { para as mulheres do campo, da floresta, das águas e das periferias urbanas. }\end{array}$ \\
\hline
\end{tabular}

(Continua)

46. No âmbito global, a meta 5.b. era restrita ao uso de tecnologias, enquanto no Brasil tanto as políticas públicas quanto o debate "estão mais avançados no sentido de ter como meta a igualdade de acesso, habilidades de uso e produção de tecnologias. (...) e também já avançaram para setores correlacionados à tecnologia: do conhecimento científico e da produção e difusão de informação e comunicação" (Ipea, 2018). Para adequar o item 5.b ao contexto nacional, compreendendo-se que esses setores são de enorme importância para alterar as estruturas da desigualdade de gênero, foram adicionadas duas novas metas. Para mais informações, ver Ipea (2018). 


\begin{tabular}{|c|c|}
\hline Meta e objetivo & Adequação da meta ao Brasil \\
\hline $\begin{array}{l}\text { 5. a Empreender reformas para dar às mulheres } \\
\text { direitos iguais aos recursos econômicos, bem } \\
\text { como o acesso à propriedade e ao controle } \\
\text { sobre a terra e outras formas de propriedade, } \\
\text { serviços financeiros, herança e os recursos } \\
\text { naturais, de acordo com as leis nacionais. }\end{array}$ & $\begin{array}{l}\text { Garantir igualdade de direitos, de acesso e de controle dos recursos econômicos, da } \\
\text { terra e de outras formas de propriedade, de serviços financeiros, de herança e de } \\
\text { recursos naturais de forma sustentável, por meio de políticas de crédito, capacitação, } \\
\text { assistência técnica, reforma agrária e habitação, entre outras; em especial para as } \\
\text { mulheres do campo, da floresta, das águas e das periferias urbanas. }\end{array}$ \\
\hline \multirow{3}{*}{$\begin{array}{l}\text { 5.b Aumentar o uso de tecnologias de base, } \\
\text { em particular as tecnologias de informação } \\
\text { e comunicação (TICS), para promover o } \\
\text { empoderamento das mulheres. }\end{array}$} & $\begin{array}{l}\text { Garantir a igualdade de gênero no acesso, nas habilidades de uso e na produção das } \\
\text { tecnologias de informação e comunicação, considerando as intersecções com raça, } \\
\text { etnia, idade, deficiência, orientação sexual, identidade de gênero, territorialidade, } \\
\text { cultura, religião e nacionalidade; em especial para as mulheres do campo, da floresta, } \\
\text { das águas e das periferias urbanas. }\end{array}$ \\
\hline & $\begin{array}{l}\text { Garantir a igualdade de gênero no acesso e na produção do conhecimento cien- } \\
\text { tífico em todas as áreas do conhecimento e promover a perspectiva de gênero na } \\
\text { produção do conhecimento, considerando as intersecções com raça, etnia, idade, } \\
\text { deficiência, orientação sexual, identidade de gênero, territorialidade, cultura, religião } \\
\text { e nacionalidade; em especial para as mulheres do campo, da floresta, das águas } \\
\text { e das periferias urbanas. }\end{array}$ \\
\hline & $\begin{array}{l}\text { Garantir a igualdade de gênero no acesso e na produção da informação, de conteúdos } \\
\text { de comunicação e de mídias, considerando as intersecções com raça, etnia, idade, } \\
\text { deficiência, orientação sexual, identidade de gênero, territorialidade, cultura, religião } \\
\text { e nacionalidade; em especial para as mulheres do campo, da floresta, das águas } \\
\text { e das periferias urbanas. }\end{array}$ \\
\hline $\begin{array}{l}\text { 5.c Adotar e fortalecer políticas sólidas e } \\
\text { legislação aplicável para a promoção da } \\
\text { igualdade de gênero e o empoderamento de } \\
\text { todas as mulheres e meninas, em todos os níveis. }\end{array}$ & $\begin{array}{l}\text { Adotar e fortalecer políticas públicas e legislação que visem à promoção da igual- } \\
\text { dade de gênero e ao empoderamento de todas as mulheres e meninas, bem como } \\
\text { promover mecanismos para sua efetivação - em todos os níveis federativos - nas } \\
\text { suas intersecções com raça, etnia, idade, deficiência, orientação sexual, identidade } \\
\text { de gênero, territorialidade, cultura, religião e nacionalidade; em especial para as } \\
\text { mulheres do campo, da floresta, das águas e das periferias urbanas. }\end{array}$ \\
\hline
\end{tabular}

Elaboração: Disoc/lpea.

\section{DESAFIOS PARA O CUMPRIMENTO DOS ACORDOS INTERNACIONAIS NO BRASIL DOS ANOS 2020}

Os Objetivos de Desenvolvimento Sustentável são avançados em termos de temas cobertos, mas atingir as metas estipuladas é tarefa complexa e de difícil execução. Compromissos anteriores - como a CEDAW, a Declaração do Rio, o Programa de Ação de Viena, a Declaração de Pequim, além da própria Declaração Universal dos Direitos Humanos, entre outros - foram fundamentais para os avanços que ocorreram nas últimas décadas, os quais permanecem relevantes. No passado, as agendas internacionais assumidas contribuíram para o desenvolvimento de novas abordagens e ajustes nas políticas públicas brasileiras, fundamentais para a construção de uma sociedade menos desigual, e continuam importantes no contexto atual. Para além de política de governo, ao se tornar signatário da Agenda 2030 para o desenvolvimento sustentável, o Estado brasileiro assumiu um conjunto de compromissos que deveriam nortear as diretrizes para as políticas públicas promovidas no país, por um intervalo maior que a duraçáo dos mandatos dos representantes eleitos por meio do voto da população brasileira. O ODS 5, por exemplo, provavelmente demandará mais tempo para ser cumprido do que a janela para a consecução da 
agenda permite. Ou seja, o país comprometeu-se com uma política de Estado que vai para além da transitoriedade dos governos e que necessitaria envolver todos os setores da sociedade em sua implementação.

Porém, para garantir o alcance das metas pactuadas até 2030, o Brasil precisará superar desafios robustos. Hoje, o cenário não parece muito promissor quanto à possibilidade de a agenda ser plenamente cumprida até 2030, apesar de o país deter bons indicadores em relação a diversas das metas que compóem o ODS 5 . Assim, pode-se considerar que algumas metas já foram alcançadas para o caso brasileiro. Contudo, para outras, as possibilidades de alcance são variadas, assim como os desafios que se apresentam para cada uma destas. Evidentemente, existem desafios comuns ao conjunto de metas do ODS 5 - e também aos demais -, como a falta de institucionalidade no Executivo federal exclusivamente direcionada às políticas para as mulheres, os novos rumos da PEB ou a escalada de moral conservadora, a qual conflita com parte dos objetivos pactuados e tem se verificado ao redor de boa parte do mundo. Outros desafios, contudo, se adequam mais a algumas das metas propostas, portanto impactam de forma distinta nas possibilidades de seu cumprimento.

A meta 5.1, que propóe a eliminação de todas as formas de discriminação de gênero, encontra como grande desafio ao cumprimento a transformação de padróes culturais sexistas, que perpetuam preconceitos e discriminaçóes de gênero, as quais atingem não apenas mulheres, mas também pessoas transgênero e a comunidade de LGBT +. Nesse caso, o arcabouço legal do país é avançado, e o debate público sobre a legislação gira em torno de dois temas fundamentais: a questão de registro (civil ou administrativo) do nome e do sexo da pessoa transgênero; e os requisitos e o efetivo acesso ao processo transexualizador e à cirurgia de transgenitalização pelo SUS.

A meta 5.2, por exemplo, diz respeito à eliminação de todas as formas de violência de gênero nas esferas pública e privada, com destaque para o tráfico de pessoas, a violência sexual e os homicídios. É importante salientar que o país detém, no âmbito legislativo, iniciativas relevantes para o atingimento da meta, contando com leis como a Lei no 11.340/2006 (Brasil, 2006), denominada Lei Maria da Penha, e a Lei no 13.104/2015, conhecida como Lei do Feminicídio, que representam marcos importantes para o enfrentamento à violência de gênero no país, sendo internacionalmente reconhecidas como duas das leis mais avançadas do mundo no que concerne à defesa dos direitos das mulheres. Não existem, contudo, dados estatísticos que permitam mensurar o fenômeno da violência, pois o país não realiza pesquisa de vitimização regular, nacional e oficial, e não há padronização para o registro de dados administrativos, o que torna a comparabilidade prejudicada.

A mera existência de legislação avançada não é suficiente para dar conta de enfrentar e eliminar o problema, visto que ainda há importante distância entre o normativo e a realidade encontrada pelas mulheres ao procurarem apoio do Estado: mulheres que não recebem esclarecimentos sobre o próprio processo, juízes 
que não participam das audiências judiciais de violência doméstica, atendimento psicossocial em quantidade insuficiente, culpabilização da vítima etc. são apenas alguns dos aspectos que necessitam de mais atenção. ${ }^{47}$ A pesquisa $O$ Poder Judiciário no enfrentamento à violência doméstica e familiar contra as mulheres (Ipea e CNJ, 2019) teve como objetivo avaliar o atendimento prestado pelo Poder Judiciário às mulheres vítimas de violência doméstica e familiar. Foi realizada por meio de pesquisa de campo para produção de informaçóes primárias em doze diferentes Unidades da Federação (UFs). O quadro 5 lista alguns dos principais resultados, compreendendo o entendimento de que o direito penal não resolve tudo, pois o problema da violência doméstica e familiar contra as mulheres (VDFM) envolve outras dimensões, que exigem atuação em rede.

QUADRO 5

Principais resultados da pesquisa $O$ Poder Judiciário no enfrentamento à violência doméstica e familiar contra as mulheres

\begin{tabular}{|c|c|}
\hline Aspectos observados & Desafios constatados \\
\hline Rede de enfrentamento & O Poder Judiciário, em regra, não tem inserção ativa na rede de enfrentamento à VDFM. \\
\hline Processos judiciais & $\begin{array}{l}\text { A tramitação dos processos de VDFM é lenta, e os servidores estão sobrecarregados com quantidade } \\
\text { desproporcional de processos em tramitação. }\end{array}$ \\
\hline Morosidade & $\begin{array}{l}\text { Existe quantidade considerável de processos antigos nas pautas de audiência, em razão de inquéritos } \\
\text { demorados, dificuldades na localização das partes e adiamentos de audiências. }\end{array}$ \\
\hline $\begin{array}{l}\text { Medidas protetivas de } \\
\text { urgência }\end{array}$ & $\begin{array}{l}\text { Principal mecanismo de proteção garantida pela LMP, possuem alto índice de deferimento pelos } \\
\text { juízes que participaram da pesquisa e no prazo legal de } 48 \text { horas; no entanto, demoram a entrar } \\
\text { em vigor pela dificuldade em encontrar o acusado e a vítima para notificá-los. }\end{array}$ \\
\hline Serviço multidisciplinar & $\begin{array}{l}\text { O serviço de atendimento multidisciplinar foi bem avaliado pelas mulheres entrevistadas, porém } \\
\text { nem sempre esteve ativo, seja pela indisponibilidade de profissionais (psicologia e serviço social), } \\
\text { seja pela percepção de que "não é necessário". }\end{array}$ \\
\hline $\begin{array}{l}\text { Ausência de informações às } \\
\text { mulheres vítimas }\end{array}$ & $\begin{array}{l}\text { No que se refere ao atendimento às mulheres nas unidades judiciais, foi constatada ausência de } \\
\text { informações às vítimas sobre o processo: etapas; ritos; tipos penais envolvidos; escolhas possíveis; } \\
\text { atores na audiência; e consequências para o agressor. }\end{array}$ \\
\hline $\begin{array}{l}\text { Práticas controversas no } \\
\text { sistema de justiça }\end{array}$ & $\begin{array}{l}\text { Práticas controversas observadas em relação às mulheres atendidas: o fato de a ausência às } \\
\text { audiências ser compreendida como renúncia tácita; uso de condução coercitiva; e aplicação de } \\
\text { multas às mulheres que não comparecem às audiências. }\end{array}$ \\
\hline $\begin{array}{l}\text { Expectativas das mulheres } \\
\text { atendidas }\end{array}$ & $\begin{array}{l}\text { As principais expectativas das mulheres são de proteção, fim da violência, mudança de comporta- } \\
\text { mento, afastamento e punição dos agressores. }\end{array}$ \\
\hline $\begin{array}{l}\text { Impressão das mulheres } \\
\text { quantos ao atendimento } \\
\text { recebido pelo sistema de } \\
\text { justiça }\end{array}$ & $\begin{array}{l}\text { As experiências relatadas pelas mulheres são de natureza positiva - como proteção, cortesia no } \\
\text { atendimento, apoio psicossocial e satisfação pela prisão provisória do acusado - e, também, de } \\
\text { natureza negativa - a exemplo de morosidade, falta de acolhimento e falta de resposta efetiva. }\end{array}$ \\
\hline
\end{tabular}

Fonte: Ipea e CNJ (2019).

Elaboração: Disoc/lpea.

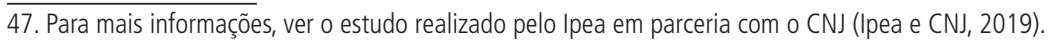


A meta 5.3 do ODS 5 refere-se à eliminação de práticas nocivas, como casamentos e unióes precoces de crianças e jovens, fenômeno que, apesar de pouco visibilizado, é elevado no país. Segundo dados do Fundo das Naçóes Unidas para a Infância (UNICEF), o Brasil tem o maior número de casamentos infantis da América Latina e o quarto mais alto do mundo, em números absolutos, considerando-se aqui todos os casamentos de pessoas com menos de 18 anos de idade. ${ }^{48}$ No caso brasileiro, contudo, a legislação autoriza o casamento de jovens entre 16 e 18 anos, com a autorização de ambos os pais ou representantes legais. Até 2019, o Código Civil permitia o casamento de quem ainda não havia alcançado a idade núbil (16 anos) em casos excepcionais, a saber, "para evitar imposição ou cumprimento de pena criminal ou em caso de gravidez" (Brasil, 2002b, art. 1.520). A Lei no 13.811/2019 alterou o Código Civil na tentativa de eliminar essas "exceçóes legais permissivas do casamento infantil" (Brasil, 2019a), estabelecendo que "não será permitido, em qualquer caso, o casamento de quem não atingiu a idade núbil" (op. cit.). No entanto, não prevê sanção para as famílias que permitam a união matrimonial de jovens em idade menor que a determinada, tampouco para os parceiros que se casem com essas jovens. Para além da necessidade de aperfeiçoar, portanto, o aparato legal, o país precisa, ademais, enfrentar o desafio de transformar costumes sociais arraigados, especialmente no interior e em áreas mais pobres, onde há menores índices de escolarização. ${ }^{49}$

A meta 5.4 propóe eliminar a desigualdade na divisão sexual do trabalho remunerado e não remunerado, inclusive no trabalho doméstico e de cuidados, promovendo uma maior autonomia das mulheres. Trata-se da chamada tradicional divisão sexual do trabalho, aspecto estruturante da desigualdade de gênero no país, com raízes históricas que remontam ao patriarcado e cujas ideias e valores se perpetuam ainda hoje. Tais paradigmas ainda alicerçam o imaginário social e têm consequências contundentes no que diz respeito à promoçáo da autonomia das mulheres. A fim de contornar o considerável peso que esse arranjo ainda representa para a vida das mulheres brasileiras, faz-se mister que o Estado atue por meio de políticas públicas, que - a exemplo das licenças parentais - visem estimular uma nova divisão das tarefas domésticas entre os sexos e ampliar a participação masculina em atividades de cuidados com filhos e demais dependentes. Além disso, é necessário também investir no aumento da participação feminina no mercado de trabalho, na diminuição das diferenças salariais entre os sexos e em políticas que combatam a segregação ocupacional. É importante, ainda, proporcionar às famílias equipamentos sociais que possibilitem que as famílias compartilhem com o

48. A Convenção sobre os Direitos da Criança (1989) define como criança toda pessoa com menos de 18 anos de idade. 0 Estatuto da Criança e do Adolescente (ECA) brasileiro utiliza duas categorias para se referir às pessoas menores de idade: crianças (pessoa com até 12 anos incompletos) e adolescente (de 12 até 18 anos). Para mais informações, ver Brasil (1990a) e o link disponível em: <http://bit.ly/2wrcbji>.

49. Para mais informações, ver Wodon et al. (2019). 
Estado as tarefas de cuidados - como a oferta de creches, restaurantes comunitários, lavanderias coletivas, escolas em tempo integral e equipamentos de acolhimento para idosos, além de aspectos ainda mais básicos, como fornecimento de energia elétrica, água encanada e esgotamento.

A meta 5.5 visa garantir a participação plena e efetiva das mulheres e a igualdade de oportunidade para liderança em todos os níveis de tomada de decisão na esfera pública. Trata-se de desafio ainda considerável para o país. A participação feminina em postos de poder e tomada de decisão é baixa na política institucional, e, ademais, é baixa também a presença de mulheres no aparato policial do Estado, bem como em posiçóes gerenciais. Ainda há muito o que avançar quanto à essa meta, e um dos aspectos inescapáveis é o enfrentamento de paradigmas tradicionais quanto aos papéis de gênero. Campanhas educativas, discussão sobre mecanismos de ação afirmativa e incentivos governamentais para a inclusão de mais mulheres nesses espaços são alguns dos mecanismos por meio dos quais o Estado pode atuar.

A meta 5.6 refere-se à promoção, à proteção e à garantia da saúde sexual e reprodutiva, bem como dos direitos sexuais e reprodutivos, em consonância com diretrizes e documentos internacionais com os quais o Brasil se encontra comprometido. De modo geral, como já mencionado, o país possui um vasto rol de indicadores sobre o tema, e o que esses indicadores demonstram - também de modo geral - são resultados positivos. Há que se avançar em determinados aspectos, como na diminuição do número de partos cesáreos, na ampliação da cobertura da vacina de HPV na população jovem de ambos os sexos, na melhoria dos índices de morte materna, na ampliaçáo do número de serviços médicos que realizam aborto legal e acolhimento de mulheres que sofrem complicaçôes em decorrência da realização de abortos ilegais, além de redução nas taxas de gravidez na adolescência. A meta 5.6 evidencia que é preciso avançar no sentido de garantir serviços mais humanizados e acolhedores para todas as mulheres, independentemente de raça, etnia, origem geográfica ou classe social. Os dados revelam que entre as mulheres a desigualdade é marcante: existe grande disparidade no acesso à saúde sexual e reprodutiva, e as mulheres negras e as indígenas contam com os piores índices.

A meta 5.a refere-se à garantia da igualdade de direitos, acesso e controle dos recursos econômicos, da terra e de outras formas de propriedade, de serviços financeiros, de herança e de recursos naturais de forma sustentável. Também aqui, como já relatado, o país encontra importantes desafios a serem superados. Apesar de não haver, no aparato legal brasileiro, óbices à assunção da propriedade por parte de mulheres, nem impedimentos legais a acesso a crédito, tomando-se esses fatores como exemplo, os dados revelam realidade marcada por significativas diferenças entre homens e mulheres no que diz respeito ao tema em tela. Elas detêm muito menos bens registrados em seus nomes, por exemplo, e acessam 
montante de crédito bastante inferior ao deles. O Estado pode atuar a fim de corrigir essas distorçóes, e o faz em alguma medida. Por exemplo, por meio das leis que regem o principal programa habitacional, no qual a titularidade das unidades habitacionais entregues é preferencialmente atribuída às mulheres, que, inclusive, ficam com o imóvel em caso de separação matrimonial. Outro exemplo é a Portaria no 981/2003 do Instituto Nacional de Colonização e Reforma Agrária (Incra), que instituiu a titularidade conjunta para homens e mulheres assentados e que garante a titularidade do lote às mulheres separadas que detenham a guarda dos filhos. Faltam, contudo, políticas públicas para alterar o cenário de desigualdade no acesso ao crédito, e é preciso investir não apenas em educação financeira para as mulheres, mas também em orientaçôes para o próprio aparato burocrático estatal, que, muitas vezes, desconhece as especificidades das demandas das mulheres e as ignora, partindo de abordagem cega ao gênero, a qual compromete, em diversas ocasióes, o acesso às linhas de crédito.

Em relação às metas 5.b.1, 5.b.2 e 5.b.3, é importante destacar que estas tratam de propostas de desdobramento da meta global 5.b, a qual aborda a questão do uso das tecnologias de base, de informaçáo e de comunicação. Os desafios para o alcance dessa meta global - ou de sua proposta nacional, desagregada em três submetas - tratam de problema estrutural: as desigualdades de gênero na produção e no acesso à informação, ao conhecimento científico e às tecnologias de comunicação e informação, as quais geram importantes repercussões em termos de possibilidades abertas às mulheres no mercado de trabalho. A proposta de meta 5.b. 1 remete à garantia da igualdade de gênero na acessibilidade, nas habilidades de uso e na produção de TICs. Homens e mulheres, no Brasil, têm grande acesso à internet e até mesmo a dispositivos como celulares. ${ }^{50}$ As habilidades de uso, contudo, são distintas, com uso mais eficiente por parte deles no que se refere a atividades que requeiram conhecimentos sobre hardware, cálculos estatísticos e instalação de programas em computadores (Cetic.br, 2017), o que contribui para a segregação ocupacional no mercado de informática, ciências da computação e ciências exatas, com amplo predomínio masculino. Esse tipo de situação engendra problemas para as mulheres que atuam nesse segmento profissional específico, criando um ambiente que, em geral, tem dificuldade de perceber demandas específicas de minoria de trabalhadoras, além de torná-lo mais sexista e mais difícil à ascensão de mulheres a postos de chefia no setor.

A proposta da meta 5.b.2, por sua vez, diz respeito à igualdade de gênero no acesso ao conhecimento científico, em todas as áreas do conhecimento, bem como na produção deste, e à promoção da perspectiva de gênero na produção do saber.

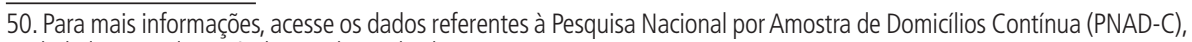
no link do IBGE disponível em: <http://bit.ly/36yamgU>. 
Em média, as mulheres brasileiras detêm mais anos de estudos que os homens e constituem maioria no ensino superior. Apesar disso, recebem aproximadamente um terço das bolsas de produtividade em pesquisa oferecidas aos pesquisadores e às pesquisadoras seniores do país, e ocupam poucos cargos de poder e tomada de decisão no âmbito da gestão da política científica e tecnológica. Nos três órgãos essenciais para essa gestão (Ministério da Ciência, Tecnologia, Inovaçôes e Comunicaçoos - MCTIC; Conselho Nacional de Desenvolvimento Científico e Tecnológico - CNPq; e Coordenação de Aperfeiçoamento de Pessoal de Nível Superior - Capes), são poucos os cargos de maior poder de decisão ocupados por mulheres. Além disso, há segregação ocupacional em determinadas áreas do conhecimento: enquanto homens são maioria em cursos de ciências exatas como matemática, computação, informática, física e engenharias -, mulheres são preponderantes em áreas afetas aos cuidados e à produção do bem-estar social. Em geral, desempenham profissóes menos valorizadas simbólica e monetariamente.

Por sua vez, a proposta da meta 5.b.3 foca na garantia da igualdade de gênero no acesso à informação - e na produção desta -, aos conteúdos de comunicação e às mídias. As mulheres compóem a maioria nas áreas de ensino superior correlatas à comunicação - como cursos de jornalismo, publicidade e marketing - e estâo em maior número no mercado de trabalho desse setor. Ainda assim, os principais postos de poder e prestígio dessas profissóes - como os cobiçados cargos de âncora, em telejornais, ou locutor, em rádio, por exemplo - são ocupados por homens, e as mulheres são maioria nos postos menos valorizados, como revisão e produção de texto (Madsen, [s.d.]). A subalternidade traz consequências para a trajetória profissional dessas mulheres, representando um desvio de mercado no qual o Estado pode interferir a fim de promover transformaçóes e maior equilíbrio.

Por fim, a meta 5.c diz respeito à adoção e ao fortalecimento, pelo país, de políticas públicas e legislação que visem à promoção da igualdade de gênero e ao empoderamento de todas as mulheres e meninas, bem como à promoção de mecanismos para a efetivação em todos os níveis federativos. O Brasil possui, no seio da arquitetura organizacional do Estado, instituiçóes que buscam garantir o pleno funcionamento das políticas públicas desenvolvidas para as mulheres. O histórico da trajetória recente dessas instituições, contudo, demonstra uma gradual perda de prestígio e de relevância do tema na agenda pública estatal desde 2015. Até esse ano, o Brasil contava com institucionalidade específica de políticas para as mulheres no Executivo federal e em boa parte dos Executivos estaduais e municipais. A existência da então Secretaria de Políticas para as Mulheres, vinculada diretamente à Presidência da República e com status ministerial, possibilitou o alcance de importantes e inéditos resultados no campo das políticas para as mulheres, a exemplo da promulgação da Lei Maria da Penha, da Central de Atendimento à Mulher - Ligue 180, do Pacto Nacional pelo Enfrentamento da Violência contra 
as Mulheres, dos planos nacionais de políticas para as mulheres, da Casa da Mulher Brasileira, entre outros avanços. Desde 2016, contudo, a SPM perdeu espaço no governo federal, ${ }^{51}$ e, em 2019, passou a compor o Ministério da Mulher, da Família e dos Direitos Humanos (MMFDH), sob o nome de Secretaria Nacional de Políticas para as Mulheres. Simultaneamente a esse processo de redução do status hierárquico da SPM, é possível acompanhar a perda de relevância do tema na agenda pública e política, tanto no governo federal quanto em suas contrapartes em estados e municípios, as quais também fecharam as secretarias de mulheres ou incorporaram estas a institucionalidades mais amplas. $\mathrm{O}$ fim de institucionalidade específica para o tema das mulheres e, consequentemente, a perda do status de ministra que sua condutora teria levam também à destruição de importantes espaços de gestão e articulação política, conferindo às açôes executadas um caráter muito mais personalista e instável.

A expressiva redução do orçamento direcionado às políticas para as mulheres ao longo dos últimos anos e, consequentemente, a redução da capacidade de execução do orçamento recebido - bem como o enxugamento de equipes, a diminuiçáo do ritmo de entregas para a sociedade e as inúmeras realocaçóes no seio da arquitetura do governo - trazem implicaçóes negativas para o pleno funcionamento da burocracia estatal e a promoção da igualdade de gênero no país. Esses movimentos se refletem no âmbito dos Executivos dos estados e dos municípios, o que gera consequências negativas para a promoção da igualdade de gênero no país.

$\mathrm{O}$ não cumprimento da meta 5.c, portanto, constituiu-se em risco para o alcance das demais metas relacionadas ao ODS 5. A falta de aparato institucional, de importância da agenda no debate público, de poder político para negociar com parceiros e de orçamentos adequados nas esferas federal, estadual e municipal são, sem dúvida, entraves para que o Brasil alcance o conjunto das metas propostas no ODS 5. Esse é um desafio de grandes proporçôes, que se torna ainda mais relevante ao considerar-se que a SNPM hoje integra um ministério que tem como foco as açōes voltadas para as famílias e, em especial, para modelos tradicionais de famílias. Não se discute aqui a importância das famílias como grupos de integração, apoio e suporte afetivo, emocional e econômico aos seus membros. Discute-se, ao contrário, a invisibilidade que as mulheres podem assumir quando se consideram as unidades familiares como eixos centrais, especialmente quando o conceito de família adotado reforça, por um lado, lugares e papéis tradicionais como destinos para as mulheres e, por outro, um modelo que exclui diferentes arranjos familiares, em especial aqueles formados por mulheres do mesmo sexo. A inexistência de instituição específica nos Executivos para tratar de políticas para

51. Para uma análise mais detalhada sobre o processo de perda da relevância institucional da SPM, ver as edições 25 e 26 deste periódico. 
as mulheres é, portanto, um desafio de grande monta para o cumprimento dos ODS, em especial o ODS 5.

Se cortes orçamentários para a SNPM já são motivo de preocupação, o atual contexto de crise econômica e ajuste fiscal agrega receios. Reduções no orçamento de políticas públicas, de modo geral - executadas por instituições como o Ministério da Saúde (MS), o Ministério da Justiça e Segurança Pública (MJSP) ou o Ministério da Cidadania -, certamente irão impactar no alcance das metas elencadas no ODS 5. Foram justamente as políticas públicas desenvolvidas pelo Estado as principais responsáveis pelas melhorias que os indicadores apontam no que diz respeito à promoção da agenda da igualdade de gênero no país.

Outra questão relevante é a ascensão de uma moral conservadora, que tem ganhado adeptos ao longo desta década. Polêmicas de ordem moral, muitas vezes associadas a questóes que envolvem gênero, sexualidade e orientação sexual, receberam destaque nacional nos anos recentes. Essas temáticas - frequentemente compreendidas como antagônicas à ordem social, à família tradicional e aos valores morais cristãos - entraram na agenda pública nacional e foram decisivas na história política recente do país. O embate sobre temas morais vem mobilizando cada vez mais a sociedade brasileira, e figuras associadas a perspectivas mais conservadoras estão se sobressaindo cada vez mais. Essa é uma questão complexa, e, no que tange ao cumprimento dos ODS, é necessário enfrentar, entre outros aspectos, a perpetuação de valores e convençóes tradicionais de gênero, tarefa difícil em uma sociedade bastante conservadora.

Finalmente, vale destacar como a atual política externa brasileira, com novos rumos e diretrizes, pode constituir-se em um desafio significativo ao alcance dos compromissos internacionais assumidos pelo país, em particular os ODS. $\mathrm{O}$ governo de Jair Bolsonaro tem apontado para a PEB direçóes diferentes das que a regiam até então. Ao longo de 2019, a atuação internacional do governo brasileiro foi pautada por unióes transitórias, provenientes de afinidades políticas, religiosas ou civilizacionais, sobrepondo-se, inclusive, a parcerias que durante anos forneceram ganhos econômicos, tecnológicos e políticos ao país. ${ }^{52} \mathrm{O}$ presidente Bolsonaro iniciou o mandato alinhado a políticos ultraconservadores, como o atual presidente dos Estados Unidos. Em comum, ambos os políticos unem-se no chamado antiglobalismo de viés conservador, bem como nas críticas ao multilateralismo, às organizaçóes internacionais e à agenda liberal progressista, cuja prioridade são questões relacionadas a direitos humanos, igualdade de gênero e racial (Freixo, 2019).

52. Medeiros e Vilas-Boas e Andrade (2019) argumentam que priorizar relações com países tradicionalmente fora da PEB em razão de afinidades com os governantes atuais é fazer justamente o que o governo diz combater (a ideologização da diplomacia). 
Outra característica do governo Bolsonaro é a importância, atribuída de forma inédita desde a Carta de 1988, a ideias baseadas no discurso de cunho religioso. $\mathrm{Na}$ cerimônia de posse, no Congresso Nacional, Bolsonaro ressaltou em seu discurso o compromisso com a valorização da família e o respeito às religiôes de tradição judaico-cristâ, além de "combater a ideologia de gênero, conservando nossos valores. O Brasil voltará a ser um País livre das amarras ideológicas" (Posse..., 2019). Em abril de 2019, durante encontro com grupo de pastores evangélicos, o presidente Bolsonaro afirmou que o Brasil passou a "votar lá na ONU, nas questôes dos Direitos Humanos, de acordo com Joâo 8:32", 53 citando a passagem bíblica que diz "E conhecerão a verdade, e a verdade os libertará".

Levantamento divulgado pelo jornal O Globo, em fevereiro de 2020, revela que em 2019 o presidente participou de 51 compromissos oficiais com religiosos, dos quais quarenta foram com lideranças evangélicas, média de três por mês. Foram encontros com pastores no Palácio do Planalto e participação em cultos e eventos religiosos e presença em duas marchas para Jesus. ${ }^{54}$ Em fevereiro de 2020, em evento de comemoraçáo da fundação de uma igreja evangélica, o presidente declarou que "O Brasil é laico, mas o presidente é cristão. O Brasil está mudando. Mais do que pelos números da economia, mas porque respeita a família" ${ }^{55}$ Nesse cenário, as pautas sobre costumes, tradicionalmente ligadas ao segmento evangélico e conservador, têm ganhado destaque na agenda pública.

Um episódio ilustrativo ocorreu em meados de 2019, quando diplomatas receberam instruçóes para vetar em textos qualquer uso do conceito e da palavra gênero, desde os anos 1990 reconhecido em tratados assinados pelo governo brasileiro. Foram dadas outras orientaçóes no sentido de não reconhecer o conceito de direitos reprodutivos e referências à possibilidade de defesa do aborto. A partir dessas diretrizes, os diplomatas vetaram textos que já haviam sido objeto de consenso anteriormente, por conter a palavra gênero e substituíram o termo "igualdade de gênero" por "igualdade entre homens e mulheres". Alguns meses depois, o Itamaraty amenizou as instruçóes de veto, com a orientação de não alteração nos casos de textos já aprovados no passado, apesar de continuar com a intenção de evitar o uso do conceito e do termo gênero. Em agosto de 2019, o ministro das Relaçóes Exteriores participou de debate na Comissão de Seguridade Social e Família da Câmara dos Deputados e confirmou aos presentes que a atual diretriz da PEB é contrária ao uso da palavra gênero, afirmando que quer garantir que a discussão

53. Para mais informações, ver matéria de O Estado de S. Paulo (Em evento..., 2019).

54. Segundo o jornal $O^{3}$ Globo, o presidente participou de quarenta compromissos com evangélicos, nove compromissos com católicos, um evento da Federação das Associações Muçulmanas do Brasil e um encontro com o presidente da Confederação Israelita do Brasil (Conib). No levantamento, não estão inclusos os compromissos realizados com parlamentares representantes de bancadas religiosas no Congresso. Para mais informações, ver matéria de $O$ Globo (Bolsonaro..., 2020).

55. Para mais informações, ver matéria de Valor Econômico (O Brasil..., 2020) e o link disponível em: <https://bit.ly/3aS9iHr>. 
sobre direitos sexuais e reprodutivos no âmbito internacional não inclua o direito ao aborto (Chade, 2019a; Brasil, 2019b).

Ao se alinhar a grupos pró-familistas, Rodrigues (2019) observa que o Brasil abandona uma liderança internacional na defesa dos direitos da comunidade LGBT+ e de mulheres, adquirida justamente com a proposição e o apoio a resoluçóes da ONU contra discriminação de violência de gênero. Almeida (2019, p. 208) ressalta que o conservadorismo dos costumes disseminado por quem disputa a prescrição da moral vigente não tem a intenção somente de alcançar os próprios seguidores, mas toda a sociedade, ao querer influenciar no campo das normas jurídicas, com seu entendimento do que deve ser a moralidade pública. Chade (2019a) considera que os valores do atual governo estão totalmente incorporados pela política externa, com atuação diplomática ideológico-religiosa. Não obstante, há percepções sobre resistências à consolidação dessa política no interior do próprio governo e também por parte de setores da diplomacia brasileira, os quais receavam que o país não fosse convidado a participar de negociaçóes diplomáticas dedicadas a direitos de minorias, em razão de aspectos discursivos que potencialmente causam prejuízos à imagem do país no exterior (Freixo, 2019; Quero e Passarinho, 2019).

$\mathrm{Na}$ apresentação da candidatura do Brasil à reeleição no Conselho de Direitos Humanos (CDH) da ONU para o triênio 2020-2022, o governo afirmou reiterar a determinação de assegurar os direitos humanos das mulheres e meninas, inclusive indicando como prioritárias as açóes de enfrentamento à violência contra a mulher. Foi destacado pela imprensa o fato de o documento, assinado pelo ministro das Relaçôes Exteriores e pela ministra da Mulher, Família e Direitos Humanos não conter nenhuma referência a gênero, tortura e desigualdade, nem citar a Agenda 2030 para o desenvolvimento sustentável - cuja perspectiva promove a igualdade. O documento anterior, referente à candidatura para o biênio 2017-2019 e assinado pelos ministros das Relaçóes Exteriores e da Justiça e Cidadania do governo anterior (gestão do ex-presidente Michel Temer), além de fazer referência aos conceitos citados, registrou como açóes dignas de nota a luta contra a violência e a discriminação de gênero e a luta contra a tortura e o direito à memória e à verdade. Além disso, reafirmava compromissos com a erradicação da pobreza e o combate às desigualdades (Brasil, 2016b; 2016c; 2019c; 2019d). Mesmo com posicionamento tão diverso dos anteriores, em 17 de outubro de 2019, o Brasil


das Naçôes Unidas, em Nova Iorque, não sem receber críticas de instituiçôes da sociedade civil à candidatura, algo inédito desde a redemocratização do país. ${ }^{56}$

56. Dias antes das eleições, carta assinada por mais de cem entidades da sociedade civil brasileira foi enviada aos governos de 193 países, recomendando que a comunidade internacional não votasse no Brasil, por considerar que o país não reunia as "condições mínimas para pleitear a renovação da candidatura ao Conselho de Direitos Humanos." Para mais informações, ver Manifesto... ([s.d.]) e Chade (2019b). 
O Brasil recebeu 153 votos, dezesseis a mais que na eleição anterior, em 2016, na qual o país foi eleito com 137 votos. De acordo com a Nota 263 do Itamaraty, publicada após o pleito, o "resultado demonstra o sólido reconhecimento internacional das credenciais do Brasil em matéria de promoção e proteção dos direitos humanos". ${ }^{57}$ Em entrevista concedida à $O N U$ News, Mauro Vieira, embaixador brasileiro na ONU, defendeu que "o número elevado de apoios representa o papel que o Brasil tem, a imagem que tem nessa instituição e, sobretudo, o legado para a defesa dos direitos humanos" ${ }^{58}$ Nessa ocasião, Vieira destacou que a defesa dos direitos humanos é um princípio constitucional brasileiro, pois o art. $4^{\circ} \mathrm{da} \mathrm{CF} / 1988$ "defende a aplicação dos direitos humanos como um dos princípios orientadores da política externa" ${ }^{59}$ A segunda vaga reservada aos países latino-americanos e caribenhos foi ocupada pela Venezuela, que obteve 105 votos. Os dois países iniciaram o mandato, com duraçáo de três anos, em 1ำ de janeiro de 2020. De acordo com a Organização das Nações Unidas, ao elegerem os novos integrantes para o CDH, os Estados-membros consideram "a contribuição dos Estados à promoção e proteção dos direitos humanos, bem como suas promessas e compromissos voluntários a esse respeito" ${ }^{60}$ Nesse contexto, é fundamental acompanhar os posicionamentos da atual $\mathrm{PEB}$ e de que maneira as orientaçóes atuais contribuirão para o cumprimento das metas estabelecidas nos ODS.

\section{DIREITOS HUMANOS DAS MULHERES: UM COMPROMISSO COM TODAS AS BRASILEIRAS}

Os direitos e as garantias fundamentais assegurados nas convençóes internacionais, na Agenda 2030 para o desenvolvimento sustentável e nos demais instrumentos aos quais o Brasil é signatário são compreendidos, à luz do direito internacional, como patrimônio de direitos humanos e sociais (Baldi e Ribeiro, 2015). Segundo Canotilho (2003), o princípio da progressividade, ou da vedação do retrocesso social, advoga no sentido de que direitos sociais já assegurados por meio de medidas legislativas não poderiam ser revogados sem que condições similares ou compensatórias fossem feitas, de modo que o núcleo essencial do direito antes assegurado seja destruído. A partir de compreensão mais alargada, Baldi e Ribeiro (2015) entendem que o Estado, em todos os seus poderes, não estaria autorizado a reduzir os patamares de direitos humanos e sociais alcançados pela sua populaçáo.

O STF tem adotado entendimentos semelhantes em diversos processos que versam sobre matérias de direitos fundamentais. Como exemplo, na Ação Direta de Inconstitucionalidade (ADI) no ${ }^{4} .717 / \mathrm{DF}$, relatada pela ministra Cármen

57. Para mais informações, ver Brasil (2019c).

58. Para mais informações, ver a matéria do portal ONU News (Brasil.., 2019b).

59. Idem.

60. Idem. 
Lúcia no Tribunal do Pleno, em 5 de abril de 2018, a Corte entendeu que a Lei no $12.678 / 2012$ não poderia reduzir área de conservaçáo, uma vez que tal redução violaria o princípio da proibição de retrocesso, uma vez que retiraria a proteção a espaços territoriais anteriormente protegidos, incidindo negativamente no direito ao meio ambiente ecologicamente equilibrado. $\mathrm{O}$ acórdão da decisão foi prolatado nos seguintes termos:

Ementa: ação direta de inconstitucionalidade. Medida Provisória n. 558/2012. Conversão na Lei no $12.678 / 2012$. Inépcia da inicial e prejuízo da ação quanto aos artigos 6o e 11 da Medida Provisória n. 558/2012 e ao art. 20 da Lei no 12.678/2012. Possibilidade de exame dos requisitos constitucionais para o exercício da competência extraordinária normativa do chefe do executivo. Ausência dos pressupostos de relevância e urgência. Alteraçáo da área de unidades de conservação por medida provisória. Impossibilidade. Configurada ofensa ao princípio da proibição de retrocesso socioambiental. Ação parcialmente conhecida e, nessa parte, julgada procedente, sem pronúncia de nulidade.

\section{(...)}

4. As alteraçôes promovidas pela Lei n. 12.678/2012 importaram diminuição da proteção dos ecossistemas abrangidos pelas unidades de conservação por ela atingidas, acarretando ofensa ao princípio da proibição de retrocesso socioambiental, pois atingiram o núcleo essencial do direito fundamental ao meio ambiente ecologicamente equilibrado previsto no art. 225 da Constituição da República.

5. Ação direta de inconstitucionalidade parcialmente conhecida e, nessa parte, julgada procedente, sem pronúncia de nulidade (STFa, 2018, p. 2, grifo nosso).

No mesmo sentido da jurisprudência do Supremo Tribunal Federal, a literatura também defende a interpretação do princípio de vedaçáo ao retrocesso aos demais direitos fundamentais (Moreira, 2017). Uma parte importante da bibliografia especializada na área considera que, enquanto os direitos humanos seriam os direitos advindos dos instrumentos normativos internacionais, os direitos fundamentais ensejariam as normas efetivamente positivadas no plano do direito interno. Apesar da distinção conceitual, assevera Mendes, Coelho e Branco (2008) que há interação recíproca entre os direitos humanos e os direitos fundamentais, na medida em que os direitos dos Estados seriam inspiração para a normatização de direitos humanos, e vice-versa.

Além de todo o sistema de justiça brasileiro, a força coercitiva dos tratados internacionais de direitos humanos está enredada em um complexo sistema, que abrange instituiçóes de alcance global e regional. O Sistema de Direitos Humanos da Organização das Naçôes Unidas é constituído por quatro organismos permanentes de direitos humanos, além de entidades temporárias; são estes: o CDH/ONU; os procedimentos especiais; os organismos de tratados da ONU; e o Escritório do Alto Comissário das Naçóes Unidas para os Direitos Humanos (ACNUDH/ONU). 
O Brasil também está vinculado ao Sistema Interamericano de Proteção dos Direitos Humanos, sendo este formado principalmente pela CIDH e pela Corte IDH da OEA. O Brasil já teve alguns casos analisados por esses órgãos, sendo o caso Maria da Penha o de maior destaque, uma vez que resultou de condenação do Brasil na CIDH, que teve como um dos resultados a criação da Lei no 11.340/2006 (Brasil, 2006), conhecida como Lei Maria da Penha.

Maria das Graças Neves (2002) recorda que os países, ao assumirem os acordos e os tratados internacionais que sustentam os direitos humanos das mulheres,

assumiram compromissos políticos com a comunidade internacional, com as Nações Unidas e, principalmente, com as mulheres de seus respectivos países, independentemente da organização do movimento de mulheres e do movimento feminista, em escala local e internacional (Neves, 2002, p. 310).

Os direitos e as garantias contidos nessa construção histórica formam um patrimônio de cada uma das brasileiras que vivem hoje e que formarão as geraçóes futuras.

Como assevera Flavia Piovesan (2002, p. 7), os direitos humanos das mulheres “compóem um construído axiológico, fruto de nossa história, de nosso passado, de nosso presente, a partir de um espaço simbólico de luta e ação social”. Os compromissos internacionais assumidos nas últimas décadas pelo país constituem-se em base, e não teto para as ações governamentais - ou seja, são um patamar mínimo a partir dos quais as açóes de governo devem ser pensadas e implementadas, de modo que a vida de cada uma das brasileiras seja vivida em patamares cada vez maiores de liberdade, direitos e dignidade humana.

\section{REFERÊNCIAS}

ALMEIDA, R. Bolsonaro presidente: conservadorismo, evangelismo e a crise brasileira. Novos estudos Cebrap, São Paulo, v. 38, n. 1, p. 185-213, abr. 2019. Disponível em: <https://is.gd/ES8wuQ>. Acesso em: 8 maio 2020.

ALONSO, J. A.; AYUSO, A. Acercar los objetivos de desarollo sostenible a la ciudadanía: el compromiso de Europa con la Agenda 2030. Barcelona: Cidob Ediciones, 2017.

ALVES, J. A. L. A Cúpula Mundial sobre o Desenvolvimento Social e os paradoxos de Copenhague. Revista Brasileira de Política Internacional, Brasília, v. 40, n. 1, p. 142-166, jun. 1997. Disponível em: <https://is.gd/1IOAxQ>. Acesso em: 18 dez. 2019.

- A Conferência de Durban contra o Racismo e a responsabilidade de todos. Revista Brasileira de Política Internacional, Brasília, v. 45, n. 2, p. 198223, dez. 2002. Disponível em: <https://is.gd/JHnx7R>. Acesso em: 18 dez. 2019. 
BALDI, C. A.; RIBEIRO, L. M. C. A proposta de revogação da Convenção 169 da OIT pelo Brasil e o princípio da vedação do retrocesso social. Fragmentos de Cultura, Goiânia, v. 25, n. 2, p. 241-252, abr./jun. 2015. Disponível em: <https:// is.gd/dbM15N>. Acesso em: 20 dez. 2019.

BANDEIRA, L. M.; ALMEIDA, T. M. C. A transversalidade de gênero nas políticas públicas. Revista do Ceam, v. 2, n. 1, p. 35-46, jan./jun. 2013. Disponível em: $<$ https://is.gd/Ic0znH>.

Vinte anos da convenção de Belém do Pará e a Lei Maria da Penha. Revista Estudos Feministas, Florianópolis, v. 23, n. 2, p. 501-517, ago. 2015. Disponível em: <https://is.gd/Rqnpvf>. Acesso em: 18 dez. 2019.

BARSTED, L. L. O direito internacional e o movimento de mulheres. Revista Estudos Feministas, Rio de Janeiro, v. 3, n. 1, p. 191-197, 1995. Disponível em: $<$ https://bit.ly/3dVrvpE>. Acesso em: 18 dez. 2019.

BOLSONARO prioriza lideranças evangélicas em agenda e políticas públicas. $\mathbf{O}$ Globo, 16 fev. 2020. Disponível em: <https://glo.bo/2xTpWYW>.

BOUTROS-GHALI, B. Introduction. In: UN - UNITED NATIONS. The United Nations and the advancement of women - 1945-1996. New York: UN, 1996 (The United Nations Blue Book Series, v. VI). Disponível em: < https:// is.gd/2pkf4V>. Acesso em: $18 \mathrm{dez} 2019$.

BRASIL. Presidência da República. Casa Civil. Subchefia para Assuntos Jurídicos. Lei no 8.069, de julho de 1990. Dispóe sobre o Estatuto da Criança e do Adolescente e dá outras providências. Brasília: PR, 1990a. Disponível em: <http://bit.ly/3anQyio>.

Presidência da República. Casa Civil. Subchefia para Assuntos Jurídicos. Decreto no 99.710, de 21 de novembro de 1990. Promulga a Convenção sobre os Direitos da Criança. Brasília: PR, 1990b. Disponível em: <http://bit.ly/2PNbTtO >.

. Câmara dos Deputados. Decreto Legislativo nº 107, de 1995. Brasília: Câmara dos Deputados, 1995. Disponível em: <https://is.gd/urYLcj>.

. Câmara dos Deputados. Decreto Legislativo no 89, de 1998. Aprova a solicitação de reconhecimento da competência obrigatória da Corte Interamericana de Direitos Humanos em todos os casos relativos à interpretaçáo ou aplicação da Convençấo Americana de Direitos Humanos para fatos ocorridos a partir do reconhecimento, de acordo com o previsto no parágrafo primeiro do art. 62 daquele instrumento internacional. Brasília: Câmara dos Deputados, 1998. Disponível em: $<$ http://bit.ly/2DOtzz3>.

------. Presidência da República. Casa Civil. Subchefia para Assuntos Jurídicos. Decreto no 4.316, de 30 de julho de 2002. 
Promulga o Protocolo Facultativo à Convenção sobre a Eliminação de Todas as Formas de Discriminação contra a Mulher. Brasília: PR, 2002a. Disponível em: <http://bit.ly/2Q9HQ09>.

—. Senado Federal. Código Civil brasileiro. Brasília: Senado Federal, 2002 b. Disponível em: <https://is.gd/WAmCE4>.

-___- Presidência da República. Secretaria-geral. Subchefia para Assuntos Jurídicos. Emenda Constitucional no 45, de 30 de dezembro de 2004. Altera dispositivos dos arts. 5o, 36, 52, 92, 93, 95, 98, 99, 102, 103, 104, 105, 107, 109, 111, 112, 114, 115, 125, 126, 127, 128, 129, 134 e 168 da Constituição Federal, e acrescenta os arts. 103-A, 103B, 111-A e 130-A, e dá outras providências. Brasília: PR, 2004. Disponível em: <https://is.gd/r8Lo5E >.

-___- Presidência da República. Secretaria-geral. Subchefia para Assuntos Jurídicos. Lei no 11.340 , de 7 de agosto de 2006. Cria mecanismos para coibir a violência doméstica e familiar contra a mulher, nos termos do $₫ 8^{\circ}$ do art. 226 da Constituição Federal, da Convenção sobre a Eliminação de Todas as Formas de Discriminação contra as Mulheres e da Convenção Interamericana para Prevenir, Punir e Erradicar a Violência contra a Mulher; dispôe sobre a criação dos juizados de violência doméstica e familiar contra a mulher; altera o Código de Processo Penal, o Código Penal e a Lei de Execução Penal; e dá outras providências. Brasília: PR, 2006. Disponível: <http://bit.ly/36SLtgk>.

. Câmara dos Deputados. Comissão de Direitos Humanos e Minorias. Reuniáo 0270/09. Brasília: Câmara dos Deputados, 2 abr. 2009. Disponível em: $<$ http://bit.ly/3aKnZMy>.

- Presidência da República. Secretaria-geral. Subchefia para Assuntos Jurídicos. Decreto n⿳o 8.892, de 27 de outubro de 2016. Cria a Comissão Nacional para os Objetivos de Desenvolvimento Sustentável. Brasília: PR, 2016a. Disponível em: $<$ https://is.gd/Vd2ucY>.

. Ministério das Relações Exteriores. Eleição do Brasil para o Conselho de Direitos Humanos das Naçóes Unidas. 28 out. 2016b. Disponível em: <https:// is.gd/92Opc3>.

. Ministério das Relaçóes Exteriores. Brasil - Candidatura do Brasil ao Conselho dos Direitos Humanos: 2017-2019. Brasília: MRE, 2016c. Disponível em: <https://is.gd/wBaE56>.

. Lei no 13.811 , de 12 de março de 2019. Confere nova redação ao art. 1.520 da Lei no 10.406, de 10 de janeiro de 2002 (Código Civil), para suprimir as exceções legais permissivas do casamento infantil. Diário Oficial, Brasília, 13 mar. 2019a. Disponível em: <http://bit.ly/2Q9HQ09>. Acesso em: 4 mar. 2020. 
- Câmara dos Deputados. Ministro confirma diretriz da política externa contra conceito de gênero e contra aborto. 7 ago. 2019b. Disponível em: <https:// bit.ly/39QLyCm>. Acesso em: 17 dez. 2019.

- Ministério das Relações Exteriores. Eleiçáodo Brasil parao ConselhodeDireitos Humanos das Naçóes Unidas. 17 out. 2019c. Disponível em: <https://bit.ly/34i0UP8>. . Ministério das Relaçóes Exteriores. Brasil - Candidatura do Brasil ao Conselho dos Direitos Humanos: 2020-2022. Brasília: MRE, 2019d. Disponível em: <https://is.gd/DuENNl>.

Câmara dos Deputados. Brasil assina relatório da Conferência de Combate ao Racismo da ONU. [s.d.]. Disponível em: <http://bit.ly/2TCWmz6>. BRASIL se alia a islâmicos em temas de sexo e família na ONU. UOL, 11 jul. 2019a. Disponível em: <http://bit.ly/39EPUgC>.

BRASIL reeleito para Conselho de Direitos Humanos da ONU. ONU News, 17 out. 2019b. Disponível em: <https://bit.ly/2JK0Tdv>.

CANOTILHO, J. J. G. Direito constitucional e teoria da Constituiçáo. 7. ed. Coimbra: Almedina, 2003.

CARVALHO, M. P.; BARCELLOS, F. C. Os Objetivos de Desenvolvimento do Milênio (ODMs): uma avaliação crítica. Sustentabilidade em Debate, v. 5, n. 3, p. 222-244, set./dez. 2014. Disponível em: <https://is.gd/eRL6Py>.

CETIC.BR - CENTRO DE ESTUDOS SOBRE AS TECNOLOGIAS DA INFORMAÇÃO E DA COMUNICAÇÃO. TIC Domicílios 2016: pesquisa sobre o uso das tecnologias de informação e comunicação no Brasil. São Paulo: Cetic.br, 2017. Disponível em: <https://bit.ly/3e2oBzl>.

CHADE, J. Diplomacia teológica brasileira: um relato de um dia nos bastidores da ONU. UOL, 27 jun. 2019a. Disponível em: <https://bit.ly/2Rgu0t7>. Acesso em: 16 dez. 2019.

Mais de cem entidades se unem contra eleição do Brasil na ONU. UOL, 8 out. 2019b. Disponível em: <https://bit.ly/39QpfN6>.

CNMP - CONSELHO NACIONAL DO MINISTÉRIO PÚBLICO. Recomendação no 41, de 9 de agosto de 2016. Define parâmetros para a atuação dos membros do Ministério Público brasileiro para a correta implementação da política de cotas étnico-raciais em vestibulares e concursos públicos. Brasília: CNMP, 2016. Disponível em: <https://bit.ly/2JSZS2x>.

CORRÊA, S. A política do gênero: um comentário genealógico. Cadernos Pagu, Campinas, n. 53, 2018. Disponível em: <https://bit.ly/39OkyDm>. Acesso em: 18 dez. 2019. 
DOSSIE III Conferência Mundial contra o Racismo. Revista Estudos Feministas, Florianópolis, v. 10, n. 1, jan. 2002. Disponível em: <http://bit.ly/2TRP4qk>.

DREZETT, J.; PEDROSO, D. Aborto e violência sexual. Ciência e Cultura, São Paulo, v. 64, n. 2, p. 35-38, jun. 2012. Disponível em: <https://bit.ly/2wYvrp9>. Acesso em: 18 dez. 2019.

EM EVENTO com evangélicos, Bolsonaro diz que Brasil segue versículo da Bíblia na ONU. Estado de S. Paulo, 11 abr. 2019. Disponível em: <https://bit. ly/2XjmYHQ>.

FONTÃO, M. A. B. As conferências da ONU e o movimento de mulheres: construção de uma agenda internacional. 2011. 60 f. Monografia (Especialização) - Universidade de Brasília, Brasília, 2011. Disponível em: <https://bit.ly/2VGJeSj>. Acesso em: 18 dez. 2019.

FREIXO, A. As relaçôes exteriores: Bolsonaro, 100 dias. Lemonde Diplomatique, 10 abr. 2019. Disponível em: <https://bit.ly/2yG7AuP>. Acesso em: 15 dez. 2019.

FUNDAÇÃO CULTURAL PALMARES. Conferência de Durban completa 10 anos. [s.d.]. Disponível em: <http://bit.ly/3cPWjYf>

GUARNIERI, T. H. Os direitos das mulheres no contexto internacional da criação da ONU (1945) à Conferencia de Pequim (1995). Revista Eletrônica da Faculdade Metodista Granbery, n. 8, p. 1-28, jan./jun. 2010. Disponível em: $<$ https://bit.ly/2yG9bAP>. Acesso em: $18 \mathrm{dez} .2019$.

IPEA - INSTITUTO DE PESQUISA ECONÔMICA APLICADA. V Relatório Nacional de Acompanhamento dos Objetivos de Desenvolvimento do Milênio. Brasília: Ipea/MP, 2014. Disponível em: <https://is.gd/h1VOcS>.

ODS: metas nacionais dos Objetivos de Desenvolvimento Sustentável. Brasília: Ipea, 2018. Disponível em: <http://bit.ly/3aRaHhm>.

—.Cadernos ODS: ODS 5-Alcançar a igualdade de gênero e empoderar todas as mulheres e meninas. Brasília: Ipea, 2019. Disponível em: <https://is.gd/9vU1xn>.

IPEA - INSTITUTO DE PESQUISA ECONÔMICA APLICADA; CNJ CONSELHO NACIONAL DE JUSTIÇA. O Poder Judiciário no enfrentamento à violência doméstica e familiar contra as mulheres. Brasília: Ipea e CNJ, 2019. Relatório. Disponível em: <https://is.gd/bpV2gH>.

LIMA, N. O.; PETERKE, S. Acesso à justiça internacional para as mulheres brasileiras: o Papel do CEDAW. Revista do Núcleo de Estudos e Pesquisas em Gênero e Direito, v. 2, p. 1-33, 2011. Disponível em: <https://is.gd/UwcQ7r>. Acesso em: 18 dez. 2019. 
MADSEN, N. Mulheres e comunicação no Brasil: 1995 a 2015. Brasília: Ipea, [s.d.]. Disponível em: <https://bit.ly/2V8g2KW>.

MANIFESTO of the Brazilian civil society organizations on the candidature of Brazil to the UN Human Rights Council. [s.d]. Disponível em: <https://bit. ly/2JNGe8d>.

MEDEIROS, K. P.; VILAS-BOAS, V.; ANDRADE, E. A divina providência política externa conservadora: uma nova matriz no Brasil? Lemonde Diplomatique, 21 mar. 2019. Disponível em: <https://bit.ly/34q1gDy>. Acesso em: 14 dez. 2019.

MENDES, G. F.; COELHO, I. M.; BRANCO, P. G. G. Curso de direito constitucional. São Paulo: Saraiva, 2008.

MESECVI - MECANISMO DE SEGUIMIENTO DE LA CONVENCIÓN DE BELÉM DO PARÁ. Guia para la aplicación de la Convención Interamericana para Prevenir, Sancionar y Erradicar la Violencia contra la Mujer. In: CONVENCIÓN DE BELÉM DO PARÁ. México: Mesecvi, 2014. Disponível em: <https://bit. ly/2Xg0doa>. Acesso em: 18 dez. 2019.

MOREIRA, E. C. P. As violaçóes de direitos aportadas pela Lei no 13.123/2015 como ofensa ao princípio de vedação de retrocesso dos direitos humanos. In: MOREIRA, E. C. P.; PORRO, N. M.; SILVA, L. A. L. (Orgs.). A "nova” Lei no 13.123/2015 no velho Marco Legal da Biodiversidade: entre retrocessos e violaçóes de direitos socioambientais. São Paulo: Instituto O Direito por um Planeta Verde, 2017.

MORTALIDADE materna sobe, e Brasil já revê meta de redução para 2030. Folha de S. Paulo, 13 ago. 2018. Disponível em: <http://bit.ly/2vfg3nd>.

NEVES, M. G. R. A condição feminina nos países do Mercosul: trabalho e educação numa perspectiva comparativa. In: COSTA, D. M.; NEVES, M. G. R. (Orgs.). A condiçáo feminina nos países do Mercosul: sistema integrado de indicadores de gênero nas áreas de trabalho e educaçáo. Rio de Janeiro: Ibam, 2002. p. 339.

"O BRASIL é laico, mas o presidente é cristão", diz Bolsonaro. Valor Econômico, 15 fev. 2020. Disponível em: <https://glo.bo/3dZvxgK>.

OEA - ORGANIZAÇÃO DOS ESTADOS AMERICANOS. Comissão Interamericana de Direitos Humanos. Relatório no 54/01. Caso 12.051. Maria da Penha Maia Fernandes. Washington: OEA, 2001. Disponível em: <http:// bit.ly/2raBLXD>.

OIT - ORGANIZAÇÃO INTERNACIONAL DO TRABALHO. Convenção e Recomendaçáo sobre Trabalho Decente para as Trabalhadoras e os Trabalhadores Domésticos. Genebra: OIT, 2011a. Disponível em: <http://bit.ly/2Q8xjlU>. 
. Conferência Internacional do Trabalho 2011: a OIT realiza a segunda rodada de discussóes sobre o tema trabalho decente para as/os trabalhadoras/os domésticas/os. Genebra: OIT, 2011b. Disponível em: <http://bit.ly/2MFiPaM>.

. Brasil ratifica Convençáo 189 da OIT sobre trabalho doméstico. $1 \stackrel{\circ}{\circ}$ fev. 2018. Disponível em: <http://bit.ly/2MIbxDe>.

ONU - ORGANIZAÇÃO DAS NAÇÓES UNIDAS. Carta das Naçóes Unidas. Nova York: ONU, 1945. Disponível em: <https://is.gd/LZHubN>.

Convenção sobre a Eliminação de Todas as Formas de Discriminação contra a Mulher. Nova York: ONU, 1979. Disponível em: <https://is.gd/4FyrXn>.

—. Declaração do Rio de Janeiro. Estudos Avançados, v. 6, n. 15, p. 153-159, 1992. Disponível em: <https://is.gd/1 ra7lo>.

—. Declaraçáo e Programa de Ação de Viena. Viena: ONU, 1993. Disponível em: <http://bit.ly/2pSF30Z >.

. Relatório da Conferência Internacional sobre População e Desenvolvimento. In: CONFERÊNCIA INTERNACIONAL SOBRE POPULAÇÃO E DESENVOLVIMENTO. Cairo: ONU, set. 1994. Disponível em: <https://bit. ly $/ 3 \mathrm{c} 0 \mathrm{dFj}$ >. Acesso em: $18 \mathrm{dez} .2019$.

Declaração e Plataforma de Açáo da IV Conferência Mundial Sobre a Mulher. Pequim: ONU, 1995. Disponível em: <http://bit.ly/2PjhDdR>.

-----. Declaração e Programa de Ação da Cúpula Mundial sobre Desenvolvimento Social. Copenhague: ONU, 1995b.

- Conferência Mundial contra o Racismo, Discriminaçáo Racial, Xenofobia e Intolerância Correlata. Durban: ONU, 2001. Disponível em: $<$ http://bit.ly/2teS3PW>.

PASINATO, W. Lei Maria da Penha: novas abordagens sobre velhas propostas onde avançamos? Civitas: Revista de Ciências Sociais, v. 10, n. 2, p. 216-232, maio/ ago. 2010. Disponível em: <https://bit.ly/2JONgtj>. Acesso em: 18 dez. 2019.

PIMENTEL, S.; PANDJIARJIAN, V. Direitos humanos a partir de uma perspectiva de gênero. Revista da Procuradoria Geral do Estado de Sáo Paulo, n. 53, p. 107-139, jun. 2000. Disponível em: <https://bit.ly/39NUqbN>. Acesso em: 18 dez. 2019.

PIMENTEL, S. C. S.; PIOVESAN, F. Direitos humanos das mulheres. In: AMB -ARTICULAÇÃO DE MULHERES BRASILEIRAS. (Org.). Articulando a luta feminista: os direitos das mulheres são direitos humanos. Recife: AMB, 2004. p. $5-12$. 
PINHEIRO, A. L. L. Direitos humanos das mulheres: retrato das desigualdades de gênero e raça. Brasília: Ipea, 2019. Disponível em: <https://bit.ly/2VbiMa9>. Acesso em: 18 dez. 2019.

PINTO, C. R. J. Feminismo, história e poder. Revista de Sociologia e Política, Curitiba, v. 18, n. 36, p. 15-23, June 2010. Disponível em: <https://is.gd/ghtbOX>. Acesso em: 7 maio 2020.

PIOVESAN, F. A Constituição brasileira de 1988 e os tratados internacionais de proteçáo dos direitos humanos. In: STJ - SUPERIOR TRIBUNAL DE JUSTIÇA; BRASIL. Presidência da República. Secretaria de Estado dos Direitos Humanos. (Org.). A proteção internacional dos direitos humanos e o Brasil. Brasília: STJ; PR, 2000. p. 87-104.

. Introdução. In: Cadernos Themis Gênero e Direito: direito sexual. Porto Alegre: Themis Assessoria Jurídica e Estudos de Gênero, 2002. ano III, n. 3.

- Ações afirmativas da perspectiva dos direitos humanos. Cadernos de Pesquisa, São Paulo, v. 35, n. 124, p. 43-55, abr. 2005. Disponível em: <https:// is.gd/RF0ad3>. Acesso em: 6 maio 2020.

POOLE, L. Génesis de la Convención de Belém do Pará: educar y promover el rechazo a la violencia. Inmujeres, México, 28 oct. 2013. Suplemento Todas (suplemento especial). Disponível em: $<\mathrm{https} / / / \mathrm{bit} . \mathrm{ly} / 3 \mathrm{e} 2 \mathrm{~s} 3 \mathrm{tV}\rangle$. Acesso em: 18 dez. 2019.

POSSE de Bolsonaro: leia a íntegra do discurso do novo presidente no Planalto. Huffpost, 1ำ jan. 2019. Disponível em: <https://bit.ly/2xb6B5m>.

PRA, J. R.; EPPING, L. Cidadania e feminismo no reconhecimento dos direitos humanos das mulheres. Revista de Estudos Femininos, Florianópolis, v. 20, n. 1, p. 33-51, 2012. Disponível em: <https://bit.ly/34hsqwa>. Acesso em: 18 dez. 2019.

QUERO, C.; PASSARINHO, N. Governo Bolsonaro ameaça prestígio internacional do país, dizem diplomatas brasileiros. BBC, 31 maio 2019. Disponível em: < https:// is.gd/OHvy00>.

RODRIGUES, R. Na ONU, Brasil promove desmonte de política progressista de direitos humanos. Gênero e Número, 19 set. 2019. Disponível em: <https:// is.gd/gPwFGK>.

SAFFIOTI, H. Enfim, sós: Brasil rumo a Pequim. Estudos Feministas, Rio de Janeiro, v. 3, n. 1, p. 198-202, 1995. Disponível em: <https://bit.ly/3e358P5>. Acesso em: 18 dez. 2019. 
SAWYER, D. Palco e bastidores da Conferência Internacional sobre População e Desenvolvimento. Revista Brasileira de Estudos Populares, São Paulo, v. 36, p. 1-9, 2019. Disponível em: <https://is.gd/ftfGuD>. Acesso em: 7 maio 2020.

SILIPRANDI, E. Mulheres e agroecologia: aconstrução de novos sujeitos políticos na agricultura familiar. 2009. Tese (Doutorado) - Centro de DesenvolvimentoSustentável, Universidadede Brasília, Brasília, 2009. Disponível em: $<$ https://is.gd/yuzKVn>.

STF - SUPREMO TRIBUNAL FEDERAL. Açáo Direta de Inconstitucionalidade no 4.717, Distrito Federal. Brasília: STF, 5 abr. 2018a. Disponível em: <https:// bit.ly/3dX2QRH>. Acesso em: 18 dez. 2019.

Habeas Corpus no 157.306, São Paulo. Brasília: STF, 25 set. 2018b. Disponível em: <https://bit.ly/2JIM8HV>. Acesso em: 12 dez. 2019.

TOMAZONI, L.; GOMES, E. Afirmação histórica dos direitos humanos das mulheres no âmbito das Naçóes Unidas. Cadernos da Escola de Direito e Relaçóes Internacionais da UniBrasil, v. 2, n. 23, p. 44-59, 2015. Disponível em: <https:// is.gd/VDVhUv>. Acesso em: $18 \mathrm{dez} .2019$.

UN - UNITED NATIONS. General Assembly. Resolutions adopted on the reports of the Third Committee. New York: UN, 1967. Disponível em: <https:// is.gd/AU6jtL>.

- Report of the World Conference of the International Women's Year. New York: UN, 1976a. Disponível em: <http://bit.ly/2X512Rb>.

General Assembly. Resolutions adopted on the reports of the Third

Committee. New York: UN, 1976b. Disponível em: <http://bit.ly/38jF9yU>

Report of the World Conference of the United Nations Decade for Woman: quality, development and peace. Copenhagen: UN, 14-30 July 1980. Disponível em: <http://bit.ly/2NTfm8r $>$.

Report of the World Conference to review and appraise the achievements of the United Nations Decade for Woman: equality, development and peace. Nairobi: UN, July, 1985. Disponível em: <http://bit.ly/2K1M5HD>.

Optional Protocol to the Convention on the Elimination of All Forms of Discrimination against Women. New York: UN, 1999. Disponível em: <http:// bit.ly/37rhz2X>.

UNESCO - UNITED NATIONS EDUCATIONAL, SCIENTIFIC AND CULTURAL ORGANIZATION. Records of the General Conference: twentieth session - Paris, 24 October to 28 November 1978. v. 1. Resolutions. Paris: Unesco, 1979. Disponível em: <http://bit.ly/36Qmdsb>. 
WODON, Q. et al. Casamento na infância e adolescência: a educação das meninas e a legislação brasileira. Washington: Banco Mundial, abr. 2018. (Erradicando o Casamento Infantil). Disponível em: <https://is.gd/BfWZB8>.

\section{BIBLIOGRAFIA COMPLEMENTAR}

BRASIL. Câmara dos Deputados. Convenção Internacional sobre a Eliminaçáo de Todas as Formas de Discriminaçáo Racial. Brasília: Câmara dos Deputados, 1968. Disponível em: <https://bit.ly/2wfWknU>. Acesso em: 18 dez. 2019.

- Ministério da Cultura. Declaraçáo e programa de açáo: adotada em 8 de setembro de 2001. In: CONFERÊNCIA MUNDIAL CONTRA O RACISMO, DISCRIMINAÇÃO RACIAL, XENOFOBIA E INTELORÊNCIA CORRELATA. Durban, Brasília: MinC, 2001. Disponível em: <https://bit.ly/2yHbTWR>.

CASARÓES, G. Abertura econômica, democracia e modernização: a política externa do governo Collor revisitada. In: ENCONTRO ANUAL DA ASSOCIAÇÃO NACIONAL DE PÓS-GRADUAÇÃO E PESQUISA EM CIÊNCIAS SOCIAIS (ANPOCS), 35., 2011, Caxambu, Minas Gerais Anais.... Caxambu: Anpocs, 2011. Disponível em: <https://bit.ly/34hr849>. Acesso em: 18 dez. 2019.

CHADE, J. Desgastado, Itamaraty suaviza instruçôes sobre gênero. UOL, 31 out. 2019. Disponível em: <https://bit.ly/2JOPmJD>. Acesso em: 16 de. 2019.

HIRST, M.; PINHEIRO, L. A política externa do Brasil em dois tempos. Revista Brasileira de Política Internacional, v. 38, n. 1, p. 5-23, 1995. Disponível em: <https://is.gd/JdiuTD>. Acesso em: 18 dez. 2019.

KINZO, M. D. G. A democratização brasileira: um balanço do processo político desde a transição. São Paulo Perspectiva, São Paulo, v. 15, n. 4, p. 3-12, 2001. Disponível em: <https://bit.ly/3aR7COF>. Acesso em: 18 dez. 2019.

MELLO E SILVA, A. O Brasil no continente e no mundo: atores e imagens na política externa brasileira contemporânea. Revista Estudos Históricos, v. 8, n. 15, p. 95-118, 1995. Disponível em: <https://is.gd/WgQQ1X>. Acesso em: 18 dez. 2019.

PINHO, C. E. S. Política subalterna: ditadura militar e bolsonarismo - política doméstica e relaçóes internacionais. Lemonde Diplomatique, 22 abr. 2019. Disponível em: <https://bit.ly/3b363wU>. Acesso em: 18 dez. 2019.

SARAIVA, M. G. Balanço da política externa de Dilma Rousseff: perspectivas futuras? Relaçóes Internacionais, Lisboa, n. 44, p. 25-35, dez. 2014. Disponível em: <https://is.gd/3VlBqI>. Acesso em: 5 jan. 2020. 
STF - SUPREMO TRIBUNAL FEDERAL. Agravo contra a decisão que não admitiu recurso extraordinário interposto contra acórdáo da Décima Segunda Câmara Cível do Tribunal de Justiça do Estado do Rio de Janeiro. Brasília: STF, 3 ago. 2015. Disponível em: <https://bit.ly/34pZMJu>. Acesso em: 18 dez. 2019.

VILELA, E.; NEIVA, P. Temas e regióes nas políticas externas de Lula e Fernando Henrique: comparação do discurso dos dois presidentes. Revista Brasileira de Política Internacional, Brasília, v. 54, n. 2, p. 70-96, 2011. Disponível em: <https://bit.ly/2UR3715>. Acesso em: 18 dez. 2019. 



\section{POLÍTICAS DE INCLUSÃO PRODUTIVA: O “ELO PERDIDO" DA PROTEÇÃO SOCIAL?}

Sandro Pereira Silva²

\section{APRESENTAÇÃO}

A população da América Latina e do Caribe convive historicamente com altos índices de pobreza e desigualdade de renda em seus países, os quais se manifestam de maneira diferenciada quando se leva em conta os distintos recortes sociais, como por gênero, etnia, idade etc. Além de ser uma realidade preocupante por si só, há evidências na literatura que expressam o fato de altos níveis de pobreza e desigualdade constituírem obstáculos significativos para o desenvolvimento sustentável dos países (Cepal, 2019b). Parte desse problema da região é explicada pela heterogeneidade da estrutura produtiva de suas economias nacionais, marcada por um largo diferencial de produtividade entre setores e empresas em atividade (Infante, 2011; Nogueira, 2019).

Por se tratar de fenômenos complexos e multidimensionais, o enfrentamento dessas questóes exige um repertório variado de intervenções por parte do poder público. Nessa perspectiva, os países vêm apresentando algumas respostas programáticas diversificadas, sobretudo a partir dos anos finais do século XX, com a abertura de novos canais de expressão das demandas populares por melhores condiçóes de vida e cidadania. O Brasil se enquadra nesse processo.

Uma dimensão importante dessas intervençôes refere-se aos programas nacionais de transferência de renda, de natureza contributiva direta ou indireta, que auxiliam no enfrentamento de problemas causados pela perda da capacidade laboral dos indivíduos e pela insuficiência de renda de algumas famílias.

Recentemente, outro eixo de atuação estatal tem ganhado espaço nas agendas de governo. Trata-se de programas voltados à inclusão produtiva de indivíduos em idade ativa, com o intuito de garantir a autonomia de renda e combater, em articulação com as demais políticas de proteção social, o ciclo geracional da pobreza. Estes programas são relevantes para a orientação de açôes dirigidas ao pacto internacional 
dos Objetivos de Desenvolvimento Sustentável (ODS) junto à Organização das Naçóes Unidas (ONU), com destaque para o ODS 1 - erradicação da pobreza -, o ODS 8 - promoção do trabalho decente e desenvolvimento econômico - e o ODS 10 - redução das desigualdades (Ipea, 2018; Cepal, 2019a).

Contudo, o termo inclusão produtiva ainda recende de uma classificação teórica e político-pragmática mais rigorosa para ser de fato encarado como um referencial de política pública presente na agenda governamental. As açôes em curso sob a responsabilidade dos governos nacionais são baseadas em múltiplas estratégias de intervenção, espalhadas sob a gestão de estruturas burocráticas distintas, sem uma coordenação bem estruturada e com poucos canais de deliberação, comprometendo seus resultados no plano operacional agregado (Cepal, 2011; 2019a; 2019c; Evans, 2011; Silva, 2020b).

É justamente sobre essa questão que este texto visa tratar. O objetivo foi realizar um enquadramento analítico sobre o repertório recente de políticas de combate à pobreza e à desigualdade de renda, suas características mais centrais e como os programas de inclusão produtiva se inserem nessa estratégia. Para tanto, traçou-se, inicialmente, um balanço desse arranjo institucional para o contexto atual latino-americano. Em seguida, o foco recaiu sobre as experiências recentes no Brasil, destacando os principais programas que se inserem em uma estratégia de proteção social em geral, e de inclusão produtiva em particular. Por fim, são apontadas algumas consideraçóes propositivas para a construção de uma estratégia nacional de inclusão produtiva a partir da realidade brasileira.

\section{POLÍTICAS SOCIAIS DE COMBATE À POBREZA E À DESIGUALDADE NA AMÉRICA LATINA}

A pobreza pode ser caracterizada de maneira sintética como uma situação de fragilidade social e privação material em que o indivíduo se encontra diante das demandas básicas de sobrevivência e cidadania. Essa situação gera no indivíduo uma série de incertezas, que, por sua vez, obedecem a uma escala de necessidades. Assim, combater a pobreza significa enfrentar as principais incertezas que a caracterizam, entre as quais se encontram: a insuficiência de renda, a precariedade de serviços públicos e a falta de oportunidades de trabalho decente (Silva, 2011).

Os países da América Latina têm empreendido, nos últimos anos, diversas estratégias de políticas públicas orientadas à superação da pobreza e, por conseguinte, redução das desigualdades sociais. Tais açôes visam não apenas contribuir para melhoraria da renda de indivíduos e famílias participantes, mas também promover - direta ou indiretamente, de acordo com o tipo de programa - o acesso a serviços sociais básicos e fomentar o trabalho decente na regiấo. Elas foram relevantes para que o período de recuperação econômica vivido em praticamente toda a região a 
partir do início dos anos 2000 resultasse também em diminuição desses indicadores de pobreza e desigualdade, embora dados mais recentes já demonstrem um refluxo dessa trajetória a partir de 2015. O gráfico 1 ilustra esses números.

GRÁFICO 1

Evolução da pobreza (\%), pobreza extrema (\%) e desigualdade de renda (índice de Gini) - América Latina e Caribe ${ }^{1}$



O conjunto dessas estratégias constitui o campo de política pública da proteção social, que é fundamental para a garantia dos direitos reconhecidos em diversos tratados e acordos internacionais, como a Declaração Universal dos Direitos Humanos das Naçóes Unidas, de 1948, e o Pacto Internacional de Direitos Econômicos, Sociais e Culturais, de 1966, além da recente Agenda 2030 para o Desenvolvimento Sustentável. Tais instrumentos normativos reconhecem como direitos o trabalho, a seguridade social e a garantia de níveis de vida adequados para os indivíduos e suas famílias. Nessa perspectiva, a ideia de proteção social está dirigida a responder não apenas a riscos sociais os mais diversos (desemprego, incapacidade laboral, velhice etc.), mas também a problemas estruturais, como a pobreza e a desigualdade, junto a outras regulaçôes do mundo do trabalho, como o salário mínimo (Cepal, 2019c).

Em particular, destaca-se recentemente nos países da região, sobretudo a partir dos anos 1980, a estruturação de políticas que podem ser enquadradas em três grupos de açóes: os benefícios previdenciários e pensóes sociais; as transferências condicionadas de renda; e os programas de inclusão produtiva (Cepal, 2011; 2019a; 2019c). Essas açóes, cujos desenho institucional, resultados 
e impactos variam de acordo com o contexto nacional de execução, podem ser consideradas como uma espécie de tripé para um sistema integral de proteção social e inclusiva. ${ }^{3}$

Os benefícios de aposentadoria e pensões sociais são constituídos por transferências monetárias providas pelo Estado associadas à velhice ou à incapacidade física para o trabalho, visando garantir a cobertura das necessidades básicas dos indivíduos que se encontram nessas condiçóes. Tais benefícios podem ocorrer mediante aportes de contribuiçóes do beneficiário ao longo de sua vida laboral, ou serem direcionados a grupos populacionais que não alcançam um tempo mínimo de contribuição direta aos sistemas oficiais de seguridade. A primeira experiência nacional desse tipo de intervenção na América Latina foi no Uruguai, em 1919. No Brasil, as experiências ocorreram de forma lenta, gradual e esparsa no tempo, tendo como marco institucional a Lei Eloy Chaves (Decreto Legislativo no 4.682/1923), até ganhar um patamar de universalidade com a Constituição Federal de 1988 (CF/1988). Ao todo, são reconhecidos atualmente na América Latina 34 programas com essas características em seu conjunto de países.

Os programas de transferências condicionadas consistem na distribuição de recursos monetários a famílias que vivem em situaçáo de pobreza, com uma atençáo especial àquelas que possuem crianças ou adolescentes residindo no domicílio. O recebimento do benefício fica associado ao cumprimento de certas condutas por parte dos beneficiários, principalmente no campo da saúde (nutrição, controle pré-natal e calendário de vacinação) e da educação (matrícula escolar primária e secundária). Com isso, eles buscam dois objetivos de maneira simultânea: i) reduzir a pobreza no curto prazo, mediante o aumento do consumo das famílias impulsionado pelas transferências monetárias; e ii) reduzir o componente intergeracional da pobreza, mediante o fortalecimento das capacidades de crianças, adolescentes e jovens, impulsionado pelas condicionalidades. Os beneficiários preferenciais são mulheres, mães de família, o que favorece novas dinâmica de autonomia de gênero na gestão dos recursos. Apesar de seu surgimento relativamente recente (primeiros casos em nível nacional no Brasil e no México em meados da década de 1990), tais programas se disseminaram na América Latina, com trinta experiências reconhecidas.

3. Conforme exposto por Cepal (2019c), a noção de proteção social inclusiva supõe uma adequada combinação articulada entre política social de corte universal, que inclui a provisão de proteção de caráter compensatório, e uma política econômica ativa que permita incorporar distintos grupos da população e gere as capacidades para superar as situações de risco em que elas são vulneráveis, considerando, assim, a garantia de proteção e promoção, direitos e oportunidades. 
Já os programas de inclusão produtiva são dirigidos principalmente a indivíduos em idade laboral que vivem sob condiçôes de vulnerabilidade social. Eles oferecem um rol extenso de serviços, tais como: formação educacional básica, capacitação técnica e profissionalizante, apoio a microemprendimentos, serviços de intermediação laboral ou até mesmo geração de empregos direta via contratação por órgãos públicos - e indireta - via subsídios econômicos a empresas para a contrataçấo de determinados segmentos sociais (Silva, 2020b). Embora haja antecedentes em anos anteriores, esses programas ganharam notoriedade no final dos anos 1990 e têm apresentado um forte crescimento a partir da década de 2000, chegando a 72 experiências nos anos recentes. A maioria envolve ações de capacitação técnica e profissional, seguida por apoio a atividades autônomas de autoemprego, e se concentram na oferta de serviços que visam responder necessidades específicas de grupos sociais que enfrentam diversas barreiras de acesso ao mercado de trabalho, por exemplo: mulheres, populaçóes rurais e de periferias urbanas, jovens, pessoas com deficiência, afrodescendentes, imigrantes, entre outros. O gráfico 2 apresenta informaçôes sobre a evolução desses programas na região. ${ }^{4}$

\section{GRÁFICO 2}

Evolução do número de programas de combate à pobreza e à desigualdade na América Latina ${ }^{1}$



4. Vale destacar que os programas considerados pela Comissão Econômica para a América Latina e o Caribe (Cepal) são majoritariamente urbanos. 
A busca da inclusão pelo trabalho parte de um entendimento de que a atividade laboral é o principal motor para a superaçáo da pobreza e um fator decisivo para a redução das desigualdades. Ademais, há toda uma literatura no campo da economia e sociologia do trabalho que destaca sua centralidade na construçáo de autonomia, identidade, dignidade pessoal, sociabilidade e previsibilidade na vida dos indivíduos. Por isso, alteraçôes repentinas na dinâmica do mercado de trabalho implicam mudanças abruptas na condição de vida dos indivíduos. O Brasil passou por mudanças dessa natureza nos últimos anos: primeiramente, houve uma elevação significativa das oportunidades de emprego, com melhora expressiva nos indicadores de emprego entre 2004 e 2014. Posteriormente, o país passou por uma forte reversão desse quadro, com elevação acelerada do desemprego e da informalidade a partir de 2015, resultante da crise econômica que levou a uma queda do produto nacional na ordem de 7\% entre 2015 e 2016, sem ser sucedida de uma recuperação considerável nos anos seguintes (Oliveira e Silva, 2018; Silva, 2018d; Ipea, 2019).

Contudo, um desafio relevante a ser considerado pelos programas de inclusão produtiva e laboral é o fato de que uma parcela significativa das pessoas adultas em situação de pobreza e pobreza extrema já exerce alguma atividade remunerada (cerca de dois terços do total), ainda que as taxas de desocupação entre esses indivíduos sejam superiores às dos demais. Essa informação contradiz uma opiniâo bastante comum de que as pessoas se encontram nessa condição devido à falta de esforço próprio ou por aversão ao trabalho. Ocorre, porém, que esses indivíduos estão inseridos em atividades de baixa remuneração e sem a garantia de direitos básicos de segurança e proteção social, o que Abramo (2015) classifica como deficit de trabalho decente. Isso não apenas inviabiliza a superação da pobreza por meio das oportunidades de emprego que lhes são oferecidas, como influe em sua própria reprodução intergeracional.

Para além da inserção laboral precária, há ainda uma evidente distinção quando se observa a realidade a partir de um recorte por gênero. Enquanto $60,6 \%$ dos homens na situação de extrema pobreza exercem alguma atividade remunerada, entre as mulheres esse índice cai para 30,1\%. Já entre os indivíduos que não estão em situação de pobreza ou pobreza extrema, essa diferença é mais amena $(77,8 \%$ contra 56,4\%), conforme ilustrado no gráfico 3. Essa informação indica a existência de outros fatores que potencializam as relaçóes de exclusão e desigualdade no mercado de trabalho, uma vez que ainda recaem majoritariamente sobre as mulheres o peso do trabalho reprodutivo e a responsabilidade do cuidado doméstico (Pinheiro et al., 2019). Ou seja, a inclusão laboral dessas mulheres depende da garantia de outros serviços públicos que lhes permita a inserção em uma jornada externa de trabalho. 
GRÁFICO 3

Condição de atividade de indivíduos em idade ativa, segundo sexo e situação de pobreza - América Latina (2016)

(Em \%)

$3 \mathrm{~A}$ - Entre homens

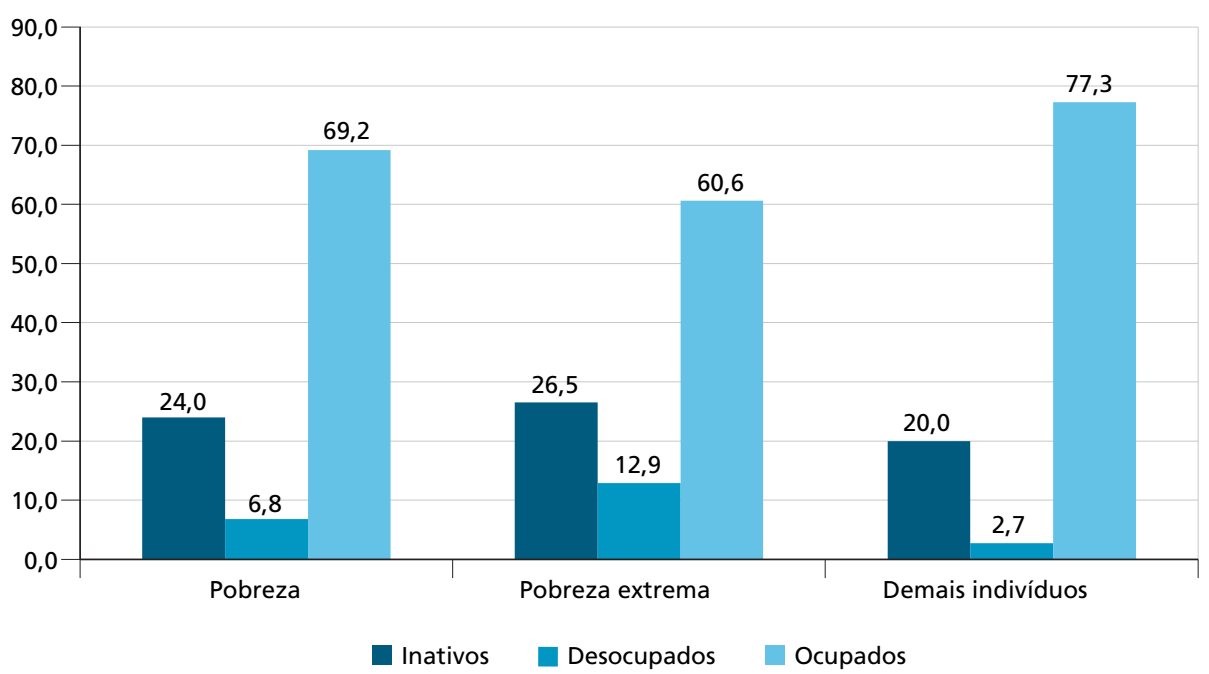

3B - Entre mulheres

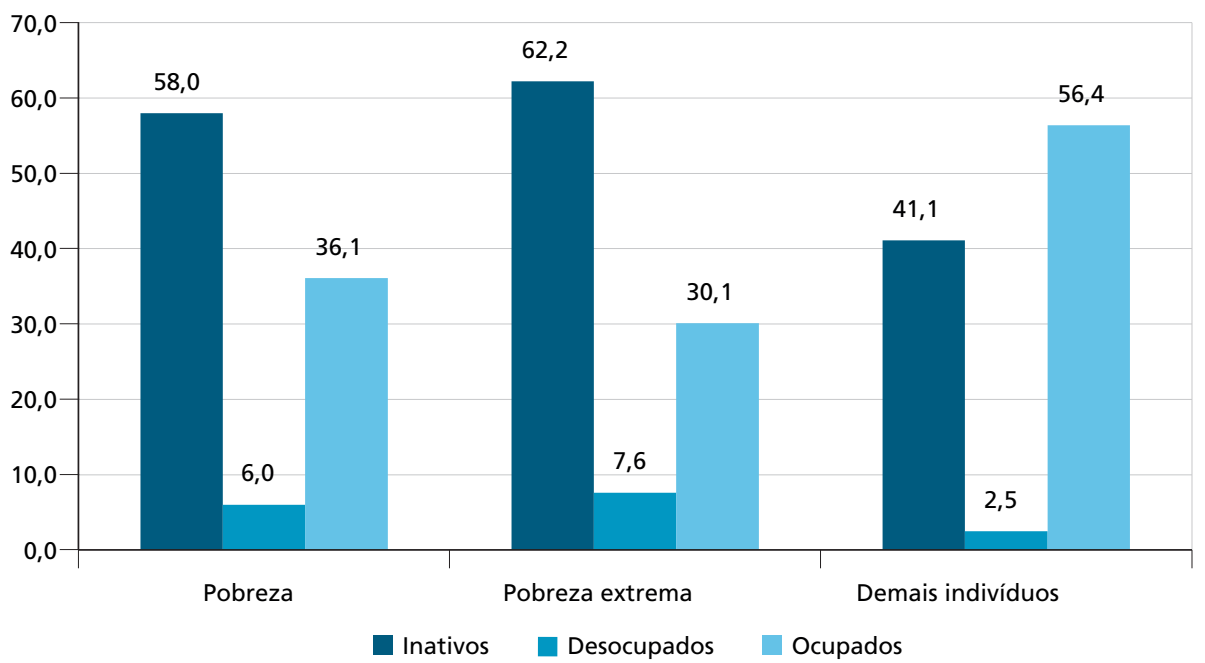

Fonte: Cepal (2019a).

Nesse sentido, o enfrentamento da exclusão social de pessoas em situação de pobreza não se encerra com a geração de emprego em horas e condições suficientes para garantir a subsistência individual. Há que se planejar uma atuação integrada que 
garanta os direitos de cidadania desses indivíduos, o que inclui, além da seguridade social, o acesso a serviços básicos e de infraestrutura domiciliar e urbana, reduzindo a heterogeneidade estrutural e a desigualdade de oportunidades no mercado de trabalho desses países.

Ademais, não se pode desconsiderar o fato de que o conjunto dos programas de proteçâo social influi de diversas maneiras na geraçáo de emprego e no crescimento econômico, diluindo, assim, a fronteira entre o que é proteção social e o que é promoção da atividade econômica. Tal influência ocorre a partir de canais interconectados que se manifestam nos níveis: micro (individual e domiciliar), com melhoria nos índices de educação e saúde, bem como na capacidade de geração de pequenas oportunidades de negócio; meso (comunidades e economias locais), com o aumento da demanda e do consumo local, adensamento de cadeias produtivas territoriais e criação de empreendimentos coletivos e redes de comercialização; e macro, pelo efeito multiplicador na dinâmica econômica nacional via estímulo à demanda agregada, à queda na desigualdade e ao fortalecimento do capital humano (Landim Junior, 2009; Alderman e Yemtsov, 2012; Jannuzzi e Pinto, 2013; Neri, Vaz e Souza, 2013; Mathers e Slater, 2014; Cepal 2019a).

\section{A INCLUSÃO PRODUTIVA COMO EIXO DE POLÍTICAS PÚBLICAS DE PROTEÇÃO SOCIAL NO BRASIL}

O Brasil tem experimentado um avanço bastante significativo em sua rede de proteção social desde a CF/1988, sobretudo no tocante à diversificação e expansão da cobertura de suas políticas públicas, distribuídas em diferentes áreas de atuação, como saúde, educação, previdência, assistência social e trabalho. Elas são fruto de uma trajetória longa de lutas e acúmulos institucionais que permitiram o delineamento dessa estrutura de seguridade ao longo do tempo.

No que se refere aos programas de proteção social considerados na seção 2, as ações em curso envolvem um volume considerável de recursos públicos e atende a um expressivo contingente populacional. Por isso, elas exigem uma estrutura complexa de capacidades estatais (Gomide e Pires, 2014), sobretudo no que tange a financiamento, coordenação federativa e gestão das atividades recorrentes.

No eixo de aposentadorias e pensóes sociais, os programas se diferenciam quanto à natureza contributiva, aos critérios de elegilidade e ao cálculo de benefícios. O principal deles em termos de recursos empregados é o Regime Geral de Previdência Social (RGPS), cujos valores dos benefícios mensais variam de acordo com a contribuição previdenciária do indivíduo ao longo de sua vida laboral. Em 2018, o programa alcançou 20,7 milhóes de beneficiários, totalizando um gasto de $\mathrm{R} \$ 468,6$ bilhóes. 
Outros dois programas de natureza contributiva, vinculados diretamente à condição de assalariado formal, são: i) Programa Seguro-Desemprego, que garante entre três e cinco prestaçóes monetárias mensais a indivíduos demitidos de seus empregos de forma imotivada, sujeito às exibilidades de acesso; e ii) Abono Salarial, benefício em parcela única de até um salário mínimo anual, a depender da quantidade de meses trabalhados no ano de referência, que atende a trabalhadores formais com rendimento médio mensal inferior a dois salários mínimos. Juntos, esses programas atingiram mais de 20 milhóes de beneficiários em 2018, com um gasto total de $\mathrm{R} \$ 53,6$ bilhóes.

Entre os programas sem uma relação direta com a capacidade contributiva dos indivíduos, destacam-se a Previdência Rural e o Benefício de Prestação Continuada (BPC). O sistema de previdência rural foi instituído na CF/1988 como uma opção de aposentadoria especial, com regras próprias em relação ao sistema geral, para trabalhadores agrícolas em regime de economia familiar que atingem a idade de 55 anos para mulher e 60 anos para homens. Ele alcança cerca de 10 milhóes de indivíduos no Brasil, com benefício mensal no valor de um salário mínimo, e é identificado como um elemento essencial de enfrentamento da pobreza rural, sobretudo em regiôes mais pobres do Norte e do Nordeste do país (Valadares e Galiza, 2017).

Já o BPC, também no valor de um salário mínimo mensal, é um benefício destinado a pessoas com deficiência ou a idosos a partir de 65 anos de idade que residem em situação domiciliar de pobreza. ${ }^{5}$ Em 2018, esse programa alcançou um contingente próximo a 5 milhôes de pessoas em todo o país, com um gasto na ordem de R \$ 55,2 bilhóes.

No eixo de transferências de renda condicionadas, o principal expoente no Brasil é o Programa Bolsa Família (PBF), criado em 2004. Em síntese, o PBF beneficia famílias em situação de pobreza e pobreza extrema, com base na definição de faixas de renda média per capita domiciliar, mediante a transferência monetária mensal, cujo valor varia em relação à quantidade de crianças e adolescentes residentes no domicílio, estabelecendo contrapartidas em termos de acesso a outros serviços públicos de educação e saúde. ${ }^{6}$ Para sua operacionalização, o governo federal atua junto aos governos estaduais e municipais, o que exige um amplo esforço de coordenação federativa. Em torno de 14 milhões de famílias recebem esse benefício atualmente no Brasil, totalizando um gasto próximo a $\mathrm{R} \$ 30$ bilhóes anuais. Entre as inovaçóes resultantes do PBF está a criação de um cadastro nacional unificado - o Cadastro Único - de famílias que atendem aos requisitos para o recebimento do

5. Para a concessão deste benefício, é exigido que a renda familiar mensal seja de até um quarto de salário mínimo por pessoa.

6. Sobre a discussão da definição de linhas de pobreza para programas de assistência social, ver Soares (2009). 
benefício, que passou a ser utilizado também para outras açóes sociais de governo, inclusive no nível subnacional, orientando procedimentos e definindo públicos prioritários. O Cadastro Único fornece ainda informações para a composição do Índice de Gestáo Descentralizada (IGD), criado como instrumento de articulação interfederativa em torno do PBF (Paiva, Falcão e Bartholo, 2013).

A tabela 1 apresenta uma síntese em termos de números de beneficiários e o total de recursos orçamentários anuais gastos com esses dois eixos de programas no Brasil.

TABELA 1

Total de beneficiários e gasto orçamentário dos principais programas sociais de transferência de renda - Brasil (2017 e 2018)

\begin{tabular}{|c|c|c|c|c|c|}
\hline \multirow[b]{2}{*}{ Programas } & \multicolumn{3}{|c|}{2017} & \multicolumn{2}{|c|}{2018} \\
\hline & \multirow{2}{*}{$\begin{array}{c}\begin{array}{c}\text { Beneficiários } \\
\text { (milhões) }\end{array} \\
\text { RGPS (urbano) }\end{array}$} & \multicolumn{2}{|c|}{$\begin{array}{c}\text { Gasto } \\
\text { (R\$ milhões) }\end{array}$} & \multirow{2}{*}{$\begin{array}{c}\begin{array}{c}\text { Beneficiários } \\
\text { (milhões) }\end{array} \\
20,7\end{array}$} & \multirow{2}{*}{$\begin{array}{c}\begin{array}{c}\text { Gasto } \\
\text { (R\$ milhões }\end{array} \\
468,6\end{array}$} \\
\hline \multirow{5}{*}{$\begin{array}{l}\text { Aposentadorias e pensões } \\
\text { sociais }\end{array}$} & & 20,3 & 455,7 & & \\
\hline & Seguro-desemprego & 7,4 & 38,0 & 6,6 & 36,3 \\
\hline & Abono salarial & 22,7 & 16,2 & 23,0 & 17,3 \\
\hline & Aposentadoria rural & 9,5 & 125,1 & 9,5 & 125,3 \\
\hline & $\mathrm{BPC}$ & 4,7 & 53,2 & 4,8 & 55,2 \\
\hline $\begin{array}{l}\text { Transferências de renda } \\
\text { condicionadas }\end{array}$ & PBF & 13,8 & 27,8 & 14,1 & 29,4 \\
\hline
\end{tabular}

Fonte: Secretaria de Previdência/Ministério da Economia. Disponivel em: <https://bit.ly/2Yh0Ooh>.

Para o eixo dos programas de inclusão produtiva, o propósito básico de seus desenhos operacionais não se refere à transferência direta de renda, mas, sim, à geração de oportunidades de trabalho e renda a jovens e adultos em idade ativa com alguma dificuldade de inserção no mercado de trabalho. A busca por essa inserção ocorre tanto pela via do trabalho assalariado quanto pela geração de negócios autônomos individuais e coletivos. Para isso, existe um amplo repertório de intervençóes governamentais, com perfis operacionais e de financiamento distintos, que guardam entre si elementos de complementaridade, sobreposição e até de contradição. Como é possível observar a partir da experiência brasileira recente (Silva, 2020b).

Pela via do trabalho assalariado, os instrumentos de intervenção mais comuns são os serviços de: i) qualificação profissional, que visam preparar os indivíduos para um perfil esperado de demanda; e ii) intermediação entre oferta e demanda por força de trabalho, que visa incidir sobre situaçóes de desemprego friccional. Esses instrumentos estâo previstos no conceito de sistema público de emprego, desenvolvido pela Organização Internacional do Trabalho (OIT) ao longo do século XX (Silva, 2020a). 
O Brasil, como signatário das principais resoluçóes da OIT que tratam sobre parâmetros básicos de um sistema público de emprego, criou sua primeira estrutura burocrática para desempenhar e acompanhar tais programas em 1975, com a criação do Sistema Nacional de Emprego (Sine). Com a CF/1988 e a Lei no 7.998/1990, foi criado o Fundo de Amparo ao Trabalhador (FAT), com a função de mobilizar recursos para a manutenção e expansão das políticas de emprego no país, tendo os estados e municípios como responsáveis pela implementação dos serviços em convênio com o governo federal. No entanto, uma série de decisóes de política fiscal, aliada a mudanças na dinâmica do próprio mercado de trabalho brasileiro, afetou a capacidade do FAT em financiar serviços de emprego. Como se trata de gastos de natureza discricionária, os programas de qualificação e intermediação sofreram seguidos cortes e contingenciamentos orçamentários, restringindo fortemente sua capacidade de cobertura no território nacional (Silva, 2018b).

Além das ações financiadas pelo FAT, o governo federal lançou o Programa Nacional de Acesso ao Ensino Técnico e Emprego (Pronatec), por meio da Lei no $12.513 / 2011$, sob a gestão do Ministério da Educação (MEC). ${ }^{7}$ Ele surgiu com o objetivo de democratizar o acesso da populaçáo brasileira à educação profissional e tecnológica. Para isso, foram disponibilizados cursos básicos e seriados, fazendo uso tanto da rede de institutos federais de educação (IFEs), que experimentaram um amplo crescimento e interiorização a partir da década anterior, quanto de escolas do Sistema S (Cassiolato e Garcia, 2014). ${ }^{8}$

Outra ação de qualificação profissional no âmbito do governo federal é o Programa Nacional de Inclusão de Jovens (Projovem). ${ }^{9}$ Ele surgiu com um duplo objetivo: a formaçáo inicial para o trabalho e a elevação da escolaridade de jovens entre 15 e 29 anos, mediante participação em cursos integrados com o sistema fundamental de ensino, com duraçấo de dezoito meses. Conforme seu desenho inicial, cada jovem integrante receberia uma bolsa no valor de $\mathrm{R} \$ 100,00$ como estímulo à sua permanência nas atividades. $\mathrm{O}$ programa possui gestão compartilhada entre os governos estaduais e municipais mediante convênios (Friedrich, Benite e Benite, 2012). Contudo, embora não tenha sido encerrado oficialmente, os recursos para a execução do programa foram se escasseando, sobretudo após o lançamento do Pronatec, e atualmente ele é praticamente inoperante, com excessão de algumas iniciativas estaduais pontuais.

7. Entre 2011 e 2014, foram oferecidos mais de seiscentos cursos (entre cursos técnicos e cursos de formação inicial e continuada), nos quais se matricularam, aproximadamente, 8,1 milhões de pessoas em mais de 4.300 municípios (Cepal, 2019a).

8. Para uma avaliação dos impactos do Pronatec junto a seus beneficiários, ver Sousa, Silva e Jannuzzi (2015) e Araújo e Gomes (2016).

9. Decreto ํㅜ 5.557, de 5 de outubro de 2005. 
Em termos de estímulo à geração de trabalho e renda pela via da formação de empreendimentos autônomos, o sistema público de emprego no Brasil também previu açôes para a oferta de microcrédito para o fomento de negócios, tanto no meio urbano quanto no rural. Duas delas valem ser destacadas. Primeiramente, por meio das disponibilidades financeiras de caixa do FAT, foram criados programas com linhas de crédito para unidades produtivas e comerciais via bancos públicos nacionais. Um deles é o Programa Nacional de Geração de Trabalho e Renda (Proger), com linhas de crédito subsidiadas para a viabilização de empreendimentos de pequeno porte (individual ou cooperativo) em todo o país. A segunda trata-se do Programa Nacional de Microcrédito Produtivo Orientado (PNMPO), criado pela Lei no 11.110/2005, que, além de dispor de recursos do FAT, conta com a destinação de $2 \%$ dos depósitos à vista dos bancos comerciais para a aplicação em operaçóes de microcrédito para diferentes atividades econômicas. Porém, conforme explicado em Silva (2018b), os recursos para programas de microcrédito também foram reduzidos signitivamente na última década com a progressiva asfixia orçamentária do FAT.

Além de linhas de microcrédito, há a disponibilização de apoio técnico a pequenos empreendedores através de algumas agências, como o Serviço Brasileiro de Apoio às Micro e Pequenas Empresas (Sebrae). Trata-se de uma organização paraestatal que tanto desenvolve açóes próprias quanto faz a mediaçáo junto a governos (federal e locais) em programas voltados ao fortalecimento de micro e pequenas empresas (Nogueira, 2019). O Sebrae monitora a operacionalização do programa Microeempredor Individual (MEI), que possui dois objetivos: simplificar a formalização de pequenos empreendimentos e proporcionar um vínculo básico ao sistema de seguridade social a esses microempresários.

Outra linha relativamente recente de atuação governamental sob o eixo de inclusão produtiva é a economia solidária. Trata-se de um referencial utilizado por movimentos sociais e organizaçóes de trabalhadores nos anos 1990 para a valorização de estratégias coletivas (urbanas e rurais) de trabalho e desenvolvimento local. À medida que o termo foi ganhando maior densidade mobilizatória junto a organizaçóes sociais, adentrando inclusive as fronteiras da academia, ${ }^{10}$ alguns governos subnacionais começaram a lançar programas próprios para apoiar iniciativas de produção e comercialização com esse perfil. O tema emergiu na agenda federal de governo em 2003, com a criação da Secretaria Nacional de Economia Solidária (Senaes), que ficou responsável por uma série de programas ao longo de quatro planos plurianuais (PPAs) subsequentes (Silva, 2011; 2018a).

10. Para uma síntese bibliométrica dos estudos científicos sobre economia solidária no Brasil, ver Silva (2018e). 
A partir de 2011, o paradigma da economia solidária foi incorporado pela iniciativa de articulação de políticas sociais lançada naquele ano pelo governo federal - o Plano Brasil Sem Miséria (PBSM), ${ }^{11}$ para o PPA 2012-2015. Na prática, o PBSM representou uma ampliação de uma agenda amadurecida ao longo dos anos de implementação de programas sociais, com alguma coordenação entre governos federal, estaduais e municipais, baseada em três frentes de intervenção: i) garantia de renda, com expansão do público beneficiário do PBF e criação de novos benefícios para públicos específicos, como o Bolsa Verde para agricultores familiares; ii) acesso a serviços públicos, para além do acompanhamento básico das condicionalidades em educação e saúde, incluindo uma linha específica do Pronatec para o público do Cadastro Único; ${ }^{12}$ e iii) inclusão produtiva, com a introdução de novas ações que impactassem direta e indiretamente na geração de trabalho e renda para populaçóes em situação de vulnerabilidade (Silva, 2011; Paiva, Falcão e Bartholo, 2013). Com o PBSM, pode-se dizer que, pela primeira vez, o termo inclusão produtiva foi inserido como eixo estratégico de articulação de políticas públicas no país, ${ }^{13}$ tendo a economia solidária como uma referência operacional. ${ }^{14}$

Entre as açôes previstas estava o apoio aos catadores de material reciclável, que compóem um grupo bastante disperso nos cenários urbanos do país e sujeitos a condiçôes de vida e trabalho bastante precárias. A ideia era que diferentes instâncias burocráticas de governo, coordenadas pelo Comitê Interministerial para Inclusão Social e Econômica dos Catadores de Materiais Reutilizáveis e Recicláveis (CIISC), pudessem fomentar a organização desses trabalhadores em cooperativas e associaçóes autônomas, a ponto de negociar em melhores condiçóes a comercialização de seus produtos ao longo da cadeia produtiva da reciclagem. Vale ressaltar que a Política Nacional de Resíduos Sólidos (PNRS) - Lei no 12.305/2010 - estabeleceu parâmetros para programas de coleta seletiva nos municípios com a inclusão de catadores no processo, inclusive com a possibilidade de contratação de seus empreendimentos coletivos para realizarem parte dos serviços (Silva, Goes e Alvarez, 2013).

11. Decreto no 7.492, de 2 de junho de 2011.

12. Até julho de 2013 já haviam sido realizadas mais de 600 mil matrículas direcionadas à população do Cadastro Único (com renda média per capita de até meio salário mínimo), em sua maioria, mulheres (dois terços das matrículas) e jovens de até 29 anos. Os cursos possuíam duração mínima de 160 horas (Paiva, Falcão e Bartholo, 2013).

13. Vale ressaltar que o termo já havia sido referido pelo Decreto no 6.393/2008 (art. 2), que estabelecia as bases para o Compromisso Nacional pelo Desenvolvimento Social, a ser firmado entre a União, os estados e o Distrito Federal. A partir dele, foi criada a Secretaria de Articulação para a Inclusão Produtiva (Saip), do então Ministério de Desenvolvimento Social e Combate à Fome (MDS). A Saip deixou de existir em 2011, sendo substituída pela Secretaria Extraordinária de Combate à Extrema Pobreza.

14. Para uma análise das diversas ações previstas no PBSM, ver Campello e Neri (2013). Ressalta-se também que, antes do PBSM, ocorreram outras tentativas de coordenação de políticas sociais a partir de uma estratégia no plano do Executivo federal, tais como o Programa Comunidade Solidária, em 1995, o Programa Fome Zero, em 2003 (Silva, 2014), e o Programa Territórios da Cidadania, em 2008 (Silva, 2013). 
Como demonstrou Silva (2018a), houve um significativo aporte orçamentário para açóes de apoio a esse público, que representou uma elevação de quase $50 \%$ do orçamento da Senaes entre 2011 e 2012. Entretanto, uma série de constrangimentos institucionais e administrativos dificultou a execução desses recursos no território nacional. A própria política de economia solidária foi perdendo espaço na agenda de governo, até a extinção no início de 2019, com as funçôes sendo absorvidas pelo recém-criado Ministério da Cidadania.

No âmbito rural, o Brasil também tem experimentado uma série de açôes voltadas para o público da agricultura familiar. $\mathrm{O}$ marco institucional mais importante na delimitação desse referencial de política pública foi a criação do Programa Nacional de Fortalecimento da Agricultura Familiar (Pronaf), em 1996, fornecendo linhas de crédito mais favoráveis para produtores historicamente excluídos dos sistemas tradicionais de financiamento agrícola no país. Como as unidades de agricultura familiar são responsáveis por um percentual significativo da ocupação no meio rural, o Pronaf assume uma função estratégica de propiciar as condições econômicas para a manutenção dessas famílias com dignidade em suas propriedades.

Outras açôes de desenvolvimento rural sáo destinadas ao acesso a mercados institucionais, à assistência técnica e à infraestrutura. No primeiro caso, destaca-se o lançamento do Programa de Aquisição de Alimentos (PAA), criado em 2003, com o objetivo de adquirir produtos diretamente de agricultores familiares para a rede de assistência social nos municípios, mediante simplificação de processos licitatórios. Posteriormente, com a reforma do Programa Nacional de Alimentação Escolar (PNAE), via Lei no 11.947/2009, o mesmo mecanismo foi adotado com a obrigação por parte dos municípios de gastarem pelo menos 30\% dos recursos transferidos pelo governo federal com a alimentação escolar (Silva, 2014; 2019). Tais programas representam uma demanda importante para esses produtores e suas organizaçóes cooperativas, garantindo a geração de renda e a manutenção de suas atividades no meio rural. No segundo caso, destaca-se o lançamento da Política Nacional de Assistência Técnica e Extensão Rural (PNATER), em 2003, quando se declarou a agricultura familiar como público prioritário das açóes de assistência técnica rural no Brasil. Programas de investimento em infraestrutura, sobretudo de eletrificação, como o Programa Luz Para Todos, e a criação de cisternas em propriedades rurais com vulnerabilidade hídrica, como o Programa Um Milhão de Cisternas, também tiveram sua relevância no favorecimento a esse segmento socioprodutivo (Mello, 2018).

Como esse conjunto de intervençóes listadas possui características bastante diversas, uma categorização sintética delas pode se basear em distintas dimensões analíticas. $\mathrm{O}$ quadro 1 expóe um exercício de categorização com base na divisão apresentada pela Cepal (2019a; 2019c), cujos programas são agrupados de acordo com sua orientação à demanda, à oferta de força de trabalho ou a ambos. 
QUADRO 1

Categorização dos principais programas de inclusão produtiva no Brasil

\begin{tabular}{|c|c|c|}
\hline $\begin{array}{l}\text { Dimensão de apoio quanto à força } \\
\text { de trabalho }\end{array}$ & Tipo de programas & Programas \\
\hline Apoio à oferta & Capacitação técnica e profissional & $\begin{array}{l}\text { Programas de Qualificação Profissional (FAT). } \\
\text { Pronatec. } \\
\text { Projovem. }\end{array}$ \\
\hline Apoio à oferta e à demanda & Serviços de intermediação & Sine/FAT. \\
\hline \multirow{4}{*}{$\begin{array}{l}\text { Apoio à demanda e estabilização } \\
\text { de renda }\end{array}$} & Microcrédito & $\begin{array}{l}\text { Proger. } \\
\text { PNMPO. } \\
\text { Pronaf. }\end{array}$ \\
\hline & Mercados institucionais & $\begin{array}{l}\text { PAA. } \\
\text { PNAE. } \\
\text { Participação de organizações de catadores } \\
\text { em programas municipais de coleta seletiva. }\end{array}$ \\
\hline & $\begin{array}{l}\text { Apoio ao trabalho autônomo (individual e } \\
\text { coletivo) }\end{array}$ & $\begin{array}{l}\text { Sebrae. } \\
\text { Programa Microempreendedor Rural (MEI). } \\
\text { Assistência Técnica e Extensão Rural (Ater). } \\
\text { Economia Solidária. }\end{array}$ \\
\hline & Infraestrutura rural & $\begin{array}{l}\text { Programas específicos de eletrificação, } \\
\text { estrutura hídrica, agroindustrialização, } \\
\text { turismo rural e habitação. }\end{array}$ \\
\hline
\end{tabular}

Elaboração do autor.

Esse relato de experiências político-programáticas relativamente recentes no Brasil associadas ao referencial de inclusão produtiva não visa esgotar as possibilidades de abordagem sobre o tema. Pelo contrário, trata-se de um exercício inicial de delimitação, uma espécie de inventário de programas, que carregam consigo suas particularidades e disponibilizam uma carga poderosa de orientaçóes para aperfeiçoamento nos rumos da intervenção estatal, visando ao enfrentamento de fenômenos complexos, como pobreza e desigualdade. Nesse sentido, os programas listados no quadro 1 abarcam as linhas mestras em direçáo a um modelo de proteçáo social inclusiva, que tem sua relevância aprofundada no contexto atual de crise global em decorrência da pandemia do novo coronavírus, cuja extensão de seus impactos nas dinâmicas econômicas nacionais ainda é imprevisível.

\section{CONSIDERAÇÕES FINAIS E PROPOSITIVAS}

A discussão empreendida neste texto demonstra que a formulação de políticas contra a pobreza e a desigualdade nos países da América Latina, e particularmente no Brasil, sob a ótica da proteção social inclusiva, consiste em um complexo desafio institucional, sobretudo em função do perfil do público a ser beneficiado. De maneira geral, são pessoas com baixa escolaridade, poucas habilidades profissionais consolidadas, que não residem próximo a centros dinâmicos e possuem competência praticamente nula de investimento em sua capacitaçáo técnica ou em alguma 
atividade produtiva própria. Portanto, sua inclusão no mundo do trabalho, sob a ótica do trabalho decente conforme apregoado pela OIT e incorporado nos ODS, requer uma ação articulada sob múltiplas dimensões.

No caso específico dos programas de inclusão produtiva, o desafio passa também pelo fato de ser um tema que ainda não se consolidou como um referencial agregador de projetos e açóes na agenda governamental. Embora tenham crescido significativamente nos últimos anos em toda América Latina, esses programas mantêm-se fragmentados, com operacionalidade difusa, financiamento instável e com dificuldade de estabelecer informaçóes agregadas que permitam avaliaçóes e acompanhamentos mais sistemáticos de seus resultados.

A análise da experiência brasileira possibilita a proposição de parâmetros para o aperfeiçoamento das estratégias de intervençấo, para que os programas de inclusão produtiva não figurem como o elo perdido das políticas de proteção social. O esforço deveria ser direcionado para uma articulação concreta entre programas e unidades burocráticas responsáveis, gerando sinergias diante de seu duplo desafio: superar a pobreza e reduzir a desigualdade. Trata-se de fomentar um círculo virtuoso da proteção social, conectando transferência de renda e inclusão laboral. Esse esforço pode ser estruturado, como ponto de partida, sob três óticas complementares.

Primeiramente, uma articulação horizontal no plano administrativo federal. Uma proposta prática para isso seria a criação de uma instituição de deliberação participativa - IDP (Silva, 2018c) específica, como um conselho gestor, ligada a um ministério da área social ou ao próprio gabinete da Presidência da República, com a tarefa de estabelecer metas de ação conjunta dos programas de geração de emprego e renda previstos no PPA 2020-2023. A IDP proposta poderia englobar atribuiçóes antes destinadas a conselhos recém-extintos ou que se encontram praticamente sem operação. ${ }^{15} \mathrm{O}$ intuito de uma instância dessa natureza seria fortalecer o potencial técnico e político do Estado na negociação de seus objetivos em termos de melhoria dos indicadores sociais.

Em segundo lugar, uma articulação vertical, levando-se em conta o federalismo brasileiro. Nessa perspectiva, deve-se estimular o envolvimento das unidades subnacionais, que já realizam, muitas vezes em parceria com organizaçóes da sociedade civil, uma série de programas que dialogam com os objetivos possíveis de uma estratégia nacional de inclusão produtiva. Embora tais experiências sejam restritas ao plano local, elas podem acrescentar bastante em termos de aprendizado operacional e de soluçóes a serem compartilhadas, e seu acompanhamento pode ser realizado por meio de um sistema de monitoramento participativo e integrado,

15. Entre os conselhos nessa situação estão: Conselho Nacional de Segurança Alimentar e Nutricional (Consea); Conselho Nacional de Economia Solidária (CNES); Conselho Nacional de Desenvolvimento Rural Sustentável (Condraf); Conselho Nacional de Juventude (Conjuve), entre outros. 
com a definição de conselhos gestores também nos níveis subnacionais. Uma ação complementar relativamente simples é o lançamento de um evento nacional anual para o reconhecimento de iniciativas de inclusão produtiva. ${ }^{16}$ Essa seria uma forma de publicizar experiências diversas no território brasileiro, propiciando a formação e o compartilhamento de um banco nacional de boas práticas de inclusão produtiva no Brasil.

Em terceiro lugar, uma articulação informacional. Trata-se do estabelecimento de um sistema dinâmico de informações, com alimentação periódica de dados e flexibilidade de manipulação para fins específicos dos diferentes programas inseridos em uma estratégia nacional. Para isso, já existe uma estrutura inicial bastante relevante que é o Cadastro Único, que, aliado a outros bancos de dados dos diferentes domínios de política social (trabalho, assistência e previdência social, saúde, educação, cultura etc.), garantiria os insumos para a geração de um sistema robusto de informaçóes a ser utilizado por gestores públicos e pesquisadores em geral. Sua manutenção demandaria uma equipe responsável por elaborar o desenho geral e para sua operacionalizaçáo (que poderia ser associada à própria secretaria-executiva da IDP proposta).

Vale ressaltar, porém, que o esforço de coordenação de políticas sociais não representa um caminho simples de ser pavimentado. O Brasil já passou por algumas experiências nesse sentido, como foi com o Programa Oportunidade Solidária, o Programa Fome Zero, o Programa Territórios da Cidadania e o PBSM, apenas para citar os mais importantes ocorridos desde os anos 1990. Por isso, as linhas de ação aqui propostas têm como intenção lançar bases operacionais mínimas para uma estratégia dessa natureza, que dependerá das capacidades de construção dos consensos necessários para sua viabilização, levando-se em conta as distintas dimensões institucionais a serem envolvidas.

Por sua vez, tais proposiçóes não descartam a necessidade de uma orientação macroeconômica para o desenvolvimento, que, por um lado, não subverta as decisóes de política social em nome de um excessivo controle fiscal e monetário e, por outro, mantenha os incentivos necessários para a geração de empregos de qualidade e o adensamento das cadeias produtivas nacionais, sem o qual dificilmente um sistema nacional de proteção social se viabiliza. Na prática, ambas as estratégias se complementam e se reforçam mutuamente.

Portanto, sem nenhuma pretensão de esgotar as possibilidades de problematização e prescriçóes para o desenho estratégico de uma política nacional de inclusão produtiva, este estudo buscou lançar alguns pontos iniciais de reflexão

16. Já existe no país alguns eventos com uma sistemática parecida, como no caso do Concurso de Inovação no Setor Público, que ocorre há mais de duas décadas, e do Prêmio Objetivos do Desenvolvimento Sustentável, com apoio técnico do Ipea e da Escola Nacional de Administração Pública (Enap). 
para qualificar uma discussão mais ampla em torno do tema. As recentes inflexões em diversos indicadores socioeconômicos, em especial o aumento substancial do desemprego e da informalidade do trabalho, e o cenário atual de crise global decorrente da pandemia declarada pela Organização Munidal de Saúde (OMS) apontam a urgente necessidade de respostas por parte do poder público à sociedade para seu enfrentamento.

\section{REFERÊNCIAS}

ABRAMO, L. Uma década de promoção do trabalho decente no Brasil: uma estratégia de ação baseada no diálogo social. Brasília: OIT, 2015.

ALDERMAN, H.; YEMTSOV, R. Productive role of safety nets: background paper for the World Bank 2012-2022 - social protection and labor strategy. Washington: Banco Mundial, 2012. (Working Paper, n. 1203).

ARAÚJO, F.; GOMES, J. Análise de impacto do Pronatec em beneficiários, Brasil Sem Miséria: resultados, institucionalidades e desafios. Cadernos de Estudos: Desenvolvimento Social em Debate, Brasília, n. 25, 2016.

CAMPELLO, T.; NERI, M. C. (Orgs.). Programa Bolsa Família. Brasília: Ipea, 2013. CASSIOLATO, M. M.; GARCIA, R. C. Pronatec: um exemplo de organização de novos arranjos institucionais para ampliar o acesso à educação profissional. In: OLIVEIRA, M. P. P. O. et al. (Orgs.). Rede de pesquisa, formaçáo e mercado de trabalho. Brasília: Ipea, 2014.

CEPAL - COMISSÃO ECONÔMICA PARA A AMÉRICA LATINA. Protección social inclusiva en América Latina. Santiago: Cepal, 2011.

Programas sociales, superación de la pobreza e inclusión laboral. Santiago: Cepal, 2019a.

. Panorama Social de América Latina, 2018. Santiago: Cepal, 2019b.

. Protección social universal en América Latina y el Caribe. Santiago: Cepal, 2019c.

EVANS, P. The capability enhancing developmental state: concepts and national trajectories. Niterói: UFF, 2011. (Texto para Discussão, n. 63).

FRIEDRICH, M.; BENITE, C. M.; BENITE, A. C. Projovem: uma análise entre a proposta oficial e a experiência vivida em Goiânia. Ensaio: Avaliação e Políticas Públicas de Educação, v. 20, n. 74, 2012.

GOMIDE, A.; PIRES, R. R. Capacidades estatais e democracia. Brasília: Ipea, 2014. 
INFANTE, R. America Latina en el "Umbral del Desarrollo": un ejercicio de convergencia productiva. Santiago: Cepal, 2011. (Documento de Trabajo, n. 14). IPEA - INSTITUTO DE PESQUISA ECONÔMICA APLICADA. Agenda 2030 - ODS. Brasília: Ipea, 2018.

Políticas Sociais: Acompanhamento e Análise. Brasília, n. 26, 2019.

JANNUZZI, P. M.; PINTO, A. R. Bolsa Famíia e seus impactos nas condições de vida da população brasileira. In: CAMPELLO, T.; NERI, M. C. (Orgs.). Programa Bolsa Família. Brasília: Ipea, 2013.

LANDIM JUNIOR, P. Os efeitos do Programa Bolsa Família sobre a economia dos municípios brasileiros. Relatório final. São Paulo: Insper, 2009.

MATHERS, N.; SLATER, R. Social protection and growth. Australian Government, 2014.

MELLO, J. Estratégias de superaçáo da pobreza no Brasil recente e impacto sobre o meio rural. Brasília: Ipea, 2018.

NERI, M.; VAZ, F. M.; SOUZA, P. H. F. Efeitos macroeconômicos do Programa Bolsa Família. In: CAMPELLO, T.; NERI, M. C. (Orgs.). Programa Bolsa Família. Brasília: Ipea, 2013.

NOGUEIRA, M. O. Um pirilampo no poráo: um pouco de luz nos dilemas da produtividade das pequenas empresas e da informalidade no Brasil. Brasília: Ipea, 2019.

OLIVEIRA, T.; SILVA, S. P. Regulação e dinâmica do mercado de trabalho. In: CARDOSO JUNIOR, J. C. (Org.). A Constituiçáo golpeada. São Paulo: FPA, 2018.

PAIVA, L. H.; FALCÃO, T.; BARTHOLO, L. Do Bolsa Família ao Brasil Sem Miséria: um resumo do percurso brasileiro recente na busca da superaçáo da pobreza extrema. In: CAMPELLO, T.; NERI, M. C. (Orgs.). Programa Bolsa Família. Brasília: Ipea, 2013.

PINHEIRO, L. et al. Os desafios do passado no trabalho doméstico do século XXI. Brasília: Ipea, 2019. (Texto para Discussão, n. 2528).

SILVA, S. P. A economia solidária na estratégia de erradicação da pobreza extrema no Brasil. Mercado de Trabalho: Conjuntura e Análise, Brasília, Ipea, n. 47, 2011.

- A abordagem territorial no planejamento de políticas públicas e os desafios para uma nova relação entre estado e sociedade no Brasil. In: BOUERI, R.; COSTA, M. A. Brasil em desenvolvimento 2013: Estado, planejamento e políticas públicas. Brasília: Ipea, 2013. v. 1. 
A trajetória histórica da segurança alimentar e nutricional na agenda política nacional: projetos, descontinuidades e consolidação. Brasília: Ipea, 2014. (Texto para Discussão, n. 1953).

A política de economia solidária no ciclo orçamentário nacional (20042018): inserção, expansão e crise de paradigma. Brasília: Ipea, 2018a. (Texto para Discussão, n. 2434).

Arranjos institucionais de financiamento das políticas públicas de trabalho e renda no Brasil: uma análise a partir da trajetória do Fundo de Amparo ao Trabalhador (FAT). Brasília: Ipea, 2018b. (Texto para Discussão, n. 2437).

Democracia, políticas públicas e instituiçóes de deliberaçáo participativa. Brasília: Ipea, 2018c. (Texto para Discussão, n. 2358).

O panorama laboral brasileiro no contexto recente da economia latinoamericana. In: CORSEUIL, C. H. L. (Ed.). Mercado de Trabalho: Conjuntura e Análise, Brasília, Ipea, n. 64, 2018d.

O campo de pesquisa da economia solidária no Brasil: abordagens metodológicas e dimensóes analíticas. Brasília: Ipea, 2018e. (Texto para Discussão, n. 2361).

. Trajetória e padróes de mudança institucional no Programa Nacional de Alimentação Escolar. Brasília: Ipea, 2019. (Texto para Discussão, n. 2529).

. O paradigma de sistema público de emprego da OIT e sua construçáo histórica no Brasil. Brasília: Ipea, 2020a. (Texto para Discussão). No prelo.

. Dimensôes analíticas do conceito de inclusão podutiva para fins de política social: uma revisão bibliométrica. In: CORSEUIL, C. H. L. (Ed.). Mercado de Trabalho: Conjuntura e Análise, Brasília, Ipea, n. 68, 2020 b.

SILVA, S. P.; GOES, F. L.; ALVAREZ, A. Situaçáo social das catadoras e dos catadores de material reciclável. Brasília: Ipea, 2013.

SOARES, S. Metodologias para estabelecer a linha de pobreza: objetivas, subjetivas, relativas, multidimensionais. Brasília: Ipea, 2009. (Texto para Discussão, n. 1381). SOUSA, M.; SILVA, Y.; JANNUZZI, P. Contribução do Programa Nacional de Acesso ao Ensino Técnico e Emprego. In: MONTAGNER, P.; MULLER, L. H. (Orgs.). Cadernos de Estudos: Desenvolvimento Social em Debate, Brasília, v. 24, 2015 . 
VALADARES, A. A.; GALIZA, M. Reforma da previdência, agricultura familiar e os riscos de desproteção social. In: CORSEUIL, C. H. L. (Ed.). Mercado de Trabalho: Conjuntura e Análise, Brasília, Ipea, n. 62, 2017.

\section{BIBLIOGRAFIA COMPLEMENTAR}

CEPAL - COMISSÃO ECONÔMICA PARA A AMÉRICA LATINA. Institucionalidad social en América Latina y el Caribe. Santiago: Cepal, 2019. IPEA - INSTITUTO DE PESQUISA ECONÔMICA APLICADA. Perspectivas da política social no Brasil. Brasília: Ipea, 2010. . Políticas Sociais: Acompanhamento e Análise. Brasília, n. 27, 2020.

SILVA, S. P.; VALADARES, A. A. Segurança alimentar e nutricional. In: LOZARDO, E. et al. (Coord.). Desafios da naçáo. Brasília: Ipea, 2018. v. 2. 


\section{Ipea - Instituto de Pesquisa Econômica Aplicada}

\section{EDITORIAL}

\section{Coordenação}

Reginaldo da Silva Domingos

\section{Assistente de Coordenação}

Rafael Augusto Ferreira Cardoso

\section{Supervisão}

Camilla de Miranda Mariath Gomes

Everson da Silva Moura

\section{Revisão}

Amanda Ramos Marques

Ana Clara Escórcio Xavier

Clícia Silveira Rodrigues

Idalina Barbara de Castro

Luiz Gustavo Campos de Araújo Souza

Olavo Mesquita de Carvalho

Regina Marta de Aguiar

Hellen Pereira de Oliveira Fonseca (estagiária)

Ingrid Verena Sampaio Cerqueira Sodré (estagiária)

\section{Editoração}

Aeromilson Trajano de Mesquita

Cristiano Ferreira de Araújo

Danilo Leite de Macedo Tavares

Herllyson da Silva Souza

Jeovah Herculano Szervinsk Junior

Leonardo Hideki Higa

\section{Capa}

Danielle de Oliveira Ayres

Flaviane Dias de Sant'ana

\section{Projeto Gráfico}

Renato Rodrigues Bueno

The manuscripts in languages other than Portuguese published herein have not been proofread.

\section{Livraria Ipea}

SBS - Quadra 1 - Bloco J - Ed. BNDES, Térreo

70076-900 - Brasília - DF

Tel.: (61) 2026-5336

Correio eletrônico: livraria@ipea.gov.br 

Composto em adobe garamond pro 11/13,2 (texto) Frutiger 67 bold condensed (títulos, gráficos e tabelas) Brasília-DF 



\section{Missão do Ipea}

Aprimorar as políticas públicas essenciais ao desenvolvimento brasileiro por meio da produção e disseminação de conhecimentos e da assessoria ao Estado nas suas decisões estratégicas.

\section{PÁTRIA AMADA \\ BRASIL \\ BRAZILIAN GOVERNMENT}

